\title{
Publieke steun voor de Europese Unie : Analyse van de publieke opinie in 12 lidstaten, 1952-1998
}

Citation for published version (APA):

Janssen, J. I. H. (2001). Publieke steun voor de Europese Unie : Analyse van de publieke opinie in 12 lidstaten, 1952-1998. [Doctoral Thesis, Maastricht University]. Universiteit Maastricht. https://doi.org/10.26481/dis.20010615jj

Document status and date:

Published: 01/01/2001

DOI:

10.26481/dis.20010615jj

Document Version:

Publisher's PDF, also known as Version of record

\section{Please check the document version of this publication:}

- A submitted manuscript is the version of the article upon submission and before peer-review. There can be important differences between the submitted version and the official published version of record.

People interested in the research are advised to contact the author for the final version of the publication, or visit the DOI to the publisher's website.

- The final author version and the galley proof are versions of the publication after peer review.

- The final published version features the final layout of the paper including the volume, issue and page numbers.

Link to publication

\footnotetext{
General rights rights.

- You may freely distribute the URL identifying the publication in the public portal. please follow below link for the End User Agreement:

www.umlib.nl/taverne-license

Take down policy

If you believe that this document breaches copyright please contact us at:

repository@maastrichtuniversity.nl

providing details and we will investigate your claim.
}

Copyright and moral rights for the publications made accessible in the public portal are retained by the authors and/or other copyright owners and it is a condition of accessing publications that users recognise and abide by the legal requirements associated with these

- Users may download and print one copy of any publication from the public portal for the purpose of private study or research.

- You may not further distribute the material or use it for any profit-making activity or commercial gain

If the publication is distributed under the terms of Article $25 \mathrm{fa}$ of the Dutch Copyright Act, indicated by the "Taverne" license above, 
Publieke steun voor de Europese Unie

Analyse van de publieke opinie in 12 lidstaten, 1952-1998 


\section{J.I.H. Janssen}

ISBN 90-5681-110-X 


\section{Publieke steun voor de Europese Unie}

Analyse van de publieke opinie in 12 lidstaten, 1952-1998

\section{PROEFSCHRIFT}

ter verkrijging van de graad van doctor aan de Universiteit Maastricht op gezag van de Rector Magnificus, Prof. dr. A.C. Nieuwenhuijzen Kruseman volgens het besluit van het College van Decanen, op vrijdag 15 juni 2001 om 14.00 uur

$$
\text { door }
$$

Joseph Ida Hendricus Janssen 
Promotor:

Prof. dr. A.F.A. Korsten

Beoordelingscommissie:

Prof. mr. N.H.M. Roos (voorzitter)

Dr. A.F.M. Bertrand (Katholieke Universiteit Nijmegen)

Prof. dr. B.J.S. Hoetjes

Prof. dr. J.G.A. van Mierlo

Prof. dr. H.C.G. Spoormans (Open Universiteit Heerlen)

Dit onderzoek was mede mogelijk door een projectsubsidie van de Nederlandse organisatie voor wetenschappelijk onderzoek (projectnummer 430-221-006). 
Voor Anja, Berend en Mathilde 



\section{Woord vooraf}

Voor $\mathrm{u}$ ligt de afsluiting van een levensfase die wat mij betreft iets te lang heeft geduurd. $\mathrm{Ik}$ geloof overigens dat er meer mensen zijn die deze mening zijn toegedaan. Het is een cliché maar daarom niet minder waar: zonder de ondersteuning en hulp van anderen zou dit bock er niet zijn gekomen.

In de eerste plaats ben ik Jan van Deth en Bob Lieshout, die aan de wieg van het projectvoorstel en dit onderzoek stonden, dank verschuldigd. Jan ben ik dankbaar voor zijn stimulansen en zijn gedetailleerde commentaar op mijn geschriften. Helaas hebben we het niet samen kunnen afmaken.

In de tweede plaats wil ik hier de vele universitaire collega's in Twente, Nijmegen en Maastricht noemen die ervoor gezorgd hebben dat ik altijd met veel plezier naar mijn werk ben gegaan. Een aantal van hen verdient het om hier met name te worden genoemd. In de eerste plaats mijn Twentse kamergenoten Peter Schuszler en Raymond Horstman; het golfen tussen de middag zal ik niet snel vergeten. Bij het terugdenken aan mijn Nijmeegse periode gaan mijn gedachten vooral uit naar Theo van de Weegen en Paul Beunk die altijd weer op zeer nauwgezette wijze orde wisten te scheppen in mijn "data". In het Maastrichtse heb ik vele leuke uren beleefd met Erik Driessen en Erik Knippenberg. Bij de daadwerkelijke afronding van het boek stonden beide Erikken op de meest ongebruikelijke tijden klaar om mij op te vangen en uit de brand te heipen. Dit zal ik nooit vergeten. Mijn Maastrichtse bazen Nico Roos en Huub Spoormans dank ik voor hun steun door de jaren heen.

Ook wil ik op deze plaats de leden van de beoordelingscommissie bedanken voor hun op- en aanmerkingen bij het manuscript.

Een bijzonder woord van dank moet uitgaan naar mijn promotor Amo Korsten. Zonder zijn niet aflatende aansporingen en controles was dit boek er niet gekomen. Amo was er altijd wanneer het nodig was. Ik ben jaloers geworden op zijn vermogen om dingen in het juiste perspectief te plaatsen en op zijn productiviteit. 
Tot slot een zeer speciaal woord van dank voor Anja. Het is met geen pen te beschrijven wat zij voor mij in de afgelopen jaren heeft betekend. Niets was haar teveel om mij uit de wind te houden in periodes dat dat nodig was. Ook dit zal ik nooit vergeten en ik zal de komende jaren proberen om de "rekening" te vereffenen. Aan haar en onze twee schatten van kinderen draag ik dit boek op.

Maastricht, mei 2001

Sef Janssen 


\section{Inhoudsopgave}

\section{Woord vooraf}

Inhoudsopgave

Tabellen

Figuren

Hoofdstuk 1 Doelstelling en onderzoeksvragen 1

1.1 Inleiding

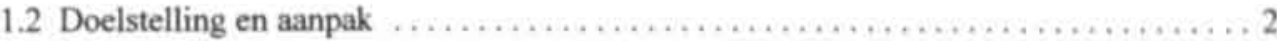

1.3 Onderzoeksvragen ....................................... 4

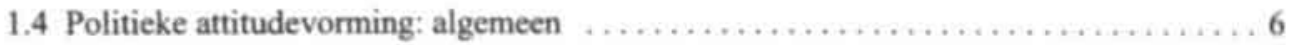

1.5 Houding ten aanzien van Europese eenwording: twee verklaringen $\ldots \ldots \ldots \ldots \ldots, 8$

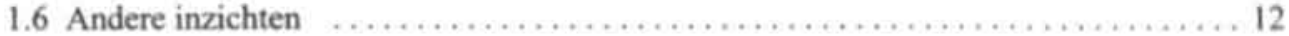

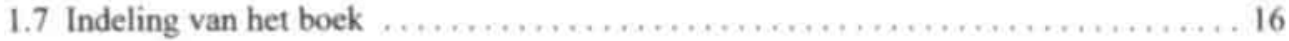

Hoofdstuk 2 West-Europese samenwerking: ontstaan en ontwikkeling 19

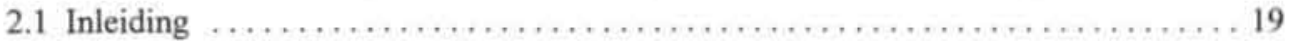

2.2 West-Europese samenwerking na WOII: internationaal-politieke achtergrond ....... 19

2.3 Ontstaan en ontwikkeling van de Europese Unie $\ldots \ldots \ldots \ldots \ldots \ldots \ldots \ldots \ldots \ldots .27$

1950-1952: Europese gemeenschap voor Kolen en Staal (EGKS) . ........... 27

Intermezzo: de militaire toekomst van West-Duitsland . . . . . . . . . . . . . . . 32

1955-1957: EEG en Euratom: een nieuwe start . . . . . . . . . . . . . . . . . . 32

Intermezzo: EU-instellingen (1957-1998) . .......................... 34

1958-1964: succesperiode ................................. 35

1965-1969: de ijstijd . ..................................... 36

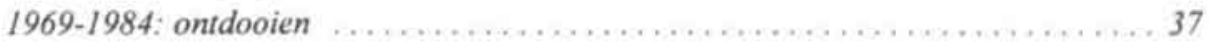

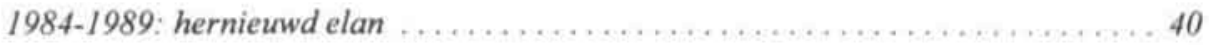

1989-1998: het einde van de Koude Oorlog .......................... 41

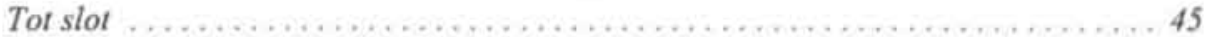

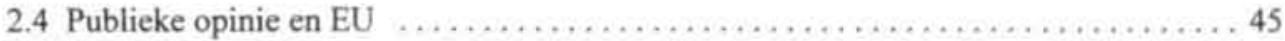

Elites of publiek? ...................................... 46

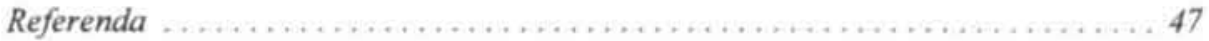

Directe verkiezingen voor het Europese Parlement .................... . . . . 49

Publieke invloed gering . . . . . . . . . . . . . . . . . . . . . . . . . . . 53 
Hoofdstuk 3 Eastons politieke-systeemtheorie: publieke steun en internationale politieke systemen

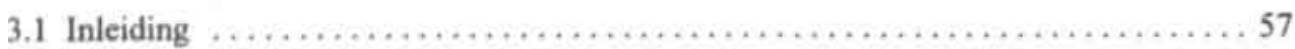

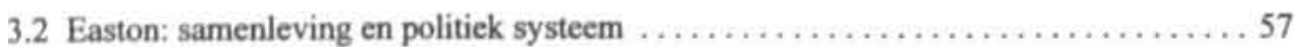

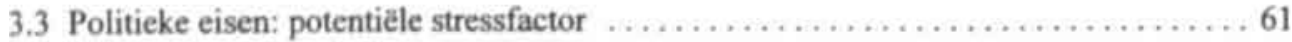

3.4 Politieke steun ....................................... 62

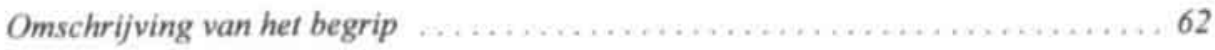

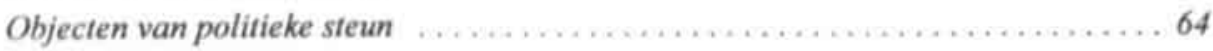

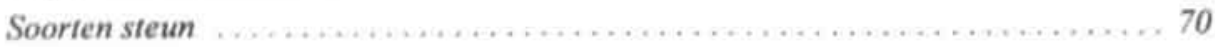

Typologie: combinatie van objectcategorieèn en soorten ................ 74

Empirische inzichten . ................................... 75

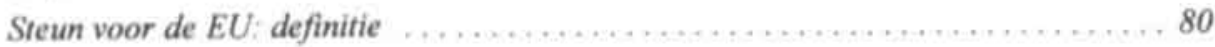

3.5 Publicke steun en internationale organisaties . . . . . . . . . . . . . . . . 81

Zijn internationale organisaties politieke systemen? . . . . . . . . . . . . . 82

Politieke steun en publieke steun . . . . . . . . . . . . . . . . . . . . . . . 84

3.6 EU: politiek systeem en publieke steun $\ldots \ldots \ldots \ldots \ldots \ldots \ldots \ldots \ldots \ldots \ldots . \ldots \ldots$

Hoe supranationaal is de $E U$ ? . . . . . . . . . . . . . . . . . . . . . . . . . 86

EU: politieke steun en publieke steun ........................ 90

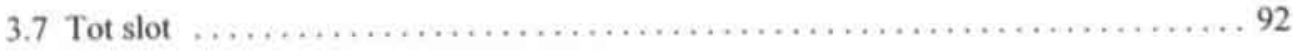

Hoofdstuk 4 Publieke opinie over de EU in 1994

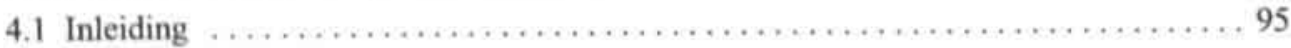

4.2 Steun voor de EU op individueel niveau: operationalisering $\ldots \ldots \ldots \ldots \ldots \ldots . . \ldots 6$

Karakterisering van de standaardvragen . . . . . . . . . . . . . . . . . . 97

4.3 Publieke opinie over de EU (1994): achtergronden . . . . . . . . . . . . . 101

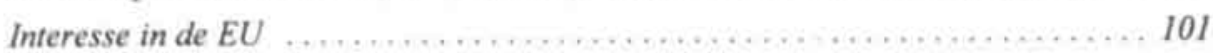

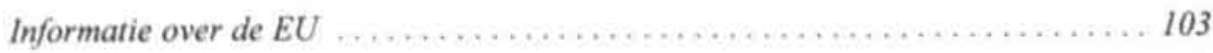

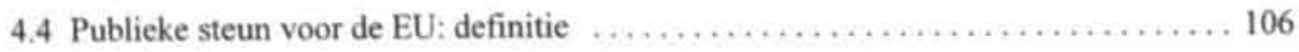

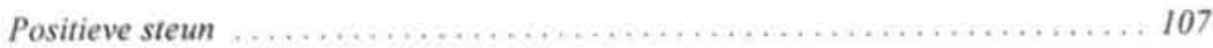

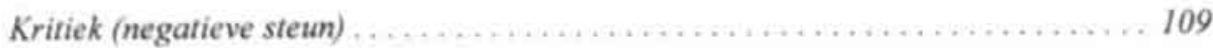

Publieke onverschilligheid ................................. 110

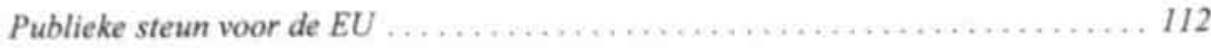

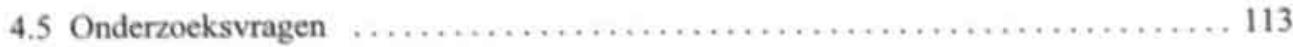

Appendix 4.1 Keuze van de indicatoren: eerdere inzichten en factoranalyse . . . . . . 115 


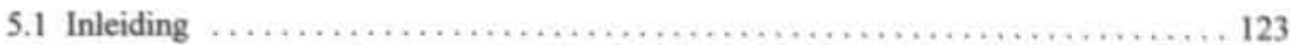

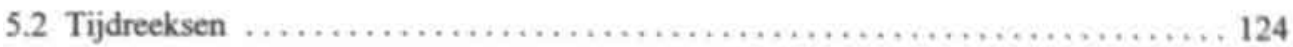

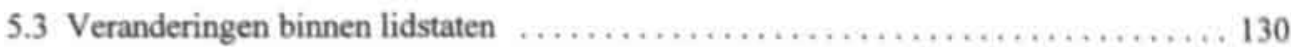

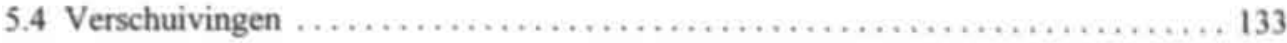

5.5 Veranderingen en verschuivingen: een kwalitatieve beschrijving $\ldots \ldots \ldots \ldots \ldots 135$

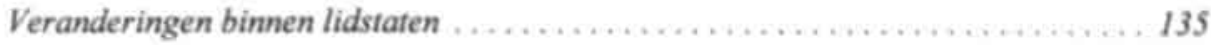

Verschuivingen tussen de lidstaten . .......................... 137

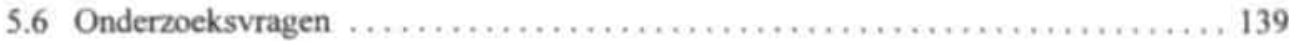

Hoofdstuk 6 Ingleharts Silent Revolution-theorie: hypothesen 141

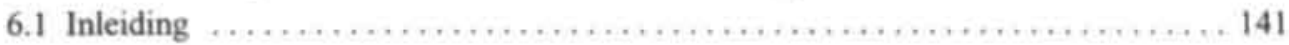

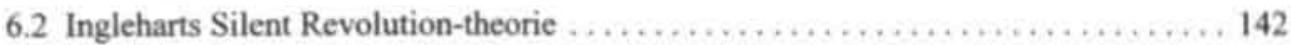

Eerste element: maatschappelijke omstandigheden (macro-setting) $\ldots \ldots \ldots \ldots \ldots, 142$

Eerste relatie: macro-setting gn micro-socialisatie . . . . . . . . . . . . . . . . .

Tweede element: waarde-oriëntaties en vaardigheden . ................ 147

Tweede relatie: invloed socialisatie op politieke denken en doen ............ 148

Derde element: politieke houdingen en politieke gedrag . . ............... 149

6.3 Postmaterialisme, cognitive mobilization en publieke steun voor de EU . . . . . . 152

6.4 Hypothesen: micro-, meso- en macro-niveau $\ldots \ldots \ldots \ldots \ldots \ldots \ldots \ldots \ldots \ldots \ldots \ldots \ldots \ldots \ldots \ldots \ldots \ldots \ldots$

Hoofdstuk 7 Zallers RAS-model: hypothesen $\quad 157$

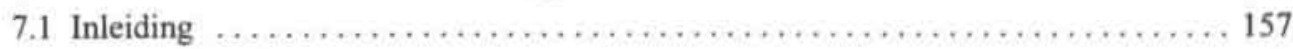

7.2 Politieke houdingen: over instabiliteit en andere beperkingen $\ldots \ldots \ldots \ldots \ldots \ldots . \ldots \ldots$

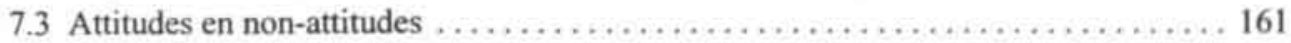

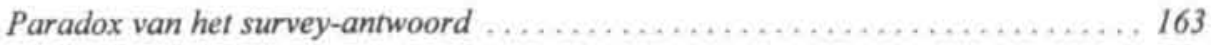

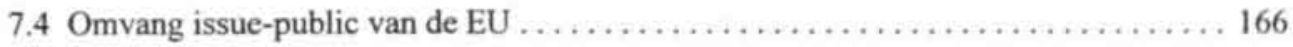

7.5 Verklaring van non-attitudes: Converse en Markus wijzen de weg . . . . . . . 169

Non-attitudes: niet random ............................. 170

Non-attitudes: Wat dan wel? . . . . . . . . . . . . . . . . . . . . . 172

7.6 Zallers RAS-model: een theorie van het survey-antwoord ................ 172

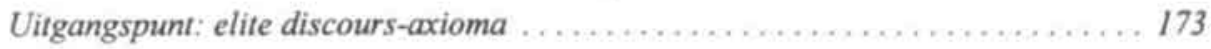

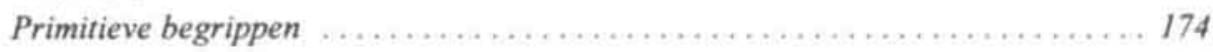

Expliciete axioma's ......................................... 175

7.7 Hypothesen: RAS-model en de publieke opinie over de EU . ............... 177 
8.1 Inleiding

8.2 Individueel niveau: postmaterialisme- en politieke vaardighedenhypothese 183

Postmaterialisme-hypothese ................................ 184

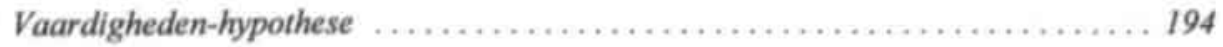

Onafhankelijkheid postmaterialisme en politieke vaardigheden? ........... 198

8.3 Meso-niveau: opeenvolgende generaties als dragers van de verandering . . . . . . . 201

Jong versus oud pooled dataset ............................... 204

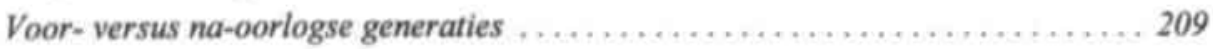

8.4 Macro-niveau: politieke waardenklimaat en cognitive mobilization $\ldots \ldots \ldots \ldots .211$

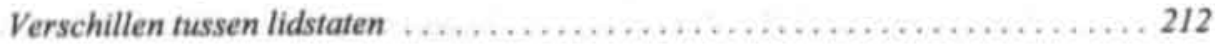

Veranderingen binnen de lidstaten . .......................... 213

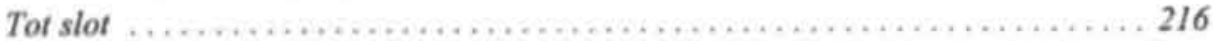

8.5 Ingleharts Silent Revolution: eindoordeel ........................ 216

Hoofdstuk 9 Zallers RAS-model: empirische toetsing 219

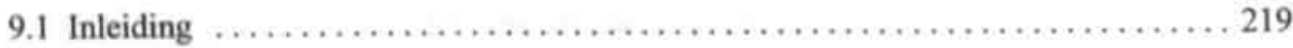

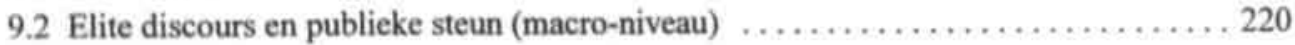

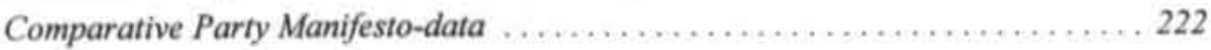

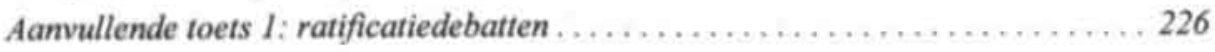

Aanvullende toets 2: de Engelse casus, 1972-1979 ................. 230

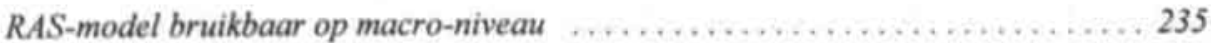

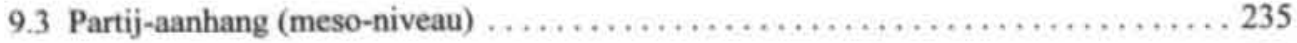

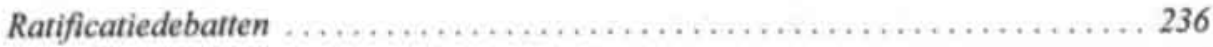

Partij-aanhang en de stemming binnen het elite discours .............. 241

De vergeten groep: partijlozen . . . . . . . . . . . . . . . . . . . . . . 244

Aamvullende toets: de Britse gegevens van Dalton en Daval .............. 246

Conclusie ................................................... 247

9.4 Partij-identificatie en het elite discours (micro-niveau) $\ldots \ldots \ldots \ldots \ldots \ldots \ldots \ldots \ldots \ldots \ldots \ldots \ldots$

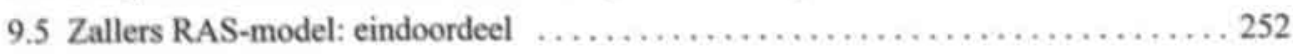


Hoofdstuk 10 Conclusies 255

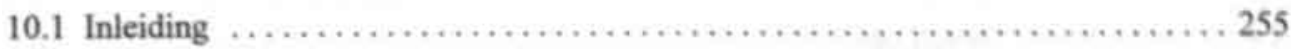

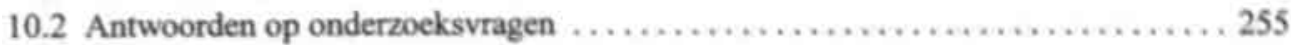

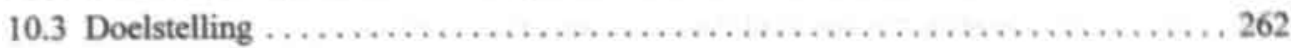

10.4 Publieke opinie en internationale politieke systemen $\ldots \ldots \ldots \ldots \ldots \ldots \ldots \ldots .265$

Appendix A: Overzicht databestanden met aantal cases per land 268

$\begin{array}{lll}\text { Literatuurlijst } & 271\end{array}$

$\begin{array}{ll}\text { Curriculum Vitae } & 281\end{array}$

Summary 283 


\section{Tabellen}

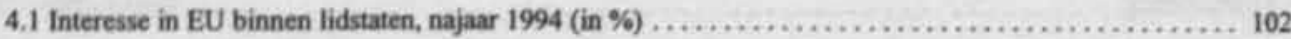

4.2 Algemene politieke interesse en interesse in Europese politiek binnen lidstaten, najaar $1994 \ldots \ldots . \ldots 103$

4.3 Gevoel hebben geinformeerd te zijn over de EU binnen lidstaten, najaar 1994 (in \%) . . . . . . . . . 104

4.4 Kennis van EU bij gevoel hebben geinformeerd te zijn over EU binnen lidstaten, najaar 1994 ....... 105

4.5 Positieve steun (in \%) voor EU binnen lidstaten (rangorde-correlaties tussen indicatoren),

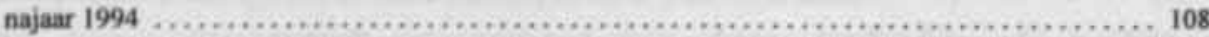

$4.6 \mathrm{Kritiek}$ (in \%) op EU binnen lidstaten (rangorde-correlaties tussen indicatoren), najaar $1994 \ldots \ldots . . .110$

4.7 Onverschilligheid (in \%) over EU binnen lidstaten (rangorde-correlaties tussen indicatoren), najaar 1994

4.8 Publieke steun (in \%) voor EU binnen lidstaten (rangorde-correlaties tussen indicatoren).

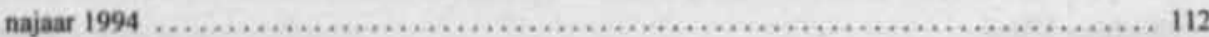

5.1 Publicke steun voor EU (in \%) binnen lidstaten op basis van unif-indicator, 1952-1995 ......... 128

5.2 Publicke steun voor EU (in \%) binnen lidstaten op basis van mem-indicator, 1973-1998 . . . . . . 129

5.3 Publieke steun voor EU (in $\%$ ) binnen lidstaten op basis van scrap-indicator, 1973-1995 . . . . . . . . 130

5.4 Extreme scores en veranderingen in tijdreeksen (unif, mem, scrap) per lidstaat (in \%) ........... 131

5.5 Trends in nationale tijdreeksen publicke steun voor de EU per lidstaat (mem, unif) . . . . . . . . . 133

5.6 Stabiliteit rangorde van lidstaten naar steun voor de EU, 1956-1998 (rangorde-correlaties) . . . ..... 134

8.1 Steun voor de EU bij postmaterialisme binnen pooled dataset, 1970-1994 . . . . . . . . . . . . 186

8.2 Steun voor de EU bij postmaterialisme binnen lidstaten, $1970-1994 \ldots \ldots \ldots \ldots \ldots \ldots \ldots \ldots \ldots . \ldots \ldots$

8.4 Steun voor de EU bij postmaterialisme (12-iteminstrument) in de lidstaten: 1973 en $1988 \ldots \ldots \ldots \ldots 191$

8.5 Steun voor de EU bij postmaterialisme onder constanthouding van links-rechts zelfplaatsing

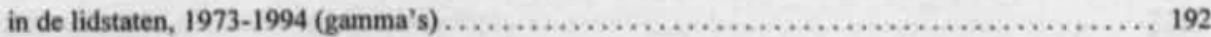

8.6 Steun voor de EU bij niveau van politieke vaardigheden in pooled dataset, 1973-1998 ... . . . . . . . 196

8.7 Steun voor de EU bij niveau van politieke vaardigheden in de lidstaten, 1973-1998 . . . . . . . . . . 197

8.8 Steun voor de EU bij politicke vaardigheden in de lidstaten: $1970-9,1980-91990-5 / 8 \ldots \ldots \ldots \ldots 198$

8.9 Steun voor de EU bij postmaterialisme bij politicke vaardigheden in de lidstaten, 1973-1994 ......200

8.10 Rangorde-correlaties tussen generaties (jong naar oud) en steun voor de EU binnen

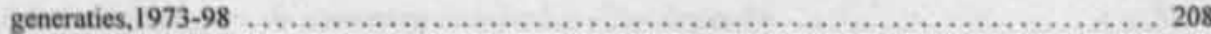

8.11 Verschil in steun voor EU tussen voor- $(<1930)$ en na-oorlogse generatie $(>1945)$ binnen

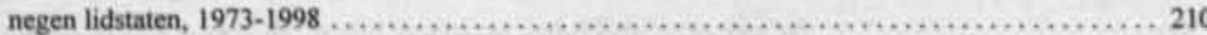

8.12 Publieke steun voor de EU bij waardenklimaat en cognitive mobilization op het niveau

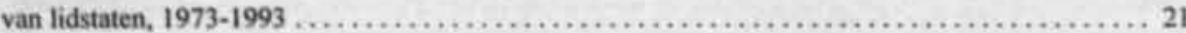

8.14 Veranderingen publieke steun voor de EU bij veranderingen waardenklimaat (12-item-

instrument) en veranderingen niveau van politieke vaardigheden, 1973-1988 $\ldots \ldots \ldots \ldots \ldots \ldots 216$

9.1 Publicke steun bij stemming in elite discours over EU in lidstaten (1951-1988), overzicht cases . . . . 227

9.3 Publicke steun bij stemming in elite discours (ratificaties) in twaalf lidstaten (1951-1992).

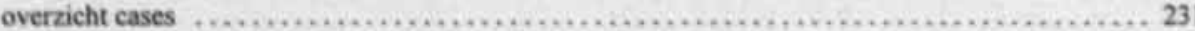

9.2 Britse publieke steun voor de EU en stemming binnen Brits elite discours

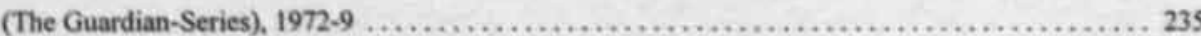

9.5 Steun voor EU onder partij-aanhang bij partijstandpunt, per lidstaat en soort verdrag ........... 241

9.6 Steun onder partij-aanhang bij partijstandpunt en stemming nationale elite discours . . . . . . . . . 244 
9.7 Steun bij stemming nationale elite discours onder partijlozen en partijaanhang

9.8 Steun onder aanhang Labour en Conservatives bij partijstandpunt (The Guardian), 1973-1979

9.9 Steun (unif-mem) bij partijstandpunt bij partij-identificatie, individueel niveau (1986 en 1992)

10.1 Extreme scores en veranderingen in tijdreeksen (unif, mem, scrap) per lidstaat (in \%) 


\section{Figuren}

8.1.Publieke steun voor de EU (unif) in drie generaties (gewogen gegevens, pooled dataset) . . . . . . . 206

8.2 Publieke steun voor EU (mem) in dric generaties (gewogen gegevens, pooled dataset) . . . . . . . . . 207

9.1 Publieke steun voor de EU bij stemming in elite discours over EU in negen lidstaten (1951-1988) . ... 227

9.2 Publieke steun voor de EU bij stemming elite discours (ratificaties) lidstaten (1951-1992) . . . . . . . . 231 


\section{Doelstelling en onderzoeksvragen}

\subsection{Inleiding}

Nationale referenda spelen een opmerkelijke rol in de recente geschiedenis van de Europese Unie (EU). In meer dan de helft van de huidige vijftien lidstaten is het nationale lidmaatschap van de EU onderwerp van een referendum geweest. Daarnaast spelen nationale referenda steeds nadrukkelijker een beslissende rol bij de ratificatie van verdragen in EU-verband zoals bij de Europese Akte (1986/7) en het Verdrag van Maastricht (1992/3). De meest in het oog springende voorbeelden zijn uiteraard de gevallen waarin een nationaal referendum een andere uitkomst oplevert dan door de nationale regering gewenst is. Zo is het Noors EU-lidmaatschap inmiddels tot tweemaal toe afgeketst op een referendum en gaf het referendum bij de Deense ratificatie van de Europese Akte uiteindelijk de doorslag nadat het Deense parlement in meerderheid tegen de Akte had gestemd. Het bekendste voorbeeld is zonder meer het Deense Nej tegen het Verdrag van Maastricht (EU-verdrag) dat in 1992 een lichte shock en crisis veroorzaakte binnen de EU. Dit maakte het uiteindelijk noodzakelijk dat de lidstaten op Deens verzoek de betekenis van het EU-verdrag nader aanscherpte middels de zogenaamde Edinburgh Agreement opdat het verdrag in tweede instantie (1993) wel de goedkeuring van het Deense volk zou kunnen wegdragen. Die opzet slaagde. Deze voorbeelden illustreren op niet mis te verstane wijze dat de publieke opinie tegenwoordig nadrukkelijk een rol speelt in het (West-)Europese integratieproces (vgl. Sinnott, 1995; Gabel, 1998: 114). Tegen die achtergrond zal in dit onderzoek worden nagegaan hoe de publieke steun voor de EU in een twaalftal EU-lidstaten zich in de periode van 1952 tot en met 1998 heeft ontwikkeld, alsmede zal een poging worden ondernomen er achter te komen wat de publieke steun voor de EU in de onderzochte lidstaten drijft.'

\footnotetext{
' Het gebruik van de term Europese Unie is in het licht van de onderzoeksperiode tot op zekere hoogte misplaatst omdat deze aanduiding voor de samenwerking in het kader van de Europese Gemeenschappen (EG) pas in het begin van de jaren negentig in zwang is geraakt toen die gemeenschappen op het punt stonden op te gaan in een meeromvattende Europese Unie. Omwille van de leesbaarheid is er echter voor gekozen om de aanduidingen EG en EU niet door of voortdurend naast elkaar te gebruiken, maar in aansluiting op het hedendaags taalgebruik enkel te spreken over de Europese Unie (EU). Alleen in hoofdstuk 2 over de geschiedenis van de EU zal gewerkt worden met de historisch gezien juiste aanduidingen in de verschillende stadia van het integratieproces.
} 
Dit eerste hoofdstuk vormt een eerste inleiding op het onderzoek. Allereerst zal aandacht worden besteed aan de doelstelling (paragraaf 1.2) en onderzoeksvragen (paragraaf 1.3); dit wil zeggen, het "waarom" respectievelijk "hoe" van dit onderzoek. Bij de behandeling van de doelstelling en onderzoeksvragen zal tevens worden stilgestaan bij de globale onderzoeksopzet en beschikbare data. In paragraaf 1.4 zullen zes algemene theoretische aanzetten ter verklaring van politieke attituden en publieke-opinievorming de revue passeren. In paragraaf 1.5 zal vervolgens kort worden ingegaan op de twee specifieke theoretische verklaringen die in dit boek centraal staan. Daarbij zal worden aangegeven in welke mate de twee specifieke verklaringen de in paragraaf 1.4 beschreven algemene theoretische aanzetten afdekken. In paragraaf 1.6 wordt ingegaan op de vraag in hoeverre de algemene aanzetten die niet door de specifieke verklaringen worden afgedekt niettemin bruikbaar zijn in het licht van de hier gekozen onderzoeksdoelstelling. Dit inleidend hoofdstuk wordt afgesloten met een toelichting op de verdere indeling van dit boek (paragraaf 1.7).

\subsection{Doelstelling en aanpak}

De reden voor deze studie ligt slechts ten dele in de toenemende invloed van en groeiende aandacht voor de rol van de publieke opinie in het integratieproces waar in de inleiding op is gewezen. De interesse in het onderwerp werd destijds bij de start van dit onderzoek primair gewekt door de constateringen van met name Inglehart (1967; 1970a,b; 1971; 1977a,b) dat de publieke steun voor de EU zonder direct aanwijsbare oorzaak in de ene lidstaat veel groter was dan in de andere lidstaat en de nieuwsgierigheid naar de empirische houdbaarheid van Ingleharts verklaring voor die verschillen. Doelstelling van dit onderzoek en de daarbij behorende onderzoeksvragen moeten vooral tegen deze achtergrond worden geplaatst. De centrale doelstelling van dit onderzoek luidt: het vergroten van het inzicht in de oorzaken van veranderingen in de publieke steun voor de EU binnen lidstaten, en de oorzaken van verschillen in de publieke steun voor de EU tussen lidstaten. Dit betekent concreet, dat we op zoek zijn naar een verklaring voor het feit dat Denen veel kritischer zijn ten aanzien van de EU dan Nederlanders, alsmede waarom de steun voor de EU in Griekenland groeit terwijl die in Duitsland afneemt.

Het bij deze doelstelling passende onderzoeksdesign is zowel longitudinaal, als landenvergelijkend van karakter. De hoop bestaat dat met een dergelijk design een originele bijdrage kan worden geleverd aan het inzicht in de processen die een rol spelen bij publiekeopinievorming ten aanzien van de EU en andere politieke issues. Er zal nadrukkelijk aansluiting 
worden gezocht bij bestaand onderzoek op dit terrein. ${ }^{2}$

Steun voor politieke systemen kan op verschillende niveaus worden onderzocht. Hierbij kan een grof onderscheid worden gemaakt tussen onderzoeken waarbij steun als individueel kenmerk (houding, gedraging, enzovoort) centraal staat, en onderzoeken waarin het begrip steun verwijst naar het kenmerk van een collectief (legitimiteit, draagvlak, enzovoort). Dit onderzoek gaat primair over het verklaren van verschillen en veranderingen in de publieke steun voor de EU op het niveau van lidstaten en past in de laatste categorie.

De mate van steun op collectief niveau is echter onlosmakelijk verbonden met steun op individueel niveau. De mate van publieke steun voor de EU is een functie van de houdingen van de burgers; om die reden wordt ook wel gesproken van steun op geaggregeerd niveau. Dit betekent echter niet dat als men in staat zou zijn om de attitudevorming op individueel niveau te doorgronden, men daarmee tegelijkertijd ook de sleutel tot de verklaring van de dynamiek van de publieke opinie op collectief (geaggregeerd) niveau in handen heeft. Wel kan het leiden tot een beter inzicht in de achtergronden van de publieke steun op lidstaatniveau. Bij een onderzoeksaanpak die zich enkel op het geaggregeerd niveau (lidstaten) richt zal het daadwerkelijke inzicht in de processen en achtergronden van de publieke opinie beperkt blijven. Een voorbeeld moge dit verduidelijken. Er zijn diverse mechanismen (op individueel niveau) denkbaar die ten grondslag kunnen liggen aan een positieve relatie tussen de lengte van het EU-lidmaatschap en de hoogte van de publieke steun voor de EU op lidstaatniveau (Inglehart, 1977a: 329-30; 1977b: 155; Inglehart en Rabier, 1978: 78). Een eerste verklaring is dat de acceptatie van een nieuw politiek systeem een kwestie van tijd is. Een tweede verklaring kan liggen in het feit dat de belangen van (de burgers van) lidstaten van het eerste uur meer gediend zijn met samenwerking dan de belangen van (de burgers van de) lidstaten die later toetreden. Een dergelijk verband kan ook het gevolg zijn van andere factoren, toeval of een combinatie van de genoemde factoren. Hoewel het aantonen van de (on)juistheid van een aantal van deze interpretaties met een relatief grote nauwkeurigheid mogelijk is door analyses op geaggregeerd niveau, kunnen alleen analyses op individueel niveau daadwerkelijk uitkomst bieden. Zonder analyses op individueel niveau blijft het gevaar van een aggregative fallacy (Swanborn, 1984: 186; Riley, 1963: 703-9) - het ten onrechte vertalen van verbanden gevonden op het geaggregeerd niveau, naar oorzakelijke relaties op individueel niveau - levensgroot aanwezig. Om dit probleem te ondervangen en tevens optimaal te profiteren van de voor handen zijnde gegevens op individueel niveau, is in dit onderzoek gekozen voor een combinatie van analyses op individueel én geaggregeerd niveau.

${ }^{2}$ Inglehart, 1967; 1970a; 1970b; 1977; 1977b; 1990; Puchala, 1970; Shepherd, 1975: 201-23; Inglehart en Rabier, 1978; Inglehart, Rabier en Reif, 1987; Dalton en Eichenberg, 1990; 1993; Wessels, 1995a; 1995b; Gabel en Palmer, 1995; Saris, 1997; Gabel, 1998; 1998 a. 


\subsection{Onderzoeksvragen}

Met het oog op de doelstelling worden antwoorden gezocht op zes verschillende onderzoeksvragen. In alle vragen is het begrip steun gebruikt, de betekenis van dit begrip moet zo worden gelezen dat we zowel geïnteresseerd zijn in positieve steun, als in negatieve steun voor (kritiek op) de EU.

De eerste vier vragen hebben betrekking op de ontwikkeling van de publieke steun over de EU in de loop der tijd, te weten:

\section{Hoe groot is de publieke steun voor de EU in de lidstaten?}

2. Hoe groot zijn de verschillen in de publieke steun voor de EU tussen de lidstaten?

3. Treden er veranderingen op in de publieke steun voor de EU binnen de lidstaten?

4. Zijn de verschillen in publieke steun voor de EU tussen de lidstaten stabiel?

Aan de hand van de antwoorden op deze vier vragen moet duidelijk worden hoe groot de te verklaren variantie in de publieke steun voor de EU binnen en tussen de lidstaten is. In het kader van de laatste twee onderzoeksvragen wordt op zoek gegaan naar een verklaring voor deze variantic. Deze vragen sluiten direct aan bij de doelstelling waarin de zoektocht naar een verklaring voor verschillen en veranderingen in de publieke steun voor de EU binnen en tussen de lidstaten centraal staat, namelijk:

5. Welke factoren kunnen de individuele houding van burgers ten aanzien van de $E U$ verklaren?

6. Welke factoren kunnen de mate van publieke steun voor de EU in een land verklaren?

Bij de beantwoording van deze laatste twee vragen staan twee theoretische modellen centraal, te weten: Ingleharts Silent Revolution-theorie en Zallers RAS-model. Deze modellen vormen de theoretische ankers van deze studie en worden uitgewerkt en getoetst in de hoofdstukken 6 tot en met 9. De beantwoording van de eerste vier onderzoeksvragen staat centraal in hoofdstuk 4 en 5 . In het slothoofdstuk zullen de onderzoeksvragen expliciet worden beantwoord.

Voor de beantwoording van de onderzoeksvragen zal gebruik worden gemaakt van een gecombineerde longitudinale en cross-sectionele onderzoeksopzet. Mede gelet op de beperkte tijd en middelen kan daarbij geen gebruik worden gemaakt van zelf verzameld materiaal, maar zijn we aangewezen op bestaand survey-materiaal. De gegevens die worden gebruikt stammen uit de periode 1952-1998 en hebben betrekking op de publieke opinie in de twaalf oudste EUlidstaten, te weten: Frankrijk, Belgiê, Nederland, West-Duitsland, Italiē, Luxemburg, Denemarken, Ierland, Groot-Brittaniē (Verenigd Koninkrijk exclusief Noord-Ierland), Griekenland, Portugal en Spanje. Alle survey-gegevens die in dit onderzoek worden gebruikt zijn verzameld door middel van mondelinge interviews met gestructureerde vragenlijsten bij de 
respondenten thuis.

De belangrijkste bron van gegevens vormen de door de Europese Commissie opgezette, georganiseerde en betaalde Eurobarometer-reeks (1970-1998). Dit zijn grootschalige surveyonderzoeken waarmee de Commissie een beeld probeert te krijgen van "... social and political attitudes of the publics in the European Community member nations [....]. Of primary concern are public awareness of. and attitudes toward the Common Market and other European Community institutions and policies" (ICPSR 1989: 1). Onderzoeken uit deze reeks zijn uitgevoerd in 1970, 1971 en 1973 (European Community Studies) en vinden sinds 1975 halfjaarlijks plaats (Eurobarometers); in de jaren negentig is het aantal bruikbare Eurobarometers per jaar soms zelfs groter dan twee. Met de toetreding van nieuwe landen tot de EU is ook het aantal landen waarin deze onderzoeken plaats vinden gestegen van zes in de jaren zeventig naar vijftien in 1998. De Eurobarometer-studies vormen de belangrijkste bron van informatie over de publieke opinie aangaande de EU.

De tweede bron van informatie vormen de studies uit de USLA XX-series. De interviews voor deze studies zijn uitgevoerd in de periode tussen 1952 en 1967 in opdracht van de United States Intelligence Agency (USIA). Onregelmatig verspreid door de tijd zijn in total achttien XXstudies uitgezet door de USIA in West-Europa. De XX-studies zijn vooral uitgevoerd in WestDuitsland, Frankrijk, Groot-Brittannië en Italiē. Daarenboven is er een Deense (1955), een Nederlandse (1956) en een Belgische (1956) XX-studie beschikbaar. Helaas is een gedeelte van de datasets in de loop der tijd verloren gegaan en bevat niet elke XX-studie vragen over de EU of Europese eenwording. Desondanks vormen de gegevens uit deze oude datasets een welkome aanvulling op de "jongere" Eurobarometer-data.

Verder zal nog gebruik worden gemaakt van het Common Market Studies-onderzoek uit 1962 (CMS62) dat destijds is uitgevoerd in vijf van de zes lidstaten (Luxemburg niet). Dit onderzoek bevat net zoals de Eurobarometers primair vragen over de EU en Europese eenwording. Deze studie maakt het mogelijk om ook enig inzicht te krijgen in de publieke steun vóór 1970 in Belgię en Nederland, twee lidstaten die in bijna geen enkele USIA XX-studie zijn meegenomen.

Een belangrijk probleem bij het gebruik van bestaand materiaal is de operationalisering van de onafhankelijke variabelen. Alle bestanden die gebruikt worden bevatten namelijk wel indicatoren om steun voor de EU of Europese eenwording op de een of andere manier te meten, maar ze bevatten lang niet allemaal indicatoren voor de meting van de predictors. Dit betekent dat bij de toetsing van diverse hypothesen gebruik zal worden gemaakt van een beperkt en voortdurend wisselend aantal datasets. 


\subsection{Politieke attitudevorming: algemeen}

Het verklaringsmechanisme voor de ontwikkeling van de publieke steun voor de EU in de lidstaten ligt uiteindelijk (ook) op individueel niveau, hoewel de invloed van de context en/of omgeving de relaties op individueel niveau kunnen doorkruisen. Het is dus logisch dat bij de zoektocht naar een geschikte verklaring aansluiting zal worden gezocht bij de bestaande literatuur over politieke attitudevorming. Kinder en Sears hebben de belangrijkste stromingen op dit terrein geschetst in hun overzichtsartikel Public Opinion and Political Action (1985). Ondanks het feit dat hun overzicht vooral gebaseerd is op na-oorlogs Amerikaans onderzoek naar kiesgedrag biedt het een nuttig uitgangspunt voor de speurtocht naar de wortels van politieke houdingen van WestEuropese burgers ten aanzien van de EU. Alleen bij het generaliseren van de belangrijkste Amerikaanse resultaten naar de West-Europese situatie is voorzichtigheid geboden gelet op de toch niet onaanzienlijke verschillen in de politieke cultuur en staatsinrichting.

Kinder en Sears onderscheiden zes beproefde visies op de vorming van politieke attituden. Uitgangspunt van hun verhaal is Converse's claim van ideological innocence. In het politieke denken over, en bij vorming van politieke houdingen ten aanzien van diverse politieke issues blijken burgers zich niet of nauwelijks te baseren op abstracte ideologieën (zie paragraaf 7.2 en 7.3). Ondanks het feit dat op Converse's werk de nodige kritiek geuit is, concluderen Kinder en Sears:

"That the original claim of ideological innocence is largely sustained"; maar voegen zij er aan toe:

"this does not mean that the American mind is empty of politics" (Kinder en Sears, 1985: 670)

Als politieke houdingen niet zijn ingegeven door ideologieën, waardoor dan wel? Het is deze vraag die Kinder en Sears zichzelf stellen bij het samenstellen van hun overzicht. Zij destilleren zes abstracte factoren (mechanismen) uit de Amerikaanse literatuur. De eerste vijf factoren zijn gebaseerd op het idee dat mensen hun houdingen ten aanzien van specifieke politieke issues of objecten afleiden van meer algemene disposities, de zesde en laatste factor is van een geheel andere orde. De factoren zijn:

1. Eigenbelang (Kinder en Sears, 1985: 671-2).

Concrete politieke houdingen zijn in deze optiek het best te begrijpen door ze te beschouwen als uitingen van wijdverspreid egoǐsme. Hoewel voor de hand liggend is de conclusie uit Amerikaans onderzoek dat deze factor nauwelijks een rol speelt bij de vorming van politieke houdingen. 
2. Lidmaatschap van of identificatie met bepaalde groepen (Kinder en Sears, 1985: 672-4). Het idee is dat mensen politieke issues en objecten in hun hoofd relateren aan belangen en/of voorkeuren van bepaalde groepen. Afhankelijk van de sympathieên en antipathieèn die een persoon koestert ten aanzien van de groepen die bij een bepaald issue in het geding zijn, ontstaat een positieve respectievelijk negatieve politieke houding. Kinder en Sears noemen de identificatie met groepen ingedeeld naar sociaal-economische status, ras, politieke voorkeur, sekse en religie als voorbeelden van in de Amerikaanse politiek relevante referentiegroepen. In deze visies zijn politieke houdingen aan te merken als een soort sociale badges. Aan iemands politieke houdingen zou men kunnen aflezen met welke groep(en) iemand zich identificeert.

\section{Leadership (Kinder en Sears, 1985: 674).}

In de Amerikaanse politiek blijkt de handel en wandel van de Amerikaanse president onder omstandigheden een enorm sterke invloed uit te oefenen op de houdingen van burgers. De redenering luidt meer algemeen dat politieke leiders zoals staatshoofden, regeringsleiders of partijleiders posities bekleden die hen in staat stellen om de publieke opinie te manipuleren. In eerste instantie zal de invloed van een leider zich beperken tot diegenen die het gezag van de leider erkennen. De invloed van leiders is groter naarmate ze geacht worden boven de partijen te staan. In geval dat een politieke leider bovenal wordt beschouwd als de leider van een specifieke politieke stroming of partij zal zijn invloed waarschijnlijk beperkt blijven tot zijn eigen achterban en mogelijk zelfs tegenreacties oproepen onder de aanhang van de oppositie. Het antwoord op de vraag of leiders door het publiek in de eerste plaats als nationaal leider worden gezien en pas in de tweede plaats als leider van een bepaalde politieke partij of stroming, hangt mede af van de persoon, de politieke constitutie, de omstandigheden en het issue.

4. Waarden (values) (Kinder en Sears, 1985:674-6).

De vierde groep factoren die volgens Kinder en Sears in de literatuur wordt genoemd als bron van concrete politieke houdingen zijn waarden. Issues, partijen en andere politieke objecten worden ondersteund in zoverre als zij bijdragen tot het bereiken van bepaalde politieke waarden. De Amerikaanse bevolking zou zich in hun politieke denken en doen met name laten leiden door de waarden individualisme en gelijkheid (egalitarianism). Waarden moeten echter niet worden opgevat als allesomvattende coherente ideologieèn, maar veeleer als richtlijnen die het denken van het publiek op sommige punten ijken.

\section{Persoonlijkheid (Kinder en Sears, 1985: 676-7).}

Als vijfde in de rij van algemene disposities die het politieke denken en doen van burgers in specifieke situaties beïnvloeden, wijzen Kinder en Sears op de factor persoonlijkheid. Zij wijzen erop dat in de literatuur nogal wat aanwijzingen bestaan dat politieke houdingen sterk 
samenhangen met persoonlijkheidskenmerken. Kinder en Sears merken op dat het hierbij gaat om in depth psychology.

\section{History or the unfolding of events (Kinder en Sears, 1985: 677-82).}

Deze factor is in tegenstelling tot de eerste vijf factoren niet gebaseerd op het idee dat de houding ten aanzien van concrete issues zijn afgeleid van meer algemene disposities. Bij deze factor wordt de verklaring voor (veranderingen in) politieke houdingen gezocht in de (veranderingen in) sociaal-economische of maatschappelijke omstandigheden (history) of concrete gebeurtenissen, the unfolding of events, die direct of indirect de houdingen ten aanzien van concrete politieke issues beīnvloeden. Daarbij kan een onderscheid worden aangebracht tussen events die de publieke opinie op de korte termijn beïnvloeden, en events die de publicke opinie op de lange termijn beïnvloeden. Bij de eerste categorie factoren moet vooral worden gedacht aan zaken als verkiezingscampagnes, een politicke crisis of een plotselinge ramp. Dit soort factoren heeft vaak een bijzonder grote en directe invloed op de publieke opinie over bepaalde politieke issues. Als voorbeeld van een event (history) waarvan verwacht mag worden dat het de publieke opinie op de lange termijn beïnvloedt, wijzen Kinder en Sears op de stelselmatige verbetering en uitbreiding van onderwijsvoorzieningen in de loop der tijd. Dit event draagt bij tot een langzame maar gestage stijging van het gemiddelde opleidingsniveau van het Amerikaanse publiek en de verwachting is dat dit ingrijpende consequenties heeft voor de politieke opvattingen en gedragingen van Amerikaanse kiezers. Men kan zich bij de invloed van dit soort lange termijn events overigens de vraag stellen of dit soort events niet in eerste instantie van invloed zijn op de algemene politieke disposities (participatiebereidheid, ideologisch denken) en pas in tweede instantie op houdingen ten aanzien van specifieke issues.

De samenvatting van Kinder en Sears geeft een relatief algemeen overzicht van mogelijk bruikbare verklaringen voor de houding ten aanzien van politieke issues in het algemeen en de houdingen ten aanzien van de EU in het bijzonder. In de volgende paragraaf worden de twee specifieke verklaringen die in dit onderzoek naar de achtergrond van publieke steun voor de EU centraal staan, geintroduceerd.

\subsection{Houding ten aanzien van Europese eenwording: twee verklaringen}

In dit boek worden uiteindelijk twee verschillende verklaringen uitgewerkt en empirisch getoetst. Op beide benaderingen volgt hieronder een korte introductie waarbij zal worden aangeven in hoeverre ze aansluiten op de door Kinder en Sears onderscheiden algemene benaderingen. 
De in de literatuur over de publieke steun voor de EU meest geciteerde verklaring is zonder twijfel Ingleharts Silent Revolution-theorie (Inglehart, 1977a; 1990; 1997). Van Deth stelt terecht dat de kern van deze theorie wordt gevormd door een eenvoudig schema met drie elementen en twee relaties (1984: 6-8). Het eerste element betreft de maatschappelijke omstandigheden in een bepaald gebied; het tweede de politieke vaardigheden en politieke waarden die individuen voornamelijk op jonge leeftijd ontwikkelen respectievelijk vormen; en het derde element vormt het politieke denken en handelen van individuen. De eerste relatie heeft betrekking op de blijvende invloed die maatschappelijke omstandigheden hebben op de inhoud van politieke waarde-oriëntaties en het niveau van politieke vaardigheden van opgroeiende jongeren. De uitkomst van de politieke socialisatie in de jeugdjaren is afhankelijk van de maatschappelijke omstandigheden waaronder iemand opgroeit. De tweede relatie gaat over de invloed van iemands niveau van politieke vaardigheden en de inhoud van iemands politieke waarde-oriëntaties op zijn politieke houdingen en gedragingen.

Op zichzelf is zo'n schema niet origineel. Wel origineel is Ingleharts (1977a) concrete invulling van tijd en plaats. Hij stelt dat onder invloed van technologische en economische ontwikkelingen een beperkt aantal hooggeïndustrialiseerde landen al vrij snel na WOII qua maatschappelijke omstandigheden en dientengevolge ook ten aanzien van de uitkomsten van de politieke socialisatie van jonge generaties over de drempel van een nieuw tijdperk stapt. WOII markeert in Ingleharts visie een waterscheiding in termen van welvaart, rust, onderwijs, mobiliteit en massamedia in West-Europa, Japan en Noord-Amerika. De na-oorlogse omstandigheden wijken op deze punten zodanig af van de voor-oorlogse omstandigheden dat de inhoud van de politieke waarde-oriëntaties en het niveau van politieke vaardigheden van na WOII opgegroeide generaties in deze landen systematisch afwijken van de voor WOII opgegroeide generaties in diezelfde landen, alsmede van hun tijdgenoten in de rest van de wereld waar de genoemde maatschappelijke omstandigheden nog niet over die drempel heen zijn.

Onder invloed van dit soort kritische veranderingen in de maatschappelijke omstandigheden en zolang de situatie op de genoemde punten niet drastisch verslechterd - voorspelt Inglehart dat zich langzaam maar zeker een "ander" electoraat ontwikkelt. Deze ontwikkeling voltrekt zich via een automatisch proces van bevolkingsvervanging. Oude voor-oorlogse generaties sterven uit en worden in de bevolking vervangen door jonge na-oorlogse generaties met systematisch afwijkende politieke waarde-oriëntaties en politieke vaardigheden. Onder invloed van dit proces neemt de nadruk die van oudsher wordt gelegd op materialistische politieke waarden af ten gunste van een sterkere nadruk op postmaterialistische waarden, en neemt het gemiddelde niveau van politieke vaardigheden geleidelijk toe. Inglehart spreekt in dit kader over de opkomst van het postmaterialisme en een proces van cognitive mobilization. Onder invloed van deze twee veranderingen, is Ingleharts (1967; 1970a; 1970b; en 1971) overtuiging, zou ook het denken van 
de bevolking over internationale samenwerking in het algemeen en de West-Europese eenwording in het bijzonder ingrijpend en blijvend veranderen. Zo zouden de voor een steeds groter gedeelte uit na-oorlogse generaties bestaande electoraten van de EU-lidstaten steeds meer open staan voor internationale politieke samenwerking. In hoofdstuk 6 (theorie) en 8 (toetsing) wordt uitvoeriger op Ingleharts theorie ingegaan.

In de meer algemene termen van Kinder en Sears draait het in Ingleharts theorie om history en values. De rol van values behoeft geen toelichting. De invloed van de history op politieke attituden komt tot uiting in de belangrijke rol die Inglehart toedicht aan maatschappelijke veranderingen. Deze beïnvloeden de politieke attitudevorming zowel direct, als indirect. Sommige maatschappelijke ontwikkelingen - zoals meer welvaart en het uitblijven van oorlogen zijn vooral van invloed op de uitkomsten van de socialisatie en hebben slechts een indirecte invloed op politieke attituden en politiek gedrag; andere ontwikkelingen - zoals de verspreiding van massacommunicatiemiddelen op grote schaal - hebben veeleer een direct effect op de politieke attitudevorming. De uitwerking respectievelijk empirische toetsing van deze theorie is te vinden in hoofdstuk 7 en 9.

De tweede benadering die in deze studie wordt getoetst is de Recieve-Accept-Sample-theorie (RAS-theorie) van de Amerikaanse politicoloog John Zaller. Zaller (1992: xi) is net zoals Kinder en Sears geĭnspireerd door het werk van Converse. Uitgangspunt is het idee dat de interesse van burgers voor concrete politieke issues over het algemeen gering is. Dit zou er de oorzaak van zijn dat de meeste burgers over de meeste politieke issues geen weldoordachte en gefundeerde opvattingen hebben. Veel opvattingen van burgers die in survey-onderzoek worden gemeten zijn daarom niet meer dan weinig stabiele, ad hoc meningen die op het moment van ondervraging slechts tijdelijk gevormd worden. Deze ad hoc meningen zijn gebaseerd op wat mensen vaak min of meer toevallig hebben gehoord over het concrete issue. Voor hun politieke informatie zijn burgers tegenwoordig bijna exclusief direct of indirect - dit wil zeggen: de buurman vertelt wat hij op de radio hoorde - aangewezen op de massamedia. Televisie, radio, kranten en tijdschriften vormen in de huidige tijd het veelal exclusieve venster op politieke ontwikkelingen en gebeurtenissen. Wat niet in de massamedia komt, is bij het grote publiek niet bekend.

Essentieel om de politieke attitudevorming van "gewone" burgers te kunnen begrijpen, is het inzicht dat politieke commentaren en interpretaties in de massamedia over politieke issues primair de meningen van een kleine elite weergeven (Zaller, 1992: 6). De berichtgeving in de massamedia weerspiegelt in die zin slechts een deel van de politieke werkelijkheid. De samenstelling van de geciteerde elite varieert overigens per concreet issue. Enerzijds zijn er mensen en organisaties die zich full-time met politiek bezig houden (politici, partijen, journalisten, enzovoort) en geacht worden over welhaast elk politiek issue een professionele 
mening te hebben. Anderzijds is er een issue-specifiek deel van professionals of organisaties die zich primair bezig houden met één bepaald beleidsterrein (wetenschappers, actiegroepen, belangengroepen, verenigingen). De verhalen, ervaringen, interpretaties en meningen die voortkomen uit zo'n tweeledige elite vormen veelal de exclusieve bron van politieke informatic voor de massamedia over concrete politieke issues.

Zo redenerend verwacht Zaller (1992: 36) dat het publieke oordeel in een land over de meest uiteenlopende politieke issues bovenal de verhouding tussen positieve en negatieve argumenten in de publieke berichtgeving over zo'n issue weerspiegelt. Zaller (1992: 45) verwacht niet dat burgers gelet op de geringe interesse voor politieke zaken erg selectief (kunnen) zijn bij het vergaren van politieke informatie, tenzij ze in een bericht over een minder interessant issue een specifiek aanknopingspunt vinden met een ander object of issue waar ze wel uitgesproken opvattingen over hebben. Bij zo'n aanknopingspunt denkt Zaller primair aan berichten waarin een directe link wordt gelegd tussen een argument over een specifiek issue enerzijds en een politicus of politieke partij anderzijds. Alleen als de berichtgeving over een specifiek issue dit soort specifieke aanknopingspunten bevatten, dan zou er een kans zijn dat burgers de informatie die ze krijgen systematisch gaan filteren. Daarbij zou informatie over issues waarbij een relatie wordt gelegd met een in de ogen van de ontvanger niet-favoriete politicus of partij, door de ontvanger niet worden verwerkt in zijn geheugen. Informatie over een issue zonder specifiek aanknopingspunt, of met een directe verwijzing naar een favoriete politicus of partij zouden daarentegen door de ontvanger wel worden opgeslagen in het geheugen. Indien een issue dus onderwerp is van een stevige partijpolitieke discussie is de kans groot dat de mening van willekeurige burgers dicht aansluit bij de opvattingen van hun favoriete partij(en). De in het geheugen opgeslagen informatie waarop een ad-hoc-mening wordt gebaseerd, zal in zo'n geval immers een systematische bias in de richting van het partijstandpunt vertonen.

Als de informatie over een politiek issue in de media echter niet gepaard gaat met duidelijke verwijzingen naar partijpolitieke bronnen, dan is het voor het gros van de burgers onmogelijk om informatie en argumenten op consistente wijze te filteren. Dit gebrek aan kritisch vermogen hangt direct samen met het feit dat leden van de politieke elite er in getraind zijn om hun standpunten goed te beargumenteren (Zaller, 1992: 47). Voor een gewone burger is het al snel te veel gevraagd om politieke argumenten (zonder duidelijke verwijzing) kritisch te bezien. Op basis van deze overwegingen is het afhankelijk van de mate van partijpolitieke discussie over een concreet issue, mogelijk meer of minder vergaande verwachtingen te formuleren over de publieke opinie over een issue.

In Zallers theorie staat de invloed van de media op de politieke attitudevorming centraal. In termen van Kinder en Sears gaat het opnieuw om history. Het gaat daarbij echter niet zozeer om lange-termijn gebeurtenissen, als wel om de invloed van de dagelijkse unfolding of events in de 
vorm van politieke berichtgeving in de massamedia. Tegelijkertijd gaat het echter ook om leadership. In het geval van een stevige partijpolitieke discussie - als de berichtgeving over een issue systematisch gepaard gaat met expliciete verwijzingen naar partijen en/of politieke stromingen - blijken partijen en politici door het ontketenen van een stevige partijpolitieke discussie in staat om hun eigen aanhang te souffleren. De uitwerking respectievelijk empirische toetsing van dit model vindt plaats in hoofdstuk 7 en 9.

De keuze voor Ingleharts theorie is primair ingegeven door het feit dat deze theorie een plausibele verklaring biedt voor alleriei ingrijpende politieke veranderingen in West-Europa en Noord-Amerika in het algemeen en de verklaring van de verschillen en veranderingen in de publieke steun voor de EU in het bijzonder. ${ }^{3}$ Inglehart claimt dat zijn theorie inzicht verschaft in de achtergronden van de publieke opinie over de EU. De keus voor Zallers theorie is daarentegen ingegeven door de aanwijzingen die er in de literatuur zijn dat houdingen ten aanzien van politieke issues in het algemeen en de publieke opinie ten aanzien van de EU in het bijzonder weinig stabiel zijn (Converse, 1964; 1970; Kitzinger, 1973: 352-70; Saris, 1997), alsmede dat partijen en politieke stromingen bij de publieke-opinievorming een cruciale rol spelen (Inglehart, 1977a: 328; 1977b: 166-75; Shepherd, 1975: 201-23; Wessels, 1995a; 1995b; Puchala, 1970). Zallers model biedt een eenvoudige verklaring voor de combinatie van deze twee fenomenen.

Beide benaderingen zoeken de verklaring voor verschillen en veranderingen in de publieke steun voor de EU in totaal verschillende richtingen. In beide is weliswaar een plaats ingeruimd voor wat Kinder en Sears the unfolding of events noemen. Bij Zaller gaat het om de invloed van the unfolding of events (inhoud massamedia) op de korte termijn, terwijl het bij Inglehart draait om the unfolding of events (maatschappelijke veranderingen) op de lange termijn. Beide verklaringen sluiten elkaar dus niet uit.

\subsection{Andere inzichten}

De keuze voor de hierboven besproken benaderingen impliceert dat een aantal van de door Kinder en Sears genoemde algemene gezichtspunten buiten beschouwing blijft. Hieronder zal kort worden toegelicht waarom - naast de gebruikelijke beperkingen die te maken hebben met ruimte, tijd en geld - de andere aanzetten hier verder geen onderwerp van onderzoek zijn.

Verklaringen in termen eigenbelang in meer of minder ruime zin blijven hier buiten beschouwing

'Inglehart, 1967; 1970; 1971; 1977a; 1977b; 1990; 1997; Inglehart en Rabier, 1978; Inglehart, Rabier en Reif, 1987: Mayhew, 1980; Handley, 1981; Wildgen en Feld, 1976; 1977; Niedermayer en Sinnott (eds.), 1995. 
omdat deze benaderingen slecht aansluiten bij de doelstelling van dit onderzoek. We zullen dit hieronder nader toelichten.

Over de rol van individueel eigenbelang in relatie tot publieke steun voor de EU is al het nodige bekend. In dit kader is onder andere onderzoek gedaan in hoeverre individuele houdingen van de EU afhankelijk zijn van de subjectief gepercipieerde respectievelijk objectief vooronderstelde belangen die individuele burgers bij het bestaan van de EU hebben. Sommige onderzoekers concluderen dat eigenbelang in deze enge zin nauwelijks van invloed is op de individuele houding ten aanzien van de EU (Bosch en Newton, 1995: 102). Daarentegen concludeert Gabel (1998) in zijn recente studie naar de verklaring van steun op individueel niveau op basis van het zogenaamde policy appraisal model dat:

"citizens manage to evaluate integration consistent with the benefits they derive from integration" (Gabel, 1998: 111).

Deze conclusie moet echter met een korrel zout worden genomen. Immers Gabels model bevat een groot aantal land-en jaar-dummy's dat op pijnlijke wijze illustreert dat zijn model nauwelijks in staat is om verschillen tussen lidstaten en veranderingen door de tijd te verklaren (Gabel, 1998: 130-141).

In andere studies wordt eigenbelang veel ruimer gedefinieerd in termen van de economische conjunctuur. De onderliggende redenering is dat politieke systemen primair verantwoordelijk worden gehouden voor de economische conjunctuur (Lipset and Schneider, 1987: 435-9; LewisBeck, 1990). Gaat het goed met de conjunctuur, dan straalt dat af op de betrokken politieke systemen; gaat het slecht, dan worden diezelfde politieke systemen minder goed beoordeeld. In sommige studies is dit idee uitgewerkt door de publieke steun voor de EU op lidstaatniveau te koppelen aan (objectieve) macro-economische gegevens zoals de economische groei, werkloosheid, inflatie, consumentenvertrouwen, de omvang van de EU-export en de som van nationale bijdragen aan en ontvangsten van de EU. Veel van deze studies claimen succes. Dalton and Eichenberg $(1990 ; 1993)$ concluderen dat de publieke steun voor de EU in acht lidstaten in de periode 1973-1988 inderdaad (negatief) samenhangt met de inflatie. Anderson en Kaltenthaler (1996) vinden op basis van gegevens uit twaalf lidstaten en een nog langere tijdreeks (19731993) aanwijzingen dat de publieke steun in een land niet slechts correleert met de inflatie (negatief), maar ook met de werkloosheid (negatief) en economische groei (positief).

Het optimisme van deze onderzoekers over de bruikbaarheid van deze economische benadering wordt hier echter niet gedeeld. Dalton en Eichenberg hebben niet minder dan zes land-dummy's nodig om te corrigeren voor de specifieke eigenschappen van lidstaten ("national traditions") en vier dummy's om te corrigeren voor de invloed van politieke gebeurtenissen (drie referenda, EP-verkiezingen) om een goede statistische fit te krijgen. Anderson en Kaltenthaler (1996: 183-4) introduceren twee discutabele niet-economische variabelen in hun model, te weten: 
timing of entry en length of membership. De reden voor de opname van de laatste variabele is gelegen in de verwachting dat naarmate een land langer lid is van de EU, de bevolking meer gewend en gehecht raakt aan de EU. ${ }^{4}$ Het argument voor de opname van de variabele timing of entry is niet al te overtuigend:

"The early joiners in the Union (Belgium, The Netherlands, Laxembourg, France, Germany and Italy) had publics that were convinced of the benefits - economic and otherwise - of the integration project. Those countries that joined in the mid-1970s (Britain, Denmark and Ireland) had publics that were reluctant vis-a-vis the idea of European unification. Such publics would thus start their membership in the EU at a lower level of support. The late joiners, that is those joined in the 1980s (Greece, Portugal and Spain), had been kept out of the EU because of their recent history of undemocratic governments, not necessarily because of their unwillingness to consider membership. One would expect the publics in those countries to have a fairly low level of support, but not quite as low as the notoriously critical middle joiners." (Anderson en Kaltenthaler, 1996: 183)

Het feit dat het publiek in de groep middle-joiners relatief kritisch was op het moment van toetreding behoeft verklaring, maar wordt met behulp van een dummy buiten de analyse geplaatst. ${ }^{5}$ De behoefte aan niet-economische dummy's in de economische modellen geeft aan dat een belangrijk deel van de variatie geen economische oorzaak heeft.

Dit alles illustreert de beperkte waarde van de economische benadering. De economische variabelen zijn vooral goed bruikbaar voor het verklaren van korte-termijn fluctuaties in de publieke steun voor de EU binnen landen, maar zijn veel minder geschikt voor het verklaren van lange-termijn veranderingen en verschillen tussen lidstaten (vgl. Bosch en Newton, 1995). Dat soort verschillen en lange-termijn veranderingen zijn echter nadrukkelijk onderwerp van deze studie.

Het perspectief dat politieke houdingen bovenal een afgeleide vormen van het lidmaatschap of de identificatie met bepaalde groepen blijft om min of meer dezelfde redenen buiten beschouwing. Ook op dit punt is er wel het een en ander bekend. De houding ten aanzien van de EU is in dit perspectief een functie van de sociale positie van een individu. Johan Galtungs artikel Foreign Policy Opinion as a Function of Social Position (1964) staat model voor deze benadering. Centraal in deze benadering staan de begrippen core/center en periphery. Dit begrippenpaar verwijst naar de plaats die individuen innemen ten aanzien van politieke

"Handley (1981:351) verwerpt het idee van zo'n "pro-European socialization".

\footnotetext{
${ }^{5}$ Een ander probleem dat in dit soort analyses wordt genegeerd is dat de publieke steun voor de EU in de meeste van de zes oorspronkelijke lidstaten vanaf het begin heel hoog is geweest (zie: Merritt en Puchala, 1968).
} 
besluitvorming, of zoals Galtung stelt:

"In the center are the topdogs of the society, in the periphery the underdogs" (Galtung, 1969: 553)

In het bijzonder ten aanzien van politieke issues die te maken hebben met buitenlandse politiek, zouden de burgers in de periferie op grote achterstand staan qua kennis en informatie. Belangrijk is ook dat burgers in de periferie meer waarde hechten aan de status-quo en niet zo gecharmeerd zijn van onbekende, nieuwe dingen. Vooral in de Scandinavische landen lijken de tegenstellingen ten aanzien van de EU langs dit soort sociale scheidslijnen te lopen (Hellevik et al, 1973; Hellevik en Gleditsch, 1973; Arter, 1995: Sogner en Archer, 1995). Shepherd (1975), Puchala (1970) en Kitzinger (1971) onderstrepen dat verschillende sociale groepen anders tegen de EU aankijken vanwege het feit dat ze uiteenlopende belangen hebben.

Gabel en Palmer (1995) en Gabel (1998; 1998a) introduceerden relatief recent een aantal moderne varianten van de core/periphery-hypothese. Uitgangspunt daarbij is dat een proces van market-liberalization de kern van de West-Europese eenwording is. De eerste is de zogenaamde human capital hypothesis. De toelichting geeft aan wat Gabel en Palmer bedoelen:

"This hypothesis is based on the premise that certain individual skills are more valuable and transferable in an advanced industrial economy. Europeans with higher education levels and more marketable occupational skills are better prepared to apply their talents in diverse international settings an to adapt to economic changes in their production sector and region. In contrast, less educated and poorly skilled Europeans have less valuable job experiences, possess less mutable skills and qualifications, are less likely to seek additional job training, and are more expandable in time of economic down-turn. For these reasons, we expect welleducated individuals in professional positions to be more optimistic about new job opportunities and less fearful of unemployment resulting form an open labour market." (Gabel en Palmer, 1995: 7)

Bovendien introduceren ze een zogenaamde capitalist hypothesis ${ }^{6}$ die er op neer komt dat rijken meer profiteren van het EU-beleid (lagere inflatie, open financiële markt, minder publieke uitgaven) dan armen. Ten slotte lanceren zij ook nog een proximity hypothesis die luidt dat EUburgers die in grensregio's wonen meer profiteren dan andere burgers. Gabel en Palmer vinden steun voor hun hypothesen, maar ook in hun modellen duikt een groot aantal dummy's op die moeten corrigeren voor de invloed van specifieke eigenschappen van de nationale context, Europese verkiezingen en het aantal WOII-slachtoffers per hoofd van de bevolking. Zonder die dummy's blijkt de verklarende kracht van het model uiterst beperkt te zijn

Uiteindelijk blijken de sociale scheidslijnen vooral bruikbaar voor de verklaring van

'In zijn eigen boek duidt Gabel dit aan als de income hypothesis (1998: 47). 
verschillen in de houding van individuen binnen landen, maar zijn minder goed bruikbaar voor de verklaring van de verschillen tussen landen. Het verklaart, met andere woorden, wel waarom Britse arbeiders minder warm lopen voor de EU dan hoog opgeleide Britse professionals, maar dit model kan niet verklaren waarom Nederlandse arbeiders veel positiever over de EU denken dan hun Britse en Deense collega-arbeiders. Gabel en Palmer (1995: 12) onderkennen dit zelf ook, maar onderstrepen dat de variantie binnen de lidstaten niet onaanzienlijk is. De sociale benadering leidt in zekere zin aan hetzelfde euvel als de economische benadering en komt daarom hier verder niet expliciet? meer aan de orde.

Tot slot is er heel bewust voor gekozen om de factor persoonlijkheid als verklarende variabele bewust buiten dit onderzoek te laten. Daar is een praktische en een meer fundamentele reden voor te geven. Het praktische bezwaar is dat de instrumenten om dergelijke variabelen te meten zelden expliciet worden meegenomen in survey-onderzoek. Het meer fundamentele bezwaar is dat het hier handelt om relatief statische variabelen die vooral goed bruikbaar zijn om attituden op individueel niveau te verklaren, maar waarvan onduidelijk is hoe ze zouden kunnen bijdragen aan het verklaren van de dynamiek van de publieke opinie op geaggregeerd niveau.

\subsection{Indeling van het boek}

Tot slot van dit eerste hoofdstuk volgt een korte vooruitblik op wat de rest van dit boek te bieden heeft. In hoofdstuk 2 staat de geschiedenis van de West-Europese samenwerking na de Tweede Wereldoorlog centraal. Daarbij zal worden ingegaan op de achtergronden van het ontstaan en de ontwikkeling van de Europese Unie in de laatste vijftig jaar. Deze inleiding staat op het eerste gezicht relatief los van de rest van het boek dat zich concentreert op de publieke steun, maar elementen uit dit hoofdstuk komen nadrukkelijk terug in hoofdstuk 3. In hoofdstuk 3 wordt aan de hand van Eastons politieke-systeemtheorie nagegaan in hoeverre mag worden verwacht dat publieke (politicke) steun een rol speelt in het functioneren en voortbestaan van politieke systemen en internationale organisaties in het algemeen, en de EU in het bijzonder. De eerste drie hoofdstukken vormen tezamen de inleiding op deze studie.

Vanaf hoofdstuk 3 wordt de focus volledig gericht op de publieke steun voor de EU. Hoofdstuk 4 en 5 bevatten de eerste kennismaking met de empirische gegevens. Hoofdstuk 4 bestaat uit een statische beschrijving van de publieke steun voor de EU in twaalf lidstaten aan

\footnotetext{
' Een deel van de ideeen over sociale scheidslijnen zit verweven in Ingleharts theorie, met name in het vooronderstelde effect van het niveau van politicke vaardigheden (opleiding) op de steun voor de EU op micro-en macro-niveau.
} 
de hand van gegevens die zijn verzameld in het najaar van 1994 (Eurobarometer 42). In dat kader wordt ingegaan op de dimensionaliteit van het begrip steun, de operationalisering van het begrip in termen van drie standaard-indicatoren en wordt getracht antwoord te geven op de eerste twee onderzoeksvragen. In hoofdstuk 5 volgt een dynamische beschrijving van veranderingen in de publieke steun voor de EU in 12 lidstaten tussen 1952 en 1998. Daarbij wordt zowel aandacht besteed aan de veranderingen in de publieke steun voor de EU binnen lidstaten, als aan veranderingen in de verschillen tussen lidstaten (verschuivingen). Het hoofdstuk mondt uit in de beantwoording van de derde en vierde onderzoeksvraag.

In hoofdstuk 6 en 7 worden de twee verklaringen die in deze studie centraal staan uitgewerkt in hypothesen. Sommige hypothesen hebben betrekking op de verklaring van individuele opinies van burgers - waarom is persoon $\mathrm{X}$ positiever over de $\mathrm{EU}$ dan persoon $\mathrm{Y}$ ? -, andere hypothesen richten zich primair op het verklaren van verschillen en veranderingen op geaggregeerd niveau (lidstaten) - waarom zijn Denen zoveel kritischer dan Luxemburgers? De hypothesen die in hoofdstuk 6 en 7 zijn geformuleerd, worden in hoofdstuk 8 - Ingieharts Silent Revolution-theorie - respectievelijk hoofdstuk 9 - Zaller RAS-model - getoetst. Hoofdstuk 10 is het slothoofdstuk waarin antwoorden worden geformuleerd op de zes onderzoeksvragen en nader zal worden ingegaan op de betekenis van de onderzoeksresultaten. 


\section{West-Europese samenwerking: ontstaan en ontwikkeling}

\subsection{Inleiding}

De wortels van een groot aantal internationale organisaties gaan terug naar het eerste decennium na WOII (1945-1955). Dit geldt ook voor een aantal West-Europese organisaties waaronder de EU. ${ }^{x}$ De na-oorlogse West-Europese samenwerking past nadrukkelijk in een breder internationaal-politiek kader. Over deze brede internationaal-politieke achtergronden van de West-Europese samenwerking in het algemeen en de eerste fase in de West-Europese samenwerking handelt paragraaf 2.2. Binnen dit algemene kader heeft elke specifieke na-oorlogse organisatie voor West-Europese samenwerking echter ook zijn eigen specifieke achtergrond. De geschiedenis en specifieke achtergrond van de EU, een organisatie die is opgericht na de eerste fase, komt aan de orde in paragraaf 2.3. Tot slot zal in paragraaf 2.4 worden nagegaan in hoeverre en welke feitelijke rol de publieke opinie heeft gespeeld in de geschiedenis van de EU.

\subsection{West-Europese samenwerking na WOII: internationaal-politieke achtergrond}

Het is geen toeval dat de wortels van allerlei organisaties waarin (aanvankelijk uitsluitend) WestEuropese landen samenwerken zoals de Europese Unie (EU), de Organisatie voor Economische Samenwerking en Overleg (OESO), de Noord-Atlantische Verdragsorganisatie (NAVO), de Raad van Europa (RvE) en de West-Europese Unie (WEU) in het eerste decennium na de Tweede Wereldoorlog (WOII) liggen. De behoefte aan dit soort organisaties is nadrukkelijk te wijten aan de onzekere machtsverhoudingen binnen Europa en de wereld na WOII. Die onzekerheid leidt al vrij snel na 1945 tot het oplaaien van een Koude Oorlog tussen de twee enig overgebleven

\footnotetext{
'De term West-Europa verwijst in beginsel naar de landen die na WOII niet tot het communistische blok gaan behoren. De werkdefinitie (Milward, 2000: I) die hier zal worden gehanteerd is dat West-Europa alle Europese landen omvat die lid zijn van de Organisatie voor Europese Economische Samenwerking (Verenigd Koninkrijk, Frankrijk, Italiē, Nederland, Oostenrijk, Griekenland, Belgię, Denemarken, Noorwegen, Turkije, Ierland, Zweden, Portugal, Spanje en West-Duitsland). Als de term gebruikt wordt in directe relatie tot een specifieke organisatie bijvoorbeeld: de West-Europese partners binnen de NAVO - dan zal de term gebruikt worden ter aanduiding van de West-Europese lidstaten van die organisatie, tenzij uit de context nadrukkelijk blijkt dat iets anders bedoeld is.
} 
supermachten - Verenigde Staten (VS) en Sovjet-Unie (SU) - die gepaard gaat met een de factoopdeling van Europa en Duitsland in een Amerikaanse en Russische invloedssfeer (De Vree en Janssen, 1998: 122-30). De na 1947 hoogoplopende spanningen tussen beide sferen leidt zowel in West-, als in Oost-Europa tot de oprichting van allerhande organisaties waarin Westrespectievelijk Oost-Europese landen op economisch, militair en politiek gebied gaan samenwerken.' Deze verklaring in termen van onzekere machtsverhoudingen en de Koude Oorlog vormt onmiskenbaar het grotere kader waarbinnen de na-oorlogse West-Europese samenwerking van de grond komt. Om uiteindelijk iets te kunnen begrijpen van de concrete stappen die in het kader van het na-oorlogse West-Europese integratieproces zijn gezet, is het echter noodzakelijk om concreter en dieper in te gaan op de machtsverhoudingen en de belangen en drijfveren van de bij dit proces betrokken landen en actoren.

In welke zin markeert het einde van WOII een nadrukkelijke breuk met het verleden in termen van internationale machtsverhoudingen? In de eerste plaats raakt Duitsland zijn rol als tijdelijke supermacht en belangrijke natiestaat binnen Europa kwijt. In afwachting van een definitieve vredesregeling wordt Duitsland in 1945 verdeeld in vier bezettingszones, elk onder gezag van een andere geallieerde macht (VS, SU, Verenigd Koninkrijk en Frankrijk). Zo is er na 1945 geen sprake meer van een soevereine Duitse staat. In de tweede plaats illustreert WOII opnieuw (evenals WOI) dat de koloniale supermachten Frankrijk en het Verenigd Koninkrijk niet meer in staat zijn om zelfstandig orde op zaken te stellen in hun eigen regio zonder hulp van de Verenigde Staten (VS) en de Sovjet-Unie (SU). Bovendien heeft de oorlog de economische en militaire macht van deze twee en andere West-Europese koloniale machten ernstig aangetast. Dit laatste leidt op zijn beurt weer tot machtsverschuivingen in andere regio's van de wereld omdat veel kolonies in deze omstandigheden hun kans schoon om het koloniale juk van zich af te schudden. Het reeds voor WOII voorzichtig gestarte dekolonisatieproces komt zo na 1945 pas echt goed op gang (De Vree en Janssen, 1998: 180-5). Het dekolonisatieproces en de teloorgang van de Europese koloniale machten zijn elkaar wederzijds versterkende processen en beide processen leiden ertoe dat in diverse regio's - en niet alleen binnen Europa - op zoek moet worden gegaan naar een nieuw machtsevenwicht. De vierde belangrijke verandering in de mondiale machtsverhoudingen is het feit dat er na WOIl geen enkele twijfel meer bestaat over het feit dat er op de wereld nog maar twee supermachten over zijn, de VS en de SU. De Vree en

\footnotetext{
"In dit hoofdstuk wordt verder niet ingegaan op de vormen van West-Europese economische en militaire samenwerking waartoe in de laatste jaren van de oorlog of in het eerste jaar na de oorlog (1944-6) is besloten door vaak kleine groepjes West-Europese landen, omdat deze vormen van samenwerking meer zijn ingegeven door kortetermijn doelstellingen en het bekomen van de schrik van de oorlog dan door de ingrijpende veranderingen in de internationaal-politieke context die uiteindelijk zo'n belangrijke rol spelen bij het verklaren van de na-oorlogse West-Europese samenwerking. Daarbij kan onder andere worden gedacht aan de oprichting van de Benelux en het Vendrag van Duinkerken. Voor meer informatie over die periode: De Vree en Janssen, 1998:153-6 en 161-4.
} 
Janssen beschrijven de na-oorlogse situatie als volgt:

"In a world lacking a true hegemonic power, a world which the Second World War had so thoroughly perfurbed, and of the future development of which very little could be said with any degree of reliability, uncertainty reigns supreme. "(De Vree en Janssen, 1998; 132); en:

"The war [JJ: WOII] had created a very delicate, potentially unstable, so highly dangerous balance between the two powers [JJ: VS en SU] on which it rested. Neither of them was sufficiently weak in relation to the other so as to make it bow to the other's wishes and accept its dominance, and to make the use of force against the other an utter impossibility. For quite some time the overwhelming economic strenght of the United States was offser by the superior strategic position and military strength of the Soviet Union in conjunction with the weakness and vulnerability of Western Europe As a consequence, it proved to be very hard indeed to make the two agree to any joint policies or decisions or to settle any issue arising between them." (De Vree en Janssen, 1998; 135)

In dit licht hoeft het geen verbazing te wekken dat de geallieerde overwinning op de Duitsland niet zoals na WOI wordt bezegeld met een gemeenschappelijke vredesregeling (Versailles) maar uiteindelijk ontaardt in een Koude Oorlog tussen de twee nieuwe supermachten.

In welke zin hebben deze veranderingen in de internationale machtsverhoudingen en de Koude Oorlog nu bijgedragen aan de West-Europese samenwerking na WOII? In het kader van hun onderlinge strijd trachten de twee grootmachten op actieve wijze hun heerschappij, economisch systeem en politieke ideologie in een zo groot mogelijk deel van de wereld te vestigen. ${ }^{10} \mathrm{Zo} \mathrm{ook}$ in Europa. Het conflict over de toekomst van het bezette en verdeelde Duitsland tussen Amerikanen - (uiteindelijk) gesteund door Britten en Fransen - aan de ene kant en de Russen aan de andere kant is uiteindelijk de concrete aanleiding voor de (onontkoombare) Koude Oorlog (1947-1989) (De Vree en Janssen, 1998: 133-5). Direct gevolg is dat zich in 1947 al een tweedeling tussen een Russische en een Amerikaanse invloedssfeer binnen Europa aftekent waarvan de grens midden door het oude Duitsland loopt (De Vree en Janssen, 1998: 122-33). De Russische invloedssfeer binnen Europa bestaat uit de door de SU bevrijde landen in Oost-Europa en het door Russische troepen bezette oostelijk deel van Duitsland; Scandinavië, West- en ZuidEuropa inclusief het door Franse, Britse en Amerikaanse troepen bezette westelijk deel van Duitsland behoort tot de Amerikaanse invloedssfeer. Zonder wederzijdse instemming en erkenning wordt in 1949 het Duitse grondgebied binnen de Amerikaanse invloedssfeer door de VS, VK en Frankrijk omgevormd tot de Bondsrepubliek Duitsland (West-Duitsland) en de

${ }^{10}$ Op 12 maart 1947 formuleert de Amerikaanse president Truman zijn nieuwe doctrine. Daarin spreken de Amerikanen de bereidheid uit om landen - in eerste instantie Griekenland-die pogen uit de Russische invloedssfeer te blijven actief economisch en militair te willen ondersteunen. De Truman-doctrine is belangrijk omdat het onderstreept dat de VS niet van plan is om net zoals na WOI haar handen van Europa af te trekken. 
Russische zone door de SU tot de Duitse Democratische Republiek (Oost-Duitsland). Door de opdeling van Europa en Duitsland ontstaan twee nieuwe politieke geografische eenheden voor onder meer internationale samenwerking. In deze zin is de West-Europese samenwerking onlosmakelijk verbonden met de Koude Oorlog en de veranderingen in de internationale machtsverhoudingen die daar aan ten grondslag liggen.

Om ook iets van de concrete stappen in het na-oorlogse integratieproces te kunnen begrijpen is het echter noodzakelijk om aandacht te besteden aan de belangen van de meest betrokken landen, met name: de VS, Frankrijk, VK, en Duitsland.

De bloei van de West-Europese samenwerking na WOII is voor een aanzienlijk deel op het conto van de VS te schrijven. De twee wereldoorlogen hebben de Amerikaanse veiligheidsgemeenschap er goed van doordrongen dat de grootste bedreiging voor de veiligheid van de VS schuilt in een overheersing van Europa door een enkele mogendheid (Lieshout, 1997: 57). Daarom besluiten de Amerikanen na WOII niet net zoals na WOI spoorslags hun handen van Europa af te trekken, maar proberen ze het ontstaan van een Russische hegemonie binnen Europa actief te voorkomen. Hoewel de VS rekening houden met een Russische militaire interventie in WestEuropa vrezen zij aanvankelijk niet zozeer de militaire kracht van de SU, als wel de populariteit van de aan Moskou gelieerde communistische politieke partijen in de West-Europese landen zelf. Die populariteit was enerzijds het resultaat van de vooraanstaande rol die de SU en communisten in het verzet tegen Duitsland hadden gespeeld, anderzijds vormde - volgens de Amerikanen - de uitzichtloze economische situatie waarin de West-Europese landen en veel van hun kiezers zich bevonden in 1945-7 een uitstekende voedingsbodem voor het communistisch gedachtegoed (Milward, 1984: 123). Regeringsdeelname van communistische partijen in Italië en Frankrijk onderstreepte dat het niet geheel ondenkbaar was dat de SU West-Europa langs democratische weg als het ware in de schoot geworpen zou krijgen (Lieshout, 1997: 58; Dinan, 1994: 15-6).

In een poging om zo'n min of meer automatische Russische hegemonie in Europa te voorkomen besluiten de Amerikanen in 1947 om een economisch hulpprogramma te ontwikkelen om het economisch herstel in West-Europa te bespoedigen. Op die manier hopen ze de succesvolle West-Europese communistische partijen de wind uit de ziel te halen. In afwachting van de voltooiing van een door de VS gesteunde wederopbouw van de West-Europese defensie en om het gevaar van een Russische militaire interventie te bezweren besluiten de Amerikanen verder om een deel van hun troepen in West-Europa achter te laten.

Om uiteindelijk succes te kunnen boeken in Europa zijn in de ogen van de VS twee zaken van eminent belang. Ten eerste dient het in de Duitse bezettingszones (binnen de Amerikaanse invloedssfeer) aanwezige economisch en militair potentieel volledig te worden benut voor de economische en militaire wederopbouw van West-Europa. In de Amerikaanse ogen kan er geen 
sterk West-Europa zijn zonder een sterk (West-)Duitsland. Ten tweede moeten de West-Europese - inclusief de Duitse bezettingszones - landen intensiever samenwerken op economisch, militair en politiek gebied. Tegen deze achtergrond hoeft het dus nauwelijks te verbazen dat de Amerikanen na WOII de felste pleitbezorgers voor vergaande economische, militaire en politieke samenwerking in West-Europa zijn.

De West-Europese landen, in het bijzonder Frankrijk en het VK, zien een vergaande WestEuropese samenwerking op economisch en militair terrein waarbij de Duitse bezettingszones binnen min of meer op voet van gelijkheid partieiperen niet zo zitten. De Fransen hebben heel andere ideeěn over de toekomst van (West-)Europa en, met name, Duitsland. De Fransen zijn volledig gepreoccupeerd met de vraag hoe hernieuwde Duitse agressie kan worden voorkomen en pleiten voor een permanent aan de geallieerde machten (VS, SU, VK en Frankrijk) ondergeschikt en gedeeld Duitsland (Lieshout, 1997:66-8). Samenwerking met (West-)Duitsland op voet van gelijkheid is voor de Fransen onbespreekbaar. De Fransen maken zich in tegenstelling tot de Amerikanen meer zorgen over de toekomstplannen van de Duitsers dan van de Russen. In de loop van 1947-8 treedt er echter een verandering op in de Franse houding als blijkt dat de VS, VK en SU niets voelen voor de Franse oplossing voor Duitsland. Lieshout stelt (vgl. Milward, 1984: 158):

$\mathrm{Nu}$ de zaken er zo voorstaan, kan in de Franse visie slechts door een proces van snelle opbouw van de Franse economie en van het Franse militair potentieel de Duitse onderschikking alsnog worden verwezenlijkt. Men is er aan Franse kant zeer goed van doordrongen dat wat de eventuele economische en militaire steun bij dit proces betreft, men van de Sovjet-Unie niets en van de Verenigde Staten juist veel te verwachten heeft. "(Lieshout, 1997: 67)

Als de deling van Europa en Duitsland zich definitief aftekent, stemmen de Fransen uiteindelijk in met de Amerikaanse wensen ten aanzien van het benutten van het economische en (in de toekomst ook) militaire potentieel van een West-Duitse eenheidsstaat (West-)Duitsland. Het controleren van West-Duitsland blijft niettemin het hoogste Franse doel. De gegarandeerde toegang tot de West-Duitse kolenvoorraden en controle over de West-Duitse zware industrie en daarmee indirect over de militaire wederopbouw in dat land - blijven voor Frankrijk absolute breekpunten in de onderhandelingen over de toekomst van West-Duitsland met het VK en de VS. Die toegang tot en controle over de Duitse kolen- en staalindustrie werd door de Fransen noodzakelijk geacht voor het welslagen van hun eigen na-oorlogse economische en militaire wederopbouw (Milward, 1984: 137). De Franse oplossing voor het Duitse probleem was dus niet langer meer gericht op de vorming van een permanent ondergeschikte, tweederangs Duitse natie maar richt zich na de onafwendbare deling van Europa en Duitsland op een indirecte controle over West-Duitsland middels een hechte Frans-Duitse politieke en economische samenwerking 
in het kader van de West-Europese integratie. Logisch gevolg van de Franse koerswijziging in 1947-8 is dat de Fransen ook meer gaan voelen voor economische, militaire en politieke samenwerking binnen West-Europa. Voor Frankrijk staat West-Europese samenwerking primair in het teken van de controle over West-Duitsland.

Het VK is weliswaar betrokken bij de na-oorlogse bezetting van Duitsland, maar de Britse prioriteit ligt nadrukkelijk niet bij intensivering van de samenwerking met de landen op het Europese vasteland (De Vree en Janssen, 1998: 152). De Britten zijn vooral uit op goede bilaterale verhoudingen met de VS en het verder in stand houden van de contacten met haar kolonies (Commonwealth). Ze voelen er er al helemaal niets voor om afstand te moeten doen van hun economische of militaire soevereiniteit omwille van het streven naar West-Europese integratic. Tegelijkertijd beseffen de VK, net zoals Frankrijk en alle andere West-Europese landen, dat zij voor de noodzakelijk economische en militaire hulp in het kader van de wederopbouw volledig zijn aangewezen op de VS en dat zij derhalve de Amerikaanse wensen met betrekking tot de West-Europese samenwerking onmogelijk volledig kunnen negeren.

Ook in de andere West-Europese landen is weinig steun te vinden voor de Amerikaanse wensen. Het optreden van deze landen wordt - overigens net zoals bij de grote landen - primair ingegeven door nationale economische en strategische belangen (Milward, 2000:427-9). In die plannen past over het algemeen geen verenigd of federaal West-Europa. De meeste kleine landen koesteren hun onafhankelijkheid, streven naar samenwerking op een meer beperkte schaal (Scandinavię) en vrezen bovenal dat Frankrijk en het VK een te sterke stempel zullen drukken op de West-Europese samenwerking; overigens, voelen de meeste kleine landen wel veel voor een grote West-Europese economische markt (inclusief West-Duitsland) zonder handelsbelemmeringen (De Vree en Janssen, 1998: 156).

Op welke wijze dragen deze uiteenlopende belangen bij tot de opmerkelijke na-oorlogse bloei van de West-Europese samenwerking? Gelet op de aarzelingen aan de kant van de WestEuropese landen hoeft het niet te verbazen dat het initiatief voor West-Europese samenwerking uiteindelijk afkomstig is van de Amerikanen. In ruil voor broodnodige economische en militaire steun aan West-Europa " en het achterlaten van een deel van de Amerikaanse troepen in WestEuropa verbinden de Amerikanen de eisen die hun belangen in de strijd met de SU dienen. De eerste eis is dat de West-Europese landen op economisch en militair gebied hun krachten dienen te bundelen in West-Europese organisaties. De tweede eis is dat de West-Europese landen dienen

\footnotetext{
"Aanvankelijk gaat het aanbod om deel te nemen aan het economisch hulpprogramma (Marshall-plan) naar alle Europese landen uit, inclusief de Sovjet-Unie en haar satellietstaten. Lieshout $(1997,82)$ suggereert dat de Amerikanen dit vooral doen om de Sovjet-Unie later de schuld van de te verwachten deling van Duitsland en Europa in de schoenen te kunnen schuiven. Geheel volgens verwachting, gelet op de daaraan verbonden eisen, wijst de SU de hulp af en dwingt het haar satellietstaten Polen en Tsjecho-Slowakije die aanvankelijk belangstelling tonen, om zich terug te trekken. Van deelname door de SU of haar satellietstaten aan een militair hulpprogramma of een Noord-Atlantische militaire alliantic is nooit sprake geweest.
} 
in te stemmen met het uitgangspunt dat het binnen de Duitse bezettingszones aanwezige economisch en militair potentieel in de nabije toekomst zal worden benut. Het gaat hierbij in wezen om een tweeledige eis. Het betekent dat in afwachting van de oprichting van een WestDuitse eenheidsstaat deze zones volwaardig zullen participeren in en profiteren van het economisch hulpprogramma (Marshall-plan), alsmede dat in de nabije toekomst - na de oprichting van de nieuwe eenheidsstaat - West-Duitse troepen zullen participeren in de verdediging van West-Europa (Lieshout, 1997: 81-3 en 90; De Vree en Janssen, 1998: 156-7). $\mathrm{Na}$ enig onderhandelen stemmen de West-Europese landen met de Amerikaanse eisen is.

Het accepteren van de vergaande Amerikaanse eisen door de West-Europese landen en met name door Frankrijk kan moeilijk los worden gezien van de manier waarop de SU in die tijd haar eigen belangen in Europa denkt te moeten behartigen. De angst voor Russische agressie binnen de West-Europese landen is aanvankelijk minder groot dan de angst voor hernieuwde Duitse agressie. Deze angst neemt in 1948 echter snel toe als gevolg van de door de Russen gesteunde communistische coup in Tsjecho-Slowakije en de Russische blokkade van West-Berlijn. Indirect draagt dit er toe bij dat er aan West-Europese zijde steeds meer begrip komt voor het Amerikaanse standpunt dat er meer van de Russen valt te vrezen dan van de Duitsers.

Zo komt het dat in februari 1948 uiteindelijk 16 West-Europese landen zich bereid verklaren om in ruil voor economische hulp de Organisatie voor Europese Economische Samenwerking (OEES) op te richten; en in ruil voor militaire hulp en blijvende Amerikaanse betrokkenheid bij de verdediging van West-Europa ondertekenen Frankrijk, VK en de Benelux-landen op 17 maart 1948 het Verdrag van Brussel waarmee de West-Europeanen tegemoet komen aan de Amerikaanse wens om ook op militair terrein samen te werken. In reactie hierop starten de Amerikanen de uitvoering van het Marshall-plan (economisch hulpprogramma) in 1948 en komen de onderhandelingen over de oprichting van een Noord-Atlantische Verdragsorganisatie (NAVO) in een stroomversnelling. De oprichting van de NAVO volgt in 1949 en maakt de weg vrij voor een omvangrijk Amerikaans militair hulpprogramma. ${ }^{12}$ Hoewel de oprichting van de NAVO vooralsnog geen oplossing biedt voor het vraagstuk van de West-Duitse bijdrage aan de West-Europese defensie - de Fransen slagen er in om die beslissing nog tot mei 1955 uit te stellen - bezegelt de oprichting van de NAVO de blijvende militaire betrokkenheid van de Amerikanen bij de defensie van West-Europa en West-Duitsland (Lieshout, 1997: 96 en 119-21).

In de slipstream van deze economische en militaire samenwerking richtten de West-Europese landen zelf nog de Raad van Europa op in 1949. Deze organisatie voor politieke samenwerking zou in de ogen van de Fransen het sluitstuk van de samenwerking binnen West-Europa moeten

${ }^{12}$ Door het niet terugtrekken van Amerikaanse troepen uit Duitsland en het reeds vrij geven van Amerikaans materieel om drie Franse divisies in West-Duitsland op oorlogssterkte te brengen in het najaar van 1948, getuigen de Amerikanen reeds eerder van hun intense betrokkenheid bij de West-Europese defensie (Lieshout, 1997:101). 
worden waarin problemen kunnen worden besproken - onafhankelijk van de VS - die de economische en militaire wederopbouw van West-Europa met zich meebrengen.

Alvorens deze paragraaf over de eerste fase in de na-oorlogse West-Europese samenwerking af te sluiten moet er nog aandacht worden gevraagd voor een bijzondere factor: de belangen van Duitse bezettingszones binnen de Amerikaanse invloedssfeer. Deze factor is van essentieel belang om uiteindelijk iets van de West-Europese samenwerking in de volgende fases te begrijpen. Formeel gezien is deze factor pas aanwezig vanaf 1949. In dat jaar wordt de Bondsrepubliek Duitsland (West-Duitsland) opgericht met een beperkte nationale soevereiniteit tot 1955 blijft West-Duitsland officieel bezet gebied (Lieshout, 1997: 71) - en ontstaat een land dat meer dan welk ander land ook gebaat is bij vergaande West-Europese samenwerking (Lieshout, 1997: 225-7; Nugent, 1999: 24-5). Allang voor de oprichting van de Bondsrepubliek is voor de aanstaande West-Duitse politici duidelijk dat alleen via de weg van verzoening en samenwerking een toekomstige West-Duitse regering het vertrouwen bij haar bezetters kan herwinnen en haar soevereiniteit terug kan verdienen. Adenauer, de eerste West-Duitse bondskanselier, beseft dit als geen ander en stuurt daarom aan op innige samenwerking met de Fransen (rapprochement) en andere West-Europese landen; verder maakt hij bewust geen vrijages in oostelijke richting, maar richt hij zich in zijn beleid exclusief op het verbeteren en intensiveren van de contacten tussen zijn land en de andere landen in de Amerikaanse invloedssfeer inclusief de VS (Westbindung) (Dinan, 1994: 22; Janssen en De Vree, 1985: 1078). Adenauer toont begrip voor het Franse wantrouwen jegens zijn land en Frankrijks streven naar veiligheid. West-Duitsland is er om die reden een voorstander van om de verzoening en rehabilitatie van West-Duitsland te doen plaats hebben binnen sterke institutionele kaders van internationale organisaties en dringt niet aan op West-Duitse herbewapening (Lieshout, 1997: 77 80 ). West-Duitsland ontpopt zich zo tot een warm pleitbezorger van vergaande West-Europese integratie. Het mes snijdt daarbij aan meerdere kanten: de Amerikanen weten zich hierdoor gesteund in hun pogingen om West-Europa te verenigen en te versterken; de Fransen krijgen de gewenste zekerheid en controle over West-Duitsland; en, West-Duitsland heeft binnen deze internationale kaders de mogelijkheid om een deel van haar soevereiniteit via een omweg terug te krijgen doordat het binnen die kaders op voet van gelijkheid met de andere lidstaten kan onderhandelen (Gleichberechtiging). Zo kan tevens de door Frankrijk zo nadrukkelijk gewenste Frans-Duitse as ontstaan die Frankrijk de nodige controle over West-Duitsland zou moeten verschaffen. Deze Frans-Duitse as vormt tot op heden de motor van de West-Europese integratie en de EU. Het uiteindelijk succes van de na-oorlogse West-Europese samenwerking in het kader van de NAVO en de EU is dus in belangrijke mate ingegeven door het feit dat West-Duitsland in de West-Europese samenwerking de mogelijkheid ziet om weer uit te kunnen groeien tot een 
De bloei van de West-Europese samenwerking na WOII is dus allerminst een toevallig proces, maar is nauw verweven met de specifieke internationaal-politieke context zoals die als gevolg van WOII was ontstaan in de wereld. Naast de West-Europese landen zelf spelen de Amerikanen bij dit alles een hoofdrol. Samenwerking was een nadrukkelijke Amerikaanse "wens" in het kader van hun strijd tegen de Russen in het kader van de Koude Oorlog en de opdeling van Europa in een Amerikaanse en Russische invloedssfeer. Dit alles neemt niet weg dat de samenwerking uiteindelijk alleen van de grond kwam omdat het zowel de belangen van de VS als die van de betrokken West-Europese landen diende (Milward, 1984; Anderson, 1997: 66; George, 1996: 57 151). In de eerste fase van de na-oorlogse samenwerking komen uiteindelijk dus drie organisaties van de grond waarbinnen de West-Europese landen gaan samenwerken: OEES, NAVO, en de Raad van Europa.

\subsection{Ontstaan en ontwikkeling van de Europese Unie}

Het ontstaan van de hedendaagse EU in het begin van de jaren vijftig past uiteraard in de bredere internationaal-politieke context uit de vorige paragraaf, maar tegelijkertijd maakt het nadrukkelijk onderdeel uit van een nieuwe fase in de na-oorlogse West-Europese samenwerking met zijn eigen eigenaardigheden. In de verdere uitbouw van de EU zijn vervolgens ook weer verschillende fasen te onderscheiden die in de deze paragraaf worden geschetst.

\section{0-1952: Europese gemeenschap voor Kolen en Staal (EGKS) en Pleven-plan}

De OEES, NAVO en Raad van Europa blijken in de praktijk niet veel meer dan relatief vrijblijvende instituties waarin de betrokken West-Europese landen onderhandelingen voeren. In die zin voldoen deze organisaties uiteindelijk allerminst aan de verwachtingen van de Fransen en Amerikanen, alleen de Britten zijn tevreden (Janssen en De Vree, 1985: 101-2; Dinan, 1994: 18-9; Nugent, 1999: 14; Milward, 1984: 206-11). De Fransen hadden gehoopt om via WestEuropese samenwerking grip te kunnen krijgen en te houden op de wederopbouw van WestDuitsland, alsmede dat West-Europa zich onder Frans-Britse leiding weer een onafhankelijk (van de VS) plaatsje op het wereldtoneel zou kunnen verschaffen. De Amerikanen zien met lede ogen aan dat de gewenste West-Europese integratie niet echt van de grond komt (Lieshout, 1997: 86-7 en 119-21; Milward, 1984: 179). De Britten die niets voelen voor een nauwe betrokkenheid bij het Europese continent, zeker niet als dit zou betekenen dat zij hier een deel van nationale soevereiniteit voor zouden moeten opgeven, zijn tevreden met de gang van zaken. Zowel de 
Fransen, als de Amerikanen betreuren de Britse opstelling en zien daarin tevens de oorzaak van het feit dat de opgerichte West-Europese organisaties niet aan hun verwachtingen voldoen.

Mede onder invloed van het ruimhartige Marshall-plan is ondertussen sprake van een opmerkelijk snel economisch herstel van West-Duitsland. Dit boezemt de Fransen begrijpelijkerwijs na drie Duitse bezettingen in nog geen honderd jaar - angst in. In beide landen staat het herstel van de zware industrie namelijk boven aan de agenda. De steenkool die nodig is voor de Franse staalindustrie moet echter uit Duitsland komen. Door de opmerkelijk snelle wederopstanding van de Duitse staalindustrie vrezen de Fransen dat de Duitse kolenleveranties aan hun land in gevaar komen. Bovendien dreigt een overschot op de staalmarkt te ontstaan. Dit zou rampzalige gevolgen hebben voor de minder efficiënte Franse staalindustrie. Frankrijk blijkt echter niet in staat ${ }^{13}$ om de, mede door de Amerikanen gepropageerde, opbouw van de Duitse zware industrie in het Ruhrgebied feitelijk iets in de weg te leggen. Dit doet de Franse regering inzien dat de koers ten aanzien van de oosterburen opnieuw moet worden verlegd. Dit inzicht wordt nog eens versterkt doordat de Amerikanen blijven hameren op de noodzaak van WestDuitse herbewapening. Alle militaire experts, ook de Franse, onderschrijven die noodzaak. Het voorspoedig economisch herstel van West-Duitsland en de verwachting dat de Verenigde Staten op korte termijn het initiatief op het punt van de West-Duitse herbewapening naar zich toe zullen trekken als de West-Europese partners niet met voorstellen komen, doet de Fransen na 1950 inzien dat het geen zin heeft om op internationaal niveau steeds nieuwe obstakels op te werpen tegen de militaire en economische wederopbouw van West-Duitsland.

In plaats van nog langer te streven naar onderschikking van West-Duitsland, zet Frankrijk zijn kaarten op supranationale samenwerking met West-Duitsland op voet van gelijkheid (Lieshout, 1997:124-8; Janssen en de Vree, 1985: 104-7). De Franse koerswijziging leidt tot een nieuwe fase in de West-Europese samenwerking waar de hedendaagse EU uiteindelijk de vrucht van is. Kenmerkend voor deze nieuwe fase zijn: Frans initiatief, Frans-Duitse toenadering en supranationalisme. De Fransen hopen op die manier uitzicht te krijgen op een sterk West-Europa onder Frans-Duitse leiding. De Britten raken in dit kader definitief uit zicht. De Fransen verwachten langs deze weg de economische en militaire wederopbouw van West-Duitsland uiteindelijk beter naar hun hand te kunnen zetten (Janssen en De Vree, 1985: 101). Het eerste resultaat van de nieuwe Franse koers is het Schuman-plan - vernoemd naar de toenmalige Franse minister van buitenlandse zaken, maar bedacht en uitgewerkt door de invloedrijke Franse topambtenaar Jean Monnet. Het plan dat op 9 mei 1950 wordt gepresenteerd betreft een voorstel om de Duitse en Franse kolen- en staalindustrie onder gemeenschappelijk gezag te brengen. Een supranationale instantie met eigen bevoegdheden waarin Frankrijk en West-Duitsland op voet

${ }^{13}$ Ook niet via de Internationale Autoriteit voor de Ruhr (Lieshout, 1997: 123: Milward, 1984: 386-9). 
van gelijkheid zouden zijn vertegenwoordigd, zou de verantwoordelijkheid krijgen voor het beheer van de gehele Franse en Duitse kolen- en staalindustrie. Hiervoor moeten Frankrijk en West-Duitsland een deel van hun nationale soevereiniteit opgeven. ${ }^{14}$ Met dit offer hoopt Frankrijk zich te kunnen verzekeren van Duitse kolenleveranties, alsmede van invloed op de productic-omvang van de West-Duitse staalindustrie. De keus voor samenwerking op het terrein van de zware industrie heeft overigens alles te maken met het feit dat de zware industrie nog altijd de basis vormt voor de militaire industrie. Via een kolen- en staalgemeenschap hoopt Frankrijk dus indirect invloed te krijgen op de economische én militaire wederopbouw bij de zo gevreesde oosterburen. Het plan gaat uit van een Frans-Duitse gemeenschap, maar is tevens een open uitnodiging aan andere West-Europese landen om deel te nemen.

De nieuwe Franse koers betekent een onmiskenbare rehabilitatie van West-Duitsland. WestDuitsland krijgt in een keer de mogelijkheid om op voet van gelijkheid met Frankrijk uit te groeien tot één van de twee kopmannen van West-Europa. Daarom hoeft het niet te verbazen Adenauer van harte instemt met het Franse plan (Lieshout, 1997: 127-8; Janssen en De Vree, 1985: 107-8; Dinan, 1994: 22). De Amerikanen reageren ook instemmend op het Franse initiatief, hoewel ze aanvankelijk even bevreesd zijn voor het ontstaan van een gigantisch kolen- en staalkartel en enig wantrouwen koesteren tegen eventuele achterliggende Franse politieke ambities (onafhankelijk West-Europa) (Milward, 1984: 399). Dit plan vergroot immers de kansen op de ook door de Amerikanen gewenste echte West-Europese integratie. De Amerikanen zijn er ook niet rouwig om dat deelname van het VK - anderszins een uiterst betrouwbare partner niet langer een noodzakelijke voorwaarde vormt voor het welslagen van de plannen voor WestEuropese integratie. Samen met de Fransen zijn zij van mening dat de geringe voortgang in de West-Europese integratie mede is te wijten aan de afstandelijke houding van de Britten. Een Frans-Duitse as biedt de VS ook meer uitzicht op succes (Dinan, 1994: 24; Lieshout, 1997: 133).

Zoals gezegd gaat het Schuman-plan aanvankelijk uit van een Frans-Duitse gemeenschap, maar is het tevens een open uitnodiging aan andere West-Europese landen. Uiteindelijk tekenen zes landen op 18 april 1951 het Verdrag van Parijs ter oprichting van de Europese Gemeenschap voor Kolen en Staal (EGKS), te weten: België, Frankrijk, Italië, Luxemburg, Nederland en WestDuitsland. De Britten wijzen de uitnodiging voor de onderhandelingen al in een vroeg stadium van de hand (Lieshout, 1997: 131). Ze voelen niets voor supranationale experimenten waarbij zij een deel van hun soevereiniteit zouden moeten afstaan. De Britten prefereren

\footnotetext{
${ }^{14}$ In het geval van West-Duitsland is eigenlijk geen sprake van het "opgeven" van nationale soevereiniteit, omdat het land op dat moment nog steeds officieel bezet is en de West-Duitse kolen en staal-industrie reeds onder controle staan van een Internationale Ruhr Autoriteit waarin de VS, Frankrijk, VK en, later ook, West-Duitsland zelf zijn vertegenwoordigd. In deze zin is er bij aanvaarding van het Schuman-plan eerder sprake van het "verkrijgen" van meer soevereiniteit, dan van het opgeven van soevereiniteit. Via het Schuman-plan krijgt West-Duitsland immers ook de mogelijkheid om invloed uit te oefenen op de Franse kolen- en staal-industrie. Voor meer informatie: Milward (1984).
} 
intergouvernementele vormen van samenwerking waarbij de lidstaten hun volledige soevereiniteit behouden. De Scandinavische landen haken om diezelfde reden af. De EGKS en in het bijzonder de Hoge Autoriteit, het supranationale hart van de EGKS, start zijn werkzaamheden in augustus 1952. De EGKS is de cerste kiem van de EU!

Nog geen half jaar na de lancering van het Schuman-plan - en dus ruim voor de ondertekening en het in werking treden van het EGKS-verdrag - ziet het zogenaamde Pleven-plan het licht, een voorstel voor de oprichting van een Europese Defensie Gemeenschap (EDG) (Lieshout, 1997: 153 e.v.). Het Pleven-plan zou de door de Amerikanen gewenste vorming van een West-Duits leger met het oog op de verdediging van West-Europa voor Frankrijk bespreekbaar maken. Een eventueel West-Duits leger zou dan geïntegreerd kunnen worden in een West-Europese legermacht onder gezamenlijk gezag. Dit plan is het tweede resultaat van de nieuwe Franse koers, hoewel het supranationale element in dit tweede plan beduidend minder zwaar wordt aangezet doordat de bevoegdheid om besluiten te nemen vooralsnog (zie plannen EPG hieronder) bij een Raad van (nationale) Ministers zal liggen. Ook het idee van samenwerken op voet van gelijkheid met West-Duitsland wordt wat naar de achtergrond gedrongen doordat de West-Duitsers hun hele legermacht en de Fransen slechts een deel van hun troepen onder het gezag van de EDG zullen brengen (Lieshout, 1997: 157).

De vrij plotselinge lancering van het Pleven-plan tijdens de nog lopende onderhandelingen over de EGKS heeft alles te maken met de inval van communistisch Noord-Korea op 25 juni 1950 in Zuid-Korea. In reactie op die gebeurtenis komen de Amerikanen, onder meer, met plannen voor een onmiddellijke opbouw van een West-Duits leger (Lieshout, 1997:110-6). Dit is nodig opdat de VS zijn nog in West-Duitsland aanwezige troepen in de nabije toekomst ook elders in wil kunnen zetten. Verder onderstreept de inval in Zuid-Korea dat ook in Europa rekening moet worden gehouden met de mogelijkheid van communistische agressie. De belangrijkste consequentie van de ontwikkelingen in Korea voor West-Europa is:

"... dat de Verenigde Staten tot de slotsom komen dat niet langer voorbij kan worden gegaan aan het allerwegen geaccepteerde inzicht dat uit oogpunt van militaire logica niet valt te ontkomen aan de West-Duitse herbewapening" (Lieshout, 1997: 154)

Hoewel deze analyse ook door Franse generaals wordt gedeeld, schieten Amerikaanse plannen in die richting opnieuw in het verkeerde Franse keelgat. Om de Amerikanen de wind uit de zeilen te nemen, komen de Fransen met het Pleven-plan. Het Pleven-plan is in die optiek een ultieme poging van Frankrijk om de militaire wederopbouw van West-Duitsland te frustreren, alsmede om te voorkomen dat de Amerikaanse plannen de nog lopende onderhandelingen met WestDuitsland over het EGKS-verdrag kunnen frustreren (Lieshout, 1997: 135-6 en 155)

De Bondsrepubliek ziet in eerste instantie niet zoveel in de Franse plannen omdat deze geen 
ruimte bieden voor een zelfstandig West-Duits leger. Na enige tijd gaat West-Duitsland echter overstag omdat Adenauer inschat de nodige successen te zullen behalen bij de onderhandelingen met Frankrijk over de precieze invulling van de plannen. De Korea-Oorlog is in die zin een welkome verrassing voor de West-Duitsers, omdat als gevolg van de ontwikkeling in Korea de Amerikaanse druk op met name Frankijk om nu eindelijk te komen tot een afdoende regeling voor de West-Duitse herbewapening snel oploopt. In de onderhandelingen slaagt West-Duitsland - gesteund door de VS - er inderdaad in om de hoofdprijs binnen te slepen (Lieshout, 1997: 164-6 en 174). Bij het in werking treden van het EDG-verdrag zal de bezetting van West-Duitsland officieel worden opgeheven. West-Duitsland krijgt zodoende uitzicht op nationale soevereiniteit. Het verdrag ter oprichting van een EDG wordt in mei 1952 door de zes EGKS-lidstaten gesloten.

Vermeldenswaard is verder dat het EDG-verdrag de kiem voor een supranationale - welhaast federale - Europese Politieke Gemeenschap (EPG) bevat (Lieshout, 1997: 189-92). De EPG zou uiteindelijk leiding moeten gaan geven aan de EDG. Een commissie uit het parlement van de net in werking getreden EGKS, bestaande uit nationale parlementariërs, wordt in september 1952 uiteindelijk belast met de uitwerking van de plannen voor zo'n heuse supranationale politieke gemeenschap. De plannen die op tafel komen, zijn sterk supranationaal gekleurd. Als de plannen voor een EDG en een EPG zouden zijn doorgegaan, zou een mate van Europese (supranationale) integratie zijn bereikt die tegenwoordig voor onmogelijk wordt gehouden.

Het EDG-verdrag en in het kielzog daarvan de ambitieuze EPG-plannen sneuvelen echter op 30 augustus 1954 bij de ratificatie in het Franse (!) parlement. Een meerderheid van de Franse parlementariërs vreest een Duitse overheersing van het West-Europese leger, bovendien steekt het de Fransen bijzonder dat de Britten op geen enkele wijze bereid zijn om concessies te doen. Volgens Lieshout (1997: 184-5) is de hele gang van zaken minder opmerkelijk dan op het eerste gezicht misschien lijkt. De lancering van het EDG-verdrag was immers in eerste instantie bedoeld om Amerikaanse plannen voor een snelle herbewapening van West-Duitsland te frustreren. Dit lukt. Het EDG-verdrag, na de voor Frankrijk teleurstellend verlopen onderhandelingen, biedt de Fransen uiteindelijk onvoldoende waarborgen om de West-Duitse herbewapening te kunnen beheersen.

Het EDG-echec betekent het voorlopige einde van de ambitieuze tweede fase die gekenmerkt wordt door vergaande supranationale initiatieven van Franse origine en Frans-Duitse samenwerking op voet van gelijkheid. Het resultaat is uiteindelijk mager en beperkt zich tot de EGKS. Alvorens verdere vooruitgang wordt geboekt op het terrein van de West-Europese samenwerking, moeten de VS en West-Europa eerst het vraagstuk van de West-Duitse herbewapening oplossen. Alvorens de volgende stappen in de transformatie van de EGKS in de EU te beschrijven, daarom eerst even aandacht voor dit thema. 
Intermezzo: de militaire toekomst van West-Duitsland

$\mathrm{Na}$ het EDG-echec eisen de Amerikanen opnieuw een snelle oplossing voor het vraagstuk van de West-Duitse herbewapening. De Fransen hebben hun krediet verspeeld. Uiteindelijk komen de Britten met een voorstel (Lieshout, 1997: 185). Het Britse voorstel is uiteraard niet supranationaal, maar intergouvernementeel van aard. Het komt wel tegemoet aan een aantal Franse bezwaren tegen een onvoorwaardelijke West-Duitse herbewapening. De kern van het Britse voorstel is dat de bezetting van West-Duitsland officieel wordt beèindigd en dat het zich mag herbewapenen op voorwaarde dat het land lid wordt van een nieuw op te richten WestEuropese militaire samenwerkingsorganisatie - de West Europese Unie (WEU) - en de NAVO. In het kader van haar WEU-lidmaatschap moet West-Duitsland verschillende, in het WEUverdrag vastgelegde, beperkingen op zijn militaire soevereiniteit aanvaarden die slechts door middel van een unaniem besluit van de andere lidstaten - waaronder Frankrijk - kunnen worden opgeheven. West-Duits WEU-lidmaatschap maakt de weg vrij voor een West-Duits NAVOlidmaatschap.

Om een en ander te bereiken wordt het reeds bestaande Verdrag van Brussel (1948) tussen VK, Frankrijk, Belgie, Nederland en Luxemburg opengebroken en uitgebreid met WestDuitsland en Italiè. Het oude verdrag wordt omgebouwd tot het verdrag tot oprichting van de West-Europese Unie (WEU) (1955). Het WEU-verdrag stelt bovengrenzen en beperkingen aan de herbewapening van West-Duitsland. Het NAVO-verdrag kent slechts ondergrenzen. $\mathrm{Na}$ acceptatie van het WEU-lidmaatschap kan West-Duitsland toetreden tot de NATO. In ruil daarvoor moet West-Duitsland (Janssen en De Vree, 1985: 133-8):

- accepteren dat geallieerde troepen uit zes verschillende landen op zijn grondgebied blijven;

- afzien van de productie van ABC-wapens;

- accepteren dat zijn legermacht beperkt blijft tot vier divisies, tenzij de WEU-leden unaniem anders beslissen.

Het West-Duitse leger zal onder de internationale commandostructuur van de NAVO komen te vallen. Zo komt in mei 1955, na tien jaar, een officieel einde aan de bezetting van WestDuitsland en treedt het land toe tot de WEU en NAVO. Deze deal maakt de weg vrij voor een West-Duitse bijdrage aan de West-Europese defensie.

\section{5-1957: EEG en Euratom: een nieuwe start}

Nu het probleem rond de herbewapening van West-Duitsland is opgelost, kan er weer aandacht worden besteed aan de verdere intensivering van de West-Europese samenwerking. Tijdens een vergadering van ministers van buitenlandse zaken van de EGKS-lidstaten in juni 1955 te Messina (Italiě) blijkt dat de Benelux-landen dit keer het heft in handen hebben genomen. De Belgische minister Spaak presenteert een Benelux-memorandum met nieuwe plannen om de samenwerking 
tussen de EGKS-lidstaten uit te breiden middels de oprichting van een Europese Unie voor Atoomenergie (Euratom) en een Europese Economische Gemeenschap (EEG). Deze plannen bevatten opnieuw supranationale elementen en vanaf het begin is duidelijk dat het welslagen van de plannen uiteindelijk staat of valt met de deelname van Frankrijk en West-Duitsland. In die twee opzichten is er dus weinig veranderd sinds het EDG-echec.

Wel verschuift het initiatief in het proces tot op zekere hoogte in de richting van de Benelux, hoewel de plannen voor Euratom nadrukkelijk uit de Franse koker afkomstig zijn. Het Euratomplan heeft vergelijkbare achtergronden als het Schuman- en Pleven-plan. ${ }^{15}$ Het Franse enthousiasme voor samenwerking op het terrein van de atoomenergie heeft vooral te maken met de verwachting dat kennis van nucleaire energie de nieuwe basis - in plaats van de zware industrie - vormt voor industriēle (energie) en militaire macht. Hoewel het West-Duitsland in het WEU-verdrag expliciet verboden is om zich bezig te houden met de productie van nucleaire wapens, zijn de Fransen bevreesd dat de West-Duitsers zich via "vreedzaam" nucleair onderzoek toch zouden kunnen ontwikkelen tot een potentięle nucleaire macht. Lieshout stelt:

"Ook mu gaat achter de retoriek van 'Europa' een poging schuil Frankrijk opnieuw in een bevoorrechte positie te brengen. " (Lieshout, 1997: 202)

De Fransen is er veel aan gelegen om alles wat in West-Duitsland met atoomenergie te maken heeft onder controle te krijgen (Janssen en De Vree, 1985: 146-9). Bovendien schat Frankrijk in dat het alleen middels een gezamenlijk West-Europees initiatief mogelijk is om de achterstand op het terrein van de nucleaire technologie op de VS in te halen (Lieshout, 1997: 194). Tegelijkertijd vrezen de Fransen echter de Benelux-plannen voor een economische gemeenschap gericht op de vorming een gemeenschappelijke markt; het protectionisme viert in Frankrijk nog altijd hoogtij (Lieshout, 1997: 195 en 200-1). De Franse regering heeft ernstige twijfels over het concurrerend vermogen van haar eigen industrie en kleinschalige landbouw. Uiteindelijk is Frankrijk onder bepaalde voorwaarden bereid zijn bezwaren tegen de EEG aan de kant te zetten met het doel om Euratom te krijgen. ${ }^{16}$

Voor de andere vijf landen geldt het omgekeerde; dit wil zeggen, ze zien niet zoveel in Euratom dat vooral een stimulans zal betekenen voor de Franse nucleaire industrie, maar hechten wel aan intensivering van de West-Europese samenwerking middels economische integratie.

\footnotetext{
${ }^{15}$ Net zoals bij de vorige supranationale Franse plannen speelt Jean Monnet weer een bijzonder grote rol op de achtergrond (Lieshout, 1997: 193-5).

${ }^{16}$ Lieshout wijst er op dat de afloop van de Suez-crisis en de Hongaarse opstand in 1956 pijnlijk duidelijk maken aan de West-Europese landen - in het bijzonder Frankrijk en het VK - hoe weinig ze hebben in te brengen tegen de twee supermachten van dat moment. Deze pijnlijke incidenten zouden de voortgang in de Frans-Duitse onderhandelingen over samenwerking in het kader van de EEG en Euratom uiteindelijk aanzienlijk hebben bespoedigd, omdat hierdoor ook het grote Franse belang bij verdere West-Europese samenwerking in een pijnlijk helder perspectief zou zijn geplaatst (Lieshout, 1997: 215 e.v; zie ook: Dinan, 1994: 31-2).
} 
Economische integratie moet de positie van West-Europa in de wereld versterken en de welvaart in deze regio verder doen groeien. Uiteindelijk stemmen de andere vijf landen in met de aanvullende Franse eisen, onder meer protectie van de landbouw, die Frankrijk stelt aan een economische gemeenschap. In februari 1957 bereiken de zes EGKS-lidstaten overeenstemming. Op 25 maart 1957 wordt het Verdrag van Rome getekend, na een snelle ratificatie kunnen Euratom en EEG op 1 januari 1958 van start. Deze twee gemeenschappen vormen een aanvulling op de beperkte samenwerking binnen de EGKS en vormen de tweede respectievelijke derde loot aan de EU-stam.

Vrij snel nadat het West-Duitse herbewapeningsvraagstuk is opgelost, slagen de WestEuropese landen er dus weer in om de supranationale samenwerking tussen de EGKS-lidstaten te intensiveren. Vooral de oprichting van de niet-sectorgebonden EEG betekent dat de deur naar samenwerking op verschillende beleidsterreinen wijd open gaat. De verdere groei richting EU in de daarop volgende decennia vindt dan ook nagenoeg exclusief plaats binnen het kader van de EEG.

\section{Intermezzo: EU-instellingen (1957-1998)}

Vooruitlopend op het verdere chronologische overzicht van de EU-geschiedenis volgt nu eerst wat meer achtergrondinformatie over de interne organisatie van de drie gemeenschappen en de ontwikkelingen daarin. De drie gemeenschappen kennen qua instellingen (organen) een in grote lijnen vergelijkbare opbouw. Het Hof van Justitie (rechtspraak) en de Gemeenschappelijke Vergadering (Europees Parlement) zijn oorspronkelijk slechts EGKS-instellingen, maar fungeren vanaf 1 januari 1958 ook als EEG- en Euratom-instellingen. Wel heeft elke gemeenschap een eigen Raad (van ministers), de vergadering van nationale ministers van de lidstaten. Daarnaast beschikt de EGKS over een Hoge Autoriteit, en de EEG en Euratom hebben een eigen Commissie. De leden van de Hoge Autoriteit respectievelijk Commissies worden door de regeringen van de lidstaten voor langere tijd benoemd en vormen tezamen het dagelijks (collegiaal) bestuur van de betreffende gemeenschap. De leden van de Hoge Autoriteit en Commissies worden geacht onafhankelijk van hun lidstaat te functioneren.

In 1967 vindt er een volledige administratieve fusie plaats van de drie Raden in één Raad, en van de Hoge Autoriteit en twee Commissies in één Europese Commissie. ${ }^{17}$ Sinds deze administratieve fusie zijn de aanduidingen Europese Gemeenschappen en Europese Gemeenschap (EG) in zwang geraakt.

In het begin van de jaren negentig komt weer verandering in door de ondertekening van het

\footnotetext{
"Juridisch is er nog altijd sprake van drie afzonderlijke Raden, eén Hoge Autoriteit en twee Commissies. Het EEG-verdrag is weliswaar omgedoopt in het EG-verdrag bij de invoering van de Europese Unie, maar het EGKSen Euratom-verdrag bestaan nog steeds.
} 
Verdrag van Maastricht (Verdrag tot oprichting van de Europese Unie). Sinds die tijd wordt meer en meer gesproken over de Europese Unie in plaats van de Europese Gemeenschap. De EU omvat naast de supranationale Europese Gemeenschappen ook nog twee intergouvernementele pijlers (zie hieronder).

Ook de interne bevoegdheidsverdeling tussen de onderdelen binnen de supranationale gemeenschappen behoeft enige aandacht om inzicht te kunnen krijgen in de betekenis van de EU voor West-Europa. De rechtsprekende bevoegdheid ligt geheel en al in handen van het Europese Hof van Justitie. In de oorspronkelijke verdragen is voor het parlementaire orgaan enkel een adviserende rol in het kader van wetgeving en bestuur weggelegd. De belangrijkste bevoegdheden op het terrein van regelgeving en bestuur binnen de gemeenschappen zijn toegekend aan de Commissie en de Raad (van ministers). De Commissie beschikt over een exclusief initiatiefrecht in het kader van de besluitvorming. De bevoegdheid om besluiten te nemen ligt uiteindelijk bij de Raad.

Commissie, EP en het Hof van Justitie vertegenwoordigen binnen de drie Gemeenschappen bij uitstek de supranationale ("Europese") elementen, terwijl de Raad de intergouvernementele ("nationale") elementen binnen de samenwerking vertegenwoordigt. De leden van de Raad zijn nationale ministers die primair optreden als vertegenwoordiger en behartiger van de eigen nationale belangen. Doordat de Raad verantwoordelijk is voor het nemen van besluiten, spelen nationale regeringen nog altijd een nauwelijks te overschatten rol binnen de EU. Dit neemt niet weg dat als gevolg van jurisprudentie en verdragsveranderingen de positie van het Hof en het EP in de loop der tijd aanzienlijk is versterkt waardoor ook de supranationale krachten wat meer op de voorgrond zijn komen te staan. In het chronologische overzicht - en in hoofdstuk 3 - zal nog uitvoerig worden ingegaan op de machtsbalans tussen nationale en supranationale (Europese) elementen binnen de EU.

\section{8-1964: succesperiode}

In de eerste periode van 1958 tot 1964 verloopt de samenwerking in het kader van de EEG ${ }^{18}$ voorspoedig (Dinan, 1994: 46-8). Desondanks is het een publiek geheim dat er vroeg of laat een conflict zal ontstaan tussen de Franse president De Gaulle enerzijds en de Commissie anderzijds. De Gaulle heeft een uitgesproken voorkeur voor intergouvernementele politieke samenwerking, terwijl de Commissie zit op de koers van supranationale economische samenwerking (Dinan, 1994: 48; Janssen en De Vree, 1985: 166-200 en 281-9). De Gaulle streeft in het bijzonder naar

\footnotetext{
is Aan de EGKS en Euratom zal bij de beschrijving van EU-geschiedenis geen aandacht meer worden besteed omdat de verder groei van de EU sinds 1957 zich nagenoeg volledig binnen het kader van de EEG heeft plaatsgevonden.
} 
intensievere West-Europese samenwerking op het gebied van defensie en buitenlands beleid. Op die manier hoopt hij West-Europa onder meer minder afhankelijk te maken van de VS. Het sluimerende conflict tussen De Gaulle (Frankrijk) en Commissie kent reeds in deze relatief succesvolle eerste periode twee kleine erupties. In 1961-2 lanceert De Gaulle plannen voor een rivaliserende politieke samenwerking tussen de EG-lidstaten buiten de Commissie en de EG om. De andere eruptie betreft het veto dat De Gaulle (Frankrijk) in 1963 uitspreekt over een mogelijke toetreding van het Verenigd Koninkrijk tot de EG op het moment de onderhandelingen tussen de Commissie en het Verenigd Koninkrijk nog in volle gang zijn. Ondanks de aanwezigheid van De Gaulle zijn de eerste zes jaar van de EEG succesvol, de economische integratie verloopt volgens plan.

Achteraf bezien wordt het belangrijkste succes in het kader van het streven naar verdere WestEuropese integratic in de rechtszaal van het Europese Hof van Justitie in Straatsburg geboekt. Het Hof weet zich in minder dan vijf jaar te ontwikkelen tot een onmiskenbare en tot op zekere hoogte onaantastbare supranationale juridische binnen de lidstaten. Middels zijn vroege jurisprudentic laat het $H o f$ van Jostitic in Luvemburg niets ass duideljikbeid te wensen over als het gaat om de supranationale status van de EU-verdragen en EU-regelgeving. Het Hof beslist in de inmiddels klassieke arresten Van Gend en Loos en Costa/Enel dat de nationale rechtsordes van de lidstaten onvoorwaardelijk ondergeschikt zijn aan de Europese rechtsorde die is ontstaan als gevolg van de oprichting van de EG (Kooijmans, 1996).

\section{5-1969: de ijstijd}

In 1965 loopt de zaak min of meer spaak. Een conflict tussen De Gaulle (Frankrijk) en de Commissie stort de EU in een crisis. Als bij besprekingen over de toekomst van het gemeenschappelijk landbouwbeleid Commissievoorstellen ter tafel komen die de macht van de EU-instellingen ten opzichte van de lidstaten zou vergroten, gaat De Gaulle pal staan. Het moment is zorgvuldig gekozen, het Verdrag van Rome bepaalt dat voor het nemen van een besluit in de Raad over een groot aantal onderwerpen per 1 januari 1966 de eis van unanimiteit zal vervallen. Dit zou betekenen dat de lidstaten hun vetomacht op een groot aantal terreinen zouden verliezen. Invoering van besluitvorming bij gewone meerderheid in de Raad, zou de macht van de Commissie aanzienlijk vergroten. De Raad, zo is vastgelegd in de verdragen, kan immers alleen besluiten nemen op voorstel van de Commissie. Deze combinatie - verlies van vetomacht en geen controle over de agenda van de Raad- is voor De Gaulle onverteerbaar. Daarom grijpt hij het meningsverschil over landbouwbeleid aan om een fundamentele crisis binnen de EG te veroorzaken.

De Gaulle kiest daarbij voor de frontale aanval (Janssen en De Vree, 1985: 281-9; Dinan, 1994: 55-9). Hij besluit de EG-instellingen te boycotten en eist dat voor besluitvorming in de 
Raad consensus vereist blijft (Nugent, 1999: 168-9). Na het nodige touwtrekken gaan de andere lidstaten akkoord met het beruchte Compromis van Laxemburg (Lieshout, 1997: 228). Het is een mondelinge overeenkomst tussen de lidstaten waarin wordt vastgelegd dat bij het nemen van besluiten (in de Raad) in beginsel gestreefd wordt naar consensus wanneer een lidstaat (zelf) meent dat haar vitale belangen in het geding zijn. Het Compromis betekent dat elke lidstaat in de praktijk over vetomacht beschikt en dat de formele hoofdregel dat de Raad met een gewone meerderheid besluiten neemt over Commissievoorstellen alleen op papier bestaat. De EU dreigt hierdoor te evolueren in een organisatie gebaseerd op intergouvernementele samenwerking.

De strijd van De Gaulle tegen versterking van de supranationale elementen van de EG verlamt uiteraard de Commissie die tot dan toe steeds het voortouw had genomen in het integratieproces. Deze patstelling duurt min of meer voort tot het einde van De Gaulle's presidentschap in april 1969. In de tussentijd, in 1967, spreekt de Gaulle nogmaals zijn veto uit over een hernieuwde Britse poging om toe te treden tot de EG. Doordat de ideeên van De Gaulle enerzijds en de EGinstellingen - vooral de Commissie - en in mindere mate de andere lidstaten anderzijds over de toekomstige samenwerking fundamenteel verschillen, komt het integratieproces in de tweede helft van de jaren zestig min of meer tot stilstand. De Fransen zijn er voortdurend op uit om de spelregels in hun eigen voordeel te veranderen. Dat de andere lidstaten dit accepteren, onderstreept de centrale positie die Frankrijk binnen de EU inneemt. Dit alles heeft wel tot gevolg dat de betrokkenheid van West-Duitsland bij de West-Europese integratie verslapt doordat de sociaal-democratische regering van West-Duitsland binnen haar buitenlandse politiek meer aandacht gaat besteden aan Oost-Europa (Ostpolitik) in het bijzonder gericht op een verzoening met Oost-Duitsland (Janssen en De Vree, 1985:290-6).

In de periode tussen 1965 en 1968 wordt het West-Europese integratieproces door De Gaulle min of meer tot stilstand gebracht. Middels het Compromis van Luxemburg is duidelijk dat de nationale krachten ook in de toekomst van de EG/EU een vooraanstaande rol zullen spelen. ${ }^{19}$

\section{9-1984: ontdooien}

$\mathrm{Na}$ het aftreden van de De Gaulle in april 1969 ontstaan er weer mogelijkheden.De Haagse topconferentie (december 1969) tussen de nieuwe Franse President Pompidou en de regeringsleiders van de vijf andere lidstaten markeert het begin van een nieuwe periode waarin ook de publieke opinie voor het eerst expliciet opduikt in de geschiedenis van de EU. Na zijn aantreden in 1969 is Pompidou er veel aan gelegen het vastgelopen integratieproces weer vlot te trekken, zonder overigens te tornen aan het Compromis van Luxemburg (Dinan, 1994: 71-2).

\footnotetext{
${ }^{19}$ Niettegenstaande de politieke problemen in deze periode gaat de feitelijke economische integratie in het kader van de EEG wel gewoon door; de onderlinge economische afhankelijkheid blijft en op 1 januari 1968 - anderhalf jaar eerder dan aanvankelijk gepland - is de EEG officieel een douane-unie (Janssen en De Vree, 1985: 308-9).
} 
In de Haagse slotverklaring komen de regeringsleiders en de Franse president overeen de komende jaren te streven naar meer eenheid door middel van het uitbreiden (meer lidstaten), het verbreden (meer beleidsterreinen) en het voltooien van de samenwerking. Deze slotverklaring markeert het einde van de "ijstijd".

Het herstel van de belangstelling van Frankrijk voor de EG en West-Europese integratie is weliswaar voor een deel toe te schrijven aan het verdwijnen van De Gaulle, maar onderstreept tegelijkertijd dat de EG vanuit Frans perspectief een middel is om West-Duitsland te beheersen en om die reden niet kan worden gemist. Frankrijk dreigt eind jaren zestig immers de grip op West-Duitsland enigszins te verliezen (Dinan, 1994: 73). De Gaulle's harde opstelling in het midden van de jaren zestig was voor West-Duistland het teken haar Ostpolitik te ontvouwen. Daarnaast heeft Frankrijk als gevolg van het weinig strakke monetaire beleid dat De Gaulle heeft gevoerd, inmiddels te maken met een economische depressie. Hoge inflatie, een uit het lood geslagen handelsbalans en een forse devaluatie van de Franse frane steken schril af tegen het Wirtschaftswunder in West-Duitsland. West-Duitsland dreigt zodoende langzaam maar zeker een politiek onafhankelijkere lijn te volgen en een economisch onaantastbare positie te krijgen. $\mathrm{Om}$ hier het hoofd aan te bieden zet Frankrijk de deur weer open voor Britse deelname aan de EG en dringt het aan op verdere intensivering van de economische en monetaire samenwerking. De Fransen hopen door het sluiten van een coalitie met de Britten de machtsbalans binnen de EG weer in hun richting te kunnen doen doorslaan (Dinan, 1994: 72). Zo herontdekt Frankrijk eind jaren zestig de waarde van West-Europese integratie als middel om een dreigende West-Duitse dominantie op het Europese continent een halt toe te roepen (Lieshout, 1997: 228-9).

De Fransen vergissen zich, meteen na toetreding blijkt al dat de Britten enkel defensieve bedoelingen nastreven met hun lidmaatschap en nagenoeg meteen - na het aantreden van premier Wilson - ruzie beginnen te maken over hun financiële bijdrage aan de EG. Het Compromis van Luxemburg in combinatie met de economische (olie)crises van de jaren zeventig vormen uiteindelijk geen omstandigheden waaronder grote stappen voorwaarts kunnen worden gezet. Het proces van economische integratie zit weliswaar niet meer muurvast, maar vooralsnog is er toch relatief weinig beweging in te krijgen. De ijstijd en de daarop volgende langdurige periode van ontdooien wordt daarom ook wel aangeduid als de periode van Eurosclerose (Dinan, 1994: 69).

Dit wil overigens niet zeggen dat er in het geheel niets gebeurt in de periode tussen 1969 en 1984. Uitbreiding ${ }^{20}$ vindt plaats door de toetreding van het Verenigd Koninkrijk, Denemarken en lerland in 1973, en Griekenland in 1981; verbreding door het opzetten van rudimentaire vormen van politieke (buitenlands beleid) en monetaire samenwerking (Europees Monetair Stelsel) tussen de lidstaten; en voltooiing door, onder andere, de introductie van eigen middelen -

${ }^{30}$ Groenland - een Deense provincie - trad na een referendum in 1982 uit de EG. 
vooral uit import-heffingen en een deel van de nationale BTW -, de toekenning van budgetrecht aan het Europees parlement (EP) en de introductie van rechtstreekse verkiezingen voor het EP in $1979 .{ }^{21}$

Een andere belangrijke gebeurtenis in deze periode is een strikt genomen niet-EGaangelegenheid die niettemin van grote invloed is op EG. Dit betreft de institutionalisering van de Europese Raad (1974) (Dinan, 1994: 239). Dit is een halfjaarlijks ${ }^{22}$ topoverleg tussen regeringsleiders en staatshoofden van de lidstaten, vergezeld door hun ministers van buitenlandse zaken en in aanwezigheid van de voorzitter en een vice-voorzitter van de Commissie. Het is uitdrukkelijk geen EG-instelling, ${ }^{3}$ maar een intergouvernementeel podium voor overleg tussen de lidstaten. De behoefte aan dit podium heeft te maken met het feit dat bij vergadering van de (gewone) Raad van ministers in EG-verband slechts over voorstellen van de Commissie kan worden gesproken en men bovendien vast zit aan de EG-vergaderorde en -besluitvormingsregels. Intergouvernementele topconferenties bieden daarentegen de mogelijkheid om vrijblijvend te praten over toekomstige besluiten en in alle rust te werken aan strategische plannen (Dinan, 1999: 243-4). Als een compromis cenmaal rijp is voor besluitvorming, dan kan de Commissie aan het werk om de EG-machinerie in werking te stellen. Door de institutionalisering van deze topconferenties verliest de supranationale Commissie de facto een deel van zijn exclusieve recht van initiatief in het kader van EG-besluitvorming aan een intergouvernementele vergadering van regeringsleiders; daarnaast betekent het bestaan van een Europese Raad die buiten de supranationale kaders van de EG valt, in zekere zin ook een verzwakking van de positie van het EP en het Hof van Justitie (Nugent, 1999: 202-4).

In het licht van het onderwerp van deze studie - de publieke opinie over de EU - is de periode van 1969-1984 nadrukkelijk een belangrijk keerpunt. In deze periode krijgt de bevolking voor het eerst de mogelijkheid om direct invloed uit te oefenen op de EG/EU. In 1979 vinden de eerste rechtstreekse EP-verkiezingen plaats. De daadwerkelijke invloed die het publiek langs deze weg op de EU uitoefent mag echter niet worden overdreven (zie paragraaf 2.4). Een nog directere manier om invloed op de EG uit te oefenen krijgt het publiek in een beperkt aantal lidstaten waar referenda over de EG worden uitgeschreven. Zo wordt de Fransen in 1972 gevraagd zich voor of tegen de toetreding van het Verenigd Koninkrijk, Ierland, Denemarken en Noorwegen uit te

\footnotetext{
${ }^{21}$ Voor 1979 bestond het EP uit afgevaardigden uit de diverse nationale parlementen.

${ }^{n}$ In eerste instantie viermaandelijks, dit wil zeggen driemaal per jaar.
}

${ }^{2}$ In de Europese Akte van 1986 wordt de Europese Raad voor het eerst als zodanig in een verdragstekst genoemd. Pas in het Verdrag van Maastricht (1991) krijgt de Europese raad een aantal specifieke taken toebedeeld (vooral artikel 4 EU-verdrag). In het Verdrag van Amsterdam (1997) is de rol van de Europese Raad verder versterkt. Alle artikelen die over de Europese Raad gaan, behoren formeel niet tot het gemeenschapsrecht en de uitleg van die artikelen vallen dus nog altijd niet onder de jurisdictie van het Europese Hof van Justitie. 
spreken. In datzelfde jaar krijgen achtereenvolgens de leren, Noren en Denen de mogelijkheid om zich uit te spreken over hun toetreding. De Fransen, Ieren en Denen stemmen toe met de uitbreiding respectievelijk toetreding, de Noorse bevolking wijst het lidmaatschap echter van de hand. De Britse bevolking spreekt zich in 1975 expliciet uit voor continuering van het EGlidmaatschap onder nieuwe voorwaarden; en de Italianen spreken zich in 1979, tegelijk met de eerste directe verkiezingen voor het EP, uit voor Italiaanse deelname aan het Europees Monetair Systeem (EMS). De invloed van publieke opinie op de EG is in deze periode dus voor het eerst heel direct en onmiskenbaar aanwezig (Nugent, 1999: 482-6).

De periode tussen 1969 en 1984 is geen "ijstijd" meer, maar ook geen periode van grote veranderingen. Achteraf bezien zijn er wel ontwikkelingen zichtbaar die uiteindelijk - bewust of onbewust - bijdragen aan de opmerkelijke doorstart van het integratieproces in het midden van de jaren tachtig, maar het ontbreekt in deze periode aan regie en visie. Een gezamenlijke WestEuropese reactie op de toch niet geringe uitdagingen van de jaren zeventig - milieu, oliecrises, werkloosheid en inflatie - blijft uit. De Commissie heeft zijn greep op de besluitvorming binnen de EG min of meer verloren aan de Europese Raad en de besluitvorming binnen de Raad stuit niet zelden op veto's. Middels rechtstreekse verkiezingen voor het EP en referenda groeit de publieke opinie uit tot een nieuwe factor van belang. De winst van deze periode is dat bij alle betrokkenen - Commissie, lidstaten (Raad) en EP - het inzicht groeit dat zonder institutionele hervormingen de integratie niet weer op gang zal komen (Dinan, 1994: 70).

\section{4-1989: hernieuwd elan}

In het midden van de jaren tachtig groeit de overtuiging dat het Compromis van Luxemburg niet langer houdbaar is. Inmiddels is overeenstemming bereikt over de toetreding van Spanje en Portugal tot de EU in 1986. Het nemen van unanieme besluiten in een Gemeenschap met 12 lidstaten is lastig, vooral ook doordat met het toetreden van Griekenland (1981), Spanje en Portugal (1986) de (economische) heterogeniteit toeneemt. Institutionele hervormingen waarbij de weegschaal weer wat meer moet doorslaan in supranationale richting zijn onontkoombaar. Een speech voor het EP van de Franse president Mitterand in mei 1984 markeert het keerpunt en zorgt voor een hernieuwd elan. Een volledig mislukt economisch experiment in eigen land doet Mitterand inzien dat een nationale aanpak van economische problemen niet meer van deze tijd is. Zijn oproep voor institutionele hervormingen en voor meer in- en externe bevoegdheden voor de EG-instellingen, wakkert het vuur van de Europese integratie weer aan (Dinan, 1994: 120-1). Tegelijkertijd laat hij een van zijn politieke adjudanten, Jacques Delors, naar Brussel gaan om de Commissie nieuw elan te geven.

Het nieuwe elan leidt uiteindelijk tot de ondertekening van de Europese Akte in 1986. In deze Akte worden institutionele hervormingen gekoppeld aan het streven naar één interne markt - 
onder druk van het Europese bedrijfsleven (Dinan, 1994: 137-9) - met vrij verkeer van goederen, arbeid, kapitaal en diensten per 1 januari 1993. ${ }^{24}$ Besluiten die betrekking hebben op voltooiing van deze markt vereisen, zo stelt de Akte, slechts een gekwalificeerde meerderheid in de Raad. Tevens krijgt het EP meer bevoegdheden waardoor haar mogelijkheden om de besluitvorming binnen de EG te beĭnvloeden groter worden. De Akte is tevens een manier om allerlei politicke, monetaire en andere vormen van samenwerking die in de loop der jaren in het kader van de EG zijn ontstaan een afdoende verdragsrechtelijke basis te geven. De Europese Akte en het daaraan gekoppelde streven naar voltooiing van één interne markt - het "1992"-project - luiden een nieuwe periode in het Europese integratieproces in. Het initiatief ligt, net zoals in een vorige succesperiode 1958-1964, bij de Commissie (Delors) - met de noodzakelijke steun vanuit de Frans-Duitse as (Mitterand-Kohl).

Ook in deze periode is er sprake van een actieve publieke opinie. Afgezien van de reguliere verkiezingen voor het EP in 1984 en 1989, zijn er in deze periode een viertal referenda. Het referendum (23 februari 1982) in Groenland leidt ertoe dat deze Deense "provincie" per 1 februari 1985 uit de EG treedt, hetgeen het territorium van de EG in één klap halveert. De Deense en lerse bevolking stemt in 1986 respectievelijk 1987 in met de Europese Akte. Middels deze referenda beschikkenen de Deense en lerse bevolking in beginsel over de mogelijkheid om het in werking treden van de Akte in alle lidstaten te blokkeren. In 1989 vindt in Italië tegelijk met de Europese verkiezingen een opiniërend referendum plaats waarbij de Italianen zich massaal scharen achter het streven om op korte termijn te komen tot een meer effectieve Unie.

In de periode 1984-9 komen de supranationale elementen binnen de EU weer tot bloei. Na bijna twintig jaar rust is er weer sprake van elan. Kenmerkend voor deze periode zijn de uitbreiding naar 12 lidstaten, een sterke Frans-Duitse as, een Commissie met een missie en de Europese Akte. De publieke opinie doet opnieuw van zich spreken middels referenda en verkiezingen voor het EP dar er langzaam maar zeker in slaagt om zijn macht binnen de EU uit te breiden.

\section{9-1998: het einde van de Koude Oorlog}

Het uiteenvallen van het Oostblok en de Sovjet-Unie, en de hereniging van Oost- en WestDuitsland in het begin van de jaren negentig markeren het definitieve einde van de Koude Oorlog. Deze ontwikkelingen markeren tevens het begin van een stromachtige fase in de geschiedenis van de EU. Dit laatste is logisch omdat het ontstaan van de EU onlosmakelijk verbonden was met de Koude Oorlog. Met het optrekken van het ijzeren gordijn tussen Oost- en West-Europa, is West-Europa in principe geen logische politieke entiteit meer en verandert

${ }^{24}$ Een resultaat wat volgens het oorspronkelijke EEG-verdrag al meer dan 20 jaar eerder had moeten worden bereikt! 
bovenal de strategische positie van West-Duitsland (Dinan, 1994: 465-7). Het herenigde Duitsland ligt midden in een min of meer open Europa en is voor haar verdere economische en politieke ontwikkeling niet meer exclusief aangewezen op West-Europa. Integendeel, vooral Duitsland met zijn lange oostgrens is onder deze omstandigheden gebaat bij een snelle politieke en economische herstructurering en integratie van Oost-Europa. In historisch perspectief hoeft het niet te verbazen dat met de hereniging van Oost- en West-Duitsland de angst bij de andere EU-lidstaten - in het bijzonder bij Frankrijk - toeneemt dat Duitslands toewijding aan de WestEuropese en Noord-Atlantische zaak onder druk komt te staan. Achteraf bezien blijkt het einde van de Koude Oorlog in 1989 vooral een belangrijke stimulans voor verdere West-Europese integratie te zijn geweest

Aanvankelijk is het West-Duitsland en eigenlijk de Duitse bondskanselier Kohl in hoogst eigen persoon, die onder invloed van de ontwikkelingen in Oost-Duitsland het tempo van de West-Europese integratie (inclusief een herenigd Duitsland) verhoogt en de richting aangeeft. De Commissie verliest haar controle over het proces. Op 9 november 1989 valt de Berlijnse muur en op 28 november tijdens een speech voor de Bondsdag komt Kohl met een tien-punten programma voor gecombineerde Duitse hereniging en verdere West-Europese integratie. Dit programma komt geheel en al uit de koker van Kohl (Dinan, 1994: 162-3). Hij voert dit keer zelfs geen overleg, zoals gebruikelijk bij Europese aangelegenheden, met Frankrijk. Duitsland start meteen de onderhandelingen met de Russische president Gorbachev over de uitkoop van Russische troepen die nog in Oost-Duitsland gelegerd zijn. De andere EG-lidstaten en de Commissie staan erbij en kijken ernaar. Kohl laat er geen enkel misverstand over bestaan dat de hereniging van de beide Duitslanden aanstaande is, maar geeft tegelijkertijd een signaal aan de EG-partners dat men niet bevreesd hoeft te zijn voor een Duitse Alleingang in Europa.

Ondertussen bezegelen de verdere ontwikkelingen in Oost-Europa de definitieve teloorgang van de Sovjet-Unie als supermacht. Daarmee valt opnieuw een van de initiële drijfveren achter de West-Europese samenwerking weg. Tegelijkertijd zorgen deze ontwikkelingen er voor dat de behoefte aan eenheid binnen de EG toeneemt. Die behoefte is enerzijds ingegeven door de wens om een effectieve en eensgezinde West-Europese vuist te kunnen maken ten opzichte van de te verwachte instabiliteit in Oost-Europa en anderzijds door de (Franse) wens om het herenigde Duitsland nog steviger aan de West-Europese ketting te leggen.

Als geen ander beseft en begrijpt Kohl de gevoeligheden bij zijn West-Europese partners (Lieshout, 1997: 231-2). Vandaar dat Kohl zelf komt met plannen voor versterking van de Westbindung. Na een mislukte Franse oproep aan West-Duitsland om het vooral rustig aan te doen met de hereniging, beseft Mitterand - zeker na de glansrijke overwinning van Kohls CDU bij de verkiezingen in maart 1990 - dat de aanstaande hereniging een feit is. Frankrijk kiest eieren voor zijn geld en steunt uiteindelijk Kohls plannen voor een snelle Duitse hereniging gekoppeld 
aan plannen voor een verdere verankering van het herenigde Duitsland binnen de EU. Door de Duitse dadendrang verschuift het initiatief in het West-Europese integratieproces in eerste instantie naar Duitsland, maar na de Franse koerswijziging ligt het weer bij de Frans-Duitse as.

$\mathrm{Na}$ een groot aantal reguliere en bijzondere bijeenkomsten van de Europese Raad en voortgedreven door de Duitse hereniging die al op 3 oktober 1990 een feit is, wordt uiteindelijk in december 1991 het Verdrag van Maastricht (Verdrag ter oprichting van de Europese Unie) ondertekend (Best, 1994). Dit verdrag behelst het opgaan van de drie bestaande Europese gemeenschappen in een de Europese Unie (EU). De EU omvat naast de drie bestaande supranationale Europese Gemeenschappen, een tweetal intergouvernementele vormen van politieke samenwerking. De eerste op het terrein van justitic en binnenlandse zaken, en de tweede op het terrein van buitenlands- en veiligheidsbeleid. Het EU-verdrag voorziet bovendien in een aantal spectaculaire wijzigingen in het EEG-verdrag ${ }^{25}$ met betrekking tot de invoering van een Europese Monetaire Unie (EMU) inclusief de oprichting van een onafhankelijke Europese Centrale Bank (ECB) voor het einde van het millennium. Verder wordt de competentie van de supranationale EG uitgebreid naar een aantal nieuwe beleidsterreinen (onder meer: cultuur, volksgezondheid, consumentenbescherming en ontwikkelingssamenwerking) en worden de EGbevoegdheden op andere beleidsterreinen (onder meer: milieu, r\&d) versterkt. Tegelijkertijd bevat het verdrag een aantal institutionele hervormingen waardoor het EP meer invloed krijgt op de besluitvorming binnen de EG-pijler van de EU. Ook nemen de mogelijkheden voor bestuurscontrole toe doordat het EP meer invloed krijgt op de samenstelling van de Commissie. De ondertekening van het Verdrag van Maastricht betekent zowel versterking van de bestaande supranationale samenwerking, als uitbreiding van de intergouvernementele samenwerking tussen de lidstaten.

Het venijn zit hem echter in de staart. De ratificatie van het ambitieuze EU-verdrag loopt uit op een anti-climax. In juni 1992 wordt het EU-verdrag ter goedkeuring voorgelegd aan de Deense en Ierse bevolking middels een referendum. Een ruime meerderheid van de leren stemt in met het EU-verdrag, maar de Denen spreken zich in meerderheid uit tegen het EU-verdrag. Dit leidt tot een diepe crisis binnen de EU. Het Deense $\mathrm{Nej}$ vereist nieuwe onderhandelingen. De gedachten gaan onwillekeurig terug naar het midden van de jaren vijftig toen het afketsen van het EDG- en EPG-verdrag in de ratificatiefase uiteindelijk leidde tot nieuwe plannen met een sterk verlaagd ambitieniveau. De Denen bewerkstelligen in de onderhandelingen dat in het verdrag meer nadruk komt te liggen op het idee van subsidiariteit en de open(baar)heid van de EG-besluitvorming (Edinburgh Agreement). Tevens openen ze de mogelijkheid om een lidmaatschap van de EU à la carte te krijgen (Best, 1994: 23-4). De Britten hadden in Maastricht een

${ }^{25}$ Tevens wordt de naam van het verdrag tot oprichting van de Europese Economische Gemeenschap (EEGverdrag), officieel gewijzigd in het Verdrag tot oprichting van de Europese Gemeenschap (EG-verdrag). 
uitzonderingspositie bedongen ten aanzien van de sociale paragraaf in het EU-verdrag, bij de nieuwe onderhandelingen bedingt Denemarken op een aantal punten een vergelijkbare uitzonderingspositie. In de daarop volgende herkansing (1993) gaat het Deense volk alsnog akkoord. Met de mogelijkheid om een lidmaatschap à la carte te krijgen lijkt het nationale veto dat in 1986 via de voordeur het pand leek te hebben verlaten, via de achterdeur weer binnen geslopen te zijn. Pas eind 1993, drie jaar na de Duitse hereniging, is de ratificatie van Maastricht en de Europese Unie een feit.

Ondanks deze tegenslagen is de periode vanaf 1989 bovenal een periode van successen voor de EU. Zo werd midden in de crisis rond de ratificatie van het Verdrag van Maastricht een uiterst belangrijke mijlpaal in het Europese integratieproces bereikt. Op 1 januari 1993 werd de gemeenschappelijke markt met vrij verkeer van diensten, arbeid, goederen, en kapitaal een feit. Verder is het aantal lidstaten in 1995 met drie uitgebreid tot vijftien. Per 1 januari 1995 zouden aanvankelijk vier nieuwe landen toetreden tot de Unie: Finland, Noorwegen, Oostenrijk en Zweden. De uiteindelijke beslissing om al dan niet tot de EU toe te treden was in elk van deze landen onderwerp van een referendum. In Oostenrijk (juni), Finland (oktober) en Zweden (november) was de uitslag positief, in Noorwegen (november) negatief, zodat uiteindelijk drie nieuwe lidstaten toetreden. Als uitvloeisel van de Verdrag van Maastricht zijn inmiddels ook de eerste stappen op weg naar een Europese Monetaire Unie (EMU) gezet: de oprichting van een onafhankelijke Europese Centrale Bank (ECB) belast met het bewaken van de inflatie in de gemeenschap en het toezicht houden op de monetaire politiek van de lidstaten (begrotingstekorten, staatsschulden) en de invoering van de girale euro op 1 januari 1999 in 11 lidstaten - Griekenland voldoet niet aan de criteria voor toetreding tot EMU, Zweden, Denemarken en het Verenigd Koninkrijk willen vooralsnog niet meedoen - gekoppeld aan een stelsel van vaste onderlinge wisselkoersen.

Verder bereikt men in januari 1997 overeenstemming over het Verdrag van Amsterdam. Dit verdrag brengt geen grote veranderingen met zich mee en is qua ambitieniveau onvergelijkbaar met het Verdrag van Maastricht. Dit heeft vooral te maken met het feit dat de lidstaten het niet eens konden worden over de overigens door iedereen onderschreven behoefte aan beleidsveranderingen (landbouwbeleid en structuurfondsen) en institutionele hervormingen met het oog op de toekomstige uitbreiding van de Unie in Oost-Europese richting. Het Verdrag van Amsterdam is daarom in de eerste plaats een revising treaty, hoewel op een aantal beleidsterreinen de supranationale elementen - versterkte rol EP en beperking van het unanimiteitsvereiste voor besluitvorming binnen de Raad - nadrukkelijk versterkt worden (Nugent, 1999: 83).

In de nabije toekomst zal de EU zich waarschijnlijk uitbreiden in oostelijke richting, hoewel op het punt van de daarvoor noodzakelijke institutionele hervormingen vooralsnog weinig 
vooruitgang wordt geboekt. Wel is Brussel actief bezig met de voorbereidingen voor de een mogelijke toetreding van de volgende landen: Bulgarije, Tsjechiē, Cyprus, Estland, Letland, Litouwen, Hongarije, Polen, Roemeniē, Slowakije, Sloveniè, Malta en Turkije. Met het einde van de Koude Oorlog lijkt dus de deur naar heuse Europese integratie opengezet.

Het optrekken van het ijzeren gordijn in Europa heeft vooralsnog geleid tot een intensivering van de bestaande West-Europese integratie, alsmede tot vergaande plannen voor een uitbreiding in oostelijke richting. De EU is inmiddels een hechte rechtsgemeenschap met vérgaande regelgevende bevoegdheden op een groot aantal beleidsterreinen en vormt inmiddels in economische zin één grote binnenmarkt. De betekenis van EU-regelgeving valt dan ook nauwelijks nog te overschatten (Dinan, 1994; Nugent, 1999; Scharpf, 1999).

\section{Tot slot}

De geschiedenis van de EU laat zien dat de totstandkoming en verdere ontwikkeling van de EU niet los te zien valt van de in de vorige paragraaf besproken bredere internationaal-politieke achtergronden van de na-oorlogse West-Europese samenwerking. Het ontstaan van de EG/EU kan alleen worden begrepen in het kader van de Koude Oorlog en de nationale belangen van de daarbij betrokken landen in die tijd in ogenschouw te nemen. Door haar (deels) supranationale karakter en de omvang van haar takenpakket onderscheidt de EU zich inmiddels echter nadrukkelijk van andere na-oorlogse West-Europese organisaties. Het is een hechte supranationale rechtsgemeenschap met supranationale instituties en de lidstaten vormen tezamen een (economische) markt met vrij verkeer van goederen, diensten, kapitaal en arbeid. Alle lidstaten hebben er veel belang bij dat deze markt goed blijft functioneren, ook nu de Koude Oorlog voorbij is. De EU lijkt inmiddels ook het onmisbare kader voor verdere samenwerking binnen geheel Europa omdat geen enkel (West-)Europees land afzonderlijk nog in staat is om Europa naar zijn pijpen te laten dansen en oplossingen voor Europese problemen af te dwingen. De aanwezigheid van zo'n sterk en supranationaal kader in het oudsher zo ernstig verdeelde Europa is onder die omstandigheden van onschatbare waarde (vgl. Lieshout, 1997: 236). De EU lijkt door deze ontwikkelingen ook bestaansrecht te hebben buiten de context van Koude Oorlog.

\subsection{Publieke opinie en EU}

In deze laatste paragraaf wordt specifiek aandacht besteed aan de feitelijke rol van de publieke opinie in de geschiedenis van de EU. De term publieke opinie wordt in dit boek nadrukkelijk gereserveerd als aanduiding voor de opinie van het "gewone volk", "de massa" of "de mensen 
in de straat". Als zodanig kan de publieke opinie worden onderscheiden van de opvattingen van de politiek-bestuurlijke elites zoals regeringsleiders, ministers, hoge ambtenaren, diplomaten en journalisten waarvan vaak wordt gezegd dat ze de mening van het volk vertolken.

\section{Elites of publiek?}

De geschiedenis van de na-oorlogse West-Europese integratie in het algemeen (2.2) en de EU in het bijzonder (2.3) overziend dringt zich bovenal het beeld van een relatief eenzijdig top-down proces op (Nugent, 1999: 97-8 en 484; Lieshout, 1997). Machtspolitiek en strategische overwegingen van de Amerikaanse, Franse, West-Duitse en, in mindere mate, andere WestEuropese na-oorlogse regeringen liggen ten grondslag aan het ontstaan en de bloei van de EU. Een cruciale rol in het integratieproces is weggelegd voor de Frans-Duitse as. Nationale ministers en regeringsleiders vervullen de hoofdrollen af en toe bijgestaan door EU-actoren. De EUgeschiedenis nauw verbonden met de namen van, met name Franse en Duitse, staatslieden, zoals: Adenauer, Schuman, Monnet, Pleven, Spaak, Hallstein, De Gaulle, Giscard d'Estaing, Schmidt, Kohl, Mitterand, Delors, enzovoort. Nationale politieke elites maken de dienst uit.

De centrale nationale actoren in die geschiedenis zijn uiteraard democratisch gekozen - of democratisch gelegitimeerde - nationale politici. In alle lidstaten bepaalt het publiek middels nationale verkiezingen in zekere zin de samenstelling en politieke kleur van haar nationale regering. Het nagenoeg ontbreken van een directe invloed vanuit de publieke opinie op de EUgeschiedenis betekent dus allerminst dat de publieke opinie niet indirect invloed uitoefent via de nationale politieke arena. Zo is de ruimhartige electorale steun vanuit het Franse publiek voor De Gaulle in de jaren zestig indirect van grote invloed geweest op de gang van zaken binnen de EU. In deze betekenis is de publieke opinie in de democratische lidstaten per definitie verantwoordelijk voor de geschiedenis van de EU. De relevante vraag die hier beantwoord moet worden, is echter of de electorale steun voor presidentskandidaten en politieke partijen in de nationale politieke arena (mede) is ingegeven door de denkbeelden van het electoraat over, en het handelen respectievelijk de standpunten van kandidaten respectievelijk partijen met betrekking tot de EU?

Is dat niet het geval, dan is er in wezen geen sprake van "echte" invloed vanuit de publieke opinie omdat er dan geen enkele garantie is dat het gedrag van de nationale politici op EU-niveau de publieke opinie in hun eigen land weerspiegelt. In de literatuur zijn nauwelijks aanwijzingen dat EU-issues een belangrijke rol spelen in het kiesgedrag van kiezers bij nationale verkiezingen. Integendeel zelfs (Butler en Stokes, 1974; Converse en Pierce, 1985). Alleen in Denemarken lijkt het EU-issue van tijd tot tijd te fungeren als invloedrijk nationaal politiek issue (Worre, 1995: 248). Er is derhalve weinig reden om te vooronderstellen dat de publieke opinie via de nationale politieke arena's in de lidstaten een grote indirecte invloed op de EU-geschiedenis heeft 
uitgeoefend, hoogstens is sprake van niet-bedoelde invloed. De feitelijke rol die de publieke opinie in de EU-geschiedenis speelt blijft vooralsnog steken bij nationale EU-referenda en rechtstreekse EP-verkiezingen (vanaf 1979). Op deze twee vormen van directe bemoeienis van het publiek met de EU wordt hieronder nader ingegaan.

\section{Referenda}

De invloed van de publieke opinie op de EU is waarschijnlijk het meest tastbaar aanwezig bij nationale referenda over EU-onderwerpen. Een dergelijk referendum vond overigens pas voor het eerst plaats in 1972, niet minder dan 20 jaar na de ratificatie van het EGKS-verdrag.

Vanaf 1972 hebben er in totaal 20 nationale referenda over de EU plaats gevonden in acht verschillende lidstaten en één niet-lidstaat (Nugent, 1999: 482-6). In 17 gevallen stemt het publiek in met het voorstel van de eigen regering, in 3 gevallen niet. ${ }^{26}$ Zowel in 1972, als in 1994 wijzen de Noren het door de eigen regering voorgestelde EU-lidmaatschap van de hand, en in 1992 wijzen de Denen het mede door de eigen regering gesloten Verdrag van Maastricht af. In 7 gevallen stemt de bevolking van een lidstaat expliciet in met de (wijzigingen in) verdragen die ten grondslag liggen aan de EU. In deze categorie valt het Franse referendum over het Verdrag van Maastricht in 1992 en de drie Deense $(1985,1993$, en 1998) en drie lerse $(1986,1992$ en 1998) referenda over respectievelijk de Europese Akte, het Verdrag van Maastricht en het Verdrag van Amsterdam. In 5 gevallen is de toetreding van een land afhankelijk van een nationaal referendum. In 1972 stemt de Deense en Ierse bevolking in met toetreding; en, in 1994 doen de Oostenrijkse, Finse en Zweedse bevolking hetzelfde. In 1 geval mag de bevolking zich uitspreken over de toetreding van andere landen. De Franse bevolking spreekt zich in 1972 positief uit over de uitbreiding van de EU met vier lidstaten. In 2 gevallen gaat het om het wel respectievelijk niet continueren van het EG-lidmaatschap. In 1975 stemt het Britse volk in met de continuering van het lidmaatschap onder de nieuwe voorwaarden die de conservatieve Britse regering na de toetreding in 1973 heeft weten te bedingen, en in 1986 stemt de bevolking van de Deense "provincie" Groenland in met het regeringsvoorstel om uit de EU te treden. Tot slot zijn er nog 2 consultatieve Italiaanse referenda geweest in 1979 en 1989 over Italiaanse deelname aan het Europees Monetair Stelsel (EMS) respectievelijk het streven naar een effectieve Europese Unie.

De introductie van nationale referenda in het begin van de jaren zeventig markeert het einde van een periode waarin van directe invloed van de publieke opinie op de EU uberhaupt geen sprake was. De uitkomsten van de referenda laten zien dat in veruit de meeste gevallen de

\footnotetext{
${ }^{\star}$ Op 28 september 2000 , een tijdstip dat buiten de onderzoeksperiode van deze studie valt, zegt het Deense volk in een referendum opnieuw Nej tegen een voorstel van de Deense regering om aansluiting te zoeken bij de EMU en over te gaan tot invoering van de euro. Door deze vierde misser komt het totaal aantal referenda op 21.
} 
bevolking instemt met het voorstel van de eigen regering, maar de missers onderstrepen dat de publieke opinie op sommige momenten toch een geheel eigen wending aan de EU-geschiedenis geeft. Zo is Noorwegen nog altijd geen lid van de EU en leidde het Deense "Nej" tot het opstellen van de zogenaamde Edinburgh Agreement. ${ }^{27}$ Naast de missers was ook de uitslag van het Deense referendum over de Europese Akte in 1986 van doorslaggevende betekenis, omdat in de Deense Folketing geen meerderheid voor de Akte was te vinden.

Desondanks is er reden om de mogelijkheden die EU-burgers hebben om middels nationale referenda invloed uit te oefenen op de EU ernstig te nuanceren. Ten eerste bestaat in een aantal lidstaten geen mogelijkheid om een referendum uit te schrijven, terwijl in andere landen waar die mogelijkheid er wel is het initiatief voor het uitschrijven van een referendum (mede) door president, regering en/of parlement moet worden genomen (Nugent, 1999: 482). Alleen in Denemarken. Noorwegen en lerland is de volksinvloed bij de ratificatie van internationale verdragen, waarbij de nationale soevereiniteit wordt beperkt, tot op zekere hoogte expliciet gewaarborgd in de nationale constitutic. In 7 van de huidige 15 lidstaten heeft echter nog nooit een referendum over de EU plaats gevonden.

Verder biedt een referendum enkel de mogelijkheid om ja of nee te zeggen tegen een reeds door de regering geformuleerd en uitgewerkt compromis. Het is, met andere woorden, een paardenmiddel.

Een derde gebrek is dat referenda in het kader van de EU bijna uitsluitend aan de orde zijn bij de ratificatie van verdragswijzigingen. Gabel (1998: 4-5) merkt terecht op dat er een opmerkelijk verschil is tussen de gewone bemoeienis van burgers met de nationale politiek aan de ene kant, en met de EU-politiek aan de andere kant. In tegenstelling tot hetgeen in de nationale politiek arena gebruikelijk is, bemoeien burgers zich op Europees niveau veel minder met de uitkomst van het politieke spel en veel meer met de regels van het spel in de vorm van verdragswijzigingen. Na wijziging van de verdragen gaan de "gordijntjes" weer dicht en hebben de politiek-bestuurlijke elites in belangrijke mate vrij spel om de uitkomsten van het spel te bepalen zonder verdere inmenging van het publiek. Met het in werking treden van de Europese Akte (juli 1987), het Verdrag van Maastricht (november 1993) en het Verdrag van Amsterdam (1999) is het EG/EU-verdrag zodanig opgerekt dat nagenoeg elk beleidsveld inmiddels tot het EU-takenpakket behoort. In de dagelijkse EU-besluitvorming binnen deze ruime kaders is vooralsnog geen plaats - of beter gezegd: wordt door de elites geen plaats ingeruimd - voor referenda. De meeste referenda gaan dus over onderwerpen waarbij geheel onduidelijk is wat de

n. De Edinburgh Agreement bevat de door de Deense regering gevraagde nadere toelichting op het Verdrag van Maastricht na het eerste desastreus verlopen Deense referendum over het Verdrag van Maastricht. Bij het opstellen van dit document werd nadrukkelijk geanticipeerd op de gevoeligheden in de Deense publieke opinie opdat het tweede Deense referendum over Maastricht niet ook op een mislukking zou uitlopen (Nugent, 1999; 484). 
inhoudelijke consequenties voor de burgers zullen zijn. Dit betekent dat Europese instituties en nationale politiek-bestuurlijke elites bij het nemen van besluiten over belangrijke beleidskwesties nog steeds vrij spel hebben, tenzij dergelijke kwesties zouden uitgroeien tot invloedrijke issues in de nationale politiek en de (her)verkiezing van nationale politieke elites beìnvloeden (indirecte invloed).

Tot slot zijn er aanwijzingen uit onderzoek dat burgers zich bij EU-referenda meer door nationale politieke overwegingen (voor/tegen zittende regering) laten leiden dan door de beoordeling van het EU-issue zelf (Marsh and Franklin, 1996: 30-1; Franklin, Van der Eijk en Marsh, 1995; 1996: 372-3, Franklin, Marsh en McLaren, 1994). Dit zou betekenen dat de uitslag van EU-referenda weliswaar richtinggevend is, maar dat de uitslag in wezen weinig met de mening van de burgers over de EU te maken heeft.

De introductie van referenda in het begin van de jaren zeventig markeert aan de ene kant dus een breuk met het verleden, aan de andere kant moeten de mogelijkheden die referenda aan het publiek bieden om direct invloed op de EU uit te oefenen vooral niet worden overdreven. De ruimte die het publiek neemt en/of van de politieke elites krijgt om langs deze weg invloed uit te oefenen op de gang van EU-zaken is over het algemeen uiterst beperkt. Het handelt hier dus om relatief willekeurige interventies. Desalniettemin hebben Noorse en in minder mate Deense referenda er daadwerkelijk voor gezorgd dat de EU-geschiedenis op een aantal punten anders is gelopen dan de politiek-bestuurlijke elites eerder overeengekomen waren.

\section{Directe verkiezingen voor het Europese Parlement}

Een andere potentiële mogelijkheid voor het publiek om direct invloed uit te oefenen op de EU en haar beleid ontstaat eind jaren zeventig met de introductie van rechtstreekse verkiezingen voor het Europees Parlement. In 1979 vinden de eerste rechtstreekse verkiezingen voor het EP plaats, voor die tijd werd het Europees parlement gevormd door afgevaardigden uit de verschillende nationale parlementen. In hoeverre bieden de introductie van rechtstreekse verkiezingen een serieuze mogelijkheid voor het grote publiek om invloed uit te oefenen op de EU?

De rechtstreekse verkiezing van het EP biedt burgers sinds 1979 de mogelijkheid om in een keer in de vijf jaar de samenstelling van een van de EU-organen te beïnvloeden. Het idee achter dit soort verkiezingen is dat:

"Proper democratic elections presuppose that the political verdict of electorates can be construed as emanating from the political preferences of voters, preferences that are relevant to the decision-making arena concerned. If this condition is met, elections can be considered to simultaneously (1) legitimize power allocated by the elections (and therefore also to legitimize policies which may be devised with this power) (2) exert electoral control by 
subjecting powerholders from a previous period to retrospective evaluation (that is, by holding officeholders accountable) and (3) represent groups of citizens and their interests in the political process (thus showing sensisitivity to their concerns). In order for elections to function in this way, a primary condition is that voters have some awareness of the political stance and record of candidades and parties in the arena under consideration. As a secondary condition, relevant media coverage of the arena in question is obviously of crucial importance." (Franklin en Van der Eijk, 1996: 6; onderstreping JJ)

Dit zou impliceren dat kiezers bij EP-verkiezingen hun partijkeuze baseren op de standpunten over EU-issues en het gedrag van partijen (of hun politici) binnen de EU. Franklin en Van der Eijk (1996: 6-7) wijzen er echter op dat burgers bij EP-verkiezingen over het algemeen niet in de gelegenheid worden gesteld om hun partijkeuze te baseren op partijstandpunten ten aanzien van EU-issues en het gedrag van politieke partijen binnen de Europese politieke arena. ${ }^{28} \mathrm{Zij}$ wijten dit vooral aan het feit dat EP-verkiezingen in nagenoeg alle lidstaten worden uitgevochten tussen nationale partijen - dit wil zeggen: politieke partijen die primair actief zijn in de nationale politiek. ${ }^{29}$ Alleen in Denemarken slagen Europese partijen er in enig succes te boeken.

Nationale partijen benaderen de EP-verkiezingen primair als een tussentijdse nationale populariteitspoll. De campagnes zijn primair nationaal van aard en gaan niet of nauwelijks over EU-issues omdat de deelnemende partijen op deze issues niet of nauwelijks stelling nemen ten opzichte van elkaar. ${ }^{30}$ Onder dit soort omstandigheden is het voor burgers praktisch onmogelijk om "Europees" te stemmen (Oppenhuis, 1995; Van der Eijk, Franklin \& Marsh, 1996).

Reif en Schmitt (1980) spreken in dit kader over tweede-orde verkiezingen. De strijd om de kiezers wordt bij Europese verkiezingen niet zozeer gevoerd in termen van EU-issues, als wel in termen van strijdpunten en issues uit de nationale politiek. Norris stelt dat nagenoeg alle studies naar partij- en kiesgedrag rond EP-verkiezingen dit beeld bevestigen en zij concludeert dat:

"... European elections are 'disappointing', because the parties fail to campaign, and certainly the public fails to be interested, in 'European' issues. The puzzle, for Europeanists, is why domestic politics repeatedly determines he outcome of European contests." (Norris, 1997: 109)

De consequenties van een en ander is dat EP-verkiezingen onmogelijk kunnen worden

\footnotetext{
${ }^{2}$ Voor meer informatie over het karakter en de problematische aspecten van EP-verkiezingen, zie onder meer: Blumler (1983); Reif (1984a, b); Lodge (1990, 1996); Oppenhuis (1995); Van der Eijk \& Franklin (1996).

${ }^{20}$ Analoog aan het onderscheid tussen nationale en lokale lijsten bij lokale verkiezingen.

${ }^{30}$ De verklaring voor dit wonderlijke fenomeen zou moeten worden gezocht in het feit dat nationale partijen vaak intern verdeeld zijn over EU-issues en er geen of weinig belang bij hebben om Europese issues hoog op te spelen (Franklin, Van der Eijk \& Marsh, 1996: 370-3).
} 
beschouwd als een serieuze mogelijkheid voor burgers om richting te geven aan de EU.

Het feit dat EP-verkiezingen zo weinig Europees zijn, wordt waarschijnlijk ook indirect bepaald door een tweede punt van zorg: de beperkte bevoegdheden van het EP. In dit kader duikt veelvuldig de term "democratische gat" op, om aan te geven dat de rechtsreeks gekozen volksvertegenwoordiging relatief weinig invloed heeft op de regelgeving en de besluitvorming binnen de EU. Voorstellen om dit gat te dichten, bevatten vaak drie verschillende elementen:

"a true bicameral legislature, with EP assent required for all EU legislation; an EP power to propose legislation; and systematic majority voting in the Council of Ministers. "(Gabel, 1998: 7-8)

Dit citaat illustreert dat burgers bij Europese verkiezingen een volksvertegenwoordiging kiezen die in vergelijking met hum eigen nationale parlement een aantal cruciale (mede)wetgevende bevoegdheden ontbeert. Dit heeft alles te maken met de omstandigheid dat toen de lidstaten (nationale partijen) in het verleden besloten om een deel van hun soevereiniteit aan de EU af te staan, ze tegelijkertijd naar mogelijkheden zochten om de nationale inbreng in de EUbesluitvorming te waarborgen. Om die reden is binnen de EU de bevoegdheid tot het nemen van besluiten over wetgeving voorbehouden aan de Raad. De Raad bestaat uit nationale ministers. Het verzorgen en bewaken van de Europese inbreng in de wetgeving is niet voorbehouden aan het EP, maar aan de Commissie. De Commissie heeft het exclusieve recht van initiatief binnen de EU-besluitvorming. De Raad kan slechts besluiten over regelgeving nemen als de Commissie een voorstel formuleert. De Commissie - en niet het EP - belichaamt in deze constructie het bij uitstek Europese (supranationale) element binnen de EU, terwijl de Raad - waarin het streven naar consensus tot in de jaren negentig de norm was (Nugent, 1999: 170) - het nationale (intergouvernementele) element belichaamt. Voor het Europees Parlement was in deze constellatie aanvankelijk slechts een raadgevende functie aan de zijlijn weggelegd. Pas in de laatste vijftien jaar als gevolg van het in werking treden van de Europese Akte (1987), het EUverdrag (1993) en Verdrag van Amsterdam (1998) heeft het EP een substantiële rol als medewetgever (naast Commissie en Raad) weten te claimen en zijn de bevoegdheden van het EP door de lidstaten langzaam maar zeker uitgebreid (Nugent, 1999: 88 e.v.). ${ }^{31}$

${ }^{31}$ In de jaren zeventig kreeg het EP reeds de beschikking over budgetrecht. In de afgelopen vijftien jaar is het EP er in geslaagd - door de rechtstreekse verkiezingen kregen de claims van het EP om meer macht een zekere legitimiteit - om steeds meer invloed te verwerven op de EU-besluitvorming. De Europese Akte (1986), het Verdrag van Maastricht (1993) en het Verdrag van Amsterdam (1999) hebben de macht van het EP steeds verder uitgebreid. De EU-verdragen bepalen nu per beleidsterrein welke rol Commissie, Raad en EP bij de besluitvorming spelen (zie: Nugent, 1999: 88 e.v.). Commissie en Raad worden hierdoor gedwongen om steeds beter naar het EP te luisteren. Dit betekent dat besluitvorming en regelgeving binnen de EU steeds minder het exclusieve domein van Commissie en Raad is, maar steeds meer een samenspel vormt tussen Commissie, Raad en EP. De grotere macht van het EP hangt ook samen met het feit dat de veto-macht van individuele lidstaten naar de achtergrond is verdwenen. Het Compromis van Luxemburg is in de loop der tijd meer en meer naar de achtergrond gedreven en anno $2001 \mathrm{kan}$ men 
In het grootse deel van de onderzoeksperiode (1952-1986) was het EP dus een primair raadgevend EU-orgaan met weinig invloed. Hoewel de positie van het EP binnen de EU in de laatste vijftien jaar nadrukkelijk is versterkt en het EP zich inmiddels heeft kunnen ontwikkelen tot medewetgever op beperkte schaal, is in vergelijking met de mogelijkheden en bevoegdheden die nationale parlementen hebben met betrekking tot (mede)wetgeving nog altijd sprake van een gemankeerd parlement. Tegen die achtergrond hoeft het gebrek aan interesse bij partijen, kiezers (lage opkomst) en media voor deze verkiezingen dus nauwelijks te verbazen.

Het gebrek aan bevoegdheden speelt de EP-verkiezingen ook nog op een andere manier parten. Daar waar het doel van sub-nationale en nationale verkiezingen vaak in belangrijke mate gaat over de vraag welke partij of partijen de nieuwe "regering" zullen vormen, speelt dit element in de Europese verkiezingen tot op heden nauwelijks een rol. Zo stellen Franklin en van der Eijk: "..., the European parliament does not have the most important power associated with parliamentary governement, since the executive of the EU is not directly affected by the balance of parliamentary representation of electoral forces. So european elctions do not initiate governement formation, as they do in most parliamentary democracies. "(Franklin en Van der Eijk, 1996: 4-5)

De rol van de "regering" wordt in de EU gespeeld door de Raad (besluitvorming) en de Commissie (uitvoering) tezamen. Het is logisch dat het EP geen enkele invloed heeft op samenstelling van de Raad, de vergadering van nationale ministers. Wel vreemd is het dat een direct gekozen Europese volksvertegenwoordiging niet of nauwelijks invloed heeft op de samenstelling van de Commissie, het supranationale hart en dagelijks bestuur van de EU, De commissarissen zijn wel verantwoording schuldig aan het EP, maar worden benoemd door de regeringen van de lidstaten. In de praktijk is elk land zelfs min of meer vrij in de keuze van haar eigen commissaris(sen) (Dinan: 1994: 207).

De mogelijkheden voor bestuurscontrole vanuit het EP op de Commissie, het dagelijks bestuur, laten ook veel te wensen over. Tot 1993 kon het direct gekozen EP alleen een eenmaal zittende Commissie in zijn geheel naar huis sturen door het aannemen ${ }^{32}$ van een motie van wantrouwen. Het EP had vervolgens echter geen enkele invloed op de samenstelling van de nieuwe Commissie. Pas met het in werking treden van het Verdrag van Maastricht in 1993 heeft het EP de mogelijkheid gekregen om op beperkte schaal ook in positieve zin invloed uit te oefenen op de samenstelling van een nieuwe Commissie. Sindsdien is namelijk bepaald dat alvorens de regeringen van de lidstaten een nieuwe Commissie kunnen benoemen, zij hun

zich zelfs afvragen of het Compromis nog enig gezag heeft.

${ }^{32}$ Het aannemen van zo'n motic behoeft een meerderheid van twee derden der uitgebrachte stemmen en die meerderheid moest bovendien een absolute meerderheid van de zetels in het EP vormen (artikel 201 EG-verdrag). 
voordracht voor zowel de nieuwe voorzitter van de Commissie als het daaropvolgende voorstel voor de samenstelling van de gehele Commissie eerst ter goedkeuring moeten voorleggen aan het nieuw gekozen EP (veto-macht). Dit betekent dat er sinds 1993 voor politieke partijen de mogelijkheid bestaat om het voorzitterschap respectievelijk de samenstelling van de Commissie tot inzet van de Europese verkiezingen te maken. Vooralsnog gebeurt dit echter niet (Franklin, Van der Eijk \& Marsh, 1996: 387). Dit is opmerkelijk omdat de ideologische scheidslijnen tussen de nationale partijen in de verschillende lidstaten veelal een zelfde achtergrond hebben, waardoor de vorming van Europese partijen of transnationale coalities die de politieke kleur van de Commissie (of haar voorzitter) expliciet tot inzet van de Europese verkiezingen maken in principe heel goed denkbaar is (Van der Eijk, Franklin en Oppenhuis, 1996: 363-5)." Een dergelijke handelwijze zou de positie van het EP ten opzichte van de Commissie en de regeringen van de lidstaten kunnen versterken en het belang van EP-verkiezingen kunnen doen toenemen. Doordat dit echter niet gebeurt, ontberen EP-verkiezingen een aansprekende functie - het bepalen van de regeringssamenstelling - die verkiezingen normaal gesproken wel hebben.

Ondanks dat de bevoegdheden en macht van het EP in de laatste jaren zijn toegenomen, staan de rechtstreekse EP-verkiezingen nog steeds niet in het teken van EU-zaken. De geringe behoefte van aan de Europese verkiezingen deelnemende nationale politieke partijen om zich bij de Europese verkiezingen ook daadwerkelijk in Europese zin te profileren, maken dat het voor de kiezers uiteindelijk min of meer onmogelijk is om langs deze weg enige invloed op het beleid van de EU uit te oefenenen. Vooral de vorming van transnationale politieke partijen die een Europese campagne voeren waarin, bijvoorbeeld, de kleur of samenstelling van de Europese Commissie expliciet tot inzet van de Europese verkiezingen worden gemaakt, zou de herkenbaarheid van Europese verkiezingen als zodanig kunnen vergroten.

\section{Publieke invloed gering}

Hierboven is vastgesteld dat de feitelijke rol die de publieke opinie in de EU-geschiedenis speelt vooralsnog uiterst beperkt is gebleven. De introductie van nationale referenda over EU-zaken heeft hier slechts tot op zekere hoogte verandering in kunnen brengen. Het gaat daarbij in wezen om relatief willekeurige interventies. Ook de introductie van rechtstreekse verkiezingen voor het EP in 1979 heeft de invloed van burgers op de EU-politiek vooralsnog nauwelijks kunnen vergroten.

${ }^{3}$ Gabel relativeert juist de mogelijkheden voor trans-nationale partijpolitieke coalities op ideologische grondslag, omdat partijen uit dezelfde ideologische hoek uit verschillende lidstaten andere belangen hebben in de EU-politiek. Die verschillen hangen samen met de verschillen in de sociaal-economische omstandigheden tussen de lidstaten (Gabel, 1998:1 19-22). Wat voor "links" goed is in een rijke lidstaat, hoeft niet perse goed te zijn voor "links" in een arme lidstaat. 
Sommige onderzoekers maken zich nadrukkelijk zorgen over de geringe betrokkenheid van burgers bij de EU en het geringe Europese karakter van de Europese verkiezingen. Vanhoonacker stelt op basis van een uitgebreide analyse van de diverse nationale ratificatieprocedures van het EU-verdrag (Verdrag van Maastricht) dat:

"The 'nej' of their citizens not only shocked the Danish government and parliament which realized that they were facing a serious communication problem with their electorate, but also caused a shock-wave throughout the whole of Europe. The reticence of the Danes woke up many European citizens who until then had been merely indifferent with regard to the Treaty and stimulated them to have a closer and more critical look at the implications of further integration." (Vanhoonacker, 1994: 4-5):

en:

"Last but not least, there is the contimuing problem of explaining the implications of the European integration process to the European citizens. If Maastricht has revealed the gap existing between Europe and its population, it remains doubtful whether the debates on the Treaty have been able to close it," (Vanhoonacker, 1994: 9).

Franklin, Van der Eijk en Marsh waarschuwen dat zolang de Europese verkiezingen een soort veredelde nationale verkiezingen blijven dat:

"It brings the risk of a breakdowm in support for European Union" (Franklin, Van der Eijk en Marsh, 1996: 381);

en:

"One thing that should have become clear in the aftermath of the Maastricht referenda, but seems to have largely escaped commentators and politicians of all stripes, is that European voters need to be involved in deliberations about the future of the European project." (Franklin, Van der Eijk en Marsh, 1996: 382)

Tegen deze achtergrond zien deze onderzoekers - paradoxaal genoeg - vooralsnog weinig positiefs in de roep om meer bevoegdheden voor het EP. Een uitbreiding van bevoegdheden zonder versterking van het Europese element in de verkiezingen door de betrokken politieke partijen zou de kans op misverstanden tussen volk en volksvertegenwoordiging immers alleen maar vergroten.

De geringe invloed van EU-burgers op de EU wordt dus nadrukkelijk gezien als een probleem, maar de oplossing ligt niet voor de hand. Gabel (1998: 122) worstelt ook met deze kwestie. Hij wijst op het gevaar dat een plotselinge toename van de betrokkenheid van burgers bij EU-zaken zelfs zou kunnen leiden tot het uiteenvallen van de EU als gevolg van een gebrek aan crosscutting cleavages. Onder dergelijke omstandigheden is de kans groot dat in publieke debatten over EU-issues de meningen van EU-burgers zich primair langs nationale scheidslijnen zullen verdelen. In zo'n situatie is de kans op het ontstaan van onoverbrugbare conflicten tussen 
burgers uit verschillende lidstaten levensgroot aanwezig. Dit alles pleit voor een geleidelijke weg en het behoedzaam creëren van een Europese politieke cultuur waarin nadrukkelijk op zoek wordt gegaan en ruimte wordt geboden aan andere dan nationale tegenstellingen. Politieke partijen zullen daarbij het voortouw moeten nemen.

In het licht van bovenstaande opmerkingen moet de vaak lichtzinnig uitgesproken wensen om de bevoegdheden van het EP uit te breiden en de band tussen EU en burgers te versterken dus nadrukkelijk worden gerelativeerd. De geringe betrokkenheid van burgers dient in zekere zin ook het voortbestaan en het succes van de EU. 


\section{Eastons politieke-systeemtheorie: publieke steun en internationale politieke systemen}

\subsection{Inleiding}

In het vorige hoofdstuk is gewezen op de geringe feitelijke invloed die de publieke opinie tot nog toe gehad heeft op de ontwikkeling van de EU. Tegen de achtergrond van de niettemin succesvolle uitbouw van de EU in de laatste vijftig jaar kan men zich derhalve afvragen: in hoeverre politieke systemen publieke steun behoeven? Niet zelden worden politicke systemen immers gekarakteriseerd als systemen die hun gezag uiteindelijk ontlenen aan het feit dat ze de naleving van hun besluiten zo nodig tegen de wil van de burgers (zonder steun) kunnen afdwingen. In dat licht zou men zelfs kunnen vooronderstellen dat publieke steun niet wezenlijk is voor het functioneren en voortbestaan van politieke systemen. Dit zou dan nog sterker gelden voor internationale organisaties als de EU, VN, NAVO en OESO die in het dagelijks functioneren nauwelijks met gewone burgers van doen hebben. In dit hoofdstuk zal aan de hand van de politieke-systeemtheorie van David Easton geprobeerd worden antwoord te geven op de vraag in hoeverre politieke systemen voor hun functioneren en voortbestaan zijn aangewezen op publieke steun. Easton staat in zijn gezaghebbende werk uitvoerig stil bij de relatie tussen politieke steun enerzijds, en het functioneren en voortbestaan van politieke systemen anderzijds. In het bijzonder zal worden nagegaan in hoeverre Eastons centrale these dat elk politiek systeem om te kunnen blijven functioneren een zekere mate van politieke steun behoeft, ook zonder meer van toepassing kan worden verklaard op internationale organisaties. In dat kader is het noodzakelijk om na te gaan of allerlei vormen van internationale samenwerking wel zijn aan te merken als politiek systemen. Verder zal worden stil gestaan bij de vraag in hoeverre het begrip politieke steun in Eastons visie moet worden opgevat als publieke steun; en zo ja, of het in het geval van internationale organisaties zoals de EU ook gaat om publieke politieke steun.

\subsection{Easton: samenleving en politiek systeem}

De Amerikaanse politicoloog David Easton gaat in zijn invloedrijke boek A Systems Analysis of 
Political Life in op de vraag welke processen en variabelen politieke systemen in staat stellen om te functioneren en te kunnen blijven voortbestaan. Het uitgangspunt van de voor dat doel opgestelde politieke-systeemtheorie is dat elke samenleving (society) een politiek (sub)systeem behoeft ter vervulling van een essentiēle functies die niet door andere (sub)systemen binnen de samenleving kunnen worden overgenomen (1965: 21-5). De term samenleving slaat op:

"... all interactions through which the members of a group seek to cope with the problems of living together. " (Easton, 1973: 293)

Om een samenleving in stand te kunnen houden moet er een politiek systeem zijn dat besluiten genereert die door alle leden van de samenleving als bindend ervaren worden, ook als die besluiten niet overeenkomen met de actuele wensen of actuele belangen van elk individueel lid. In het laatste ligt tevens de noodzaak van een politiek (sub)systeem besloten. Sommige besluiten zijn noodzakelijk om als groep te kunnen blijven samenleven, maar kunnen niet aan het vrije initiatief van en onderhandelingen tussen burgers zelf overgelaten worden. ${ }^{34} \mathrm{De}$ interacties binnen een samenleving die gericht zijn op het voortbrengen van dit soort besluiten, duidt Easton aan als het politieke systeem. Elke vorm van samenleven behoeft zo'n politiek (sub)systeem, net zoals elke samenleving een economisch en cultureel (sub)systeem heeft. Als zodanig moeten politieke systemen:

"... be able to allocate values for a society: they must also manage to induce most members (JJ: of the society) to accept these allocations as binding, at least most of the time. "(Easton, 1965: 22-4)

De functie van politieke systemen is het voortbrengen van besluiten over de toedeling van waarden - dit wil zeggen: de keuze om binnen de samenleving aanwezige alternatief aanwendbare schaarse middelen aan te wenden voor het bereiken van bepaalde doelstellingen (terugdringen criminaliteit, verbeteren onderwijs, aanpak wachtlijsten, lastenverlichting, enzovoort) (vgl. Easton, 1975: 161 en 269) - voor de gehele samenleving, alsmede er voor zorg te dragen dat die besluiten ook daadwerkelijk - "to induce most members to accept these allocations as binding, at least most of the time" - worden geaccepteerd door de samenleving. De combinatie van gezaghebbendheid ${ }^{35}$ - geaccepteerd weten te krijgen van besluiten door de samenleving - en besluitvaardigheid - het nemen van besluiten voor de samenleving - vormt het

\footnotetext{
"Zo stelt Easton (1975: 269): "All [J]: political] systems require of individual members, groups and often of whole generations that they sacrifice present goods for future rewards."

"Om misverstanden te voorkomen, gezaghebbendheid klinkt mogelijkerwijs liever dan het is bedoeld. Waar in het citaat wordt gesproken van "to induce members" moet nadrukkelijk ook aan het gebruik van geweld worden gedacht. Geweld kan een bijzonder effectief middel zijn om onwillige leden van de samenleving die het bindende karakter van genomen besluiten betwisten te laten beseffen dat het beter is om hun verzet op te geven. Gezag impliceert dus geenszins vrijwillige instemming, hoewel een systeem dat voortdurend en voornamelijk geweld gebruikt om zijn gezag te vestigen waarschijnlijk geen lang leven beschoren is.
} 
wezenskenmerk van politieke systemen.

Of er sprake is van een politiek systeem is dus een empirische vraag. De vraag of een politiek systeem gezag heeft, is af te leiden uit de mate van acceptatie - most members, most of the time van politieke besluiten door de samenleving. In het geval van een volledig gezaghebbend systeem worden de uitkomsten van de besluitvorming door de leden van de samenleving zonder meer als bindend ervaren. Om te kunnen spreken van een politiek systeem moet het tegelijkertijd gaan om een besluitvaardig systeem. Dit wil zeggen, een systeem dat er onder alle - ook moeilijke omstandigheden in slaagt om besluiten over de toedeling van waarden voor de samenleving te nemen. Zoals reeds vermeld gaat het bij de toedeling van waarden om besluiten aangaande de inzet van schaarse middelen voor concrete doeleinden (Easton, 1975: 269-70); het stellen van gemeenschappelijke - in de meest letterlijke betekenis van het woord - prioriteiten.

Verliest een politiek systeem zijn gezaghebbendheid en/of zijn besluitvaardigheid, dan betekent dit het einde van het politieke systeem. Dit vormt tevens een directe bedreiging voor het voortbestaan van de samenleving als zodanig, immers als (Easton, 1965: 24):

"... the [JJ: political] authorities are consistently unable to make decisions or if they strive to do so, the decisions are no longer regularly accepted as binding. Under these conditions, authoritative allocations of values are no longer possible and the society would collapse for want of a system of behaviour to fulfill one of its vital functions"

De samenleving in het algemeen, maar bovenal de personen die rollen vervullen binnen het politieke systeem hebben er dus belang bij dat de gezaghebbendheid (de vertaling van het engelse authorative) en besluitvaardigheid van het politieke systeem voortdurend op peil blijven.

Hoewel politieke systemen noodzakelijk zijn, is het voortbestaan van bestaande politieke systemen (en samenlevingen) allerminst vanzelfsprekend. De gezaghebbendheid en besluitvaardigheid van bestaande systemen wordt namelijk voortdurend beïnvloed vanuit de interne (vanuit de eigen samenleving) en externe (vanuit andere samenlevingen) omgeving van het politieke systeem. Easton spreekt in dit kader over inputs (1965:26-7). Hij maakt een analytisch onderscheid tussen twee categorieën inputs, te weten: politieke steun (political support) en politieke eisen (political demands). Inputs kunnen het functioneren van het politieke systeem zowel positief, als negatief beïnvloeden.

Als inputs de gezaghebbendheid en/of besluitvaardigheid van een systeem negatief beïnvloeden, dan ontstaat stress. ${ }^{36}$ Het binnen de perken houden van de stress die wordt veroorzaakt door omgevingsinvloeden, is in Eastons visie een noodzakelijke voorwaarde voor het voortbestaan van een politiek systeem. Met andere woorden, stressmanagement is geen

${ }^{36}$ Stress is het gevaar de "essential variables [of political life] are pushed beyond what we may designate as their critical range" (Easton, 1965:23). De essentielle factoren zijn de besluitvaardigheid en de gezaghebbendheid. 
bijzaak maar hoofdzaak. De manieren waarop politieke systemen omgaan met stress is een van de centrale thema's in Eastons werk. In abstracto kennen politieke systemen eigenlijk maar één manier om stress te bestrijden, het nemen van besluiten (outputs). Door middel van besluiten kan het systeem invloed uitoefenen op zijn omgeving en trachten de stressfactoren op een zodanige wijze te beïnvloeden dat ze niet langer een bedreiging vormen voor de gezaghebbendheid en/of besluitvaardigheid. Daarbij kan er een onderscheid worden gemaakt tussen besluiten die gericht zijn op beìnvloeding van de omgeving enerzijds, en besluiten die het politieke systeem zelf betreffen. In het eerste geval probeert het systeem met politieke besluiten ongewenste situaties in de samenleving aan te pakken. Als de oorzaak van de stress echter in het politieke systeem zelf - bijvoorbeeld: een in de ogen van de omgeving ondeugdelijke regering - is gelegen, dan kan slechts een besluit om te komen tot aanpassingen binnen het politieke systeem - in dit geval, de vorming van een nieuwe regering - soelaas bieden. Deze laatste categorie besluiten heeft Eastons speciale belangstelling en vormt de afhankelijke (te verklaren) variabele in zijn politiekesysteemtheorie. De belangstelling voor stress, steun en eisen komt namelijk direct voort uit zijn wens om te kunnen verklaren waarom sommige politieke systemen probleemloos functioneren en onveranderd voortbestaan, terwijl andere politieke systemen voortdurend aan veranderingen onderhevig zijn of zelfs volledig ten onder gaan (vgl. Easton, 1965: 14-6; 1973: 282-3 en 29599). Easton probeert primair een verklaring te geven voor de stabiliteit respectievelijk instabiliteit van politieke systemen. In zijn ogen moet de belangrijkste oorzaak voor de (in)stabiliteit van politieke systemen worden gezocht in de mate en de aard van de stress die twee typen omgevingsfactoren - eisen en steun - veroorzaken. De instabiliteit van politieke systemen moet als zodanig primair worden begrepen als expliciete pogingen om steun- en eisenstress te reduceren.

Eastons politieke-systeemtheorie probeert de dynamische relatie tussen politieke systemen en hun omgeving in kaart te brengen. Het doel dat Easton daarbij voor ogen staat, is het vinden van een verklaring voor, en het vergroten van het inzicht in de (in)stabiliteit van politieke systemen. In dit kader introduceert hij het theoretische concept politieke steun. Bij dit concept zal in deze studie naar de publieke steun voor de EU nadrukkelijk aansluiting worden gezocht en om die reden zal er hieronder (paragraaf 3.4) de nodige aandacht aan worden besteed. Omwille van de volledigheid zal eerst worden gekeken naar de andere input en potentiële stressfactor, politieke eisen. 
Welke invloeden vanuit de omgeving op het politieke systeem vallen onder de noemer politieke eisen? En wanneer veroorzaken politieke eisen stress? Op deze twee vragen zal getracht worden een antwoord te geven.

Easton omschrijft een politieke eis als volgt:

".. an expression of opinion that an authoritative allocation with regard to a particular subject matter should or should not be made by those responsible for doing so. " (Easton. 1965: 38)

Onder de noemer politieke eisen vallen dus allerhande expliciete verzoeken vanuit de omgeving aan het adres van het politieke systeem om met betrekking tot een concreet onderwerp een voor de gehele samenleving bindend besluit te nemen. Eisen vormen vaak een reactie op of zijn een uitvloeisel van situaties die door een deel van de omgeving als ongewenst of problematisch worden ervaren. Politieke eisen zullen meestal afkomstig zijn vanuit de eigen samenleving, maar de omgeving omvat nadrukkelijk meer dan de eigen samenleving zodat eisen ook van "buiten" andere politieke systemen of actoren uit andere samenlevingen - kunnen komen.

Politieke eisen als zodanig leiden niet noodzakelijkerwijs tot stress. Integendeel, door het bestaan van politieke eisen weten de mensen die actief zijn binnen het politieke systeem welke verwachtingen er in de omgeving ten aanzien van hun functioneren worden gekoesterd. Door adequaat in te spelen op deze verwachtingen kan een politiek systeem zijn bestaansrecht onderstrepen. Eisen leiden pas tot stress als het systeem er niets mee doet of niets mee kan, en de omgeving door krijgt dat het systeem niet (meer) in staat is om adequaat op eisen te reageren. Easton onderscheidt twee soorten demand stress (1965: 58-69). Als het aantal eisen vanuit de omgeving aan het adres van het politieke systeem (systematisch) groter is dan een politiek systeem aan kan, ontstaat volume (demand) stress doordat eisen noodgedwongen steeds langer zullen blijven liggen. Daarenboven kan de oorzaak van stress echter ook liggen in de inhoud van de eisen. Dan is sprake van content (demand) stress. Dit is bijvoorbeeld het geval als de omgeving onrealistische hoge - de politiek moet er voor zorgen dat iedereen gelukkig is - of tegenstrijdige - kruisraketten wel respectievelijk niet plaatsen - eisen formuleert. In deze gevallen kiest het systeem in de ogen van de hele omgeving respectievelijk een deel van de omgeving de verkeerde oplossingen.

De term demand stress is weinig gelukkig gekozen. Dit suggereert dat het niet adequaat reageren op eisen direct tot stress leidt. Easton suggereert weliswaar op sommige plaatsen dat er sprake is van zo'n directe relatie (vooral: Easton, 1975: 58-9), maar een nauwkeurige bestudering van zijn werk leert dat het blijven liggen van eisen slechts indirect tot stress kan leiden. Dit blijkt 
onder meer uit de volgende passage:

"... to the extent that demands remain unfulfilled, it is strongly possible, although not inevitable, that what I shall designate as output failure, will occur. This is a condition in which outputs prove insufficient to hold the minimal support of the politically significant members. [...] the failure to meet the demands of at least the politically powerful members in a system will undermine the basic support for the system." (Easton, 1965: 59-60)

Eisen die blijven liggen zullen pas tot stress als er een situatie van output failure ontstaat (Easton, 1965: 230-1). Dit wil zeggen als de omgeving het systeem verantwoordelijk houdt voor het feit dat politieke besluiten en/of de effecten van politieke besluiten onvoldoende aansluiten bij in de omgeving levende politieke eisen. Zolang de omgeving echter vindt dat de schuld voor het uitblijven van een adequate politieke reactie op eisen niet bij het systeem zelf moet worden gezocht maar in andere omstandigheden (conjunctuur, natuurrampen, andere politieke systemen) zal er geen stress ontstaan. Stress ontstaat omdat een output failure de steun voor het systeem aantast. Eisen die blijven liggen leiden dus slechts indirect via een afname van de politieke steun tot een aantasting van gezaghebbendheid en/of besluitvaardigheid, maar dit neemt niet weg dat de kans op stress - ceteris paribus - groter is naarmate het aantal eisen waar een systeem mee te maken krijgt groter is, en de eisen heterogener en/of ambitieuzer van aard zijn. Eisen kunnen dus alleen indirect een bedreiging vormen voor de stabiliteit van politieke systemen. De gevolgen van afnemende steun komen in de volgende paragraaf aan de orde

\subsection{Politieke steun}

De stabiliteit, gezaghebbendheid en besluitvaardigheid van politieke systemen komen blijkbaar wel in het geding bij een afname van de politieke steun (support stress) vanuit de omgeving. Aangezien politieke steun één van de centrale begrippen in deze studie is, zal aan dit concept uitgebreid aandacht worden besteed. Daarbij fungeert Eastons werk (1965, 1973, 1975, en 1979) als vertrekpunt.

\section{Omschrijving van het begrip}

In Eastons werk zoekt men tevergeefs naar één vaste definitie van de term politieke steun. Wel vindt men verschillende passages waaruit de betekenis van de term uit kan worden afgeleid, zoals:

"... the sentiments they [JJ: the members of the system] display toward the political system as a whole, its institutions and its leaders." (Easton, 1965: 155); en: 
“... an attitude by which a person orients himself to an object either favorably or unfavorably, positively or negatively. Such an attitude may be expressed in parallel action. In short, in its common usage support refers to the way a person evaluatively orients himself towards the system through either his attitudes or his behavior. " (Easton, 1975: 436)

Onder de term politieke steun of political support vat Easton dus elke houding en/of gedraging die een beoordeling van het politieke systeem of een onderdeel van het systeem inhoudt. De uitkomst van zo'n beoordeling kan variëren van positief, neutraal of onverschillig, tot negatief (Easton, 1965: 162-4). Anders dan het woord support misschien suggereert, handelt het dus ook om niet-positieve beoordelingen. Als burgers aangeven de regering van hun land te wantrouwen, dan is er in Eastons terminologie sprake van negative support voor de regering. Om misverstanden te voorkomen zal in dit boek het contrasterende begrippenpaar steun en kritiek worden gebruikt ter aanduiding van respectievelijk positive en negative support.

Eastons stelling is dat de aanwezigheid van een zekere mate van politieke steun vanuit de omgeving een noodzakelijke voorwaarde is voor het (kunnen) functioneren en (kunnen) voortbestaan van politieke systemen. Een politieke systeem is:

"... a means through which the resources and energies of society are mobilized and oriented to the pursuit of goals. [...] highlighting the need for marshalling the support of the members [JJ: of the society] if the system is to be able to act at all. " (Easton, 1965: 153) Enerzijds is elke samenleving voor de vervulling van een aantal essentiële functies dus noodzakelijkerwijs aangewezen op een politiek (sub)systeem. Anderzijds is elk politiek systeem voor de effectuering van zijn besluiten sterk afhankelijk van de samenleving als deel van de voor het politieke systeem relevante omgeving. In reactie op de inputs - steun en eisen - vanuit de omgeving genereert het politieke systeem outputs. De outputs bestaan uit besluiten over de toedeling van waarden binnen de samenleving. Voor de daadwerkelijke uitvoering van politieke besluiten moet het systeem echter een beroep doen op of gebruik maken van de schaarse middelen die in handen zijn van de leden van de samenleving (Easton, 1965: 153, 159). In het meest minimale geval moet de samenleving de gevolgen van een besluit gedogen (Easton, 1965: 240), maar niet zelden zal de effectuering van een concreet besluit een actieve of substantiële bijdrage van de leden vereisen - tijd, geld, inspanning, aanvaarden van beperkingen, enzovoort. ${ }^{37}$ De bereidheid van de samenleving om de gevraagde medewerking te geven, wordt in beginsel bepaald door de mate van politieke steun. Langs deze weg komt Easton tot zijn stelling dat elk politiek systeem enige mate van politieke steun behoeft om überhaupt te kunnen functioneren en voortbestaan.

Zakt de steun vanuit de omgeving voor - of; stijgt de kritiek vanuit de omgeving op - een

3 Niet zelden is er naast een groep actoren die een bijdrage moet leveren, ook een groep die een bijdrage tegemoet kan zien. De medewerking van deze laatste groep is over het algemeen niet problematisch. 
politiek systeem onder een bepaald niveau (the threshold) dan ontstaat support stress. Een afname tot onder de drempel vormt in de eerste plaats een bedreiging voor de gezaghebbendheid van een systeem. In een kritische omgeving zullen politieke besluiten die aanzienlijke offers vragen van de omgeving, ceteris paribus, minder welwillend worden ontvangen. Minder steun betekent, met andere woorden, dat de kans op een bereidwillige acceptatie van politieke besluiten door de omgeving daalt. Dit heeft op zijn beurt weer een negatieve invloed op de besluitvaardigheid. Als een politiek (sub)systeem er rekening mee moet houden dat zijn besluiten in minder goede aarde vallen, dan is het voor het politieke systeem moeilijker om grote offers te vragen van zijn omgeving zonder te moeten vrezen voor een verder verlies aan gezaghebbendheid. Steun is, met andere woorden, in sterke mate bepalend voor de vrijheidsgraden die politici hebben bij het formuleren van hun reacties op politieke eisen. Immers:

"In those systems where the leadership cannot anticipate and rely upon the unquestioning support of the membership, the extent to which the human or even material resources of the system can be committed is seriously curtailed. "(Easton, 1965: 161).

Een daling van de politieke steun is dus in potentie een bedreiging zowel voor de gezaghebbendheid, als voor de besluitvaardigheid van politieke systemen. Als de steun onder een bepaald niveau zakt wordt het aanvaardbaar functioneren in de ogen van de omgeving lastiger, en neemt de kans op een output failure en verdere aantasting van de steun toe.

De mate van politieke steun vanuit de omgeving voor het politieke systeem is, volgens Easton, in belangrijke mate bepalend voor de gezaghebbendheid en besluitvaardigheid van een politiek systeem. Een afname van de politieke steun is bijgevolg een potentiële stressfactor en vergroot de kans op veranderingen (instabiliteit) binnen politieke systemen. Om zinvolle uitspraken te kunnen doen over de veranderingen binnen politieke systemen die het gevolg zijn van support stress acht Easton het zinvol om onderscheid te maken tussen verschillende typen steun. In dat kader maakt hij een onderscheid tussen soorten en objecten van politieke steun.

\section{Objecten van politieke steun}

In principe kan elk denkbaar aspect van een politiek systeem object van politieke kritiek of steun zijn dan wel worden. Daarbij valt te denken aan: een minister-president, een grondrecht, een kiesstelsel, een concreet politiek besluit, een regering, een constitutie, het takenpakket van de overheid, enzovoort. Easton acht het niet zo zinvol om een oneindig aantal objecten te onderscheiden. Daarentegen introduceert hij een analytisch onderscheid tussen drie objectcategorieën: politieke gezagsdragers, politieke regime en politieke gemeenschap.

De keuze voor deze driedeling is ingegeven door Eastons streven om zinvolle uitspraken te kunnen doen over verschillende vormen van instabiliteit. De keuze voor juist deze categorieën 
ligt in het feit dat het gaat om objectcategorieền:

¿. with respect to which support may vary independently and with respect to which fluctuations in the level of support may stimulate stress in different ways. These in turn may provoke differential coping responses on the part of the members of a system. "(Easton, 1965:

172, onderstreping $J J)$

De driedeling is primair ingegeven door en gekoppeld aan Eastons preoccupatie met de (in)stabiliteit van politieke systemen. De bij de gekozen driedeling behorende " differential coping responses" om stress te reduceren zijn (Easton, 1973: 295-6):

1. State change in the system (vervangen zittende politieke gezagsdrager(s));

2. System type (regime) change (wijzigen van het politieke regime);

3. Political community change (uiteenvallen bestaande politieke gemeenschap / opgaan in respectievelijk samengaan met andere politieke gemeenschap);

Vreemd genoeg onderscheidt hij geen vierde objectcategorie maar wel een vierde vorm van instabiliteit, te weten (Easton, 1973: 296):

4. Basic system change.

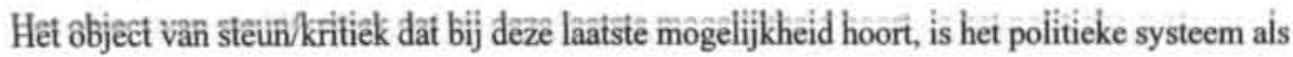
zodanig. Bij een basic system change houdt een bestaand systeem helemaal op te bestaan. Er voltrekt zich als het ware een onomkeerbare gelijktijdige verandering van gezagsdragers, regime én gemeenschap; met andere woorden, het oude politieke systeem houdt op te bestaan en wordt vervangen door een of meer nieuwe systemen. Een verdere uitwerking van veranderingen en bijbehorende objectcategorieën volgt hieronder.

Het eerste object van steun zijn de political authorities, hier verder aan te duiden met de Nederlandse term politieke gezagsdragers (Easton, 1965: 212-9). Politieke gezagsdragers zijn diegene die:

"... engage in the daily affairs of a political system; they must be recognized by most members of a system as having responsibility for these matters; and their actions must be accepted as binding most of the time by most of the members as long as they act within the limits of their roles. "38 (Easton, 1965: 212)

De term politieke gezagsdragers slaat in de eerste plaats op individuen die binnen het politieke systeem een functie bekleden en als zodanig in de ogen van de omgeving verantwoordelijk zijn

3t De vraag of de acties van gezagsdragers als bindend aanvaard worden, kan direct afhankelijk zijn van de vraag of er voldoende steun bestaat voor de gezagsdragers, hoewel hun gezag ook ontleend kan worden aan de steun voor andere onderdelen van het politieke systeem. Door de gezaghebbendheid van gezagsdragers expliciet in de definitie op te nemen, bestaat het gevaar dat hetgeen verklaard moet worden (steun voor de gezagsdragers) al in de definitie is opgenomen. Daarom is het volgens mij beter de definitie te beperken tot diegene die door het publiek politiek verantwoordelijk worden gehouden voor de politieke besluiten, los van de vraag of de besluiten vervolgens aanvaard worden. 
voor de politieke besluitvorming - dit wil zeggen, de omzetting van inputs in outputs - binnen de samenleving. De term slaat echter ook op groepen personen die tezamen een gezaghebbende politieke institutie - de ministerraad, de regering, het parlement, de oppositie, enzovoort - vormen die als zodanig betrokken is bij de politieke besluitvorming. Bij steun voor of kritiek op gezagsdragers gaat het echter niet om een beoordeling van de functies en instituties als zodanig, maar nadrukkelijk om een evaluatie van de persoonlijke bezetting van functies en instituties. $\mathrm{Om}$ te kunnen spreken van een gezagsdrager is wel noodzakelijk dat de omgeving de functionaris respectievelijk de groep mensen die een institutie vormt verantwoordelijk houden voor de politieke besluitvorming. Kritiek op gezagsdragers kan alleen ontstaan als de omgeving vindt dat de functionarissen en/of groepen hun functie niet adequaat uitoefenen. Het behoeft, mijns inziens, nauwelijks toelichting dat ernstige kritiek op de zittende gezagsdragers het gezag van door diezelfde gezagsdragers genomen en aangekondigde besluiten kan aantasten, alsmede dat zware kritiek politieke gezagsdragers kan hinderen bij het zoeken van creatieve oplossingen voor dagelijkse politieke problemen.

Stress die het gevolg is van een gebrek aan steun voor gezagsdragers is relatief makkelijk te bestrijden door de zittende gezagsdragers te vervangen. Easton duidt dit aan als een state change in the system aangezien het bij het vervangen van gezagsdragers slechts handelt om:

"... changes in the states of major variables that do not lead to modifications in the characteristic way in which a system operates. " (Easton, 1973: 295)

Indien de kritiek de functies van de gezagdagers als zodanig zou betreffen, dan is uiteraard meer nodig dan een state change. De functies en de functieverdeling maken deel uit van de tweede objectcategorie, het politieke regime.

In democratische systemen is de mogelijkheid voor zo'n state change expliciet onderdeel van de constitutionele orde - eveneens een onderdeel van het politieke regime. Middels periodieke verkiezingen kan het volk zich uitspreken over het al dan niet aanblijven van zijn belangrijkste gezagsdragers. In niet-democratische systemen die geen regeling hebben voor de vreedzame vervanging van gezagsdragers, culmineert aanhoudende kritiek op de zittende gezagsdragers niet zelden in een gewelddadige vervanging. In een dictatuur is het doden van de zittende dictator vaak een even simpele, als doeltreffende manier om tegemoet te komen aan de politieke stress als gevolg van kritiek op de zittende dictator. Richt de kritiek zich niet zozeer op de persoon van de dictator maar op de dictatuur als zodanig, dan biedt het vervangen van de ene dictator door de andere uiteraard geen soelaas. De kritiek zal voortbestaan, tenzij de nieuwe dictator er door zijn handelen - goed bestuur, propaganda of terreur - er in zou weten te slagen om de kritiek op de dictatuur als zodanig de kop in te drukken.

Op nationaal niveau zijn (minister-)presidenten, ministers en parlementariërs over het algemeen de meest zichtbare en in de ogen van de omgeving belangrijkste individuele politieke 
gezagsdragers. Regering en parlement zijn de meest in het oog springende instituties die een meer of minder aantrekkelijke personele bezetting kunnen hebben. De term gezagsdragers kan echter ook betrekking hebben op gezaghebbende ambtenaren en ambtelijke instituties. Rechters, het leger of de politie die ook met staatsgezag bekleed zijn, kunnen onder omstandigheden uitgroeien tot ernstige bron van politieke stress, of door hun handelen juist stress wegnemen. In het kader van de EU, het systeem wat in dit boek centraal staat, moet bij de term gezagsdragers worden gedacht aan individuele Commissarissen en Euro-parlementariërs, maar ook kan worden gedacht aan de concrete personele bezetting van het Europees Parlement, het Europese Hof van Justitie, de (Europese) Raad of de Commissie in zijn geheel.

Het tweede complex van objecten dat Easton onderscheidt, is het political regime. Het heeft betrekking op de organisatie van en de randvoorwaarden voor de politieke interacties binnen een samenleving en valt als zodanig weer uiteen in drie componenten:

"The regime as sets of constraints on political interaction in all systems may be broken down into three components: values (goals and principles), norms, and structure of authority. The values serve as broad limits with regard to what can be taken for granted in the guidance of day-to-day politics without violating deep feelings of important segments of the community. The norms specify the kinds of procedures that are expected and acceptable in the processing and implementation of demands. The structure of authority designate the formal and informal patterns in which power is distributed and organized with regard to the authoritative making and implementing of decisions - the roles and their relationships through which authority is distributed and exercised." (Easton, 1965: 193)

Belangrijk punt in deze omschrijving is dat het politieke regime zowel betrekking heeft op de formele, als ook op de informele aspecten van de organisatie en de randvoorwaarden voor politieke interacties. De term norms - regels - slaat op de procedures die worden gevolgd bij het proces van het omzetten van eisen in politieke besluiten; met andere woorden, de formele en informele regels voor het omzetten van inputs in outputs. Regels belichamen wat bij die omzetting - de besluitvorming binnen het politieke systeem - gebruikelijk is. De structure structuur - heeft betrekking op de formele en informele verdeling van politieke macht binnen het systeem. Dit betreft onder andere de verdeling van taken en bevoegdheden over functies en instituties - die worden bezet door gezagsdragers - binnen het systeem. Values - waarden markeren de buitengrenzen van het politieke domein binnen een samenleving: waar mag de politiek zich wel en niet mee bemoeien? Als in strijd met de waarden van een politiek systeem wordt gehandeld, dan zal dit het gezag van het systeem aantasten; dit wil zeggen, de aanvaarding van besluiten door de leden van samenleving wordt minder waarschijnlijk.

Een voorbeeld van een regel van het Nederlandse politieke regime is dat wetten de 
instemming behoeven van regering en Staten-Generaal tezamen, of dat administratieve vormfouten kunnen leiden tot de vrijlating van verdachten in een strafzaak. De formele en informele rolverdeling tussen parlement en regering is een structuur-aspect van het Nederlandse politieke regime, evenals de rolverdeling tussen politie en openbaar ministerie bij het opsporen van strafbare feiten. De waarden van een systeem zijn over het algemeen relatief abstract en treden weinig op de voorgrond. Binnen de Nederlandse politiek valt onder andere te denken aan de scheiding tussen kerk en staat, respect voor grondrechten of het beginsel dat een verdachte niet hoeft mee te werken aan zijn eigen veroordeling. In het geval van de EU valt bij regels te denken aan de besluitvormingsprocedures binnen de EU en de regel dat alleen de Commissie over initiatiefrecht heeft. Onder de structuur valt onder andere het verdeling van taken en bevoegdheden over de Commissie, Raad en EP, maar ook de informele spilrol die de FransDuitse as in de praktijk speelt. Bij waarden van de EU valt onder meer te denken aan de terughoudende rol die de EU speelt op het gebied van defensie, het supranationale karakter van het EU-recht en het streven naar vrede door samenwerking.

Het politieke regime belichaamt de karakteristieke gang van zaken binnen een politiek systeem. System type changes als gevolg van regimekritiek veranderen de karakteristieke manier waar op een systeem placht te functioneren. Zo'n verandering kan meer - de overgang van een dictatuur naar een democratie - of minder ingrijpend - het uitbreiden van het aantal ministersposten - van karakter zijn.

De political community (politieke gemeenschap) is de derde objectcategorie. De term verwijst naar een:

".. group of persons bound together by a political division of labor. " (Easton 1979: 171-189) De politieke gemeenschap bestaat uit de groep burgers die onder het gezag van een politiek systeem vallen. De samenstelling van de politieke gemeenschap is in de praktijk van sommige politieke systemen een hardnekkig en explosief twistpunt. Het gaat daarbij zelden om de vraag welke individuele burgers wel en niet tot de gemeenschap dienen te behoren, als wel om de vraag of bepaalde regio's al dan niet aanspraak kunnen maken op een zekere mate van politieke autonomie. Vaak gaat het daarbij om regio's met een afwijkende culturele - taal, geschiedenis, religie - identiteit (Noord-lerland, Baskenland). In het geval van internationale politieke organisaties spitst de discussie zich veelal toe op de vraag welke landen wel en niet voor een lidmaatschap van een bepaalde organisatie in aanmerking dienen te komen. Moet Turkije wel of niet lid kunnen worden van de Europese Unie? Kan de EU de uitbreiding in oostelijke richting wel dragen?

Steun voor de politieke gemeenschap belichaamt een zekere mate van onderlinge solidariteit en "wij-gevoel". Een gebrek aan steun voor de gemeenschap uit zich meestal in het feit dat 
burgers van uit verschillende regio's of behorend tot verschillende groepen niet bereid zijn om offers voor elkaar te brengen. Politieke besluiten die toevalligerwijs of expliciet een herverdeling van schaarse middelen over deze regio's of groepen impliceren zullen onder dergelijke omstandigheden per definitie op weerstand kunnen rekenen. Het behoeft geen toelichting dat een dergelijke omstandigheid het functioneren van politieke systemen bemoeilijkt.

Een community change kan in dergelijke situaties stress wegnemen. Meestal gaat het om de splitsing van een bestaande politieke gemeenschap in twee of meer aparte politieke gemeenschappen waarbinnen de benodigde onderlinge solidariteit die nodig is voor het kunnen implementeren van noodzakelijke politieke besluiten er wel is. Het kan echter ook anders lopen. De verbondenheid tussen de leden van twee verschillende politieke gemeenschappen kan in de praktijk zo groot zijn, dat ze op een bepaald moment besiuiten om samen verder te gaan. Zo'n samensmelting kan overigens ook het gevolg zijn van externe druk, het noodlot, agressie of een koele kosten-baten afweging.

Het uiteenvallen van de Sovjet-Unie, Joegoslaviē en Tsjecho-Slowakije illustreert hoe bestaande politieke gemeenschappen uiteen kunnen vallen. In deze gevallen lijkt de oorzaak op zijn minst deels te moeten worden gezocht in de verlammende uitwerking van de onderlinge rivaliteit tussen verschillende regio's (volkeren, culturen, religies) op de politieke besluitvorming binnen de voormalige gemeenschap. De hereniging van West-en Oost-Duitsland onder het WestDuitse politieke regime en de West-Duitse gezagsdragers laat zien dat het ook anders kan. De EU heeft tot nu toe vooral ervaring met uitbreidingen van de politieke gemeenschap. Sinds de oprichting is het aantal lidstaten meer dan verdubbeld. Opvallend is dat deze veranderingen vaak gepaard gingen met of gevolgd werden door veranderingen in het EU-regime, met name in de vorm van aanpassingen in de regels van de besluitvorming. Het uittreden van de Deense "provincie" Groenland na een referendum, en het tot tweemaal afwijzen van het EU-lidmaatschap door de Noorse bevolking illustreert aan de andere kant dat men het lidmaatschap van de EUgemeenschap in sommige regio's in meerderheid niet ziet zitten.

Er is sprake van een basic system change als een politiek systeem simpelweg op houdt te bestaan. Dit is het geval als binnen een samenleving het bedrijven van politiek onmogelijk wordt; dit wil zeggen:

"... a given society is unable to provide for the persistence of those processes through which authoritative allocations are characteristically made. " (Easton, 1973: 296)

In tegenstelling tot de andere drie soorten "veranderingen" gaat het in dit geval dus om een verandering die het einde van het bestaande politieke systeem in al zijn onderdelen bezegelt. $\mathrm{Er}$ is sprake van een persistence failure (Easton, 1973: 297). In dergelijke gevallen vindt als het ware een gelijktijdige verandering van gezagsdragers, regime en gemeenschap plaats. Een basic 
system change is vaak het gevolg van of gaat gepaard met het uiteenvallen van de bijbehorende samenleving. De mogelijkheid van een basic system change suggereert dat het politieke systeem als zodanig ook is aan te merken als afzonderlijke objectcategorie van politieke steun. In afwijking van Easton zelf zal in dit onderzoek het politieke systeem als zodanig dan ook worden beschouwd als aparte objectcategorie van politieke steun. Bij steun voor of kritiek op het politieke systeem als zodanig gaat het dus niet zozeer om de beoordeling van specifieke deelaspecten, maar gaat het primair om een beoordeling van het systeem als geheel. Natuurlijk zal de beoordeling van het politieke systeem als zodanig niet geheel onafhankelijk zijn van de beoordeling van de onderdelen, maar de beoordeling van het geheel hoeft niet noodzakelijkerwijs de som of het gemiddelde van beoordeling van de delen te zijn. Ook is het voorstelbaar dat mensen geen gedifferenticerd oordeel hebben over alleriei deelaspecten van een politiek systeem, maar slechts beschikken over een algemeen oordeel.

\section{Soorten steun}

Een onderscheid naar vier objectcategorieèn van politieke steun heeft, volgens Easton, nog onvoldoende onderscheidend vermogen om zinvolle uitspraken te kunnen doen over de (in)stabiliteit van politieke systemen. Voor dat doel is het noodzakelijk om nog een verdere onderverdeling aan te brengen naar de aard van de steun voor - of kritiek op - een bepaalde objectcategorie. De gevoelens ten aanzien van een specifiek object kunnen immers nogal uiteenlopend van aard zijn. Kritiek op een zittende (minister-)president kan diverse achtergronden hebben, zoals: hij is van de verkeerde partij; hij rommelt met stagiaires; politici zijn überhaupt niet te vertrouwen; hij functioneert slecht; hij hangt het verkeerde geloof aan; hij komt zijn afspraken niet na of zijn laatste besluit is in slechte aarde gevallen. De eventuele aanpassingen in een politiek systeem die nodig zijn om support stress te beteugelen, zijn niet slechts afhankelijk van het object van kritiek maar ook van de aard van de kritiek, immers:

"One step on the road to a solution of this puzzle has seemed to me to require us to recognize that support is not all of a piece. The consequences for the system will vary with the differences. Some types of evaluations are closely related to what the political authorities do and how they do it. Others are more fundamental in character because they are directed to basic aspects of the system. " (Easton, 1975: 437)

Easton introduceert een analytisch onderscheid tussen twee soorten steun, te weten: specifieke en diffuse steun.

Specifieke steun voor een politiek systeem is een quid pro quo voor het tegemoet komen aan politieke eisen. Specifieke steun of specifieke kritiek is de uitkomst van een vergelijking van de inhoud en effecten van actuele politieke besluiten met actuele politieke eisen - onder andere: 
voorkeuren, prioriteiten, wensen, enzovoort - van de beoordelaar (vgl. Westle, 1989: 184-6). Vormt een concreet besluit of een reeks van politieke besluiten in de ogen van de beoordelaar een adequate reactie op zijn of haar politieke eisen, dan ontstaat specifieke steun; sluiten besluit(en) en eisen niet op elkaar aan, dan ontstaat specifieke kritiek. Kenmerkend voor specifieke steun is het instrumentele karakter en de directe link met dagelijkse politieke besluiten (outputs). Westle spreekt terecht van:

"... output-orientiert [...] mit der Eigenschaft 'Kürzfristigkeit'." (Westle, 1989: 184: vgl. Easton, 1965: 268)

Door deze eigenschappen biedt specifieke steun onvoldoende garanties voor het functioneren en voortbestaan van politieke systemen op de lange termijn. In de hypothetische situatie dat de politieke steun voor een systeem enkel uit specifieke steun bestaat, zal de acceptatie van elk concreet besluit door burgers immers direct afhankelijk zijn van de mate waarin de specifieke output aansluit bij individuele eisen. ledere criticus zal onder deze omstandigheden moeten worden gedwongen of worden gecompenseerd alvorens hij medewerking zal verlenen aan het besluit. Een dergelijke werkwijze is op de lange termijn onhoudbaar. Dit soort praktijken draagt immers het gevaar in zich dat aanvankelijke voorstanders zich omwille van het gebruikte geweld of de extra kosten alsnog tegen een besluit gaan verzetten, dan wel omwille van de verwachte compensatie zullen veinzen tegenstanders te zijn. Zodoende komt het systeem in een wurgende geweldsspiraal of in een niet in de hand te houden stelsel van compensaties terecht waardoor het uiteindelijk onmogelijk wordt om een concreet besluit te nemen.

Ook de mogelijkheid dat een politiek systeem bij het volledig ontbreken van niet-specifieke steun slechts besluiten neemt waar iedereen achter staat, is bij nader inzien geen echte oplossing. Weliswaar is onder die omstandigheden de gezaghebbendheid (de acceptatie) van eenmaal genomen besluiten verzekerd, maar politieke systemen kunnen het zich niet permitteren om politieke eisen waar geen algemeen aanvaarde oplossing voor bestaat categorisch te negeren. Zo'n lijdzame rol staat op gespannen voet met een van de twee wezenskenmerken van politieke systemen, de besluitvaardigheid. Politieke systemen hebben vaak juist primair de functie om met oplossingen te komen voor problemen waar nu juist geen algemeen aanvaarde oplossing voor is. Dit is één van de belangrijkste bestaansreden voor politieke systemen. Algemeen aanvaarde besluiten komen ook vaak tot stand buiten het politieke systeem om. Een al te lijdzame rol van politieke systemen leidt dus tot demand-stress en resulteert gemakkelijk in een situatie van output failure. De roep om een ander responsiever (besluitvaardiger) politiek systeem zal dan onherroepelijk klinken.

Een politiek systeem dat zijn gezag enkel baseert op specifieke steun is een wandelende tijdbom die vroeg of laat uit elkaar zal spatten. Voor het functioneren en voortbestaan van politieke systemen op de lange termijn is het derhalve noodzakelijk dat het gezag van een 
systeem - en de acceptatie van besluiten - niet slechts berust op specifieke steun. Specifieke steun als zodanig vormt geen toereikende basis voor het functioneren en voortbestaan van politieke systemen.

Om het voortbestaan van politieke systemen op de lange termijn te kunnen garanderen is dus een zekere mate van diffuse steun nodig. Diffuse steun is noodzakelijk om er voor te zorgen dat critici van concrete politieke besluiten in de hierboven beschreven specifieke zin, desondanks bereid zijn om de consequenties van de gewraakte besluiten vrijwillig - dit wil zeggen: zonder voortdurende dwang of voortdurende compensatie - te accepteren. Diffuse steun of kritiek ontstaat wanneer mensen beoordelen:

"...what an object is or represents - to the general meaning it has for a person - not of what it does. " (Easton 1975: 444-5)

De precieze betekenis van diffuse steun is het best uit te leggen door het af te zetten tegen specifieke steun.

Diffuse steun is more durable en basic in a special sense dan specifieke steun, en in tegenstelling tot specifieke steun niet direct afhankelijk van de evaluatie van:

"outputs and performance [JJ: of the political system] in the short run." (Easton, 1975: 445) Diffuse steun is in die zin een veel stabielere en betrouwbare basis dan specifieke steun. De reden hiervoor ligt in de verschillende achtergronden die beide soorten steun hebben. Specifieke steun is direct gekoppeld aan en volledig gebaseerd op de evaluatie van outputs and performance of the political system in the short run; een instrumentele en directe beoordeling - hier en nu - van door het systeem genomen besluiten. De achtergrond van diffuse steun is meer divers van karakter en wordt ingegeven door:

"... socialization [JJ: tijdens de jeugd] and continuing adult socialization, and from direct experience." (Easton, 1975: 445)

Via socialisatieprocessen kan het burgers geleerd worden dat het normaal is om democratisch genomen politieke besluiten als bindend te ervaren, een gemeenschapsgevoel te hebben en het gezag van het politiek systeem niet op voorhand in twijfel te trekken. Het feit dat direct experience ook een rol speelt, onderstreept dat diffuse steun ook tot op zekere hoogte afhankelijk is van de evaluatie van het functioneren van politieke systemen. Zo stelt Easton:

"Diffuse support may also [...] derive from experience. It is only because this is a source usually associated with specific support, its significance for diffuse support may easily be overlooked or underemphasized." (Easton, 1975: 446)

De stelling dat Easton zou vooronderstellen dat diffuse steun output-onafhankelijk is, is een misvatting en karikatuur van Eastons werk op dit punt. Eastons stelt herhaaldelijk dat elke vorm van steun in meer of mindere mate afhankelijk is van de prestaties van het systeem (Easton, 
1965: 267, 278 en 464-6: 1975: 445). In tegenstelling tot specifieke steun is diffuse steun echter slechts indirect (en niet uitsluitend) afhankelijk van de beoordeling van outputs and performance, immers:

"Even though the orientations derive from responses to particular outputs initially, they become in time disassociated from performance. They become transformed into generalized attitudes towards the authorities or other political objects. " (Easton, 1975: 446)

Bij diffuse steun gaat het om generalized attitudes ten aanzien van de prestaties van het systeem. Het verschil tussen specifieke en diffuse steun zit hem dus niet zozeer in het wel respectievelijk niet output-onafhankelijk zijn, maar wel in de directe (korte termijn) respectievelijk indirecte ${ }^{39}$ afhankelijkheid.

In aanvulling hierop komt Easton nog met een onderverdeling van diffuse steun in een minder en meer output-afhankelijke vorm: legitimiteit respectievelijk vertrouwen (1975: 447). Vertrouwen of 'trust' slaat op:

"Trust may be defined by in Gamson's terms as 'the probability ... that the political system (or parts of it) will produce preferred outcomes even if left unintended. [...]' In other words. it is the probability of getting preferred outcomes without the group doing anything to bring them about." (Easton, 1975: 447)

Vertrouwen - of wantrouwen - is net zoals specifieke steun primair instrumenteel van karakter. Vertrouwen (steun) respectievelijk wantrouwen (kritiek) is het resultaat van een cumulatie van dagelijkse ervaringen (Easton 1975: 447-50). In afwijking van specifieke steun kan vertrouwen daarenboven ook zijn ingegeven door politieke socialisatie.

Diffuse steun in de vorm van legitimiteit ontstaat wanneer iemand de objecten van steun:

"... in some vague or explicit way ... sees these objects as conforming to his own moral principles, his own sense of what is right and proper in the political sphere." (Easton, 1965:

Het gaat hierbij dus in de eerste plaats om een primair normatieve - non-instrumentele beoordeling van politieke objecten. De vraag is vooral of de wijze waarop een politiek systeem in elkaar zit en functioneert, overeenkomt met iemands politieke normen, waarden en gevoelens over hoe een politiek systeem in elkaar behoort te zitten en behoort te functioneren. Desondanks wordt ook de legitimiteit van politieke objecten tot op zekere hoogte afhankelijk geacht van de prestaties van een politiek systeem. Daarbij lijkt vooral te moeten worden gedacht aan de mogelijkheid dat onder invloed van de enorme voordelen (nadelen) die aan een in eerste instantie niet (wel) legitiem politiek systeem worden toegeschreven, mensen hun normatieve ideeën over hoe politieke systemen in elkaar dienen te zitten en dienen te functioneren aanpassen. Dus

\footnotetext{
${ }^{30}$ Ter illustratic: "Such attachment [JJ: diffuse support] may be a product of spill-over effects from evaluations of a series of outputs and performance over a long period of time." (Easton, 1975: 446)
} 
indirect kan de legitimiteit van politieke systemen ook beīnvloed worden door het feitelijk functioneren van een politiek systeem.

\section{Typologie: combinatie van objectcategorieèn en soorten}

Door beide dimensies, vier objectcategorieën en drie soorten, te combineren ontstaat een typologie van 12 verschillende soorten politieke steun, namelijk:

\section{Soort steun}

object

gemeenschap

regime

gezagsdragers

politick systeem

\section{specifiek}

\section{diffuus}

\section{vertrouwen legitimiteit}

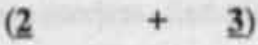

5

6

\section{9}

12

Eastons oorspronkelijke typologie omvat slechts zes typen, te weten: $2 / 3,5,6,7,8$ en 9 (in het schema onderstreept en vertgedrukt). Hij komt tot deze reductie doordat hij het politieke systeem niet expliciet onderscheidt als apart object van steun; specifieke steun exclusief relateert aan de objectcategorie gezagsdragers (7); en, hij met betrekking tot de gemeenschap geen onderscheid maakt tussen vertrouwen en legitimiteit (2/3). Specifieke steun is in Eastons typologie dus objectspecifiek, terwijl steun voor de gemeenschap soort-specifiek is. Het feit dat diffuse steun wel op alle onderdelen van het systeem betrekking kan hebben, is de reden waarom Easton diffuse steun more basic in a special sense noemt. In zijn werk besteedt Easton nauwelijks aandacht aan het politieke systeem als object van steun. Hij erkent slechts dat politieke systemen als zodanig in onderwerp van verandering kunnen zijn (basic system change).

Westle en, in mindere mate, Fuchs stellen dat er eigenlijk geen dwingende redenen zijn om de typologie te beperken tot de zes typen die Easton onderscheidt. Zij zien geen reden waarom, onder meer, specifieke steun niet aan alle objecten kan worden gekoppeld (Westle 1989: 194205; Fuchs 1989: 21-31). De redenering is dat dagelijkse besluiten weliswaar door gezagsdragers worden genomen, maar dat de inhoud van concrete politieke besluiten niet uitsluitend aan gezagsdragers hoeft te worden toegeschreven. Zo is het niet uitgesloten dat mensen klagen over halfslachtig EU-landbouwbeleid maar dit niet zozeer wijten aan de gezagsdragers, maar veeleer aan de procedures voor besluitvorming (regime) of aan het heterogene gezelschap lidstaten (gemeenschap). Er is op voorhand geen reden om te vooronderstellen dat specifieke steun niet 
aan alle objectcategorieèn kan worden gekoppeld. Logischerwijs zijn er eveneens geen dwingende redenen om een onderscheid tussen de legitimiteit en het vertrouwen in de politieke gemeenschap achterwege te laten, alsmede lijkt het zinvol om mede gelet op de door Easton (1973) zelf aangeduide mogelijkheid van een basic system change politieke systemen als zodanig aan te merken als aparte objectcategorie. Er is, met andere woorden, geen dwingende noodzaak om de typologie op voorhand te beperken.

In hoeverre deze uitputtende typologie uiteindelijk in dit onderzoek gebruikt zal worden, is afhankelijk van de beschikbare empirische data en de empirische waarde van deze typologie in relatie tot de EU. Nu zal eerst worden ingegaan op de vraag in hoeverre Eastons typologie in het algemeen empirische waarde heeft.

\section{Empirische inzichten}

Volgens Tromp (1995: 137-8) is de belangrijkste kritiek op Eastons politieke-systeemtheorie dat het model weliswaar descriptieve waarde heeft, maar door het hoge abstractieniveau nauwelijks empirische waarde heeft. Het zou, met andere woorden, nagenoeg onmogelijk zijn om falsifieerbare hypothesen af te leiden over de precieze relatie tussen de inputs - eisen en steun enerzijds en de instabiliteit, functioneren en voorbestaan van politieke systemen anderzijds. De interesse voor Eastons werk in dit onderzoek komt voort uit het feit dat Easton veel werk heeft gemaakt van de conceptualisering van het begrip politieke steun. Tegen die achtergrond is er in dit onderzoek vooral interesse in de empirische waarde van dat concept.

Er is een aanzienlijk aantal empirische studies dat inzicht verschaft in de empirische waarde van Eastons typologie. In de meeste studies is expliciet aandacht voor de dimensionaliteit van het begrip politieke steun. Het proefschrift van Westle (1989) geeft een overzicht van de resultaten van empirisch onderzoek naar de waarde van Eastons typologie tot het midden van de jaren tachtig, en omvat daarnaast nog een zeer uitgebreide eigen empirische test van Eastons typologie. Uit haar literatuuroverzicht blijkt dat bijna alle research zich beperkt tot twee van de drie objectcategorieën: politieke gezagsdragers en het politieke regime. Daarbij wordt vaak ten onrechte een een-op-een relatie voorondersteld tussen diffuse steun en steun voor het regime enerzijds, en specifieke steun en steun voor de gezagsdragers aan de andere kant. Het eindoordeel van Westle over de bestaande pogingen om Eastons typologie in empirisch onderzoek te gebruiken is daarom allesbehalve onverdeeld positief en staat volgens haar geen eindoordeel toe (1989: 165-6).

In haar eigen onderzoek probeert Westle tegemoet te komen aan deze kritiek. De typologie die zij uiteindelijk toetst is weliswaar nog uitgebreider dan Eastons typologie - vier soorten steun en drie objectcategorieën die elk weer uiteengelegd worden in meerdere aspecten -, maar de 
dimensies en hoofdlijnen van Eastons typologie blijven zonder meer zichtbaar. Aan de hand van een West-Duitse dataset met gegevens uit 1985/6 gaat zij na in hoeverre de typologie aansluit bij de gedachtewereld van Duitse burgers. Op het einde van haar grondige studie concludeert zij dat de door Easton op theoretische gronden aangebrachte driedeling tussen politieke gezagsdragers, politieke regime en politieke gemeenschap empirisch zinvol is (Westle, 1989: 275). De beoordelingen van deze drie objectcategorieën zijn in de Duitse publieke opinie zinvol van elkaar te scheiden. De empirische waarde van het onderscheid naar soorten steun is weliswaar op sommige punten wat minder duidelijk, maar rechtvaardigt in grote lijnen een onderscheid tussen meer output-afhankelijke (instrumentele) vormen van politieke steun en meer normatiefideologisch gekleurde (non-instrumentele) vormen van steun (Westle, 1989: 261-4).

Ook na het proefschrift van Westle zijn er nog interessante studies op dit terrein verschenen. Weils (1989: 683-5) onderzoek naar de achtergronden van politieke steun in Italie, Spanje, het Verenigd Koninkrijk, West-Duitsland en de Verenigde Staten is hier een mooi voorbeeld van. Weil vraagt zich af wat er mis was met de stroom van zogenaamde new left en neo-conservatives crisis-theorieën uit het midden van de jaren zeventig. Op basis van deze theorieên werden

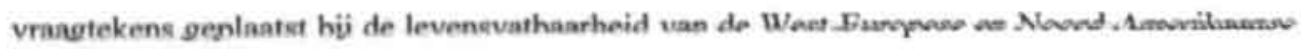
representatieve democratieên. Startend vanuit verschillende premissen komen beide groepen theoretici tot vergelijkbare doemscenario's. De politieke systemen in beide genoemde regio's zouden direct in hun voortbestaan worden bedreigd door een almaar wassende stroom politieke eisen.

Weil constateert dat de crisistheoretici geheel ten onrechte de toenemende onvrede over het optreden en functioneren van politici, parlement en regering ten tijde van de economische crises in de jaren zeventig en begin jaren tachtig hebben beschouwd als een (voor)teken van afnemende steun voor het politieke systeem als zodanig. Als een expliciet onderscheid wordt aangebracht tussen indicatoren van steun voor politici, parlement en regering - aangeduid als political confidence $^{40}$ - aan de ene kant en indicatoren voor de democratie als zodanig aan de andere kant, dan blijkt namelijk dat de mate van steun voor de democratie als zodanig - aangeduid als legitimation (support for democracy) - in de genoemde periode niet of nauwelijks afneemt.

Weil gaat verder. Hij constateert dat de political confidence in politici, parlement en regering in een land positief samenhangt en varieert met veranderingen in de politieke - stakingen, demonstraties, enzovoort - en economische conjunctuur op de korte termijn. De economische en politieke conjunctuur heeft echter nauwelijks invloed op de legitimation. Op zijn beurt blijkt de legitimation wel sterk afhankelijk te zijn van de kwaliteit van de oppositie-structuur in een land.

\footnotetext{
${ }^{*}$ Weils aanduiding van de meer specifieke vormen van steun voor politici, parlement en regering als political confidence is in het licht van Eastons typologie weinig gelukkig. Easton gebruikt de term confidence nu juist om een vorm van diffuse steun aan te duiden.
} 
Bij het vaststellen van de kwaliteit van een democratie staat Weil de volgende ideale democratie voor ogen:

"... the party system should present voters with clear alternatives, each capable of rotating into office, and none likely to destroy democracy. And governing coalitions should be stable and reflect' voters choices as directly as possible. " (Weil, 1989: 684)

Een matig functionerende oppositiestructuur wordt gekenmerkt door een sterk gefragmenteerd en/of gepolariseerd partijstelsel, kabinetten die steunen op een minderheid respectievelijk een veel ruimere dan noodzakelijke meerderheid in het parlement, en/of veelvuldig en snel wisselende regeringscoalities. Aan de hand van deze elementen bepaalt Weil de kwaliteit van de oppositie-structuur in de door hem onderzochte landen na 1945. Weils analyse is in die zin te interpreteren als een nadere illustratie van de empirische waarde van het onderscheid tussen diffuse en specifieke politieke steun enerzijds en het onderscheid tussen steun voor politieke gezagsdragers en steun voor het politiek regime anderzijds."

Weatherfords (1992) secundaire analyse van Amerikaanse surveygegevens op micro-niveau leidt tot vergelijkbare conclusies als Weils analyse op macro-niveau. Weatherford start met een beschrijving van de dimensies die macro-sociologen in hun theorieèn onderscheiden als het hebben over political legitimacy - hier verder aan te duiden als: legitimiteit. Vervolgens gaat hij na in hoeverre deze dimensies zijn terug te vinden in survey-gegevens op micro-niveau.

Weatherfords legitimiteit blijkt uiteindelijk een soort containerbegrip te zijn. Het omvat naast evaluatieve ook non-evaluatieve dimensies, alsmede naast politieke ook niet-politieke dimensies. Het is in die zin veel ruimer dan Eastons concept politieke steun. Eastons concept omvat enkel

${ }^{41}$ Het is jammer dat Weil zo weinig aansluiting zoekt bij Eastons werk en terminologic. Weil refereert in het geheel niet aan Eastons betoog dat alleen op basis van informatie over specifieke steun geen betrouwbare uitspraken zouden kunnen worden gedaan over de instabiliteit van politicke systemen (1965: 269-70), of Eastons opmerkingen over de functie die goed functionerende representatieve structuren hebben bij het genereren van diffuse steun (Easton, 1965: 252-3). Zo stelt Easton al in 1965 heel expliciet dat het in stand houden van goed functionerende representatieve structuren is:

"... a response that seeks less to mute the differences or blend groups than to provide avenues for negotiation and reconciliation."

en:

"It [JJ: representation] provides those who are affiliated with groups an opportunity to meet each other in a common forum so as to undertake negotiations to discover the exact nature of their differences, the degree of flexibility of each other 's positions, and the extent to which reconciliation of points of view and demands is feasible. This lies at the heart of political interaction as demands move to conversion into outputs. It is a process no less typical of dictatorial than of democratic systems, of non-literate than of modern ones. These varying systems differ, not because of the presence or complete absence of representative structures, but by virtue of the scope of the representation - who is represented? - and of control over the representatives, whether it is effective, virtual, spurious, or non-existent. There need be no reason to believe in advance that any given substantive issue must lend itself to settlement. [...] Nevertheless, effective political expression for a demand, through the processes of representation, at least provides the satisfaction that an opportunity has been presented for trying to bridge the gap among differences. " (Easton, 1965: 252-3) 
politieke en evaluatieve aspecten. Voorbeelden van non-evaluatieve aspecten in Weatherfords concept zijn politieke interesse (political interest) en politieke competentie (subjective political competence). Deze dimensies zijn non-evaluatief omdat uit de waarde van deze variabelen geen eenduidige positieve of negatieve beoordeling van (aspecten van) het politieke systeem spreekt. Zowel politieke interesse, als ook politieke desinteresse kunnen in deze zin samen gaan met - of zelfs het gevolg zijn van - kritiek op of steun voor het politieke systeem in Eastons betekenis. Niet-politiek zijn die aspecten waarbij een ander object dan (onderdelen van) het politieke systeem centraal staat (staan). Zelfvertrouwen (personal efficacy) - het object is de beoordelaar zelf - is daar een voorbeeld van. Weatherfords concept political legitimacy en zijn empirische analyse omvat dus veel meer dan nodig is voor de beoordeling van de empirische waarde van Eastons concept political support. Desondanks is Weatherfords studie noemenswaardig.

Weatherfords analyse levert namelijk twee hoofddimensies op, te weten: judgments of system performance en personal/citizenship traits. Deze tweedeling komt overeen met een tweedeling tussen politieke en niet-politieke aspecten. In het licht van de speurtocht naar de empirische waarde van Eastons typologie beperken we ons hier tot de eerste. Het feit dat deze dimensie louter op evaluatieve items is gebaseerd, is in dit kader uitermate verheugend. Verder is interessant te weten in hoeverre Weatherfords politieke dimensie ook uiteenvalt in een diffuse en specifieke subdimensie. Dit blijkt inderdaad het geval:

"... the two components of their 'political' antecedents, representational procedures and governemental performance, are correlated. But again, the fact that they share just over a third of their variance leaves a good deal of empirical support for the hypothesis that linkage institutions and policymaking performance are distinct objects of evaluation. "Weatherford, 1992: (61)

De eerste politieke sub-dimensie behelst de evaluatie van representational procedures en komt, zeker als men let op de concrete indicatoren die eraan ten grondslag liggen, min of meer overeen met wat Weil als legitimation of democracy aanduidt. Deze sub-dimensie is het best te typeren als non-instrumenteel en valt op zijn beurt weer uiteen in twee deelaspecten. Aan de ene kant gaat het om de vraag in hoeverre burgers denken dat verkiezingen en partijpolitieke concurrentie bijdragen aan de responsiviteit van hun (nationale) democratie. Aan de andere kant gaat het om de vraag in hoeverre de burgers denken dat ambten (regering en parlement) en ambtsdragers (parlementariërs) op de hoogte zijn (en blijven) van wat er onder het electoraat en in de samenleving leeft. Beide deelaspecten hebben betrekking op de vraag in hoeverre de werking van de politiek in de buurt komt van het ideaal van een responsieve representatieve democratie.

De tweede politieke sub-dimensie (governmental performance) is zonder meer te karakteriseren als instrumenteel. Het handelt onder andere om de vraag in welke mate burgers denken dat publieke ambten en publieke ambtsdragers in de praktijk efficiënt omgaan met schaarse 
middelen, alsmede in hoeverre de beleidsopbrengsten daadwerkelijk op de juiste plaats terechtkomen. Ook Weatherfords analyse illustreert dat het onderscheid tussen instrumentele en non-instrumentele vormen van politieke steun in de empirie bruikbaar is. Opmerkelijk is verder dat aspecten van de objectcategorieên gezagsdragers en het politieke regime zowel object van instrumentele (specifieke) steun, als van non-instrumentele (diffuse) steun kunnen zijn. Dit onderstreept dat ook uit de empirie blijkt dat er geen dwingende redenen zijn om voor de beperkte typologie - niet alle combinaties van soorten en objecten - te kiezen.

De typologie van Easton blijkt echter niet onder alle omstandigheden empirische waarde te hebben. Zo vinden Mischler en Rose $(1994 ; 1996)$ dat de politieke steun voor (aspecten van) de nieuwe democratische politieke systemen in vijf voormalige Oostbloklanden direct na het wegvallen van het ijzeren gordijn (1991) uni-dimensionaal van karakter is. De onderzoekers wijten dit aan het feit dat de desbetreffende politieke regimes nog relatief jong zijn. Daarbij gaat het er niet zozeer om dat de tijd waarin burgers zich een gedifferentieerd oordeel kunnen vormen nog te kort zou zijn geweest. Er is meer aan de hand. Ondanks de economische recessie die mede het gevolg is van de politieke omwentelingen is de waardering voor de nieuwe op democratische leest geschoeide systemen namelijk consequent hoger dan voor de oude op communistische leest geschoeide systemen. Deze hogere waardering blijkt te worden ingegeven door een combinatie van fear-and-hope. Aan de ene kant is er de angst voor een terugkeer naar de verfoeide communistische orde. Op individueel niveau blijken de felste critici van het oude regime, tevens de felste pleitbezorgers voor het nieuwe regime. Aan de andere kant is er de hoop op betere tijden als gevolg van de introductie van een liberale democratie. Hoewel de macro-economische situatie anno 1991 veel slechter is en slechter wordt beoordeeld dan vijf jaar daarvoor (1986) - nog onder het communistische regime-, denkt men dat de situatie over vijf jaar veel beter (1996) zal zijn dan vijf jaar geleden (1986). Deze hoop blijkt ook op individueel niveau een belangrijke determinant te zijn van de houding ten aanzien van het regime op het moment van ondervraging (1991). Dit duidt er op dat nieuwe politieke systemen niet zozeer worden gesteund om wat ze zijn en doen, maar om wat ze niet zijn en in de toekomst naar verwachting van de burgers zullen gaan doen. Vooralsnog steunen de nieuwe regimes op een (vooralsnog) onvoorwaardelijk noninstrumenteel krediet - min of meer onafhankelijk van de beoordeling van de outputs. Onder dit soort omstandigheden blijkt er dus geen ruimte voor een onderscheid tussen diffuse en specifieke steun.

Ook in Weils (1989: 692-6) artikel zijn aanwijzingen te vinden voor een uni-dimensionale steun in het geval van nieuwe regimes. Na de dood van dictator Franco in 1975 wordt in Spanje een democratisch regime gevestigd. De eerste verkiezingen vinden plaats in 1977 . Ondanks de toenmalige recessie die de Spaanse economie hard trof, groeien specifieke en diffuse steun voor 
de jonge Spaanse democratie in de beginperiode hand in hand. Weil spreekt in dit kader over een "honeymoon period" (1989: 694-5 en 699-700). Ook in het na-oorlogse West-Duitsland gaan specifieke en diffuse steun voor de nieuwe orde aanvankelijk hand in hand. Het West-Duitse voorbeeld spreekt echter minder tot de verbeelding omdat de opbouw van de West-Duitse democratie gepaard ging met een ongekende economische groei. Niettemin zijn er dus sterke empirische aanwijzingen dat de steun voor nieuwe regimes onder omstandigheden uit een noninstrumenteel stuk kan bestaan.

Evans en Whitefield (1995) constateren eveneens dat de directe invioed van de economische laagconjunctuur op de beoordeling van de nieuwe democratieên in tien voormalige Oostbloklanden gering is. Zo is het mogelijk dat een meerderheid van de Oost-Europeanen de nieuwe democratische orde in hun land steunen, terwijl tegelijkertijd een nog grotere meerderheid onderkent dat hun persoonlijke economische situatie en de macro-economische situatie van hun land aanzienlijk is verslechterd. Dit onderstreept dat onder bepaalde omstandigheden het onderscheid tussen specifieke en diffuse steun geen empirische waarde heeft.

Concluderend: Het onderscheid tussen specifieke en diffuse steun is soms wel en soms niet empirisch zinvol. lets vergelijkbaars geldt ook voor Eastons onderscheid naar objectcategorieën. Het onderscheid tussen steun voor gezagsdragers en het politieke regime blijkt in veel situaties zinvol. In de praktijk zijn er nog nauwelijks (Westle, 1989) serieuze pogingen ondernomen om de steun voor de politieke gemeenschap als afzonderlijke type in kaart te brengen, zodat over de onderscheidende waarde van de politieke gemeenschap als afzonderlijk object van politieke steun geen echt oordeel mogelijk is. De conclusie moet derhalve zijn dat hoewel de twee dimensies objectcategorieën en soorten - die ten grondslag liggen aan Eastons typologie onder omstandigheden empirisch bruikbaar zijn, het gebruik van de typologie niet onder alle omstandigheden zinvol is. Dit betekent dat van systeem tot systeem en van tijd tot tijd moet worden gekeken in hoeverre het onderscheiden van verschillende typen politieke steun empirische meerwaarde heeft. Hoe een en ander uitpakt in het geval van de EU, wordt in hoofdstuk 4 (appendix 4.1 ) bespreken.

\section{Steun voor de EU: definitie}

Gelet op de niet eenduidige empirische inzichten met betrekking tot Eastons typologie is er voor gekozen om bij de afbakening van het concept steun voor de $E U$ niet op voorhand een onderscheid te maken tussen verschillende typen EU-steun. Pas in het volgende hoofdstuk zal worden nagegaan met de typologie van Eastons in het achterhoofd - en voor zover de beschikbare data dat toelaten - in welke mate gevoelens van politieke steun voor de EU gedifferentieerd zijn. In hoeverre het uiteindelijk zinvol is om in dit onderzoek verschillende typen steun voor de EU 
te onderscheiden is in de eerste plaats immers een empirische vraag, en zal verder worden ingegeven door de theoretische verklaringen die in dit boek centraal zullen staan en de eisen die het landenvergelijkende en dynamische onderzoeksdesign aan de te gebruiken data stellen. Dientengevolge is gekozen voor een eerste voorzichtige en globale definitie van het theoretische concept dat nauw aansluit bij omschrijvingen van Easton:

Steun voor de EU is een individuele houding of gedraging waarmee een individu uiting geeft aan zijn of haar positieve of negatieve evaluatie van de EU of een specifiek aspect van de EU.

Negatieve steun voor de EU wordt in dit boek aangeduid met de term kritiek op de EU. Steun en kritiek zijn in beginsel individuele kenmerken. Van publieke steun voor de EU is pas sprake als de mate van steun voor respectievelijk kritiek op de EU binnen een bepaalde groep individuen op de een of andere manier wordt geaggregeerd naar groepsniveau.

Essentieel element van de definitie is het feit dat het moet gaan om een houding respectievelijk gedraging waaraan een evaluatie (positief, negatief, onverschilligheid, neutraal) ten grondslag ligt. Dit betekent dat non-evaluatieve dimensies zoals interesse in, kennis van, en geïnformeerd zijn over de EU waarschijnlijk niet onder de noemer steun voor de EU vallen, hoewel niet op voorhand valt uit te sluiten dat onder omstandigheden dat ook aan dit soort dimensies in de empirie nadrukkelijk een evaluatie van het systeem ten grondslag ligt. Er zal derhalve expliciet moeten worden nagegaan in hoeverre dergelijke op het eerste gezicht nonevaluatieve aspecten in de praktijk ook daadwerkelijk buiten het concept steun voor de EU vallen. In hoofdstuk 4 zal worden ingegaan op de operationalisering en op de vraag in hoeverre een verdere differentiatie noodzakelijk en mogelijk is.

\subsection{Publieke steun en internationale organisaties}

De centrale vraag uit het begin van dit hoofdstuk luidde in hoeverre politieke systemen wel publieke politieke steun behoeven? In het begin van de vorige paragraaf is betoogd dat politieke systemen niet zonder politieke steun kunnen. Eastons opmerkingen over politieke steun en het functioneren van politieke systemen zijn vooral toegesneden op, en blijken bovenal empirisch zinvol in relatie tot nationale politieke systemen. In het algemeen wijken nationale politieke systemen qua organisatie, taken, bevoegdheden en functioneren echter sterk af van internationale politieke organisaties. ${ }^{42}$ In het kader van dit onderzoek naar publieke steun voor de EU zijn

42 De term internationale politieke systemen gebruik wordt hier gebruikt als aanduiding van zogenaamde internationale gouvernementele organisaties. Het betreft organisaties die zijn opgericht als gevolg van een overeenkomst tussen staten. Non-gouvernementele organisaties zoals Greenpeace of Amnesty International blijven hier volledig buiten beschouwing. Voor een uitputtende classificatie van alle mogelijke internationale organisaties, 
daarom twee aanvullende vragen van groot belang. Ten eerste of hedendaagse internationale politieke organisaties wel zijn aan te merken als politieke systemen; en ten tweede in welke mate de noodzakelijke politieke steun voor politieke systemen uit publieke steun bestaat.

\section{Zijn internationale organisaties politieke systemen?}

In hoeverre zijn internationale organisaties te beschouwen als volwaardige politieke systemen? Om van volwaardige politieke systemen te kunnen spreken moeten internationale organisaties gezaghebbend en besluitvaardig zijn.

In dit licht is het belangrijk om een analytisch onderscheid te maken tussen internationale organisaties met een intergouvernementeel en een supranationaal regime. ${ }^{33} \mathrm{Bij}$ samenwerkingsvormen op intergouvernementele basis behouden de lidstaten in principe hun volledige soevereiniteit, terwijl bij vormen van supranationale samenwerking de lidstaten een deel van hun soevereiniteit overdragen aan de op te richten internationale organisatie. Het woord soevereiniteit:

"... refers to the legal capacity of national decision-makers to take decisions without being subject to external restraints. "(Nugent, 1999: 502)

Samenwerking tussen staten binnen intergouvernementele internationale organisaties beperken de wetgevende capaciteit van de nationale staten niet, tenzij de lidstaten zich vrijwillig bereid verklaren om besluiten die zijn genomen binnen zo'n organisatie te respecteren. De acceptatie of het gezag - van besluiten die binnen zo'n organisatie worden genomen berust op een vorm van vrijwillige zelfbinding. Het behoud van soevereiniteit binnen intergouvernementele organisaties komt tot uiting in het feit dat elke lidstaat de besluitvorming kan blokkeren door het uitspreken van een veto, of de mogelijkheid behoudt om de uitkomst van de besluitvorming naast zich neer te leggen. Internationale organisaties met een intergouvernementeel regime zijn er in beginsel niet op ingericht om besluitvaardig en gezaghebbend te zijn.

Kenmerkend voor een supranationale internationale organisatie is dat lidstaten bij de oprichting een deel van hun soevereiniteit overdragen. Hierdoor ontstaat een organisatie die in beginsel bindende besluiten kan nemen voor haar lidstaten op dat terrein waar de lidstaten afstand hebben gedaan van hun soevereiniteit - bijvoorbeeld: de regulering van de kolen- en staalindustrie. De lidstaten hebben dus niet langer de vrijheid om zelf regels te maken op dat terrein, hoewel niet valt uit te sluiten dat de supranationale organisatie daar toch ruimte voor laat. In principe beschikken supranationale organisaties dus over taken en bevoegdheden die ze onafhankelijk van haar lidstaten kunnen uitoefenen. Idealiter beschikt een supranationale

zie Archer (1992: 38-70).

${ }^{*} \mathrm{Vgl}$. Kooijmans, P.H. (1996) Internationaal publiekrecht in vogelvlucht (zesde druk). Groningen: WoltersNoordhoff, pp. 156-7. 
internationale organisatie dan ook over mogelijkheden om staten, alsmede bedrijven en burgers binnen de lidstaten aan te kunnen pakken indien zij zich niet houden aan de genomen besluiten. Internationale organisaties met een supranationaal regime zijn er dus in tegenstelling tot die met een intergouvernementeel regime in beginsel wel op ingericht om besluitvaardig en gezaghebbend te zijn.

Aangezien het regime - in de zin van de structuur, regels en normen die betrekking hebben op de besluitvorming - van geen enkele hedendaagse internationale organisatie in alle opzichten ook de EU niet (zie hieronder) - volledig op supranationale leest is geschoeid, blijft vooralsnog onduidelijk in hoeverre Eastons stelling dat elk politiek systeem een minimale mate aan (diffuse) steun behoeft om te kunnen functioneren en voortbestaan ook van toepassing is op hedendaagse internationale organisaties. Om op dit punt duidelijkheid te krijgen is het noodzakelijk na te gaan in hoeverre intergouvernementele organisaties politieke steun behoeven om te kunnen voortbestaan respectievelijk te kunnen functioneren.

Het gezag - nodig voor de acceptatie van besluiten door de lidstaten - van intergouvernementele organisaties zal gelet op het onderliggende regime primair gebaseerd zijn op specifieke steun. Deze organisaties kunnen immers geen besluiten nemen of implementeren zonder de expliciete instemming van de betrokken lidstaten. Dit betekent dat als binnen zo'n organisatie geen onderlinge overeenstemming kan worden bereikt over de gezamenlijke aanpak van een probleem, de lidstaten de volledige vrijheid behouden om te kiezen voor een nationale of andere internationale oplossing. De samenwerking beperkt de wetgevende capaciteit van de lidstaten niet. Dit is niet zonder consequenties. Het feit dat er alternatieve mogelijkheden zijn maakt dat het uitblijven van besluiten in een intergouvernementele context niet snel zal leiden tot een situatie van output failure en stress. Een output failure vooronderstelt dat de omgeving de organisatie expliciet verwijt dat er geen besluit komt. Alle betrokkenen zijn echter op de hoogte van de beperkingen van een intergouvernementeel regime, waardoor het ontstaan van een output failure niet voor de hand ligt. In dat kader kan worden gewezen op allerlei slapende internationale verdragen (WEU) die alleen in uitzonderlijke situaties als de leden het opportuun achten, van stal worden gehaald. Slapende organisaties slagen er dus in voort te bestaan zonder te functioneren - zij genereren geen besluiten. Er zijn dus redenen om te vooronderstellen dat Eastons inzichten aangaande de noodzakelijke aanwezigheid van voldoende politieke steun niet onverkort van toepassing kunnen worden verklaard op internationale organisaties met een intergouvernementeel regime. Het voortbestaan van zulke organisaties vereist geen diffuse steun - tenzij de kosten van de organisatie zo hoog zijn dat de begroting van de organisatie zwaar op de begroting van de lidstaten drukt -, terwijl voor het dagelijks functioneren specifieke steun volstaat. Dit betekent ook dat intergouvernementele organisaties in principe kunnen voortbestaan 
zonder te functioneren en zonder politieke steun - diffuus, noch specifiek - vanuit de omgeving. ${ }^{4}$

De vraag of diffuse steun noodzakelijk is voor het voortbestaan van hedendaagse internationale organisaties is dus in de eerste plaats afhankelijk van de mate waarin het onderliggende besluitvormingsregime supranationale trekjes heeft. Met de oprichting van een supranationale organisatie sluiten lidstaten de weg naar alternatieve nationale of internationale oplossingen expliciet af. Alvorens deze alternatieve vormen van besluitvorming weer in beeld kunnen komen, moet de overgedragen bevoegdheid weer "vrij" komen. Haperende besluitvorming binnen een supranationale organisatie leidt daarom wel tot een situatie van output failure en het ontstaan van stress. De politieke eisen waar het supranationale systeem de antwoorden op moet formuleren blijven liggen. Indien de problemen die blijven liggen nijpend genoeg zijn, komt het voortbestaan van de organisatie onder druk te staan. De roep om oplossingen zal toenemen. Een van de meest voor de hand liggende oplossingen is dat de overdracht van bevoegdheden aan de internationale organisatie ter discussie komt te staan. Supranationale internationale organisaties kunnen daarom in tegenstelling tot intergouvernementele organisaties op de lange termijn niet voortbestaan zonder te functioneren. Naarmate de besluitvorming binnen een internationale organisaties een sterker supranationaal karakter draagt, zal het functioneren en voortbestaan van het systeem dus sterker afhankelijk zijn van de aanwezigheid van diffuse steun.

Het onderscheid tussen internationale organisaties met een meer intergouvernementeel en een meer supranationaal karakter is dus van groot belang bij het beantwoorden van de vraag of internationale organisaties zonder een minimale mate van diffuse steun kunnen functioneren en voortbestaan. In de volgende paragraaf zal expliciet worden ingegaan op de vraag in hoeverre de $\mathrm{EU}$ is te typeren als een supranationale internationale organisatie.

\section{Politieke steun en publieke steun}

Het tweede onderwerp van deze paragraaf betreft de vraag naar de kwaliteit van de noodzakelijke politieke steun. Tot nu toe is niet ingegaan op het feit dat de term politieke steun in Eastons theorie geen equivalent is voor de term publieke steun. Steun opgevat als een noodzakelijke voorwaarde voor het functioneren van een politiek systeem is in Eastons werk namelijk onlosmakelijk verbonden met de notie dat de medewerking van bepaalde leden van de gemeenschap of delen van de omgeving belangrijker zijn voor een succesvolle uitvoering van besluiten dan die van andere leden of delen. Zo is het functioneren van internationale organisaties vaak sterker afhankelijk van de medewerking van rijke lidstaten dan van arme lidstaten, omdat

\footnotetext{
${ }^{44}$ Easton linkt de uitzondering op de regel dat specifieke steun volstaat, mijns inziens, geheel ten onrechte niet aan het gemankeerde politicke karakter van de meeste intemationale organisaties. Hij erkent wel dat binnen dit soort systemen "the proportion of actions taken through authorative decisions is ... extremely low", maar concludeert niettemin dat het om politieke systemen gaat (Easton, 1965:284-5).
} 
die eerste groep het merendeel van de middelen verschaft die nodig zijn voor de uitvoering van besluiten. Easton (1965: 222) stelt dat het begrip noodzakelijke steun ten allen tijde gerelateerd is aan de vraag wie de politically relevant members of a system zijn. Wie precies de relevante leden van een politiek systeem zijn varieert in het algemeen van systeem tot systeem, alsmede van tijd tot tijd. Bij internationale organisaties krijgt dit vraagstuk nog een extra dimensie, namelijk: wie zijn de leden van de organisatie? Burgers of lidstaten?

Internationale organisaties worden weliswaar opgericht door regeringen van staten als zodanig, maar het uiteindelijke succes van de organisaties is afhankelijk van de vraag of de leden van de nationale politieke gemeenschappen de consequenties van binnen deze gremia genomen besluiten accepteren en aanvaarden. Veel internationale organisaties proberen deze acceptatie te verkrijgen door de concrete uitvoering van hun besluiten over te laten aan de betrokken lidstaten. $\mathrm{Bij}$ internationale organisaties met een puur intergouvernementeel regime is dit ook logisch. De internationale organisaties en hun besluiten liften op die manier mee op de steun voor en het gezag van de onderliggende nationale politieke systemen. Het gezag van internationale organisaties en hun besluiten is daarom vaak in eerste instantie afhankelijk van de mate van politieke steun onder de politiek-bestuurlijke elites van de betrokken lidstaten - regeringsleden, parlementariërs, diplomaten, hoge ambtenaren, rechters, enzovoort - die primair verantwoordelijk zijn voor het omzetten van een internationaal besluit in nationaal beleid en/of regelgeving. Zodoende is voor het uiteindelijke succes of falen van internationale organisaties weliswaar de medewerking van de burgers der lidstaten van essentieel belang, maar is paradoxaal genoeg geen directe publieke steun voor de internationale organisatie nodig zolang er maar sprake is van voldoende politieke steun vanuit de nationale politiek-bestuurlijke elite voor de internationale organisatie en voldoende publieke steun voor het nationale politieke systeem vanuit de bevolking. De noodzakelijkerwijs relevante politieke steun die nodig is om internationale organisaties te kunnen laten functioneren - dit wil zeggen: besluiten nemen en die geaccepteerd weten te krijgen door de lidstaten -, bestaat dus normaliter slechts uit steun voor bij de uitvoering betrokken nationale politiek-bestuurlijke elites.

Onder bepaalde omstandigheden kan publieke steun of kritiek echter ook direct van invloed zijn op het functioneren van internationale organisaties. In het vorige hoofdstuk hebben we al gezien dat via referenda en verkiezingen een gebrek aan publieke steun het functioneren van internationale organisaties en de acceptatie van haar besluiten kan beïnvloeden. Dit is ook het geval als er sprake is van een waarlijk supranationaal regime waarbij internationale besluiten zonder tussenkomst van de nationale politiek respectievelijk het nationaal bestuur bindende gedragsregels genereren voor de burgers. In juridische termen gaat het om organisaties die direct werkende besluiten kunnen nemen. Als burgers zich eenmaal bewust zijn van de supranationale oorsprong van bepaalde besluiten, dan zal naar verwachting ook de mate van acceptatie van dat 
soort besluiten afhankelijk worden van publieke steun voor de betrokken supranationale organisaties. Onder deze omstandigheden kan directe publieke steun voor internationale organisaties zelfs uitgroeien tot de belangrijkste bron van politieke steun. In zo'n geval draait het niet meer om een indirecte invloed van afzonderlijke nationale publieke opinies, maar om de directe invloed van een internationale - of beter nog: supranationale - publieke opinie op de internationale organisatie

Voor zover politieke steun een noodzakelijke voorwaarde is voor het functioneren van internationale organisaties zal het dus niet vaak gaan om publieke politieke steun. Om te kunnen functioneren en te kunnen blijven voortbestaan is het veelal voldoende dat internationale organisaties zich gesteund weten door de politiek-bestuurlijke elites uit de betrokken lidstaten, omdat die elites zorg dragen voor de daadwerkelijke uitvoering van internationale besluiten. Publieke steun is wel noodzakelijk voor zover er sprake is van een supranationale organisatie die ook als zodanig herkenbare, direct werkende besluiten neemt die burgers direct raken; of voor zover er via referenda, rechtstreekse verkiezingen of anderszins een directe relatie ontstaat tussen publiek en de (internationale) organisatie. Aangezien dit laatste slechts sporadisch voorkomt bij hedendaagse internationale organisaties, kan de betekenis van publieke politieke steun voor internationale organisaties gemakkelijk worden overschat.

\subsection{EU: politiek systeem en publieke steun}

In deze paragraaf zullen de centrale vragen uit de vorige paragraaf opnieuw onder de loep worden genomen maar nu in relatie tot de EU. Ten eerste zal worden ingegaan op de vraag hoe de $\mathrm{EU}^{45}$ scoort op de karakteristieke kenmerken van politieke systemen: gezaghebbendheid en besluitvaardigheid. De vraag is eigenlijk: hoe supranationaal is de EU? Vervolgens komt de vraag aan de orde welke rol er in het EU-kader is weggelegd voor publieke politieke steun. In deze paragraaf zal veelvuldig worden gerefereerd aan reeds eerder in hoofdstuk 2 beschreven ontwikkelingen in de geschiedenis van de EU.

Hoe supranationaal is de EU?

Het besluitvormingsregime binnen de EU tijdens de onderzoeksperiode (1952-1998) kenmerkt zich formeel door een gematigd supranationalisme. De formele hoofdregel is dat de (intergouvernementele) Raad beslissingsbevoegd is, maar slechts kan beslissen op voorstellen

\footnotetext{
${ }^{45}$ Hier wordt de aandacht uiteraard volledig geconcentreerd op het supranationale hart van de EU - de EGKS, EURATOM, en de E(E)G; de twee intergouvernementele pijlers blijven buiten beschouwing.
} 
van de (supranationale) Commissie. De Raad - de vergadering van nationale ministers op een bepaald beleidsterrein - neemt Commissievoorstellen in beginsel aan met een gewone meerderheid - de helft van de nationale ministers plus ćén -, afwijken van een Commissievoorstel vereist een unaniem besluit. Een bindend besluit kan dus alleen tot stand komen op initiatief van de Commissie, en behoeft niet noodzakelijkerwijs de steun van elke lidstaat als er maar een meerderheid van de lidstaten voor is. In de praktijk en de historie van de EU is deze (formele) supranationale hoofdregel echter eerder uitzondering, dan regel. Een drietal factoren doorkruisen de werking van deze hoofdregel.

De eerste storende factor is het Compromis van Luxemburg (1966). Deze afspraak heeft de daadwerkelijke doorwerking van bovenstaande hoofdregel per 1 januari 1966, zoals overeengekomen in het Verdrag van Rome, in de kiem gesmoord. Hierdoor beschikte elke lidstaat praktisch gezien bij elk besluit in principe over veto-macht. Het Compromis heeft de daadwerkelijke invoering van besluitvorming bij meerderheid in de Raad zo'n twintig jaar vertraagd (Dinan, 1994: 251-4). De wreking ervan heeft tot het midden van de jaren tachtig een zware intergouvernementele schaduw over de besluitvorming in de EU geworpen.

Een tweede mechanisme dat de vrije werking van de supranationale hoofdregel in de praktijk ondermijnt, is de instelling van de Europese Raad in 1974. Dit instituut fungeert als een intergouvernementele "kraamkamer" voor ingrijpende Commissie-voorstellen. Compromissen die in de Europese Raad tot stand komen, worden doorgesluisd naar de Commissie om vervolgens vrij geruisloos door de Raad te worden geloodst. Tegenwoordig lijkt de Europese Raad ook steeds vaker dienst te doen als crisis- en opvangcentrum voor debatten die vastgelopen zijn in de Raad. Door de introductie van de Europese Raad heeft de Commissie in de praktijk, formeel niet, een deel van haar exclusieve initiatiefrecht verloren, alsmede is de mogelijkheid ontstaan voor de lidstaten (de Raad) om besluiten buiten de EU om te leiden en buiten bereik te houden van bijvoorbeeld het EP en het Hof van Justitie (Lodge, 1989: 48-50; Nugent, 1999: 202). Ook deze ontwikkeling betekent per saldo een versterking van de intergouvernementele krachten.

De derde factor die de supranationale hoofdregel doorkruist zijn verdragsbepalingen die voorschrijven dat Raadsbesluiten op bepaalde beleidsterreinen slechts mogelijk zijn met unanimiteit of een gekwalificeerde meerderheid. Dit worden er overigens wel steeds minder (zie hieronder).

Deze drie factoren zorgen er voor dat het in beginsel supranationale regime van de EU in de praktijk lang niet altijd uit de verf komt. De macht van de lidstaten binnen de EU is veel groter dan men op basis van het formele besluitvormingsregime zou mogen verwachten. In de praktijk is de soevereiniteit van de lidstaten derhalve veel groter dan op papier. 
Daar tegenover staat echter een aantal ontwikkelingen dat het formeel gematigd supranationale karakter van het EU-regime juist versterkt (George, 1996: 53-4). In de eerste plaats is dat het groeiend aantal lidstaten waardoor het praktisch onmogelijk is geworden om het Compromis van Luxemburg (vetorecht bij vitaal belang) binnen de Raad overeind te houden. Met het in werking treden van de Europese Akte (1987), het Verdrag van Maastricht (1993) en het Verdrag van Amsterdam (1998) is voor het nemen van besluiten op steeds meer beleidsterreinen nog slechts een gewone of gekwalificeerde meerderheid binnen de Raad nodig. Hoewel men aanvankelijk na het in werking treden van de Akte nog bleef streven naar consensus, is besluitvorming bij meerderheid inmiddels heel gewoon. Het groeiend aantal lidstaten en verdragsaanpassingen hebben het Compromis van Luxemburg naar de achtergrond verdrongen (Nugent, 1999: 170).

Een andere ontwikkeling die het supranationale karakter versterkt, is de groeiende macht van het Parlement (Lodge, 1989: 58-79; Dinan, 1994: 273-292). Hoewel de macht en bevoegdheden van het EP op een aantal essentiele punten nog altijd schril afsteken tegen die van de Raad en Commissie enerzijds, en vergelijkbare nationale parlementen binnen de lidstaten anderzijds, is de positie van het Parlement de afgelopen decennia onmiskenbaar versterkt. Wat de medewetgevende taak betreft, was de Raad aanvankelijk slechts verplicht om advies te vragen aan het EP over elk Commissievoorstel (consultatie-procedure). In de jaren zeventig komt daar een beperkt budgetrecht bij waardoor het EP invloed krijgt op de jaarlijkse vaststelling van de begroting. In 1979 vinden de eerste rechtstreekse verkiezingen plaats. Dit verschaft het EP een legitimatie om meer macht te eisen. Met de ondertekening van de Europese Akte, Verdrag van Maastricht en Amsterdam worden die eisen tot op zekere hoogte ingewilligd. Het Parlement heeft nu in heel veel gevallen de mogelijkheid om Raadsbesluiten dwingend te amenderen en/of te blokkeren, hoewel initiëren en besluiten nog steeds het exclusieve domein van de Commissie respectievelijk Raad blijft. De gerechtvaardigde conclusie lijkt echter dat het EP in de jaren negentig is uitgegroeid tot medewetgever naast de Raad en de Commissie (Lauwaars en Timmermans, 1994: 60-2; Nugent, 1999: 205-13).

Verder is het toezicht vanuit het EP op het bestuur van de EU, de Commissie, in de loop der tijd steeds verder versterkt. Sinds de start van de EU beschikt het EP al over de mogelijkheid om de Commissie in zijn geheel naar huis te sturen. Dit had echter weinig zin doordat men vervolgens geen invloed had op de nieuwe samenstelling. Die mogelijkheid heeft het Parlement met het Verdrag van Maastricht echter gekregen. De keuze van de voorzitter en de samenstelling van de Commissie door de lidstaten behoeft sinds 1993 de expliciete goedkeuring van het EP. Niettegenstaande het tandeloze imago is het Parlement er dus ook op het punt van de bestuurscontrole inmiddels in geslaagd om uit te groeien tot een in potentie supranationale machtsfactor.

De belangrijkste supranationale factor binnen de EU is echter het Hof van Justitie. Het 
optreden van het Hof van Justitie in Luxemburg laat niets aan duidelijkheid te wensen over als het gaat om de supranationale status en gezaghebbende karakter van EU-besluiten. De verhouding tussen gemeenschapsrecht en de nationale rechtsordes is vastgelegd in de inmiddels klassieke arresten Van Gend en Loos en Costa/Enel. In het eerste arrest bepaalt het Hof dat:

"De Gemeenschap vormt in het volkenrecht een nieuwe rechtsorde ten bate waarvan de staten, zij het op een beperkt terrein, han soevereiniteit hebben begrensd en waarbinnen niet slechts deze Lid-Staten, maar ook hin onderdanen gerechtigd zijn." ${ }^{\text {"4 }}$

Dit arrest stelt dat het EU-recht - verdragen en besluiten - rechtstreeks, zonder tussenkomst van de nationale wetgever, deel uitmaakt van de nationale rechtsordes van de lidstaten. Dit betekent dat elke burger zich bij de rechter kan beroepen op rechten die hij krachtens EU-verdragen of EU-besluiten meent te hebben. In Costa/Enel bepaalt het Hof twee jaar later:

"... dat de Staten tegen de rechtsorde, die zij op basis van wederkerigheid hebben aanvaard, niet kunnen ingaan met een later, eenzijdig afgekondigd wettelijk voorschrift; dat een dergelijk voorschrift derhalve niet boven de rechtsorde van de Gemeenschap kan worden gesteld. "at7

Deze uitspraak betekent dat elke nationale rechter bij een conflict tussen een nationale wet en EU-regelgeving voorrang moet geven aan het gemeenschapsrecht. Rechtstreekse werking en voorrang vormen zodoende de pijlers onder het EU-recht (Nugent, 1999: 260-1). Sterker had het supranationale karakter van het gemeenschapsrecht nauwelijks kunnen worden gegrondvest. Voor juristen staat het supranationale karakter van de EU dan ook buiten kijf.

Een andere vrij recente (Verdrag van Maastricht) versterking van het supranationale karakter betreft de bevoegdheden van de Commissie. Lidstaten die hun EU-verplichtingen niet nakomen konden aitijd al door de Commissie of andere lidstaten voor het Hof worden gedaagd. De uitspraak van het Hof was in beginsel bindend, maar tot 1993 waren er eigenlijk geen middelen om niet-naleving van de uitspraak te bestraffen. Tegenwoordig kan de Commissie een lidstaat die een uitspraak van het Hof niet wenst te aanvaarden zo nodig een dwangsom opleggen. Deze procedure onderstreept de in potentie ondergeschikte positie van de lidstaten ten opzichte van het EU-recht, de Commissie en Hof.

Deze ontwikkelingen betekenen stuk voor stuk (potentiële) versterkingen van het in beginsel gematigd supranationale besluitvormingsregime van de EU. Op dit moment lijken de supranationale elementen sterker dan ooit, hoewel het EP nog veel kansen laat liggen (zie paragraaf 2.4).

\footnotetext{
${ }^{4}$ Hof van Justitie EG, 5 februari 1963, Van Gend en Loos (26/62).

${ }^{* 7}$ Hof van Justitie EG, 5 juni 1964, Costa/Enel (6/64).
} 
Dus tegenover de factoren die het reeds gematigde supranationale EU-regime verder ontkrachten, zijn er dus ook ontwikkelingen en factoren die het supranationale karakter van de EU juist onderstrepen. De EU is weliswaar geen volledig supranationale organisatie doordat met name op het punt van de besluitvaardigheid intergouvernementele elementen (de Raad) een belangrijke rol blijven spelen, maar de EU is nadrukkelijk meer dan een "gewone" intergouvernementele organisatie. De EU lijkt daarom het best te typeren als een soort mengvorm. Dit impliceert dat de EU slechts tot op zekere hoogte is te typeren als een volwaardig politiek systeem. In het licht van hetgeen in de vorige paragraaf is geconcludeerd, betekent dit dat voor het functioneren en voortbestaan van de EU tot op zekere hoogte diffuse politieke steun nodig is.

\section{EU: politieke steun en publieke steun}

De tweede vraag is in hoeverre het bij deze noodzakelijke politieke steun gaat om publieke politieke steun? In dit kader is van belang om vast te stellen dat de meeste EU-besluiten de burgers van de lidstaten direct binden. Dit betekent dat het voortbestaan en functioneren van de EU in beginsel dus ook afhankelijk is van publieke politieke steun. Tegelijkertijd zijn er redenen

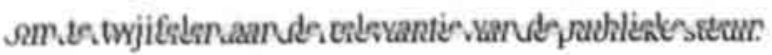

Ten eerste betreft de bulk van de direct werkende Europese besluiten economische regelgeving waar vooral ondernemingen - boerderijen, fabrieken, winkels, enzovoort - en overheidsorganisaties direct mee te maken hebben, maar individuele burgers veel minder (Nugent, 1999: 259). Dit komt ook omdat de EU-regelgeving op een beleidsterrein bijna nooit uitputtend is. Dit betekent dat de EU-regels in de praktijk vaak worden ingevuld via of aangevuld met nationale regels, waardoor het voor burgers lastig is om het primaat van de onderliggende EU-regels als zodanig te (her)kennen. Ondanks de grote invloed die direct werkende EUbesluiten op het dagelijks leven van burgers hebben, is die invloed door diezelfde burgers hierdoor slechts met moeite tot de Europese bron te herleiden.

Hiermee samenhangend is er nog een tweede factor die het zicht van burgers op het werkelijke belang van EU-besluiten waarschijnlijk ernstig versluiert. Dit heeft te maken met de organisatie van de implementatie van EU-besluiten. De implementatie is bijna altijd in handen van de lidstaten. Bij richtlijnen gebeurt dit zelfs expliciet. Een richtlijn verplicht lidstaten slechts een bepaalde doelstelling te realiseren voor een bepaald tijdstip. De middelen voor het bereiken van dat doel mag elke lidstaat zelf kiezen. Weliswaar houdt de Commissie toezicht op de naleving van richtlijnen en is ze min of meer verantwoordelijk voor de uitvoering en controle op de toepassing van beschikkingen en verordeningen, maar in de praktijk stelt dit alles niet zoveel voor omdat de Commissie daar de ambtenaren niet voor heeft. $\mathrm{Na}$ het opstellen van de regelgeving - en even afgezien van de directe bemoeienis met enkele onderdelen van EU-beleid zoals het toezicht op fusies in het kader van het karteltoezicht - heeft de Commissie eigenlijk 
nauwelijks directe bemoeienis met de uitvoering van en controle op de toepassing van haar regels op de werkvloer. De staf van de Commissie omvat geen supranationale douane, immigratiedienst, veterinaire dienst, enzovoort. Dus waar de regelgeving er werkelijk toe doet - op boerderijen, in fabrieken, havens, vliegvelden, enzovoort - leunt de Commissie zwaar op nationale instanties en ambtenaren (Nugent, 1999: 345-50 en 376-7; Dinan, 1994: 221-2; George, 1996: 30-2; en Tutt, 1989: 125-6). Zoals bij veel internationale organisaties is het functioneren van de EU zodanig georganiseerd dat wordt meegelift op het gezag van het nationale bestuur. Dit versluiert het zicht van burgers op de macht van de EU.

De derde factor betreft de organisatie van de rechtspraak. Een vergelijkbaar mechanisme als bij de implementatie wordt toegepast, is ook in de rechtspraak herkenbaar. Zo komen burgers die een geschil hebben waarbij EU-regels in het geding zijn niet terecht bij een Europese rechter, maar moeten zij zich wenden tot een nationale rechter. De nationale rechters zien toe op de naleving van het gemeenschapsrecht. Nationale rechters mogen, en de hoogste nationale rechters moeten (!) zelfs, naar het Hof van Justitie voor advies (prejudiciële verwijzing) als ze niet volledig zeker zijn over de uitleg van een EU-regel. Middels prejudiciële beslissingen bewaakt het Hof de rechtseenheid binnen de EU en stuurt het de nationale rechters aan. Het Hof doet in zo'n procedure overigens geen uitspraak in de zaak, maar geeft een bindende interpretatie van de EU-bepaling die in het geding is. De uitspraken laten over het algemeen echter weinig aan duidelijkheid te wensen over wat het Hof vindt dat de nationale rechter in de concrete zaak moet beslissen. Via de prejudiciële procedure liggen de nationale rechters weliswaar stevig aan de Europese ketting, maar de burger heeft in de praktijk slechts te maken met de nationale rechter. ${ }^{48}$ De acceptatie (het gezag) van de jurisprudentie van het Hof door de burgers kan onder deze omstandigheden dus volledig gebaseerd worden op het gezag van en ontzag voor nationale rechters. Publieke steun voor het Hof in het bijzonder of de EU in het algemeen speelt zodoende nauwelijks een rol.

Ook bij het vergaren van financiēle middelen slaagt de EU erin om mee te liften op het gezag van de lidstaten. De inkomsten van de EU komen voort uit importheffingen op landbouwproducten, douanerechten op de import van andere producten en een gedeelte van de nationale BTW. In reactie op de snel groeiende uitgaven en gegeven de eis dat uitgaven en inkomsten binnen de Gemeenschap in evenwicht dienen te zijn, is in 1988 nog een andere bron van inkomsten aangeboord, de rechtstreekse bijdragen van de lidstaten. Heffingen, rechten, belasting en bijdragen worden door de lidstaten verzameld en vervolgens overgedragen aan de Gemeenschap (Kooijmans, 1996: 210-1). Dus ook op het punt van de financiële middelen

\footnotetext{
"Alleen in het uitzonderlijke geval dat een burger denkt dat een EU-besluit, dat hem individueel en direct raakt, genomen is in strijd met de EU-verdragen kan hij als burger zelf naar het Hof stappen. De kosten van een dergelijk geding zijn echter excessief hoog en niet op te brengen voor een modale burger.
} 
onderhoudt de EU geen directe relatie met de burgers zelf.

Deze factoren doen vermoeden dat het functioneren en voortbestaan van de EU slechts in zeer beperkte mate afhankelijk is van publiek politieke steun. Easton stelde al in 1965(!):

"... it has been surmised that the growth of the European political community may depend less upon the emergence, at the outset, of a sense of common identity among the people of the various nations than upon elites in different economic and political sectors working together for specific, functional ends. [...] It is quite conceivable that the initial and major bonds among the relevant political systems of Europe, if a European political community, in our sense, finally succeeds in emerging, will depend upon leadership rather than the general members of all cooperating national political units. A possible sequence would be simply to identify. Each unit would be tied to an emerging European political community through the fact first, that the leadership of each unit has such sentiments; second, that the followers in each unit identify closely with their elite; and third, that support from the followers will continue to be available even if the policies of the leadership lead to the subordination of each political system to a European suprasystem. In due course, however, we might anticipate that the continuation of a new political community might depend upon nurturing some direct bonds between the general members as individuals and the new political community." (Easton, 1965: 228-9)

De rechtstreekse verkiezingen voor het Europees Parlement (sinds 1979) en referenda in een aantal lidstaten vormen vooralsnog de meest tastbare directe relaties tussen EU en burgers. De vooraanstaande rol die politici en ambtenaren van de lidstaten spelen in de dagelijkse praktijk van de uitvoering en handhaving van EU-besluiten versluieren het zicht van burgers op het supranationale karakter van de EU. De relevantie van publieke politieke steun wordt op die manier ook beperkt. Doordat supranationale elementen binnen het EU-regime vooral de laatste vijftien jaar aan kracht hebben gewonnen, en verdragsveranderingen (Akte, Maastricht, Amsterdam) de bemoeienis van de EU met nagenoeg elk denkbaar beleidsterrein mogelijk maken, wordt het waarschijnlijk steeds moeilijker om de supranationale macht van de EU op het dagelijks leven ven de EU-burgers te verbergen. De aanwezigheid van publieke politieke steun zodoende waarschijnlijk steeds noodzakelijker.

\subsection{Tot slot}

Alleen internationale organisaties met een supranationaal regime zijn aan te merken als politiek systeem zoals bedoeld in Eastons politieke-systeemtheorie. Internationale organisaties met een intergouvernementeel regime zijn in die zin geen politieke systemen; zij kunnen voortbestaan 
zonder diffuse politieke steun. Supranationale organisaties behoeven wel een zekere mate van diffuse politieke steun om te kunnen voortbestaan. Vervolgens is nagegaan in hoeverre supranationale organisaties publieke politieke steun behoeven. De behoefte aan publieke steun lijkt vooral afhankelijk van de mogelijkheid om direct werkende - dit wil zeggen: de burgers van de lidstaten bindende - besluiten te nemen.

De EU is een internationale organisatie met een gematigd supranationaal regime dat veelvuldig gebruik maakt van de mogelijkheid om direct werkende supranationale besluiten te nemen. Dit betekent dat de EU in beginsel is aan te merken als politiek systeem dat om te kunnen functioneren en voortbestaan behoefte heeft aan publieke politieke steun. Die behoefte wordt in de praktijk nadrukkelijk door twee zaken getemperd. In de eerste plaats spelen intergouvernementele elementen (Raad) in de besluitvorming van de EU nog altijd een dominante rol. In de tweede plaats is de EU als supranationaal orgaan nauwelijks zichtbaar aanwezig in het dagelijks leven omdat de EU voor uitvoering, handhaving, financiële middelen en rechtspraak meelift op het gezag van de lidstaten. In de praktijk lijkt het voortbestaan en functioneren van de EU dan ook in de eerste plaats afhankelijk van voldoende politieke steun vanuit de nationale politieke elites, maar tegelijkertijd is het duidelijk dat de EU niet geheel zonder publieke politieke steun kan. 


\section{HOOFDSTUK 4}

\section{Publieke opinie over de EU in 1994}

\subsection{Inleiding}

Dit hoofdstuk staat in het teken van de operationalisering van de centrale afhankelijke variabele (publieke) steun voor de EU en een eerste kennismaking met de data. Om een indicatie te krijgen van de publieke steun voor de EU in de lidstaten, blijft de beschrijving in dit hoofdstuk beperkt tot slechts één tijdstip. Daarbij is de keuze gevallen op gegevens van Eurobarometer 42 verzameld in het najaar van 1994. De redenen om deze dataset te kiezen worden hieronder uiteengezet. In hoofdstuk 5 volgt een dynamische analyse van de ontwikkelingen in de publieke steun voor de EU in de verschillende lidstaten. In dit hoofdstuk zal geprobeerd worden een eerste voorlopig antwoord te formuleren op de eerste twee onderzoeksvragen, te weten:

1. Hoe groot is de publieke steun voor de EU in de lidstaten?;

2. Hoe groot zijn de verschillen in de publieke steun voor de EU tussen de lidstaten?

Alvorens antwoord kan worden gegeven op deze vragen zullen de concepten steun voor de EU op individueel niveau en publieke steun voor de $E U$ op geaggregeerd niveau moeten worden geoperationaliseerd. In paragraaf 4.2 en appendix 4.1 wordt ingegaan op de keuze van de indicatoren om steun op individueel niveau te meten. In dat kader wordt onder andere aandacht besteed aan de vraag in hoeverre het noodzakelijk is om het concept "steun " in het specifieke geval van de EU in meerdere typen uiteen te leggen. In paragraaf 4.3 wordt aandacht besteed aan een aantal andere aspecten van publieke opinie dan steun. Paragraaf 4.4 staat geheel in het teken van de mate van publieke steun voor de EU in 1994 op het niveau van de lidstaten. Daarin zal eerst aandacht worden besteed aan de wijze waarop in dit onderzoek de gevoelens van steun voor de EU onder individuele burgers van een lidstaat worden geaggregeerd om de mate van publieke steun voor de $E U$ in een lidstaat te kunnen vaststellen. Vervolgens zal worden nagegaan in hoeverre de publieke steun voor de EU tussen de twaalf onderzochte lidstaten anno 1994 verschilt. Op het einde van dit hoofdstuk wordt een (voorlopig) eerste antwoord geformuleerd op de eerste twee onderzoeksvragen (paragraaf 4.5). 


\subsection{Steun voor de EU op individueel niveau: operationalisering}

Hoe moet het begrip steun voor de $E U$ op individueel niveau worden geoperationaliseerd in concrete indicatoren? Naast de gebruikelijke eisen van betrouwbaarheid en geldigheid moeten de te gebruiken indicatoren, gelet op de onderzoeksvragen en onderzoeksdesign, tevens een vergelijking door de tijd en tussen lidstaten mogelijk maken.

Het vraagstuk van de validiteit van het meetinstrument betekent dat de concrete indicatoren die worden gekozen om steun voor de EU op individueel niveau te meten in ieder geval moeten passen binnen de in het vorige hoofdstuk opgestelde definitie van het concept steun voor EU, te weten:

Steun voor de EU is een individuele houding of gedraging waarmee een individu uiting geeft aan zijn of haar positieve of negatieve evaluatie van de EU of een specifiek aspect van de EU. Aan de hand van de te kiezen indicatoren moet het bovendien mogelijk zijn dat er relatieve lange tijdreeksen worden gemaakt. Die laatste eis betekent dat we in de praktijk op een beperkt aantal standaardvragen uit de Eurobarometer-enquêtes (1970-1998) is aangewezen, waarvan er één ook in de vragenlijsten van de oude USIA XX-studies (1952-1967) en CMS-studie (1962) voor komt. De volgende drie standaardvragen maken het mogelijk om de gewenste relatief lange tijdreeksen te vormen (zie ook: Niedermayer en Sinnott, 1995; Anderson en Kaltenthaler, 1996; Dalton en Eichenberg, 1993):

- Bent $\mathrm{u}$ in het algemeen vóór of tegen pogingen om West-Europa te verenigen? (antwoord afwachten) (indien voor/tegen doorvragen) Bent $\mathrm{u}$ daar erg voor/tegen of tot op zekere hoogte voor/tegen? (unif);

- Als u morgen zou horen dat de EG/EU [JJ: voor/nal994] - de Europese Unie (Gemeenschap)

- zou worden opgeheven, zou U dan erg teleurgesteld zijn, zou het $U$ niet kunnen schelen of zou U juist opgelucht zijn? (serap);

- In het algemeen gesproken, vindt $u$ het een goede zaak, een slechte zaak of noch het een noch het ander, dat <eigen land > lid is van de Europese Gemeenschap/Europese Unie/ [ $\mathrm{J}$ : voor/na 1994]? (mem) ${ }^{49}$

De vetgedrukte en tussen haakje geplaatste aanduidingen (unif, scrap en mem) achter de vragen

\footnotetext{
"De tekst van de vragen is afgeleid en gebaseerd op een standaard Engelse en Franse vragenlijst. De tekst van de oorspronkelijke Engelse vragen luidt:

SCRAP: If you were told tomorrow that the European Community/European Union had been scrapped, would you be very sorry about it, indifferent or very relieved?

UNIF: In general, are you for or against efforts being made to unify Western Europe?

MEM: Generally speaking, do you think that [country's name] memberschip of the European Community/European Union is a good thing, a bad thing, or neither good nor bad?
} 
geven aan hoe deze standaardindicatoren in de rest van dit boek zullen worden aangeduid.

\section{Karakterisering van de standaardvragen}

In hoeverre sluit de definitie van het concept steun voor de $E U$ nu aan bij deze indicatoren? Bij de beantwoording van deze vraag zijn de verschillende vragen allereerst getypeend in het licht van de in het vorige hoofdstuk uitgewerkte typologie. Dit laatste wordt ook gedaan met het oog op de expliciet in het vorige hoofdstuk gemaakte opmerking dat in een later stadium de empirische noodzaak om te komen tot een nadere differentiatie van het concept EU-steun zou moeten worden nagegaan. De eveneens in het vorige hoofdstuk uitgewerkte typologie biedt in dat kader de nodige handreikingen. De vraag die bij zo'n noodzakelijke empirische analyse centraal moet staan, is vooral in hoeverre het gebruik van de drie hierboven genoemde vragen, c.q. indicatoren, een nadere differentiatie in verschillende typen steun voor de EU vereisen. In aanloop naar de bespreking van de belangrijkste conclusies van de resultaten van de nadere empirische analyse die in appendix 4.1 is opgenomen, zullen de drie indicatoren daarom eerst op face validity worden getypeerd in termen van de twee dimensies die aan de uitgewerkte typologie ten grondslag liggen: het object van steun en de soort steun.

Het te beoordelen object in de unif-vraag is het streven naar een verenigd West-Europa. Hoewel in de vraag geen directe verwijzing staat naar de EU, lijkt deze vraag niettemin wel in te passen binnen de definitie van het concept steun voor de EU. In termen van de typologie zou men kunnen zeggen dat het concrete object van de vraag, het streven naar West-Europese eenwording, verwijst naar een centrale waarde van het politieke regime van de EU. De formulering in de vraag in termen van het begrippenpaar "voor-tegen" lijkt op voorhand het best te typeren als primair non-instrumenteel (diffuus) van aard. Hoewel de vraag door respondenten die bij het beantwoorden van de vraag vooral letten op de directe verwijzing naar de pogingen om West-Europa te verenigen in de vraagtekst, de vraag ook kunnen opvatten als een verzoek om een meer instrumenteel oordeel te geven over recente plannen die er gemaakt zijn om te komen tot verdere West-Europese eenwording. In termen van de in het vorige hoofdstuk ontwikkelde typologie lijkt de unif-indicator op face validity het best te typeren als een indicator voor diffuse steun voor het politieke regime van de EU. Het valt echter niet op voorhand uit te sluiten dat de unif-indicator ook instrumentele (specifieke) evaluaties uitlokt.

Het te beoordelen object in de scrap-vraag is zonder twijfel de EU als zodanig, meer in het bijzonder een plotselinge opheffing van de EU. Een verwijzing naar een concreet (deel)object (gezagsdragers, gemeenschap of regime) ontbreekt. De respondenten wordt gevraagd om hun oordeel over een mogelijke opheffing uit te drukken in een gevoel - teleurstelling, opluchting of onverschilligheid. Het gaat hierbij dus nadrukkelijk om een affectieve, non-instrumentele, beoordeling. De scrap-vraag dus kan het beste worden getypeerd als een indicator voor de meting 
van diffuse steun voor de $\mathrm{EU}$ als zodanig.

Het object van de mem-vraag is het EU-lidmaatschap van het eigen land, Dit lijkt een zonder meer een verwijzing naar een aspect van de politieke gemeenschap. Deze indicator is reeds door verschillende andere onderzoekers als primair instrumenteel aangemerkt. Het contrasterende begrippenpaar goed versus slecht in de formulering van de antwoordcategorieën goede zaak en slechte zaak bieden op voorhand echter geen reden om aan een instrumentele beoordeling te denken. De vraag zal daarom op het eerste gezicht het best op te vatten als een vraag naar de mate van gegeneraliseerde instrumentele steun (diffuse steun, vertrouwen). Daarom wordt deze indicator getypeerd als een indicator voor vertrouwen (diffuse steun) in de politieke gemeenschap van de EU.

\section{Differentiatie noodzakelijk?}

Nu er op het eerste gezicht geen redenen zijn om te vooronderstellen dat de standaard-indicatoren niet aansluit bij de definitie van het concept, komen we bij de vraag naar de empirische noodzakelijkheid van een differentiatie van het concept steun voor de EU in verschillende typen. In hoeverre staan de drie standaardindicatoren voor verschillende typen steun voor de EU?

Daartoe is een nadere analyse op de gegevens uit Eurobarometer 42 (najaar 1994) uitgevoerd. De keuze voor juist deze dataset is ingegeven door twee overwegingen. Ten eerste, andere onderzoeken die op dezelfde vraag ingaan zijn primair gebaseerd op oudere Eurobarometer-data (Oppenhuis, 1995: 173-5; Duchesne en Frognier, 1995; Inglehart 1977b; Wildgen en Feld, 1976; Mayhew, 1980). Om die reden is gekozen voor een relatief recente dataset. Daarenboven bleek de vragenlijst van Eurobarometer 42 naast de die drie standaardvragen ook nog een groot aantal andere bruikbare indicatoren (helaas geen trendvragen) voor de meting van het concept steun voor de EU te bevatten. Middels een factoranalyse op een correlatiematrix van 14 verschillende indicatoren - inclusief de drie standaardvragen - is in Appendix 4.1 nagegaan of het gebruik van de drie standaardvragen een nadere differentiatie van het concept steun voor de EU vereist. De resultaten van de analyse op de EB42-dataset en een overzicht van de inzichten uit andere studies op dit punt worden uitvoerig besproken in appendix 4.1.

Uit die nadere analyse blijkt dat er geen enkele empirische noodzaak bestaat om bij gebruik van de hierboven geïntroduceerde drie standaard-indicatoren te komen tot een nadere differentiatie van het concept steun voor de EU. De drie indicatoren zijn te beschouwen als valide indicatoren voor de meting van een en het zelfde (ongedifferentieerde) begrip steun voor de $E U$. De houdingen van burgers ten aanzien van de EU blijken in de praktijk een stuk minder gedifferentieerd dan de ontwikkelde typologieën (vgl. Niedermayer en Sinnott (eds.), 1995; Lindberg en Scheingold, 1970; Shepherd, 1975; Anderson en Kaltenthaler, 1996; Dalton en 
Eichenberg, 1990). ${ }^{50}$ In appendix 4.1 is verder geconstateerd dat dit resultaat niet wezenlijk afwijkt van de resultaten uit eerder onderzoek.

Op basis van dit resultaat zou de constructie van een samengestelde factor- of schaalscore op basis van de drie indicatoren voor de hand liggen. Het gebruik van zo'n schaal wordt echter niet opportuun geacht, aangezien dit leidt tot een drastische beperking van het aantal meetpunten. Niet in elke gebruikte studie zijn immers alle drie de standaardvragen opgenomen. Om het aantal meetpunten door de tijd niet te zeer te beperken zullen de drie indicatoren daarom naast en onafhankelijk van elkaar worden gebruikt. Hoewel het bij de drie standaard-indicatoren in eerste instantie lijkt te gaan om indicatoren met een op het eerste gezicht (face validity) geheel verschillend profiel, blijkt uit de analyse dat het hier handelt om in empirische zin nauw aan elkaar verwante indicatoren.

De nadere analyse in appendix 4.1 laat overigens wel zien dat binnen de publieke opinie ten aanzien van de EU wel een duidelijk onderscheid bestaat tussen niet-evaluatieve en evaluatieve opinies; dit wil zeggen, de mate van interesse in en kennis van de EU (non-evaluatief) respectievelijk de steun voor de EU (evaluatief). Dit laatste betekent concreet dat de interesse voor de EU, onder meer, los staat van de beoordeling van de EU. Het is dus niet zo dat alle uitingen van EU-burgers ten aanzien van de EU een ongedifferentieerd geheel vormen, maar wel dat er binnen de evaluatieve (steun) oriëntaties geen empirische differentiatie zit.

Bij de concrete vertaling van de antwoorden van de respondenten op de drie standaardindicatoren naar steun voor de EU zijn de antwoordcategorieën op de drie standaardvragen ingedeeld in drie categorieën, te weten: steun (positief), kritiek (negatief) en onverschilligheid (neutraal). Mensen zijn onverschillig als ze zich op een vraag waar expliciet gevraagd wordt naar een evaluatie van de EU positief, noch negatief over de EU uitlaten. Dit betekent dat ook de ondervraagden die op een vraag geen antwoord geven, of expliciet aangeven geen mening te hebben over het onderwerp van de vraag in deze middencategorie eindigen.

Wat de vragen over de pogingen om West-Europa te verenigen (unif) en de mening over het nationale EU-lidmaatschap (mem) betreft ligt deze indeling voor de hand. Met betrekking tot de unif-indicator zullen de ondervraagden die zeggen erg tegen respectievelijk tegen eenwording te zijn, worden geacht kritisch te staan ten opzichte van de EU; diegene die erg voor respectievelijk voor eenwording zijn, worden geacht de EU te steunen; ten slotte zijn diegene die

\footnotetext{
${ }^{50}$ Dit weerhoudt sommige onderzoekers er echter niet van om op basis van face validity bepaalde surveyvragen aan te merken als indicatoren voor specifieke steun, en andere surveyvragen aan te merken als indicatoren van diffuse steun (o.a. Inglehart en Rabier, 1978; Handley, 1981; Anderson en Kaltenthaler, 1996). Niet zelden onderbouwen ze hun keuze door te wijzen op het feit dat de ontwikkeling van de publieke steun op basis van de ene indicator sterk afwijkt van de ontwikkeling op basis van de andere indicator. Vaak echter zijn de verschillen waar deze onderzoekers op wijzen het resultaat van tussentijdse veranderingen in de vraagstelling die de onderzoekers verder niet vermeiden of niet hebben opgemerkt.
} 
niet antwoorden of geen mening hebben, in de neutrale categorie ingedeeld." $\mathrm{Bij}$ de mem-vraag is het antwoord dat het nationale EU-lidmaatschap een goede zaak is, getypeerd als een teken van steun voor de EU. Het antwoord dat het nationale EU-lidmaatschap wordt beschouwd als een slechte zaak, is opgevat als kritiek op de EU. Diegene die noch goed, noch slecht antwoorden, geen antwoord geven of expliciet aangeven geen mening te hebben, komen in de neutrale categorie.

Bij de scrap-vraag over het opheffen van de EU ligt de indeling minder voor de hand. Twijfel bestaat er niet over de indeling van ondervraagden die antwoorden erg teleurgesteld te zijn of opgelucht te zijn over de opheffing van de EU. De eerste groep geeft zonder twijfel blijk van steun, terwijl de tweede groep zonder meer is aan te merken als kritisch. Minder duidelijk is echter waar de mensen die antwoorden dat een eventuele opheffing van de EU hen niets kan schelen thuis horen. Enerzijds is er veel voor te zeggen om het antwoord van de ondervraagde burgers letterlijk op te vatten. Respondenten worden immers niet gedwongen om uit een van de aangeboden antwoordcategorieën te kiezen, het staat hen vrij om een vraag niet te beantwoorden. Bij zo'n letteriijke interpretatie is zonder meer sprake van een kritische evaluatie, een opheffing van de EU kan hen immers niets schelen. Anderzijds is er wat voor te zeggen om deze groep als onverschillig (neutraal) aan te merken, omdat het antwoord letterlijk die sfeer ademt. Waarschijnlijk zitten er onder de respondenten die voor dit antwoord kiezen ook mensen die in het voortbestaan van de EU ook geen enkel probleem zien. Het is bekend dat mensen in interviewsituaties een zekere sociale druk voelen om te antwoorden (zie paragraaf 7.3), zodat respondenten die geen uitgesproken voor- of tegenstander van de EU waarschijnlijk in deze middencategorie eindigen. In het licht van deze overwegingen is er uiteindelijk voor gekozen om de mensen die zeggen dat een eventueel verdwijnen van de EU hen niets kan schelen aan te merken als onverschillig.

De vertaling van de verschillende mogelijke antwoorden op de drie standaardvragen in het concept steun voor de EU is hieronder in schema (schema 4.1) gezet. Uit de empirische analyse komt naar voren dat de dimensies die ten grondslag liggen aan de uitgebreide typologie uit het vorige hoofdstuk ten aanzien van de EU anno 1994 onvoldoende empirische waarde hebben om te komen tot een nadere differentiatie van het concept steun voor de EU in dit onderzoek.

11 De reden dat bij de analyse in principe geen gebruik zal worden gemaakt van het onderscheid tussen mensen die antwoorden "erg voor" of "tot op zekere hoogte voor" respectievelijke "erg tegen"of "tot op zekere hoogte tegen" te zijn, heeft te maken met het feit dat deze verbijzonderingen ontbreken in de oorspronkelijke versie van de unif-vraag in de oude USIA-studies. 


\begin{tabular}{|lrrr|}
\hline & SCRAP & UNIF & MEM \\
Steun (positief) & erg teleurgesteld & erg voor/voor & goed ding \\
Onverschillig & niets schelen/ & geen antwoord/ & geen antwoord/ \\
(aeutraal) & geen antwoord/ & geen mening & geen mening \\
Kritiek (negatief) & geen mening & & \\
\hline
\end{tabular}

\subsection{Publieke opinie over de EU (1994): achtergronden}

In het kader van de eerste kennismaking met de data zal in deze paragraaf nog even worden stil gestaan bij een aantal non-evaluatieve aspecten van de publieke opinie over de EU. Op die manier wordt getracht er achter te komen of de geringe mate van differentiatie in de houdingen misschien iets te maken heeft met een gebrek aan interesse in, informatie over of kennis van de EU. ${ }^{52}$ Aan deze aspecten wordt in de vragenlijst van Eurobarometer 42 ook aandacht besteed. Uit de nadere analyse is gebleken dat deze non-evaluatieve aspecten nadrukkelijk zijn te onderscheiden van de steun (evaluatief) voor de EU. Dit betekent, bijvoorbeeld, dat de interesse voor de EU nadrukkelijk een andere achtergrond heeft dan de steun voor de EU op individueel niveau.

\section{Interesse in de $E U$}

In de vragenlijst van Eurobarometer 42 is aan de respondenten gevraagd om aan te geven in hoeverre ze geïnteresseerd zijn in EU-zaken. De verdeling van de scores in de verschillende lidstaten staan in tabel $4.1 .^{53}$

Een half jaar na de rechtstreekse verkiezingen voor het EP in juni 1994 geeft een meerderheid van de burgers aan slechts weinig of geen interesse in EU-zaken te hebben. Enkel in Denemarken

52 Voor alle analyses op het niveau van de lidstaten in dit boek geldt dat gebruik wordt gemaakt van gewogen gegevens. Met de weging wordt gecorrigeerd voor de onder- respectievelijk oververtegenwoordiging van bepaalde groepen (in ieder geval leeftijd, geslacht en regio) in de nationale steekproeven. Het aantal respondenten dat in de tabellen wordt gerapporteerd betreft uiteraard de ongewogen aantallen.

"In alle tabellen zullen de landen worden aangeduid met de volgende afkortingen: $\mathrm{FR}=\mathrm{Frankrijk;} \mathrm{BE}=\mathrm{Belgie}$; $\mathrm{NL}=$ Nederland; WD=West-Duitsland; IT=Italie; $\mathrm{LU}=$ Luxemburg; $\mathrm{DK}=$ Denemarken; EI=Ierland; $\mathrm{GB}=\mathrm{Groot}$ Brittanie (exclusief Noord-lerland); GR=Griekenland; $\mathrm{SP}=$ Spanje; en, $\mathrm{PO}=$ Portugal. 
To what extent would you say you are interested in European polities, that is to say matters related to the European Union (European Community): a great deal, to some extent, not much or not at all?

\begin{tabular}{|rcccccc|}
\hline FR & a great deal & to some & not much & not at all & no answer & N \\
BE & 8 & 31 & 39 & 22 & 0 & 1007 \\
NL & 4 & 25 & 35 & 34 & 2 & 1043 \\
WD & 5 & 22 & 55 & 16 & 1 & 1047 \\
IT & 6 & 28 & 49 & 16 & 1 & 1018 \\
LU & 6 & 30 & 40 & 23 & 1 & 1055 \\
DK & 12 & 41 & 35 & 12 & 0 & 500 \\
EI & 19 & 40 & 33 & 7 & 0 & 1001 \\
GB & 6 & 32 & 29 & 33 & 1 & 1002 \\
GR & 10 & 35 & 30 & 24 & 1 & 1045 \\
SP & 11 & 36 & 33 & 18 & 2 & 1002 \\
PO & 6 & 32 & 24 & 35 & 3 & 1006 \\
\hline
\end{tabular}

Bron: Eurobarometer 42 (EB42 - najaar 1994).

en Luxemburg blijkt de interesse in de EU iets groter. ${ }^{54}$ Relatief de minste interesse in de EU tonen de Portugezen, Belgen en Nederlanders.

De relatief grote interesse voor EU-zaken in Denemarken is mogelijk het gevolg van de referendumcampagnes in 1992 (nee!) en 1993 (ja!) over het Verdrag van Maastricht. De invloed van referenda op de interesse voor de EU moet echter niet te snel worden aangenomen, omdat in Frankrijk en Ierland waar in 1992 ook referenda over het Verdrag van Maastricht plaats vonden in 1994 niets meer van een relatief grote interesse te merken is. De relatief grote interesse in Luxemburg valt mogelijk te verklaren uit het feit dat de voormalige Luxemburgse ministerpresident Santer in de zomer van 1994 is aangewezen als de nieuwe voorzitter van de Europese Commissie die op 1 januari 1995 haar werkzaamheden moet starten.

Over het algemeen is de interesse voor de EU onder de bevolking van de lidstaten niet bijzonder groot. Het aantal respondenten dat aangeeft sterk geïnteresseerd te zijn in de EU is zelfs bijzonder gering te noemen.

Om bovenstaande percentages iets beter op waarde te kunnen schatten, is een vergelijking gemaakt met de meer algemene interesse in politieke zaken. Dit was mogelijk omdat voorafgaand aan de vraag over specifieke interesse in de Europese politiek, respondenten de vraag is gesteld in hoeverre ze in politiek in het algemeen geïnteresseerd zijn. De respondenten hadden bij beide vragen de keus uit dezelfde antwoordcategorieěn, Voor elke lidstaat zijn de gemiddelde scores

\footnotetext{
${ }^{34}$ Een $t$-test wijst uit dat de Deense interesse in de Europese politiek significant $(\mathrm{p}<.01)$ hoger is dan in elk van de elf andere lidstaten.
} 


\begin{tabular}{|c|c|c|c|c|c|c|c|}
\hline \multirow{2}{*}{$\begin{array}{l}\text { EUR: } \\
\text { Land: }\end{array}$} & \multicolumn{7}{|c|}{$\begin{array}{l}\text { To what extent would you say you are interested in European politics, that is to say matters } \\
\text { related to the European Union (European Community)? } \\
\text { (antwoordeategorieên: a great deal (4), to some extent (3), not much (2) or not at all (1)?) }\end{array}$} \\
\hline & ALG & EUR & sign a) & Land: & ALG & EUR & sign a) \\
\hline FR & 1.34 & 1.25 & .00 & DK & 1.94 & 1.71 & .00 \\
\hline $\mathrm{BE}$ & 1.02 & 0.99 & 14 & EI & 1.31 & 1.10 & .00 \\
\hline NL. & 1.46 & 1.16 & .00 & GB & 1.52 & 1.31 & .00 \\
\hline WD & 1.38 & 1.23 & .00 & GR & 1.31 & 1.41 & .00 \\
\hline IT & 1.26 & 1.19 & .00 & SP & 1.06 & 1.08 & .83 \\
\hline LU & 1.53 & 1.52 & .66 & PO & 0.85 & 0.90 & .07 \\
\hline
\end{tabular}

Bron: EB42 (najaar 1994), voor aantallen respondenten zie tabel 4.1.

a) t-test op verschil in gemiddelden.

berekend en met elkaar vergeleken. De verrassende resultaten staan in tabel 4.2.

Opmerkelijk genoeg is de interesse in de EU-politick in een aantal lidstaten nauwelijks geringer dan de algemene politieke interesse. In Griekenland is de belangstelling voor de Europese politiek zelfs groter dan de algemene politieke interesse!? In Belgię, Luxemburg, Spanje en Portugal wijken specifieke en algemene interesse niet significant van elkaar af. Slechts in zeven lidstaten is de algemene politieke interesse grotere dan de specifieke interesse in de EU. De grootte van de verschillen in de gemiddelde scores zijn over het algemeen verrassend klein.

De Deense cijfers laten zien dat de relatief grote Deense interesse in EU-zaken geen geïsoleerd fenomeen is, de Denen blijken sowieso veel met politiek bezig te zijn. ${ }^{55}$ Dit onderstreept opnieuw dat men voorzichtig moet zijn met ad-hoc verklaringen (referenda) om verschillen tussen lidstaten te verklaren.

Hoewel de interesse onder de bevolking voor de EU niet echt groot te noemen is, blijkt dus de interesse in de EU-politiek binnen de lidstaten over de hele linie niet veel lager is dan de algemene politieke interesse. Dit resultaat suggereert dat de geringe mate van differentiatic in de houdingen van burgers ten aanzien van de EU slechts deels moet worden gezocht in een gebrek aan interesse in de EU.

\section{Informatie over de EU}

In aanvulling hierop is nagegaan in hoeverre de bevolking in de lidstaten vindt dat ze voldoende geïnformeerd zijn over de EU als zodanig, haar beleid en haar instituties. Nu de oorzaak van de

"Oppenhuis (1995: 173-4) stuit hier ook tijdens een analyse van data van de European Elections Study 1989. Ook op het punt van de kennis van aanstaande uitbreidingen van de EU in 1973, 1980 en 1985 blijken Denen (en Luxemburgers) in de jaren zeventig en tachtig steeds bijzonder hoog te scoren (Westle, 1995: 314-6). 
geringe differentiatie niet lijkt gelegen in de geringe interesse, is het zeer wel denkbaar dat de belangrijkste oorzaak voor de geringe differentiatie van de houdingen van burgers is gelegen in een gebrek aan informatie over de EU.

Tabel 4.3 Gevoel hebben geinformeerd te sijn over de EU binnen lidstaten, najaar 1994 (in \%)

\begin{tabular}{|c|c|c|c|c|c|}
\hline \multicolumn{6}{|c|}{$\begin{array}{l}\text { All things considered, how well informed do you feel you are about the European Union, its policies } \\
\text { and its institutions? Very well, quite well, not very well, not at all well? }\end{array}$} \\
\hline & $\begin{array}{l}\text { INFORMI } \\
\text { very/quite well }\end{array}$ & $\begin{array}{l}\text { ABOUT EU } \\
\text { not very/not at all }\end{array}$ & & $\begin{array}{l}\text { INFORM } \\
\text { very /quite well }\end{array}$ & $\begin{array}{l}\text { ABOUT EU } \\
\text { not very/not at all }\end{array}$ \\
\hline FR & 29 & 70 & DK & 41 & 58 \\
\hline BE & 40 & 58 & El & 34 & 63 \\
\hline $\mathrm{NL}$ & 33 & 65 & GB & 27 & 72 \\
\hline WD & 35 & 62 & GR & 22 & 77 \\
\hline IT & 21 & 76 & SP & 26 & 71 \\
\hline LU & 46 & 51 & PO & 20 & 74 \\
\hline
\end{tabular}

Bron: EB42 (najaar 1992), voor aantallen respondenten zie tabel 4.1.

De gegevens in tabel 4.3 laten zien dat de meerderheid van het publiek in elk der lidstaten inderdaad het gevoel heeft onvoldoende geïnformeerd te zijn over de EU. Dit is belangrijk want als mensen het verschil tussen Commissie en Raad niet kennen, niet op de hoogte zijn van EUbeleid of niet weten welke thema's er hoog op de Europese agenda staan dan kan men ook geen gefundeerde en gedifferentieerde opinies ten aanzien van deze verschillende aspecten verwachten. Tegen deze achtergrond hoeft het geen verbazing te wekken dat de publieke opinie over de EU in de praktijk weinig gedifferentieerd is.

Zwak punt in bovenstaande redenering is dat respondenten gevraagd wordt om zelf een inschatting te maken van de mate waarin ze geïnformeerd zijn. Het is onduidelijk in hoeverre die inschatting correct is. Daarom is nagegaan in hoeverre de subjectieve inschatting overeenkomt met de kennis die burgers van EU-zaken hebben. Dit is mogelijk omdat de vragenlijst van Eurobarometer 42 ook diverse kennisvragen omvat.

Ten eerste zijn er vragen gesteld over de op handen zijnde uitbreiding van de EU met vier landen (Oostenrijk, Finland, Zweden en Noorwegen). In elk van deze vier landen is in het najaar van 1994 een nationaal referendum over de EU-toetreding georganiseerd. De interviews zijn direct na het laatste referendum afgenomen. Aan de respondenten is gevraagd of ze wisten in welke landen referenda over toetreding waren gehouden. De respondenten werden daarbij wel enigszins geholpen doordat in de vorige vraag hun mening werd gevraag over de mogelijke toetreding van 11 potentièle lidstaten. Op de lijst met 11 landen die zij daarbij kregen aangereikt, stonden ook de namen van de vier toetreders in spe. Daarna is de respondenten, zo nodig, verteld in welke vier landen referenda waren gehouden en is hen gevraagd naar de uitslag. 
Verder is gevraagd naar de datum van de laatste EP-verkiezingen die nog geen half jaar voor de interviews waren gehouden ( 9 of 12 juni 1994). Om het antwoord goed te kunnen rekenen hoefden respondenten slechts het goede jaar - 1994 of "dit jaar" - te noemen.

Tot slot is de respondenten gevraagd naar de naam van de zittende (Delors) en aanstaande (Santer, vanaf 1-1-95) voorzitter van de Europese Commissie, alsmede de naam (namen) van de zittende en aanstaande EU-commissarissen) van hun eigen land te noemen In tabel 4.4 is aangegeven hoe het is gesteld met de feitenkennis van de bevolkingen in de EU-lidstaten. ledere respondent kon maximaal 13 goede antwoorden geven. ${ }^{56}$ Naast het gemiddeld aantal goede antwoorden per land is aangegeven hoe groot de samenhang is tussen feitenkennis en het gevoel goed geïnformeerd te zijn op individueel niveau.

Tabel 4.4 Kennis van EU bij gevoel hebben geinformeerd te zijn over EU binnen lidstaten, najaar 1994

\begin{tabular}{|lcc|ccc|}
\hline & $\begin{array}{c}\text { KENNIS } \\
\text { gemiddelde }\end{array}$ & $\begin{array}{c}\text { kennis } \\
\text { geinformeerd } \\
\text { correlatie }\end{array}$ & & $\begin{array}{c}\text { KENNIS } \\
\text { gemiddelde }\end{array}$ & $\begin{array}{c}\text { kennis } x \\
\text { geinformeerd } \\
\text { correlatie }\end{array}$ \\
BE & 4.8 & $.13^{*}$ & DK & 9.3 & $.33^{*}$ \\
NL & 5.8 & $.27^{*}$ & EI & 4.7 & $.37^{*}$ \\
WD & 5.5 & $.39^{*}$ & GB & 3.6 & $.39^{*}$ \\
IT & 6.7 & $.39^{*}$ & GR & 3.2 & $.36^{*}$ \\
LU & 3.3 & $.25^{*}$ & SP & 3.1 & $.41^{*}$ \\
\hline
\end{tabular}

Bron: EB42, voor aantallen respondenten zie tabel 4.1 ; significantic: ${ }^{*}=p<01$.

Uit tabel 4.4 blijkt dat de kennis van de EU sterk varieert van land tot land. Uit een hier niet getoonde frequentieverdeling blijkt dat slechts 300 van de bijna 12000 ondervraagden 13 vragen goed hadden. De verdeling van deze personen over de lidstaten is allesbehalve gelijkmatig, er zitten disproportioneel veel Luxemburgers en Denen tussen. In Luxemburg gaf meer dan $20 \%$ van de ondervraagden 13 goede antwoorden; ${ }^{57}$ terwijl in Denemarken meer dan de helft van de ondervraagden een score van 10 of hoger haalt.De scores in de Zuid-Europese landen steken hier schril tegen af. Van de Spaanse en Portugese respondenten kon meer dan $30 \%$ zelfs geen enkele vraag goed beantwoorden, dus ook niet de vraag over wanneer de Europese verkiezingen waren! In de Deense steekproef zaten slechts 2 respondenten - minder dan 1\% - die geen enkele vraag goed wisten te beantwoorden.

\footnotetext{
${ }^{\text {So }}$ Het noemen van de correcte namen van een of beide nationale Euro-commissarissen door respondenten in de grote lidstaten met twee commissarissen is als 1 goed antwoord geteld.

" Dit heeft naar alle waarschijnlijkheid alles te maken met de aanstaande benoeming van de voormalige Luxemburgse minister-president Santer tot Commissievoorzitter, waardoor de EU in het kleine Luxemburg waarschijnlijk volop in de belangstelling heeft gestaan in de laatste maanden voor het interview.
} 
Zowel op het niveau van de staten als op individueel niveau blijkt het subjectieve gevoel voldoende geinformeerd te zijn over, en objectieve kennis te hebben van EU-zaken met elkaar samen te hangen. Op beide landenlijstjes staan de Denen en de Luxemburgers bovenaan, en vinden we de Zuid-Europese landen en Groot-Brittannie̋ onder aan de rij. .8 Op individueel niveau is er binnen alle lidstaten sprake van een positieve samenhang, hoewel niet in alle lidstaten even sterk. Over de hele EU-steekproef gerekend bedraagt de correlatie op individueel niveau: .37 .99 De gevonden samenhang is niet dermate sterk dat daar uit mag worden afgeleid dat burgers heel goed zelf kunnen inschatten of ze veel of weinig van de EU weten, maar van enige samenhang tussen het subjectieve gevoel goed geĩnformeerd te zijn en de daadwerkelijk aanwezige kennis van EU-zaken is zonder meer sprake.

Een onmiskenbare gebrek aan kennis van EU-zaken in sommige lidstaten en het wijdverbreide gevoel bij een meerderheid van de EU-burgers niet echt goed geïnformeerd te zijn over EU-zaken zijn er mogelijkerwijs de oorzaak van dat de steun voor de EU in de praktijk niet echt sterk gedifferenticerd is.

\subsection{Publieke steun voor de EU: definitie}

Hoe groot is de publieke steun voor de EU in de diverse lidstaten anno 1994? Het feit dat in dit onderzoek slechts lidstaten worden onderzocht en in maar liefst 5 van 12 onderzochte lidstaten het EU-lidmaatschap mede afhankelijk was van de uitslag van een referendum doet vooraf vermoeden dat de stemming in de meeste lidstaten niet bijzonder kritisch zal zijn. De beperking tot lidstaten - primair ingegeven door de beschikbaarheid van data en de wens om een vergelijking door de tijd te kunnen maken - draagt in die zin het gevaar van zelfselectie in zich, waardoor de variatie op de afhankelijke variabele door de keuze van de onderzoekseenheden als het ware kunstmatig wordt beperkt.

Voor de meting van de publieke steun voor de $E U$ in een lidstaat wordt uitgegaan van zogenaamde verschilscores. De mate van publieke steun voor de EU in een bepaalde lidstaat zal in dit onderzoek worden berekend door het percentage "critici" (negatieve steun) af te trekken van het percentage "supporters" (positieve steun). De uitkomst van de verschilscore wordt mede bepaald door het percentage onverschillige burgers in de middencategorie, omdat dit laatste

"De rang-orde correlatie tussen de nationale percentages respondenten in een land die het gevoel hebben goed geinformeerd te zijn en het gemiddeld aantal goede antwoorden in een land bedraagt . $83(\mathrm{p}<.01 ; \mathrm{N}=12)$. De vergelijkbare rang-orde correlaties tussen de nationale gemiddelde scores voor interesse in de EG (zie tabel 4.2) aan de ene kant, en kennis en het gevoel voldoende geĭnformeerd te zijn aan de andere kant blijken daarentegen niet significant te zijn.

" $\mathrm{p}<01 ; \mathrm{N}=11735$. 
percentage het minimum en maximum van de verschilscore begrenst. Deze operationalisering van het concept publieke steun voor de EU past ook goed bij de theoretische verklaringen die in hoofdstuk 6 en 7 worden uitgewerkt. In die verklaringen staat niet zozeer het absolute niveau van positieve steun centraal, maar nadrukkelijk het publieke opinieklimaat in termen van de verhouding tussen (positieve) steun en kritiek (negatieve steun).

Alvorens aandacht te besteden aan de hoogte van de publieke steun voor de EG in de lidstaten in termen van verschilscores, zal eerst aandacht worden besteed aan de afzonderlijke elementen: de mate van (positieve) steun, de mate van kritiek (negatieve steun) en de mate van onverschilligheid. ${ }^{\infty}$ Dit stelt ons in staat om nog enige bijzonderheden van de drie standaardindicatoren die naast elkaar worden gebruik voor het voetlicht te halen.

\section{Positieve steun}

In tabel 4.5 staan de percentages (positieve) steun per lidstaat in 1994 op een rijtje. De tabel geeft aan welk deel van de respondenten in de verschillende lidstaten in het najaar van 1994 middels het antwoord op elk van de drie standaardvragen blijk heeft gegeven van een positieve houding ten opzichte de EU. In de eerste kolom van tabel 4.5 (unif) vindt u het percentage ondervraagden per lidstaat dat aangeeft voor pogingen te zijn om West-Europa verder te verenigen; in de tweede kolom (mem) staat het percentage dat het nationale EU-lidmaatschap een goede zaak vindt; en de derde kolom (scrap) bevat het percentage ondervraagden dat heeft geantwoord teleurgesteld te zullen zijn als de EU morgen zou worden opgeheven. De landen zijn per indicator - van hoog naar laag - gerangschikt.

Op de vraag hoe groot de positieve steun voor de EU in een lidstaat is, blijkt onmogelijk een eenduidig antwoord te geven. Het beeld dat men krijgt, is namelijk sterk afhankelijk van de gebruikte indicator. Op basis van de unif-vraag blijkt de steun voor de EU in de meeste lidstaten groter dan op basis van de mem-vraag, terwijl de mem-scores op hun beurt weer hoger zijn dan de scrap-scores.

Voor een deel heeft dit te maken met de constructie van de onderliggende vragen en in het bijzonder met de omstandigheid of respondenten bij een vraag al dan niet de mogelijkheid wordt geboden om voor een neutrale middencategorie te kiezen. Bij de unif-vraag krijgen respondenten slechts de keuze om zich vóór of tegen de EU uit te spreken. Bij de mem- en scrap-vraag wordt daarentegen expliciet een neutrale middencategorie aangeboden. Dit is waarschijnlijk de belangrijkste reden waarom de unif-percentages in tabel 4.5 relatief hoog zijn.

Voor een deel hebben de verschillen echter ook te maken met de inhoud van de vragen. In de vorige paragraaf is weliswaar betoogd dat de antwoorden op de standaard-indicatoren op indivi-

\footnotetext{
${ }^{\infty}$ De correlaties tussen verschilscores en de losse onderdelen - positieve steun en kritiek (negatieve steun) - is logischerwijs bijzonder hoog.
} 


\begin{tabular}{|c|c|c|c|c|c|}
\hline \multicolumn{2}{|c|}{ unif } & \multicolumn{2}{|c|}{ mem } & \multicolumn{2}{|c|}{ scrap } \\
\hline IT & 85 & EI & 82 & $\overline{L U}$ & 67 \\
\hline GR & 81 & LU & 80 & EI & 61 \\
\hline LU & 78 & NL & 77 & IT & 57 \\
\hline EI & 78 & IT & 70 & GR & 49 \\
\hline BE & 77 & GR & 65 & WD & 46 \\
\hline ES & 77 & WD & 63 & FR & 44 \\
\hline NL & 76 & BE & 61 & NL & 42 \\
\hline PO & 76 & FR & 58 & DK & 37 \\
\hline FR & 72 & PO & 56 & ES & 35 \\
\hline WD & 72 & DK & 53 & BE & 34 \\
\hline GB & 60 & ES & 47 & PO & 30 \\
\hline DK & 58 & GB & 42 & GB & 25 \\
\hline \multicolumn{4}{|c|}{ unif $x$ mem } & \multicolumn{2}{|c|}{ mem $x$ scrap } \\
\hline \multirow{2}{*}{\multicolumn{2}{|c|}{ rangorde-correlatie (spearman) }} & \multicolumn{2}{|c|}{$.58 * *$} & \multicolumn{2}{|c|}{$.92 *$} \\
\hline & & \multicolumn{2}{|c|}{12} & \multicolumn{2}{|c|}{12} \\
\hline
\end{tabular}

Bron: EB42 (najaar 1994), voor aantallen respondenten zie tabel 4.1 ; significantic: ${ }^{*}=\mathrm{p}<.01 ;{ }^{* *} \mathrm{p}<.05$.

dueel niveau dezelfde grondhouding weerspiegelen, maar dat wil niet zeggen dat respondenten bij het beantwoorden van deze vragen geen oog hebben voor de verschillen tussen de vragen. Oppenhuis (1995: 173-5) heeft laten zien dat de drie gebruikte standaardindicatoren onderdeel zijn van een Mokken-schaal. Dit wil zeggen dat individuele respondenten de scrap-vraag als moeilijker ervaren dan de mem-vraag, en de mem-vraag op zijn beurt weer als moeilijker ervaren dan de unif-vraag. In concreto betekent dit dat respondenten die op de scrap-vraag een positief antwoord geven met een grote mate van waarschijnlijkheid op de andere twee, makkelijkere vragen ook positief scoren; en mensen die positief scoren op de mem-vraag met een grote mate van waarschijnlijkheid positief scoren op de makkelijkere unif-vraag, maar niet noodzakelijkerwijs positief scoren op de moeilijkere scrap-vraag. Deze verschillen in moeilijkheid zijn ook terug te vinden in tabel 4.5 .

Rekening houdend met de bijzonderheden van elk van de drie standaardvragen kan aan de hand van de scores in tabel 4.5 wel een globaal beeld van de mate van positieve steun voor de EG in de verschillende lidstaten worden geschetst. Een eventuele opheffing van de EU (scrap) zou anno 1994 slechts in drie landen - Luxemburg, Ierland en Italië - door een meerderheid van de burgers worden betreurd. In de andere negen landen geeft minder dan de helft van de ondervraagden aan een dergelijke ontwikkeling te betreuren. Het minst verknocht aan de EU zijn de Denen, Britten en Portugezen. In deze drie landen zou minder dan één op drie burgers treuren over een snel einde van de EU! Afgaande op de antwoorden op de unif-vraag komt een veel rooskleuriger beeld naar voren. Anno 1994 blijkt in alle lidstaten een ruime meerderheid van de bevolking achter het streven naar West-Europese eenwording te staan. Ook de scores op mem-vraag over 
het nationale EU-lidmaatschap leveren een veel positiever beeld op dan de scrap-vraag. ${ }^{61}$ In de meeste lidstaten blijkt een meerderheid van de burgers het EU-lidmaatschap van hun eigen land positief te beoordelen.

In tabel 4.5 is ook aangegeven in hoeverre de volgorde van de landen op basis van de verschillende indicatoren onderling overeenkomen. De significant positieve rangorde-correlaties geven aan dat, ondanks de grote absolute verschillen in de positieve steun, de onderlinge rangorde van meer en minder positief ingestelde lidstaten niettemin relatief eensluidend is. De scores van alle drie de indicatoren geven aan dat de positieve steun voor de EU in lerland, Luxemburg en Italiê relatief het hoogst is en in Groot-Brittannię, Portugal, Spanje en Denemarken juist relatief het laagst. Hieronder bij de bespreking van de verschilscores nog wat dieper op de verschillen tussen de lidstaten worden ingegaan.

\section{Kritiek (negatieve steun)}

De kritiek op de EU binnen de lidstaten is tot op zekere hoogte het complement van de publieke steun. Op basis daarvan valt te verwachten dat de landen waar de publieke steun het hoogst is, de kritiek juist het laagst is.

In tabel 4.6 is aangegeven welk deel van de in het najaar van 1994 ondervraagde personen in de lidstaten zich kritisch heeft uitgelaten over de EU. In de eerste kolom (unif) vindt u het percentage ondervraagden in een lidstaat dat aangeeft tegen pogingen te zijn om West-Europa verder te verenigen. In de tweede kolom (mem) is het percentage opgenomen dat aangeeft welk deel van de respondenten heeft geantwoord het nationale EU-lidmaatschap een slechte zaak te vinden. In de laatste kolom (scrap) treft $\mathrm{u}$ het percentage aan dat aangeeft dat een opheffing van de EU hen zou opluchten. De landen zijn opnieuw per indicator - deze keer van laag naar hoog gerangschikt naar het niveau van kritiek.

Logischerwijs blijken de scores opnieuw sterk afhankelijk van de gebruikte indicator. De percentages in tabel 4.6 maken duidelijk dat critici in sommige lidstaten - met name Denemarken en Groot-Brittannië - weliswaar een niet onaanzienlijke minderheid vormen, maar dat - zoals verwacht - in geen enkele lidstaat sprake is van een kritische meerderheid. Uitgaande van bovenstaande percentages blijkt de EU in geen enkele lidstaat anno 1994 zwaar onder vuur te liggen.

De publieke kritiek is in absolute zin het grootst als de kritiek wordt gemeten met de unifindicator. Dit lijkt misschien vreemd omdat die indicator ook de hoogst gemeten niveaus van positieve steun oplevert en steun en kritiek in zekere zin elkaars complement vormen. De verklaring voor de verschillen lijkt net zoals bij de positieve steun opnieuw te moeten worden

${ }^{6}$ Nogmaals deze verschillen tussen de drie indicatoren staan niet in de weg dat de antwoorden op de standaardvragen op individueel niveau uit dezelfde grondhouding voortkomen (zie paragraaf 4.2 en appendix 4.1). 


\begin{tabular}{|c|c|c|c|c|c|}
\hline \multicolumn{2}{|c|}{ unif } & \multicolumn{2}{|c|}{ mem } & \multicolumn{2}{|c|}{ scrap } \\
\hline IT & 6 & NL & 4 & IT & 3 \\
\hline EI & 10 & IT & 5 & EI & 3 \\
\hline GR & 11 & EI & 5 & LU & 5 \\
\hline PO & II & LU & 5 & NL & 6 \\
\hline ES & 14 & BE & 7 & GR & 6 \\
\hline $\mathbf{L U}$ & 16 & GR & 8 & BE & 6 \\
\hline BE & 16 & WD & 10 & PO & 8 \\
\hline NL & 17 & PO & 11 & WD & 10 \\
\hline FR & 19 & FR & 12 & FR & 11 \\
\hline WD & 20 & ES & 18 & ES & 11 \\
\hline GB & 29 & DK & 22 & DK & 24 \\
\hline DK & 39 & GB & 23 & GB & 27 \\
\hline \multicolumn{4}{|c|}{ unif $\times$ mem } & scrap & mem $\times$ scrap \\
\hline \multirow{2}{*}{\multicolumn{2}{|c|}{$\begin{array}{l}\text { rangorde-correlatic (spearman) } \\
\text { aantal (N) }\end{array}$}} & \multicolumn{2}{|c|}{.54} & $7 *$ & $.92^{*}$ \\
\hline & & \multicolumn{2}{|c|}{12} & & 12 \\
\hline
\end{tabular}

Bron: EB42 (najaar 1994), voor aantallen respondenten zie tabel 4.1 ; significantie: ${ }^{*}=\mathrm{p}<.01 ;{ }^{* *}=\mathrm{p}<.05$.

gezocht in het ontbreken van een neutrale middencategorie bij de unif-vraag, waardoor mensen die geen uitgesproken voor- of tegenstander van de EU zijn toch min of meer worden gedwongen een keuze voor of tegen de EU te maken. De unif-scores suggereren dat naast de uitgesproken critici - zie mem- en scrap-scores - in elke lidstaat ook nog een kleine groep potentiële critici aanwezig is.

De rang-orde correlaties onderstrepen opnieuw dat ondanks de absolute verschillen tussen de indicatoren, het antwoord op de vraag welke landen meer en minder kritisch zijn niet wezenlijk verschilt van indicator tot indicator. ${ }^{62}$ Denemarken en Groot-Brittannië sluiten in alle drie de gevallen de rij als meest kritische landen, terwijl onder de leren, Luxemburgers en Italianen zich relatief gezien de minste critici bevinden.

\section{Publieke onverschilligheid}

Het complement van steun en kritiek, is publieke onverschilligheid. Voor zover die onverschilligheid een gevolg is van een gebrek aan kennis van of informatie over de EU, valt op basis van hetgeen hierboven is gezegd over kennis van en geïnformeerd zijn over de EU te verwachten dat de onzekerheid het grootst is in de Zuid-Europese landen en Groot-Brittannië en het geringst in Denemarken en Luxemburg. Het is echter ook mogelijk dat deze middencategorie vooral gevuld wordt door goed geïnformeerde twijfelaars.

In de eerste kolom (unif) vindt $u$ het percentage ondervraagden dat de unif-vraag niet heeft beantwoord of expliciet heeft aangegeven geen keus voor of tegen te kunnen maken. In de andere

${ }^{2}$ De niet significante rang-orde correlatic tussen de rangordes volgens de mem- en unif-vraag lijken vooral te wijten aan het feit dat kleine verschillen grote verschuivingen in de rangordes tot gevolg hebben De gewone correlatie tussen de unif- en mem-scores is sterk en significant positief, te weten: $+.76(\mathrm{p}>.01: \mathrm{N}=12)$. 
kolommen omvatten de percentages daarenboven respondenten die antwoorden het nationale EUlidmaatschap een goede, noch slechte zaak (mem) te vinden respectievelijk onverschillig (niets kan schelen) te staan ten opzichten van een opheffing van de EU (scrap). De landen zijn in tabel 4.7 opnieuw per indicator - deze keer van laag naar hoog - gerangschikt.

Tabel 4.7 Onverschilligheid (in \%) over EU binnen lidstaten (rangorde-correlaties hussen indicatoren), najaar 1994

\begin{tabular}{|c|c|c|c|c|c|}
\hline \multicolumn{2}{|c|}{ unif } & \multicolumn{2}{|c|}{ mem } & \multicolumn{2}{|c|}{ scrap } \\
\hline DK & 3 & EI & 13 & $\mathbf{L U}$ & 28 \\
\hline BE & 6 & LU & 15 & EI & 36 \\
\hline LU & 7 & NL & 19 & DK & 39 \\
\hline NL & 7 & DK & 25 & IT & 40 \\
\hline GR & 8 & IT & 25 & WD & 44 \\
\hline IT & 9 & GR & 27 & FR & 45 \\
\hline WD & 9 & WD & 27 & GR & 46 \\
\hline ES & 9 & FR & 30 & GB & 48 \\
\hline FR & 9 & BE & 32 & NL & 52 \\
\hline GB & 11 & PO & 33 & ES & 54 \\
\hline PO & 13 & ES & 35 & BE. & 60 \\
\hline E.I & 13 & GB & 35 & PO & 62 \\
\hline \multirow{3}{*}{\multicolumn{2}{|c|}{$\begin{array}{l}\text { rangorde-correlatic (spearman) } \\
\text { aantal (N) }\end{array}$}} & unif & \multicolumn{2}{|c|}{ unif $x$ scrap } & mem $x$ serap \\
\hline & & \multicolumn{2}{|c|}{.26} & \multicolumn{2}{|c|}{$.76^{*}$} \\
\hline & & \multicolumn{2}{|c|}{12} & \multicolumn{2}{|c|}{12} \\
\hline
\end{tabular}

Bron: EB42 (najaar 1994), voor aantallen respondenten zie tabel 4.1 ; significantie: $\bullet=p<.01 ; \cdots=p<.05$.

De mate van onverschilligheid per lidstaat varieert veel sterker van indicator tot indicator dan de positieve steun en kritiek. Het feit dat de scrap- en mem-vraag wel en de unif-vraag niet een expliciete neutrale middencategorie heeft, is daar de belangrijkste oorzaak van. Dientengevolge is de onverschilligheid gemeten aan de hand van de unif-indicator relatief gering. Afgaande op de antwoorden op de scrap-vraag heeft ongeveer de helft van de burgers geen uitgesproken positieve of negatieve mening over de EU. Dit suggereert dat de publieke opinie over de EU waarschijnlijk relatief fragiel is. De mate van onverschilligheid blijkt vooral in Groot-Brittannië, Portugal en Spanje relatief groot en in Denemarken en Luxemburg juist vrij gering. Dit laatste onderstreept dat de mate van onverschilligheid ten aanzien van de EU op lidstaat-niveau tot op zekere hoogte samenhangt met de mate waarin de bevolking meent voldoende geïnformeerd te zijn over, en kennis heeft van de $\mathrm{EU} ;^{63}$ op individueel niveau is een dergelijk verband ook

\footnotetext{
${ }^{\text {as }}$ De gemiddelde kennis van de EU (vergelijk tabel 4.4) en de mate van onverschilligheid op basis van de memen scrap-scores op lidstaat-niveau $(\mathrm{N}=12)$ blijken inderdaad te leiden tot negatieve rangorde-correlaties, te weten: kennis $x$ unif $=-.30$ (niet significant, $p>.05$ ); kennis $x$ mem $=-.62(p<.05)$; kennis $x$ scrap $=-.74(p<.01$ ). De rangorde correlaties op lidstaatniveau tussen de mate het gevoel te hebben voldoende geinnformeerd te zijn over EUzaken aan de ene kant en de mate van onverschilligheid aan de andere kant zijn wel negatief, maar alleen in het geval van de unif-scores significant negatief: geinformeerd zijn $x$ unif $=-.60(p<.05)$; geïnformeerd zijn $x$ mem $=$ -.46 (niet significant, $\mathrm{p}>.05$ ); geinformeerd zijn $x$ scrap $=-.50$ (niet significant, $p>.05$ ).
} 


\section{Publieke steun voor de EU}

Nu de constituerende elementen ${ }^{65}$ van de publieke steun voor de $E U$ afzonderlijk zijn besproken met al hun bijzonderheden, is het tijd om na te gaan in hoeverre de publieke steun voor de EU tussen de lidstaten verschilt. De (netto-)verschilscores die hiervoor gebruikt worden kunnen theoretisch gezien variëren van $-100 \%$ tot $+100 \%$, maar deze maxima worden aan beide uiteinden van het continuüm beperkt door het percentage onverschilligen in een lidstaat. Zoals al eerder is betoogd mag niet worden verwacht dat er veel negatieve scores uitrollen, aangezien het onderzoek zich beperkt tot lidstaten. In tabel 4.8 staan de verschilscores die de mate van publieke steun voor de EU in het najaar van 1994 weerspiegelen netjes op een rij.

Tabel 4.8 Publicke steun (in \%) voor EU binnen lidstaten (rangorde-correlaties tussen indicatoren), najaar 1994

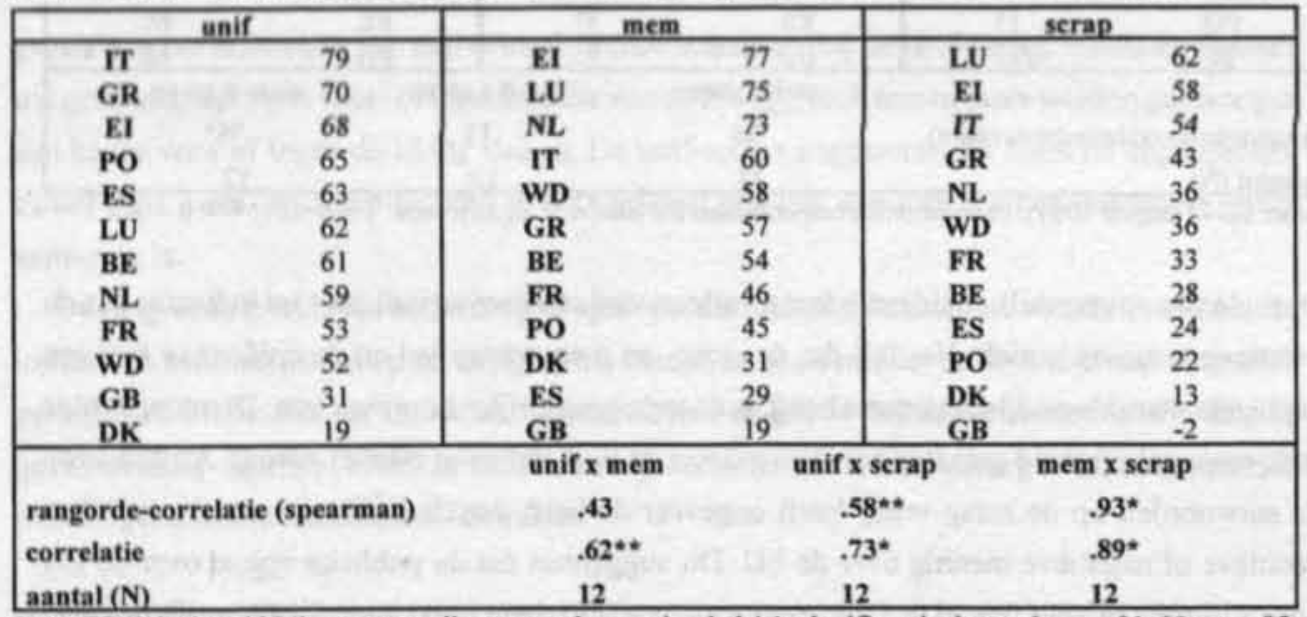

Bron: EB42 (najaar 1994), voor aantallen respondenten zie tabel 4.1 ; significantieniveau: ${ }^{*}=p<01 ; * *=p<.05$.

Zoals hierboven al is geconstateerd is er geen eenduidig antwoord mogelijk op de vraag hoe groot de publieke steun voor de EU binnen een lidstaat is. Het antwoord blijkt in de praktijk sterk afhankelijk van de gebruikte indicator. Ondanks deze verschillen geven de percentages in tabel 4.8 aan dat het opinieklimaat in geen van de lidstaten als uiterst vijandig jegens de EU moet

\footnotetext{
${ }^{*}$ De correlatie op individueel niveau tussen kennis van EU-zaken respectievelijk het gevoel goed geīnformeerd te zijn over de EU aan de ene kant en de mate van onverschilligheid aan de andere kant bedraagt - .30 ( $p<.01$; $\mathrm{N}=12029)$ en $-.27(\mathrm{p}<.01 ; \mathrm{N}=11739)$. De mate van onverschilligheid is bepaald door na te gaan hoe vaak een individu een neutraal antwoord geeft op de drie indicatoren.

ss De onderlinge correlaties tussen de constituerende elementen en de verschilscore is berekend over alle lidstaten en alle beschikbare studies (1952-1998), bijzonder hoog. Weliswaar variêren de correlaties wat per element en per indieator maar de meeste correlaties liggen boven de +.90 , en de laagste correlatie ligt zelfs nog boven +.80 .
} 
worden aangemerkt, wel weten supporters en critici elkaar in sommige lidstaten redelijk in evenwicht te houden. In de meeste landen overtreffen de supporters, de critici in aantal ruimschoots.

Het overzicht maakt in één oogopslag duidelijk dat er inderdaad substantielle verschillen bestaan in de mate van publieke steun voor de EU tussen de twaalf lidstaten. De onderlinge verschillen zijn zonder meer groot te noemen. ${ }^{\star} \mathrm{Op}$ basis van de scrap-indicator (laatste kolom) zijn de lidstaten netjes gespreid over een continuüm lopend van licht kritisch (Verenigd Koninkrijk) tot uiterst loyaal (Luxemburg).Bij de mem- en unif-vraag blijft de variatie beperkt van minder tot meer loyaal. Afgaande op de laatste twee indicatoren overtreft het percentage critici (negatieve steun) in geen enkele lidstaat het percentage supporters (positieve steun). De volgorde van de landen van meer naar minder loyaal in de drie kolommen komt in grote lijnen met elkaar overeen, zo blijkt uit de rangorde-correlaties en correlaties in tabel 4.8. ${ }^{67}$ Denemarken en Groot-Brittanniē zijn de lidstaten met het meest kritische publiek, terwijl de bevolkingen van Luxemburg, Italiě en lerland op alle drie de indicatoren relatief hoog scoren.

In 1994 blijken er dus inderdaad aanzienlijke verschillen te bestaan in de publieke steun voor de EU tussen de twaalf onderzochte lidstaten. Het blijkt zeker niet zo te zijn dat het lidmaatschap van de EU tevens betekent dat het publiek in elke lidstaat volledig loyaal is.

\subsection{Onderzoeksvragen}

Aan de hand van de analyses in dit hoofdstuk zal tot slot een eerste (voorlopig) antwoord op de eerste twee onderzoeksvragen worden geformuleerd.

\section{Hoe groot is de publieke steun voor de EU in de lidstaten?}

De vraag naar de grootte van de publieke steun voor de EU in de lidstaten, blijkt minder makkelijk te beantwoorden dan misschien op het eerste gezicht wel werd gedacht. Het beeld dat men van de grootte van de publieke steun voor de EU in een land krijgt blijkt primair te worden bepaald door de concrete indicator die men gebruikt om de publieke steun te meten.

De verschillen tussen de drie standaardindicatoren zijn zodanig groot dat het geven van een eenduidig antwoord op de eerste onderzoeksvraag onmogelijk is. Op basis van de drie

\footnotetext{
${ }^{\infty}$ Een chi-kwadraat toets op de onafhankelijkheid van de onderliggende nationale verdelingen laat zien dat voor elk van de drie indicatoren er sprake is van significante verschillen tussen de lidstaten. Een ANOVA-analyse leidt tot een vergelijkbare conclusie.

${ }^{67}$ Omdat de lidstaten op de unif-scores onderling vaak slechts marginaal van elkaar afwijken, zijn deze keer naast de rang-orde-correlaties - die onder dit soort omstandigheden bijzonder gevoelig zijn voor een procentje meer of minder - ook gewone correlaties berekend.
} 
standaard-indicatoren die in dit onderzoek centraal staan, blijkt wel dat eigenlijk in geen van de lidstaten anno 1994 sprake is van een vijandige publieke opinie jegens de EU. Behalve in Groot-Brittanniez en in mindere mate in Denemarken worden critici qua aantal ruimschoots overtroffen door supporters. Over het algemeen lijken de burgers van de twaalf onderzochte lidstaten dus loyaal jegens de EU. Verdergaande conclusies staan de beperkte analyses in dit hoofdstuk niet toe.

2. Hoe groot zijn de verschillen in de publieke steun op de EU tussen de lidstaten? De tweede onderzoeksvraag heeft betrekking op de verschillen tussen de lidstaten. De analyse is op dit punt veel robuuster. Het gebruik van drie verschillende indicatoren levert weliswaar problemen op bij het beantwoorden van de vraag hoe groot de publieke steun voor de EU in een lidstaat is, maar veel minder bij het beantwoorden van de vraag of de bevolking van het ene land meer of minder loyaal is ten opzichte van de EU dan de bevolking van een andere lidstaat. Op dit punt levert ook het gebruik van drie verschillende indicatoren geen enkel probleem op. De analyses leveren een relatief consistent beeld op van meer en minder loyale lidstaten. Daarbij is er anno 1994 sprake van aanzienlijke verschillen in publieke steun voor de EU tussen de lidstaten. De Denen en Britten blijken relatief het meest kritisch ten opzichte van de EU. Aan de andere kant blijken Luxemburgers, Ieren en Italianen het meest loyaal aan de EU te zijn. In het licht hiervan hoeft het dus niet te verbazen dat twee jaar daarvoor het Deense referendum over het Verdrag van Maastricht (1992) niet en het Ierse en Franse referendum wel goed uitpakte voor de EU. ${ }^{68}$

* Voor bijzonderheden over de nationale debatten en referenda rond het verdrag van Maastricht, zie: Laursen F. and S. Vanhoonacker (eds.), The Ratification of the Maastricht Treaty. Issues, Debates and Future Implications. Maastricht: EIPA/ Martinus Nijhoft Publishers. 


\section{Appendix 4.1 Keuze van de indicatoren: eerdere inzichten en factoranalyse}

In deze appendix zal worden nagegaan in hoeverre de drie standaard-indicatoren (unif, mem, en scrap) verwijzen naar verschillende dimensies van het begrip steun voor de EU. Om er achter te komen in hoeverre het gebruik van de drie indicatoren een differentiatie van het concept steun voor de EU binnen deze studie vereist, zijn twee dingen gedaan. Aan de ene kant is een eigen factoranalyse op deze drie en aantal andere mogelijke indicatoren van steun voor de EU uitgevoerd, en aan de andere kant is nagegaan wat voor keuzes andere onderzoekers die met dit zelfde probleem hebben geworsteld hebben gemaakt. De analyse is uitgevoerd op de gegevens uit EB42 (1994). Er is bewast gekozen voor een recente dataset omdat de resultaten uit andere onderzoeken vooral inzicht geven in de dimensionaliteit van de steun voor de EU in de jaren zeventig en tachtig. Op deze manier kan dus ook nog worden nagegaan in hoeverre de uitkomsten door de tijd stabiel zijn.

Onderstaande vragen zijn meegenomen als potentiële indicatoren voor de steun voor de EU in de eigen factor-analyse.

DEMOCEU: On the whole are you very satisfied, fairly satisfied, not very satisfied or not at all satisfied with the way democracy works in the European Union? (1-4)

FEELEU: In the near future do you see yourself as [respondent's nationality] only, [respondent's nationality] and European, European and [respondent's nationality], or European only? (1-4)

UNIF: In general, are you for or against efforts being made to unify Western Europe? [IF: FOR or AGAINST] Are you very much for/against or to some extent for/against? (1-4)

MEM: Generally speaking, do you think that [respondent's country's] membership of the European Union is a good thing, a bad thing, or neither good nor bad? (1-3)

BENEFIT: Taking everything into consideration, would you say that [respondent's country] has on balance benefited or not from being a member of the European Union? ( $1=$ benefited; 2 =don't know; $3=$ not benefited) SCRAP: If you were told tomorrow that the European Union had been scrapped, would you be very sorry about it, indifferent or very relieved? (1-3)

EUGOV: Are you for or against the formation, for the European Union, of a European government responsible to the European parliament? ( $1=$ for; 2 =don't know; 3 = against)

FUTURE: On this list there are four descriptions of how Europe might be organised in the future. Please tell me which one you would prefer.

1. Each country keeps its sovereignty and cares only about its own affairs;

2. The countries work together sometimes, but do not give up their sovereignty and never have to submit to decisions taken by a majority of countries;

3. The countries regularly work together on certain matters within common organisations, to which they transfer a part of their sovereignty; that is, they have to submit to the majority decisions of these common organisations on these matters ;

4. The countries transfer all their sovereignty to a single common European state.(1-4) 
EPEVAL: As a European citizen, do you think that the European Parliament protects your interests very well, fairly well, not very well, or not at all well? (1-4)

ECB: (What is your opinion on each of the following proposals? Pleas tell me for each proposal, whether you are for it or against it?) Their should be a European Central Bank pursuing a policy of monetary stability that is fighting inflation? ( $1=$ for; 2 =don't know; 3 = against)

SUPRA: (What is your opinion on each of the following proposals? Pleas tell me for each proposal, whether you are for it or against it?) The European Union should have a European Government responsible to the European parliament and to the European Council of Heads of National Government? ( $1=$ for; 2 =don't know; $3=$ against) POLINTEU: To what extent would you say you are interested in European politics, that is to say matters related to the European Union (European Community): a great deal, to some extent, not much or not at all? (1-4)

EUKNOWL: All things considered, how well informed do you feel about the European Union, its policies, its institutions? (READ OUT) Very well, quite well, not very well, or not at all well? (1-4)

De indicatoren lijken op het eerste gezicht (face validity) nogal divers van karakter tegen de achtergrond van de in paragraaf 3.4 besproken typologie die is gebaseerd op twee dimensies: object van steun en soort steun. Als EU-burgers daadwerkelijk beschikken over sterk gedifferentieerde gevoelens van steun ten aanzien van de EU, dan zou de factoranalyse eigenlijk geen factoren mogen opleveren met een hoge eigenwaarde.

Op basis van face validity verwijzen de verschillende indicatoren nadrukkelijk naar verschillende soorten steun. Met opzet is er een aantal op het eerste gezicht instrumentele (BENEFIT, EPEVAL) en non-instrumentele indicatoren (SCRAP, FEELEU en FUTURE) die in de analyse worden meegenomen. Bij een aantal indicatoren is het niet duidelijk of zij instrumenteel (specifieke steun) of non-instrumenteel (diffuse steun) van karakter zijn. Verder zijn er nog een tweetal op het eerste gezicht non-evaluatieve indicatoren opgenomen (POLINTEU en EUKNOWL). Deze laatste indicatoren zouden idealiter een aparte factor moeten vormen omdat ze eigenlijk niet passen binnen het begrip steun voor de EU.

De gekozen indicatoren verwijzen ook nadrukkelijk naar verschillende objecten van steun. Zo zijn er indicatoren bij die verwijzen naar aspecten van de politieke gemeenschap (FEELEU, BENEFIT en MEM), het regime (EUGOV, FUTURE, ECB, SUPRA) en de gezagsdragers (EPEVAL). In paragraaf 4.1 vindt $\mathrm{u}$ een meer uitgebreide typering van de drie standaardindicatoren in termen van de typologie uit paragraaf 3.4 .

De vraag die in deze appendix moet worden beantwoord, is in hoeverre het gebruik van de drie standaard-indicatoren een differentiatie van het concept steun voor de EU noodzakelijk maken? Naarmate de steun voor de EU in de empirie een sterkere differentiatie naar objecten en soorten kent, zal de factoranalyse meer factoren moeten opleveren. De minimale verwachting is dat evaluatieve en non-evaluatieve indicatoren in ieder geval als onafhankelijk van elkaar staande dimensies uit de factoranalyse komen. Gelet op eerdere analyses van andere onderzoekers (zie 
hieronder) is het echter zeer de vraag in hoeverre binnen het cluster van evaluatieve indicatoren nog een zinvol onderscheid kan worden gemaakt tussen objecten en soorten steun. Aan het einde van deze appendix treft $u$ de onderliggende correlatiematrix (tabel A4.1) en de matrix van (geroteerde) factorladingen (tabel A4.2) aan. Deze matrices zijn gebaseerd op de volledige (ongewogen) dataset met respondenten uit 12 lidstaten uit EB42 (najaar 1994). Daarnaast zijn er ook nog twaalf nationale factor-analyses uitgevoerd. Het overzicht van substantic̈le factoriadingen per land staat in tabel A4.3.

Een eerste initiēle componenten-analyse op de volledige dataset waarvan de resultaten hier niet zijn weergegeven, suggereert dat er gezocht moet worden naar een drie factor-oplossing." Dit illustreen dat de gevoelens van steun onder EU-burgers in ieder geval niet sterk gedifferentieerd zijn. In dat geval zou de eerste component niet zo'n grote eigenwaarde hebben.

$\mathrm{Na}$ deze componenten-analyse is overgestapt op factor-analyses waarbij wordt geaccepteerd dat de indicatoren naast een gemeenschappelijke achtergrond ook een deels uniek karakter hebben. De factor-analyse met varimax-rotatie, gericht op de vorming van zo eenduidig mogelijke factoren, levert vervolgens drie relatief goed te interpreteren factoren op. Omwille van de duidelijkheid zijn slechts factorladingen groter dan .30 in de matrix met factorladingen (tabel A4.2) opgenomen. Onderstaande beschrijving van de uitkomsten is primair gebaseerd op de uitkomst van de factor-analyse op de volledige dataset van 12 lidstaten (tabel A4.1 en A4.2).

Uit de analyse komt het meest duidelijk naar voren dat evaluatieve en non-evaluatieve aspecten van de houdingen ten aanzien van de EU, zoals verwacht, nadrukkelijk van elkaar te onderscheiden zijn. De twee non-evaluatieve indicatoren - interesse (POLINTEU) en geïnformeerd zijn (EUKNOWL) - laden alleen op de derde factor, terwijl alle andere indicatoren enkel op de eerste twee factoren laden. Interesse in en geïnformeerd zijn over de EU staan dus nadrukkelijk los van de andere evaluatieve indicatoren. Ook in de verschillende "nationale" factor-analyses (tabel A4.3) - met uitzondering van België - is dit onderscheid te vinden.

De eerste en belangrijkste factor weerspiegeit een bonte mengeling van evaluatieve indicatoren. De drie standaard-indicatoren vormen samen met de BENEFIT-indicator de kern van deze factor. Ondanks de op het eerste gezicht (face validity) niet onaanzienlijke verschillen tussen deze indicatoren blijken de antwoorden op deze vragen in de empirie dus een grote gemeenschappelijke deler te hebben. Burgers blijken geen duidelijk onderscheid tussen instrumentele en non-instrumentele beoordelingen van de EU te maken. De instrumentele indicator BENEFIT heeft samen met de non-instrumentele indicatoren SCRAP en MEM zeer hoge factorladingen op de eerste factor. De beoordeling van het democratisch functioneren

\footnotetext{
* De eigenwaarden van de drie factoren uit de initiele componenten-analyse zijn (tussen haakjes percentage verklaarde variantie): $5.6(43 \%), 1.4(11 \%)$ en $1.1(9 \%)$. In tien van de twaalf lidstaten - behalve Belgie en Ierland levert een nationale componenten-analyse een in grote lijnen vergelijkbaar beeld op.
} 
(DEMOCEU), het Europees Parlement (EPEVAL) en het algemene oordeel over West-Europese eenwording (UNIF) completeren deze eerste factor. De gerechtvaardige conclusie is derhalve dat EU-burgers bij het beoordelen van de EU in ieder geval geen scherp onderscheid maken tussen specifieke en diffuse steun.

Van een differentiatie naar objecten van steun blijkt ook weinig. Zo laden indicatoren die op het eerste gezicht nadrukkelijk lijken te refereren aan verschillende objecten - onder andere: BENEFIT en MEM (gemeenschap) versus EPEVAL (regime) en DEMOCEU (gezagsdragers) allemaal hoog op de eerste algemene factor. Alleen de tweede factor die uit de analyse komt lijkt tot op zekere hoogte objectspecifiek. De indicatoren die de tweede factor vormen, refereren aan plannen die er in 1994 waren om de supranationale dimensie binnen de EU te versterken. Het betreft vragen die in de meest ruime zin betrekking hebben op aspecten van het politieke regime van de EU. De twee vragen die gaan over de vorming van een politiek verantwoordelijke Europese regering binnen de EU en de vorming van een Europese Centrale Bank betreffen structuurelementen van het regime. De vraag over de toekomstige verhouding tussen de EU en de lidstaten refereert direct aan de centrale waarden - supranationaal versus intergouvernementeel - van het regime. De algemene UNIF-indicator laadt ook op deze tweede factor. Dit is niet zo vreemd omdat bij de UNIF-indicator expliciet wordt gerefereerd aan efforts being made to unify Western Europe. Steun voor het politieke regime van de EU - c.q. de discussie over versterking van de supranationale structuur van de EU - is dus tot op zekere hoogte te onderscheiden van de meer algemene eerste factor, hoewel twee van de vijf indicatoren die op de tweede factor hoog laden ook nadrukkelijk op de eerste factor laden.

Burgers in de onderzochte lidstaten anno 1994 maken bij de boordeling van de EU dus nauwelijks onderscheid tussen specifieke en diffuse steun, en slechts tot op zekere hoogte wordt gedifferentieerd naar objecten of deelaspecten van de EU. Belangrijkste conclusie is, dat de drie standaardvragen die in dit boek centraal staan zijn op te vatten als valide indicatoren voor een relatief ongedifferentieerde vorm van steun voor de EU als zodanig. We gaan er daarbij van uit dat burgers over het algemeen een weinig gedifferentieerd oordeel hebben over de EU. Wel is er een duidelijke scheiding aanwezig tussen evaluatieve en non-evaluatieve aspecten van de houdingen te aanzien van de EU, zodat niet zonder meer alles op een hoop moet worden gegooid.

In hoeverre sluiten bovenstaande conclusies aan bij de resultaten van andere onderzoekers?

Duchesne en Frognier (1995) en Inglehart (1977b) hebben, net zoals hier is gedaan, de standaard-indicatoren tezamen met andere vragen onderworpen aan een factoranalyse. Zij komen tot een vergelijkbare conclusie en stellen dat de antwoorden op de drie standaard-indicatoren voor een belangrijk deel zijn terug te voeren op een en dezelfde grondhouding. Ook meer beperkte analyses op oudere Eurobarometer-studies wijzen in die richting (vgl. Shepherd, 1975: 139-143; 
Inglehart, 1971a: 13-5; Wildgen en Feld, 1976; Maybew, 1980).

Vermeldenswaard in dit kader is verder de analyse van Oppenhuis (1995: 173-5) op data uit het Europees verkiezingsonderzoek dat aan de vooravond van de EP-verkiezingen in 1989 is uitgevoerd in twaalf lidstaten. Oppenhuis laat zien dat de drie standaard-indicatoren (MEM, SCRAP en UNIF) tezamen met de BENEFIT-indicator in alle twaalf lidstaten een sterke unidimensionale mokkenschaal ( $E C$-appproval) vormen. Dit illustreert dat de indicatoren weliswaar qua moeilijkheid (zie paragraaf 4.3) van elkaar verschillen, maar dat de antwoorden op de onderliggende vragen niettemin terug te voeren zijin op één en dezelfde grondhouding.

De conclusies van Blondel, Sinnot en Svensson op basis van een factoranalyse op Eurobarometer-gegevens uit het begin van de jaren negentig sluiten min of meer naadloos aan bij de conclusies van onze eigen analyse (1998: 215-22). Ook zij vinden geen aanwijzingen dat er een empirische noodzaak zou zijn om te komen tot een differentiatie van het concept steun voor de EU.

Tot slot, de resultaten van de (confirmatorische) factor-analyse van Gabel (1998: 15-35) - op ander andere de MEM- en UNIF-indicator (geen SCRAP) - naar de empirische houdbaarheid van Eastons onderscheid tussen specifieke en diffuse steun lijken op het eerste gezicht in tegenspraak met bovenstaande inzichten. De UNIF-en MEM-indicator moeten volgens Gabel primair worden opgevat als indicator voor diffuse (affective) respectievelijk specifieke (utilitarian) steun voor de EU. Uit de analyse blijkt echter dat de affective en utiliatarian factor bijzonder sterk met elkaar correleren (.61) en dat een specificatie van het model waarbij de UNIF-indicator op beide factoren laadt, uiteindelijk de beste resultaten oplevert. Ook Gabels analyse onderstreept dus in zekere zin dat de twee van de drie standaardvragen zijn te beschouwen als nauw aan elkaar verwante en valide indicatoren voor hetzelfde concept steun voor de EU.

De belangrijkste conclusie van deze appendix is derhalve dat de drie standaard-indicatoren die in dit onderzoek worden gebruikt om de verschillen en veranderingen in de publieke steun tussen respectievelijk binnen lidstaten in kaart te brengen, zijn te beschouwen als valide indicatoren voor de meting van het empirisch ongedifferentieerde concept steun voor de EU. Er is geen enkele empirische noodzaak om in dit onderzoek een nadere differentiatie van het concept steun voor de EU aan te brengen. 
Tabel A4./ Correlatiematrix

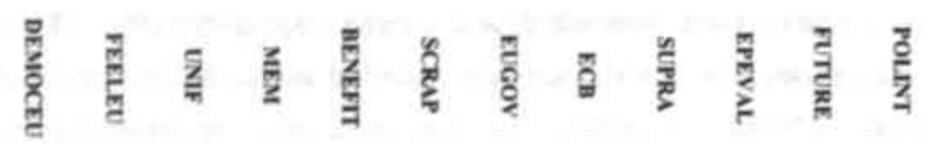

FEELEU -9

UNIF $29 \quad-26$

$\begin{array}{llll}\text { MEM } & 33 & -24 & 58\end{array}$

$\begin{array}{lllll}\text { BENEFTT } & 31 & -19 & 43 & 60\end{array}$

$\begin{array}{llllll}\text { SCRAP } & 31 & -29 & 56 & 64 & 53\end{array}$

$\begin{array}{lllllll}\text { EUGOV } & 24 & -23 & 43 & 43 & 31 & 40\end{array}$

$\begin{array}{llllllll}\text { ECB } & 21 & -22 & 39 & 38 & 30 & 38 & 42\end{array}$

$\begin{array}{lllllllll}\text { SUPRA } & 20 & -17 & 33 & 30 & 21 & 29 & 53 & 41\end{array}$

$\begin{array}{llllllllll}\text { EPEVAL } & 40 & -15 & 36 & 42 & 39 & 40 & 32 & 29 & 27\end{array}$

$\begin{array}{lllllllllll}\text { FUTURE } & -12 & 29 & -33 & -34 & -26 & -34 & -30 & -31 & -25 & -23\end{array}$

$\begin{array}{llllllllllll}\text { POLINTEU } & .08 & -02 & .22 & .02 & .17 & .30 & .10 & .12 & .10 & -.18 & .20\end{array}$

$\begin{array}{lllllllllllll}\text { EUKNOW } & .15 & -.21 & .15 & .21 & .16 & .21 & .11 & .14 & .16 & -.22 & .12 & .40\end{array}$

(a) EB42 (najaar 1994); $\mathrm{N}=12029$

Tabel A4,2 Rotated FactorMatrix: loadings $2|, 30|$

Factoren

I II $\underline{\text { III }}$

DEMOCEU $\quad .42$

FEELEU

$\begin{array}{lll}\text { UNIF } & .55 \quad .39\end{array}$

MEM $\quad .75$

BENEFTT $\quad .69$

SCRAP $\quad .66$

$\begin{array}{lll}\text { EUGOV } & .30 \quad .67\end{array}$

ECB $\quad .53$

$\begin{array}{ll}\text { SUPRA } & .68\end{array}$

EPEVAL $\quad .48$

FUTURE $\quad-.36$

POLINTEU $\quad .81$

EUKNOWL 51

(a) EB42 (najaar 1994); $\mathrm{N}=12029$

(b) Factor-analyse: varimax-rotatie 


\begin{tabular}{|c|c|c|c|c|c|c|c|c|c|c|c|c|c|c|c|c|c|c|}
\hline & & FR & & & BE & & & NL & & & GE. & & & IT & & & LUX & \\
\hline & 1 & II & III & 1 & II & III & 1 & II & III & 1 & II & III & 1 & II & III & I & II & III \\
\hline DEMOCEU & & $\mathrm{x}$ & & $x$ & & & $\mathbf{x}$ & & & & $x$ & & & $x$ & & & $\mathrm{x}$ & \\
\hline FEELEU & $\mathrm{x}$ & & & & & $\mathbf{x}$ & & $\mathbf{x}$ & & $\mathrm{x}$ & & & $\mathrm{x}$ & & & & & \\
\hline UNIF & $\mathrm{x}$ & $\mathrm{x}$ & & $\mathbf{x}$ & $\mathrm{x}$ & $\mathbf{x}$ & $\mathrm{x}$ & & & $\mathbf{x}$ & $\mathrm{x}$ & & $\mathbf{x}$ & $\mathbf{x}$ & & $x$ & & \\
\hline MEM & $x$ & $\mathrm{x}$ & & $\mathbf{x}$ & $\mathrm{x}$ & $\mathrm{x}$ & $\mathbf{x}$ & & & $\mathrm{x}$ & $\mathbf{x}$ & & $\mathbf{x}$ & $\mathbf{x}$ & & $\mathbf{x}$ & & \\
\hline BENEFIT & $\mathrm{x}$ & $\mathrm{x}$ & & $\mathrm{x}$ & $\mathrm{x}$ & & $\mathrm{x}$ & & & $\mathrm{x}$ & $\mathrm{x}$ & & $x$ & $\mathrm{x}$ & & $\mathrm{x}$ & & \\
\hline SCRAP & $x$ & $\mathrm{x}$ & & & & $\mathrm{x}$ & $\mathrm{x}$ & $x$ & & $\mathrm{x}$ & $x$ & $x$ & $x$ & $x$ & & $x$ & & \\
\hline EUGOV & & & $x$ & & $x$ & & & & $\mathrm{x}$ & $x$ & $\mathrm{x}$ & & & & & & $\mathrm{x}$ & \\
\hline ECB & $\mathrm{x}$ & & $\mathrm{x}$ & & $\mathbf{x}$ & & & & $x$ & $\mathrm{x}$ & & & $\mathrm{x}$ & & & $\mathrm{x}$ & & \\
\hline SUPRA & & & $\mathrm{x}$ & & $\mathrm{x}$ & & & & $\mathrm{x}$ & $\mathrm{x}$ & & & & & & & $\mathrm{x}$ & \\
\hline EPEVAL & & $\mathbf{x}$ & $\mathrm{x}$ & $x$ & & & $\mathbf{x}$ & & & & $\mathrm{x}$ & & & $\mathbf{x}$ & & & & \\
\hline FUTURE & $x$ & & & & & $\mathrm{x}$ & & $\mathbf{x}$ & & $x$ & & & & & & $x$ & & \\
\hline POLINTEU & & $\mathrm{x}$ & & & & $\mathrm{x}$ & & $\mathrm{x}$ & & & & $x$ & & & $x$ & & & $\mathrm{x}$ \\
\hline EUKNOW & & $x$ & & $x$ & & & & $\mathrm{x}$ & & & & $x$ & & & $x$ & & & $x$ \\
\hline & & DK & & & EI & & & GB & & & GR & & & ES & & & PO & \\
\hline & $\underline{I}$ & II & III & I & II & III & I & II & III & I & II & III & I & II & III & I & II & III \\
\hline DEMOCEU & $\mathrm{x}$ & & & & & & $x$ & & & $\mathrm{x}$ & & & $\mathrm{x}$ & & & $x$ & & \\
\hline FEELEU & & & $x$ & & & & $\mathrm{x}$ & & & & & $\mathrm{x}$ & & & $\mathrm{x}$ & & & \\
\hline UNIF & $x$ & & & $\mathrm{x}$ & & & $x$ & & & $x$ & $x$ & & $\mathrm{x}$ & $\mathrm{x}$ & & $x$ & & \\
\hline MEM & $x$ & & & $\mathrm{x}$ & & & $\mathrm{x}$ & & & $x$ & $\mathbf{x}$ & & $\mathrm{x}$ & & & $x$ & & \\
\hline BENEFIT & $\mathrm{x}$ & & & $\mathrm{x}$ & & & $\mathrm{x}$ & $\mathrm{x}$ & & $\boldsymbol{x}$ & & & $\mathbf{x}$ & & & $\boldsymbol{x}$ & & \\
\hline SCRAP & $\mathbf{x}$ & & $\mathbf{x}$ & $\mathrm{x}$ & & & $\mathrm{x}$ & $\mathrm{x}$ & & $\mathrm{x}$ & & & $\mathrm{x}$ & & & $\mathrm{x}$ & & $\mathrm{x}$ \\
\hline EUGOV & & $\mathrm{x}$ & & & & $x$ & $\mathbf{x}$ & & & & $\mathrm{x}$ & & & $x$ & & $x$ & $x$ & \\
\hline ECB & $\mathrm{x}$ & $\mathrm{x}$ & & & & $x$ & & $\mathrm{x}$ & & $x$ & $\mathrm{x}$ & & $x$ & $x$ & & & $x$ & \\
\hline SUPRA & & $\mathrm{x}$ & & & & $x$ & & $x$ & & & $x$ & & & $\mathrm{x}$ & & & $x$ & \\
\hline EPEVAL & $x$ & & & $x$ & & & $\mathrm{x}$ & $x$ & & $x$ & & & $x$ & & & $x$ & $x$ & \\
\hline FUTURE & $\mathbf{x}$ & & $\mathrm{x}$ & & & & $x$ & $x$ & & & & & & $\mathrm{x}$ & & & $\mathrm{x}$ & \\
\hline POLINTEU & & & $x$ & & $x$ & & & & $x$ & & & $x$ & & & $x$ & & & $\mathrm{x}$ \\
\hline EUKNOW & & & $\mathrm{x}$ & & $\mathrm{x}$ & & & & $x$ & & & $x$ & & & $x$ & & & $x$ \\
\hline
\end{tabular}

(a) EB 42 (najaar 1994), voor aantallen respondenten zie tabel 4.1

(b) Factor-analyse: varimax-rotatic 


\section{HOOFDSTUK 5}

\section{Veranderingen en verschuivingen}

\subsection{Inleiding}

Dit hoofdstuk bevat een dynamische beschrijving van de publieke steun voor de EU in twaalf EU-lidstaten. Daarbij zal onderscheid worden gemaakt tussen veranderingen en verschuivingen. De term verandering is in dit hoofdstuk gereserveerd om wijzigingen in de publieke steun binnen een lidstaat te duiden. De term verschuiving wordt gebruikt om wijzigingen in de verschillen tussen lidstaten mee aan te geven. Verschuivingen zijn in tegenstelling tot veranderingen relatief van karakter doordat daarbij verschillende lidstaten met elkaar worden vergeleken. De publieke opinie in twee lidstaten kan dus veranderen, zonder te verschuiven. Het onderscheid tussen verandering en verschuiving ligt ook ten grondslag aan de twee volgende onderzoeksvragen, te weten:

3. Treden er veranderingen op in de publieke steun voor de EU binnen de lidstaten?

4. Zijn de verschillen in publieke steun voor de EU tussen de lidstaten stabiel?

Dit onderscheid is van belang omdat daardoor belangrijke informatie verkregen kan worden over de aard van de factoren die de dynamiek van de publieke steun voor de EU mede kunnen verklaren.

Het concept verandering biedt binnen dit onderzoek overigens maar tot op zekere hoogte houvast doordat de EU, het object van steun, in de loop der tijd voortdurend aan veranderingen onderhevig is geweest (zie hoofdstuk 2). Het is in die zin niet helemaal duidelijk welke conclusie op zijn plaats zou zijn als, bijvoorbeeld, het publieke steun voor de EU (EGKS) in 1954 precies even hoog zou zijn als in 1996. In absolute zin is er geen sprake van een verandering. Tegelijkertijd is het object van steun, de EU, in de tussentijd ingrijpend veranderd. Van een beperkte vorm van supranationale samenwerking tussen zes landen op het exclusieve terrein van de kolen- en staal-industrie is de EU uitgegroeid tot een welhaast volwaardige economische en monetaire unie van inmiddels vijftien landen met supranationale bevoegdheden op vele beleidsterreinen. Als men rekening zou houden met de groei van de EU tussen 1954 en 1996, zou men dus ook kunnen volhouden dat de publieke steun voor de EU rekening houdend met de ontwikkeling van het object in wezen is toegenomen. In dit hoofdstuk zal het begrip verandering louter gebruikt worden in de eerste, absolute betekenis; dit wil zeggen, er wordt bij het 
beschrijven van de veranderingen binnen de lidstaten geen rekening gehouden met de feitelijke ontwikkelingen binnen de EU.

In de volgende paragraaf (5.2) wordt ingegaan op de mogelijkheden en beperkingen van de tijdreeksen waarmee veranderingen en verschuivingen in de publieke steun voor de EU in kaart moeten worden gebracht. Paragraaf 5.3 staat geheel in het teken van veranderingen binnen de lidstaten, en in paragraaf 5.4 wordt ingegaan op de vraag of de veranderingen ook hebben geleid tot verschuivingen. Paragraaf 5.5 bevat een korte kwalitatieve beschrijving van de belangrijkste veranderingen in de steun voor de EU binnen de 12 onderzochte lidstaten en de belangrijkste verschuivingen tussen de lidstaten. In paragraaf 5.6 worden de eerste voorlopige antwoorden op de derde en vierde onderzoeksvraag geformuleerd.

\subsection{Tijdreeksen}

Om veranderingen en verschuivingen in de publieke steun voor de EU op het niveau van de lidstaten op te sporen zijn tijdreeksen nodig. Een tijdreeks bestaat uit een aantal door de tijd vergelijkbare metingen van de publieke steun voor de EU in een lidstaat. Voor de meting van de publieke steun en de creatie van de relevante tijdreeksen wordt gebruik gemaakt van de in hoofdstuk 4 geïntroduceerde indicatoren (scrap, mem en unif).

In hoofdstuk 1 is al aangegeven dat gewerkt zal worden met gegevens uit ongeveer 50 verschillende studies uit drie verschillende bronnen: USIA XX-series (1952-67), Common Market Study (1962) en de Eurobarometer-reeks (1970-1998). Idealiter zou dit betekenen dat voor elk van de twaalf lidstaten drie tijdreeksen (drie indicatoren) met zijn 50 verschillende meetpunten (studies) beschikbaar zouden zijn. Door de beperkte opzet van sommige studies en het feit dat in lang niet alle studies de drie standaard-indicatoren zijn opgenomen bevatten de meeste tijdreeksen veel minder dan 50 meetpunten en beginnen sommige tijdreeksen pas ergens in de jaren zeventig of tachtig. Alvorens de tijdreeksen te presenteren zullen de belangrijkste beperkingen hieronder worden besproken.

In de eerste plaats zijn er beperkingen die voortvloeien uit het feit dat lang niet elke studie is uitgevoerd in twaalf lidstaten. De USIA beperkte zijn surveys veelal tot de vier grote WestEuropese landen: West-Duitsland, Frankrijk, Italië en Groot-Brittanniě. Alleen voor deze vier landen beschikken we over een reeks met zo'n tien verschillende meetpunten uit de periode voor 1970. De USIA XX-studies leveren daarnaast nog een Deense (1955), een Belgische (1955) en een Nederlandse (1956) meting op. Voor de andere vijf EU-lidstaten in dit onderzoek Griekenland, Ierland, Luxemburg, Portugal en Spanje - bieden de USIA-data überhaupt geen soelaas. Het CMS-onderzoek (1962) was eveneens beperkt van opzet. Dit onderzoek heeft slechts 
in vijf van de zes toenmalige lidstaten plaats gehad, te weten: West-Duitsland, Frankrijk, Italie, Nederland en Belgie . Voor de eerste drie grote landen is het een extra meting bovenop de USIAmeting uit hetzelfde jaar, voor Nederland en Belgie is het echter een welkome aanvulling op de enige USIA-meting uit het midden van de jaren vijftig. De Eurobarometer-onderzoeken zijn ook beperkt van opzet en beperken zich in beginsel tot (bijna-)lidstaten.

Dit alles betekent concreet dat de lerse en Luxemburgse tijdreeksen pas in 1973 starten; de Griekse eind jaren zeventig; en de Spaanse en Portugese tijdreeksen pas in de jaren tachtig. ${ }^{70}$ Naast deze vijf relatief korte tijdreeksen, beginnen de nationale tijdreeksen van de andere kleine lidstaten (Nederland, Belgiê en Nederland) pas in het midden van de jaren vijftig en vertonen zij verder grote gaten, zoals in: Denemarken (1956-1973); Belgie (1956-1961 en 1963-1969) en Nederland (1957-1961 en 1963-1969). Alleen voor de drie grote lidstaten van het eerste uur Frankrijk, Italië en West-Duitsland - en Groot-Brittanniê is een redelijk complete tijdreeks vanaf 1952 tot 1998 voor handen, hoewel zelfs daarin enkele hinderlijke lacunes inzitten (1958-1961 en 1968-1969). Het laatste meetpunt van alle reeksen ligt in 1998.

De tweede categorie beperkingen heeft te maken met de afwezigheid van de drie standaardvragen in de vragenlijsten van sommige studies. De unif-indicator levert qua beschikbaarheid relatief de minste problemen op. De unif-vraag ontbreekt alleen in Eurobarometers 5-9 (1976-8) en Eurobarometer 45-49 (1996-8). De unif-reeksen worden in tegenstelling tot de beperktere mem- en scrap-reeksen echter geplaagd door andere problemen. De opstellers van de vragenlijsten hebben op een aantal momenten aan de formulering van de vraag "geknutseld".

De oorspronkelijke USIA-vraag (1952-1967) luidt:

Are you in general for or against making efforts towards uniting Western Europe? Vanaf 1955 tot 1967 is hier voor de Britse ondervraagden aan toegevoegd "... Western Europe, including Great-Britain?." Deze aanpassing is in zekere zin begrijpelijk omdat Britse ondervraagden anders mogelijkerwijs het idee zouden kunnen krijgen dat hun oordeel wordt gevraagd over het continentale proces van West-Europese eenwording. Hun eigen land staat in die tijd in zekere zin nog aan de zijlijn omdat het geen lid is van de EU. Wel zijn de Britten nauw betrokken bij allerlei andere vormen van West-Europese samenwerking in die tijd (zie hoofdstuk 2). Vanuit dit oogpunt is de aanpassing van de vraag zonder meer te billijken en lijkt het de vergelijkbaarheid met de latere metingen na de toetreding tot de EU alleen maar te bevorderen. Een vergelijkbare toevoeging - including Italy / Western Germany - is ook toegepast in een beperkt aantal Italiaanse en West-Duitse USIA-vragenlijsten in de tijd dat werd gediscussieerd

\footnotetext{
${ }^{*}$ Bij de eerste Griekse, Spaanse en Portugese Eurobarometer-onderzoeken, toen deze landen nog officieel geen EU-lidstaat waren, is in die landen gewerkt met een uitgeklede vragenlijst. Dit doet zich vooral gevoelen bij de empirische toetsing in hoofdstuk 8 en 9 doordat de meetinstrumenten voor de centrale onafhankelijke variabalen ontbreken.
} 
over de toetreding van de voormalige agressors uit WOII tot de WEU en NAVO (zie hoofdstuk 2).

Ernstiger is een andere, tijdelijke," wijziging in de unif-vraag die door de ontwerpers van de Eurobarometer-vragenlijsten wordt aangebracht als zij 1970 het "stokje" van de USIA overnemen. In plaats van de Amerikaanse formulering ongewijzigd over te nemen, veranderen $z e$ de bewoordingen van de vraag en voegen er een neutrale antwoordcategorie aan toe. ${ }^{n}$ Door deze nieuwe formulering worden respondenten minder dan voorheen uitgenodigd om positie (voor of tegen) te kiezen. Hierdoor neemt het percentage onverschillige (neutrale) antwoorden toe ten koste van het percentage voor- en tegenstanders. Doordat in dit onderzoek gewerkt wordt met verschilscores - percentage voorstanders minus percentage tegenstanders - wordt dit effect tot op zekere hoogte geneutraliseerd. Na enige tijd van afwezigheid duikt gelukkig in 1978 de oude USIA-formulering weer op in de Eurobarometer-vragenlijsten. Door het wegvallen van een aantal metingen (ECS'71 en 1976-7) en het gebruik van een andere formulering zijn de unifreeksen in het begin van de jaren zeventig in vergelijkend perspectief minder betrouwbaar. De unif-vraag verschijnt voor het laatst in 1995 (EB43) in de Eurobarometer.

De scrap- en mem-reeksen kennen veel ernstiger beperkingen in termen van beschikbaarheid doordat deze indicatoren alleen in de Eurobarometer-studies (vanaf 1973) voorkomen. Met de mem- en scrap-reeksen kunnen we dus niet verder terug in de tijd dan 1973. De mem-vraag is vanaf 1973 in alle Eurobarometer-studies meegenomen, dit laatste kan niet gezegd worden van de scrap-vraag. De scrap-vraag wordt regelmatig vergeten en verdwijnt, net zoals de unif-vraag, na EB43 (1995) uit beeld. Aan de tekst van de vragen is niks wezenlijks verandert in de loop der tijd. De mem-reeksen vormen een onafgebroken tijdreeks met halfjaarlijkse metingen die loopt van 1973 tot en met 1998; in de scrap-reeksen die van 1973 tot 1995 lopen zitten de nodige gaten.

\footnotetext{
"Betreft ECS'70, ECS'70 en Eurobarometers 3 en 4 (1975). In ECS'70 en Eurobarometer 5 tot en met 9 is de unif-vraag uberhaupt niet opgenomen.

72 In plaats van te vragen (Engelse vraagtekst); Are you in general for or against making efforts towards uniting Western Europe?: vroegen ze in die jaren: Are you in general in favour, indifferent, or not in favour of the European unification?. Op twee punten wijkt de vraag af. Ten eerste is de toevoeging Western in de tweede formulering weggelaten, verder - en dat is waarschijnlijk van meer invloed - is er een neutrale antwoordcategorie toegevoegd. Vanaf Eurobarometer 10 (najaar 1978) is men gelukkig weer teruggekeerd naar de oude formulering.

Een andere, probleemloze, verandering tussen de unif-en USIA-versie van de unif-vraag is dat in de Eurobarometer-studies (1970-1995) is doorgevraagd bij respondenten die antwoorden voor of tegen te zijn, namelijk:

(If for/against) Are you very much for/against, or to some extent for/against?

De unif-vraag in de Eurobarometer kan dus behalve in een 3-punts index (voor/onverschillig / tegen) voor steun voor de EU (zie schema 4.1), dus ook als 5-puntsindex (erg voor / voor / onverschillig / tegen / erg tegen) worden gebruikt, Van deze laatste mogelijkheid wordt alleen gebruik gemaakt bij de toetsing van hypothesen op individueel niveau en voor zover bij die toetsingen geen USIA-data, die slechts de vorming van een 3-punts index toestaan, worden gebruikt.
} 
De daadwerkelijk beschikbare tijdreeksen zijn dus verre van ideaal. Alleen over de periode tussen 1985 en 1995 zijn er in beginsel drie tijdreeksen voor twaalf landen, hoewel de scrap-reeksen ook in die periode enige gaten vertoont. Voor de eerste twee decennia van de onderzoeksperiode moet geheel terug gevallen worden op de unif-indicator. De scrap-en mem-reeksen komen pas in beeld vanaf 1973.

In de tabellen 5.1, 5.2 en 5.3 zijn de beschikbare unif, mem- en scrap-tijdreeksen weergegeven. De reeksen in die tabellen vormen het basismateriaal voor de speurtocht naar veranderingen en verschuivingen in dit hoofdstuk. De aantallen respondenten waarop de percentages betrekking hebben zijn te vinden in het Appendix A waarin precies is aangegeven hoeveel respondenten in elke lidstaat zijn geĩnterviewd in het kader van de verschillende studies.

Omwille van de vergelijkbaarheid door de tijd zijn bij de berekening van de Britse scores de data van Noor-lerse respondenten (pas beschikbaar na 1975) buiten beschouwing gelaten, en is bij de berekening van de West-Duitse tijdreeksen geen rekening gehouden met de hereniging van Oost- en West-Duistland in 1990. Dit betekent dat de West-Duitse tijdreeksen ook na de hereniging in oktober 1990 slechts de mening van het West-Duitse deel van Duitsland weerspiegelen. De mening van de Oost-Duitsers blijft in dit onderzoek derhalve geheel buiten beschouwing. 
Tabel 5.1 Publieke steun voor EU (in \%) binnen lidstaten op basis van unif-indicator. 1952-1995 (maxima en minima binnen reeksen vetgedruki) a)

\begin{tabular}{|c|c|c|c|c|c|c|c|c|c|c|c|c|}
\hline jaar/kwart. & FR & BE. & NL & WD & IT & LU & DK & E.1 & GB & GR & ES & PO \\
\hline $\begin{array}{l}52-3 \\
54-4\end{array}$ & $\begin{array}{l}44 \\
54\end{array}$ & & & $\begin{array}{l}60 \\
78 \\
66\end{array}$ & $\begin{array}{l}43 \\
54\end{array}$ & & & & $\begin{array}{l}43 \\
74\end{array}$ & & & \\
\hline $\begin{array}{l}55-1 \\
55-3\end{array}$ & 34 & 73 & & $66 c$ & $44 c$ & & & & $57 \mathrm{c}$ & & & \\
\hline $55-4$ & 33 & & & $63 c$ & $42 c$ & & 46 & & $52 \mathrm{c}$ & & & \\
\hline 56-1 & 39 & & 72 & $73 \mathrm{c}$ & 59 & & & & $49 c$ & & & \\
\hline $56-4$ & 60 & & & 77 & & & & & $60 c$ & & & \\
\hline 57.2 & 46 & & & 68 & 52 & & & & $52 c$ & & & \\
\hline $\begin{array}{l}62-1 \\
62-2\end{array}$ & 64 & 60 & 83 & 77 & 56 & & & & $25 c$ & & & \\
\hline $\begin{array}{l}62-2 \\
64-1\end{array}$ & $\begin{array}{l}62 \\
75\end{array}$ & & & & $\begin{array}{c}61 \mathrm{e} \\
75\end{array}$ & & & & $\begin{array}{l}25 c \\
41 c\end{array}$ & & & \\
\hline $65-2$ & 69 & & & 79 & 61 & & & & $58 \mathrm{c}$ & & & \\
\hline $67-2$ & 65 & & & 85 & 64 & & & & $48 c$ & & & \\
\hline $70-2 b$ & 62 & 61 & 63 & 70 & 72 & & & & & & & \\
\hline $73-4 b$ & 64 & 56 & 58 & $n$ & 66 & 78 & 12 & 40 & 7 & & & \\
\hline $75-2 b$ & 73 & 52 & 57 & 74 & 74 & 76 & 11 & 43 & 29 & & & \\
\hline $75-4 b$ & 73 & 53 & 57 & 68 & 74 & 85 & 7 & 45 & 28 & & & \\
\hline $78-4$ & 72 & 62 & 72 & 72 & 78 & 56 & 16 & 60 & 41 & & & \\
\hline $79-2$ & 63 & 63 & 76 & 75 & 83 & 82 & 18 & 54 & 42 & & & \\
\hline $79-4$ & 66 & 62 & 72 & 73 & 81 & 81 & 8 & 55 & 39 & & & \\
\hline $80-2$ & 63 & 60 & 61 & 73 & 78 & 77 & -1 & 48 & 34 & & & \\
\hline $80-4$ & 57 & 55 & 67 & 70 & 74 & 74 & 15 & 41 & 42 & 37 & & \\
\hline $81-2$ & 60 & 50 & 67 & 56 & 72 & 80 & 11 & 36 & 24 & 35 & & \\
\hline $81-4$ & 72 & 63 & 57 & 63 & 75 & 68 & 4 & 46 & 43 & 49 & 50 & \\
\hline $82-2$ & 69 & 58 & 65 & 67 & 71 & 71 & 0 & 38 & 24 & 41 & 49 & 24 \\
\hline $82-4$ & 73 & 50 & 60 & 54 & 68 & 67 & 1 & 41 & 40 & 48 & 50 & 26 \\
\hline $83-2$ & 68 & 61 & 61 & 78 & 74 & 66 & 8 & 41 & $4 I$ & 48 & 53 & 29 \\
\hline $83-4$ & 70 & 62 & 57 & 68 & 74 & 68 & -4 & 50 & 57 & 60 & 46 & 30 \\
\hline $84-2$ & 73 & 57 & 71 & 60 & 70 & 74 & -7 & 44 & 40 & 36 & 48 & \\
\hline $84-4$ & 74 & 73 & 72 & 69 & 80 & 69 & -4 & 47 & 54 & 51 & & \\
\hline 85- 2 & 80 & 79 & 68 & 67 & 79 & 80 & -10 & 46 & 53 & 48 & & \\
\hline $85-4$ & 74 & 70 & 63 & 58 & 78 & 62 & -10 & 44 & 48 & 29 & 66 & 48 \\
\hline $86-2$ & 75 & 66 & 70 & 74 & 78 & 75 & 9 & 48 & 52 & 39 & 74 & 57 \\
\hline $86-4$ & 79 & 72 & 57 & 72 & 86 & 68 & 6 & 51 & 51 & 56 & 70 & 71 \\
\hline $87-2$ & 79 & 72 & 68 & 62 & 82 & 63 & -7 & 50 & 55 & 44 & 71 & 62 \\
\hline $87-4$ & 80 & 70 & 67 & 64 & 81 & 73 & 6 & 48 & 51 & 54 & 66 & 68 \\
\hline $88-2$ & 77 & 65 & 61 & 53 & 76 & 64 & -5 & 48 & 35 & 51 & 66 & 60 \\
\hline $88-4$ & 79 & 73 & 69 & 63 & 87 & 65 & 10 & 65 & 34 & 70 & 73 & 68 \\
\hline $89-2$ & 76 & 71 & 63 & 57 & 84 & 55 & 21 & 65 & 51 & 69 & 74 & 65 \\
\hline $89-4$ & 71 & 77 & 61 & 69 & 80 & 56 & 27 & 64 & 52 & 75 & 70 & 65 \\
\hline $90-2$ & 70 & 74 & 64 & 67 & 84 & 51 & 31 & 67 & 54 & 73 & 75 & 72 \\
\hline $90-4$ & 70 & 71 & 61 & 69 & 82 & 65 & 35 & 76 & 59 & 72 & 80 & 77 \\
\hline $91-2$ & 69 & 73 & 60 & 66 & 83 & 54 & 36 & 68 & 53 & 70 & 83 & 80 \\
\hline $91-4$ & 67 & 72 & 58 & 66 & 83 & 55 & 35 & 71 & 46 & 73 & 76 & 80 \\
\hline $92-2$ & 59 & 68 & 60 & 50 & 80 & 55 & 26 & 75 & 50 & 76 & 70 & 79 \\
\hline $92-4$ & 54 & 58 & 56 & 53 & 74 & 63 & 33 & 62 & 25 & 71 & 65 & 73 \\
\hline $93-2$ & 51 & 64 & 52 & 56 & 75 & 56 & 31 & 67 & 33 & 67 & 66 & 68 \\
\hline $93-4$ & 55 & 55 & 57 & 54 & 76 & 46 & 26 & 64 & 30 & 79 & 68 & 63 \\
\hline $94-2$ & 56 & 54 & 56 & 52 & 84 & 61 & 25 & 70 & 35 & 71 & 66 & 49 \\
\hline $94-4$ & 53 & 61 & 59 & 52 & 79 & 62 & 19 & 67 & 31 & 70 & 63 & 65 \\
\hline $95-2$ & 52 & 62 & 55 & 56 & 78 & 67 & 25 & 68 & 24 & 62 & 49 & 54 \\
\hline $95-4$ & 49 & 45 & 59 & 36 & 77 & 69 & 30 & 62 & 21 & 62 & 60 & 63 \\
\hline
\end{tabular}

Bron: USIA XX-series (1952-67), Common Market Studies (1962), ECS70/3 (1970/3),EB3-4 (I975) en EBI0-44 (1978-95).

a) Are you in general for or against making afforts towards uniting Western Europe?

b) Are you in general in favour, indifferent, or not in favour of the European unification?

c) Are you in general for or against making efforts towards uniting Western Europe, including (respondent's country]? 
Tabel 5.2 Publieke steun voor EU (in \%) binnen lidstaten op basis van mem-indicator, 1973-1998 (maxima en minima binnen reeksen vetgedrukt) a)

\begin{tabular}{|c|c|c|c|c|c|c|c|c|c|c|c|c|}
\hline jaar/kwart. & FR & BE & NL & WD & IT & LU & DK & EI & GB & GR & ES & PO \\
\hline $73-4$ & 56 & 53 & 60 & 59 & 67 & 65 & 12 & 41 & -3 & & & \\
\hline $75-2$ & 60 & 53 & 61 & 49 & 69 & 55 & 11 & 30 & 27 & & & \\
\hline $75-4$ & 62 & 55 & 63 & 55 & 72 & 74 & 15 & 55 & 27 & & & the \\
\hline $76-2$ & 50 & 56 & 71 & 37 & 57 & 60 & 7 & 25 & 3 & & & \\
\hline $76-4$ & 45 & 64 & 71 & 52 & 62 & 75 & -5 & 27 & 5 & & & \\
\hline $77-2$ & 59 & 64 & 77 & 45 & 67 & 82 & -1 & 40 & -5 & & & \\
\hline $77-4$ & 48 & 55 & 68 & 52 & 64 & 69 & 4 & 40 & -2 & & & \\
\hline $78-2$ & 46 & 52 & 72 & 54 & 59 & 68 & 4 & 37 & -10 & & & \\
\hline $78-4$ & 52 & 62 & 81 & 59 & 71 & 49 & 10 & 51 & 8 & & & 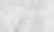 \\
\hline $79-2$ & 47 & 62 & 81 & 61 & 75 & 80 & 13 & 40 & -0 & & & \\
\hline $79-4$ & 53 & 53 & 75 & 61 & 73 & 83 & 13 & 46 & -12 & & & tat \\
\hline $80-2$ & 42 & 55 & 72 & 59 & 71 & 81 & 4 & 33 & -25 & & & \\
\hline $80-4$ & 37 & 49 & 69 & 56 & 67 & 70 & 3 & 20 & -24 & 17 & & \\
\hline $81-2$ & 39 & 44 & 70 & 40 & 67 & 75 & -1 & 24 & -24 & 20 & & \\
\hline $81-4$ & 46 & 51 & 71 & 51 & 65 & 72 & 2 & 31 & -15 & 17 & 45 & \\
\hline $82-2$ & 49 & 51 & 72 & 47 & 64 & 69 & 4 & 25 & -15 & 17 & 46 & 20 \\
\hline $82-4$ & 48 & 32 & 69 & 42 & 60 & 68 & 7 & 27 & -11 & 32 & 41 & \\
\hline $83-2$ & 46 & 58 & 72 & 55 & 66 & 67 & 10 & 25 & -9 & 29 & 45 & 19 \\
\hline $83-4$ & 46 & 57 & 76 & 47 & 64 & 71 & 9 & 16 & 8 & 36 & 43 & 19 \\
\hline $84-2$ & 58 & 53 & 76 & 49 & 66 & 78 & 2 & 20 & 3 & 20 & 40 & \\
\hline $84-4$ & 57 & 60 & 75 & 52 & 69 & 76 & 5 & 27 & 4 & 29 & 44 & 13 \\
\hline $85-2$ & 62 & 58 & 71 & 47 & 68 & 81 & -2 & 33 & 6 & 28 & & \\
\hline $85-4$ & 59 & 59 & 80 & 54 & 75 & 76 & 9 & 36 & 8 & 15 & 49 & 33 \\
\hline $86-2$ & 64 & 62 & 82 & 57 & 71 & 80 & 30 & 43 & 8 & 29 & 58 & 56 \\
\hline $86-4$ & 59 & 66 & 75 & 51 & 76 & 79 & 16 & 44 & 15 & 40 & 62 & 62 \\
\hline $87-2$ & 66 & 65 & 79 & 40 & 70 & 74 & 8 & 42 & 17 & 34 & 50 & 66 \\
\hline $87-4$ & 70 & 66 & 80 & 57 & 76 & 86 & 10 & 56 & 23 & 47 & 59 & 65 \\
\hline $88-2$ & 60 & 59 & 73 & 37 & 70 & 71 & 8 & 52 & 8 & 40 & 56 & 50 \\
\hline $88-4$ & 63 & 66 & 76 & 50 & 81 & 76 & 23 & 65 & 27 & 58 & 65 & 68 \\
\hline $89-2$ & 60 & 58 & 78 & 48 & 78 & 67 & 20 & 67 & 33 & 63 & 64 & 61 \\
\hline $89-4$ & 60 & 66 & 80 & 56 & 70 & 73 & 14 & 62 & 35 & 68 & 58 & 59 \\
\hline $90-2$ & 56 & 64 & 79 & 54 & 71 & 64 & 25 & 67 & 34 & 69 & 57 & 59 \\
\hline $90-4$ & 58 & 69 & 78 & 63 & 74 & 74 & 38 & 69 & 37 & 70 & 63 & 63 \\
\hline $91-2$ & 63 & 71 & 87 & 62 & 76 & 80 & 44 & 72 & 43 & 70 & 74 & 76 \\
\hline $91-4$ & 54 & 67 & 85 & 59 & 74 & 75 & 41 & 68 & 42 & 66 & 66 & 75 \\
\hline $92-2$ & 47 & 62 & 81 & 47 & 71 & 73 & 35 & 70 & 41 & 68 & 54 & 69 \\
\hline $92-4$ & 46 & 55 & 82 & 50 & 63 & 72 & 53 & 62 & 18 & 63 & 49 & 65 \\
\hline $93-2$ & 43 & 57 & 79 & 48 & 65 & 71 & 44 & 68 & 25 & 60 & 43 & 54 \\
\hline $93-4$ & 42 & so & 75 & 41 & 61 & 66 & 36 & 65 & 20 & 69 & 40 & 48 \\
\hline $94-2$ & 40 & 50 & 75 & 42 & 65 & 68 & 29 & 70 & 23 & 58 & 39 & 40 \\
\hline $94-4$ & 46 & 54 & 73 & 53 & 65 & 75 & 31 & 77 & 20 & 57 & 29 & 45 \\
\hline $95-2$ & 42 & 58 & 77 & 50 & 67 & 76 & 30 & 72 & 21 & 51 & 24 & 36 \\
\hline $95-4$ & 40 & 41 & 73 & 37 & 63 & 67 & 31 & 73 & 18 & 48 & 39 & 44 \\
\hline $96-2$ & 28 & 33 & 70 & 25 & 59 & 64 & 14 & 71 & 8 & 47 & 40 & 46 \\
\hline $96-4$ & 25 & 35 & 66 & 25 & 53 & 69 & 16 & 70 & -2 & 43 & 40 & 44 \\
\hline $97-2$ & 35 & 24 & 67 & 23 & 63 & 61 & 31 & 80 & 12 & 52 & 44 & 50 \\
\hline $98-2$ & 36 & 33. & 72 & 29 & 64 & 66. & 34 & 76. & 21 & 50. & 42 & 54. \\
\hline
\end{tabular}

Bron: ECS'73 (1973) en Eurobarometer 3-47 (1975-1997) en 49 (1998).

a) Generally speaking, do you think that [respondent's country's] membership of the European Community

(Common Market) / European Union is a good thing, a bad thing, or neither good nor bad? 
Tabel 5.3 Publieke steun voor EU (in \%) binnen lidstaten op basis van scrap-indicator, 1973-1995 (maxima en minima binnen reeksen vetgedrukt) a)

\begin{tabular}{|c|c|c|c|c|c|c|c|c|c|c|c|c|}
\hline Jaar/kwart. & FR & BE & NL & WD & IT & $\mathbf{L U}$ & DK & EI & GB & GR & ES & PO \\
\hline $73-3$ & 39 & 35 & 42 & 53 & 40 & 49 & 2 & 21 & -17 & & & \\
\hline $75-4$ & 47 & 40 & 48 & 49 & 42 & 58 & 6 & 36 & 14 & & & \\
\hline $77-4$ & 41 & 40 & 55 & 48 & 44 & 63 & -4 & 29 & -2 & & & \\
\hline $81-2$ & 26 & 19 & 44 & 34 & 47 & 55 & -6 & 16 & -26 & 11 & & \\
\hline $81-4$ & 34 & 26 & 41 & 41 & 41 & 55 & 0 & 22 & -19 & -0 & & \\
\hline $82-2$ & 37 & 29 & 53 & 46 & 44 & 59 & -0 & 21 & -17 & 9 & & \\
\hline $82-4$ & 38 & 22 & 46 & 36 & 38 & 50 & -5 & 17 & -18 & 13 & & \\
\hline $83-2$ & 36 & 36 & 52 & 52 & 43 & 54 & 12 & 25 & -8 & 17 & & \\
\hline $83-4$ & 35 & 32 & 51 & 40 & 38 & 53 & -2 & 10 & -1 & 25 & & \\
\hline $84-2$ & 39 & 29 & 49 & 40 & 38 & 62 & -7 & 17 & -8 & 9 & & \\
\hline $84-4$ & 38 & 30 & 46 & 48 & 37 & 58 & -6 & 17 & -5 & 11 & & \\
\hline $85-2$ & 46 & 32 & 47 & 42 & 39 & 60 & -12 & 22 & -10 & 17 & & \\
\hline 85.4 & 48 & 28 & 54 & 45 & 47 & 58 & -2 & 25 & -7 & 13 & 29 & 17 \\
\hline $86-2$ & 48 & 35 & 55 & 50 & 43 & 65 & 12 & 28 & -7 & 20 & 37 & 29 \\
\hline $86-4$ & 46 & 42 & 49 & 43 & 41 & 59 & 4 & 29 & -4 & 25 & 36 & 36 \\
\hline $87-2$ & 50 & 42 & 48 & 38 & 45 & 56 & -1 & 30 & 4 & 18 & 34 & 36 \\
\hline $87-4$ & 51 & 39 & 51 & 47 & 50 & 69 & 2 & 46 & 4 & 27 & 38 & 39 \\
\hline $88-4$ & 47 & 38 & 49 & 41 & 48 & 54 & -3 & 40 & .3 & 26 & 34 & 30 \\
\hline $93-2$ & 25 & 31 & 43 & 36 & 52 & 52 & 23 & 51 & 4 & 45 & 32 & 35 \\
\hline $93-4$ & 30 & 27 & 42 & 27 & 52 & 53 & 19 & 48 & 2 & 60 & 30 & 28 \\
\hline $94-2$ & 38 & 26 & 39 & 31 & 54 & 62 & 6 & 53 & 3 & 46 & 35 & 18 \\
\hline $94-4$ & 33 & 27 & 37 & 35 & 53 & 65 & 14 & 58 & -2 & 43 & 25 & 22 \\
\hline $95-2$ & 28 & 26 & 30 & 36 & 58 & 62 & 17 & 54 & -3 & 39 & 17 & 20 \\
\hline
\end{tabular}

Bron: ECS73 (1973), Eurobarometer 4 (1975), 8 (1977), 15-29 (1981-8), 39-43, 41.1, 42 en 43.1 (1993-5)

a) If you were told tomorrow that the European Community (Common Market) / European Union had been scrapped, would you be very sorry about it, indifferent or very relieved?

\subsection{Veranderingen binnen lidstaten}

Om na te gaan in hoeverre de publieke steun voor de EU binnen de lidstaten is veranderd, is in eerste instantie de spreiding binnen de nationale tijdreeksen bekeken. In tabel 5.4 zijn de extreme scores - maximum en minimum - in elke tijdreeks onder elkaar gezet. Vervolgens zijn de aan de maximum en minimum-score ten grondslag liggende verdelingen van antwoorden nader onder de loep genomen. Op basis van die verdeling zijn gemiddelde scores berekend en die zijn met elkaar vergeleken (t-test). In de tabel is voor elke afzonderlijke nationale reeks aangegeven of de gemiddelden die ten grondslag liggen aan de maximum- en minimumscore significant van elkaar afwijken.

De gegevens in de tabel geven aan dat de publieke steun binnen alle lidstaten, ongeacht de lengte van de onderliggende reeksen, onderhevig is aan (significante) veranderingen. De absolute grootte van de veranderingen in de publieke steun voor de EU binnen de verschillende reeksen varieert van $18 \%$ tot $68 \%$. Daarbij vallen een aantal zaken op. In de scrap-reeksen zijn de veranderingen over het algemeen veel kleiner dan mem-en unif-reeksen - vergelijk tabel 5.1,5.2. en 5.3. Aan de ene kant is dit logisch omdat de scrap-reeksen korter zijn dan de andere reeksen. Aan de andere kant is dit vreemd, omdat de relatief hoge absolute scores binnen de mem- en unif- 
reeksen in principe minder ruimte bieden voor verandering dan de in absolute zin veel lagere scrap-scores (ceiling effects). Verder zijn er opmerkelijke verschillen tussen de lidstaten waarneembaar. De verschillen zijn relatief het kleinst in Luxemburg en Nederland, en relatief het grootst in Denemarken, Portugal en Groot-Brittannič.

Tabel 5.4 Extreme scores en veranderingen in tijdreeksen (unif, mem, scrap) per lidstaat (in \%)

\begin{tabular}{|c|c|c|c|c|c|c|c|c|c|c|c|c|c|}
\hline Lidstaat: & F & B & NL & WD & I & L & DK & EI & GB & GR & E & P \\
UNIF-INDICATOR & \\
maximum & 80 & 79 & 83 & 85 & 87 & $82^{*}$ & 46 & 76 & 74 & 79 & 83 & 80 \\
minimum & 33 & 45 & 52 & 36 & 43 & 46 & -10 & 36 & $21^{*}$ & 29 & 46 & $24 \%^{*}$ \\
verschil & $47^{*}$ & $34^{*}$ & $31^{*}$ & $49^{*}$ & $45^{*}$ & $36^{*}$ & $56^{*}$ & $40^{*}$ & $53^{*}$ & $50^{*}$ & $37^{*}$ & $56^{*}$ \\
\hline \\
maximum
\end{tabular}

Bron: Zie tabel $5.1-5.3 ;{ }^{*}=\mathrm{p}<.01$, t-test op verschillen tussen maximum en minimum per lidstaat.

a) De unif-scores gebaseerd uit het de sterk afwijkende formulering van de unif-vraag in het begin van de jaren zeventig (1970-5) zijn bij het maken van dit overzicht buiten beschouwing gelaten (zie noot tabel 5.1).

Op zichzelf is het niet verbazingwekkend dat de publieke steun voor de EU binnen de lidstaten aan veranderingen onderhevig is. Het object van steun, de EU, is immers zelf voortdurend aan veranderingen onderhevig geweest. Dit roept de vraag of de oorzaak van de veranderingen in de publieke steun binnen de lidstaten gezocht moet worden in de ontwikkeling van de EU. Daarom is in aanvulling op bovenstaande analyse nog nagegaan in hoeverre er een gemeenschappelijke EU-brede trend in de veranderingen binnen de nationale tijdreeksen te ontdekken is.

Om er achter te komen welke trends er zijn, zijn de nationale tijdreeksen aan een simpele regressie-analyses onderworpen. De parameter die wordt geschat, is de "b" in de volgende formule: ${ }^{3}$

$$
\% \text { publieke steun in een land op tijdtsip } t=\text { constante }+(b \cdot t)^{74}
$$

\footnotetext{
${ }^{n}$ Bij de schattingen op de unif-reeksen is nog een dummy opgenomen in de vergelijking om te corrigeren voor de verstorende effecten van de herformulering van de unif-vraag in het begin van de jaren zeventig.

"De variabele " $\mathrm{t}$ " geeft aan wanneer een survey is gehouden. Bij Eurobarometer 41 en 42 - tweede respectievelijk vierde kwartaal 1994 - horen de t-waarden 94,25 en 94,75 . Bij de regressic-analyses op de unifreeksen heeft een dummy meegelopen. De dummy is 1 in de jaren 1970, 1973 en 1975 toen niet de oorspronkelijke formulering van de vraag werd gebruikt, maar de aangepaste vraag met cen neutrale antwoordcategorie. Deze
} 
De scrap-reeksen blijven helemaal buiten deze analyse omdat deze reeksen relatief weinig metingen omvatten en de nodige gaten hebben. Een positieve b wijst op een in de tijd toenemende publieke steun; een negatieve b op het afnemen van de publieke steun door de tijd; niet significant van nul afwijkende b's geven aan dat van een lineaire trend geen sprake is. Een b-coelfficiěnt van +.008 duidt erop dat de netto-steun voor de EU in een land elk jaar met 0,8 procent toeneemt; dit zou betekenen dat de publieke steun voor de EU in 25 jaar met zo'n $20 \%$ toeneemt. Alle significante b's $(p<.05)$ en de bijbehorende $\mathrm{R}^{2}$-waarden staan in het bovenste gedeelte van tabel 5.5 .

Aangezien de unif- en mem-reeksen nogal sterk uiteenlopende periodes bestrijken en de recksen van sommige lidstaten veel meer metingen bevatten dan de vergelijkbare reeksen van andere lidstaten, zijn de zoveel als mogelijk vergelijkbare (qua periode en aantallen metingen) mem- en unif-reeksen uit de periode 1978-1995 aan aparte analyse onderworpen. De resultaten van deze analyse staan in het onderste gedeelte van tabel 5.5. De relatief korte Griekse, Portugese en Spaanse reeksen die pas later beginnen (zie tabel 5.1-5.3) zijn omwille van diezelfde vergelijkbaarheid buiten deze nadere analyse gebleven. De resultaten van de analyse op de gestandaardiseerde reeksen van negen lidstaten staat in het onderste gedeelte van tabel 5.5.

Alvorens de resultaten te bespreken dient nogmaals te worden benadrukt dat met deze schattingen slechts lineaire trends worden opgespoord. Golfbewegingen of ander niet-lineaire ontwikkelingen kunnen niet met deze eenvoudige regressie-vergelijkingen worden opgespoord. Het niet vinden van een significante trend wil dus niet zeggen dat er in de loop der tijd geen significante veranderingen zijn opgetreden (zie ook tabel 5.4).

De resultaten van de regressie-analyses op de volledige mem- en unif-reeksen geven aan dat aan de veranderingen binnen de lidstaten geen gemeenschappelijke Europese trend ten grondslag ligt. Integendeel, de uitkomsten suggereren in de eerste plaats nationale dynamiek. In sommige lidstaten blijkt de steun voor de EU systematisch toe te nemen, terwijl de steun in andere lidstaten in diezelfde periode juist systematisch daalt. Zowel binnen de volledige mem- en uniftijdreeksen, als ook binnen de verkorte tijdreeksen zijn er aanwijzingen voor significante trends in beide richtingen. In sommige reeksen blijkt überhaupt geen lineaire trend te ontdekken.

Uit de analyse van de goed vergelijkbare korte reeksen (1978-1995) komt eenzelfde beeld naar voren. In Denemarken en lerland ontwikkelt de steun zich in opwaartse richting, terwijl in WestDuitsland en in mindere mate Nederland en Frankrijk in diezelfde periode juist sprake is van een neerwaarts trend. De daling van de Franse steun in de periode 1978-1995 is opmerkelijk als men in ogenschouw neemt dat de analyse op de volledige unif-reeks (1952-1998) suggereert dat de Franse steun juist lineair stijgt. Dergelijke paradoxale combinaties van trends op de lange en

dummy is uiteindelijk alleen in die landen gehandhaafd waar de dummy het verwachte negatieve teken had. 
Tabel 5.5 Trends in nationale tijdreeksen publieke steun voor de EU per lidstaat (mem, unif)

\begin{tabular}{l|l|l|l|l|l|l|l|l|l|l|l|l|l|}
\hline & FR & BE & NL & WD & IT & LU & DK & EI & GB & GR & ES & PO \\
unif-volledige reeksen (a) & \\
begin reeks & 1952 & 1955 & 1956 & 1952 & 1952 & 1973 & 1955 & 1973 & 1952 & 1980 & 1981 & 1982 \\
einde reeks & 1995 & 1995 & 1995 & 1995 & 1995 & 1995 & 1995 & 1995 & 1995 & 1995 & 1995 & 1995 \\
b & +.004 & ns & -.006 & -.004 & +.008 & -.011 & ns & +.017 & -.003 & +.025 & +.011 & +.027 \\
R-kwadraat & .21 & .10 & .51 & .32 & .76 & .46 & .03 & .59 & .29 & .59 & .19 & .41 \\
N & 50 & 40 & 40 & 50 & 49 & 37 & 38 & 37 & 48 & 30 & 26 & 24 \\
\hline begin reeks & 1973 & 1973 & 1973 & 1973 & 1973 & 1973 & 1973 & 1973 & 1973 & 1980 & 1981 & 1982 \\
einde reeks & 1998 & 1998 & 1998 & 1998 & 1998 & 1998 & 1998 & 1998 & 1998 & 1998 & 1998 & 1998 \\
b & -.005 & ns & +.003 & -.007 & ns & ns & +.015 & +.022 & +.014 & +.025 & -.005 & +.012 \\
R-kwadraat & .10 & .06 & .12 & .21 & .10 & .06 & .50 & .62 & .28 & .50 & .14 & .10 \\
N & 46 & 46 & 46 & 46 & 46 & 46 & 46 & 46 & 46 & 34 & 31 & 28 \\
\hline
\end{tabular}

Bron: zie tabel 5.1, 5.2 en 5.3.

n.s. = geschatte b wijkt niet significant af van nul, t-waarde $<1.96$

a) Bij de schatting van de regressievergelijking op basis van de volledige unif recksen is een dummy toegevoegd voor de metingen tussen 1970 en 1975 i.v.m. afwijkende vraagstelling (zie noot tabel 5.1).

middellange termijn lijken zich ook voor te doen in Italiẽ en Denemarken. De analyse van de onderling identieke korte reeksen onderstreept niettemin dat de veranderingen in de publieke steun voor de EU in de verschillende lidstaten geen gezamenlijke Europese trend volgen. ${ }^{75}$ Dit maakt het minder waarschijnlijk dat de belangrijkste oorzaak voor de veranderingen in de publieke steun voor de EU in de ontwikkeling van de EU zelf moet worden gezocht.

De belangrijkste conclusie van deze paragraaf is dat de publieke steun voor de EU binnen alle lidstaten aan verandering onderhevig is, alsmede dat de grootte en richting van de veranderingen in de steun van lidstaat tot lidstaat verschilt.

\subsection{Verschuivingen}

Het feit dat de veranderingen in de publieke opinie binnen de verschillende lidstaten geen

\footnotetext{
${ }^{3}$ Niedermayer (1995: 62-5) suggereert weliswaar dat de publieke steun binnen alle lidstaten op de korte termijn in zekere zin de conjunctuurgolven volgen, maar de resultaten van zijn analyse onderschrijven - mijns inziens - die conclusie niet.
} 
Europese trend volgen maar veelal een nationale dynamiek lijken te hebben, doet vermoeden dat de veranderingen ook moeten hebben geleid tot verschuivingen - dit wil zeggen: tot veranderingen in de verschillen tussen de lidstaten.

Om na te gaan of er verschuivingen hebben plaats gevonden is onderzocht in hoeverre de rangorde van meest loyale tot meest kritische lidstaten door de tijd heen stabiel is gebleven. Hiertoe zijn zogenaamde rangorde-correlaties berekend. Deze correlaties geven aan in hoeverre de volgorde van de lidstaten op basis van de mate van publieke steun voor de EU op twee verschillende tijdstippen met elkaar overeenkomen. Een sterk negatieve rang-orde correlatie duidt erop dat de lidstaten die op het ene tijdstip nog de meest loyale publieke opinie ten aanzien van de EU hebben, op het andere tijdstip juist de meest kritische publieke opinie hebben; en omgekeerd. Een significant positieve rangorde-correlatie zou daarentegen onderstrepen dat er nauwelijks verschuivingen zijn opgetreden en dat de rangorde op het ene tijdstip overeenkomt met de rangorde op het andere tijdstip. Om na te gaan in hoeverre de veranderingen binnen de lidstaten hebben geleid tot verschuivingen tussen de lidstaten, zijn de rangordes van de lidstaten op vijf verschillende tijdstippen met elkaar vergeleken. De vergeleken tijdstippen zijn: 1956, $1962,1973,1986$ en 1995. Door ook de vroege jaren in de analyse te betrekken wordt optimaal geprofiteerd van de lengte van sommige unif-reeksen. In tabel 5.6 zijn de verschillende correlaties voor elk van de drie indicatoren op een rijtje gezet. Bij elke vergelijking tussen jaren dit wil zeggen: bij elke coëfficiënt - is aangegeven hoeveel landen in de vergelijking zijn betrokken. Zo heeft de vergelijking van de rangorde op basis van de nationale unif-scores uit 1956 met die uit 1962 slechts betrekking op vijf lidstaten, terwijl de vergeleken rangordes op de unif-indicator uit 1986 en 1995 maar liefst twaalf lidstaten omvatten.

Tabel 5.6 Stabiliteit rangorde van lidstaten naar steun voor de EU, 1956-1998 (rangorde-correlaties)

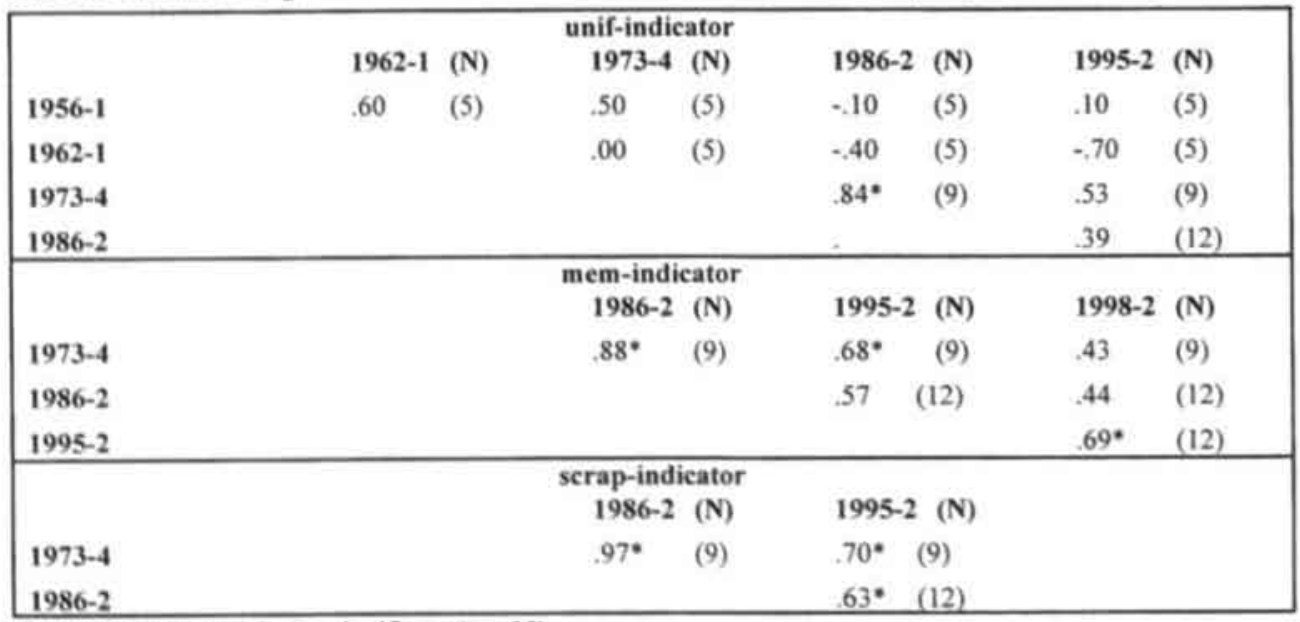

Bron: zie tabel $5.1-5.3 ;^{*}=$ significant $(p<05)$. 
De vele niet-significant positieve en negatieve rang-orde correlaties geven aan dat er inderdaad verschuivingen hebben plaatsgevonden. De stabiliteit van de rangordes neemt over het algemeen af naarmate de vergeleken tijdstippen verder uit elkaar liggen. Dit laatste duidt er op dat de verschuivingen die optreden geleidelijk verlopen. De veranderingen in de publieke steun voor de EU binnen de lidstaten zorgen dus voor geleidelijke en ingrijpende verschuivingen. ${ }^{76}$ Dit is opnieuw een aanwijzing dat van een Europese trend geen sprake kan zijn.

\subsection{Veranderingen en versehuivingen: een kwalitatieve beschrijving}

In het kader van de kennismaking met de tijdreeksen, zullen in deze paragraaf de belangrijkste veranderingen en verschuivingen binnen de tijdreeksen uit tabel 5.1, 5.2 en 5.3 tot slot nog eens in meer kwalitatieve zin worden beschreven.

\section{Veranderingen binnen lidstaten}

Het Franse publiek staat in het begin van de jaren vijftig relatief kritisch ten opzichte van de EU. In de decennia daarna loopt de steun voor de EU langzaam maar zeker op om op het einde van de jaren tachtig een voorlopig hoogtepunt te bereiken. Gedurende de jaren zeventig en tachtig ligt de steun op een relatief hoog niveau in vergelijking met de andere lidstaten. Aan het einde van de jaren tachtig behoort het land zonder meer tot de groep meest "eurofiele" landen. Ten tijde van en na het referendum over het Verdrag van Maastricht in 1992 daalt de publieke steun, waardoor Frankrijk in de tweede helft van de jaren negentig uit die laatste groep wegvalt.

De Belgen zijn voor zover na te gaan van 1955 tot eind jaren tachtig relatief loyale EUburgers. In de tweede helft van de jaren tachtig en begin jaren negentig is de Belgische publieke steun voor de EU het hoogst. In die tijd behoort België zonder twijfel tot de groep lidstaten met de meest loyale publieke opinie. In de loop van de jaren negentig treedt net zoals in Frankrijk een zekere kentering op. Hierdoor kan ook Belgiè op het einde van de jaren negentig niet meer tot de koplopers binnen de EU worden gerekend.

Nederland is samen met Luxemburg het land met relatief de meest stabiele publieke opinie. De Nederlanders blijken door de jaren heen relatief warme voorstanders te zijn van de EU, hoewel toch ook in Nederland in de jaren negentig een lichte terugval van de steun voor de EU valt te bespeuren. In tegenstelling tot België en Frankrijk is Nederland nog steeds een land met één van de meest loyale bevolkingen.

* Deze conclusie is in tegenspraak met die van Inglehart (1977a: 345-7) en Niedermayer (1995: 53-72) die volhouden dat ondanks een relatief grote variatie aan onderliggende nationale trends de verhoudingen tussen de lidstaten relatief stabiel blijven. 
De publieke steun voor de EU onder West-Duitsers is ook relatief stabiel door de tijd. In de eerste drie decennia van de EU was de West-Duitse publieke steun relatief groot. In de jaren negentig komt de steun voor de EU in het West-Duitse deel van het inmiddels herenigde Duitsland echter steeds meer onder druk te staan. In de jaren negentig bereikt de publieke steun in West-Duitsland zelfs een na-oorlog dieptepunt. Desondanks behoort West-Duitsland ook in de jaren negentig nog altijd niet tot de groep landen met een relatief kritische publieke opinie jegens de EU, het is nog altijd een middenmoter.

De ontwikkeling van de publieke steun in Italie̋ vertoont op sommige punten sterke overeenkomsten met de ontwikkeling in Frankrijk. In de jaren vijftig en zestig zijn de Italianen de meest kritische volgers van de EU. In de jaren zeventig trekt de steun voor de EU aan en groeien de Italianen in sneltreinvaart uit tot een van de meest "eurofiele" bevolkingen. Dit laatste geldt eigenlijk nog steeds, want in tegenstelling tot Frankrijk is er van een daling van de Italiaanse publieke steun in de jaren negentig geen sprake.

Hierboven is al aangegeven dat Luxemburg een relatief stabiele publieke opinie heeft. De steun voor de EU onder de inwoners van het Groothertogdom was en is relatief groot. Mogelijkerwijs als gevolg van de benoeming van hun voormalige minister-president Santer tot voorzitter van de Europese Commissie in 1995 is van een daling van de steun in de jaren negentig zoals die in veel andere lidstaten heeft plaats gevonden weinig te merken. Samen met Italië en lerland vormt Luxemburg op het einde van de jaren negentig de groep lidstaten met de meest loyale publieke opinie.

Denemarken is daarentegen zonder meer aan te merken als een land met een uiterst kritische bevolking. Vanaf het begin van het lidmaatschap (1973) heeft een groot deel van Deense bevolking bedenkingen tegen de EU. De balans slaat in de jaren zeventig en tachtig zelfs diverse malen in de negatieve richting door. Vanaf de tweede helft van de jaren tachtig groeit de steun voor de EU binnen Denemarken en lijkt de steun voor de EU zich te nestelen op een niveau dat systematisch hoger ligt dan in de jaren zeventig en tachtig. Desondanks blijft Denemarken behoren tot de groep landen met relatief gezien een van de meest kritische bevolkingen, zoals bij de het referendum in 1992 over het verdrag van Maastricht ook bleek.

lerland is afgezien van de opstartproblemen in de eerste tien jaar een echt succesverhaal. Als het land in 1973 toetreedt tot de EU is de publieke opinie loyaal, noch kritisch te noemen. In tegenstelling tot Denemarken en Groot-Brittanniě is de Ierse publieke steun na de toetreding in 1973 begonnen aan een langzame, maar zekere opmars. Afgezien van een kleine dip in het begin van de jaren tachtig - die in heel veel lidstaten zichtbaar is en waarschijnlijk alles te maken heeft met de tegenvallende West-Europese conjunctuur in die periode (Niedermayer, 1995: 62-5) stijgt de publieke steun voor de EU in lerland steeds verder door. Onder invloed van deze ontwikkelingen moet lerland vanaf het midden van de jaren negentig worden gerekend tot de 
koplopers.

Groot-Brittanniē is een geheel ander verhaal. Was de steun voor de samenwerking met WestEuropese landen - het land was toen nog geen lid van de EU - in de jaren vijftig nog relatief hoog. Bij de toetreding in 1973 blijft van dat aanvankelijke enthousiasme weinig over. In de jaren zeventig en begin jaren tachtig blijft de Britse steun op een relatief laag peil hangen, alleen in het referendumjaar 1975 valt nog een lichte piek te ontwaren. In het begin van de jaren tachtig, ten tijde van de economische laagconjunctuur in West-Europa en het Thatcher-regime, is de stemming onder de Britse bevolking van tijd tot tijd misschien wel het best te typeren als potentieel vijandig (zie vooral scores Britse scrap-en mem-reeks). In het tweede gedeelte van de jaren tachtig en het begin van de jaren negentig krabbelt de Britse steun uit dit dal, om daarna weer een klein beetje weg te zakken. De Britse publieke steun ligt in de jaren negentig op een hoger niveau dan in het begin van de jaren tachtig, maar de Britten zijn samen met de Denen de meest kritische volgers van de EU.

De Griekse steun kent na de toetreding in 1981 aanvankelijk een valse start. In 1985 is het opinieklimaat nog aan te merken als uiterst kritisch. Daarna is de steun voor de EU snel gestegen en bereikt de steun een (voorlopig) hoogtepunt aan het begin van de jaren negentig. Daarna is de steun weer licht afgenomen, maar de publieke steun in de jaren negentig ligt vooralsnog op een hoger niveau dan in de jaren tachtig.

Over de veranderingen in de relatief korte Spaanse en Portugese reeksen valt relatief weinig te zeggen. In beide landen is de steun na toetreding gestegen en in de loop van de jaren negentig weer licht gedaald. In deze twee landen ligt de steun in de jaren negentig weliswaar op een vrij hoog niveau, maar de landen zijn vooralsnog geen "hoogvliegers".

\section{Verschuivingen tussen de lidstaten}

Er zijn zeven landen - Frankrijk, Belgiē, Nederland, West-Duitsland, Italię, Denemarken en Groot-Brittannië - met een unif-tijdreeks die terug gaat tot in de jaren vijftig. De verhoudingen tussen deze lidstaten zijn ingrijpend veranderd in de laatste 45 jaar. Meest opvallende verschuiving (zie tabel 5.1) in deze groep van zeven lidstaten vormt de onstuitbare opmars van Italië en Frankrijk. In het midden van de jaren vijftig is de steun voor de EU in deze landen nog relatief laag, terwijl de bevolking van West-Duitsland, Nederland en België in die tijd nog juist relatief enthousiast zijn. Denen en Britten die in tegenstelling tot Fransen en Italianen nog niet tot de EU (EGKS) behoren, nemen in de jaren vijftig nog een soort tussenpositic in. Voor zover kan worden nagegaan neemt de steun voor de EU in Frankrijk en Italiê in de jaren zestig weliswaar met horten en stoten - toe. Terwijl Britse toenaderingen tot de EU tot tweemaal toe op een Frans veto stuiten, daalt de steun in Groot-Brittannie. Deze trends leiden er toe dat Franse en Italiaanse steun voor de EU al in de loop van de jaren zestig uittorent boven de achterblijvende 
Britse steun. De stijging van de steun in Frankrijk en Italië gaat zo snel dat de steun al vroeg in de jaren zeventig niet meer onder doet voor de steun in België, Nederland en West-Duitsland.

In de jaren zeventig en het eerste deel van de jaren tachtig ontstaat zo een soort tweedeling binnen deze groep van zeven landen. Aan de ene kant staan de nieuwe EU-lidstaten Denemarken en Groot-Brittannië met een bij tijd en wijle welhaast vijandige publieke opinie, en aan de andere kant staan de andere vijf lidstaten met een uiterst loyale publieke opinie. Op het einde van de jaren tachtig en in de jaren negentig komt daar pas weer beweging in. De Denen en in mindere mate de Britten verliezen een deel van hun vroegere scepsis, terwijl de steun voor de EU in WestDuitsland, België en Frankrijk langzaam afkalft. Aangezien ook de steun in Nederland en Italië op het einde van de twintigste eeuw licht inzakt, zijn de verschillen tussen de zeven lidstaten in de jaren negentig beduidend minder groot dan in de jaren zeventig en tachtig. Zodoende is er in de jaren negentig ook geen sprake meer van een tweedeling tussen oude en nieuwe lidstaten, maar ontstaat er cen continuüm. Aan het ene uiteinde staan Italiě en Nederland met een relatief loyale bevolking, aan de andere kant staan de Britten en Denen die - hoewel minder kritisch dan in de jaren zeventig en tachtig - de EU nog altijd niet in hun harten hebben gesloten. De WestDuitsers, Fransen en Belgen bevinden zich ergens tussen deze twee uitersten in. Over de periode van 1952 tot 1998 vinden er dus inderdaad een aantal ingrijpende veranderingen plaats in de onderlinge verschillen tussen deze zeven lidstaten.

Beperkt men zich tot de periode na 1973 en betrekt men ook, zoveel als mogelijk, de andere vijf lidstaten in de beschrijving dan ontstaat op sommige punten een geheel ander beeld van verschillen en verschuivingen. Zo is de tweedeling tussen oude lidstaten en nieuwkomers in het begin meteen al veel minder scherp doordat de publieke opinie in lerland veel milder is dan in Denemarken en Groot-Brittannië. Voor zover er toch nog sprake is van een waterscheiding tussen nieuw en oud komt ook daar een eind aan in de jaren tachtig door de gestage stijging van de publieke steun voor de EU in lerland.

De juistheid van de vooronderstelde tweedeling tussen oud en nieuw komt ook nog door een andere ontwikkeling op losse schroeven te staan. In de jaren tachtig treden Griekenland, Spanje en Portugal tot de EU toe. Met name Spanje en Portugal hebben vanaf het begin een relatief positieve publieke opinie. In het begin van de jaren tachtig nemen deze landen samen met Ierland nog een soort tussenpositie in tussen Denemarken en het Verenigd Koninkrijk aan de ene kant en de oorspronkelijke lidstaten aan de andere kant. Zo lijkt eerder sprake van een drie- dan van een tweedeling. In het tweede gedeelte van de jaren tachtig stijgt de publieke steun voor de EU in deze Mediterrane landen en komt de mate van publieke steun voor de EU op een niveau te liggen dat vergelijkbaar is met de steun voor de EU in sommige oorspronkelijke lidstaten. Tegen het einde van de jaren tachtig ontstaat zo een soort nieuwe tweedeling tussen Denemarken en het 
Verenigd Koninkrijk aan de ene kant en alle andere lidstaten aan de andere kant.

In de jaren negentig lijkt alles langzaam maar zekere naar elkaar toe te groeien. ${ }^{n}$ De verschillen tussen de twaalf lidstaten worden geleidelijker kleiner en de tweedeling vervaagt doordat de Denen en Britten in de jaren negentig veel minder kritisch zijn dan in de twee decennia daarvoor en de steun in een aantal lidstaten van het eerste uur (West-Duitsland, Frankrijk en Belgiē) daalt.

\subsection{Onderzoeksvragen}

De aard van de veranderingen en verschuivingen die hierboven zijn gevonden vormen een eerste aanwijzing voor de richting waarin de verklaring voor de (in)stabiliteit moet worden gezocht (Handley, 1981; Anderson en Kaltenthaler, 1996). Gezien de verschillende nationale trends valt het min of meer uit te sluiten dat de ontwikkeling van de publieke opinie in de lidstaten het gevolg is van lidstaat-onafhankelijke internationale factoren (conjunctuur, groei van de EU, externe bedreigingen). Dit wil niet zeggen dat internationale factoren geen rol kunnen spelen, maar wel dat het effect van dit soort factoren op zijn minst ingekleurd wordt door de nationale context. Dit betekent dus onder andere dat maatschappelijk processen als schaalvergroting, mobiliteit, globalisering en internationalisering geen allesoverheersend eenduidig effect op de publieke steun voor de $\mathrm{EU}$ in de diverse lidstaten hebben.

Alles wijst er dus op dat nationale factoren en nationale omstandigheden een hoofdrol spelen bij de veranderingen in de publieke steun voor de EU binnen, en de veranderingen in de verschillen tussen (verschuivingen) de lidstaten. De natie-staten blijven in een of andere vorm politieke context, communicatiestructuren, cultuur, historie, enzovoort - van buitengewoon groot belang voor de ontwikkeling van de publieke opinie ten aanzien van de EU (vgl. Van Deth, 1995a).

Het voornaamste doel van vergelijkend onderzoek is vervolgens om er achter te komen waar

\footnotetext{
7 Door voor elke survey in de jaren 1973-1998 de standaard-deviatie te berekenen bij de gemiddelde publieke steun in een lidstaat kan een idee worden gekregen van de grootte van de verschillen tussen de lidstaten. Door vervolgens de verschillende standaard-deviaties van alle surveys uit de jaren zeventig, respectievelijk jaren tachtig en negentig te middelen, kan een idee worden gekregen in hoeverre de verschillen tussen de lidstaten in de loop der tijd toe- of afnemen. De resultaten van een dergelijke analyse waarbij - omwille van de vergelijkbaarheid door de tijd - enkel de publieke steunscores van de negen landen die in 1973 lid waren van de EG zijn meegenomen, staan hieronder. De gemiddelde standaard-deviatie voor de surveys in de jaren zeventig bedraagt voor de unif-, mem- en scrap-vraag achtereenvolgens (tussen haakjes het aantal surveys waarop de gemiddelde standaard-deviatie is berekend): .22 (6), .25 (11) en .20 (3); in de jaren tachtig zijn de vergelijkbare scores: .22 (20), .26 (20) en .22 (15); en in de jaren negentig: 15 (12), .18 (16) en .18 (5). Berekend over de twaalf landen die in 1986 hid van de EU zijn bedraagt de gemiddelde standaard-deviatie in surveys van de jaren tachtig: .19 (14), 22 (13) en .20 (6); en in de surveys van de jaren negentig: .14 (11), 16 (22) en .16 (5).
} 
die nationale context voor staat; of zoals Przeworski en Teune zo prachtig verwoorden:

"The goal of comparative research is to substitute names of variables for the names of social systems," (Przeworski en Teune, 1970: 8)

Welke variabelen maken dat in de ene natie ontwikkeling $\mathrm{X}$ wordt gevonden, terwijl in dezelfde periode in een ander land ontwikkeling $\mathrm{Y}$ zich voordoet? Zoals gezegd is een belangrijke beperking op onze zoektocht het gegeven dat dit onderzoek zich beperkt tot lidstaten. Hierdoor treedt een soort van automatische beperking in de variatie op de afhankelijke, en mogelijk - maar dat is vooralsnog onbekend - ook in de relevante onafhankelijke variabelen op. Desondanks is het streven erop gericht de relevante onafhankelijke variabalen te vinden die de niet geringe veranderingen binnen en tussen lidstaten kunnen.

Op basis van de analyses in dit hoofdstuk kunnen de volgende antwoorden op de derde en vierde onderzoeksvraag worden geformuleerd.

3.Treden er veranderingen op in de publieke steun voor de EU binnen de lidstaten?

Het antwoord op de derde onderzoeksvraag vraag is een volmondig "ja". In geen enkele lidstaat blijkt sprake van een volledig stabiele publieke steun, hoewel de grootte van de veranderingen variëren van lidstaat tot lidstaat. Zo verandert de publieke opinie in Griekenland in minder dan vijftien jaar van uiterst kritisch in uiterst loyaal, terwijl in Nederland over een veel langere periode slechts relatief kleine veranderingen optreden. In de veranderingen is geen Europese trend zichtbaar die er, bijvoorbeeld, op zou kunnen duiden dat de veranderingen in de publieke opinie zijn ingegeven door de ontwikkeling die de EU, het object van steun, zelf heeft ondergaan in de onderzoeksperiode.

4. Zijn de verschillen in publieke steun voor de EU tussen de lidstaten stabiel?

Het antwoord op deze vraag is nee! De veranderingen binnen de lidstaten leiden eveneens tot veranderingen in de verschillen tussen de lidstaten, zogenaamde verschuivingen. Dit betekent dat de vierde onderzoeksvraag ontkennend dient te worden beantwoord. Dit betekent overigens niet dat de verschillen tussen alle lidstaten aan veranderingen onderhevig zijn. Voor een aantal lidstaten geldt echter dat hun positie in het klassement van lidstaten met de hoogste publieke steun voor de EU aan de nodige veranderingen onderhevig is geweest. Vooral de opmars van Italië en Frankrijk, en later ook lerland, zijn in dat opzicht vermeldenswaard. 


\section{HOOFDSTUK 6}

\section{Ingleharts Silent Revolution-theorie: hypothesen}

\subsection{Inleiding}

"European integration has slowed down since the mid-50's, and has stopped or reached a plateau since 1957-8. " Deze conclusie van de bekende Amerikaanse politicoloog Karl Deutsch (1966: 355) doet Ronald Inglehart in 1967 in de pen klimmen. Op basis van een nadere analyse van Deutsch' materiaal in combinatie met eigen onderzoek naar de mening van West-Europese jongeren over West-Europese eenwording komt Inglehart tot een geheel andere conclusie, namelijk:

"Far from finding a stagnation of integrative processes since 1958, I would argue that, in

some respects, European integration may have moved into full gear only since 1958."

(Inglehart, 1967; 91)

Gelet op het jaar - 1967 - waarin hij deze stelling poneert, mag het gerust een gewaagde stellingname worden genoemd. Immers, sinds 1965 bevindt het West-Europese integratieproces zich in een diepe crisis (zie hoofdstuk 2). De vooruitzichten voor het West-Europese integratieproces lijken op het moment van publicatie ronduit slecht. De tijd heeft inmiddels Inglehart en niet Deutsch in het gelijk gesteld.

Ingleharts artikel uit 1967 over de publieke steun voor West-Europese integratie is de eerste in een lange en nog immer wassende reeks van gezaghebbende publicaties over de samenhang tussen veranderingen in de maatschappelijke en sociaal-economische omstandigheden enerzijds en politieke veranderingen anderzijds. Hoewel Inglehart zijn theorie in eerste instantie slechts gebruikt voor de verklaring van politieke veranderingen in de hooggeïndustrialiseerde landen van West-Europa en Noord-Amerika (Inglehart, 1977a), zijn de mechanismen die ten grondslag liggen aan zijn uitspraken in principe algemeen geldend (Inglehart en Abrahamson, 1994: 437). Alleen in deze twee regio's overschrijden de omstandigheden waaronder jongeren opgroeien vrij snel na WOII belangrijke kritische grenzen die het raderwerk van Ingleharts Silent Revolutiontheorie in werking stellen. Eén van de politieke gevolgen van deze kritische veranderingen is volgens Inglehart een grotere acceptatie van supranationale politieke systemen. De hapering in het West-Europese integratieproces en de conclusie van Deutsch tasten Ingleharts vertrouwen in een toename van de publieke legitimiteit van het Europese integratieproces niet aan. 
Van Deth stelt dat de kern van Ingleharts Silent Revolution-theorie - vernoemd naar de titel van Ingleharts boek waarin hij zijn ideeën over politieke veranderingen systematisch uitwerkt - wordt gevormd door een eenvoudig schema met drie elementen en twee relaties (Van Deth, 1984: 6-8; Van Deth en Scarborough, 1995: 5-8; Inglehart, 1977a: 5; 1990: 6). Het eerste element betreft de economische, fysieke en technologische omstandigheden in een regio of land op een bepaald moment, de zogenaamde macro-setting (Van Deth, 1995b). Het tweede element wordt gevormd door de politieke vaardigheden en politieke waarde-orièntaties die individuen binnen zo'n gebied op jonge leeftijd ontwikkelen respectievelijk vormen. Het derde element tenslotte wordt gevormd door het politieke denken en handelen van het electoraat in zo'n gebied. De relaties hebben betrekking op de invloed van het eerste op het tweede element, respectievelijk het tweede op het derde element. Zo vooronderstelt Inglehart dat de ontwikkeling van vaardigheden en vorming van waarde-oriëntaties in sterke mate bepaald worden door de macro-setting waarin iemand opgroeit. Vaardigheden en waarden bepalen op hun beurt weer voor een belangrijk gedeelte het politieke denken en doen van burgers.

Ingleharts theorie is in ons kader vooral interessant omdat hij pretendeert een verklaring te kunnen geven voor veranderingen in de publieke steun voor de EU. Na in paragraaf 6.2 uitvoerig te zijn ingegaan op het algemene schema dat ten grondslag ligt aan Ingleharts theorie, wordt in paragraaf 6.3 specifiek aangegeven op welke wijze Inglehart zijn theorie verbindt met het thema publieke steun voor de EU. Dit mondt in paragraaf 6.4 uit in een vijftal hypothesen over de relatie tussen politieke waarde-oriëntaties en het niveau van politieke vaardigheden enerzijds, en de steun voor de EU op micro- (individueel), meso- (generaties) en macro-niveau (electoraat) anderzijds. Deze hypothesen worden in hoofdstuk 8 empirisch getoetst.

\subsection{Ingleharts Silent Revolution-theorie ${ }^{78}$}

Ingleharts theorie bestaat uit een simpel schema van drie elementen en twee relaties. Deze paragraaf is een uitgebreide toelichting op de elementen en relaties.

Eerste element: veranderingen in maatschappelijke omstandigheden (macro-setting)

De basis van Ingleharts theorie wordt gevormd door het inzicht dat de maatschappelijke omstandigheden in hoge mate bepalend zijn voor de uitkomsten van de politieke socialisatie van opgroeiende jongeren. Deze uitkomsten zijn belangwekkend omdat ze op hun beurt in

\footnotetext{
"Voor nog meer bijzonderheden over de theorie, zie: Inglehart, (1977a, 1990, 1997), Van Deth (1984, 1995b), Scarborough (1995) en Thome (1985).
} 
belangrijke mate het politieke denken en doen van de jongeren op latere leeftijd bepalen. Om ingrijpende veranderingen in het politieke denken en doen van het electoraat te kunnen begrijpen moet in deze visie primair worden gekeken naar de verschillen in de maatschappelijke omstandigheden waaronder vertrekkers en nieawkomers in het electoraat opgroeien. De vertrekkers behoren hoofdzakelijk tot de oudste generatie kiezers die letterlijk het electoraat uitsterven, terwijl de nieuwkomers vooral bestaan uit leden van jonge generaties die het electoraat in-groeien. ${ }^{70}$ Uitgangspunt van Ingleharts verklaring van hedendaagse politieke veranderingen vooral in West-Europa en Noord-Amerika - vormt dan ook een beschrijving van de verschillen in de maatschappelijke omstandigheden waaronder de oude en jonge generaties in deze regio's zijn opgegroeid.

Inglehart beschrijft een aantal technologische, maatschappelijke en economische ontwikkelingen die de macro-setting in West-Europa en Noord-Amerika - de zogenaamde westerse hooggeïndustrialiseerde landen - ingrijpend hebben doen veranderen. Hij concludeert dat de voor- en na-oorlogse omstandigheden op een viertal punten "kritisch" van elkaar verschillen. "Kritisch" wil zeggen dat de verschillen zodanig zijn dat het gevolgen heeft voor de uitkomsten van de politieke socialisatie van opgroeiende jongeren (1977a: 3-11).

De eerste ontwikkeling betreft de toename van de welvaart (reelle koopkracht) in deze landen. Als gevolg van de enorme economische groei in West-Europa en Noord-Amerika overschrijdt de welvaart in deze gebieden direct na WOII een kritische grens. Kritisch omdat door de welvaartsstijging de gezinssituatie in een aanzienlijk aantal gezinnen - dus niet slechts een kleine rijke toplaag - gekenmerkt wordt door een grote mate van economische zekerheid. Dit wil zeggen dat in die gezinnen eigenlijk voortdurend voldoende middelen voor handen zijn om op adequate wijze te voorzien in de primaire levensbehoeften - eten, drinken en huisvesting - van de gezinsleden. Steeds minder kinderen ervaren tijdens hun jeugd de ontberingen van honger en armoede ervaren. Dit is een belangrijk verschil met de veelal onzekere economische omstandigheden waaronder het merendeel van de leden van de voor-oorlogse generaties zijn opgegroeid. Het feit dat Inglehart zijn theorie alleen van toepassing acht op de Westerse hooggeïndustrialiseerde landen heeft vooral te maken met het feit dat alleen in deze staten de welvaart op een zodanig hoog niveau ligt dat er sprake is van een kritische verbetering in de hierboven besproken betekenis. De welvaart is na WOII verder blijven stijgen, zodat een steeds groter deel van de gezinnen in een relatief onbezorgde economische situatie verkeren. Meer en meer groeien de kinderen in West-Europa en Noord-Amerika op in een gezinssituatie die wordt gekenmerkt door een aanzienlijke mate van economische zekerheid.

\footnotetext{
" Emigratie en immigratie worden geacht van ondergeschikt belang te zijn.
} 
Het tweede belangrijke verschil in de macro-setting wordt gevormd door het einde van de oorlog op West-Europees grondgebied. Na WOII zijn er op West-Europees en NoordAmerikaans grondgebied ook geen nieuwe oorlogen meer uitgevochten. De leden van de vooroorlogse West-Europese generaties hebben tijdens hun jeugd bijna allemaal wel direct of indirect het gevoel van fysieke onveiligheid ervaren die een oorlog (WOI en/of WOII) met zich meebrengt. De leden van na-oorlogse generaties groeien daarentegen op in een tijdperk van vrede. Dit wil niet zeggen dat er geen enkele jongere na de oorlog bloot heeft gestaan aan een levensbedreigende situatie, maar in het algemeen zijn de jeugdjaren van de na-oorlogse generaties (vooral in West-Europa) op het punt van de fysieke zekerheid relatief veel veiliger dan de jeugdjaren van de voor-oorlogse generaties.

Een derde politiek relevante ontwikkeling is de stijging van het opleidingsniveau. Dit hangt samen met de industrialisatie en de daarmee gepaard gaande specialisatie en arbeidsdeling, alsmede de meer recente groei van de dienstensector. Door deze ontwikkeling is de behoefte aan goed opgeieid, professioneel personeel gegroeid. De aan deze ontwikkelingen gekoppelde stijging van de arbeidsproductiviteit maakt dat ouders en de samenleving als geheel ook in staat zijn om kinderen ook langer naar school te laten gaan. Het gemiddelde opleidingsniveau van de hedendaagse jeugd is daarom hoger dan dat van hun ouders en grootouders.

Tenslotte is er nog een vierde ontwikkeling die van grote politieke betekenis is. Dit betreft de grootschalige verspreiding van transport- en massacommunicatiemiddelen. Het bezit van een auto, telefoon, radio, televisie en de toegang tot internationale computernetwerken heeft de horizon van veel burgers ingrijpend verruimd. Het beeld van de wereld als een global village komt hierdoor steeds dichter bij. Belangrijkste winstpunt is de welhaast ongecontroleerde toegang tot informatie. De blik op de wereld en de politiek hoeft daardoor niet langer bepaald te worden door die ene nationale omroep, krant, pastoor, dominee of familielid. Dalton stelt:

"The contemporary media provide voters with a great variety of information sources, and potentially a more critical perspective of established political actors such as parties, labor unions, and industries. Access to a diverse media environment enables the public to become active selectors [J: curisivering in origineel] of information rather than passive consumers [idem] of political cues provided by others. " (Dalton, 1995: 346-7)

Deze laatste ontwikkeling komt overigens ten goede aan de politieke emancipatie van zowel jonge als oude burgers.

Van Deth (1995b) laat zien dat de door Inglehart beschreven veranderingen in de macrosetting inderdaad plaats hebben gevonden in West-Europa in de periode 1950-1990. De welvaart is toegenomen, het aantal jongeren dat hoger onderwijs volgt is gestegen, de verspreiding van moderne transport- en communicatiemiddelen heeft een hoge vlucht genomen en de vrede duurt voort. 
Eerste relatie: macro-setting en micro-socialisatie

Het belang van deze macro-setting zit, volgens Inglehart, in het effect dat hiervan uitgaat op de uitkomst van de politieke socialisatie van jongeren. De verschillen in de omstandigheden voor en na WOIl zijn zo ingrijpend, dat Inglehart voorspelt dat de uitkomst van de socialisatie van voor- en na-oorlogse generaties op twee punten systematisch van elkaar afwijken. Ten eerste voorspelt Inglehart dat na-oorlogse (jonge) generaties relatief postmaterialistische politicke waarde-oriëntaties zullen vormen onder invloed van de toegenomen welvaart en voortdurende vrede, alsmede een relatief hoog niveau van politieke vaardigheden ontwikkelen in vergelijking met de leden van voor-oorlogse (oude) generaties (zie verder bij hweede element hieronder). Deze verschillen zijn niet van alle tijden en illustreren niet de verschillen tussen jong en oud in het algemeen, maar zouden samen hangen met de kritische veranderingen in de macro-setting. Wat bedoelt Inglehart met de termen politieke waarde-orientatie en politieke vaardigheden? En, hoe relateert hij deze micro-concepten aan de macro-setting?

Inglehart stelt dat de inhoud van politieke waarde-oriêntaties die in de jeugdjaren worden gevormd, sterk gekleurd worden door de macro-setting. Alvorens in te gaan op de micro-macro relatie moet duidelijk zijn wat er bedoeld wordt met het begrip politieke waarde-oriëntatie. Een politieke waarde valt aan te duiden als een voorstelling van een wenselijke maatschappij en de belangrijkste middelen om die te bereiken (Van Deth, 1984: 83; Van Deth en Scarbrough, 1995: 21-47). Bij een politieke waarde valt dus te denken aan: een socialistische heilstaat, anarchisme, gelijkheid, law and order, vrijheid van drukpers, inkomensnivellering, sterke defensie,enzovoort. Een verzameling van politieke waarden met bijbehorende prioriteiten - waarde $\mathrm{A}$ is wenselijker dan waarde B - vormt een politieke waarde-orièntatie.

Inglehart stelt dat de inhoud van iemands individuele politieke waarde-orientatie primair afhankelijk is van de mate waarin iemand te maken krijgt met fysieke en economische onzekerheid - armoede en onveiligheid - in zijn jeugd. In wezen gaat het dus niet zozeer om de macro-setting, maar om de micro-setting - de individuele omstandigheden - waarin iemand opgroeit. Tegelijkertijd kan men zeggen dat de betreffende kenmerken in de meeste gevallen in belangrijke mate worden bepaald door de macro-setting op deze punten. De absolute welvaart in individuele gezinnen wordt in sterke mate bepaald door de arbeidsproductiviteit in een bepaalde regio. Gevoelens van onveiligheid hangen vaak samen met de aanwezigheid van oorlogen of binnenlandse conflicten. De relatie tussen omstandigheden en de vorming van een politieke waarde-oriëntatie is door Inglehart vastgelegd in twee hypothesen, te weten:

- de schaarstehypothese: de prioriteiten van een individu weerspiegelen zijn sociaaleconomische omstandigheden; men kent de hoogste waarde toe aan zaken die schaars zijn; 
- de socialisatiehypothese: de "basic values" van individuen weerspiegelen de omstandigheden waarin men is opgegroeid.

De eerste geeft aan dat de prioriteiten die aan uiteenlopende politieke waarden worden gegeven en die ten grondslag liggen aan een waarde-oriëntatie, worden ingegeven door zaken die als schaars zijn aan te merken in de omgeving van een individu. De waarde-oriëntatie vormt, met andere woorden, het spiegelbeeld van gebreken in de omgeving. Men kent veel waarde toe aan hetgeen schaars is. De tweede hypothese geeft aan dat Inglehart vooronderstelt dat dit spiegelbeeld zich niet doorlopend blijft aanpassen aan de schaarsteverhoudingen in de omgeving, maar dat de omstandigheden in de jeugdjaren mede bepalend zijn voor de waarde-oriëntatie op latere leeftijd.

Ingleharts voorspellingen zijn echter onmogelijk te begrijpen zonder een derde impliciete vooronderstelling. Deze is een nadere uitwerking van de wijze waarop de sociaal-economische omstandigheden uit de schaarste-hypothese van invloed zijn op de inhoud van iemands waardeoriêntatie. Deze assumptie is geènt op Maslows idee van een universele behoeftenhiërarchie, waarbij er van uit wordt gegaan dat mensen die leven in een uiterst berooide omgeving ("alles is schaars") primair streven naar fysieke en economische zekerheid (veiligheid, dak boven het hoofd, eten en drinken) en daarbij weinig oog hebben voor andere, zogenaamd hogere, behoeften. Hogere behoeften (intellectuele en sociale behoeften en de behoefte aan zelf-ontplooiing) krijgen pas aandacht (prioriteit) als de primaire levensbehoeften zijn vervuld. Maslow onderscheidt zeven hiërarchisch geordende behoeften, Inglehart maakt een grove tweedeling tussen materialistische en post-materialistische behoeften. Materialistisch zijn de behoeften aan fysieke en economische zekerheid; post-materialistische zijn de behoeften aan moraliteit, sociale betrokkenheid, emancipatie en (intellectuele) zelfontplooiing. Ingleharts derde impliciete hypothese zou men als volgt kunnen formuleren:

- de hiërarchiehypothese: zaken die primair bijdragen aan de bevrediging van postmaterialistische behoeften kunnen pas prioriteit krijgen als materialistische behoeften in hoge mate zijn bevredigd.

Deze stelt dus als het ware dat de waarde-oriëntaties niet zozeer worden bepaald door de omstandigheden in de omgeving, als wel door de mate van economische en fysieke zekerheid in de omgeving. De socialisatiehypothese stelt dat de inhoud van een individuele politieke waardeoriëntatie wordt gevormd gedurende de jeugdjaren, waarna deze nog slechts moeilijk is te veranderen.

Het individuele niveau van politieke vaardigheden is, volgens Inglehart, ook sterk afhankelijk van de macro-setting. Het niveau van politieke vaardigheden bepaalt in welke mate een individu in staat is om zelfstandig politiek te handelen. De vaardigheden stellen hem in staat om actief 
gebruik te maken van politieke informatiebronnen en relevante media. Het niveau van politieke vaardigheden wordt primair ingegeven door de cognitieve vaardigheden - lezen, schrijven, talenkennis, kennis van wetten en regels, enzovoort - waarover iemand beschikt. Secundair, maar niet minder noodzakelijk, wordt het niveau van politieke vaardigheden bepaald door de toegang die mensen hebben tot relevante politieke informatie. Zonder toegang tot de relevante politieke informatie kunnen cognitieve vaardigheden zich onmogelijk ontwikkelen tot politieke vaardigheden. Een ongehinderde toegang tot politieke informatie in combinatie met een hoog niveau van cognitieve vaardigheden, leidt tot een hoog niveau van politieke vaardigheden. De cognitieve vaardigheden stellen mensen in staat om zelfstandig en op eigen kracht de beschikbare politieke informatie te ordenen en te interpreteren. De opkomst van allerhande massamedia en de verbeterde mobiliteit maken dat nagenoeg iedereen met voldoende cognitieve vaardigheden in principe in staat is om toegang te krijgen tot relevante politieke bronnen. Het verzamelen van informatie is tegenwoordig geen tijdrovende kwestie meer.

De inhoud van individuele politieke waarde-oriëntatie en het individuele niveau van politicke vaardigheden wordt, volgens Inglehart, in hoge mate bepaald door de macro-setting waaronder men opgroeit. Op de keper beschouwd is de individuele (gezins) situatie (micro-setting) bepalend, maar de voor de politieke socialisatie relevante kenmerken in de micro-setting - welvaart, veiligheid, opleidingskansen en toegang tot massamedia - worden in belangrijke mate ingegeven door de macro-setting in een bepaald gebied en/of land.

\section{Tweede element: waarde-oriëntaties en vaardigheden}

Gegeven de kritische na-oorlogse veranderingen in de West-Europese en Noord-Amerikaanse macro-setting en de mechanismen via welke de omgeving doorwerkt in de politieke socialisatie, komt Inglehart tot een aantal concrete voorspellingen over de verschillen in politieke waardeoriëntaties en politieke vaardigheden tussen voor- en na-oorlogse generaties in deze gebieden. De relevante veranderingen zijn hieronder opgesomd.

De vrede en groeiende welvaart in West-Europa en Noord-Amerika zorgen na WOII voor een combinatie van ongekende economische en fysieke zekerheid in veel gezinnen. Daar waar de meeste leden van de voor-oorlogse generaties tijdens hun jeugd nog te maken hebben met armoede, honger en/of oorlog(sdreiging), heeft een aanzienlijk - en onder invloed van de welvaart steeds groter wordend - deel van de na-oorlogse generaties daar geen last meer van. Welvaart en veiligheid zijn voor veel leden van na-oorlogse generaties welhaast vanzelfsprekend en allerminst een schaars goed. Waar voor-oorlogse jongeren onder invloed van de onzekere sociaaleconomische omstandigheden - WOI en minder absolute welvaart - tijdens hun jeugd 
overwegend materialistische waarde-oriëntaties vormen, verwacht Inglehart dat onder invloed van de groeiende welvaart en voortdurende vrede een steeds groter percentage van de opeenvolgende na-oorlogse generaties meer postmaterialistische waarde-oriëntaties ontwikkelen. Voor de juistheid van deze these bestaan inmiddels sterke empirische aanwijzingen (zie vooral: Inglehart, 1997: 131-59).

Als gevolg van het feit dat West-Europese jongeren steeds langer naar school gaan, beschikken ze in steeds ruimere mate over cognitieve vaardigheden die hen in staat stellen om een relatief hoog niveau van politieke vaardigheden te bereiken. De andere voorwaarde voor het ontwikkelen van politieke vaardigheden is dat burgers toegang hebben tot relevante politieke informatie. Aan deze voorwaarde wordt voldaan doordat steeds meer burgers toegang hebben tot diverse nationale en internationale media en andere bronnen van politieke informatie. De aanwezigheid van bibliotheken, kranten, radio, televisie en het internet verschaft nagenoeg iedereen met een redelijke stel hersens de mogelijkheid om zich te ontwikkelen tot een politiek vaardige burger. Door de toegenomen mobiliteit zijn mensen bovendien in staat om zelf hun licht elders op te steken. Voor diegene die toegang heeft tot de moderne media, ligt de wereld als het ware binnen handbereik. Weliswaar staan de media open voor iedereen - jong en oud -, maar te verwachten valt dat vooral jongeren die beschikken over een relatief hoog niveau van cognitieve vaardigheden hier het meest van profiteren. Hoewel de veranderingen in de macro-setting bijdragen aan de politieke emancipatie van het gehele electoraat, draagt de opkomst van allerhande massamedia en de verbeterde mobiliteit vooral bij aan de ontwikkeling van een hoog niveau van politieke vaardigheden onder relatief goed opgeleide jongeren (Inglehart, 1990: 3427).

De uitkomsten van de politieke socialisatie van jongeren, het tweede element uit het schema, verschuift systematisch na WOII als gevolg van de ingrijpende veranderingen in de maatschappelijke omstandigheden. Inglehart verwacht dat de leden van na-oorlogse generaties relatief post-materialistisch zijn en gemiddeld over een hoger niveau van politieke vaardigheden beschikken dan de leden van voor-oorlogse generaties.

Tweede relatie: invloed micro-socialisatie op politieke denken en doen van electoraat De tweede relatie uit het schema ligt voor de hand. De inhoud van een individuele politieke waarde-oriëntatie en het individuele niveau van politieke vaardigheden worden geacht van invloed te zijn op het politieke denken en doen van de betrokken individuen. Systematische verschillen in de politieke waarde-oriëntaties en het niveau van politieke vaardigheden tussen jonge en oude generaties, zouden zodoende op termijn min of meer automatisch moeten leiden 
tot veranderingen in het politieke denken en doen van het electoraat. Het mechanisme dat de uitkomsten van de micro-socialisatie verbindt met electorale veranderingen, is het proces van bevolkingsvervanging.

Het mechanisme werkt als volgt: naarmate de tijd verstrijkt sterven de oudste generaties in het electoraat letterlijk uit en worden zij vervangen door leden van jonge generaties die de kiesgerechtigde leeftijd bereiken. Zo wordt het electoraat dus voortdurend ververst met nieuw, jong bloed. Dit betekent onder invloed van de veranderde maatschappelijke omstandigheden in de westerse hooggeîndustrialiseerde landen dat relatief materialistische, minder politiek vaardige voor-oorlogse generaties worden vervangen door relatief post-materialistische, politieke vaardige na-oorlogse generaties. Het gaat, met andere woorden, niet alleen om jong bloed, maar ook om bloed van een andere samenstelling. Een groeiend percentage postmaterialisten en een langzame stijging van het gemiddelde niveau aan politieke vaardigheden op het niveau van het electoraat is het logische gevolg.

Zolang oorlogen of andere rampen niet de natuurlijke aanwas van jonge generaties verstoren, zet dit proces door. Pas als de oudste generatie die aan de beurt is uit te sterven onder gelijkwaardige omstandigheden (qua economische en fysieke zekerheid, en scholing) is opgegroeid als de jongste generatie die op het punt staat hen te vervangen in het electoraat, zal de groei van het postmaterialisme en de stijging van het gemiddeld niveau van politieke vaardigheden stoppen. De stijging van het gemiddeld niveau van politieke vaardigheden wordt door Inglehart ook wel aangeduid met de term cognitive mobilization.

\section{Derde element: politieke houdingen en politieke gedrag (micro- en macro-perspectief)}

Welke veranderingen in het politieke denken en doen van het electoraat zijn er te verwachten als gevolg van het opkomend postmaterialisme en het proces van cognitive mobilization? Op dit punt wordt volstaan met een korte opsomming van de te verwachten veranderingen. ${ }^{80}$ In de volgende paragraaf zal vervolgens uitgebreid worden ingegaan op de invloed die deze ontwikkelingen volgens Inglehart zouden hebben op de publieke steun voor de EU.

Alvorens in te gaan op de verwachte veranderingen in het politieke denken en doen, echter eerst nog een korte opmerking over het tijdstip waarop naar verwachting de systematische verschillen in waarde-oriëntaties en vaardigheden tussen de opeenvolgende generaties (intergenerationele verschillen) gaan doorwerken in het electoraat. De veranderingen in de uitkomsten van de politieke socialisatie komen aan het licht op het moment dat de eerste andere (van hun ouders afwijkende) generaties de kiesgerechtigde leeftijd bereiken en daarmee een electorale factor van betekenis worden. Uitgaande van het feit dat de kritische veranderingen in

\footnotetext{
${ }^{\text {*0 }}$ Voor een uitgebreid overzicht zie: Inglehart, 1990 en 1997.
} 
de maatschappelijke omstandigheden pas hebben plaats gevonden na WOII, is de verwachting dat de eerste tekenen van politieke verandering midden jaren zestig aan het licht komen. Het is dit inzicht dat Ingleharts theorie een bijzondere glans geeft. De theorie is namelijk in staat om de woelige jaren zestig in West-Europa en Noord-Amerika te verklaren. Geheel onverwachts werden deze gebieden in het midden van de jaren zestig overspoeld door een golf van politiek protest en onrust vooral gevoed vanuit zeer actieve studentenbewegingen (na-oorlogse jongeren!). Het tijdstip waarop deze golf van protest losbarst, past perfect in Ingleharts theorie.

Ingleharts eerste verwachting luidt dat met het toetreden van relatief post-materialistische generaties tot het electoraat, de politieke agenda in de hooggeĩndustrialiseerde landen op zijn kop gezet zal worden. De vraagstukken en problemen waarvoor het electoraat de aandacht van de politici vraagt, zullen veranderen. Individuen met een puur materialistische waarde-oriëntatie (materialisten) geven immers prioriteit aan politieke issues die primair bijdragen aan de vergroting van de economische en fysieke zekerheid. Een sterke defensie, misdaadbestrijding en economische groei zijn voorbeelden van typisch materialistische issues. Dit soort issues staan niet hoog op het verlanglijstje van mensen met een post-materialistische waarde-oriëntatie (postmaterialisten). Postmaterialisten zoeken binnen de politieke arena naar het creëren van mogelijkheden om hogere behoeften te bevredigen: individuele zelf-ontplooiing en aandacht voor politieke vraagstukken die positief kunnen bijdragen aan de bevrediging van morele, intellectuele en sociale (the need for belonging) behoeften. Bij typische postmaterialistische issues kan men denken aan inspraak, democratisering, de kwaliteit van de leefomgeving, onderwijs, cultuur, rechten van minderheden en consumentenbescherming. Dat, onder andere, democratisering, inspraak, milieubescherming en meer aandacht voor welzijn in plaats van welvaart onderdeel uitmaakten van de eisen van de politieke protestbeweging uit de jaren zestig hoeft in dat licht niet te verbazen. Een groeiend percentage post-materialisten leidt ertoe dat deze postmaterialistische issues een hogere prioriteit krijgen op de politieke agenda ten koste van materialistische issues.

Mede als uitvloeisel van deze inhoudelijke verschuiving denkt Inglehart dat traditionele religieuze en class-based (arm-rijk) - politieke scheidslijnen aan politieke betekenis gaan inboeten. Class-based scheidslijnen worden geacht bijzonder invloedrijk te zijn omdat economische issues een boven geordende positie op de politieke agenda innemen. Toenemende sympathie voor postmaterialistische issues ontneemt economische issues die positie en tast daarmee indirect het onderscheidend vermogen van dergelijke scheidslijnen aan. Door de toegenomen welvaart verliest de arm-rijk tegenstelling aan zeggingskracht. Knutsen (1995) concludeert echter dat de opkomst van postmaterialistische waarden in de West-Europese politieke arena's niet betekent dat de traditionele economische tegenstellingen veel aan betekenis inboeten. Uit zijn gedegen analyse blijkt weliswaar dat de oude tegenstellingen minder sterk zijn 
gekoppeld aan bepaalde sociale groepen ("klassen"), maar dat de onderliggende links-rechts tegenstelling in economische termen nog steeds een vooraanstaande plaats inneemt in het politieke denken en doen van het electoraat. De betekenis van religieuze scheidslijnen - vooral als gevolg van een proces van secularisering - neemt inderdaad in betekenis af (Jagodzinski en Dobbeleare, 1995a: 113-5; 1995b). Inglehart benadrukt dat het voor ouders, kerkelijke instituties en anderen steeds moelijker is om traditionele waarden over te dragen op kinderen. Kinderen zijn voor hun informatie niet langer primair aangewezen op één of twee gecensureerde kanalen, maar hebben toegang tot diverse media en zijn door hun relatief hoge opleidingsniveau vaak in staat om relatief zelfstandig hun politieke weg te zoeken. Traditie maakt zodoende plaats voor verandering. Kerken verliezen met de opkomst van vrij toegankelijke massamedia (radio, televisie) de greep op de politieke informatie van hun gelovigen. Die gelovigen komen via radio en televisie in aanraking met andere bronnen en andere meningen. Politieke emancipatie van gelovigen en burgers is het gevolg. De verwachting is wel dat er nieuwe scheidslijnen rond specifieke postmaterialistische thema's (milieu, democratisering) aan belang zullen winnen (Nas, 1995).

Verder denkt Inglehart dat de politieke emancipatie van burgers ook een andere stijl van politiek bedrijven met zich meebrengt. Onder invloed van de toegenomen politieke vaardigheden - en gevoed door hun andersoortige idealen - zullen jongeren een meer elite-challenging koers volgen. De rijkelijk aanwezige politieke vaardigheden stellen jongeren in staat om relatief zelfstandig en buiten de plat getreden paden van de traditionele vormen van politieke participatie -stemmen en partijlidmaatschap-te treden. Aangezien de betreffende jongeren tegelijkertijd ook relatief postmaterialistisch zijn hechten ze relatief weinig waarde law and order (materialistisch), waardoor meer militante vormen van politieke actie niet bij voorbaat onaanvaardbaar zijn. Zo wordt het repertoire aan politieke acties in de jaren zestig fors uitgebreid met een groot scala aan buiten-parlementaire acties zoals blokkades, sit-ins, protestmarsen, stakingen, bezettingen en, in sommige landen zelfs, terroristische aanslagen. Daar waar de stijl van voor-oorlogse generaties valt te typeren als onzelfstandig en primair geïnspireerd door politieke elites (elite-directed), hanteren de na-oorlogse generaties steeds vaker een meer elite-challenging stijl van politiek bedrijven (Gundelach, 1995; Inglehart, 1997: 312-5). Een aantal van deze elite-challenging uitingen zijn inmiddels geïnstitutionaliseerd en/of algemeen geaccepteerd.

Tenslotte verwacht Inglehart dat de houding ten aanzien van internationale politieke systemen en nationalistische sentimenten wordt beïnvloed door de opkomst van het postmaterialisme en het proces van cognitive mobilization. Hierop wordt in de volgende paragraaf uitgebreid terug gekomen.

Tot zover Ingleharts algemene model dat heeft gediend als rijke inspiratiebron voor empirisch 
onderzoek naar politieke veranderingen (zie onder meer: Van Deth en Scarbrough (eds.), 1995). Belangrijk is te constateren dat er inderdaad empirische aanwijzingen zijn dat het proces van bevolkingsvervanging inderdaad leidt tot een groeiend aantal postmaterialisten onder de bevolkingen van West-Europese landen (Inglehart, 1997: 131-59; Scarbrough, 1995: 123-59); tevens zijn er ook sterke empirische aanwijzingen voor een proces van cognitive mobilization (Inglehart, 1990: 335-47 en 358-63). Het algemene model wordt nu verlaten en de aandacht wordt volledig geconcentreerd op de manier waarop Inglehart verschillen en veranderingen in politieke waarde-oriëntaties en het niveau van politieke vaardigheden verbindt met steun voor de $E U$.

\subsection{Postmaterialisme, cognitive mobilization en publieke steun voor de EU}

Inglehart stelt dat een meer postmaterialistische waarde-oriëntatie en een hoger niveau van politieke vaardigheiden ook van invloed zijn op de houding ten aanzien van supra-nationale politieke systemen. In een groot aantal publicaties heeft Inglehart een directe link gelegd tussen de opkomst van het postmaterialisme en de stijging van politieke vaardigheden enerzijds, en de publieke steun voor de EU anderzijds (Inglehart 1967; 1970,a,b; 1971, 1977a,b; 1990; Inglehart en Rabier, 1978; Inglehart et al., 1986). Maar op welke wijze worden postmaterialisme en politieke vaardigheden geacht gerelateerd te zijn aan de houding ten aanzien van de EU?

Het vertrekpunt van Inglehart opmerkingen over de publieke steun voor de EU is zijn constatering in 1967 dat jongeren over het algemeen veel positiever over West-Europese eenwording oordelen dan ouderen (1967). Inglehart vooronderstelt dat de verschillen met betrekking tot de EU een uiting zijn van een veel algemener fenomeen. Hij verwacht dat jongere primair na-oorlogse - generaties in West-Europa in principe meer open zouden staan voor internationale politieke samenwerking dan oudere - primair voor-oorlogse - generaties. De oorzaak van de verschillen tussen jong en oud moet, volgens Inglehart, worden gezocht in de verschillen in de politieke waarde-oriëntaties en politieke vaardigheden waarvoor beide groepen de basis hebben gelegd in hun jeugd (Inglehart 1977: 5 en 334-52; Inglehart en Rabier, 1978).

Onder jongeren bevinden zich relatief veel postmaterialisten. Postmaterialisten zouden er een zeker behagen in scheppen om, onder andere, binnen de politieke arena hun intellectuele behoeften te bevredigen (Inglehart, 1977a: 57-60 en 330-41: 1990: 1997: $43-4$ en 307-15). Dientengevolge is de verwachting dat postmaterialisten meer interesse in politiek tonen dan materialisten. Dit zou zich binnen de politieke arena nog verder toespitsen op een relatief grote interesse in abstracte politieke issues. Het abstractieniveau van issues op het terrein van de internationale politiek is over het algemeen hoog. Inglehart verwacht daarom dat juist de 
interesse voor deze issues vooral uit postmaterialistische hoek afkomstig is. De issues zouden meer tot de verbeelding van postmaterialisten dan van materialisten spreken. Gabriel en Van Deth vinden empirische steun voor deze hypothese (1995). $\mathrm{Zij}$ constateren een grotere interesse voor public affairs onder postmaterialisten dan onder materialisten. Verder blijken postmaterialisten inderdaad meer interesse te hebben voor internationale politick dan materialisten. Materialisten zouden daarentegen gepreoccupeerd zijn met materialistische (prive)behoeften en geen intrinsieke interesse stellen in abstracte issues, tenzij het issue een bijzondere en directe band heeft met de bevrediging van hun materialistische behoeften. In die zin zouden materialisten relatief narrow-minded zijn. Postmaterialisten hebben een bredere horizon en zouden om die reden ook meer "in" zijn voor veranderingen en vernieuwingen (Inglehart, 1977a: 57-62; 1997: 43-4). Postmaterialisten zouden, met andere woorden, meer kosmopolitisch en minder parochiaal zijn ingesteld dan materialisten (Inglehart 1977a: 57-60 en 330-41). Dit is de eerste reden waarom Inglehart verwacht dat jongere, na-oorlogse generaties in West-Europa in beginsel meer open - in de betekenis van open-minded - ten opzichte van de EU en het thema West-Europese eenwording staan dan oudere, voor-oorlogse generaties.

Ook op een andere manier draagt het relatief postmaterialistische karakter van de jongeren bij aan een meer open houding ten aanzien van de EU. Postmaterialisten hebben een veel sterkere drang dan materialisten om zich te identificeren ("need for belonging"). Dit zou zich binnen het politieke domein uiten in een drang naar identificatie met politieke gemeenschappen waarvan men deel uitmaakt. Dit op zichzelf zou echter nauwelijks reden zijn om te verwachten dat postmaterialisten meer open zouden staan ten opzichte van de EU of de West-Europese integratic dan materialisten. Er zijn immers genoeg andere mogelijkheden buiten de EU - gemeente, regio, provincie, departement, natie, wereld - om deze behoefte te bevredigen. Doordat de natie-staat echter primair geassocieerd zou worden met de zorg voor de macro-economisch situatie en de verdediging van burgers tegen in- en extern geweld (economische en fysieke zekerheid) ligt het niet voor de hand dat postmaterialisten een sterk ontwikkelde nationale identiteit ontwikkelen (Inglehart, 1977a: 57-60). De ontwikkeling van nationalistische gevoelens is meer iets voor materialisten - voor zover ze behoefte aan identificatie hebben - dan voor post-materialisten. Postmaterialisten richten hun aandacht sterker op sub- en/of supra-nationale politieke gemeenschappen (Inglehart, 1997: 304-5). Mede gelet op het feit dat postmaterialisten relatief kosmopolitisch zijn ingesteld, ligt het volgens Inglehart voor de hand dat postmaterialisten zich veel makkelijker en sneller zullen identificeren met supra-nationale politieke systemen dan materialisten. Er zijn empirische aanwijzingen dat een meer postmaterialistische waardeoriēntatie inderdaad bijdraagt aan een meer kosmopolitische politieke identiteit, respectievelijk het gevoel Europeaan te zijn (Janssen, 1991: 454-8; Duchesne en Frognier, 1995); alsmede dat materialisten meer nationalistisch ingesteld zijn dan postmaterialisten (Inglehart, 1990: 408-14). 
Een grotere sociale behoefte in combinatie met eca geringere waardering voor de natiestaat (die in de hoofden van burgers vooral verbonden wordt met de zorg voot economische en fysieke zekerheid) is de tweede reden waarom Inglehart verwacht dat postmaterialisten relatief open stan ten opzichte van West-Europese eenwording in vergelijking met materialisten.

Niet alleen op basis van hun meer postmaterialistische waarde-oriëntaties verwaeht Inglehart dar jongere generaties relatief kosmopolitisch zijn en zodoende ook relatief open staan ten opzichte van supra-nationnle samenwerking. Het feit dat jongeren over ten relatief hoog niveau van: politieke vaardigheden beschikken zou hier mede debet aan zijn (Inglehart, 1970: 46.8; 1977a: 337-8). Het is voor mensen met een hoge opleiding namelijk ved makkeliker om met abstraeties: om te gaan dan voor mensen met minder opleiding. Het begrijpen en interpreteren van de internationale politiek vereist over het algemeen een relatief hoog abstractieniveau. Ontbeertmen het benodigde abstractievermogen dan is het nagenoeg uitgesloten dat lemand informatievanof over, onder andere, de EU of de NAVO zelfstandig zou kunnen "vertalen" of begrijpen. Bij gebrek aan een voldoende niveau van politicke vaardigheden blijt de internationale politiek onbegrijpelijk. Deze redenering is eerder wel eens als volgt samengevat:

"Skills determine whether a person is capable of processing information at a certain level of abstraction. Information about European integration and international politics is supposed to be at a high level of abstraction. The concept 'abstraction' is used by Inglehart to indicate the ease with which persons can understand political messages and relate these to their own thoughts and personal situation. [...] Inglehart expects that for people with more skills the EC is more familiar and less threatening than for people with fewer skills." (Janssen, 1991: 445). Meer politieke vaardigheden leveren in deze zin dus een zelfstandige bijdrage aan een meer open houding ten aanzien van supranationale politieke samenwerking. Supra-nationale politieke systemen zullen op mensen met meer politieke vaardigheden minder bedreigend overkomen.

Inglehart legt in beginsel slechts een relatie tussen de kans op identificatie met de EU enerzijds, en postmaterialisme en politieke vaardigheden anderzijds. Uit zijn werk blijkt echter ook dat hij verwacht dat die openheid tevens bijdraagt aan een positieve houding ten aanzien van de EU. Inglehart stelt immers dat:

"one must become aware of it before one can develop a sense of commitment", hoewel hij tegelijkertijd inziet dat:

"Awarenesse does not necessarily lead to favorable feelings. [...] But for those with high levels of political awareness there is a least a good chance [JJ: cursivering in origineel] that one will come to identify with a supranational political community: for those who lack them, the probability seems low." (Inglehart, 1977a: 338) 
Een grotere kans op identificatie met een supranationale politieke gemeenschap vergroot, met andere woorden, de kans op een positieve houding ten aanzien van de EU. Om al deze redenen zou de kans op een positieve houding ten aanzien van de EU op individueel niveau positief moeten samen hangen met het meer of minder postmaterialistische karakter van iemands politieke waarde-oriêntatie en het niveau van politieke vaardigheden.

Dus zowel op basis van hun politieke waarde-oriēntaties, als op basis van hun relatief hoge niveau van politieke vaardigheden valt te verwachten dat leden van de na-oorlogse generaties een positiever houding ten aanzien van de EU hebben dan de leden van de voor-oorlogse generaties. Dit verklaart ook waarom Inglehart het stellig oneens is met de stelling van Deutsch (waar dit hoofdstuk mee begon) die midden jaren zestig op basis van een analyse van im- en exportstromen, toeristenstromen, briefverkeer en andere indices concludeert dat het integratieproces stagneert.

\subsection{Hypothesen: micro-, meso- en macro-niveau}

Uit Ingleharts theorie is het mogelijk een aantal hypothesen af te leiden die ons kunnen helpen bij het zoeken naar een verklaringen voor de verschillen in de houding ten aanzien van de EU op het niveau van individuen, generaties en de bevolking (vgl. Janssen, 1991).

Op het niveau van individuen vooronderstelt Inglehart dat de verschillen in de houding ten aanzien van de EU variëren als gevolg van het verschil in waarde-oriëntaties en het niveau van politieke vaardigheden. In aansluiting op hetgeen in de vorige paragraaf is gezegd luiden de twee hypothesen op micro-niveau:

Hypothese 1: Naarmate iemand een meer postmaterialistische politieke waarde-oriezntatie heeft, des te groter is de kans op een positieve houding ten aanzien van de EU;

Hypothese 2: Naarmate iemand over een hoger niveau van politieke vaardigheden beschikt, des te groter is de kans op een positieve houding ten aanzien van de EU.

Ingleharts theorie gaat er van uit dat politieke veranderingen het resultaat zijn van de verschillende omstandigheden waaronder de opeenvolgende generaties in het electoraat zijn opgegroeid. Intergenerationele verschillen vormen de kern van zijn verklaring. Zijn aanval op de pessimistische voorspelling van Karl Deutsch, waarmee dit hoofdstuk opende, is ook gebaseerd op de overtuiging dat jongere generaties in West-Europa de dragers van de politieke verandering zijn. Dit vormen de zogenaamde hypothesen op meso-niveau. Een serieuze toets van Ingleharts 
theorie omvat ook een test op intergenerationele verschillen. De te toetsen hypothese luidt: Hypothese 3: De steun voor de EU onder jongere generaties is groter dan onder oudere generaties.

Tenslotte kunnen uit Ingleharts theorie ook hypothesen ter verklaring van de publieke steun voor de EU op macro-niveau worden afgeleid. Verschillen in de publieke steun voor de EU tussen landen en veranderingen in de steun binnen landen zouden volgens Ingleharts theorie te wijten moeten zijn aan veranderingen in het waardenklimaat en het niveau van politieke vaardigheden. De term waardenklimaat is bedoeld om de waardering voor uiteenlopende politieke waarden binnen een samenleving als geheel, op een zeker moment aan te duiden. In een land met een meer post-materialistisch waardenklimaat krijgen postmaterialistische waarden een hogere prioriteit dan in een land met een meer materialistisch waardenklimaat. Een meer postmaterialistisch waardenklimaat en cognitive mobilization zouden beiden positief bijdragen aan de publieke steun voor de EU. De hypothesen op macro-niveau luiden derhalve:

Hypothese 4: Naarmate het waardenklimaat in een land post-materialistischer is, des te groter is de publieke steun voor de EU.

Hypothese 5: Naarmate het gemiddelde niveau van politieke vaardigheden (de mate van cognitive mobilization) in een land hoger is, des te groter is de publieke steun voor de EU.

Ingleharts gedachtegang en de vijf hypothesen worden in hoofdstuk 8 kritisch besproken en empirisch getoetst. 


\section{HOOFDSTUK 7}

\section{Zallers RAS-model: hypothesen}

\subsection{Inleiding}

Dit hoofdstuk staat in het teken van het Receive-Accept-Sample model (RAS-model) van de Amerikaanse politicoloog John Zaller (1992). Aan Zallers model liggen geheel andersoortige uitgangspunten en ideeèn ten grondslag dan aan Ingleharts theorie. Zallers model is een poging om meer inzicht te krijgen in het soms grillige karakter van de publieke opinie ten aanzien van politieke onderwerpen. Volgens dit model spelen massa-media en politieke elites een centrale rol bij de publieke opinievorming. De belangrijkste politieke gemeenschappen zijn tegenwoordig dermate grootschalig van karakter dat burgers voor relevante politieke informatie noodgedwongen zijn aangewezen op de berichtgeving via de media die primair gevoed wordt door politici en andere professionals die zich full-time met politiek - of één specifiek beleidsveld - bezig houden. Kenmerkend voor het RAS-model is verder het uitgangspunt dat ten aanzien van de meeste politieke issues, het gros van de burgers geen stabiele politieke opvattingen hebben. In die zin is het werk van Zaller een nadere uitwerking van het destijds grensverleggende werk op het terrein van de politieke attitudevorming van de Amerikaanse politicoloog Philip Converse (1964, 1970; en, Converse en Markus, 1979).

De tweede en derde paragraaf van dit hoofdstuk staan daarom geheel in het teken van het werk van Converse. In paragraaf 6.2 staat centraal hoe Converse tot het inzicht kwam dat veelomvattende politieke ideologieën nauwelijks een rol spelen in het politieke denken en doen van gewone burgers, almede dat de meeste politieke opvattingen van gewone burgers gekenmerkt worden door een grote mate van instabiliteit. Zijn visie op de achtergronden van de door hem geconstateerde instabiliteit van politieke attituden wordt nader belicht in paragraaf 6.3 aan de hand van de termen attitudes, non-attitudes en issue-public. In paragraaf 6.4 is nagegaan hoe Converse's inzichten zich verhouden tot het EU-issue en de publieke opinie ten aanzien van de EU. De verwachting is dat het zogenaamde issue-public van de EU in de lidstaten waarschijnlijk erg klein is, waaruit volgt dat de publieke opinie waarschijnlijk voor een belangrijk deel bestaat uit instabiele non-attitudes. De rest van het hoofdstuk staat in het teken van de zoektocht naar een zinvolle, inhoudelijke verklaring van het verschijnsel non-attitudes. Die zoektocht start bij de interessante suggesties van Converse en Markus (1979). Die suggesties bieden echter geen 
sluitende verklaring. Zallers model biedt dat wel. In Zallers RAS-model zijn de inzichten van Converse en de interessante suggesties van Converse en Markus ingepast in een algemeen kader. Het model is uiteindelijk te beschouwen als een algemene theorie voor het antwoord op surveyvragen over politieke onderwerpen (objecten, issues, stellingen). Aan de hand van dit model worden uiteindelijk een aantal hypothesen ter verklaring van de publieke opinie over de EU afgeleid die in hoofdstuk 9 empirisch worden getoetst.

\subsection{Politieke houdingen: over instabiliteit en andere beperkingen}

Het onderzoek van de Amerikaanse politicoloog Philip Converse $(1964 ; 1970)$ naar de achtergronden van individuele politieke houdingen van Amerikaanse burgers in de jaren vijftig en zestig heeft nogal wat stof doen opwaaien. De centrale vraag in de oorspronkelijke studie van Converse is in hoeverre political belief systems een centrale rol spelen in het politicke denken en doen van gewone burgers. Een belief system is:

"... a configuration of ideas and attitudes in which the elements are bound together by some form of constraint or functional interdependence." (Converse, 1964: 207)

$\mathrm{Er}$ is dus sprake van een political belief system als iemand beschikt over een geheel van houdingen ten aanzien van politieke objecten met een zekere onderlinge of functionele samenhang. Centraal thema in Converse's werk is in hoeverre politieke gedragingen en politieke houdingen van burgers worden ingegeven door en zijn te begrijpen vanuit een samenhangend geheel van politieke ideeèn en opvattingen. Het gebruik van political belief systems is kenmerkend voor het politieke denken en doen van politieke elites (politici, vakbondsleiders, journalisten, enzovoort). Bij het beoordelen en analyseren van politieke vraagstukken kijken elites primair of iets past binnen hun visie op politiek en samenleving. Het denken en doen van deze elites staat, met andere woorden, in het teken van een ideologie. Liberale politici hebben zodoende meestal een andere mening over concrete politieke issues dan hun sociaaldemocratische of christen-democratische collegae.

In de eerste plaats is Converse nagegaan in hoeverre Amerikaanse burgers bij de dagelijkse beoordeling van politieke onderwerpen ook gebruik maken van dergelijke politieke ideologieën. Daarbij maakt hij een onderscheid tussen het actief en passief gebruik van ideologieën. Voor het passief gebruik is slechts nodig om te weten welke politieke ideeën en opvattingen (over issues) bij elkaar horen; met andere woorden, kennis hebben van what goes with what (Converse, 1964: 212 en 239). Iemand die passief gebruik maakt van een linkse ideologie weet slechts dat sommige standpunten (solidariteit met sociaal zwakkeren in de samenleving, inkomensnivellering, vertrouwen in overheidsingrijpen, invloed werknemers op bedrijven, enzovoort) horen bij 
bepaalde partijen (PvdA, SP, Groen Links). Passief gebruik van een ideologie betekent dat het politieke denken en doen bestaat uit het reproduceren van (aan)geleerde houdingen en opvattingen. Het actieve gebruik van ideologieenn vooronderstelt contextuele kennis van why what goes with what (Converse, 1964: 212). Het politieke denken en doen van burgers die actief gebruik maken van ideologieen kenmerkt zich door zelfstandig redeneren en deduceren van concrete politieke houdingen uit abstracte ideologische - liberale, sociaal-democratische, christen-democratische, enzovoort - principes. Ingleharts Silent Revolution-theorie is een typisch voorbeeld van een theorie waarin wordt voorondersteld dat burgers op zijn minst passief ideologisch denken. Inglehart denkt immers dat de reactie van burgers op politieke issues voor een belangrijk deel wordt ingegeven door de inhoud van iemands politieke waarde-oriëntatie. In deze redenering fungeert de waarde-orièntatie als een soort ideologie.

Aan de hand van de antwoorden van burgers op een open vraag waarin gevraagd werd om de situatie in de Amerikaanse politiek ten tijde van de ondervraging in eigen woorden te beschrijven, is Converse (1964: 214-9) nagegaan in hoeverre gewone burgers actief gebruik maken van min of meer algemeen aanvaarde ideologische labels. Uit zijn analyse blijkt dat de liberal-conservative tegenstelling die een welhaast allesoverheersende plaats inneemt in de debatten binnen de Amerikaanse politieke arena's, een volstrekt ondergeschikte rol speelt in het politieke denken van modale Amerikaanse burgers." Slechts een uiterst kleine groep "ideologues" -in Converse's onderzoek minder dan 5\% van het electoraat - blijken actief gebruik te maken van deze standaard-ideologieèn. De rest van het electoraat valt te classificeren in vier hiërarchisch te ordenen groepen die worden gekenmerkt door een steeds lager level of conceptualization. Een kleine groep near-ideologues gebruikt weliswaar de ideologische labels liberal en conservative, maar uit de rest van hun antwoord blijkt dat ze die labels verder niet actief aanwenden of ze kennen slechts een zeer enge betekenis aan die labels toe (de kennis van what goes with what blijft beperkt tot een relatief klein aantal politieke objecten). De derde en grootste groep denkt in termen van de voor- en nadelen die bepaalde politieke besluiten en objecten hebben voor specifieke sociale groepen (group interest) zoals: boeren, blanken, zwarten, rijken, arbeiders, armen, enzovoort. Nog lager in de hiërarchie staat de nature of times-groep die partijen of kandidaten enkel in verband brengen met hun betrokkenheid bij bepaalde gebeurtenissen in het verleden (welvaart, depressie, oorlog) of met één specifiek beleidsveld of issue. De mensen in de laatste groep ( $n o$ issue content) geven een analyse waarin op geen enkele wijze een verband wordt gelegd met issues of politieke objecten. Het actieve gebruik van de ideologische labels liberal en conservative bij de beschrijving van de actuele politieke situatie blijft dus beperkt tot een uiterst kleine groep burgers. Het overgrote deel van het Amerikaanse

\footnotetext{
" De betekenis van de liberal-conservative tegenstelling in de Amerikaanse politiek is vergelijkbaar met de links-rechts tegenstelling in de West-Europese politiek.
} 
electoraat blijkt niet te beschikken over de noodzakelijke kennis over why what goes with what om zich consistent liberal respectievelijk conservative te kunnen gedragen en/of uiten.

Het niet actief gebruiken van deze standaard-ideologieèn sluit niet uit dat burgers in staat zijn om passief ideologisch te denken in deze termen, of (actief of passief) ideologisch denken in andere termen (materialisme-postmaterialisme). Passief ideologisch denken vooronderstelt slechts kennis van what goes with what in een liberal respectievelijk conservative visie. Nadat aan de burgers was gevraagd om aan te geven welke van de twee Amerikaanse politieke partijen (Democrats en Republicans) meer conservative of liberal is, werd vervolgens aan hen gevraagd om uit te leggen wat typisch conservative respectievelijk liberal is. Slechts $17 \%$ van de ondervraagden weet zowel de partijen te koppelen aan het juiste ideologische label, als ook adequaat te verwoorden wat de betekenis van het label is. Nog eens $34 \%$ weet weliswaar de partijen aan de juiste labels te koppelen, maar kan slechts in zeer beperkte mate aangeven wat de betekenis van de labels is. De andere helft van de ondervraagden slaagt er überhaupt niet in om de labels op de juiste wijze te koppelen aan partijen en standpunten. Ook het passieve gebruik van de standaard-ideologieên laat dus te wensen over. Het grootste deel van het electoraat blijkt zijn politieke gedrag en houdingen actief, noch passief te organiseren met behulp van de standaard-ideologieën die in de Amerikaanse politieke arena's gemeengoed zijn.

Vervolgens is Converse nog nagegaan in hoeverre de leden van het electoraat dan misschien actief respectievelijk passief gebruik maken van andere algemene ideologieën - bijvoorbeeld: postmaterialisme - of andere puur individuele political belief system. Dit zou betekenen dat burgers er andere respectievelijk geheel eigen ideeën op na houden over why what goes with what en/of what goes with what dan Amerikaanse politici. Het gebruik van een belief system vooronderstelt slechts een zekere samenhang tussen afzonderlijke politieke houdingen ("political idea-elements"). Een dergelijke samenhang zou in ieder geval moeten leiden tot door de tijd relatief stabiele attituden. Om te kunnen nagaan of burgers überhaupt gebruik maken van belief systems is Converse daarom nagegaan hoe stabiel individuele politieke houdingen door de tijd zijn. Hoewel de houding van Amerikaanse burgers ten aanzien van politieke partijen en politieke leiders relatief stabiel is, blijkt de stabiliteit van opvattingen over concrete politieke issues uiterst gering. Het ontbreken van kennis over de standaard-ideologieën blijkt dus niet of nauwelijks te worden gecompenseerd door het gebruik van andere algemene of individuele belief systems (Converse, 1964: 231). Integendeel, gebrek aan samenhang en instabiliteit blijkt eerder regel dan uitzondering. Dit alles duidt erop dat verreweg de meeste burgers geen gebruik maken van wideranging belief systems bij de vorming van politieke attituden. Ideologisch denken blijkt slechts voorbehouden aan een kleine groep van burgers. Het ontbreken van ideologische kaders en de wijdverbreide instabiliteit van individuele politieke houdingen is volgens Converse:

".. not a pathology limited to a thin and disoriented bottom layer of the lumpenproletariat; 
they are immediately relevant in understanding the bulk of mass behavior. "(Converse, 1964: 213)

De boodschap van Converse is dat gewone burgers in hun politieke denken en doen nauwelijks gebruik maken van ideologieèn of andere wide-ranging political belief systems. Het gebruik van ideologieên blijft beperkt tot een uiterst kleine groep, door Converse aangeduid als ideologues. Het overgrote deel van het electoraat behoort tot een relatief grauwe politieke massa. De samenhang in het politieke denken en doen van leden van deze massa beperkt zich tot een klein aantal politieke issues en objecten. Van een veelomvattende samenhang tussen politieke opvattingen is geen sprake. Concrete politieke opvattingen lijken veeleer op zichzelf te staan en zijn door de tijd weinig stabiel.

\subsection{Attitudes en non-attitudes}

Nog belangwekkender dan zijn ontnuchterende conclusies over het gebruik van ideologieën door gewone burgers is dat Converse er in slaagt om op zijn minst in statistisch-technische zin een empirische verklaring te geven voor de geringe stabiliteit van politieke houdingen. Hij doet dit met behulp van het zogenaamde black-and-white model. Dit model is gebaseerd op het idee dat het electoraat ten aanzien van elk politiek object/issue uiteenvalt in twee groepen: het issuepublic en de rest. De leden van het issue-public stellen een bijzondere interesse in een bepaald issue in tegenstelling tot de niet-geïnteresseerde "rest". Een issue-public bestaat veelal ook uit twee verschillende groepen. Enerzijds uit leden van de politieke elite - bijvoorbeeld: politici, politicologen en journalisten - die een veelal beroepsmatige interesse hebben in nagenoeg elk politiek issue (Converse, 1964: 245-6). Anderzijds bestaat het issue-public uit een variabel deel. Dit betreft burgers die met betrekking tot de meeste issues behoren tot de onwetende massa, maar die uit hoofde van bijzondere individuele belangen - deze kunnen samenhangen met hun woonplaats, leeftijd, beroep, hobby, enzovoort - een bijzondere interesse stellen in een bepaald issue. Het idee is, dat het merendeel van de burgers niet allesomvattend ideologisch denkt, maar zich in de politieke arena concentreert op een paar issues waar ze belang aan hechten. Zo stelt Converse:

"A realistic picture of political belief systems in the mass public, then, is not one that omits issues and policy demands completely nor one that presumes widespread ideological coherence; it is rather one that captures with some fidelity the fragmentation, narrowness, and diversity of these demands." (Converse, 1964: 247)

Het is dus niet zozeer dat de modale burger geen enkel idee heeft van politieke objecten en 
issues, als wel dat het aantal politieke objecten (partijen, leiders, instituties, enzovoort) of politieke issues (Europese eenwording, abortus, asielzoekers, enzovoort) dat tot zijn verbeelding spreekt uiterst beperkt is. Bij die issues die tot zijn of haar specifieke verbeelding spreken behoren gewone burgers tot het issue-public. Bij de meeste politieke issues zullen modale burgers echter behoren tot de "rest-groep".

Kern van Converse's black-and-white-model (1964: 242-3; en 1970: 173-5) is dat de tweedeling - issue-public versus rest - wordt gekoppeld aan vooronderstellingen over de stabiliteit van de opvattingen over een specifiek issue in beide groepen. De leden van een issuepublic worden geacht een stabiele houding ten aanzien van het issue te hebben. Een bijzonder interesse in en belangstelling voor een issue zou garant staan voor de vorming van een weldoordachte, gefundeerde en derhalve stabiele (uitgekristalliseerde) houding. Kennis van en de specifieke betrokkenheid voor het issue zou immers garant staan voor de vorming van weldoordachte en gefundeerde aan de kant van de leden stabiele opvattingen en standpunten ten aanzien van het specifieke issue te hebben. De houdingen van de zogenaamde "rest" - niet lid van het issue-public - worden geacht volstrekt instabiel te zijn. Als gevolg van een gebrek aan interesse in het object of issue mag niet worden verwacht dat de leden van deze groep beschikken over een weldoordachte, gefundeerde houding ten aanzien van het issue. Nadat de respondenten op elk issue waren ingedeeld ${ }^{32}$ bij het issue-public of "de rest" is op basis van het model een schatting gemaakt van de stabiliteit van de houdingen ten aanzien van elk issue. Bij de meeste issues levert het black-and-white-model schattingen op die opvallend dicht in de buurt liggen van de daadwerkelijk gevonden (in)stabiliteit. De zogenaamde empirische "fit" van het black-andwhite-model is, met andere woorden, bijzonder goed. Het idee van een gesegmenteerde publieke opinie met aan de ene kant een groep burgers met stabiele attituden, en aan de andere kant een groep burgers met volstrekt instabiele houdingen lijkt inderdaad een passende verklaring te bieden voor de geringe stabiliteit van individuele politieke houdingen.

Een belangrijk punt is dat de omvang van het issue-public (en de "rest") sterk varieert van issue tot issue (Converse 1964; 1970; Converse en Markus, 1979; en, Neumann, 1986: 182-5). De stabiliteit van de houdingen ten aanzien van een concreet politiek issue op individueel niveau is op te vatten als een indirecte indicator voor de omvang van het issue-public. Het meest stabiel blijken de houdingen ten aanzien van politieke partijen. Dit wijst erop dat partijen een centraal element vormen in de politieke belevingswereld van relatief veel burgers. Het minst stabiel blijken de houdingen ten anzien van foreign policy-issues. Deze zou erop duiden dat onderwerpen op het terrein van de buitenlandse politiek het kleinste issue-public kennen. In een

\footnotetext{
${ }^{2}$ Op basis van de eerste twee metingen kon Converse de respondenten indelen in twee groepen: stabielen en instabielen. Vervolgens is de daadwerkelijke samenhang (correlatie) tussen de tweede en derde meting vergeleken met de schatting op basis van het model.
} 
latere publicatie komen Converse en Markus met een uitgewerkte rangorde, te weten: partijen, politieke leiders, moral-issues, domestic policy-issues en foreign policy-issues (Converse en Markus, 1979: 45-9). De wijdverbreide instabiliteit van de mening ten aanzien van issues op het terrein van de buitenlandse politiek duidt er volgens Converse (1964: 245) op dat veel burgers "do not have meaningful beliefs" ten aanzien van dit soort onderwerpen.

\section{Paradox van het survey-antwoord}

Met behulp van omvangrijke lijsten gesloten vragen slagen survey-onderzoekers in face-to-face interviews er desondanks in om de ondervraagden meningen te ontfutselen over de meest uiteenlopende politieke issues. Schuman en Presser (1980: 1214) wijzen er op dat één van de vooronderstellingen die aan survey-onderzoek ten grondslag ligt is, dat de geïnterviewden voorafgaand aan het interview reeds een mening hebben over de onderwerpen waar de surveyvragen over gaan. ${ }^{3}$ Het is immers zinloos mensen te vragen naar een mening die ze niet hebben. De achterliggende gedachte is dat bij ontstentenis van een mening respondenten niet antwoorden. Het krijgen van antwoorden impliceert, met andere woorden, de aanwezigheid van een mening. Dit staat op gespannen voet met Converse's stelling dat hoewel veel ondervraagden antwoord geven op allerlei vragen over de meest uiteenlopende politieke issues, niet kan worden volgehouden dat deze mensen ook allemaal beschikken over een "echte" houding of mening. Deze paradox roept enerzijds vragen op over de vooronderstellingen die ten grondslag liggen aan survey-onderzoek, anderzijds over de aard van de politieke opinies die worden gemeten in survey-onderzoek.

Schuman en Presser $(1980 ; 1981:$ 147-60) hebben onderzocht in hoeverre de vooronderstellingen die aan survey-onderzoek ten grondslag liggen, een empirische toets kunnen doorstaan. Dit hebben ze gedaan door burgers hun mening te vragen over een niet bestaand politiek besluit en een bestaand, maar uiterst obscuur politiek besluit. In beide gevallen wordt de vraag door iets meer dan $25 \%$ van de ondervraagden beantwoord. Hoewel de overgrote meerderheid terecht geen antwoord geeft, gaat tegelijkertijd niet minder dan een kwart van de

\footnotetext{
Desterhof onderscheidt, geinspireerd door het werk van de Franse socioloog Pierre Bourdieu, zelfs drie verschillende discutabele vooronderstellingen op basis waarvan men vraagtekens kan plaatsen bij de validiteit van het survey-instrument, te weten:

1. "... asking everyone the same question implies that there is consensus that the question is worth asking. ... When a problem is seen as important by political elites this concern, however, need not match the concerns of the mass public";

2. "... since everyone is equally liable to be asked to participate in a survey, it is assumed that everyone will have an opinion":

3. "... it is assumed that all answers are political opinions. ... Bourdieu asserts that answers can only be legitimate political opinions if they are produced by respondents who are competent to recognize the political properties of the question" (Westerhof, 1994: 46-9).
} 
respondenten in de fout. De surveyvragen meten houdingen die er onmogelijk voor het interview geweest kunnen zijn. Deze meningen zijn louter het gevolg van - of: ontstaan als gevolg van het stellen van de vraag. Converse wijdt dit fenomeen aan het feit dat:

"... the attitude questionnaire is approached as though it were an intelligence test, with the "don't know" and "can't decide" confessions of mental incapacity." (Converse, 1970: 177) De interviewsituatie zelf legt een zekere druk op de ondervraagden om te antwoorden. Ten onrechte gaan survey-onderzoekers er van uit dat het krijgen van een antwoord het bewijs is van de aanwezigheid van een reeds voor het interview gevormde mening.

In de door Schuman en Presser onderzochte gevallen ging het om totaal onbekende politieke besluiten. In dit onderzoek gaat het echter om een issue - de EU - waarvan waarschijnlijk alle burgers wel eens iets gehoord hebben. Enerzijds betekent dit dat het aantal mensen met een "echte"mening groter is, anderzijds zal de angst bij de "meningslozen" om een dom figuur te slaan ook groter zijn. De druk op de laatste groep respondenten om toch maar een mening te geven, zal daarom groot zijn. Aangezien bekend is dat het overgrote deel van het electoraat niet beschikt over een wide-ranging belief system dat hen in staat zou kunnen stellen om houdingen ten aanzien van concrete issues te deduceren uit andere politieke opvattingen en een aantal abstracte principes, kan men zich in het licht van bovenstaande resultaten tevens afvragen wat de status van antwoorden op surveyvragen over de EU is? Als meningen (antwoorden) niet de uitkomst zijn van ideologische deductie en ze in statistische zin bovendien een random-patroon door de tijd lijken te volgen, ligt het voor de hand te vooronderstellen dat het om niets- of weinigzeggende meningen gaat! Dit wil zeggen, het gegeven antwoord is geen reflectie van een weldoordachte houding maar veeleer een ad hoc reactie op de gestelde vraag. Politieke surveys zouden in deze zin moeten worden opgevat als te moeilijke multiple-choice tentamens waarbij het beter is te gokken dan niets in te vullen. Zo'n tentamen onderscheidt slechts de allerbeste studenten - in dit geval: de ideologues - van de rest - de politieke massa. Veel survey-antwoorden zijn in deze optiek niet meer dan beredeneerde gokjes. Tegen deze achtergrond hoeft het ook niet langer te verbazen dat de formulering van de vraag van grote invloed is op het beeld dat men krijgt van de publieke opinie over de EU (zie hoofdstuk 4).

Wat is het karakter van de beredeneerde gokjes die respondenten maken als een interview wordt afgenomen over zaken die hen nauwelijks interesseren? Converse introduceert in dit kader de term non-attitudes (1970). In Converse's optiek zijn non-attitudes inherent instabiele meningen van burgers die niet tot het issue-public van het onderwerp - politiek object of issue van de surveyvraag behoren. De antwoorden van de leden van een issue-public zijn daarentegen stabiel en vormen de weerspiegeling van "echte" attitudes - weldoordachte en gefundeerde houdingen. De burgers die niet tot het issue-public behoren, kunnen bij gebrek aan interesse in het onderwerp in het algemeen geen beroep doen op zo'n "echte" houding. Zij hebben simpelweg 
nog nooit over het onderwerp nagedacht. Het gebrek aan interesse draagt er toe bij dat mensen minder goed geînformeerd zijn over het onderwerp. $\mathrm{Zij}$ zullen zich noodgedwongen beperken tot de vorming van een nagenoeg ongeinformeende ad hoc opinie gedurende het interview. Bij gebrek aan ideologische bagage zal het daarbij veelal gaan om een weinig betrouwbare - in termen van stabiliteit - keuze uit de aangeboden antwoorden. Non-attitudes zijn het resultaat. Converse's claim is dat in veel politieke surveys hoofdzakelijk non-attitudes worden gemeten. " Met andere woorden, ad hoc opinies over objecten of issues waar de respondent tot aan het interview geen duidelijke mening over had. Dit impliceert dus niet dat respondenten bewust zo maar iets antwoorden. Ze doen waarschijnlijk wel hun best - een beredeneerde gok - bij de beantwoording, maar bij ontstentenis van achtereenvolgens een ruime ideologische bagage, een reeds gevormde mening én ruime kennis over het onderwerp van de vraag zit er niet meer in dan een min of meer toevallige keuze uit de aangeboden antwoorden.

Op deze uiterst originele claim van Converse is veel onterechte (vgl. Kinder en Sears, 1985: 666-71) kritiek geleverd. De kritiek luidt dat de gevonden instabiliteit vooral het gevolg is van slechte vragen (Achen, 1975 en 1983). De empirische onderbouwing van die kritiek - het "vinden" van stabiele attituden - is niet bijzonder overtuigend, omdat de critici de te verklaren variantie in de houdingen grotendeels onder het tapijt vegen onder het mom van de correctie voor meetfouten (vgl. Zaller, 1992: 31-2 en 75; Van Deth, 1989: 95). Door het probleem op deze manier te benaderen krijgt het innemen van een standpunt iets van een keuze uit twee "geloven". Aan Zallers RAS-model ligt een duidelijke keuze voor het niet-technische kamp ten grondslag, die aansluit bij de conclusie van Kinder en Sears:

"Instability largely reflects the fleeting attention commonly paid to politics and the preeminence of private desires over public ones." (Kinder en Sears, 1985: 668) In hoofdstuk 9 zullen de merites van deze "geloofskeuze" op empirische kwaliteiten moeten worden beoordeeld. De consequenties van deze keuze worden hieronder verder uitgewerkt en in hoofdstuk 9 aan een empirische test onderworpen.

De paradoxale combinatie van survey-antwoorden en het ontbreken van weldoordachte, door de tijd stabiele politieke opvattingen zou dus deels kunnen worden verklaard uit de onjuistheid van de vooronderstellingen die aan survey-onderzoek ten grondslag liggen. Verder zegt het waarschijnlijk iets over de status van survey-antwoorden. De antwoorden op surveyvragen reflecteren immers niet noodzakelijkerwijs reeds voor het interview gevormde, weldoordachte meningen. Het survey-interview zelf blijkt in sommige gevallen aanleiding voor de vorming van

"Westerhof (1994) wijst erop dat Bourdieu dergelijke antwoorden uberhaupt niet wenst aan te merken als houdingen. Bourdieu stelt dan ook dat een "publieke opinie" vaak iets is wat als zodanig niet bestaat, maar ontstaat als gevolg van het optreden van de survey-onderzoeker. Het is een creatie van survey-onderzoekers. Ik ben het niet eens met deze stelling, aangezien zo'n "gemaakte" publieke opinie niettemin bijzonder invloedrijk kan zijn. 
niet reeds aanwezige meningen. Dit betekent dat niet elk antwoord op een survey-antwoord kan worden opgevat als de uiting van een weldoordacht, gefundeerde houding. Er moet rekening mee worden gehouden dat in politieke surveys - waaronder de hier gebruikte Eurobarometers veelvuldig dit soort zogenaamde non-attitudes worden verzameld. Om dichter bij een verklaring te kunnen komen voor de publieke opinie en individuele attituden ten aanzien van politieke issues, zal dus primair moeten worden gezocht naar het antwoord op de vraag: Welke factoren zijn bepalend voor de uitkomst van processen van ad hoc meningsvorming tijdens surveyinterviews? In paragraaf 7.5 en 7.6 wordt geprobeerd deze vraag te beantwoorden, in de volgende paragraaf volgt eerst een klein uitstapje naar het EU-issue.

\subsection{Omvang issue-public van de EU}

Alvorens de zoektocht naar de achtergrond van ad hoc opinievorming daadwerkelijk in te zetten, mest ess. even. stil. gestaan. worden. bij, de vaag in. heeverse de resultaten. van, dit, primair. Amerikaanse onderzoek zijn te generaliseren naar de EU-lidstaten, alsmede wat een en ander betekent voor de houdingen ten aanzien van de EU (EU-issue).

Over het eerste punt kunnen we kort zijn. Er lijkt weinig reden om aan te nemen dat er grote verschillen bestaan in de politieke beleving van West-Europese en Noord-Amerikaanse burgers. Uitkomsten van bestaand onderzoek geven daar geen aanleiding toe (Converse en Pierce, 1985: 109-50 en 241-83; Butler en Stokes, 1983: 319-321), hoewel er wel enige aanwijzingen zijn dat de situatie in West-Europese landen minder ernstig is dan in de Verenigde Staten (Thomassen, 1991; Fuchs en Klingemann, 1991; Granberg en Holmberg, 1996). ${ }^{85}$ Kortom, er is geen reden om te vooronderstellen dat Converse's belangrijkste inzicht dat het politieke denken en doen van de meeste burgers niet wordt ingegeven door wide-ranging ideologieën of belief systems, niet toepasbaar zou zijn op de West-Europese situatie. Deze paragraaf beperkt zich verder dan ook tot tweede punt. Wat betekent een en ander voor de publieke opinie over de EU? Hoe erg "vervuild" zijn de hier te gebruiken survey-data met non-attitudes? Hoe groot is het issue-public van de EU? Ik zal langs twee lijnen proberen antwoord te geven op deze vragen.

Ten eerste zijn er in de literatuur algemene - welhaast normatieve - aanwijzingen dat de publieke interesse voor politieke aangelegenheden moeilijk kan worden overschat. Zo valt te wijzen op

\footnotetext{
${ }^{\text {ss }}$ Er zijn ook onderzoekers die menen dat het met de instabiliteit van de politieke attituden in West-Europa wel meevalt. Helaas gaat het daarbij bijna altijd om onderzoek waarin geen paneldata zijn gebruikt! Niet zelden wordt uit de stabiliteit van de publieke opinie op geaggregeerd niveau, afgeleid dat ook de politieke attituden op individueel niveau stabiel zouden zijn. Prachtige voorbeelden hiervan zijn te vinden in Kaase en Newton (1995: 79. 81 en 109-11).
} 
een aantal invloedrijke critici die betogen dat serieus en actief politiek bedrijven voor de meeste burgers - niet voor politici of andere burgers die hun geld verdienen aan de politiek - een weinig aantrekkelijk tijdverdrijf is. In de kem komt de redenering er op neer dat de (te verwachten) baten van politieke inspanningen over het algemeen in geen enkele verhouding staan tot de kosten (Downs, 1957: 238-59; Neumann, 1986: 172-3). Schumpeter heeft een en ander treffend verwoordt:

"De individuele burger is lid van een onpraktisch comité, het comité van de gehele natie: en daarom besteedt hij minder inspanning aan het onder de knie krijgen van een politiek probleem dan hij besteedt aan een spelletje bridge. [..] Aan de bridgetafel hebben wij een welomlijnde taak; er zijn regels waaraan wij ons houden; welslagen en mislukking sijn duidelijk omschreven; en wij worden ervan weerhouden ons onverantwoordelijk te gedragen, omdat elke fout die wij maken niet alleen direct blijkt maar ook onmiddellijk aan ons wordt toegeschreven. Die voorwaarden, waaraan niet wordt voldaan bij het politieke gedrag van de gewone burger, laten zien waarom hij in de politiek alle waakzaamheid en onderschei-

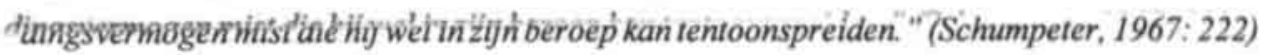
Politiek is, met andere woorden, een ondoorgrondelijk en moeilijk spel met onduidelijk regels. De spelers in de arena hoeven zich niet gedisciplineerd gedragen. De consequenties van beslissingen worden immers afgewenteld op het collectief, waardoor een belangrijke rem op onbezonnen gedrag wegvalt. Objectief gezien is er dus weinig reden voor een burger om zich serieus te verdiepen in politieke zaken. Om een probleem op de politieke agenda te krijgen en vervolgens ook nog een gewenst besluit te krijgen, is een hachelijke onderneming. De individuele kosten om een gewenst besluit van het comité van de gehele natie (zie citaat) te krijgen, wegen haast nooit op tegen de individuele baten die voortvloeien uit een collectieve regeling. Daarom is het veelal rationeel en begrijpelijk dat burgers weinig interesse in politiek hebben en weinig tijd en energie besteden aan het onder de knie krijgen van politieke zaken.

Het EU-issue combineert een zeer omvangrijke politieke gemeenschap - een zeer onpraktisch comité! - met een heel indirecte relatie met de belangen van burgers (Schumpeter, 1957: 222; vergelijk Converse en Pierce, 1986: 238). In hoofdstuk 3 is al uitvoerig betoogd dat ondanks de moeilijk te onderschatten invloed van EU-regelgeving op het leven van alledag, de EU in het dagelijks leven van de modale burger niettemin nauwelijks zichtbaar is. EU-besluiten verschijnen niet zelden aan het publiek in de vorm van of in combinatie met nationale regelgeving. Nationale ambtenaren en instanties spelen een cruciale rol bij de uitvoering van EU-besluiten, en de handhaving van en rechtspraak over EU-regels. Zelfs voor de vergaring van haar financiële middelen vertrouwt de EU op de nationale lidstaten. De link tussen de EU en de burger loopt primair via de nationale staat. Daarenboven stellen Weidenfeld en Piepenschneider (1989: 8-9) heel treffend dat besluitvormingsprocessen binnen de EU relatief complex en ondoorzichtig zijn, 
mogelijkheden voor personificatie van de EU-politiek nauwelijks aanwezig zijn, democratische controle te wensen over laat en de structuur van de EU nauwelijks overeenkomt met die van vertrouwde nationale politieke systemen. De effecten van het functioneren en de werking van de EU zijn zodoende nauwelijks als zodanig waarneembaar. De EU valt daarom te typeren als een relatief abstract en perifeer issue. Het issue is abstract omdat het functioneren van de EU voor een modale burger moeilijk te volgen is. Het issue is perifeer omdat sprake is van een bijzonder indirecte relatie tussen het politieke denken en doen van burgers en het functioneren en optreden van dit grootschalig politiek systeem. Daarmee is dus niet gezegd dat EU-besluiten niet van grote invloed kunnen zijn op het dagelijkse leven van burgers, maar wel dat die besluiten voor die burger niet als EU-besluit herkenbaar zijn en dat het voor een modale burger min of meer onmogelijk is om de achterliggende besluitvorming te doorgronden en/of te beĭnvloeden. Wat voor politicke zaken in het algemeen geldt, lijkt dus in extreme mate toepasbaar op het EU-issue. Op basis van deze inzichten is de verwachting dat het issue-public van het EU-issue in de lidstaten relatief klein is.

Ten tweede zijn er ook directe empirische aanwijzingen voor een relatief klein issue-public. Zo is de stabiliteit van houdingen ten aanzien van foreign policy issues over het algemeen veel geringer dan die ten aanzien van zogenaamde domestic policy issues (Converse, 1964; Converse en Marcus, 1979: 39-44). Converse en Pierce (1986: 233-9) constateren dat de geringe samenhang tussen links-rechts plaatsing en de houding ten aanzien van West-Europese integratie in Frankrijk aan het einde van de jaren zestig, sterk overeenkomt met de gebrekkige samenhang tussen links-rechts plaatsing en andere vraagstukken op het terrein van de buitenlandse politiek en schril afsteekt tegen de samenhang tussen links-rechts plaatsing en domestic policy issues. Butler en Stokes gebruiken het EU-issue zelfs om te illustreren hoe instabiel (paneldata) politieke houdingen kunnen zijn! Ze wijzen erop dat in 1963-4 de houdingen van Britse burgers ten aanzien van de Britse toetreding tot de EU extreem instabiel zijn en concluderen:

"The most reasonable interpretation of the remarkable instability of responses is that Britain's policy towards the Common Market was in 1963-4 a matter on which the mass public had formed attitudes to only a very limited degree. " (Butler en Stokes, 1974: 279) Saris (1997) komt op basis van een relatief recent drie-golfs panelonderzoek in Nederland tot een vergelijkbare conclusie. De Nederlandse publieke opinie ten aanzien van Europese integratie bleek op individueel niveau bijzonder instabiel te zijn. Veranderingen in de vraagstelling hebben ingrijpende gevolgen voor het beeld dat men krijgt van de publieke opinie. Zo vindt Saris dat:

"- relatively small changes in the questions led to quite different results;

- it was quite simple to change the public opinion considerably during one interview from a nationalistic to a European position; 
- it was possible to reverse this back again to a national position within a short time. " (Saris, 1997: 428)

De beschrijving van de achtergronden van de publicke opinie in paragraaf 4.3 geven geen enkele aanleiding om te vooronderstellen dat de situatie op deze punten in de ander lidstaten rooskleuriger is. Ook een analyse van Eurobarometerdata (geen paneldata!) geeft reden te vooronderstellen dat de publieke opinie voor een belangrijk deel uit non-attitudes bestaat (Janssen, 1991: 448-53; Blondel, Sinnott en Svensson, 1998: 55-84 en 239-40). Kortom, er zijn nogal wat door de tijd en over de lidstaten verspreide empirische aanwijzingen dat individuele houdingen ten aanzien van de EU instabiel zijn. Dit versterkt het vermoeden dat de publieke opinie ten aanzien van de EU voor een belangrijk deel uit weinig doordachte ad hoc- of nonattitudes bestaat.

Zowel op basis van meer algemene theoretische inzichten, als op basis van resultaten van empirische onderzoek bestaat het vermoeden dat het issue-public van de EU in EU-lidstaten vrij klein is. Dit zou betekenen dat de in dit onderzoek gebruikte surveydata ernstig "vervuild" zijn met non-attitudes. Wat betekent dit voor de zoektocht naar een verklaring van de publieke opinie over de EU?

\subsection{Verklaring van non-attitudes: Converse en Markus wijzen de weg}

De verwachting dat de publieke opinie over de EU voor een belangrijk deel uit non-attitudes bestaat, maakt het er op het eerste gezicht niet makkelijker op om een zinvolle verklaring te vinden voor de veranderingen en verschuivingen in de publieke steun voor de EU in de lidstaten. Voor een succesvolle verklaring is het noodzakelijk om meer inzicht te krijgen in de processen van ad hoc politieke opinievorming. Als het daadwerkelijk gaat om volstrekt willekeurige (random) processen zoals Converse assumeert in zijn black-and-white model, dan kan de zoektocht naar een inhoudsvolle verklaring worden gestaakt. In de literatuur zijn er echter aanwijzingen dat zogenaamde door de tijd instabiele non-attitudes niet de uitkomst zijn van een volstrekt randomproces. Schuman en Presser ontdekken bijvoorbeeld dat de antwoorden op de vraag over het niet-bestaande en uiterst obscure issue niet geheel onafhankelijk zijn van andere politieke attituden en zij concluderen dat het niet om bewuste random-antwoorden gaat (1981: 159). Schuman en Presser (1981: 159) en Neumann (1986: 183-5) spreken daarom ook liever van quasi- of pseudo-attitudes dan over non-attitudes, omdat (vgl. Achen, 1975;1983; Zaller, 1992):

"Respondents make an educated (though often wrong) guess as to what the obscure acts (JJ: een fictief en een volstrekt onbekend politiek besluit) represent, they answer reasonably in 
their own terms about the constructed object. Such responses fit Converse's notion of nonattitude in the sense that there was no thought about the object prior to the interview, but our evidence on the way the responses are consistent over time and linked to other issues suggests that the attitudes themselves are often quite real. "(Schuman en Presser, 1981: 159) Het onderwerp van deze en de volgende paragraaf betreft de factoren en omstandigheden de uitkomst bepalen van dit soort ad hoc processen. In deze paragraaf wordt daarbij het spoor van Converse (en Markus) gevolgd, in de volgende paragraaf wordt gekeken wat Zaller daar nog aan toevoegt. Daarbij blijven de evidente effecten van de formulering en redactie van vraag en antwoorden (aantal positieve en negatieve antwoorden, formulering, sociale wenselijkheid) op de ad hoc opinievorming buiten beschouwing (Schuman en Presser, 1981; Saris, 1997). De aandacht gaat primair uit naar de processen die aan de non- of quasi-attitudes ten grondslag liggen.

\section{Non-attitudes: niet random}

$\mathrm{Na}$ de bijdrage uit 1964 waar Converse het bestaan van het fenomeen non-attitudes min of meer ontdekt, gaat hij in zijn tweede gezaghebbende bijdrage Attitudes and non-attitudes: continuation of a dialogue uit 1970 dieper in op achtergronden, gevolgen en implicaties van dit fenomeen (zie ook: Converse en Markus, 1979). In dat kader legt hij een relatie met zogenaamde cognitive consistency of balance theories die door sommige sociaal psychologen worden gebruikt om attitudeveranderingen te verklaren (vergelijk: Festinger, 1957; Converse, 1970:184-6). Kern van dit soort theorieën is dat mensen bij het vormen van attitudes streven naar consistentie. Het ontdekken of ontstaan van inconsistenties stelt in principe een proces van attitudeverandering in werking met als doel om de consistentie te herstellen.

Converse's vermoeden is dat bij de vorming van politicke attituden het streven naar consistentie ook een centrale rol speelt. De gedachte is dat attituden ten aanzien van de minder centrale politieke objecten zoveel mogelijk in overeenstemming worden gebracht met de houding ten aanzien van meer centrale politieke objecten. ${ }^{86}$ Naarmate de centrality van een object of issue groter is, is het issue en de houding ten aanzien van het issue ingebed in meer actieve associaties (kennis, informatie, affectie). Om die reden zal bij het streven naar behoud van consistentie de houding van minder centrale objecten eerder worden aangepast aan de houding ten aanzien van

${ }^{4}$ Converse definicert de centrality van een issue of politiek object in dispositionele termen. Een object is meer centraal - of minder perifeer - indien er sprake is van een (Converse, 1970: 182-3):

1) verhoogde interesse in het object, leidend tot een grotere alertheid op het selecteren van informatie over dit object uit het geheel van informatie waar het individu toegang toe heeft;

2) grotere kans op het succesvol opslaan en weer kunnen terughalen van informatie over het object, leidend tot meer informatie over het object en een grotere verscheidenheid aan kennis over het object;

3) toename van het aantal "actieve" associaties tussen het object en andere objecten in de vorm van verschillende typen van linking informatie. 
meer centrale objecten dan andersom. Bij het wijzigen van een houding ten aanzien van een centraal object moeten immers ook de vele associaties worden doordacht. Aanpassing van de houding ten aanzien van een minder centraal object vereist minder aanpassingen. Dit laatste is makkelijker en gaat sneller en verdient daarom de voorkeur. Bovendien mag worden verwacht dat de houding ten aanzien van meer centrale objecten intenser is doordat er al vaker over is nagedacht.

Converse en Markus koppelen dit idee aan de empirische gegevens over de stabiliteit van individuele houdingen ten aanzien van verschillende politieke objecten en issues. De redenering is dat de meest centrale elementen in de politieke beleving van mensen, tevens de meest stabiele elementen zijn. De stabiliteit van een houding wordt in deze visie vooral bepaald door het aantal cognitieve associaties waarin een houding is ingebed. Dit brengt Converse en Markus op de volgende redenering:

"It is not hard to imagine that attifudes which show higher individual-level stability have cansal primacy relative to less stable attitudes. If this simple surmise is meaningful, then it would seem that where political evaluations are concerned, a party $\rightarrow$ leader $\rightarrow$ issue flow may be dominant [...] The huge discrepancies in individual-level contimuities between party loyalties on the one hand and issue positions on the other, ..., argues for an overwhelming primacy of the party term when party-issue congruence does occur." en:

"The additional fact, .... that reactions to political leaders display levels of contimuity intermediary between partisanship and policy preferences, raises a number of further interesting possibilities. Such a data configuration may, for example, suggest a significant margin for policy leadership available to major political figures, whereby admirers are quite susceptible to influence leading them to adopt policy positions more congruent with those espoused by their heroes. Or again, the greater contimuity in evaluations of leaders as compared with issue positions may simply reflect the fact that party attachments anchor both leader assessments and issue positions, but do so more effectively in the case of leaders because the common voter can maintain much more firm and unequivocal cognitive links berween parties and their most prominent leaders than between parties and positions on various issues." (Converse en Markus, 1979: 49)

Hun suggestie is dat burgers bij het streven naar behoud van de consistentie in hun politieke belevingswereld de neiging zullen hebben om bij de beoordeling van politieke issues aansluiting te zoeken bij de standpunten van hun favoriete politieke partij (politici). Dit zou betekenen dat burgers bij de vorming van ad hoc opinies ten aanzien van minder centrale politieke issues de neiging hebben om het standpunt van hun eigen favoriete partij (of politiek leider) te verwoorden.

Naast deze indirecte aanwijzingen uit het onderzoek van Converse en Markus, zijn er concrete 
en in het kader van dit onderzoek relevante aanwijzingen voor de validiteit van dergelijke mechanismen. Zo vindt Eichenberg in zijn studie naar de achtergronden van de publieke opinie ten aanzien van de NAVO aanwijzingen voor wat hij noemt het elite leadership model (1989: 216-8). Wessels (1995: 155-62) vindt aanwijzingen dat politieke partijen in de EU-lidstaten in de aanloop naar de nationale verkiezingen in staat blijken om hun achterban te mobiliseren om het partijstandpunt ten aanzien van de EU over te nemen.

\section{Non-attitudes: Wat dan wel?}

Uitgaande van het idee dat non-attitudes - ondanks hun instabiliteit - geen random-antwoorden op surveyvragen zijn, doen Converse en Markus een eerste inhoudelijke suggestie voor de verklaring van non-attitudes. $\mathrm{Zij}$ verwachten dat burgers op surveyvragen over issues waar ze voor het interview eigenlijk geen uitgesproken mening over hebben, proberen een zinnig antwoord te geven dat consistent is met hun andere politieke opvattingen. $\mathrm{Bij}$ het formuleren van een ad hoc opinie zal worden gezocht naar relaties tussen het issue en de in hun ogen centrale politieke objecten. Aangezien politieke partijen en politieke leiders vaak de meeste stabiele en meest centrale elementen in de politieke belevingswereld van de gemiddelde burger blijken te zijn, valt te verwachten dat partijstandpunten en uitspraken van politici een zekere mate van gezag genieten onder hun aanhangers die andere bronnen moeten ontberen. De suggestie is dus dat burgers bij de ad hoc vorming van politieke meningen ten aanzien van de meest uiteenlopende politieke strijdpunten zich makkelijk zullen laten souffleren door hun favoriete partij en/of politicus.

Dat deze suggestie van Converse en Markus slechts een eerste vingerwijzing voor de oplossing van het probleem is, blijkt uit de fundamentele vragen die hun oplossing oproept. Hoe is de instabiliteit van individuele politieke houdingen te rijmen met het feit dat partijen en politici over het algemeen bijzonder stabiele opvattingen hebben? Hoe waarschijnlijk is het dat burgers op de hoogte zijn van de standpunten van partijen en politici over issues waar ze zelf weinig interesse in hebben? Converse en Markus geven geen antwoord op deze voor de hand liggende essentiële vragen. Ze komen niet verder dan de opmerking dat het mechanisme blijkbaar gebrekkig werkt. In de volgende paragraaf zal blijken dat de algemene inzichten van Converse en de besproken suggestie van Converse en Markus niettemin aanknopingspunten bieden voor een inhoudsvolle verklaring van het fenomeen non-attitudes.

\subsection{Zallers RAS-model: een theorie van het survey-antwoord}

De suggestie van Converse en Markus werkt, maar is gebrekkig en roept nieuwe vragen op. Wat 
gebeurt er als burgers geen aanknopingspunten kunnen vinden? Hoe gaan mensen die geen partijvoorkeur hebben te werk? Zijn die antwoorden wel "random"? Bij het oplossen van deze nieuwe vraagstukken en het verder uitwerken van de suggestie van Converse en Markus stuit men onherroepelijk op het werk van Zaller. Zaller heeft de inzichten van Converse en suggestie van Converse en Markus verder uitgewerkt en vervolmaakt. Zaller (1992; xi) beschouwt zijn eigen Receive-Accept-Sample model (RAS-model) als de synthese en verdere uitwerking van de ideeên van Converse over politieke attitudevorming. Het model vormt een soort algemene theorie van het politieke survey-antwoord en richt zich primair op de verklaring van opinion statements over politieke onderwerpen. Dit wil zeggen:

"This term [JJ: opinion statement] implies that the expression of opinion is genuine without also implying that it either represents prior reflection or destined for a long half-life. " Zaller, 1992: 50)

Onder deze noemer vallen zowel stabiele, als instabiele opinies. Met andere woorden, de term opinion statements omvat attitudes (stabiel) en non-attitudes (instabiele, ad hoc opinies). Zaller verwerpt de suggestie dat survey-antwoorden zijn op te vatten als volstrekt willekeurige keuzes uit de aangeboden antwoordcategorieën, maar heeft tegelijkertijd wel een zeer lage dunk van het politieke onderscheidingsvermogen van burgers. Desondanks is Zallers uitgangspunt bij de verklaring van opinion statements dat elk survey-antwoord:

"is the outcome of a process in which people receive new information, decide whether to accept it, and then sample at the moment of answering questions. "(Zaller, 1992: 51)

In Zallers ogen ligt aan elk antwoord dus een meer of minder bewust cognitief proces ten grondslag. Het RAS-model is een poging om dit proces te begrijpen. Minimale voorwaarde is dat het model een verklaring biedt voor de voor politieke houdingen zo kenmerkende instabiliteit op individueel niveau. Zallers model bestaat uit een impliciet axioma, vier expliciete axioma's en drie primitieve begrippen die hieronder worden besproken

\section{Uitgangspunt: elite discours-axioma}

Bij de behandeling van de bouwstenen van het RAS-model moet worden begonnen met de bespreking van een belangrijke (impliciete) vooronderstelling die aan het model ten grondslag ligt. Het volgende citaat verwoordt de kern van het (impliciete) elite discours-axioma:

"Citizens in large societies are dependent on unseen and usually unknown others for most of their information about the larger world in which they live. [..] The "others"on whom we depend, directly or indirectly, for information about the world are, for the most part, persons who devote themselves full time to some aspect of political or public affairs - which is to say. political elites. These elites include politicians, higher-level government officials, journalists, some activists, and many kinds of experts and policy specialists." (Zaller, 1992: 6) 
De interpretatie en het duiden van relevante politieke feiten ligt primair in handen van de politieke elite - politici en andere professionals die zich full-time met politiek of een politiek issue bezig houden. De leden van de politieke elite bereiden de "hapklare brokken" voor die de massamedia in de huiskamers brengen. De politieke elite is de primaire bron van politieke informatie voor de massamedia, terwijl de massamedia de primaire bron van politieke informatie voor de burgers is. Massamedia fungeren als doorgeefluik voor de interpretaties van elites. Het geheel van berichten dat zo ontstaat zal hier verder worden aangeduid als het elite discours. Individuele attituden ten aanzien van politieke issues zijn veelal niet gebaseerd op eigen ervaringen en/of direct contact met het attitude-object, maar zijn (noodgedwongen) gebaseerd op argumenten afkomstig uit het elite discours met betrekking tot het issue (Zaller, 1992: 6-9). Zelfs de politieke berichten die burgers oppikken via gesprekken met buren, vrienden of kennissen zijn uiteindelijk veelal afkomstig uit het elite discours. Zallers impliciete axioma is dat massamedia de welhaast exclusieve bron van politieke informatie zijn voor "gewone" burgers die zich niet fulltime met politiek bezig houden en dat de inhoud van de berichtgeving over politieke issues in de massamedia primair weerspiegelt wat de diverse leden van de politieke elite denken.

\section{Primitieve begrippen}

Zallers bouwwerk rust verder op de volgende drie primitieve begrippen: argument (persuasive political messages), cue (cueing political messages) en overweging (consideration).

Argumenten en cues zijn (nieuws)berichten met informatie over politieke objecten. Een argument of een persuasive political message is een boodschap:

“... providing a reason for taking a position or point of view." (Zaller, 1992: 41)

Een voorbeeld van een argument is het volgende bericht: Het bestaan van de EU vermindert de kans op een nieuwe oorlog tussen Frankrijk en Duitsland. Dit bericht zou als zodanig een argument kunnen zijn waarom mensen voor de EU te zijn. Belangrijk is op te merken dat argumenten op zichzelf niet feitelijk juist hoeven te zijn. Een subjectieve mening of een onjuistheid kan dus ook fungeren als een argument.

Een cue of cueing political message is net als een argument een bericht over een politiek issue of object. Cues zijn echter bijzondere argumenten. Elke cue bevat een argument, maar niet elk argument is een cue. De omschrijving van een cue luidt:

"Cueing messages consist of "contextual information" about the ideological or partisan implications of a persuasive message. "(Zaller, 1992: 42)

Een cue is een argument dat vergezeld gaat met een expliciete verwijzing - vaak een bronverwijzing - naar een partij of ideologie. Een voorbeeld van een cue is: "De VVD vindt de Nederlandse financiële bijdrage aan de EU te hoog". De mening dat de Nederlandse bijdrage aan 
de EU te hoog is, is een argument dat mensen kunnen meenemen bij het maken van een beoordeling van de EU. In het bericht gaat het argument vergezeld van een expliciete verwijzing naar een politieke partij, waardoor een cue ontstaat.

Het laatste primitieve begrip is een overweging of consideration. Een overweging is:

"...every reason that might induce an individual to decide a political issue one way or the other. " (Zaller, 1992: 40)

Een consideration is een argument of een cue ten aanzien van een specifiek issue dat door een individu is geaccepteerd als een geldig argument pro respectievelijk contra het issue. Acceptatic betekent dat het argument of de cue wordt opgeslagen in het geheugen als een geldige overweging. Het verschil tussen geaccepteerde - overwegingen dus! - en niet-geaccepteerde argumenten en cues is essentieel. Argumenten die niet uitgroeien tot overwegingen worden niet in het geheugen opgeslagen en kunnen dus ook geen rol meer spelen in de attitudevorming op een later tijdstip.

\section{Expliciete axioma's}

Vier expliciete axioma's completeren het fundament van Zaller RAS-model. De axioma's zijn bedoeld als plausibele ${ }^{87}$ vooronderstellingen over de wijze waarop mensen berichten over politieke objecten verwerken tot politieke opinies. Het eerste axioma heeft betrekking op de mate waarin individuen geacht worden berichten - argumenten en cues - over uiteenlopende issues op te pikken. Dit zogenaamde reception-axiom luidt:

"The greater a person's level of cognitive engagement with an issue, the more likely he or she is to be exposed to and comprehend - in a word, receive - political messages concerning that issue." (Zaller, 1992: 42)

De vooronderstelling is dat naarmate iemand meer cognitieve affiniteit (kennis van, bekend zijn met, geïnformeerd zijn over) heeft met een bepaald issue, de kans groter is dat hij nieuwe berichten over het issue opvangt en begrijpt. Het idee is dus dat mensen die al meer kennis van het EU-issue hebben, sneller en makkelijker tegen nieuwe argumenten en cues met betrekking tot de EU aanlopen dan mensen die minder of niets van de EU weten. In de terminologie van Converse betekent dit dat leden van het issue-public meer en makkelijker informatie over het specifieke issue oppikken en verwerken dan de burgers die geen lid zijn van het issue-public.

Het tweede axioma gaat over de omstandigheden waaronder mag worden verwacht dat de argumenten die verpakt zitten in cueing messages niet worden geaccepteerd en dus niet worden omgezet in overwegingen. Het resistance-axiom luidt:

"People tend to resist arguments that are inconsistent with their political predispositions, but

"Zaller poneert niet slechts assumpties, maar tracht ook zijn axioma's nog te schragen met expliciete verwijzingen naar inzichten uit politicologisch en sociaal-psychologisch onderzoek. 
they do so only to the extent that they possess the contextual information necessary to perceive a relationship between the message and their predispositions. " (Zaller, 1992: 45)

Dit axioma ademt in zekere zin de suggestie van Converse en Markus dat partijstandpunten een zeker gezag hebben. Uit de toelichting op het axioma blijkt namelijk dat Zaller bij political predispositions primair denkt aan de veelal uiterst stabiele en diepgewortelde partijvoorkeur van individuele burgers. Er is echter ook een fundamenteel verschil tussen de suggestie van Converse en Markus en Zallers axioma. Uit Zallers axioma valt af te leiden dat burgers berichten over politieke issues klakkeloos accepteren als geldige overwegingen, tenzij het om een cue gaat die niet past bij de eigen partijvoorkeur of andere predisposities. Zaller stelt onomwonden:

"This postulate makes no allowance for citizens to think, reason, or deliberate about politics: if citizens are well informed, they react mechanically to political ideas on the basis of external cues about their partisan implications, and if they are too poorly informed to be aware of these cues, they tend to be uncritically accept whatever ideas they encounter. "(Zaller, 1992:

Met andere woorden, aanhangers van politieke partijen baseren zich bij de vorming van politieke attituden dus niet zozeer exclusief op de argumenten en standpunten van hun eigen partij, maar gebruiken hun partijvoorkeur vooral om argumenten afkomstig van niet-favoriete partijen te weren. Partijvoorkeur fungeert in het model van Zaller dus primair als een negatief selectiecriterium, terwijl Converse en Markus er vooral een positief selectiecriterium in zagen. Het uitgangspunt van Zaller is dat burgers in principe elk politiek argument waar ze tegen aanlopen zonder meer zullen accepteren, tenzij ze in staat zijn om het bericht te ontmaskeren als inconsistent met hun eigen partijvoorkeur. ${ }^{88}$ Dit verschil is belangrijk omdat het betekent dat Zallers model ook is te gebruiken in situaties waar burgers niet op de hoogte zijn van de argumenten en standpunten van de politieke partijen, alsmede in die gevallen waarin burgers geen expliciete partijvoorkeur hebben. In die situaties bood de redenering van Converse en Markus geen soelaas.

Het accessibility-axiom is het derde axioma. In dit axioma wordt vastgelegd dat meer recent ontvangen of gebruikte - dit wil zeggen: uit het geheugen opgeviste - overwegingen makkelijker in herinnering kunnen worden geroepen dan overwegingen van oudere datum of minder recent gebruikte overwegingen. De formulering is:

"The more recently a consideration has been called to mind or thought about, the less time it takes to retrieve that consideration or related considerations from memory and bring to the

" Op basis van het eerste axioma verwacht Zaller bovendien dat de cognitive engagement met politieke zaken van nogal wat burgers zo gering is dat eigenlijk niet moet worden verwacht dat ze uberhaupt in staat zouden zijn tot een selectie van argumenten. Zaller stelt (1992: 44-5): "politically inattentive persons will often be unaware of the implications of the persuasive communications they encounter, and so often end up "mistakenly" accepting them". 
top of head for use." (Zaller, 1992: 48)

Dit axioma heeft twee belangrijke implicaties. Ten eerste betekent dit dat als men maar weinig tijd heeft om zich een opinie te vormen, men zich noodgedwongen zal beperken tot de laatst ontvangen of gebruikte argumenten. Een andere belangrijke implicatie van dit axioma is dat bij het selecteren van overwegingen uit het geheugen op geen enkele wijze inhoudelijke criteria worden aangelegd.

Het derde axioma krijgt vooral reliěf in combinatie met het laatste axioma waarin door Zaller is vastgelegd hoe mensen uiteindelijk tot hun survey-antwoord komen. Het response-axiom luidt:

"Individuals answer survey questions by averaging across the considerations that are immediately salient or accessible to them." (Zaller, 1992: 49)

Dit axioma geeft aan hoe attitudes en non-attitudes uiteindelijk tot stand komen. Surveyantwoorden weerspiegelen de verhouding tussen negatieve en positieve overwegingen (geaccepteerde argumenten) die iemand bij een bepaalde survey-vraag te binnen schieten in de enkele seconden die hij normaliter krijgt voor de beantwoording van een vraag tijdens een survey-interview. Is het aantal positieve overwegingen groter (kleiner) dan het aantal negatieve argumenten, dan zal het object van de vraag positief (negatief) geëvalueerd worden. Schiet er helemaal niets te binnen, dan geeft hij geen antwoord. De combinatie van het derde en vierde axioma biedt een verklaring voor de instabiliteit van politieke houdingen op individueel niveau.

De drie primitieve begrippen en behandelde axioma's vormen te samen een uitdagend model ter verklaring van de publieke opinie ten aanzien van politieke issues. ${ }^{89}$ De centrale gedachte is dat burgers voor hun politieke attitudevorming primair zijn aangewezen op de politieke informatie die de massamedia verspreiden. Voor een deel wordt het nieuws gemaakt door de media (journalisten) zelf, maar minstens zo belangrijk is de mening van de leden van de zogenaamde politieke elite die door de media worden doorgegeven aan het grote publiek. Hieronder worden uit de axioma's een aantal concrete hypothesen afgeleid die behulpzaam kunnen zijn bij de verklaring van de publieke opinie ten aanzien van de EU.

\subsection{Hypothesen: RAS-model en de publieke opinie over de EU}

Om de publieke opinie over de EU te kunnen verklaren is het noodzakelijk om het RAS-model nog iets verder uit te werken. Uitgangspunt bij het zoeken naar een verklaring is dat de surveyantwoorden op vragen over de EU in belangrijke mate bestaan uit ad hoc opinies of non-

\footnotetext{
${ }^{\text {no }}$ Het model is bewust bedoeld voor politieke issues. Zaller zet zich om die reden ook bewust af tegen het meer algemene model van opinievorming van Petty en Cacioppo (1986).
} 
attituden.

Volgens het RAS-model zijn alle antwoorden op survey-vragen de uitkomst van een min of meer bewust cognitief proces (response-axiom). De uitkomst van dit proces wordt bepaald door de overwegingen (eerder opgepikte geaccepteerde argumenten) die iemand in zijn geheugen heeft ten aanzien van het te beoordelen object. Doordat tijdens een survey-interview vaak maar weinig tijd is voor de vorming van een opinie, beperken de respondenten zich bij hun afweging noodgedwongen tot een klein aantal overwegingen. Ze hebben geen tijd om alles wat ze ooit over de EU hebben gehoord weer uit hun geheugen naar boven te halen en bij de ad hoc afweging te betrekken. Het accessibility-axiom geeft aan dat in zo'n geval enkel de meest recent opgepikte of gebruikte overwegingen worden gebruikt. Bij de selectie van de overwegingen - een reeds geaccepteerd argument voor of tegen de EU - worden geen inhoudelijke criteria gebruikt. De te vormen ad hoc opinie over de EU zal positief zijn, als het aantal pro-EU overwegingen in de geselecteerde set groter is dan het aantal contra-EU overwegingen; en negatief, als het aantal contra-EU overwegingen groter is dan het aantal pro-EU overwegingen. Als iemand zich niks kan herinneren over de EU, zal hij geen mening hebben; en, als pro- en contra-argumenten elkaar in evenwicht houden dan zal hij, zo mogelijk, een genuanceerd antwoord geven. Volgens het RAS-model weerspiegelen antwoorden op surveyvragen over de EU dus primair de verhouding tussen pro- en contra-argumenten in de berichtgeving over de EU die de respondent relatief recentelijk over de EU heeft geaccepteerd.

Op basis hiervan is nog op geen enkele manier aan te geven wat de publieke opinie over de EU en de individuele opinie van respondenten inhoudelijk bepaalt. Om hier meer zicht op te krijgen is het noodzakelijk om te kijken naar de wijze waarop burgers de geldigheid van argumenten bepalen. Sommige argumenten die ze horen worden geaccepteerd als geldige overweging, andere argumenten worden van de hand gewezen als zijnde ongeldig. De uiterste consequentie van de eerste twee axioma's is dat burgers in principe alle argumenten over politieke issues die ze opvangen klakkeloos accepteren, tenzij het gaat om cues waaruit de ontvangers kunnen opmaken dat een argument op gespannen voet staat met hun politieke predisposities. Mede gelet op de centrale conclusie van Converse's werk dat er slechts een klein stratum van de bevolking in staat is om actief ideologisch te denken, verwacht Zaller (1992: 47) dat slechts weinig burgers in staat zijn om te beoordelen of politieke argumenten al dan niet consistent zijn met hun eigen politieke predisposities. Zeker bij een abstract en perifeer issue als de EU valt te verwachten dat het aantal burgers dat tot een zelfstandige kritische beoordeling van argumenten in staat is, uitermate gering is. De meeste burgers ontberen waarschijnlijk de 
intellectuele bagage en het inzicht in EU-zaken om kritisch te zijn op EU-argumenten. ${ }^{90}$ De enige denkbare situatie die tot een actieve selectie van argumenten leidt is volgens Zaller als berichten heel expliciete cues bevatten richting politieke partijen. Alleen in die gevallen acht Zaller burgers in staat om argumenten als inconsistent te duiden en effectief te weren uit het geheugen. Dit betekent concreet dat (bijna alle) burgers berichten met EU-argumenten alleen dan kritisch bejegenen als er in het bericht een expliciete link wordt gelegd tussen het argument en een politieke partij. Als de eigen partij achter het argument zit, zal het argument zonder pardon worden geaccepteerd. Alleen als er een andere partij achter het bericht zit die de ontvanger bovendien ontmaskert als zijnde inconsistent met zijn eigen partijvoorkeur, zal een argument niet worden geaccepteerd. De kans is klein dat burgers in staat zijn om EU-argumenten ideologisch of partijpolitiek te duiden. De verwachting is dat burgers over het algemeen weinig kritisch zijn op de EU-argumenten waar ze tegen aanlopen. De meeste argumenten zullen zonder meer worden geaccepteerd als geldige overweging.

Dit zou betekenen dat de overwegingen die de meeste burgers gebruiken als ze antwoord moeten geven op een surveyvraag over de EU bestaan uit argumenten uit het elite discours waarvan ze via de massamedia kennis hebben genomen. Onder deze omstandigheden mag worden verwacht dat de verhouding tussen positieve en negatieve overwegingen in de hoofden van de ondervraagden, een afspiegeling vormt van diezelfde verhouding binnen het elite discours. Het elite discours is immers de bron van informatie voor de massamedia. Aangezien de media binnen de EU nog altijd primair op nationale schaal zijn georganiseerd, zal de stemming - de verhouding tussen positieve en negatieve EU-argumenten - binnen het nationale elite discours in belangrijke mate bepalend zijn voor de verhouding tussen positieve en negatieve argumenten in het geheugen van de respondenten in een lidstaat." De eerste concrete hypothese ter verklaring van de publieke steun voor de EU in de lidstaten luidt dan ook:

Hypothese 1: Naarmate de stemming binnen het elite discours over de EU in een lidstaat positiever is, des te groter zal de publieke steun voor de EU zijn.

${ }^{90}$ Dat hij tot deze conclusie komt, komt mede omdat Zaller gelooft dat (1992: 47): "Bad as the arguments of many politicians may be, politicians (and their media consultants) try to be persuasive". Politieke argumenten zijn, met andere woorden, over het algemeen nooit zo dom en ondoordacht dat ze door gewone burgers zijn te ontmaskeren als klinkklare onzin. Dit is volgens Zaller weer een belangrijk verschil tussen zijn model en het meer algemene model van Petty en Cacioppo (1986).

"Uit het reception-axiom is af te leiden dat niet mag worden verwacht dat burgers alle berichten over de EG horen, lezen of zien. Gezien het abstracte en perifere karakter van het issue, mag zelfs worden verwacht dat burgers maar weinig van de in de media beschikbare EG-berichten opvangen en in hun geheugen opslaan. De precieze samenstelling van de individuele set recente EG-overwegingen - opgepikte berichten over de EG: argumenten en cues - die respondenten gebruiken voor het bepalen van hun ad hoc opinie over de EG, zal daarom ook van individu tot individu variêren. Het is dus niet zo dat na 10 positieve berichten over de EG valt te verwachten dat de publieke opinie in een keer unaniem positief is. 
Deze hypothese heeft zowel betrekking op de attitudevorming van individuele EU-burgers, als op de mate van publieke steun voor de EU in de lidstaten.

Zallers resistance-axiom vormt de basis voor een tweede hypothese. In deze hypothese wordt gespecificeerd wat er gebeurt als politieke partijen (of politieke leiders) van mening verschillen over een issue. Het valt te verwachten dat de massamedia in zo'n geval de verschillende standpunten van de politieke partijen (leiders) proberen voor het voetlicht te krijgen. Op basis van Zallers model mag worden verwacht dat in zo'n situatie burgers hun partijvoorkeur gaan gebruiken als negatief selectief criterium. Dit wil zeggen dat burgers argumenten die afkomstig zijn van andere dan hun favoriete partij(en) niet zullen accepteren. Het resultaat zal zijn dat burgers in principe alle argumenten over, bijvoorbeeld, de EU die ze in de media tegenkomen zullen accepteren, tenzij de argumenten vergezeld gaan van een cue naar niet-favoriete politieke partijen (politici) bevat. Als partij-aanhangers eenmaal op de hoogte zijn van het partijstandpunt en de door de partij gebruikte argumenten is het zelfs mogelijk dat ze omwille van hun partijvoorkeur andere standpunten en argumenten als inconsistent zullen herkennen. Dit zorgt er voor dat in het geheugen van partij-aanhangers min of meer automatisch een relatief homogene set van overwegingen ten aanzien van zo'n issue zal ontstaan. Dit zou op zijn beurt de kans dat het survey-antwoord van partij-aanhangers relatief dicht in de buurt van het partijstandpunt komt te liggen, vergroten. Het gaat altijd om een kans omdat de meeste burgers en partij-aanhangers niet in staat mogen worden geacht om alle inconsistente cues en/of inconsistente argumenten (zonder cues) als zodanig te ontmaskeren. Dit leidt tot de volgende hypothese op meso-niveau: Hypothese 2: Partijpolitieke verschillen in de steun voor de EU binnen het elite discours, leiden tot vergelijkbare verschillen in de steun voor de EU tussen de aanhang van politieke partijen binnen de publieke opinie.

Deze hypothese kan zowel op het niveau van individuele partij-aanhangers worden getoetst, als op niveau van groepen partij-aanhangers. Mensen zonder expliciete partijvoorkeur zullen zich in zo'n situatie laten leiden door argumenten van alle partijen, zij hebben immers geen negatief selectiecriterium, en hun mening zal dus een afspiegeling blijven van de verhoudingen binnen het totale elite discours. Dit zou betekenen dat de steun voor de EU onder niet partij-aanhangers ergens in het midden tussen aanhangers van pro-EU partijen en anti-EU partijen zou moeten liggen.

Tenslotte is er nog een derde hypothese af te leiden uit het RAS-model die relevant is in het kader van dit onderzoek. Deze hypothese heeft betrekking op de uiteenlopende effecten die partijstandpunten hebben op de houding van meer en minder intense partij-aanhangers. Sterker 
bij een partij betrokken aanhangers zullen volgens het reception-axiom makkelijker en sneller berichten over hun eigen partij oppikken, verwerken en dientengevolge accepteren. Dit zou betekenen dat ze ook EU-cues met een verwijzing naar de eigen partij eerder zullen oppikken. Hierdoor zullen intense partij-aanhangers sneller en beter weten wat het standpunt van hun partij is. Dit stelt ze vervolgens weer beter in staat om negatief te selecteren, dit wil zeggen argumenten van andere partijen te ontmaskeren als zijnde inconsistent. Dit alles leidt tot de verwachting dat partijpolitieke tegenstellingen ten aanzien van het EU-issue, het sterkst doorwerken in de houdingen van de meest fervente partij-aanhangers. De te toetsen hypothese luidt dan ook: Hypothese 3: Naarmate iemand zich sterker identificeert met een politieke partij, des te sterker zal de samenhang tussen partijstandpunt en iemands houding ten aanzien van de EU zijn.

Deze laatste hypothese zal op individueel (micro-)niveau worden getoetst. 


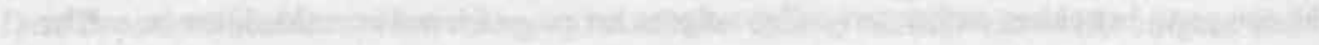

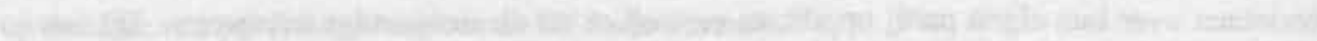

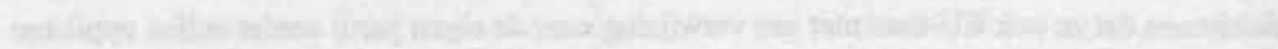

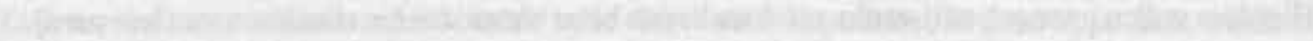

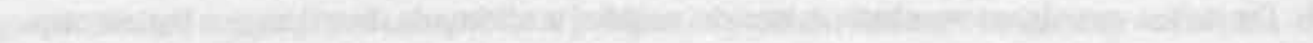

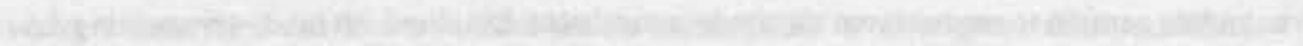

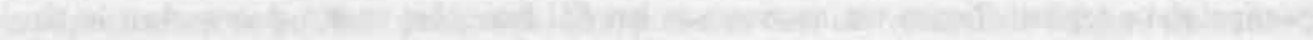

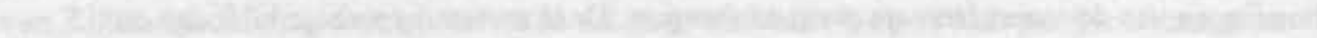
-

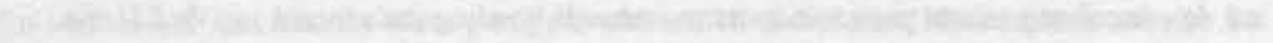

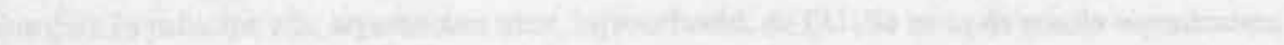

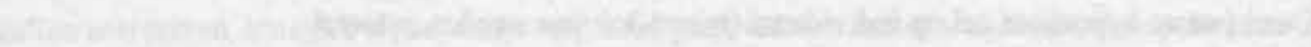
(15)

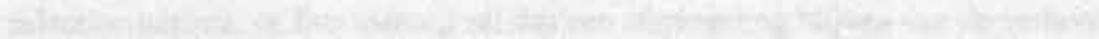

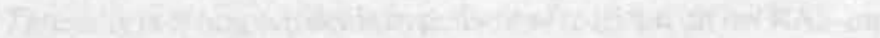

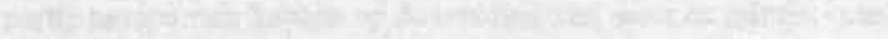




\section{Ingleharts Silent Revolution-theorie: empirische toetsing}

\subsection{Inleiding}

De empirische toetsing van de hypothesen die in hoofdstuk 6 zijn afgeleid uit Ingleharts Silent Revolution-theorie zal centraal staan in dit hoofdstuk. Allereerst worden de hypothesen die betrekking hebben op de attitudevorming ten aanzien van de EU op individueel niveau (microniveau) tegen het licht gehouden (paragraaf 8.2). In dat kader zal nadrukkelijk aandacht worden geschonken aan de operationalisering van de centrale onafhankelijke variabelen - postmaterialisme en politieke vaardigheden. Paragraaf 8.3 gaat over de vraag in hoeverre er sprake is van intergenerationele verschillen (meso-niveau) in de steun voor de EU. Naast aandacht voor de opgestelde hypothese in termen van jonge en oude generaties zal daar ook aandacht worden besteed aan een andere specificatie van intergenerationele verschillen, gebaseerd op ideeën uit het vroegere werk van Inglehart. In paragraaf 8.4 zal worden nagegaan in hoeverre veranderingen in de publieke steun voor de EU op het niveau van de lidstaten (macro-niveau) iets te maken hebben met veranderingen in het politieke waardenklimaat en de mate van cognitive mobilization. In de slotparagraaf (8.5) wordt een eindoordeel geveld over de empirische houdbaarheid en bruikbaarheid van Ingleharts theorie in het licht van dit onderzoek.

\subsection{Individueel niveau: postmaterialisme- en politieke vaardighedenhypothese}

In deze paragraaf komt de vraag aan de orde in hoeverre de uit Ingleharts Silent Revolutiontheorie afgeleide postmaterialisme-en politieke vaardigheden-hypothese die betrekking hebben op de individuele attitudevorming ten aanzien van de EU ook daadwerkelijk in overeenstemming zijn met de empirie. In de eerste subparagraaf wordt nagegaan in hoeverre de vooronderstelde positieve relatie tussen postmaterialisme en steun voor de EU bestaat (8.2.1). De invloed van meer of minder politieke vaardigheden op de steun voor de EU staat centraal in subparagraaf 8.2.2. Vervolgens zal aandacht besteed worden aan de vraag in hoeverre het effect van postmaterialisme op de steun voor de EU in feite geen schijnsamenhang blijkt te zijn omdat steun en postmaterialisme beide positief samenhangen met het niveau van politieke vaardigheden 
(8.2.3). De paragraaf wordt afgesloten met een conclusie over de empirische houdbaarheid van de twee hypothesen (8.2.4).

\subsubsection{Postmaterialisme-hypothese}

Inglehart vooronderstelt dat post-materialisme en steun voor de EU positief met elkaar samenhangen. Dit wil zeggen: de kans dat iemand de EU steunt is groter, naarmate hij of zij over een meer postmaterialistische waarde-oriëntatie beschikt. Aan deze verwachting liggen twee gedachten ten grondslag. Ten eerste zouden postmaterialisten meer intellectuele behoeften gevoelen en daarom meer interesse tonen in abstracte zaken. Dit leidt ertoe dat postmaterialisten aldus Inglehart minder parochiaal en meer kosmopolitisch ingesteld zijn dan materialisten, hetgeen - ceteris paribus - de kans op een positieve houding ten aanzien van de EU vergroot. Ten tweede meent Inglehart dat postmaterialisten veel meer dan materialisten op zoek zijn naar een politieke identiteit ter bevrediging van hun grotere need for belonging. Dit streven zou niet zozeer worden bevredigd door de vorming van nationalistische gevoelens, als wel door de vorming van sub- of supranationale identiteiten. Op basis van deze redenering komt Inglehart tot de volgende hypothese:

Hypothese 1: Naarmate iemand een meer postmaterialistische politieke waarde-oriëntatie heeft, des te groter is de kans op een positieve houding ten aanzien van de EU.

\section{Meting postmaterialisme}

Om er achter te komen of iemand een meer of minder post-materialistische waarde-oriëntatie heeft, wordt gebruikt gemaakt van het veelvuldig gevalideerde 4-iteminstrument van Inglehart (Van Deth, 1983; Inglehart 1970 en 1998; Inglehart en Abramson, 1999). Daarbij wordt respondenten gevraagd om uit een lijstje met vier lange-termijn doelstellingen de in hun ogen twee belangrijkste te kiezen. Het lijstje van vier bestaat uit twee materialistische en twee postmaterialistische doelstellingen. Respondenten die de twee materialistische doelstellingen kiezen worden vervolgens aangeduid als materialisten; respondenten die de twee postmaterialistische doelstellingen kiezen worden aangemerkt als post-materialisten; de rest is gemengd. De meest gehanteerde formulering van de vraag (met de Nederlandse vertaling van de verschillende doelstellingen tussen haakjes) luidt:

There is a lot of talk these days about what [name country]'s goals should be for the next ten or fifteen years. On this card are listed some of the goals that different people say should be given top priority. Would you please say which one of them you yourself consider to be most important in the long run? What would be your second choice?

a. Maintaining order in this country (De orde in dit land handhaven):

- b. Giving people more say in important government decisions (De politieke inspraak van de burgers vergroten):

c. Fight rising prices (Prijsstijgingen tegengaan):

- d. Protecting freedom of speech (De vrijheid van meningsuiting beschermen). 
De post-materialistische alternatieven zijn voorzien van een sterretje.

In een tweetal Eurobarometer-studies is het meer uitgebreide en meer betrouwbare 12iteminstrument ter meting van postmaterialisme opgenomen (Inglehart 1990: 115; Abramson en Inglehart, 1992: 339). Naast een keuze uit de hierboven genoemde vier doelstellingen, wordt de respondenten daarbij gevraagd ook een keuze te maken uit de volgende twee lijstjes met vier doelstellingen, te weten:

e. Maintaining a high rate of economic growth (Een hoge mate van economische groei handhaven);

f. Making sure that this country has strong defence forces (Zorgen voor een sterk leger);

- g. Seeing that the people have more say in how things get decided at work and in their communities (De mensen meer inspraak geven bij beslissingen op hun werk en in hun woonplaats);

- h. Trying to make our cities and countryside more beautiful (Proberen onze steden en het platteland te verfraaien);

en:

i. Maintain a stable economy (Een stabiele economie handhaven);

- j. Progress towards a less impersonal, more human society (Streven naar een vriendelijker en minder onpersoonlijke samenleving);

k. Fight against crime (De strijd tegen de misdaad);

- 1. Progress toward a society where ideas are more important than money (Streven naar een samenleving waarin ideeên belangrijker zijn dan geld).

De afzonderlijke scores (materialist, gemengd of postmaterialist) op de drie verschillende lijstjes worden bij elkaar opgeteld en vormen tezamen een 9-punts postmaterialisme-index.

In dit hoofdstuk zal zowel van het 4-item-, als van het 12-iteminstrument gebruik worden gemaakt. Beide instrumenten om postmaterialisme op individueel niveau te kunnen meten komen niet voor in de USIA-studies (1952-67) en CMS-studie (1962). Voor de toetsing van de postmaterialisme-hypothese zijn we dus volledig aangewezen op Eurobarometer-studies. Het 12 iteminstrument komt slechts in twee bruikbare Eurobarometers voor, te weten: ECS73 (1973) en EB29 (1988). ${ }^{92}$ Het 4-iteminstrument zit wel in vrijwel alle Eurobarometer-studies tot 1994 (EB42). ${ }^{93} \mathrm{Na} 1994$ lijkt het instrument echter voorgoed uit de Eurobarometer-vragenlijsten verdwenen. Dit betekent dat voor de empirische toetsing van de in hoofdstuk 6 opgestelde hypothesen gebruik kan worden gemaakt van Eurobarometer-gegevens uit de periode 1970 tot 1994.

Voor de meting van steun voor de EU wordt gebruik gemaakt van de drie standaardindicatoren (unif, scrap en mem). In de tabellen wordt omwille van de overzichtelijkheid uitsluitend

${ }^{92}$ Van het ECS71-onderzoek waar het 12-iteminstrument ook in zit wordt hier geen gebruik gemaakt omdat geen van de drie standaard-indicatoren om steun voor de EU te meten daar in voorkomt.

${ }^{9}$ Het 4-item instrument is opgenomen in de volgende onderzoeken: ECS70-73, Eurobarometer 6-10 (1976-8), $12-40$ (1979-1993) en 42 (1994). 
gerapporteerd aan de hand van de unif- en mem-indicator. ${ }^{94}$ Uit inspectie van resultaten blijkt namelijk dat het gebruik van de scrap-indicator - voor zover aanwezig in de verschillende studies - tot nagenoeg exact dezelfde resultaten leidt als het gebruik van de mem-indicator. In sommige tabellen zijn zelfs de resultaten van de analyses met de unif-indicator omwille van diezelfde overzichtelijkheid achterwege gelaten. Dit weglaten van de resultaten uitgevoerd met een of twee van de standaard-indicatoren is uiteraard alleen gedaan als de uitkomsten niet wezenlijk verschillen.

Een laatste opmerking vooraf betreft alle analyses op individueel niveau in dit en het volgende hoofdstuk. Bij de toetsing van hypothesen op individueel niveau zal gebruik worden gemaakt van ongewogen data. Voor alle andere analyses, op meso- en macro-niveau, wordt gebruik gemaakt van gewogen data.

\section{Pooled dataset: alle lidstaten, alle tijdstippen}

Welke empirische aanwijzingen zijn er voor een positieve samenhang tussen postmaterialisme en steun voor de EU op individueel niveau? In tabel 8.1 staan de resultaten van de eerste analyse op de zogeheten pooled dataset. In deze dataset zijn de data van respondenten uit alle lidstaten en alle bruikbare verschillende Eurobarometer-onderzoeken op een hoop geveegd (pooled).Om de sterkte van de samenhang tussen postmaterialisme en steun voor de EU in deze dataset uit te drukken, wordt gebruik gemaakt van een gamma-coëfficiënt. De waarde van deze maat voor de samenhang tussen twee ordinale variabelen kan in principe variëren van -1 tot +1 . Als de postmaterialisme-hypothese klopt, dan zouden we een significant positieve gamma moeten vinden.

Tabel 8, I Steun voor de EU bij postmaterialisme binnen pooled dataset, 1970-1994

\begin{tabular}{|l|c|c|c|c|}
\hline & \multicolumn{2}{|c|}{$\begin{array}{c}\text { postmaterialisme - unif a) } \\
\text { Gamma }\end{array}$} & $\mathbf{N}$ & Gostmaterialisme - mem a) \\
& .08 & 366316 & .08 & N \\
\hline \multicolumn{1}{|c|}{ EU-totaal: } & & & & 391301 \\
Periode: & .14 & 47393 & .09 & 72378 \\
$70-\operatorname{er}(1970-9)$ & .07 & 217336 & .04 & 217336 \\
$80-\operatorname{er}(1980-9)$ & .06 & 101587 & .10 & 101587 \\
$90-\operatorname{er}(1990-4)$ & & & & \\
\hline
\end{tabular}

Bron: ECS70, ECS73, EB6-10 (1976-1978), EB12-40 (1979-1993)en EB42 (1994); Groot-Brittanniẽ vanafECS73;

Griekenland vanaf 1980 (EB14); Spanje en Portugal vanaf $1985($ EB24); * = niet significant, p> 01.

a) ECS70 bevat geen mem-vraag; EB6-9 (1976-8) bevat geen unif-vraag.

\footnotetext{
${ }^{\text {M }}$ Doordat de onafhankelijke variabele postmaterialisme alleen in de Eurobarometer-studies voorkomt, kan voor de analyses op individueel niveau waarbij gebruik wordt gemaakt van de unif-index zo nodig gebruik worden gemaakt van een S-punts unif-index, te weten: erg tegen (1), tegen (2), weet niet (3), erg voor (4), erg voor (5). Voor de mem- en scrap-vraag wordt gebruik gemaakt van 3-puntsindex (zie schema 4.1).
} 
In de bovenste rij van tabel 8.1 staat aangegeven hoe postmaterialisme en steun voor de EU zich tot elkaar verhouden in de pooled dataset. Er blijkt, zoals verwacht, sprake van een significant positief verband. De gamma in de bovenste rij heeft betrekking op de gegevens uit alle lidstaten en alle tijdstippen tezamen. De drie gamma's die daaronder staan hebben betrekking op alle lidstaten en de studies uit achtereenvolgens de jaren zeventig, tachtig en negentig. De eveneens significant positieve gamma's in de onderste rijen geven aan dat de samenhang door de jaren heen niet ingrijpend is veranderd. Wel lijkt de samenhang tussen steun en postmaterialisme in de jaren tachtig minder sterk dan in de jaren zeventig.

De absolute grootte van de berekende gamma's duiden op een relatief zwak verband. Om een idee te krijgen wat de betekenis is van een gamma van +.08 (pooled dataset), is hieronder een aantal percentages op een rijtje gezet die de sterkte van de samenhang mede bepalen. Op de mem-vraag geeft $65 \%$ van de postmaterialisten aan het nationale EU-lidmaatschap een goede zaak te vinden. Onder materialisten ligt dit percentage op 56\%. Dit verschil is niet gering, maar er zit nog een addertje onder het gras waardoor de grootte van de gamma negatief beinvioed wordt. Van de postmaterialisten geeft tegelijkertijd 13\% aan het nationale EU-lidmaatschap een slechte zaak te vinden, terwijl dit percentage onder materialisten op $10 \%$ (lager!) ligt. Bij de unifvraag is iets vergelijkbaars aan de hand, het percentage voor- en tegenstanders onder postmaterialisten ligt op $77 \%$ respectievelijk $15 \%$, en onder materialisten op $69 \%$ en $11 \%$. Onder postmaterialisten zitten dus zowel meer "supporters" als crici van de EU dan onder materialisten. Per saldo is de steun voor de EU onder postmaterialisten groter dan onder materialisten, maar de licht positieve gamma onderstreept dat het verband niet al te sterk is.

De analyse op de pooled dataset geeft geen reden om te twijfelen aan de empirische houdbaarheid van de postmaterialisme-hypothese.

\section{Lidstaten}

Uit de eerdere hoofdstukken is bekend dat de publieke opinie betreffende de EU nogal verschilt van lidstaat tot lidstaat. Dit roept de vraag op of, en zo ja in hoeverre de achtergrond van die publieke opinie in de verschillende lidstaten ook van elkaar verschilt. In dit licht is nagegaan of de positieve samenhang tussen postmaterialisme en steun wel in alle lidstaten terug te vinden is. De resultaten van deze analyse staan in tabel 8.2.

De cijfers geven aan dat in 10 van de 12 lidstaten sprake is van een (significant) positieve samenhang tussen steun en postmaterialisme, maar dat in Denemarken en Griekenland sprake is van een (significant) negatief verband. Alle indicatoren - ook de niet getoonde scrap-indicator schetsen op dit punt exact hetzelfde beeld. De resultaten in Denemarken en Griekenland zijn in strijd met de postmaterialisme-hypothese. De vraag lijkt dan ook gerechtvaardigd of er in deze landen iets bijzonders aan de hand is wat deze afwijkingen verklaard en de postmaterialisme- 


\begin{tabular}{|c|c|c|c|c|}
\hline & \multicolumn{2}{|c|}{ postmaterialisme - unif } & \multicolumn{2}{|c|}{ postmaterialisme - mem } \\
\hline & Gamma & $\mathbf{N}$ & Gamma & $\mathbf{N}$ \\
\hline EU-totaal: & .08 & 366316 & .08 & 391301 \\
\hline Frankrijk & 22 & 40623 & 21 & 38053 \\
\hline Belgie & 20 & 37337 & .18 & 34843 \\
\hline Nederland & .13 & 39452 & .23 & 36801 \\
\hline West-Duitsland & .14 & 39486 & .13 & 37734 \\
\hline Italie & .17 & 42030 & .14 & 39471 \\
\hline Luxemburg & .08 & 12388 & .10 & 11239 \\
\hline Denemarken & -.07 & 37541 & -.11 & 33813 \\
\hline lerland & .11 & 37390 & .09 & 33498 \\
\hline Groot-Brittannic & .10 & 39431 & .11 & 35241 \\
\hline Griekenland & .04 & 28169 & -.12 & 28169 \\
\hline Spanje & .18 & 18741 & .17 & 18741 \\
\hline Portugal & 13 & 18713 & .11 & 18713 \\
\hline
\end{tabular}

Bron: zie tabel $8.1:^{\bullet}-$ niet significant $p>0.01$.

hypothese kan redden.

Instabiliteit: eerste poging tot redding van postmaterialisme-hypothese

Inglehart constateert zelf ook dat zijn postmaterialisme-hypothese in Denemarken geen stand kan houden (1977a; Inglehart, Rabier en Reif, 1987). Toch ziet hij daarin geen reden om deze hypothese af te danken. Integendeel, hij vecht de Deense anomalie (de Griekse merkt hij nooit op) aan met ad-hoc verklaringen die de zwakte van het verband tussen postmaterialisme en steun in het algemeen en de Deense negatieve samenhang in het bijzonder moet verklaren.

Eén van de twee pogingen die Inglehart onderneemt om te voorkomen dat de postmaterialisme-hypothese volledig moet worden afgeschreven, grijpt terug op het idee dat de EU een voortdurende ontwikkeling doormaakt waarmee rekening dient te worden gehouden. Het feit dat de samenhang tussen postmaterialisme en steun voor de EU gerekend over de gehele onderzoeksperiode nogal zwak is, zou aldus Inglehart, Rabier en Reif (1987) te maken kunnen hebben met het feit dat het imago van de EU in de loop der tijd meer materialistisch en minder postmaterialistisch is geworden:

"In so far the European institutions seemed to promote the evolution of a less nationalistic, more egalitarian society, they held a strong appeal for postmaterialists. [...] By the mid1970 s, the European Community was increasingly perceived as a set of huge, hierarchical and remote bureaucracies, wholly preocccupied with the conflicts of interest groups, firmly tied to the status quo, and unlikely to lead to the qualitatively different type of society sought by the more articulate postmaterialists." (Inglehart, Rabier en Reif, 1987: 150-2) 
Een imagoverandering die zou zijn ingezet in het midden van de jaren zeventig wordt dus als verklaring aangedragen voor het feit dat het verband in de pooled dataset relatief zwak is en in de jaren tachtig nog zwakker wordt. Alvorens deze ad-hoc verklaring op zijn empirische merites te toetsen moet eerst stil worden gestaan bij de betekenis van deze ad-hoc verklaring voor de postmaterialisme-hypothese als zodanig.

Een kwalijk bijgevolg van deze ad-hoc verklaring is namelijk dat de postmaterialismehypothese als het ware boven elke empirische kritiek verheven wordt. Er ontstaat een heuse cirkelredenering. Een positief verband tussen postmaterialisme en steun duidt er op dat de EU een post-materialistisch imago heeft. In het geval van een negatief of qua sterkte afnemend positief verband is het imago blijkbaar materialistisch of verandert het van overwegend postmaterialistisch naar meer materialistisch. Hierdoor wordt de centrale vraag of de individuele houding ten aanzien van de EU uberhaupt wel iets te maken heeft met een meer of minder postmaterialistische waarde-oriëntatie wordt boven elke empirische toetsing verheven. De relatie tussen iemands waarde-oriëntatie en steun voor de EU verwordt zodoende tot een assumptie. Deze handelwijze is weinig bevredigend omdat die uiteindelijk op geen enkele wijze kan bijdragen aan ons inzicht in de achtergronden van de publieke opinie over de EU.

\section{Instabiliteit binnen de lidstaten?}

Overigens betekent dit alles niet dat de ad-hoc verklaring van Inglehart, Rabier en Reif feitelijk onjuist is. Als de gegeven verklaring juist is, betekent dit wel dat kennis van de inhoud van iemands waarde-oriëntatie als zodanig ons eigenlijk niet echt verder helpt bij het verklaren van iemands houding ten aanzien van de EU. Daarom is nagegaan in hoeverre de ad-hoc verklaring empirisch houdbaar is. De vraag daarbij is, in welke mate de relatie tussen steun voor de EU en postmaterialisme in de loop der tijd geërodeerd is?

Net zoals in tabel 8.1 is gedaan voor de zogeheten pooled dataset is de sterkte van de relatie binnen de afzonderlijke lidstaten in drie periodes berekend, te weten: 1970-9, 1980-9 en 1990-4 . De resultaten van die berekeningen staan in tabel 8.3.

Daaruit blijkt eigenlijk weinig van een systematische erosie van de sterkte van de samenhang die duidt op een imagoverandering. Weliswaar neemt de sterkte van het verband tussen postmaterialisme en steun voor de EG in sommige landen af, maar daar staat tegenover dat de sterkte van het verband in andere landen in het geheel niet verandert of zelfs toeneemt. In alle lidstaten is sprake van een relatief stabiele relatie tussen postmaterialisme en steun voor de EU. In Griekenland en Denemarken is sprake van een stabiele negatieve relatie tussen steun en postmaterialisme.

In aanvulling hierop is nog een analyse uitgevoerd waarbij gebruik is gemaakt van het meer betrouwbare 12-iteminstrument om postmaterialisme te meten. Ook daarmee kan de samenhang 
tussen steun en postmaterialisme voor (1973) en na (1988) de vooronderstelde imagoverandering in kaart worden gebracht (tabel 8.4). Het gebruik van het meer betrouwbare 12-iteminstrument blijkt geen nieuwe of andere inzichten op te leveren. De samenhang tussen postmaterialisme en steun voor de EU in de diverse lidstaten anno 1973 wijkt niet systematisch af van die in 1988.

Tabel 8.3 Steun voor de EU bij postmaterialisme in de lidstaten: 1970-9, 1980-9 en 1990-4 (gamma's)

\begin{tabular}{|c|c|c|c|c|c|c|}
\hline \multirow[b]{2}{*}{ periode: } & \multicolumn{3}{|c|}{ postmaterialisme- unif } & \multicolumn{3}{|c|}{ postmaterialisme - mem } \\
\hline & $1970-9(\mathrm{~N})$ & $1980-9(N)$ & $1990-4(N)$ & $1970-9(\mathrm{~N})$ & $1980-9(\mathrm{~N})$ & $1990-4$ N) \\
\hline EU-totaal: & $.14(47393)$ & $.07(217336)$ & $.06(101587)$ & $.09(72378)$ & $.04(217336)$ & $.10(101587)$ \\
\hline Frankrijk & $21(8056)$ & $22(21165)$ & $26(8832)$ & $.12(10626)$ & $.23(21165)$ & $.25(8832)$ \\
\hline Belgie & $.26(5604)$ & $20(20530)$ & $.21(8709)$ & $.20(8098)$ & $.16(20530)$ & $.21(8709)$ \\
\hline Nederland & $.19(6355)$ & $.13(21445)$ & $.15(9001)$ & $.18(9006)$ & $.20(21445)$ & $.28(9001)$ \\
\hline West-Duitsland & $.22(7587)$ & $.13(21013)$ & $.15(9134)$ & $.17(9339)$ & $.11(21013)$ & $.16(9134)$ \\
\hline Italie & $.16(7635)$ & $.17(22709)$ & $.19(9127)$ & $.10(10194)$ & $.13(22709)$ & $.16(9127)$ \\
\hline Luxemburg & $.05(879)$ & $.08(6506)$ & $.17(3854)$ & $-.02(2028)$ & $.08(6506)$ & $.20(3854)$ \\
\hline Denemarken & $.06(4103)$ & $-.12(20947)$ & $-.11(8763)$ & $-.17(7831)$ & $-.19(20947)$ & $-.16(8763)$ \\
\hline Ierland & $.11(3165)$ & $.07(21467)$ & $.12(8866)$ & $.06(7057)$ & $.06(21467)$ & $.06(8866)$ \\
\hline Gr.-Brittannie & $.07(4009)$ & $.07(21900)$ & $.18(9332)$ & $.06(8199)$ & $.08(21900)$ & $.17(9332)$ \\
\hline Griekenland & & $-.03(19453)$ & $-.02(8716)$ & & $-.15(19453)$ & $-.12(8716)$ \\
\hline Spanje & & $.21(10144)$ & $.15(8597)$ & & $.20(10144)$ & $.15(8597)$ \\
\hline Portugal & & $.17(10057)$ & $.09(8656)$ & & $.09(10057)$ & $.12(8656)$ \\
\hline
\end{tabular}

Bron: zie tabel $8.1^{*}=$ niet significant, $p>.01$.

Ook nu weer blijkt weinig van substantiële veranderingen in de sterkte van de samenhang. Alleen in Denemarken - sterker negatief (!) verband in 1988 dan in 1973 - en West-Duitsland - minder sterk positief - lijkt een trend te ontwaren die zou kunnen duiden op een minder postmaterialistisch imago. Duidelijk is dat dit het Deense probleem niet opheft. In Ierland is tegelijkertijd echter een tendens in de andere richting waarneembaar. Dus voor zover er al substantiele veranderingen in de sterkte van het verband optreden tussen 1973 en 1988, wijzen deze veranderingen niet eenduidig in de vooronderstelde richting.

Opmerkelijk is wel dat de analyse met dit meer betrouwbare meetinstrument voor postmaterialisme nog een aantal extra afwijkingen aan het licht brengt. In de Britse data is zowel in 1973 als in 1988 geen sprake van een significant positief verband tussen steun en postmaterialisme; hetzelfde geldt voor de West-Duitse en Portugese data in 1988. Dit suggereert dat de problemen met de postmaterialisme-hypothese in Griekenland en Denemarken niet op zichzelf staan.

De over het algemeen relatief zwakke samenhang tussen postmaterialisme en steun voor de EU binnen de lidstaten enerzijds en de Deense anomalie anderzijds valt dus niet te wijten aan een 
imagoverandering die de EU tijdens de onderzoeksperiode zou hebben doorgemaakt. De relatie tussen postmaterialisme en steun voor de EU blijkt binnen de lidstaten relatief stabiel. Dit geldt ook voor Denemarken en Griekenland de twee landen waar sprake is van een negatief verband tussen postmaterialisme en steun. De ad-hoc verklaring van Inglehart, Rabier en Reif (1987) is dus niet alleen bedenkelijk in het licht van dit onderzoek, maar is eenvoudig onjuist want niet

Tabel 8.4 Steun voor de EU bij postmaterialisme (12-itemintsument) in de lidstaten: 1973 en 1998 (gamma's)

\begin{tabular}{|c|c|c|c|c|c|c|c|c|}
\hline & \multicolumn{4}{|c|}{ Postmaterialisme - MEM } & \multicolumn{4}{|c|}{ Postmaterialisme - UNIF } \\
\hline & 1973 & $\mathbf{N}$ & 1988 & $\mathbf{N}$ & 1973 & $\mathbf{N}$ & 1988 & $\mathbf{N}$ \\
\hline EU - totaal: & .09 & 13484 & .02 & 11729 & .12 & 13484 & .10 & 11729 \\
\hline Frankrijk & .06 & 2227 & $.07 *$ & 993 & 22 & 2227 & 10 & 993 \\
\hline Belgie & .16 & 1266 & 15 & 1022 & .18 & 1266 & .14 & 1022 \\
\hline Nederland & .13 & 1464 & .13 & 1023 & .17 & 1464 & .11 & 1023 \\
\hline West-Duitsland & 20 & 1957 & $.07^{*}$ & 1007 & 17 & 1957 & .13 & 1007 \\
\hline Italie & 22 & 1909 & .14 & 1021 & .18 & 1909 & .17 & 1021 \\
\hline Luxemburg & $.03^{*}$ & 330 & $.18^{*}$ & 300 & $12 *$ & 330 & .19 & 300 \\
\hline Denemarken & -.20 & 1199 & -.37 & 1009 & -.13 & 1199 & -.27 & 1009 \\
\hline Ierland & $.01^{*}$ & 1199 & .06 & 992 & $.07^{*}$ & 1199 & .16 & 992 \\
\hline Groot-Brittanniē & $-.05^{*}$ & 1933 & $.03^{*}$ & 1014 & $-.01^{*}$ & 1933 & $.02^{*}$ & 1014 \\
\hline Griekenland & & & -.24 & 1000 & & &,- 14 & 1000 \\
\hline Spanje & & & .15 & 1017 & & & 17 & 1017 \\
\hline Portugal & & & $.00^{*}$ & 1000 & & & $.03^{*}$ & 1000 \\
\hline
\end{tabular}

Bron: ECS73 (1973) en EB29 (1988); ${ }^{\bullet}=$ niet significant, $p>.01$.

in overeenstemming met de feiten. Het biedt geen oplossing voor het Deense en Griekse probleem.

Politieke invloeden: tweede poging tot redding van postmaterialisme-hypothese

In 1977 had Inglehart $(1977 \mathrm{a}, 344)$ al aangegeven dat de negatieve Deense samenhang niet zozeer het ongelijk van zijn postmaterialisme-hypothese bewijst, als wel onderstreept dat ook andere variabelen een belangrijke rol spelen in de attitudevorming. In dat kader merkt Inglehart op:

"In short, the linkage between Post-Materialist values and pro-European policy preferences is not the result of some universal law, it 's only a probabilistic tendency. Denmark's reversal of the general pattern reflects the fact that, while Postmaterialists tend to be supranationally oriented, they have an even stronger [JJ: cursivering in origineel] tendency to support the Left. And at the time of our survey, much of the Danish Left was bitterly hostile to membership in the European Community." (Inglehart, 1997a: 344)

Ingleharts stelt dat onder omstandigheden politieke invloeden (links-rechts) de positieve 
samenhang tussen postmaterialisme en steun kunnen overschaduwen. Op de precieze invloed die de nationale politieke context uitoefent op de publieke opinievorming rond de EU, zal in het volgende hoofdstuk expliciet en uitvoerig worden ingegaan. In dit kader dient slechts de vraag beantwoord te worden in hoeverre er sprake is van een positieve samenhang tussen postmaterialisme en steun voor de EU indien rekening wordt gehouden met het effect van die politieke invloeden? Daartoe zijn de beschikbare gegevens over de links-rechts zelfplaatsing van burgers bij de analyse betrokken."

Ten eerste is nagegaan of de links-rechts zelfplaatsing aan de ene kant en postmaterialisme en steun aan de andere kant inderdaad met elkaar samenhangen. In de tweede kolom van tabel 8.5 kan de lezer aflezen (wat overigens ook al uit ander onderzoek bekend was) dat postmaterialisten over het geheel genomen linkser zijn dan materialisten (Inglehart en Klingemann, 1976; Fuchs, 1989; Fuchs en Klingemann, 1990). Het gaat daarbij uitdrukkelijk niet om een geìsoleerd Deens of Grieks verschijnsel.

Tabel 8.5 Steun voor de EU bif postmaterialisme onder constanthouding van links-rechts zelfplaatsing in de lidstaten, 1973-1994 (gamma's)

\begin{tabular}{|c|c|c|c|c|c|c|}
\hline & \multirow[t]{2}{*}{ Ir - pmat } & \multirow[t]{2}{*}{ Ir-mem } & \multirow{2}{*}{$\begin{array}{c}\text { pmat - } \\
\text { mem }\end{array}$} & \multicolumn{3}{|c|}{ pmat-mem o.c.v. links-rechts plaatsing } \\
\hline & & & & links & midden & rechts \\
\hline EU-Totaal: & -.27 & .10 & .07 & .03 & .10 & .09 \\
\hline $\mathrm{N}:$ & 327555 & 327555 & 327555 & 62082 & 207261 & 58212 \\
\hline Frankrijk & -.32 & .04 & .20 & .19 & .25 & .13 \\
\hline Belgię & -.18 & .09 & .18 & .24 & .19 & .15 \\
\hline Nederland & -.35 & .06 & .21 & .22 & .25 & .21 \\
\hline West-Duitsland & -.34 & -.02 & .12 & .18 & .13 & .06 \\
\hline Italiē & -.26 & .10 & .10 & .10 & .16 & .05 \\
\hline Luxemburg & -.24 & .08 & .10 & .09 & .11 & .14 \\
\hline Denemarken & -.33 & .53 & -.13 & -.31 & $.01^{*}$ & .12 \\
\hline Ierland & -.20 & .09 & .09 & .02 & .11 & .11 \\
\hline Gr.-Brittanniê & -.28 & .09 & .11 & .22 & .13 & .03 \\
\hline Griekenland & -.36 & 58 & -.15 & -.09 & $.00^{*}$ & .11 \\
\hline Spanje & -.31 & -.13 & .17 & .23 & .18 & $-.01^{*}$ \\
\hline Portugal & -.16 & .23 & .07 & -.06 & .11 & .26 \\
\hline
\end{tabular}

Bron: zie tabel 8.1, exclusief ECS70, EB 11, EB 34 en EB 41: ${ }^{*}=$ niet significant, $p>01$.

${ }^{9}$ De vraag luidt: "Als men het over politiek heeft, worden vaak de termen "links" en "rechts" gebruikt. U ziet hier tien hokjes tussen de woorden links en rechts. Wilt u met behulp van deze schaal aangeven hoe links, rechts of daartussen uw eigen politieke richting ligt?"'. De antwoorden zijn als volgt gehercodeerd in drie categorieên: 1-3 = links; 4-7 = midden ; 8-10 = rechts. Deze vraag blijkt een uitstekende indicator voor de positie die burgers innemen op het links-rechts continuïm dat in de politiek in het algemeen en de partijsystemen in het bijzonder van nagenoeg alle West-Europese landen zo'n centrale rol speelt (Klingemann, 1995: 192-6). 
Vervolgens is gekeken in hoeverre het EU-issue in de verschillende lidstaten is gepolitiseerd in links-rechts termen. In alle lidstaten blijkt sprake te zijn van een significante samenhang tussen links-rechts zelfplaatsing en steun voor de EU. Zowel de richting als de sterkte van het verband zijn niet hetzelfde in alle lidstaten. In Spanje en West-Duitsland zijn linkse burgers iets meer proEU, terwijl in alle andere lidstaten de steun voor de EU onder rechtse burgers juist groter is dan onder linkse. Belangrijk in het licht van Ingleharts verklaring voor de Deense anomalie, is vooral dat het EU-issue inderdaad relatief sterk gepolitiseerd is in die landen waar sprake is van een negatieve samenhang, dan wel geen samenhang tussen postmaterialisme en steun. In Denemarken, Griekenland en in mindere mate Portugal (zie tabel 8.4) blijkt het EU-issue inderdaad voor relatief sterke tegenstellingen tussen politiek links en rechts georiènteerde burgers te zorgen.

Het feit dat het EU-issue inderdaad het sterkst gepolitiseerd is in die twee landen waar een negatieve samenhang tussen postmaterialisme en steun is gevonden, biedt hoop op de redding van de postmaterialisme-hypothese. Voor die redding zou binnen de ideologisch homogene groepen geen negatieve samenhang tussen postmaterialisme en steun voor de EU meer mogen worden gevonden. In de laatste drie kolommen van tabel 8.5 staat hoe postmaterialisme en steun voor de EU met elkaar samenhangen in de verschillende ideologisch homogene groepen.

De samenhang binnen de drie groepen - links, rechts, midden - wijkt in de lidstaten waar het EU-issue geen scherpe tegenstellingen tussen links en rechts oproept, nauwelijks af van de bivariate samenhang. In Griekenland, Denemarken en Portugal de landen waar het EU-issue de meest scherpe tegenstellingen tussen links en rechts oproept, blijkt het verband tussen EU-steun en postmaterialisme nader gespecificeerd te worden. Onder linkse burgers in deze drie landen is sprake van een negatief verband tussen steun en postmaterialisme, terwijl onder rechtse burgers sprake is van een positieve samenhang. Dit betekent dat de postmaterialisme-hypothese niet gered kan worden door te wijzen op het feit dat Deensen en Griekse postmaterialisten linkser zijn. Het "links-zijn" kan immers niet verklaren waarom de steun voor de EU onder linkse postmaterialisten in Denemarken en Griekenland lager is dan onder linkse materialisten.

De ad-hoc verklaring geeft precies aan waar de schoen wringt bij de postmaterialismehypothese. In een context waarin het EU-issue onderwerp is van een politieke controverse, wordt de steun voor de EU op individueel niveau niet positief beïnloed door een meer postmaterialistische waarde-oriëntatie.

\section{Postmaterialisme-hypothese: conclusie}

Het wel of niet beschikken over een meer of minder postmaterialistische waarde-oriëntatie heeft slechts een eenduidige, zwak positieve invloed op de steun voor de EU in landen waar het EUissue niet gepolitiseerd is. Er werd echter geen positieve relatie gevonden tussen postma- 
terialisme en steun voor de EU in Denemarken en Griekenland waar het issue onderwerp lijkt van politieke links-rechts controverse. Dit betekent dat de postmaterialisme-hypothese allen stand houdt onder specifieke omstandigheden.

\subsubsection{Vaardigheden-hypothese}

In deze subparagraaf staat de vaardigheden-hypothese centraal. Bij de toetsing van de hypothese zal in grote lijnen hetzelfde stramien worden gevolgd als in de vorige subparagraaf.

Alvorens in te gaan op de wijze van meting van de variabele politieke vaardigheden, eerst nog even iets over de achtergronden van de vaardigheden-hypothese. In een eerdere publicatie is de gedachtegang van Inglehart achter deze hypothese als volgt samengevat:

"Skills determine whether a person is capable of processing information at a certain level of abstraction. Information about European integration and international politics is supposed to be at a high level of abstraction. The concept 'abstraction' is used by Inglehart to indicate the ease with which persons can understand political messages and relate these to their own thoughts and personal situation. [... Inglehart expects that for people with more skills the EC is more familiar and less threatening than for people with fewer skills. "(Janssen, 1991, 445) De kern van zijn redenering is dus dat mensen met meer politieke vaardigheden minder angst en moeite met de EU zullen hebben dan mensen met minder politieke vaardigheden. Een hoger niveau van politieke vaardigheden zou om die reden, ceteris paribus, de kans op het ontwikkelen van een positieve houding ten aanzien van de EU vergroten. De concrete hypothese luidt:

Hypothese 2: Naarmate iemand over een hoger niveau van politieke vaardigheden beschikt, des

te groter is de kans op een positieve houding ten aanzien van de EU.

\section{Meting niveau van politieke vaardigheden}

Het meetinstrument waarmee het niveau van politieke vaardigheden van individuele respondenten zal worden gemeten, bestaat uit een combinatie van twee elementen. In hoofdstuk 6 is al betoogd dat een noodzakelijke voorwaarde voor het ontwikkelen van een hoog niveau van politieke vaardigheden een hoog niveau van cognitieve vaardigheden is. Dit aspect van politieke vaardigheden wordt gemeten door te kijken tot welke leeftijd iemand fulltime onderwijs heeft gevolgd. Hoewel er veel valt aan te merken op deze operationalisering, is er binnen de beschikbare datasets geen beter alternatief - wat is uw hoogste afgesloten opleiding of een registratie van relevante cognitieve vaardigheden (schrijven, lezen, talenkennis, enzovoort) - voor handen. Op zichzelf vormt een hoog niveau van cognitieve vaardigheden echter nog geen voldoende voorwaarde voor het ontwikkelen van een hoog niveau van politieke vaardigheden. Om een hoog niveau van politieke vaardigheden te bereiken is het nodig dat mensen hun cognitieve vaardigheden ook in politieke zin aanwenden. Dit element wordt gemeten door 
respondenten te vragen of ze met vrienden en/of familie wel eens over politiek praten. ${ }^{96}$ Met deze vraag wordt als het ware de mate van (actieve) politieke interesse gemeten (Gabriel en Van Deth, 1995: 395). Dit gegeven vormt het tweede element van het meetinstrument. Het niveau van politieke vaardigheden is afhankelijk van beide elementen. De index die op basis van deze twee elementen wordt samengesteld bestaat uiteindelijk uit vijf categorieěn."

De keuze voor deze operationalisering betekent dat ook voor de empirische toetsing van de vaardigheden-hypothese wederom slechts een beroep kan worden gedaan op Eurobarometerdata. De USIA-studies (1952-67) en CMS-studie (1962) bevatten geen vragen waarmee het niveau van politieke vaardigheden kan worden gemeten.

\section{Pooled dataset: alle landen, alle tijdstippen}

Allereerst is ook nu weer gekeken in hoeverre de verwachte positieve relatie tussen politieke vaardigheden en steun voor de EU aanwezig is in de pooled dataset (alle lidstaten, alle tijdstippen). Daartoe zijn net zoals hierboven gamma's berekend die inzicht geven in de richting en sterkte van het verband tussen deze twee individuele kenmerken. Tabel 8.6 geef inzicht in de empirische houdbaarheid van de vaardigheden-hypothese binnen de pooled dataset. Op basis van de hypothese verwachten we een significant positieve samenhang tussen vaardigheden en de steun voor de EU.

Binnen deze dataset blijkt de steun voor de EU op individueel niveau inderdaad positief samen te hangen met het niveau van politieke vaardigheden. Er is bovendien sprake van een relatief sterke samenhang $(.19 / 20)$ in vergelijking met de relatie tussen postmaterialisme en steun $(.08 / .08)$. De richting van het verband is door de tijd heen stabiel, hoewel de samenhang in de jaren zeventig over het algemeen sterker is dan in de jaren tachtig en negentig. Daarbij moet wel worden bedacht dat de samenhang in de jaren zeventig betrekking heeft op een andere groep lidstaten, dan in de jaren tachtig en negentig. Griekse, Portugese en Spaanse data komen immers pas beschikbaar in de loop van de jaren tachtig.

* De (Engeise) vraagtekst luidt: When you are together with your friends, would you say that you discuss political matters frequently, occasionally, or never?

${ }^{97}$ De index-waarde wordt als volgt berekend (Inglehart, 1977a; 1990):

Politieke

discussie

nooit

soms

vaak fulltime onderwijs tot :

$$
\begin{gathered}
<=15 \text { jaar } \\
1 \text { - laag } \\
2 \\
3
\end{gathered}
$$

16-19 jaar

2

3

4

$$
\begin{gathered}
>=20 \text { jaar } \\
3 \\
4 \\
5-\text { hoog }
\end{gathered}
$$

De noodzakelijke elementen om deze variabele te construeren ontbreken in ECS70, EB34, EB41 (deels), EB42, en EB44 (deels). Dat de vragen deels missen in EB41 en EB44 heeft te maken met het feit dat deze onderzoeken uit meerdere parallelle steekproeven $(41.0 / 41.1,44.0 / 44.1 / 44.2)$ bestaan waaraan niet exact dezelfde vragenlijsten zijn voorgelegd. 


\begin{tabular}{|c|c|c|c|c|}
\hline \multirow[b]{2}{*}{ Land: } & \multicolumn{2}{|c|}{ politieke vaardigheden - unif a) } & \multicolumn{2}{|c|}{ politieke vaardigheden - mem } \\
\hline & Gamma & N & Gamma & $\mathbf{N}$ \\
\hline EU - totaal: & , 19 & 467029 & .20 & 579526 \\
\hline Periode: & & & & \\
\hline $70-e r(1973-9)$ & 30 & 56394 & .26 & 98947 \\
\hline 80 -er $(1980-9)$ & .19 & 235485 & .18 & 235160 \\
\hline 90 -er $(1990-5 / 8)$ & .15 & 175150 & .19 & 245419 \\
\hline
\end{tabular}

Bron: ECS73 (1973), Eurobarometer 3-33 (1975-1990), 35-46 en 48 (1991-1998); Griekenland: vanaf 1980(EB14);

Spanje en Portugal: vanaf 1982 (EB18), EB 23 echter niet; $*=$ niet significant, p $>01$.

a) EB6-9 (1976-1978) en EB45-48 (1996-8) bevatten geen unif-vraag.

Om een idee te krijgen van de verschillen in steun tussen individuen met meer en minder vaardigheden, volgen hieronder enkele percentages. Onder mensen met veel politieke vaardigheden (hoogste score op index) geeft $72 \%$ aan het EU-lidmaatschap (mem-vraag) van hun land een goede zaak te vinden, terwijl slechts $12 \%$ het lidmaatschap een slechte zaak vindt. Onder mensen met weinig politieke vaardigheden (laagste score) liggen diezelfde percentages op $45 \%$ respectievelijk $12 \%$. Op de unif-vraag bedraagt het percentage voor- respectievelijk tegenstanders onder mensen met een hoog niveau van politieke vaardigheden $81 \%$ en $16 \%$, en onder mensen met een laag niveau van politieke vaardigheden liggen deze percentages op $56 \%$ en $14 \%$. Met name bij de positieve steun gaat het om grote verschillen, terwijl de mate van kritiek (negatieve steun) nauwelijks varieert. Dit is wel vreemd omdat een belangrijk aspect van het mechanisme dat ten grondslag ligt aan de hypothese gebaseerd is op het idee dat mensen met minder vaardigheden meer angst voor abstracte politieke systemen zouden hebben. Dientengevolge zou men verwachten dat burgers met relatief weinig vaardigheden juist vaker tegen de EU gekant zouden zijn dan mensen met meer politieke vaardigheden. Blijkbaar zorgen vaardigheden er alleen maar voor dat de EU more familiar wordt.

\section{Lidstaten}

In de vorige subparagraaf bleek dat de relatie tussen postmaterialisme en steun in de lidstaten nogal verschillend uitpakte. De volgende vraag is of de relatie tussen vaardigheden en steun net zo gevoelig is voor de nationale context?

Een eerste inspectie van de gegevens in tabel 8.7 laat zien dat de samenhang tussen vaardigheden en steun voor de EU in ieder geval in geen der lidstaten negatief is. Een hoger niveau van politieke vaardigheden draagt in alle lidstaten positief bij aan de steun voor de EU op individueel niveau.

In sommige landen is sprake van een relatief sterk verband (Frankrijk, België, Italiě, Neder- 


\begin{tabular}{|l|c|c|c|c|}
\hline \multirow{2}{*}{} & \multicolumn{2}{|c|}{ politieke vaardigheden - unif } & \multicolumn{2}{c|}{ politieke vaardigheden - mem } \\
& Gamma & $\mathrm{N}$ & Gamma & N \\
\hline FU - totaal: & .19 & 467029 & .20 & 579526 \\
Belgie & .26 & 46348 & .24 & 58294 \\
Nederland & .31 & 41985 & .28 & 53020 \\
West-Duitsland & .18 & 42577 & .30 & 53803 \\
Italie & .22 & 46277 & .23 & 57035 \\
Luxemburg & .29 & 47616 & .22 & 59034 \\
Denemarken & .19 & 15115 & .23 & 20138 \\
lerland & .11 & 42005 & .11 & 52860 \\
Gr. Brittannie & .25 & 41548 & .26 & 52472 \\
Griekenland & .23 & 46900 & .27 & 58638 \\
Spanje & .16 & 34605 & .07 & 40640 \\
Portugal & .23 & 31373 & .18 & 38343 \\
\hline
\end{tabular}

Bron: zie tabel $8.6 ;^{\bullet-}$ niet significant, $p>.01$.

land, lerland, Groot-Brittannië). Wat de sterkte van het verband betreft vallen de Denen en Grieken opnieuw ietwat uit de toon met een veel minder sterke positieve samenhang. Dit doet vermoeden dat de vaardigheden-hypothese ook niet volledig immuun is voor politisering van het EU-issue. Alles overziend biedt de analyse in de verschillende lidstaten echter geen reden om te twijfelen aan de juistheid van de vaardigheden-hypothese.

\section{Stabiliteit binnen de lidstaten}

Vervolgen is gekeken naar de stabiliteit van de relatie tussen vaardigheden en steun binnen de lidstaten. In de pooled dataset bleek de relatie tussen vaardigheden en steun in de jaren zeventig veel sterker dan in de twee daaropvolgende decennia. Dit zou er mogelijkerwijs op kunnen duiden dat naarmate de EU langer bestaat het ook voor burgers met minder politieke vaardigheden een steeds vanzelfsprekender onderdeel van het politieke leven wordt. Dit zou betekenen dat de samenhang tussen vaardigheden en steun binnen de lidstaten langzaam afkalft in de loop der tijd (tabel 8.8).

De gegevens in tabel 8.8 geven aan dat in alle lidstaten tijdens elk decennium sprake is van een positief verband tussen steun en vaardigheden. Al meer dan 25 jaar blijkt in alle onderzochte lidstaten een hoger niveau van politieke vaardigheden bij te dragen aan een meer positieve houding ten aanzien van de EU. Er blijkt echter niets van een over de hele linie afnemende sterkte van het verband. In België, Nederland, West-Duitsland, Spanje en Portugal zijn er wel aanwijzingen voor zo'n neerwaartse trend, maar in Frankrijk, Ierland en Groot-Brittannië is de 
sterkte van de samenhang nauwelijks veranderd in de afgelopen decennia. In Denemarken en Griekenland is de sterkte van het verband in de jaren negentig zelfs beduidend hoger dan in de jaren tachtig. Voor zover er sprake is van een trend gaat het dus opnieuw niet om één EU-trend als wel om diverse nationale trends. Gevolg van de verschillende trends is wel dat de sterkte van de samenhang tussen vaardigheden en steun voor de EU in de verschillende lidstaten in de jaren negentig naar elkaar toe groeit.

Tabel 8.8 Steun voor de EU bij politieke vaardigheden in de lidstaten: 1970-9, 1980-9 1990-5/8 (gamma's)

\begin{tabular}{|l|l|l|l|l|l|l|}
\hline & \multicolumn{3}{|c|}{ politieke vaardigheden - unif } & \multicolumn{3}{c|}{ politieke vaardigheden - mem } \\
\hline \multicolumn{1}{|c|}{ periode: } & $1970-9(\mathrm{~N})$ & $1980-9(\mathrm{~N})$ & $1990-5(\mathrm{~N})$ & $1970-9(\mathrm{~N})$ & $1980-9(\mathrm{~N})$ & \multicolumn{1}{c|}{$1990-8 \mathrm{~N})$} \\
\hline EU-totaal: & $.30(56394)$ & $.19(235485)$ & $.16(175150)$ & $.26(98947)$ & $.18(235160)$ & $.19(245419)$ \\
Frankrijk & $.36(7637)$ & $.30(21801)$ & $.24(16910)$ & $.25(13540)$ & $.30(21801)$ & $.25(22953)$ \\
Belgie & $.46(6665)$ & $.32(21250)$ & $.25(14070)$ & $.44(11592)$ & $30(21250)$ & $.25(20178)$ \\
Nederland & $.29(6369)$ & $.18(21875)$ & $.18(14333)$ & $.38(11435)$ & $.28(21875)$ & $.25(20493)$ \\
W.-Duitsland & $.38(6814)$ & $.20(22182)$ & $.24(17281)$ & $.32(11551)$ & $.20(22182)$ & $.26(23302)$ \\
Italic & $.35(7417)$ & $.29(23013)$ & $.28(17186)$ & $.24(12670)$ & $.24(23013)$ & $.23(23351)$ \\
Luxemburg & $.23(1795)$ & $.19(6738)$ & $.19(6582)$ & $.21(3284)$ & $.24(6738)$ & $.23(10116)$ \\
Denemarken & $.08(6336)$ & $.04(21838)$ & $.12(13831)$ & $.06(11210)$ & $.03(21838)$ & $.10(19812)$ \\
Ierland & $.27(6155)$ & $.25(21574)$ & $.21(13819)$ & $.24(11129)$ & $.24(21574)$ & $.25(19769)$ \\
Gr-- & $.30(7206)$ & $.22(22551)$ & $.22(17143)$ & $.29(12536)$ & $.25(22551)$ & $.28(23551)$ \\
Brittannie & & $.14(20737)$ & $.19(13868)$ & & $.01 *(20737)$ & $.14(19903)$ \\
Griekenland & & $.31(14671)$ & $.19(16702)$ & & $.27(15685)$ & $.14(22658)$ \\
Spanje & & $.30(17255)$ & $.18(13425)$ & & $.28(15916)$ & $.21(19333)$ \\
Portugal & & & & & & \\
\hline
\end{tabular}

Bron: zie tabel $8.6 ;^{*}=$ niet significant $(p>.01)$.

\section{Vaardigheden-hypothese: conclusie}

De empirische toetsing biedt geen reden om te twijfelen aan de juistheid van vaardighedenhypothese. Een hoger niveau van politieke vaardigheden blijkt inderdaad in alle lidstaten bij te dragen aan een grotere steun voor de EU op individueel niveau. Dit zou er volgens de Silent Revolution-theorie op duiden dat de EU in de ogen van burgers met meer politieke vaardigheden vooral - Ingleharts bewoordingen - more familiar en less threathening is. De vaardighedenhypothese blijft ook overeind in die lidstaten waar het EU-issue tot op zekere hoogte gepolitiseerd is en waar de postmaterialisme-hypothese faalde.

\subsubsection{Onafhankelijkheid postmaterialisme en politieke vaardigheden?}

In deze subparagraaf zal worden stil gestaan bij de vraag in hoeverre de invloed van postmaterialisme en politieke vaardigheden op de steun voor de EU onafhankelijk van elkaar beschouwd kunnen worden. Lafferty (1976: 133-4), en De Graaf \& De Graaf (1988: 50-64) 
stellen dat postmaterialisme, voor zover is na te gaan, sterker afhangt van opleidingsniveau dan van de economische omstandigheden waaronder iemand opgroeit. Opleidingsniveau bepaalt ook voor een belangrijk deel het niveau van politieke vaardigheden. Het niveau van politieke vaardigheden en postmaterialisme - beide onafhankelijke variabelen in Ingleharts theorie - lijken daarom allesbehalve onafhankelijk van elkaar. De vraag rijst dan ook: in hoeverre zijn de effecten die beide variabelen geacht worden te hebben op andere variabelen wel onafhankelijk van elkaar?

Met betrekking tot de houding ten aanzien van de EU stelt Inglehart nadrukkelijk dat beide variabelen een onafhankelijke invloed hebben (Inglehart, 1971: 28; 1977b: 155; Inglehart en Rabier, 1978: 86-92). Wildgen en Feld $(1976 ; 1977)$ stellen daarentegen dat het bij de positieve relatie tussen postmaterialisme en steun voor de EG om een schijnrelatic gaat. Zij suggereren dat de relatie het indirecte gevolg is van de samenhang tussen cognitieve variabelen enerzijds en postmaterialisme en steun voor de EU anderzijds. Dit lijkt zeker niet ondenkbeeldig temeer daar de toelichting die Inglehart geeft op zijn hypothese dat postmaterialisme op individueel niveau bijdraagt aan steun voor de EU, sterk cognitief van karakter is. Postmaterialisten worden geacht meer dan materialisten bevrediging te zoeken voor intellectuele behoeften. Dit zou zich moeten vertalen in een grotere interesse voor abstracte zaken. Een dergelijke redenering komt bijzonder dicht in de buurt van het verhaal - beter in staat abstracte politieke informatie te verwerken en daarom minder bevreesd zijn en meer open staan voor abstracte politieke systemen - dat ten grondslag ligt aan de vaardigheden-hypothese. Dit doet vermoeden dat de samenhang tussen postmaterialisme en steun voor de EU tot op zekere hoogte een schijnsamenhang is.

Een en ander is nagegaan door te kijken naar de samenhang tussen postmaterialisme en steun voor de EU onder constant houding van het niveau van politieke vaardigheden. De resultaten staan in tabel 8.9.De eerste kolommen in de tabel illustreren dat postmaterialisme en vaardigheden in alle lidstaten sterker of minstens even sterk met elkaar correleren als postmaterialisme en steun voor de EU. Postmaterialisten beschikken gemiddeld over meer politieke vaardigheden dan materialisten.

In de laatste drie kolommen is te zien hoe sterk de relatie is tussen steun en postmaterialisme onder constant houding van het niveau van politieke vaardigheden. Een vergelijking van de gamma's in de laatste drie kolommen met de bivariate gamma in de derde kolom (mem-pmat) geeft aan in hoeverre de samenhang tussen postmaterialisme en steun voor de EU een schijnsamenhang is die te wijten is aan het feit dat postmaterialisten over het algemeen over meer politieke vaardigheden beschikken dan materialisten. Onder constanthouding van het niveau van vaardigheden blijkt dat van de reeds relatief zwakke positieve relaties tussen postmaterialisme en steun, zoals verwacht, nog minder overblijft. Onder mensen met een hoog niveau van politieke vaardigheden (laatste kolom) blijken er in de diverse lidstaten zelfs meer niet-significante en significant negatieve verbanden te vinden dan dat er significant positieve verbanden zijn. 
Tabel 8.9 Steun voor de EU bij postmaterialisme bij politieke vaardigheden in de lidstaten, 1973-1994

\begin{tabular}{|c|c|c|c|c|c|}
\hline & $\begin{array}{c}\text { pmat- } \\
\text { poL.vaard. }\end{array}$ & $\begin{array}{c}\text { mem - pmat } \\
\text { (gamma) }\end{array}$ & $\begin{array}{l}\text { mem - p } \\
\text { laag }\end{array}$ & $\begin{array}{l}\text { v politieke } \\
\text { midden }\end{array}$ & $\begin{array}{l}\text { gheden } \\
\text { hoog }\end{array}$ \\
\hline EU-totaal: & (gaypma) & .07 & .04 & .03 & -.06 \\
\hline$(\mathrm{N})$ & (363719) & (363719) & (177175) & (105276) & (81268) \\
\hline Frankrijk & .43 & 21 & .13 & .13 & .09 \\
\hline Belgic & 36 & .18 & .09 & .09 & .13 \\
\hline Nederland & 36 & 22 & 21 & .13 & $.03^{*}$ \\
\hline W-Duitsland & 35 & .12 & .06 & .06 & .08 \\
\hline Italie & 40 & 13 & .12 & $.01^{*}$ & -.06 \\
\hline Luxemburg & 31 & .10 & $.04^{*}$ & .04 & $.03^{*}$ \\
\hline Denemarken & 47 & -.12 & -.04 & -.15 &.,- 36 \\
\hline Ierland & .16 & .08 & .09 & $.01^{\circ}$ & $.00^{\circ}$ \\
\hline Gr-Brittannie & .24 & .11 & .05 & .05 & .10 \\
\hline Griekenland & 38 &. .13 & $.02^{*}$ & -.17 & -.27 \\
\hline Spanje & 44 & .17 & 18 & .08 & $-.04^{*}$ \\
\hline Portugal & 36 & .11 & .10 & $.00^{*}$ & -.07 \\
\hline
\end{tabular}

Bron: ECS73, EB6-10 (1976-8), EB12-33 (1979-90), EB35-40 (1991-3) en EB42 (1994); Griekenland vanaf 1980

(EB14); Spanje en Portugal vanaf $1985($ EB24); $*$ niet significant, $\mathrm{p}>.01$.

Deze uitkomst sluit ook aan op de uitkomsten van multivariate analyses van andere auteurs (Wildgen en Feld, 1976; 1977; Duchesne en Frognier, 1995:218-20; Wessels, 1995a: 125-6). Voor zover er sprake is van een positieve samenhang tussen postmaterialisme en steun voor de EU blijkt die samenhang op zijn minst voor een belangrijk deel het gevolg te zijn van het feit dat postmaterialisten gemiddeld genomen over meer politieke vaardigheden beschikken dan materialisten. Postmaterialisme draagt in die zin dus nog minder bij aan de steun voor de EU op individueel niveau dan aanvankelijk werd gedacht.

\subsubsection{Silent Revolution-theorie: bruikbaar of overbodig?}

In hoeverre biedt Ingleharts Silent Revolution-theorie nu uitzicht op een beter inzicht in de individuele attitudevorming ten aanzien van de EU? De eindconclusie kan niet onverdeeld positief zijn.

De postmaterialisme-hypothese als zodanig moet worden verworpen. In lidstaten waar het EUissue gepolitiseerd is, is van een positieve relatie tussen postmaterialisme en steun voor de EU geen sprake. In die landen waar postmaterialisme wel positief samenhangt met steun voor de EU, gaat het in veel gevallen (deels) om een schijnsamenhang die vooral moet worden geweten aan het feit dat postmaterialisten over het algemeen over meer politieke vaardigheden beschikken dan materialisten. Onder constanthouding van het niveau van politieke vaardigheden blijft van het 
oorspronkelijke verband vaak niets over.

De vaardigheden-hypothese doorstaat de empirische toetsen zonder enig probleem. In alle lidstaten vinden we een door de tijd stabiel positief verband tussen politieke vaardigheden en de steun voor de EU. Mensen met een hoger niveau van politieke vaardigheden staan in het algemeen positiever ten opzichte van de EU dan mensen met minder politieke vaardigheden.

Ingleharts Silent Revolution-theorie kan dus slechts een klein steentje bijdragen aan de verdieping van ons inzicht in de achtergronden en oorzaken van de steun voor de EU op individueel niveau. In dat licht is het interessant om na te gaan in hoeverre de theorie op meso(cohort/generaties) en macro-niveau meer oplevert.

\subsection{Meso-niveau: opeenvolgende generaties als dragers van de verandering}

De oorspronkelijke kem en kracht van Ingleharts theorie ligt in het idee dat in een samenleving waarin de welvaart hoog is, en oorlog, gewelddadige binnenlandse conflicten en natuurrampen die het directe fysieke voortbestaan van de bevolking bedreigen langdurig uitblijven, politieke veranderingen in principe worden ingegeven door de verschillen in politieke houdingen en opvattingen van opeenvolgende generaties. Die veranderingen zouden onder andere de grotere acceptatie van en steun voor supranationale politieke systemen betreffen. Ingleharts verwachting is immers dat jonge generaties onder invloed van hun meer postmaterialistische waardeoriëntaties en gemiddeld hoger niveau van politieke vaardigheden de vorming van supranationale politieke systemen in het algemeen meer zien zitten dan hun oudere landgenoten. De hypothese luidt:

Hypothese 3: De steun voor de EU is onder jongere generaties groter dan onder oudere generaties.

De gedachtegang die ten grondslag ligt aan deze hypothese lijkt in het licht van de conclusies uit de vorige paragraaf niet bijzonder aantrekkelijk meer en roept de vraag op in hoeverre de toetsing van de hypothese over intergenerationele verschillen nog wel zinvol is. Er zijn twee redenen waarom zo'n toetsing in dit onderzoek toch zinvol wordt geacht. Ten eerste valt niet uit te sluiten dat de intergenerationele verschillen toch optreden, omdat de vaardighedenhypothese die mede ten grondslag ligt aan deze hypothese niet verworpen is. De tweede reden is dat Inglehart (1967) in zijn vroegere werk op een tweetal specifieke factoren, die direct samenhangen met het thema Europese eenwording, heeft gewezen die zouden verklaren waarom jongere generaties positiever over de EU denken dan oudere generaties. Er is, met andere woorden, ook nog een alternatief 
verklaringsmechanisme voor handen. ${ }^{98}$ Op dit alternatief zal nu eerst worden ingegaan.

\section{Voor- versus na-oorlogse generaties}

In zijn publicatie in de American Political Science Review van 1967 doet Inglehart een drietal constateringen met betrekking tot het optreden van intergenerationele verschillen ten aanzien van steun voor de EU. Ten eerste blijken er opmerkelijke verschillen te bestaan in de houdingen ten aanzien van de EU tussen jongeren (13- 19 jaar) en volwassenen in Nederland, Frankrijk, WestDuitsland en Groot-Brittanniě. Jongeren oordelen veel positiever over samenwerking binnen de EU dan volwassenen. Ten tweede vindt hij ook onder volwassenen verschillen tussen oud en jong, maar ontdekt hij tegelijkertijd dat de verschillen tussen (volwassen) generaties nogal sterk varielren van land tot land. De derde in dit kader relevante constatering is, dat de steun voor WestEuropese integratie onder jongeren uit de EU-staten hoger blijkt te zijn dan onder Britse jongeren.

Vervolgens komt Inglehart met een interessante, specifiek op het EU-issue toegesneden verklaring voor de gevonden intergenerationele versehillen. Deze verklaring gaat er net zoals zijn latere Silent Revolution-theorie van uit dat jeugdervaringen een blijvende invloed op de politieke attituden van mensen hebben. Men speurt in de publicatie van 1967 echter tevergeefs naar intermediërende variabelen zoals politieke waarde-oriëntaties en politieke vaardigheden terwijl deze in zijn latere theorie zo'n vooraanstaande rol krijgen. Inglehart suggereert daarentegen dat de gevonden verschillen in de steun voor de EU tussen ouderen en jongeren iets te maken hebben met de vraag in hoeverre de jeugdjaren van de opeenvolgende generaties zijn beīnvloed door twee factoren, te weten:

$" 1$. The absence of divisive memories (but this is not enough in itself).

2. A sense of positieve participation in substantial common activities." (Inglehart, 1967: 94) De term divisive memories gebruikt Inglehart om te verwijzen naar herinneringen aan WOI en WOII die sommige generaties met zich meedragen. Tijdens deze twee oorlogen stonden EUlidstaten elkaar letterlijk en figuurlijk naar het leven. Dergelijke gebeurtenissen hebben volgens Inglehart ingrijpende en blijvende gevolgen voor het politieke denken van generaties die gedurende die oorlogen opgroeien (jeugdjaren). Nagenoeg alle burgers die in het midden van de jaren zestig volwassen zijn, hebben gedurende hun jeugdjaren te maken gehad met een van deze twee oorlogen. De jongeren die hij in het midden van de jaren zestig laat interviewen behoren daarentegen tot de eerste na-oorlogse generatie, een generatie zonder divisive memories. Dit zou het verschil in steun voor de EU tussen jong en oud verklaren in de vier onderzochte landen.

\footnotetext{
"Bovendien zou men altijd nog kunnen wijzen op het meer algemene inzicht dat jongeren in het algemeen meer open staan voor nieuwe uitdagingen en veranderingen dan ouderen (Glenn, 1977; Abramson, 1983; Zaller 1992: 172-80).
} 
Om zijn verklaring verder kracht bij te zetten wijst Inglehart er op dat de versehillen in de steun voor de EU tussen de oudste (55+) en minder oude generaties in Frankrijk, West-Duitsland en Groot-Brittanniê veel groter zijn dan die in Nederland. Dit wijt hij aan het feit dat Nederland niet actief heeft deelgenomen aan WOI (1914-8). Zo stelt Inglehart:

"It seems plansible that the effect of a major war on one's feeling of trust and kinship with the "enemy" people (e.g. the French toward the Germans) is strongly negative. The "over 55" group in France, Germany and Britain had a powerful dose of the influences of World war I in iets early years: the corresponding group in Holland was much less affected by them. " (Inglehart, 1967: 93)

Ten slotte wijst Inglehart erop dat de na-oorlogse jongeren niet alleen opgroeien zonder divisive memories, maar ook opgroeien in een tijd waarin de West-Europese landen elkaars bondgenoten worden en intensief samenwerken in allerlei gezamenlijke organisaties. Ook dit zou van invloed zijn op de houding van die jongeren ten aanzien van de EU. Dit zou verklaren waarom Britse jongeren minder positief over de West-Europese integratie oordelen dan de jongeren in de andere drie landen, immers:

"Britain has not participated in the institutions of the European Community. Youth in the other three countries, however, have grown up with some awareness of a common endeavour, and this may explain, at least in part, their greater degree of backing for European integration measures." (Inglehart, 1967: 94)

In zijn publicatie van 1967 legt Inglehart dus een directe link tussen heel specifieke jeugdervaringen en de houding ten aanzien van de EU. Op basis van deze directe en specifieke links stelt Inglehart dat te verwachten valt dat het streven naar West-Europese eenwording een grote toekomst heeft, omdat de jeugd de toekomst draagt.

Het idee dat politieke opvattingen uiteenlopende jeugdervaringen weerspiegelen werkt Inglehart (1970a; 1970b; 1971; 1977a; 1977b; alsmede 1990; 1997), zoals gezegd, later in meer algemene zin uit in zijn Silent Revolution-theorie. Oorlogservaringen zijn ook in die algemene theorie van bijzonder groot belang voor de politieke vorming van burgers. Hij legt echter niet langer een link tussen specifieke jeugdervaringen en de houding ten aanzien van specifieke issues. Daarentegen legt hij een link tussen enerzijds algemene jeugdervaringen, de inhoud van op jeugdige leeftijd te ontwikkelen algemene politieke waarde-oriëntaties en de vorming van politieke vaardigheden in het algemeen, en anderzijds een link tussen deze waarde-oriëntaties en politieke vaardigheden en specifieke politieke gedragingen en houdingen.

Langs deze weg worden de specifieke jeugdervaringen die hij in 1967 nog relevant acht om de verschillen in de houdingen van opeenvolgende generaties ten opzichte van de EU te verklaren onder meer algemene noemers gebracht, te weten: fysieke en economische zekerheid, onderwijs en de toegang tot massamedia en massacommunicatiemiddelen. Het opgroeien onder West- 
Europese instituties als relevante jeugdervaring die medebepalend zou zijn voor de houding ten aanzien van de EU, verdwijnt daarmee echter uit beeld. Gevolg is ook dat Inglehart in zijn uitspraken en voorspellingen steeds minder de nadruk gaat leggen op het verschil tussen vooren na-oorlogse generaties, maar daarentegen steeds meer de nadruk legt op jonge en oude generaties.

In hoofdstuk 6 over Ingleharts Silent Revolution-theorie is primair de laatste meer algemene gedachtenlijn gevolgd. De daar afgeleide hypothese is gebaseerd op het idee dat jongere generaties postmaterialistischer zijn en over meer politieke vaardigheden beschikken dan oudere generaties, en om die reden ook positiever ten opzichte van de EU zouden staan. Indien echter geen empirische aanwijzingen worden gevonden voor intergenerationele verschillen tussen jonge en oude generaties, zal worden nagegaan in hoeverre een verklaring gebaseerd op het idee van divisive memories en a sense of positive participation in substantial common activities, die leidt tot de verwachting dat er een waterscheiding loopt tussen voor- en na-oorlogse generaties, wel empirisch houdbaar is.

\section{Jong versus oud: pooled dataset}

In hoeverre verschillen jonge en oude generaties nu van elkaar op het punt van de steun voor de EU? Om een eerste indruk te krijgen van mogelijke intergenerationele afwijkingen zijn de verschillen tussen jonge en oude generaties in de pooled (alle landen, alle lidstaten; gewogen) dataset in figuur 8.1 en 8.2 grafisch weergegeven. Omwille van de overzichtelijkheid worden daarbij slechts drie generaties onderscheiden. De jongste generaties omvat alle respondenten geboren na de Tweede Wereldoorlog, de middelste generatie betreft respondenten geboren in de periode 1926-1945 en de oudste generatie betreft respondenten geboren vóór 1926 (echter niet boven de 90 jaar). In figuur 8.1 (unif) en 8.2 (mem) is aangegeven hoe de steun voor de EU binnen deze drie generaties zich heeft ontwikkeld in de periode $1973-1995 / 8 .{ }^{99}$ Daarbij dient men zich wel te realiseren dat de percentages door de tijd niet optimaal vergelijkbaar zijn, omdat de percentages uit de verschillende jaren immers gebaseerd zijn op data uit een uiteenlopend aantal lidstaten. Bovendien gaat het om gewogen data en dit betekent dat de respondenten uit de grote lidstaten veel zwaarder meetellen dan de respondenten uit de kleinere lidstaten. Dit betekent dat West-Duitse en Franse respondenten waarschijnlijk tien keer zo zwaar meetellen bij de berekening van de generatiescores dan Deense, lerse en Belgische respondenten. De periode 1973-1979 heeft slechts betrekking op de negen lidstaten die in 1973 lid zijn van de EU. In 1980 komt Griekenland daarbij en in 1985 volgen Spanje en Portugal. Voor de meting van de mate van steun voor de EU binnen een generatie wordt, net zoals voor de meting van publieke steun binnen

\footnotetext{
* Gegevens omtrent de exacte leeftijd van de respondenten ontbreken in ECS'70 zodat deze studies noodgedwongen buiten de cohortanalyses blijven.
} 
de lidstaten, gebruik gemaakt van netto-verschilscores - \% positieve steun minus $\%$ kritiek (negatieve steun).

Uit beide grafieken valt af te leiden dat er ook in de periode 1973-1995/8 tot op zekere hoogte sprake is van systematische intergenerationele verschillen in de steun voor de EU. De steun binnen de oudste generatie - geboren vór 1926 - blijkt op alle tijdstippen lager dan in de twee jongere generaties. Deze verschillen blijken ook in nagenoeg alle jaren statistisch significant te zijn. ${ }^{100}$

Dit laatste is niet het geval bij de verschillen tussen de twee andere generaties. De verhoudingen tussen deze generaties zijn met name in de jaren zeventig en eerste helft van de jaren tachtig veel minder duidelijk, hoewel in de jaren negentig de steun voor de EU vanuit de jongste generatie wel duidelijk uit torent boven de steun in de middelste generatie. ${ }^{101}$

Uit de grafieken blijkt dat de verschillen tussen de generaties over het algemeen veel kleiner zijn dan de veranderingen binnen de generaties. Dit geeft aan dat de dynamiek van de publieke opinie slechts in beperkte mate uit het proces van bevolkingsvervanging kan worden begrepen. De grafieken en aanvullende analyses op de pooled dataset bieden vooralsnog geen reden om te twijfelen aan het bestaan van intergenerationele verschillen tussen jong en oud met betrekking tot de steun voor de EU.

\section{Lidstaten}

In aanvulling op bovenstaande analyses betreffende de pooled dataset is nagegaan in hoeverre er sprake is van systematische intergenerationele verschillen tussen jonge en oude generaties binnen de verschillende lidstaten. Hierboven bleek al dat het bestaan van een relatie binnen de pooled dataset niet echt een garantie hoeft te bieden voor het bestaan van eenzelfde relatie binnen de lidstaten. Voor de analyses binnen de lidstaten zijn alle respondenten op basis van hun geboortejaar (<1905, 1916-1925, 1926-1935, 1936-1945, 1946-1955, 1956-1965, 1966-1975, 1976-1985) ingedeeld in acht generaties. In elke lidstaat is per drie jaar (zes Eurobarometers tezamen) voor iedere generatie de mate van steun voor de EU berekend. Vervolgens is nagegaan in hoeverre de steun voor de EU onder jongere generaties inderdaad systematisch hoger blijkt te liggen dan onder oudere generaties. Voor elke lidstaat in elke periode is de rang-orde correlatie berekend tussen de hoogte van de steun binnen een generatie en het generatienummer (hoe jonger, hoe hoger). In tabel 8.10 staan de resultaten. Op basis van Ingleharts hypothese valt te

${ }^{100}$ Een Kolmogorov-Smimov test is gebruikt om de verschillen tussen twee generaties te testen (Siegel, 1988: 144-50); de meest geêigende toets is eigenlijk een Jonckheere test (Siegel, 1988: 216-22) waarmee de verschillen tussen de drie generaties in één keer kan worden getest, deze test was helaas niet voor handen in de gebruikte programmatuur.

${ }^{101}$ Kolmogorov-Smirnov test $(p<.01)$. 
Figuur 8.1. Publicke steun voor de EU (unif) in drie generaties (gewogen gegevens, pooled dataset)

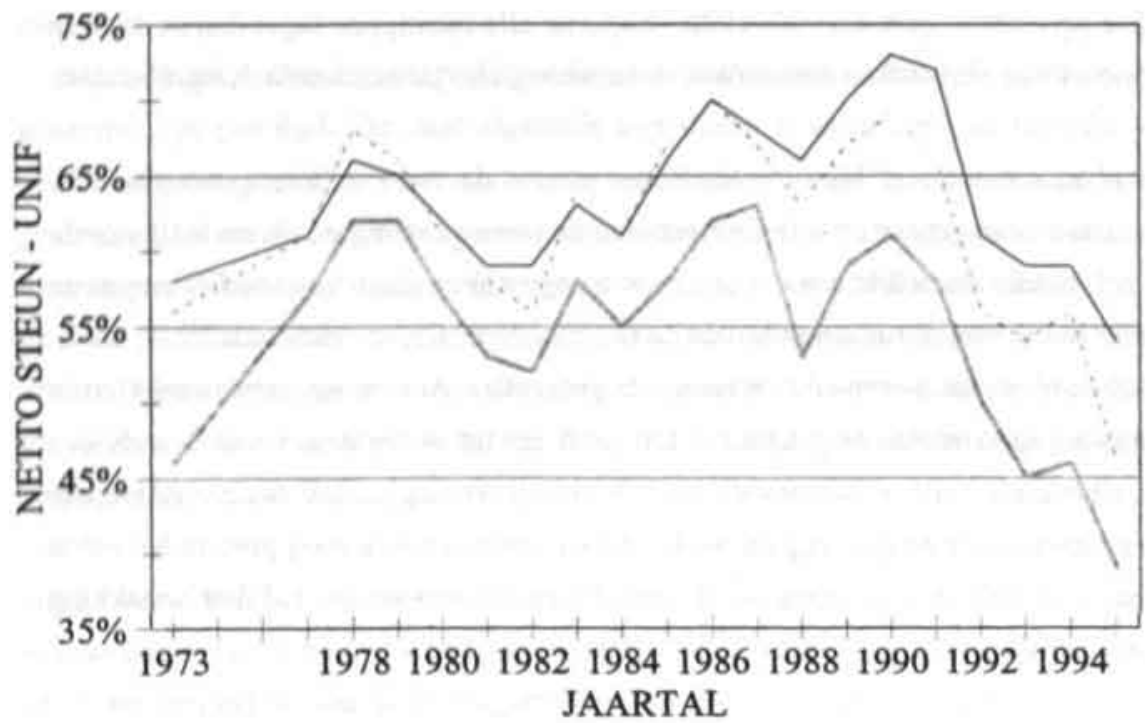

$1870-1925 \cdots 1926-1945-1946-1983$ 


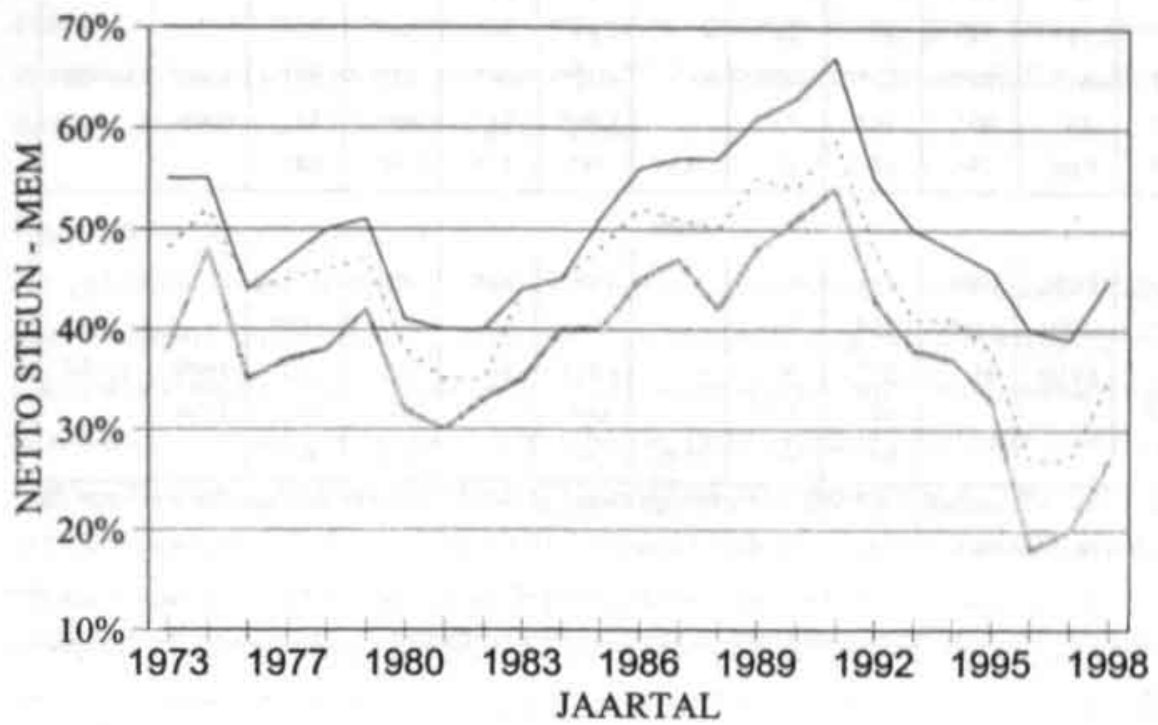

$1870-1925 \cdots 1926-1945-1946-1983$ 
Tabel 8.10 Rangorde-correlaties tussen generaties (jong naar oud) en steun voor de EU binnen generaties, 1973-98

\begin{tabular}{|c|c|c|c|c|c|c|c|c|c|c|c|c|}
\hline & FR & BE & NL & WD & IT & LU & DK & EI & GB & GR & ES & PO \\
\hline \multicolumn{13}{|c|}{ periode: } \\
\hline 73-78 & $.50^{\circ}$ & .89 & $.79^{*}$ & . & - & . & -.89 & $.04^{\circ}$ & - & & \multirow{5}{*}{$\begin{array}{l}1001 \\
0086\end{array}$} & \multirow{5}{*}{$1 \mathrm{e}+08$} \\
\hline $79-83$ & .89 & $.71^{\circ}$ & $.14^{\circ}$ & $.03^{\circ}$ & .89 & - & -.89 & $.60^{\circ}$ & $.54^{\circ}$ & $-37^{\circ}$ & & \\
\hline $84-88$ & $.71^{\circ}$ & $.61^{\circ}$ & $.07 *$ & $.25^{\circ}$ & 1.00 & - & $-.75^{\circ}$ & $68^{\circ}$ & $36^{\circ}$ & $.07^{*}$ & & \\
\hline $89-93$ & $26^{\circ}$ & .83 & $.49^{\circ}$ & $.36^{\circ}$ & $.77^{\circ}$ & - & $-.09^{*}$ & $.71^{\circ}$ & .89 & .83 & & \\
\hline $94-5$ & $39^{\circ}$ & 1.00 & $.79^{\circ}$ & .96 & .93 & -0.89 & $.14^{*}$ & $.57^{\circ}$ & 1.00 & $68^{\circ}$ & & \\
\hline \multicolumn{6}{|c|}{ periode: } & \multicolumn{6}{|l|}{ mem } & \\
\hline $73-78$ & .86 & 1008 & -899 & . & - & - & -.86 & $.61^{\circ}$ & $.10^{*}$ & & & \\
\hline 79.83 & $.77^{\circ}$ & 9100 & 3100 & $60^{\circ}$ & .94 & - & -.96 & .94 & $.77^{\circ}$ & $-.49^{*}$ & & \\
\hline $84-88$ & .96 & 8910 & 96 & $.57^{\circ}$ & .96 & - & $-.61^{*}$ & .86 & .93 & $-.46^{*}$ & 1009 & $1 e+07$ \\
\hline $89-93$ & $.66^{\circ}$ & 0 & & .89 & $.77^{\circ}$ & . & $.09^{\circ}$ & .94 & .93 & $.26^{\circ}$ & 3100 & \\
\hline 94-98 & .86 & & & .93 & .93 & -0.89 & $29^{*}$ & .93 & 1.00 & .89 & & \\
\hline
\end{tabular}

Bron: zie tabel 5.1 en 5.2 , exclusief ECS70; - = niet significant, $\mathrm{p}>.05 ;-=$ minder dan zes cohorten met elk minimaal 500 respondenten.

verwachten dat slechts significant positieve rang-orde correlaties in alle lidstaten zullen worden gevonden. ${ }^{102}$

De rangorde-correlaties in tabel 8.10 ondersteunen Ingleharts hypothese over systematische intergenerationele verschillen binnen de lidstaten niet. De vele niet-significante correlaties in de tabel duiden op allesbehalve perfecte rangordes. De negatieve rang-orde correlaties - sommige zelfs significant - die opduiken in Deense, Luxemburgse en Griekse data zijn zelfs in flagrante tegenspraak met Ingleharts hypothese. De negatieve coëfficiënten duiden er op dat oudere generaties positiever over de EU oordelen dan jongere generaties. De conclusie kan dan ook niet anders zijn dat de hypothese dat de steun onder jonge generaties voor de EU systematisch hoger zou zijn dan onder oudere generaties onhoudbaar is en moet worden verworpen.

Dit neemt niet weg dat in sommige lidstaten (België, Italië, Spanje en Portugal) de steun voor de $\mathrm{EU}$ inderdaad systematisch varieert naar gelang de leeftijd van de respondenten. Het fenomeen blijft echter beperkt tot een klein aantal lidstaten. In een nadere analyse is nog nagegaan in hoeverre de gevonden Deense en Griekse negatieve correlaties eventueel te wijten zouden zijn aan invloed van de politieke context. Ook binnen de ideologisch (links-rechts) homogene groepen in Denemarken en Griekenland is echter geen sprake van systematische intergenerationele verschillen.

In aanvulling op deze meso-analyse, is nog een analyse op individueel niveau uitgevoerd.

102 Alleen generatic-percentages die gebaseerd zijn op minimaal 500 respondenten zijn in de analyse meegenomen. De correlaties in de tabel zijn allemaal gebaseerd op een vergelijking van minimaal zes cohorten. 
Daarbij is gekeken in hoeverre er een positieve samenhang tussen steun voor de EU en geboortejaar bestaat, onder constanthouding van het meetmoment. Ook uit die analyse blijkt dat van een systematisch positief verband in lang niet alle landen sprake is.

De hypothese dat de steun voor de EU onder jonge generaties systematisch hoger is dan onder oudere generaties moet dus worden verworpen, omdat er in een groot aantal gevallen geen systematische verschillen gevonden worden. ${ }^{109}$ Van systematische verschillen tussen jonge en oude generaties in alle lidstaten is geen sprake.

\section{Voor-versus na-oorlogse generaties}

$\mathrm{Nu}$ gebleken is dat er binnen de lidstaten geen systematische verschillen bestaan tussen opeenvolgende jonge en oude generaties, zal hieronder nog worden nagegaan in hoeverre Ingleharts vroegere - meer specifiek op de EU toegesneden - verklaring in termen van voor-en na-oorlogse generaties wel empirisch houdbaar is. In die verklaring staan niet zozeer jong en oud tegenover elkaar, als wel voor-oorlogse tegenover na-oorlogse generaties. De jeugd van de vooroorlogse generaties (geboren voor 1930) kenmerkt zich door oorlog, armoede en een onderling verdeeld Europa, terwijl de na-oorlogse (geboren na 1945) generaties zonder oorlog zijn opgegroeid onder gemeenschappelijke Europese instituties. Dit roept de vraag op in hoeverre er wel systematische verschillen tussen voor- en na-oorlogse generaties bestaan op het punt van de steun voor de EU.

Alvorens in te gaan op de uitkomsten van de analyse, eerste enkele opmerkingen over de data die niet in de analyse zijn meegenomen. De gegevens van Griekenland, Portugal en Spanje zijn buiten beschouwing gelaten omdat deze landen pas in de jaren tachtig tot de EU zijn toegetreden en de meeste na-oorlogse Griekse, Spaanse en Portugese generaties tijdens hun jeugdjaren vooral ervaring hebben opgedaan met een dictatoriaal regime en weinig met gemeenschappelijke Europese instituties.

Voor de na-oorlogse generaties in Denemarken, Groot-Brittannië en lerland ligt dit geheel anders, hoewel deze landen ook pas in 1973 tot de EU toetreden. In deze landen is om die reden eerst gekeken naar een tweedeling voor-1955 versus na-1965. Het idee hierachter is dat alleen generaties uit deze drie landen die na 1965 zijn geboren de samenwerking binnen de EU (toetreding in 1973) nog tijdens hun jeugdjaren ervaren. Deze specificatie levert in alle drie de lidstaten geen wezenlijke andere resultaten op dan de tweedeling voor- versus na-oorlogs, zodat

${ }^{19}$ Deze conclusie lijkt moeilijk te rijmen met de gegevens in figuur 8.1 en 8.2 . Een blik op tabel 8.10 laat echter zien dat de oorzaak voor deze discrepantie moet worden gezocht in het feit dat de figuren gebaseerd zijn op gewogen data. Vooral in kleinere lidstaten worden geen systematische verschillen tussen jong en oud gevonden, terwijl in de grotere landen die verschillen vaak wel opduiken. Bij het wegen van de data wordt aan de respondenten uit de grote landen een groter gewicht toegekend, waardoor het logisch is dat de figuren wel intergenerationele verschillen taten zien maar de analyses op het niveau van lidstaten niet. 
in deze drie landen uiteindelijk gewoon de tweedeling voor-versus na-oorlogs is toegepast zoals dat ook is gebeurd in de andere zes lidstaten.

De verwachting is dat de steun voor de EU in de na-oorlogse generatie groter is dan in de voor-oorlogse generatic. De respondenten met een geboortejaar tussen 1930 en 1945 zijn bewust buiten beschouwing gelaten, omdat de jeugdervaringen van die groep in zekere zin een mix is van slechte en goede herinneringen - dit wil zeggen, een mix van divisive memories en a sense of positive participation in substantial common activities. Aangezien er voor deze analyse slechts twee groepen hoeven te worden vergeleken, zijn de gemiddelde scores op de steun-indicatoren binnen die twee groepen met elkaar vergeleken. ${ }^{104}$ In tabel 8.11 staan de verschillen voor alle lidstaten in vijf verschillende periodes op een rijtje. Bij elk verschil is aangegeven of er sprake is van een significant verschil. Positieve verschillen duiden er op dat de na-oorlogse generatie gemiddeld positiever over de EU oordeelt dan de voor-oorlogse generatie. Negatieve verschillendie we idealiter niet zouden mogen vinden - duiden er op dat de voor-oorlogse generatie beter scoort.

Tabel 8.1I Verschil in steun voor EU tussen voor $(<1930)$ en na-oorlogse generatie $>1945)$ binnen negen lidstaten, 1973-1998

\begin{tabular}{|c|c|c|c|c|c|c|c|c|c|}
\hline & FR & $\mathbf{B E}$ & NL & WD & IT & LU & DK & EI & GB \\
\hline periode: & \multicolumn{9}{|c|}{ unif } \\
\hline 73-78 & $-.02^{*}$ & .22 & .15 & .12 & $.05^{*}$ & $.08^{*}$ & -.19 & $-.03^{*}$ & $.09^{\bullet}$ \\
\hline $79-83$ & $-.01^{*}$ & .10 & -.07 & $-.01^{*}$ & .06 & -.12 & -.25 & $.03^{*}$ & $.04^{*}$ \\
\hline $84-88$ & -.06 & .08 & $-.03^{\bullet}$ & $.04^{*}$ & .14 & -.19 & -.28 & .07 & $.03^{*}$ \\
\hline $89-93$ & $-.04^{*}$ & $.05^{*}$ & .15 & $.01^{*}$ & .17 & -.16 & $-.05^{\star}$ & .17 & .23 \\
\hline $94-5$ & $.00^{*}$ & .12 & .14 & .13 & 20 & $-.10^{*}$ & $-.10^{\circ}$ & .17 & .43 \\
\hline \multicolumn{10}{|c|}{ periode: } \\
\hline $73-78$ & 7090 & 1812 & 1108 & .11 & $.03 *$ & $.05^{*}$ & -.21 & $.03^{*}$ & $1 \mathrm{e}+09$ \\
\hline $79-83$ & 7040 & 1108 & 0713 & $.03 *$ & .07 & $.00^{*}$ & -.18 & .10 & \\
\hline $84-88$ & 5 & 13 & 12 & .05 & .10 & $-.02^{*}$ & -.22 & .07 & \\
\hline $89-93$ & & & & $.03^{*}$ & .10 & $-.01^{*}$ & $-.03 *$ & .10 & \\
\hline $94-98$ & & & & 08 & .12 & $-.02^{*}$ & -.05 & .11 & \\
\hline
\end{tabular}

Bron: zie tabel 5.1 en 5.2 , exclusief ECS70; ${ }^{*}=$ niet significant, t-test: $\mathrm{p}>.05$.

De resultaten van deze analyse geven geen aanleiding om op onze eerdere negatieve conclusie over het bestaan van systematische intergenerationele verschillen terug te komen. Ook tussen

${ }^{104}$ Opnieuw is een ondergrens van minimaal 500 personen per generatie aangehouden. Voor het berekenen van de gemiddelde score per generatie zijn de antwoorden van respondenten op de unif-vraag als volgt gescoord: ( 1 ) erg tegen; (2) tegen; (3) weet niet / geen antwoord; (4) voor; (5) erg voor. De individuele antwoorden op de memvraag zijn als volgt gescoord: (1) slechte zaak; (2) goed, noch slecht/geen mening / geen antwoord; (3) goede zaak. 
voor- en na-oorlogse generaties blijken binnen verschillende lidstaten geen systematische verschillen op te treden. De vele positieve verschillen ten spijt, zijn er ook de nodige significant negatieve en niet-significante verschillen te vinden. Vooral in Luxemburg en Denemarken is de steun voor de EU onder leden van voor-oorlogse generaties niet zelden groter dan onder leden van de na-oorlogse generatie. Het oorspronkelijke idee van Inglehart dat er een waterscheiding zou bestaan tussen voor- en na-oorlogse generaties op het punt van de steun voor de EU is dus empirisch onhoudbaar.

\section{Tot slot}

Hoewel in sommige jongere generaties inderdaad positiever over de EU oordelen dan oudere generaties, geldt dit zeker niet voor alle lidstaten. Met name in Luxemburg en Denemarken lijken op sommige momenten de ouderen zelf significant positiever dan de jongeren. Ingleharts hypothese over systematische intergenerationele verschillen dient dan ook te worden verworpen. Ook een alternatieve formulering van de hypothese in termen van systematische verschillen tussen voor- en na-oorlogse generaties doorstaat de empirische toetsing niet.

\subsection{Macro-niveau: politieke waardenklimaat en cognitive mobilization}

Ondanks de ontnuchterende resultaten die de toetsing van Ingleharts theorie aan de empirie in de vorige twee paragrafen opgeleverd heeft, zal in deze pragraaf nog kort worden stil gestaan bij de macro-hypothesen. Inglehart verwacht dat de mate van publieke steun voor de EU in een land (onder andere) een functie is van het politieke waardenklimaat en het niveau van politieke vaardigheden in dat land. Om de mate waarin het politieke waardenklimaat in een land postmaterialistisch is te kunnen meten, is gekeken naar het percentage postmaterialisten. ${ }^{105}$ In een land met een meer postmaterialistisch klimaat zou supranationale politieke samenwerking minder problemen opleveren. Veranderingen in het waardenklimaat van een land zouden dan ook zichtbaar moeten worden in veranderingen in de steun voor de EU. Om de mate van cognitive mobilization in een land te meten is gekeken naar het gemiddeld niveau van politieke vaardigheden. Het achterliggende idee is, dat naarmate er in een land steeds meer mensen wonen die in staat zijn om relatief abstracte politieke informatie om te gaan, het begrip en de waardering voor de EU onder de bevolking ook zal toenemen. De hypothesen die hieronder getoetst zullen worden, luiden als volgt:

${ }^{10 s}$ Het werken met een verschilscore waarbij ook rekening wordt gehouden met het percentage materialisten leidt niet tot andere conclusies. Voor zover gebruik wordt gemaakt van het 12 -item-instrument is overigens gewerkt met een gemiddelde index-score. 
Hypothese 4: Naarmate het waardenklimaat in een land post-materialistischer is, des te groter is de publieke steun voor de EU.

Hypothese 5: Naarmate het gemiddelde niveau van politieke vaardigheden (de mate van cognitive mobilization) in een land hoger is, des te groter is de publieke steun voor de EU.

In deze paragraaf zal eerst worden nagegaan in hoeverre de verschillen in publieke steun voor de EU tussen de lidstaten kunnen worden verklaard uit verschillen in het politieke waardenklimaat en verschillen in het niveau van politieke vaardigheden (de mate van cognitive mobilization) tussen de lidstaten. Vervolgens zal worden nagegaan in hoeverre veranderingen in de publieke steun voor de EU binnen de lidstaten samenhangen met veranderingen in het waardenklimaat en veranderingen in het niveau van politieke vaardigheden. Als zou blijken dat veranderingen en verschillen in het waardenklimaat en het niveau van politieke vaardigheden de veranderingen en verschillen in de publieke steun voor de EU binnen respectievelijk tussen lidstaten kunnen verklaren, dan zal nog moeten worden nagegaan in hoeverre beide effecten onafhankelijk van elkaar optreden. ${ }^{106}$

\section{Verschillen tussen lidstaten}

In hoeverre zijn de verschillen in de publieke steun voor de EU tussen de EU-lidstaten terug te voeren op verschillen in het politieke waardenklimaat en de mate van cognitive mobilization? Om daar achter te komen zijn voor elke lidstaat in 9 periodes van een of twee jaar (1973-1993)meestal vier opeenvolgende Eurobarometers tezamen - scores op de afhankelijke en onafhankelijke variabelen berekend (gewogen gegevens). ${ }^{107}$ Nationale scores die op minder dan 500 respondenten zijn buiten de analyse gelaten.

$\mathrm{Er}$ is nagegaan in hoeverre aan de hand van informatie over het niveau van vaardigheden en het meer of minder postmaterialistische waardenklimaat in de lidstaten, de verschillen in de

${ }^{106}$ De correlatie tussen het niveau van politicke vaardigheden en postmaterialisme op geaggregeerd-niveau bedraagt overigens,$+ 72(\mathrm{~N}=117)$. Onder constanthouding van het meetmoment bedraagt de correlatie,+ 70 , en onder constant houding van de nationale context,+ 68 . Het niveau van politieke vaardigheden en een meer of minder postmaterialistisch waardenklimaat blijken dus inderdaad nauw met elkaar verbonden op macro-niveau. Het is verder erg geruststellend dat er in de data sterke aanwijzingen zijn te vinden voor de juistheid van Ingleharts centrale verwachtingen dat het niveau van politieke vaardigheden in de loop der tijd stijgt, alsmede het percentage postmaterialisten in de loop der tijd groeit. De correlatic tussen jaartal en het gemiddeld niveau van politieke vaardigheden respectievelijk de mate waarin het waardenklimaat postmaterialistisch is - onder constanthouding van de nationale context - bedraagt maar liefst,+ 52 respectievelijk,+ 55 .

${ }^{107}$ Voor de berekening van de nationale scores die gebruikt zijn in de macro-analyse is slechts gèbruik gemaakt van studies die meetinstrumenten bevatten voor zowel beide onafhankelijke variabalen (postmaterialisme en politieke vaardigheden), en de mem en unif-vraag. Dit betekent dat slechts de volgende studies beschikbaar waren: ECS73, EB10 (1978), EB12-33 (1979-1990) en EB35-40 (1991-1993). De surveys die in de volgende periodes vallen zijn bij elkaar gevoegd, te weten: 1973, 1978-9 (EB10 en EB12), 1980-1 (EB13-16), 1982-3 (EB17-20), 1984-5 (EB21-24), 1986-7 (EB25-28), 1988-9 (EB29-32), 1990-1 (EB33 en EB35-36) en 1992-3 (EB37-40). 
publieke steun voor de EU tussen de lidstaten kunnen worden verklaard. Daartoe zijn partiele correlaties berekend tussen de ene onafhankelijke variabele (waardenklimaat of cognitive mobilization) aan de ene kant en de steun voor de EU aan de andere kant, onder constanthouding van het meetmoment en de andere onafhankelijke variabele. Het constanthouden van het meetmoment is nodig om de invloed van ander factoren (verkiezingen, conjunctuur, enzovoort) op de steun voor de EU in de lidstaten uit te schakelen. Als met de invloed van dit soort factoren geen rekening wordt gehouden, dan zou mogelijkerwijs ten onrechte geen verband kunnen worden gevonden tussen verschillen in het waardenklimaat en de mate van cognitieve mobilisatie enerzijds en verschillen in publieke steun voor de EU anderzijds.

Tabel 8.12 Publieke steun voor de EU bij waardenklimaat en cognitive mobilization op het niveau van lidstaten, $1973-1993$

\begin{tabular}{|llll|}
\hline Publieke steun voor de EU: & unif & $(\mathrm{N})$ & $\mathbf{m e m}(\mathrm{N})$ \\
\hline $\begin{array}{l}\text { bij waardenklimaat (postmaterialisme) } \\
\text { o.c.v. meetmoment en cognitive mobilization }\end{array}$ & -.19 & $(97)$ & $.00^{*}(97)$ \\
$\begin{array}{l}\text { cognitive mobilization (niveau van politieke vaardigheden) } \\
\text { o.c.v meetmoment en waardenklimaat }\end{array}$ & $-.10^{*}$ & $(97)$ & $.05 *(97)$ \\
\hline
\end{tabular}

Bron: 1973, 1978-9 (EB10 en EB12), 1980-1 (EB13-16), 1982-3 (EB17-20), 1984-5 (EB21-24), 1986-7 (EB25-28), 1988-9 (EB29-32), 1990-1 (EB33 en EB35-36) en 1992-3 (EB37-40); * = niet significant p $>05$

De correlaties in tabel 8.12 bestendigen het beeld dat in de rest van dit hoofdstuk al opgetekend is. Ook nu weer is er weinig steun te vinden voor Ingleharts theorie. Er blijkt geen significant positief verband te bestaan tussen verschillen in de publieke steun voor de EU tussen de lidstaten aan de ene kant, en verschillen in het waardenklimaat en de mate van cognitive mobilization aan de andere kant. Integendeel zelfs. Voor zover er al een significant verband gevonden wordt, is er sprake van een negatieve relatie tussen een meer postmaterialistisch waardenklimaat en steun voor de EU.

De zoektocht naar de achtergronden van de verschillen in steun voor de EU tussen de EUlidstaten op een bepaald tijdstip moet in elk geval worden voortgezet. Deze verschillen zijn, zoveel is duidelijk, in elk geval niet primair te begrijpen in termen van Ingleharts SilentRevolution-theorie.

\section{Veranderingen binnen de lidstaten}

Het feit dat de verschillen tussen de lidstaten nauwelijks verband houden met het waardenklimaat en het niveau van de politieke vaardigheden in een land, wil nog niet zeggen dat veranderingen in de publieke opinie binnen de lidstaten niet zouden kunnen samenhangen met veranderingen 
in het waardenklimaat en/of de mate van cognitive mobilization. Daarom is ook nagegaan hoe de veranderingen in de twee onafhankelijke variabalen en de afhankelijke variabele tussen twee opeenvolgende periodes met elkaar samenhangen (tabel 8.13).

Tabel 8.13 Veranderingen in de publieke steun voor de EU bij veranderingen in het waardenklimaat (1973-1994) en veranderingen in de mate van cognitive mobilization, 1978-1993

\begin{tabular}{|lllll|}
\hline Veranderingen in de publieke steun voor de EU: & unif & (N) & mem & (N) \\
\hline veranderingen in het waardenklimaat - o.c.v lidstaat & .42 & $(85)$ & .42 & $(85)$ \\
o.c.v. lidstaat en cognitive mobilization & .42 & $(85)$ & .43 & $(85)$ \\
o.c.v. lidstaat en inflatic & $.03^{*}$ & $(85)$ & $.04^{*}$ & $(85)$ \\
& & & & \\
.bij niveau van politieke vaardigheden - o.c.v. lidstaat & $.07^{*}$ & $(85)$ & $.07^{*}$ & $(85)$ \\
o.c.v. lidstaat en waardenklimaat & $-.01^{*}$ & $(85)$ & $.09^{*}$ & $(85)$ \\
o.c.v. lidstaat en inflatie & $.02^{*}$ & $(85)$ & $.03^{*}$ & $(85)$ \\
\hline
\end{tabular}

Bron: 1973 (basisjaar), 1978-9 (EB10 en EB12), 1980-1 (EB13-16), 1982-3 (EB17-20), 1984-5 (EB21-24), 1986-7

(EB25-28), 1988-9 (EB29-32), 1990-1 (EB33 en EB35-36) en 1992-3 (EB37-40); * = niet significant p>.05

De correlaties in tabel 8.13 geven aan dat veranderingen in de publieke steun voor de EU binnen de lidstaten een sterke, significant positieve samenhang vertonen met veranderingen in het waardenklimaat. Dit mag gerust verrassend genoemd worden in het licht van de resultaten uit de vorige paragrafen. Als het waardenklimaat in een land postmaterialistischer wordt, dan lijkt de steun voor de EU ook toe te nemen. Veranderingen in de publieke steun voor de EU binnen de lidstaten vertonen echter geen positieve samenhang met een stijging van het niveau van politieke vaardigheden zoals gespecificeerd in hypothese 5 .

De vraag is nu, hoe de opmerkelijke samenhang tussen veranderingen in het waardenklimaat en veranderingen in de steun voor de EU op macro-niveau valt te verklaren? De analyses op micro- en meso-niveau gaven immers weinig hoop op succes, en ook de verschillen tussen lidstaten bleken geen enkel verband te houden met de verschillen in het waardenklimaat tussen de lidstaten. De oplossing van deze puzzel blijkt te zitten in het meetinstrument dat is gebruikt om postmaterialisme te meten.

Het is bekend dat het 4-iteminstrument om postmaterialisme te meten erg gevoelig is voor stijgende en dalende inflatiecijfers (Inglehart, 1990: 94-9). Een van de vier items waaruit respondenten mogen kiezen is fight rising prices (prijsstijgingen tegengaan). Als de inflatie stijgt, dan groeit het aantal mensen dat dit materialistisch item uit de vier doelstellingen kiest. Op het niveau van lidstaten is het dus logisch dat het percentage materialisten stijgt en het percentage postmaterialisten daalt als de inflatie stijgt; en omgekeerd als de inflatie daalt. Uit eerder onderzoek naar de dynamiek van de publieke steun voor de EU is bekend dat de veranderingen in de steun ook sterk samenhangen met de economische conjunctuur in de lidstaten (Dalton en 
Eichenberg, 1991, 1993; Anderson en Kaltenthaler, 1996).

Daarom is uiteindelijk nagegaan in hoeverre de gevonden relatie tussen veranderingen in de steun en het waardenklimaat binnen lidstaten is te wijten aan de invloed van de inflatie op beide grootheden. Daartoe zijn de gemiddelde inflatiecijfers voor de twaalf lidstaten in de onderscheiden periodes op een rijtje gezet en is nagegaan in hoeverre de relatie tussen veranderingen in het waardenklimaat en veranderingen in de steun voor de EU binnen de lidstaten stand houdt, als gecorrigeerd wordt voor de invloed van de inflatie op de veranderingen in de steun. ${ }^{104}$

De uitkomst van deze analyse laat geen enkele ruimte voor twijfel over de achtergrond van de positieve samenhang tussen veranderingen in het waardenklimaat aan de ene kant, en veranderingen in de publieke steun voor de EU aan de andere kant. Er is zeer nadrukkelijk sprake van een schijnsamenhang die te wijten is aan het feit dat zowel veranderingen in de steun, als de veranderingen in het waardenklimaat sterk afhankelijk zijn van de inflatiecijfers in de verschillende landen.

Om tegemoet te komen aan de problemen die optreden bij het gebruik van het 4-item instrument, is ook nog een analyse uitgevoerd waarbij gebruik is gemaakt van metingen op basis van het meer betrouwbare, en minder conjunctuurgevoelige 12-item instrument. De basis van tabel 8.14 wordt gevormd door de veranderingen die optreden in de gemiddelde scores tussen 1973 en 1988 in de twee onafhankelijke variabelen en twee steun-indicatoren. Deze keer is de scrap-indicator naast de mem-indicator gebruikt, omdat de unif-vraagtekst uit het ECS73-onderzoek sterk afwijkt van de formulering uit 1988 (EB29) hetgeen de vergelijkbaarheid uiteraard niet ten goede komt. In de tabel is voor elke lidstaat per variabele aangegeven hoe groot het verschil tussen de twee gemiddelden is, alsmede of er sprake is van een significant verschil. Indien er sprake is van een significant verschil, dan is de richting van de verandering tussen 1973 en 1988 ook aangeduid. Doordat Griekenland, Spanje en Portugal niet in ECS73 zitten, blijft de vergelijking beperkt tot negen lidstaten.

Uit tabel 8.14 blijkt dat afgaande op de scores op 12 item-instrument niet in alle lidstaten het waardenklimaat tussen 1973 en 1988 postmaterialistischer is geworden. Alleen in WestDuitsland, Denemarken, Groot-Brittannië en Italië is sprake van een postmaterialistischer waardenklimaat. In de andere lidstaten treedt of geen significante verandering in het waardenklimaat op, dan wel is het klimaat zelfs materialistischer (Nederland, Ierland, Belgie) geworden. Behalve in Luxemburg, neemt tussen 1973 en 1988 wel in alle landen het gemiddeld niveau van politieke vaardigheden toe.

1et Eurostat (1978-1993) Monthly Bulletin of General Statistics, Luxemburg: European Union. 
Tabel 8.14 Veranderingen publieke steun woor de EU bij veranderingen waardenklimaat (I2-iteminstrument) en veranderingen niveau van politieke vaardigheden, 1973-1988

\begin{tabular}{|c|c|c|c|c|c|c|c|c|}
\hline \multirow[b]{2}{*}{ West-Duitsland } & \multicolumn{2}{|c|}{$\begin{array}{l}\text { Veranderingen in: } \\
\text { waardenklimaat } \\
\text { postmat / mat }\end{array}$} & \multicolumn{2}{|c|}{$\begin{array}{l}\text { polit. vaardigh. } \\
\text { hoog / laag }\end{array}$} & \multicolumn{2}{|c|}{$\begin{array}{l}\text { steun- mem } \\
\text { hoog / laag }\end{array}$} & \multicolumn{2}{|c|}{$\begin{array}{l}\text { steun- scrap } \\
\text { hoog / laag }\end{array}$} \\
\hline & pmat &,+ 58 & hoog & +.14 & laag & -.17 & laag & -.12 \\
\hline Denemarken & pmat & +38 & hoog & +.43 & - & $-.05^{*}$ & - & $-.05^{*}$ \\
\hline Ver. Koninkrijk & pmat & +38 & hoog & +.32 & hoog & +.11 & hoog & +.14 \\
\hline Italie & pmat & +.28 & hoog & +.12 & - & $+.03^{*}$ & - & +.04 \\
\hline Frankrijk & - &,$- 03^{\circ}$ & hoog & +.42 & hoog & +.08 & hoog & +.12 \\
\hline Lexemburg & - &,$- 09 \bullet$ & $\cdot$ & $-.05^{\circ}$ & $\cdot$ & $+.06^{*}$ & $\cdot-4$ & +05 \\
\hline Nederland & mat &,- 09 & hoog & +.47 & hoog & +.13 & hoog & +09 \\
\hline Ierland & mat & -.27 & hoog & +.16 & hoog &,+ 11 & hoog & +.19 \\
\hline Belgie & mat & -.68 & hoog & +.32 & hoog & +.06 & - & $+.05^{*}$ \\
\hline
\end{tabular}

Bron: ECS73 en EB29 (voorjaar 1988), zie tabel 8.4 voor aantallen respondenten; ${ }^{*}=$ niet significant, $t$-test: $p>05$.

Gelet op de veranderingen in de onafhankelijk variabelen kan er strikt genomen op basis van Ingleharts theorie alleen voor West-Duitsland, Denemarken, Groot-Brittannië en Italië een concrete verwachting over de verandering van de steun voor de EU worden geformuleerd. Allen in deze vier landen zou de steun voor de EU gestegen moeten zijn. Uit de tabel blijkt echter dat de publieke steun voor de EU in West-Duitsland tussen 1973 en 1998 is gedaald, in Denemarken en Italie̋ treedt geen verandering op en alleen in Groot-Brittannië is sprake van een stijging.

Dit onderstreept dat veranderingen in de publieke steun voor de EU binnen de lidstaten onmogelijk kunnen worden verklaard uit de veranderingen in het waardenklimaat en de mate van cognitive mobilization in de lidstaten.

\section{Tot slot}

Het verhaal wordt eentonig. Ook op macro-niveau blijft weinig over van Ingleharts theorie. Zowel de hypothesen over de relatie tussen publieke steun en het politieke waardenklimaat, als de hypothese over de relatie tussen publieke steun en het niveau van politieke vaardigheden moeten worden verworpen. Aan de hand van het waardenklimaat en de mate van cognitive mobilization kan onmogelijk een afdoende verklaring worden gegeven voor de veranderingen en verschuivingen in de publieke steun voor de EU op het niveau van de lidstaten.

\subsection{Ingleharts Silent Revolution: eindoordeel}

Ingleharts opmerkelijke voorspelling in het midden van de jaren zestig dat de samenwerking 
binnen de EU in de toekomst op steeds meer begrip zou kunnen gaan rekenen aangezien jongere generaties in de lidstaten veel meer zouden zien in West-Europese integratie dan de oudere generaties, blijkt drie decennia later op drijfzand gebouwd. De intergenerationele verschillen in steun voor de EU tussen jonge en oude generaties die Inglehart in het midden van de jaren zestig ontdekte, zijn namelijk allang niet meer aanwezig in alle lidstaten. Wel zijn de leden van die jongere generaties postmaterialistischer en beschikken ze over meer politieke vaardigheden dan de leden van de oudere generaties (Inglehart, 1990; 1997), maar hierboven hebben we gezien dat dit zich niet (meer) vertaalt in systematische intergenerationele verschillen op het punt van de steun voor de EU (zie ook: Wessels, 1995a: 121-4). Hypothesen over het optreden van systematische intergenerationele verschillen in de steun voor de EU moesten hierboven dan ook verworpen worden.

De aan de voorspelling van intergenerationele verschillen ten grondslag liggende postmaterialisme-hypothese die stelt dat de steun voor de EU op individueel niveau positief beînvloedt wordt door een meer post-materialistische waarde-orięntatie moet ook worden verworpen. Deze hypothese blijkt alleen onder specifieke omstandigheden houdbaar. De andere hypothese die betrekking heeft op de individuele attitudevorming is uiteindelijk de enige hypothese die de empirische toets wel kan doorstaan. De steun voor de EU op individueel niveau blijkt in alle landen en in verschillende periodes positief samen te hangen met het niveau van politieke vaardigheden. Dit suggereert dat de vraag of een individu de EU steunt inderdaad voor een deel wordt bepaald door de vraag of iemand in staat is om met abstracte politiek informatic om te gaan.

De macro-hypothesen waarin op het niveau van de lidstaten een relatie tussen publieke steun voor de EU aan de ene kant en het waardenklimaat en de mate van cognitie mobilization aan de andere kant wordt voorondersteld, blijken ook empirisch onhoudbaar. De primaire oorzaken voor de in hoofdstuk 5 beschreven veranderingen en verschuivingen in de publieke steun voor de EU op het niveau van de lidstaten, zoveel is duidelijk, moeten dus nadrukkelijk niet in Ingleharts Silent Revolution-theorie worden gezocht. Deze theorie en de daaruit afgeleide hypothesen blijken geen wezenlijke (zelfstandige) bijdrage te kunnen leveren aan onze speurtocht naar de diepere achtergronden van de publieke steun voor de EU (zie ook: Janssen, 1991; Gabel, 1998: 112). Dit magere inzicht vormt de belangrijkste conclusie van dit hoofdstuk. 
-

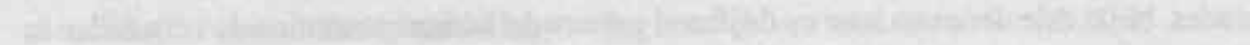

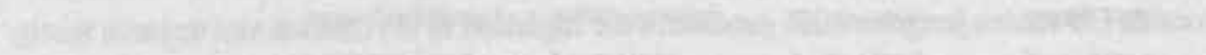

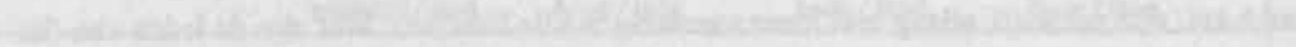

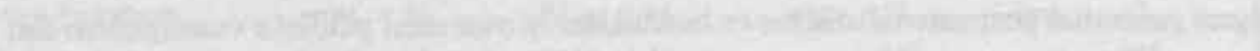
r

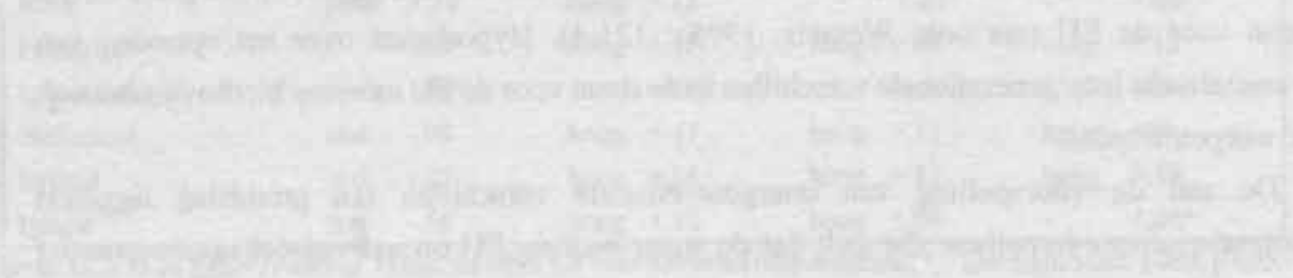

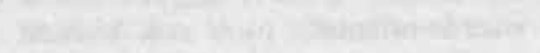

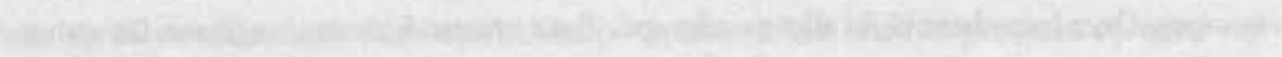

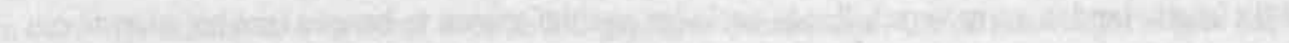

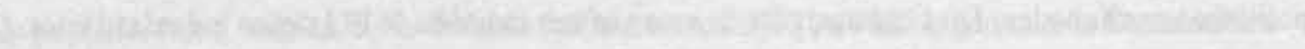

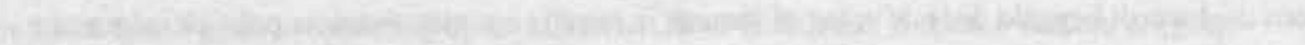

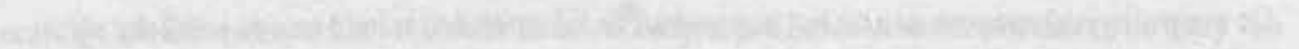

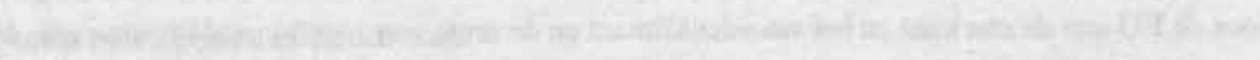

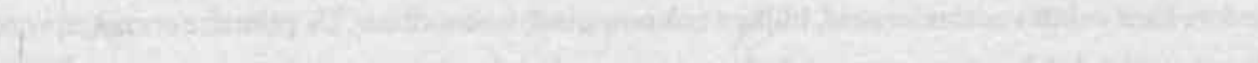

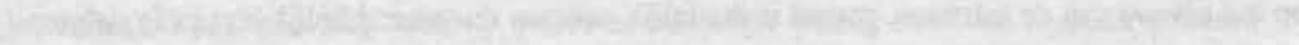

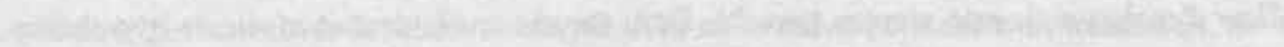

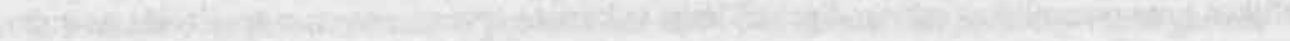

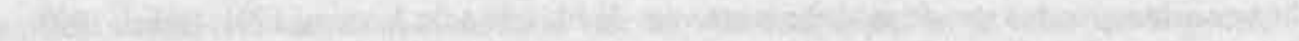




\section{Zallers RAS-model: empirische toetsing}

\subsection{Inleiding}

Dit hoofdstuk bevat de resultaten van de empirische toetsing van de in hoofdstuk 7 opgestelde hypothesen over de rol die de politieke elite en politieke partijen spelen bij de vorming van de publieke opinie ten aanzien van de EU. De hypothesen zijn gebaseerd op het Receive-AcceptSample-model (RAS-model) van John Zaller.

Allereerst zal de relatie tussen de stemming binnen het nationale elite discours over de EU en de publieke opinie over de EU op het niveau van lidstaten (macro-niveau) worden getoetst (9.2). De primaire vraag daarbij is of de mate van publieke steun voor de EU in een lidstaat inderdaad afhankelijk is van de stemming binnen het elite discours over de EU. In dat kader zal tevens uitgebreid stilgestaan moeten worden bij de dataproblemen die een recht-toe-recht-aan toetsing van de hypothesen bemoeilijken.

Vervolgens zal worden nagegaan in hoeverre de partij-aanhang (meso-niveau) van verschillende partijen zich door het elite discours als zodanig in hun land laten leiden, dan wel zich bij voorkeur laten souffleren door hun favoriete politieke partij (9.3). In dit verband is de belangrijkste vraag in hoeverre eventuele partijpolitieke scheidslijnen uit het elite discours terug te vinden zijn in de publieke opinie binnen de lidstaten. In paragraaf 9.4 wordt aandacht besteed aan de vraag of de mate waarin individuele partij-aanhangers zich laten souffleren door hun partij. afhankelijk is van de mate waarin zij zich identificeren met een politieke partij. Het idee daarachter is dat partij-aanhangers die zich meer betrokken voelen bij een partij meer oor voor partijstandpunten plegen te hebben dan aanhangers die zich minder sterk met een partij identificeren. In de afsluitende paragraaf wordt een eindoordeel gegeven over de bruikbaarheid van de inzichten uit Zallers RAS-model ter vergroting van het inzicht in de oorzaken van de verschillen in de publieke steun voor de EU binnen respectievelijk tussen de lidstaten. In dat kader zal ook expliciet aandacht worden besteed aan twee alternatieve verklaringen die strikt genomen ook verenigbaar zijn met de uitkomsten van de empirische analyses in dit hoofdstuk.

Voor de meting van de publieke steun zal in dit hoofdstuk vooral gebruik worden gemaakt van de unif-indicator, omdat bij de empirische toetsing dit keer ook USIA-data uit de jaren vijftig gebruikt zullen worden. In de USIA-studies komt alleen de unif-indicator voor. Voor een aantal 
analyses dat betrekking heeft op de periode na $1973 \mathrm{zal}$ echter ook een beroep op de memindicator worden gedaan. ${ }^{109}$

\subsection{Macro-niveau: elite discours en publieke steun}

In deze paragraaf staat de publieke steun voor de EU op het niveau van de lidstaten centraal. De vraag is in hoeverre de veranderingen in de steun binnen de lidstaten, alsmede de verschillen tussen de lidstaten zijn te verklaren uit verschillen en veranderingen in de stemming van het elite discours over de EU binnen respectievelijk tussen de lidstaten. Alvorens de resultaten van de empirische toetsing te bespreken zal echter aandacht besteed moeten worden aan het begrip elite discours en aan de manier waarop de stemming in het elite discours over de $E U$ kan worden gemeten.

De publieke steun voor de EU in een land is volgens het RAS-model primair afhankelijk van de inhoud van het zogeheten elite discours over de EU. De term elite slaat op:

"The "others" on whom we depend, directly or indirectly, for information about the world are, for the most part, persons who devote themselves full time to some aspect of politics or public affairs - which is to say, political elites. These elites include politicians, higher-level government officials, journalists, some activists, and many kinds of experts and policy specialists. Even when we learn from friends or family members about some aspect of public affairs, often we may still be secondhand consumers of ideas that originated more distantly among some type of elite." (Zaller, 1992: 6)

Deze zogeheten politieke elites proberen politieke feiten en gebeurtenissen te vertalen voor de burgers in hapklare brokken, waardoor:

"The information that reaches the public is never a full record of important events and developments in the world. It is, rather, a highly selective and stereotyped view of what has taken place. It could hardly be otherwise. But even if it could, the, the public would have little desire to be kept closely informed about the vast world beyond its personal experience. It requires news presentations that are short, simple, and highly thematic - in a word stereotyped." (Zaller, 1992: 7);

en:

"The political information carried in elite discourse is, as we have seen, never pure. It is

${ }^{10} \mathrm{~B}$ ij nagenoeg geen enkele analyse in dit hoofdstuk kon gebruik worden gemaakt van de scrap-indicator. Juist in die jaren (1972-1979 en de combinatic 1986/1992) waarvoor metingen van de onafhankelijke variabelen voorhanden waren, bleken vaak geen scrap-scores voorhanden te zijn. 
rather an attempt by various types of elite actors to create a depiction of reality that is sufficiently simple and vivid that ordinary people can grasp it. This "information" is gemainely information in the sense that it consists of what may be assumed to be sincere attempts to capture what is most important about what is happening in the world and to convey it in proper perspective. But it is never "just information, "because it is unavoidably selective and unavoidably enmeshed in stereotypical frames of reference that highlight only a portion of what is going on." (Zaller, 1992: 13)

Het zijn dit soort stereotiepe, vereenvoudigde en allerminst objectieve opinies over, onder andere, het EU-issue die in de massamedia verschijnen en die het elite discours over de EU in een lidstaat vormen. In het geval van het EU-issue bestaat de elite onder andere uit: ministers, Europarlementariërs, EU-Commissarissen, nationale parlementariërs, journalisten, lobbyisten, ambtenaren en andere mensen die zich full time met de EU bezighouden. Gelukkig is er onder de elites bijna altijd wel sprake van tegenstrijdige belangen zodat het voor de massamedia mogelijk is om verschillende interpretaties van EU-zaken voor het voetlicht te brengen. Het leveren van een bijdrage aan het elite discours over de EU staat in principe open voor iedereen die in de ogen van de massamedia een zeker gezag op het terrein van de EU uitdraagt.

Het elite discours heeft in onze hedendaagse samenleving een heel duidelijke functie doordat het politieke zaken binnen handbereik brengt die normaliter buiten het gezichtsveld of bevattingsvermogen van "gewone" burgers plegen te vallen. Op die manier worden burgers in staat gesteld:

"...to form conceptions of and, more importantly, opinions about events that are beyond their full personal understanding." (Zaller, 1992: 14)

Het elite discours bereikt de burgers via de massamedia. De vooronderstelling daarbij is dat burgers in de EU-lidstaten voor politieke berichtgeving primair zijn aangewezen op nationale media. Bij het opstellen van de hypothesen is al aangegeven dat van de vooronderstelling wordt uitgegaan dat nationale politieke partijen en hun vertegenwoordigers in dat kader een bijzonder invloedrijke bron van politieke informatie vormen.

Informatie uit het elite discours is niet neutraal, maar nadrukkelijk gekleurd. Het gaat om feitelijke informatie, gekoppeld aan een evaluatie of interpretatie. Het elite discours over de EU bevat dus zowel positieve als negatieve overwegingen ten aanzien van de EU. De stemming in het elite discours wordt bepaald door de verhouding tussen pro- en contra-EU evaluaties die in de massamedia op een bepaald moment voor het voetlicht komen. Om de hypothesen te toetsen moeten we op de een of andere manier een adequaat meetinstrument construeren, waarmee de verhouding tussen positieve en negatieve opvattingen over de EU in de massamedia in kaart kan worden gebracht. Dit is geen sinecure omdat systematische databestanden over de inhoud van 
de nationale massamedia over de EU niet voorhanden zijn. ${ }^{110}$ Voor de analyses zal dus gebruik worden gemaakt van andere meetinstrumenten die langs een indirecte weg een beeld geven van de stemming in het elite discours over de EU in een lidstaat. In dit onderzoek is er voor gekozen om de stemming primair in kaart te brengen aan de hand van de houdingen van de - naar verwachting - meest invloedrijke en gezaghebbende bronnen in het politieke discours: politieke partijen en hun vertegenwoordigers (partijpolitici).

Dit betekent dat de mening van niet partij-politieke elites buiten beeld blijft bij het bepalen van de stemming in het elite discours. Dit probleem is misschien minder groot dan het op het eerste gezicht lijkt omdat politieke partijen in West-Europa in zekere zin de weerspiegeling zijn van allerlei andere maatschappelijke krachten (vakbonden, werkgevers, milieu-organisaties, enzovoort) en waarden in een land (Lane en Ersson, 1991: 159-73; Aarts, 1995; Knutsen en Scarbrough, 1995: 519-521). In die zin mag worden verwacht dat in de standpunten van partijen ten aanzien van een bepaald issue ook de mening van andere elites die zich met een issue bezighouden doorklinkt. De uiterste consequentie van deze handelwijze zou kunnen zijn dat door alleen te kijken naar de houding van partij-politieke elites, ten onrechte geen relatie wordt gevonden tussen de stemming binnen het elite discours en de publieke steun voor de EU. Dit betekent dat bij het trekken van conclusies eventueel rekening moet worden gehouden met het feit dat voor de meting van de stemming eigenlijk uitsluitend is gekeken naar de meningen van partij-politieke elites.

Hoe uiteindelijk de stemming in het (partij-politieke) elite discours binnen de verschillende lidstaten concreet in kaart is gebracht wordt verder uitgewerkt in subparagraaf 9.2.1, 9.2.2 en 9.2.3. De hypothese die in deze drie subparagrafen aan een empirische toets zal worden onderworpen luidt:

Hypothese 1: Naarmate de stemming binnen het elite discours over de EU in een lidstaat positiever is, des te groter zal de publieke steun voor de EU zijn.

In subparagraaf 9.2.4 zal worden nagegaan in hoeverre deze hypothese uit Zallers RAS-model op macro-niveau empirisch houdbaar is.

\subsubsection{Comparative Party Manifesto-data}

In eerste instantie zal voor de meting van de stemming binnen het elite discours over de EU in de verschillende lidstaten gebruik worden gemaakt van data verzameld in het kader van de werkzaamheden van de zogenaamde Party Manifesto Research Group (Volkens en Klingemann, 1991; Budge, Robertson en Hearl, 1987). In het kader van dit onderzoeksproject is gedurende

${ }^{40}$ De enige beperkt bruikbare uitzondering op de regel zal hieronder worden besproken in subparagraaf 9.2.2. 
vele jaren de inhoud van politieke partijprogramma's in diverse West-Europese landen in kaart gebracht. Daarbij hebben de onderzoekers alle "quasi-sentences" uit de programma's gecodeerd. Een zogenaamde "quasi-sentence" is een argument in de zin van "a verbal expression and evaluation of a political idea or issue". Het codeschema bestaat uit 56 verschillende politieke "ideas or issues". Elk argument omvat een evaluatie zodat elk argument is te typeren als positief of negatief ten aan van een van de 56 politieke objecten. De EU is één van de 56 onderscheiden thema's in het uitgebreide codeerschema. De beschikbare dataset gaat voor de meeste landen terug tot de eerste na-oorlogse verkiezingsprogramma's. Dit betekent concreet dat we dus gegevens hebben over het aantal positieve en negatieve evaluaties van de EU in de partijprogramma's van de belangrijkste politieke partijen in de meeste lidstaten vanaf de start van de Unie in 1951/2. Het gebruik van deze dataset brengt ook een aantal ernstige beperkingen en praktische problemen met zich mee.

Een belangrijke beperking is dat er binnen de gebruikte dataset geen informatie voor handen is over Spaanse, Portugese en Griekse partijprogramma's. Een tweede probleem wordt veroorzaakt door het gegeven dat de gebruikte dataset niet verder gaat dan het tweede gedeelte van de jaren tachtig. Dit beperkt de mogelijkheden voor empirische toetsing aanzienlijk. Een derde probleem is dat over het algemeen slechts de programma's van de belangrijkste politieke partijen zijn geanalyseerd. Dat niet alle "kleine" partijen in de analyse zijn meegenomen, valt te billijken vanwege de geringe invloed die deze partijen hoogstwaarschijnlijk hebben op het elite discours. Dit kan echter niet rechtvaardigen dat soms zelfs partijen die meerdere zetels in het nationale parlement bezetten niet zijn meegenomen. Het gesignaleerde probleem speelt vooral in landen met een meer-partijen systeem zoals Nederland, Denemarken, Frankrijk, Italię en Belgiè. Aangezien de kritische geluiden over de EU in deze landen vaak afkomstig zijn van deze kleine partijen - communisten, radicaal links, nationalisten (Hix en Lord, 1997: 50) - is zonder meer sprake van validiteitsprobleem. Zo kan bij het construeren van een index voor de meting van de stemming binnen het elite discours op basis van de standpunten van de grote partijen geheel ten onrechte een beeld van een beeld van unanimiteit ontstaan, dat geen recht doet aan de kritische geluiden van de kleine partijen die ook nadrukkelijk hoorbaar zijn binnen het elite discours.

Een verdere complicatie is dat de metingen van de partijstandpunten geen continu karakter dragen, doch het ritme van de nationale verkiezingen in een land volgen. Dit betekent ook dat de meting van het elite discours in de verschillende lidstaten op verschillende tijdstippen plaats vindt. Hierdoor is het dus bijvoorbeeld onmogelijk om verschuivingen en verschillen in het (partij-politieke) elite discours van jaar tot jaar in beeld te krijgen. Daar kan echter tegen in worden gebracht dat politieke partijen over het algemeen instituties zijn met een stevige ideologische basis (Klingemann, 1995: 189-91). Partijprogramma's vormen in die zin de neerslag 
van een relatief inert gedachtegoed. Partijstandpunten ten aanzien van specifieke issues liggen verankerd in en worden afgeleid uit een relatief stabiel ideologisch kader. Hierdoor is het probleem dat de manifesto-data het ritme van de verkiezingen volgen waarschijnlijk minder groot dan op het eerste gezicht lijkt.

De laatste complicatie betreft het feit dat partijprogramma's slechts het officiēle partijstandpunt van een partij weergeven. Het is vaak onduidelijk in hoeverre het officiële partijstandpunt de praktijk dekt. Zo valt niet uit te sluiten dat in de alledaagse politieke praktijk (een deel van) de fractie in het parlement een andere koers vaart zonder dat daarvan ook maar iets in het partijprogramma terug te vinden is. Bovendien kan door het simpel turven van quasisentences gemakkelijk een vertekend beeld van het partijstandpunt ontstaan. Zo kan één negatief argument in een programma belangrijker zijn voor de uiteindelijke standpuntbepaling van een partij ten aanzien van de EU dan drie positieve argumenten bij elkaar. Zo kan een partij in zijn programma stellen in principe tegen het EU-lidmaatschap gekant te zijn, om vervolgens (gegeven dat het nationaal EU-lidmaatschap nu eenmaal een feit is) de bestaande samenwerking op drie punten te accorderen. Als men zich enkel baseert op het tellen van pro- en contra-argumenten, dan komt deze partij ten onrechte als pro-EU uit de bus. Dus door te vertrouwen op het tellen van pro- en contra-argumenten in partijprogramma's kan niet worden uitgesloten dat vertekeningen optreden die de bonte politieke werkelijkheid onvoldoende weerspiegelen.

Gelet op alle problemen en bezwaren is het vertrouwenwekkend te constateren dat Ray (1999) vrij recentelijk een relatief sterke samenhang heeft gevonden tussen partijstandpunten ten aanzien van de EU aan de hand van de Comparative Party Manifesto-data enerzijds, en een inventarisatie van partijstandpunten ten aanzien van de EU op basis van een expertsurvey in 17 landen anderzijds. Bovendien is al aangegeven dat niet alle complicaties even ernstig zijn. Derhalve lijkt het gebruik van Party Manifesto-data goed verdedigbaar en mag zelfs worden verwacht dat aan de hand ervan een relatief betrouwbaar en valide beeld kan worden geschetst van de stemming binnen het (partijpolitieke) elite discours over de EU in de lidstaten in de verkiezingsjaren.

\section{Meten}

De uiteindelijke meting van de stemming binnen het elite discours in een lidstaat, verloopt in twee stappen. Allereerst is per partijprogramma vastgesteld of het aantal argumenten voor of tegen de EU overheerst. Er zijn drie verschillende uitkomsten mogelijk, te weten:

1. Tegen: meer argumenten contra-EU dan pro-EU;

2. Verdeeld: evenveel argumenten pro-EU als contra-EU; 


\section{Voor: meer argumenten pro-EU dan contra-EU. ${ }^{\prime \prime \prime}$}

Nadat op bovenstaande wijze de afzonderlijke partijstandpunten zijn vastgesteld, is het zaak uit de standpunten van de diverse partijen in een land een soort nationale index te construeren die de stemming binnen het nationale elite discours weergeeft. De stemming in het elite discours is uiteindelijk als volgt bepaald:

[(antal partijen voor - aantal partijen tegen) / (aantal partijen voor +tegen +verdeeld) $]^{*} 100$

De waarde van deze index kan theoretisch varièren van -100 (alle partijen contra-EU) tot +100 (alle partijen pro-EU).

\section{Toetsing}

Tot nu tot zijn we niet toegekomen aan de centrale vraag of de stemming in het elite discours positief samenhangt met de publieke steun voor de EU. Dit wil zeggen, of de indexwaarden waarmee de stemming binnen het nationale elite discours in de lidstaten worden gemeten inderdaad positief samenhangen met de unif-scores waarmee de publieke steun voor de EU in de lidstaten is gemeten.

Voor zover mogelijk zijn de elite-gegevens uit de negen lidstaten gekoppeld aan gegevens over de publieke steun voor de EU in hetzelfde jaar. Als dat niet mogelijk bleek, zijn de gegevens over het elite discours gekoppeld aan gegevens over de publieke opinie in een naastliggend jaar. De rechtvaardiging voor deze werkwijze is gelegen in het reeds hierboven aangehaalde argument dat verwacht mag worden dat partijstandpunten onderdeel zijn van een relatief inert ideologisch gedachtegoed op basis waarvan verwacht mag worden dat deze partijstandpunten relatief stabiel zijn en zeker niet van jaar tot jaar veranderen. Deze koppeling levert in totaal 70 bruikbare cases in negen lidstaten op. Elke casus is een lidstaat in een bepaald verkiezingsjaar. Voor elk van deze 70 cases beschikken we over een indexwaarde waarmee de stemming binnen het elite discours aan de hand van partijprogramma's in een bepaald verkiezingsjaar wordt gemeten en een meting van de publieke steun voor de EU aan de hand van de unif-indicator uit hetzelfde jaar, een jaar eerder of een jaar later op basis van een of meer surveys. Tabel 9.1 bevat een overzicht van de beschikbare cases.

De empirische gegevens ondersteunen op niet mis te verstane wijze de verwachting dat de publieke opinie over de EU en de stemming binnen het elite discours over de EU op het niveau van lidstaten sterk met elkaar samenhangen. Een correlatie van +.61 geeft aan dat meer dan $35 \%$ van de variatie in de publieke steun voor de EU is te verklaren uit de verschillen in de stemming binnen het elite discours. Dit is tegen de achtergrond van het gebrekkige meetinstrument dat is

"II De vierde logische mogelijkheid, die enkele keren voorkomt, is dat een partijprogramma uberhaupt geen EU. argumenten bevat. Deze partijen zijn verder buiten de berekeningen gelaten. 
gebruikt om de stemming binnen het elite discours te meten een opmerkelijk goed resultaat.

In de bijbehorende figuur 9.1 is duidelijk te zien dat de stemming onder de elites in de negen lidstaten in nagenoeg alle gevallen bijzonder positief is. Alleen de Deense elites detoneren nadrukkelijk. De kritische houding van de Deense elites weerspiegelt zich, zoals verwacht, in een relatief kritische houding van het Deense publiek ten aanzien van de EU.

De resultaten van de eerste empirische test ondersteunen de hypothese dat naarmate de stemming binnen het elite discours in een lidstaat positiever is, de publieke steun voor de EU in die lidstaat ook positiever is. Bij dit resultaat moet wel worden aangetekend dat de empirische test in deze subparagraaf slechts negen lidstaten betrof en dat gegevens over het elite discours in de jaren negentig ontbreken. Mede daarom is nog gezocht naar andere manieren om de stemming binnen het elite discours te meten, zodat aan deze tekortkomingen tegemoet gekomen kan worden.

\subsubsection{Aanvullende toets 1: ratificatiedebatten}

Een van de bezwaren tegen het gebruik van Party Manifesto-data was dat er in de dataset geen gegevens over Spaanse, Portugese en Griekse partijen voor handen waren. Een ander probleem is dat het onduidelijk is in hoeverre partijprogramma's en officiële partijstandpunten de politieke praktijk dekken. Partijstandpunten verwoorden weliswaar de mening van de partij, maar dit wil niet zeggen dat alle leden en politici van een bepaalde partij die mening ook delen en in de praktijk respecteren. Binnen partijprogramma's is er vaak geen ruimte voor verdeeldheid. In de dagelijkse politiek is die ruimte er vaak wel en komt de verdeeldheid boven drijven. Bovendien kunnen er zich omstandigheden voordoen of ontwikkelingen plaatsvinden die de partij nopen het partijstandpunt in een concreet geval of in een bepaalde periode te heroverwegen. Door de stemming in het elite discours te bepalen aan de hand van het gedrag van nationale politieke partijen kan aan beide bezwaren tegemoet worden gekomen.

Hoewel de relatie tussen de nationale politiek en de EU over het algemeen nogal indirect is, zijn de nationale parlementen uiteindelijk de hoeders en bezitters van de (nationale) soevereiniteit. ${ }^{112}$ In die zin vormen zijn ze ook de onmiskenbare pijlers onder het supranationale Europese bouwwerk (Smith, 1996: 13-5). Zonder uitdrukkelijke en expliciete instemming van de nationale volksvertegenwoordigingen is er geen internationale of supranationale samenwerking mogelijk, noch kan die samenwerking door de internationale organisatie zelfstandig worden geintensiveerd of uitgebreid. Over de overdracht van bevoegdheden en het

112 De nationale parlementen zijn de Herren der Vertrage zoals door het Bundesverfassunggericht is bepaald in haar arrest (1993) over de grondwettigheid van het Verdrag van Maastricht. 
Publieke steun $\mathbf{x}$ elite discours (party manifesto-data)

Correlatie

N

sign

61

70

.00

Overzicht verkiezingsjaren, tussen haakjes eventuele afwijkende jaren voor meting publieke opinie:

Frankrijk (10) 1951 (1952), 1956, 1958 (1957), 1962, 1967, 1973, 1978, 1981, 1986, 1988

Belgie (8) 1954 (1955), 1961 (1962), 1971 (1970), 1974 (1973/5), 1978, 1981, 1985, 1987

Nedertand (8) 1956, 1963 (1962), 1971 (1970), 1972 (1973), 1977 (1978), 1981, 1982, 1986

West-Duitsland (10) 1953 (1952/4), 1957, 1961 (1962), 1965, 1969 (1970), 1972 (1973), 1976, 1980, 1983, 1987

Italie (9) 1953 (1952/4), 1958 (1957), 1963 (1962), 1968 (1967), 1972 (1973), 1976 (1975), 1979, 1983, 1987

Luxemburg (3) 1974 (1973/5), 1979, 1984

Denemarken (9) 1957 (1956), 1973, 1975, 1977, 1979, 1981, 1984, 1987, 1988

lerland (5) 1973,1977 (1978), 1981, 1982, 1987

Groot-Brittannie (8) 1951 (1952), 1955, 1964, 1966 (1965/7), 1974 (1973/5), 1979, 1983, 1987

Figuar 9.I Publieke steun voor de EU bij stemming in elite discours over EU in negen lidstaten (195/-1988)

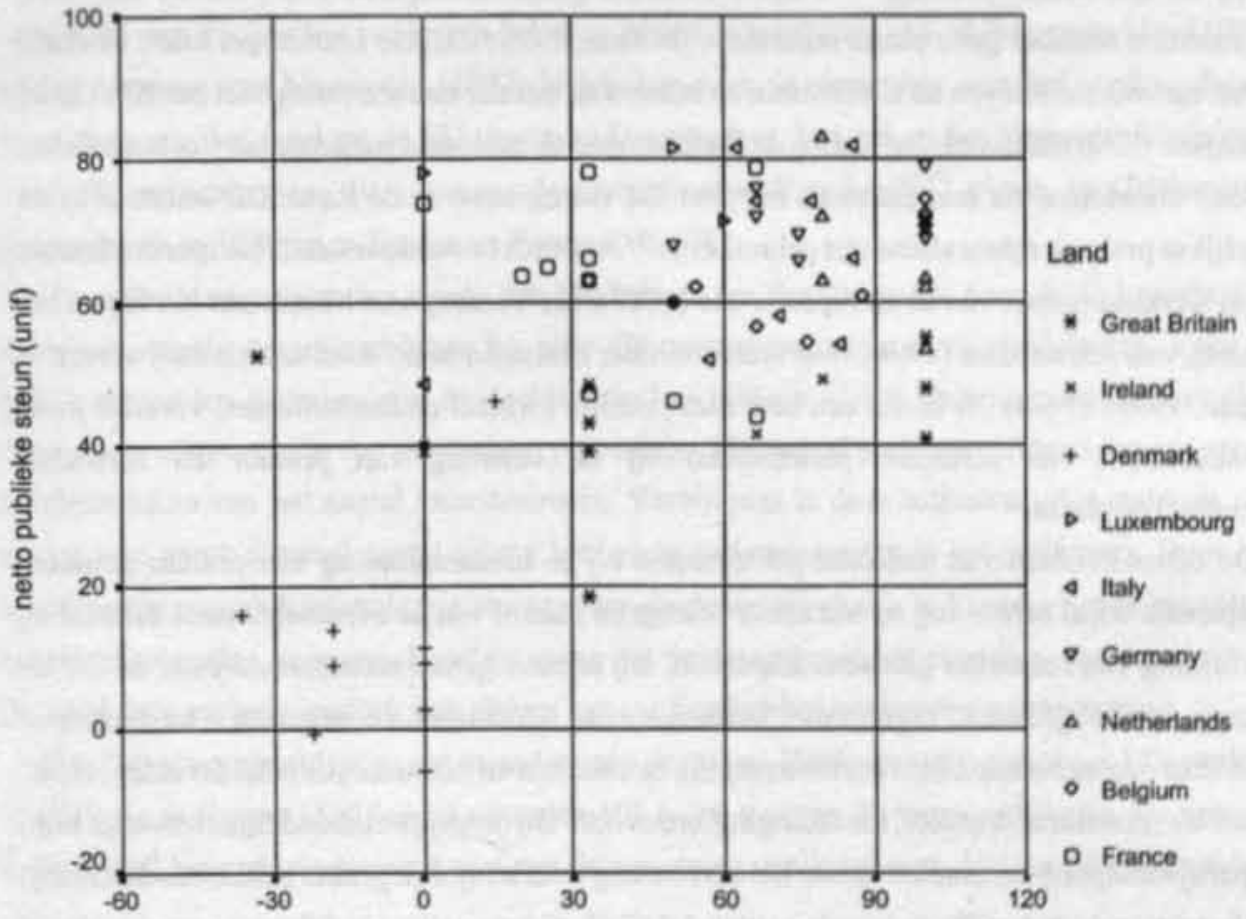

stemming elite discourse 
afstaan van soevereine rechten wordt in de praktijk ${ }^{13}$ beslist in de nationale parlementen. Elk nationaal parlement beschikt op dit punt dus over vetomacht. Zonder haar instemming kan een lidstaat niet worden gebonden aan nieuwe afspraken. Om wijzigingen te kunnen aanbrengen in de oorspronkelijke verdragen (noodzakelijk, onder andere, in het geval van toetreding van nieuwe lidstaten, uitbreiden van de bevoegdheden van de $\mathrm{EU}$, reorganisatie van de besluitvorming of de institutionele structuur van de EU) is telkens een expliciete en uitdrukkelijke goedkeuring van alle afzonderlijke nationale parlementen vereist. Met andere woorden, om te kunnen komen tot besluitvorming over primair gemeenschapsrecht (EU-verdragen) is expliciete steun vanuit nationale parlementen uiteindelijk onontbeerlijk

In hoeverre is het zinvol om bij het bepalen van de partijstandpunten van nationale politieke partijen ook te kijken het gedrag van partijen bij de besluitvorming binnen de EU over secundair (verordeningen, richtlijnen en beschikkingen) gemeenschapsrecht? Het antwoord op deze vraag is om twee duidelijke reden ontkennend.

Bij de EU-besluitvorming over het secundaire gemeenschapsrecht is voor de nationale parlementen formeel geen plaats ingeruimd (Norton, 1996: 27). De hoofdregel luidt: de Raad beslist op voorstellen van de Commissie en in meer of minder nauw overleg met het EP. Op de dagelijkse EU-besluitvorming binnen de Raad kunnen de nationale parlementen slechts indirect invloed uitoefenen via hun nationale minister die zitting heeft in de Raad. Dit laatste is in de dagelijkse praktijk echter allerminst gebruikelijk ${ }^{114} \mathrm{en}$ wordt bovendien steeds lastiger omdat met het in werking treden van de Europese Akte (1987), het Verdrag van Maastricht (1993) en het Verdrag van Amsterdam (1998) voor steeds minder besluiten in de Raad unanimiteit vereist is (Dinan, 1999: 296-8). Er is dus een heel nadrukkelijk formeel en fundamenteel verschil in de betrokkenheid van nationale parlementen bij de vorming van primair en secundair gemeenschapsrecht.

De betrokkenheid van nationale parlementen bij de totstandkoming van primair gemeenschapsrecht wijkt echter nog op een ander belangrijk punt af van de eventuele betrokkenheid bij de vorming van secundair gemeenschapsrecht. Bij primair gemeenschapsrecht staat de EU als zodanig - bevoegdheden, organisatie, besluitvorming, institutionele structuur - ter discussie. Secundair gemeenschapsrecht heeft betrekking op concrete en inhoudelijke beleidsvelden, zoals: landbouw, consumentenrecht, mededinging, enzovoort. Bij dergelijke inhoudelijke kwesties blijft het partijstandpunt ten aanzien van de EU als zodanig waarschijnlijk geheel buiten beschouwing. Het ligt dus voor de hand te vooronderstellen dat alleen tijdens nationale debatten over de primair

113 In het Verenigd Koninkrijk is het ratificeren van een verdrag in principe een bevoegdheid van de regering. maar in de praktijk kan dit niet zonder instemming van het parlement (vgl. Jacobs en Roberts, 1987).

\footnotetext{
${ }^{n 4}$ Alleen in Denemarken is het gebruikelijk dat ministers voorafgaand aan een vergadering van de Raad overleg plegen met een parlementaire commissie over het - veelal ruime - mandaat (Jensen, 1996: 46).
} 
gemeenschapsrecht partijen en politici hun houding ten aanzien van de EU als zodanig prijsgeven, terwijl dit bij eventuele discussies in de nationale politieke arena's over secundair gemeenschapsrecht niet of nauwelijks voor de hand ligt.

Dit betekent dat als men de stemming binnen het elite discours over de EU binnen de lidstaten in kaart willen brengen aan de hand van het gedrag van nationale politieke partijen, men is aangewezen op een analyse van debatten in de nationale parlement over primair gemeenschapsrecht.

\section{Beschikbare debatten}

In de oorspronkelijke zes lidstaten is daartoe uiteindelijk de ratificatie van vier versehillende verdragen met betrekking tot de oprichting en verder uitbouw van de EU onder de loep genomen. Het betreft de ratificatie van het EGKS-verdrag (1951), EEG-verdrag (1957), Europese Akte (1986) en het Europese Unie-verdrag (Maastricht, 1992). ${ }^{115}$

Voor de zes lidstaten die pas in de jaren zeventig en tachtig tot de EU zijn toegetreden, is de ratificatie van slechts drie verdragen bekeken. Naast de ratificatie van de Europese Akte (1986) en het Verdrag van Maastricht (1992) is gekeken naar de stemming over het verdrag dat de toetreding van het land tot de EU regelt. In Denemarken, Ierland en het Verenigd Koninkrijk vond de ratificatie van dit zogenaamde toetredingsverdrag in 1972 plaats, in Griekenland gebeurde dit in 1980 en in Spanje en Portugal in 1985.

Voor de lidstaten van het eerste uur beschikken we dus over vier door de tijd verspreide metingen van de stemming binnen het elite discours op basis van ratificatiedebatten. Voor de later toegetreden lidstaten zijn er slechts drie beschikbaar. ${ }^{116}$ De stemming binnen het elite discours is uitgedrukt in een netto-steun percentage. Het aantal parlementariërs dat tegen stemt is afgetrokken van het aantal voorstemmers. Vervolgens is deze uitkomst uitgedrukt als een percentage van het totaal aantal zitting hebbende parlementariërs in het parlement. Door het totaal aantal zitting hebbende parlementariërs als percentagebasis te kiezen en niet het totaal aantal uitgebrachte stemmen, komt tot uiting dat de stemming in het elite discours negatiever is in geval veel parlementariërs zich tijdens een ratificatiedebat onthouden van stemming.

Een fictief voorbeeld moge een en ander verduidelijken. Bij de stemming over een EU-verdrag in de Tweede Kamer (150 leden) stemmen 105 leden voor en 30 tegen ratificatie. De rest, 15 leden, heeft bewust of onbewust niet aan de stemming deel genomen. Het aantal voorstanders

\footnotetext{
${ }^{113}$ Op het moment dat het manuscript voor dit boek werk werd goedgekeurd bestond er nog geen overzicht van partijstandpunten tijdens de ratificatie van het Verdrag van Amsterdam (1998). Om die reden zijn de ratificatiedebatten rond het verdrag van Amsterdam buiten beschouwing gebleven in de analyse.

"16 De ratificatiedebatten over de verdragen die de toetreding van nieuwe lidstaten tot de EU regelt in de parlementen van de lidstaten die op zo'n moment reeds lid zijn, zijn niet in de analyse betrokken. Bij deze debatten gaat het immers niet om de EU als zodanig zoals bij de Europese Akte en het Verdrag van Maastricht.
} 
overtreft het aantal tegenstemmers met 75 (105 minus 30). De netto steun (stemming in het elite discours) bedraagt dus $+50 \%$ ( 75 van 150). Aangezien het onderzoek zich beperkt tot lidstaten is het in beginsel uitgesloten ${ }^{117}$ dat deze index een negatieve waarde heeft.

\section{Toetsing}

Voor zover mogelijk zijn de gegevens over de stemmingen gekoppeld aan surveygegevens. Noodgedwongen zijn we daar enigszins creatief om moeten gaan met de koppeling van gegevens over het elite discours in een bepaald jaar aan de gegevens over de publieke opinie in een bepaald jaar. Voor zover mogelijk zijn uiteraard de opiniegegevens uit hetzelfde jaar gebruikt. Was dat niet mogelijk dan zijn data uit een naastliggend jaar gebruikt. Uiteindelijk blijken er 37 bruikbare cases te zijn. In tabel 9.3 staat een overzicht van de cases.

De uitkomsten van de empirische analyse op basis van de meting van de stemming van het elite discours aan de hand van het stemgedrag van partijen tijden ratificatiedebatten in de nationale parlementen geeft opnieuw geen enkele aanleiding om de hypothese te verwerpen. Net zoals in de vorige subparagraaf vinden we een relatief sterke positieve samenhang tussen de stemming binnen het nationale elite discours en de publieke steun voor de EU. Naarmate EUverdragen in de nationale politieke arena op bredere parlementaire steun kunnen rekenen, blijkt de publieke steun voor de EU groter. De sterkte van de gevonden samenhang in deze (.62) en de vorige paragraaf komen nagenoeg overeen. Figuur 9.2 geeft, in tegenstelling tot het beeld in figuur 9.1, aan bij de analyse in deze subparagraaf niet slechts de Deense cases verantwoordelijk zijn voor de positieve samenhang, maar dat sommige Franse, Griekse en Britse cases daar ook nadrukkelijk aan bijdragen.

\subsubsection{Aanvullende toets 2: de Engelse casus, 1972-1979}

De tweede aanvullende test op de aanwezigheid van een samenhang tussen de stemming binnen het elite discours en de publieke steun voor de EU, is in tegenstelling tot de empirische tests in de vorige subparagrafen uiterst beperkt van opzet. De test heeft enkel betrekking op het Britse elite discours en de Britse publieke opinie in de periode van 1972 tot en met 1979. Het bijzondere aan deze test is echter dat voor de meting van de stemming onder het Britse elite discours in deze acht jaar kan worden terug gevallen op een welhaast ideale dataset.

Dalton en Duval (1986) hebben in het kader van een vooralsnog relatief weinig geciteerde, maar niettemin uiterst indrukwekkende studie naar de relatie tussen de politieke omgeving en foreign policy opinions, gedurende achtjaar in de dinsdag-, woensdag-en donderdagkrant van The Guar-

\footnotetext{
"1" Er is én uitzondering. In 1986 stemde een meerderheid van de Deense Folketing (75:80) tegen ratificatie van de Europese Akte. De positieve uitslag van een daaropvolgend referendum gaf vervolgens de doorslag.
} 


\section{Correlatie}

Publieke steun $\mathbf{x}$ elite discours (ratificatiedebatten)

$\mathrm{N}$
sign

.62
37

Overzicht jaartallen ratificaties, tussen haakjes eventuele afwijkende jaren voor meting publieke opinie:

$\begin{array}{ll}\text { Frankrijk (4) } & 1951 \text { (1952), 1957, 1986, 1992 } \\ \text { Belgie (2) } & 1986,1992 \\ \text { Nederland (3) } & 1957 \text { (1956), 1986, 1992 } \\ \text { West-Duitsland (4) } & 1952,1957,1986,1992 \\ \text { Italie (4) } & 1952,1957,1986,1992 \\ \text { Luxemburg (2) } & 1986,1992 \\ \text { Denemarken (3) } & 1972 \text { (1973), 1986, 1992 } \\ \text { lertand (3) } & 1971 / 2(1973), 1986,1992 \\ \text { Groot-Brittannic (3) } & 1972 \text { (1973), 1986, 1992 } \\ \text { Griekenland (3) } & 1979 \text { (1981), 1986, 1992 } \\ \text { Spanje (3) } & 1985,1986,1992 \\ \text { Portugal (3) } & 1985,1986,1992\end{array}$

Figuar 9.2 Publieke steun voor de EU bij stemming elite discours (ratificaties) lidataten (1951-1992)

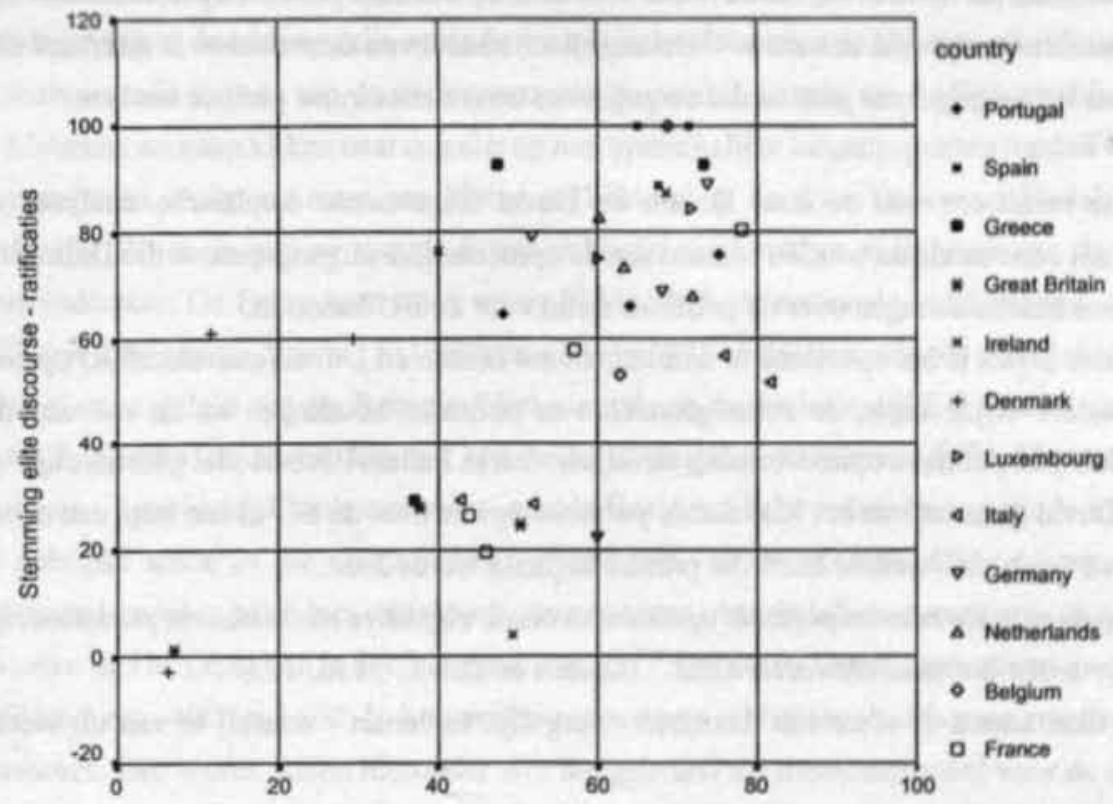

Publieke opinie - netto steun (unif) 
dian alle artikelen bekeken die te maken hadden met het thema European integration. In totaal troffen zij 3.788 artikelen over dit thema aan. Elk artikel is geanalyseerd en gescoord op de volgende zaken: subthema (landbouwbeleid, EU-instellingen, handel, enzovoort), lengte, de actor of bron van het bericht (EU-instellingen, Groot-Brittannie, Labour, Conservative, ander EU-land, enzovoort) en toonzetting (positief/negatief). Bij het bepalen van de toonzetting is gelet op (Dalton en Duval, 1986: 121):

"how the average citizen would expect the event to affect British national interests or the specific groups involved in the event."

De op deze wijze uitgevoerde inhoudsanalyse op The Guardian weerspiegelt, in tegenstelling tot de analyse van partijprogramma's of partijpolitieke standpunten tijdens ratificatiedebatten, de volle breedte en bonte werkelijkheid van het Britse politieke en maatschappelijke debat over het EU-thema in de periode 1972-9. Uit de in het artikel gepresenteerde staatjes blijkt overduidelijk dat er in een krant nadrukkelijk ook aandacht is voor de EU-mening van andere relevante actoren - EU-instellingen, buitenlandse regeringen, wetenschappers, journalisten, enzovoort - dan nationale politieke partijen. In die zin bevatten deze data de welhaast perfecte operationalisering van het centrale concept elite discours. ${ }^{118}$ Belangrijkste nadeel van deze dataset is uiteraard dat het enkel om Britse gegevens gaat en dat de gegevens een relatief korte periode beslaan.

Alvorens de resultaten van de door Dalton en Duval uitgevoerde empirische analyses te bespreken, zal eerst aandacht worden besteed aan de opmerkelijke uitgangspunten die Dalton en Duval bij hun beschouwingen over de publieke steun voor de EU hanteren.

In de eerste plaats is het opvallend te constateren dat Dalton en Duval (aanvankelijk) op een volstrekt andere wijze tegen de achtergronden van politieke houdingen en de rol van de massamedia bij de publieke opinievorming aankijken dan in Zallers RAS-model gebruikelijk is. Dalton en Duval gaan uit van het idee dat de publieke opinie over de EU in een land een soort "normale" of "stabiele" waarde heeft die primair bepaald wordt door:

"... long-term influences on political opinions - values, cognitive mobilization, partisanship and other socio-political characteristics. "(Dalton en Dival, 1986: 133)

Het hele artikel ademt de sfeer van theorieèn - vergelijk Inglehart - waarbij er van uit wordt

11 Een extra check op de betrouwbaarheid en validiteit van de verzamelde gegevens bestond uit een vergelijking van de gegevens van The Guardian met die uit het meer populaire dagblad The Sun - verzameld gedurende slechts(!) 30 maanden. The Guardian bleek beduidend meer krantenpapier vuil te maken aan het thema Europese integratie dan de Sun. Tevens was de berichtgeving in The Guardian over het algemeen kritischer dan in de Sun. Desondanks was er sprake van een bijzonder sterke samenhang tussen de hoeveelheid aandacht die per maand aan het thema werd besteed in beide kranten, en tussen de maandelijkse balans van positieve en negatieve berichten in beide kranten. Dalton en Duval concluderen dan ook dat The Guardian-series:

"provides a good approximation of the general trends in the public coverage of Britain's relations with Europe." (Dalton en Daval, 1986:121) 
gegaan dat burgers over weldoordachte, uitgekristalliseerde en in andere sociale en politicke kenmerken gewortelde houdingen ten aanzien van de $\mathrm{EU}$ beschikken. Zoals hierboven is aangegeven laat Zaller deze vooronderstelling heel bewust vallen en gaat hij er in zijn model vanuit dat politieke houdingen net zo goed tijdelijk ad-hoo geformuleerde opinies (non-attitudes) kunnen zijn.

Een tweede opmerkelijk punt betreft de wijze waarop Dalton en Duval tegen politieke berichtgeving en de rol van de massamedia aankijken. Ze vooronderstellen dat nieuws over de EU een natuurlijke neiging zou hebben om te tenderen naar het negatieve. Immers:

"A conflict over Community policy or the failure of a Community programme may generate headlines, while a successful policy is often less newsworthy. Consequently events presented in the public record generally are critical of Community affairs." (Dalton en Dival, 1986:

121-2)

Het empirische feit dat de balans in de Britse berichtgeving over Europese integratie in de periode 1972-1979 voornamelijk doorslaat in negatieve richting zien zij als het ultieme bewijs voor hun opmerkelijke stelling. Uit hun analyse blijkt verder dat zij de invloed van de EUberichtgeving in de massamedia op de Britse publieke steun voor de EU dan ook primair typeren en analyseren in termen van verstoringen op de "normale" waarde van de Britse publieke steun.

Alvorens we gaan kijken naar de gelet op hun opmerkelijke uitgangspunten ronduit verrassende conclusies, volgt nu eerst een kleine toelichting op de door Dalton en Duval gevolgde werkwijze. Voor de meting van de Britse publieke steun maken ze gebruik van de mem- en scrap-indicator. De Britse toetreding tot de EU in 1973, de nationale verkiezingen in 1974 en 1977, het referendum over het EU-lidmaatschap in 1975 en de verkiezingen voor het EP in 1979 hebben ertoe geleid dat de Britse publieke opinie in de periode 1972-9 relatief intensief is gevolgd. Dalton en Duval kunnen zodoende beschikken over maar liefst 42 verschillende metingen - waaronder Eurobarometers - van de Britse publieke opinie in de periode 1972-1979. De publieke steun in die onderzoeken varieert van $-30 \%$ tot $+30 \%$. Deze 42 verschillende metingen koppelen ze in hun onderzoek aan gegevens over de balans tussen pro- en contra-EU artikelen in The Guardian in een bepaalde maand. ${ }^{119}$ Dalton en Duval rapporteren maandscores variërend van -400 tot +600 . In hun artikel rapporteren zij helaas slechts geaggregeerde nettojaarscores. Die scores zullen hieronder worden gebruikt als meetinstrument voor de stemming binnen het Britse elite discours over de EU in de periode 1972-9.

De belangrijkste uitkomst van Dalton en Duvals empirische analyse is - geheel in lijn met onze hypothese - dat veranderingen in de maandelijkse berichtgeving over de EU een zonder

\footnotetext{
${ }^{119}$ Het is niet volledig duidelijk hoe hun index, die de stemming binnen het elite discours weergeeft, is berekend. Er zijn echter aanwijzingen dat een score van $+100 \mathrm{er}$ op duidt dat de ruimte ingeruimd voor positieve berichten, de ruimte voor negatieve berichten met 100 column inches krantenpapier overtreft.
} 
meer sterke positieve samenhang vertonen met veranderingen in de publieke steun. Hoe anders de uitgangspunten van Dalton en Duval aanvankelijk ook waren sluit uiteindelijk ook hun centrale conclusie wonderwel aan bij de uitgangspunten die aan Zallers RAS-model ten grondslag liggen, namelijk:

"This broader perspective on the events-opinion linkage holds additional implications for the process of European integration. Contimued exposure to Community institutions and policies is said to develop diffuse support for European integration. [...] However, the evidence for Britain argues against this model on several grounds. Firstly, stable opinions have not yet developed: the past decade has seen considerable volatility in opinions on the EC." (Dalton en Duval, 1986: 130)

Uit deze slotopmerkingen blijkt heel duidelijk dat Dalton en Duval niet uit de voeten kunnen met het uitgangspunt dat Britse burgers ten aanzien van de EU over weldoordachte en uitgekristalliseerde houdingen beschikken. Dus ook in deze welhaast ideale dataset is steun te vinden voor de uitgangspunten die ten grondslag liggen aan Zallers RAS-model en de daaruit afgeleide hypothese dat de stemming in het elite discours over de EU in een land nauw verbonden is met de publieke steun voor de EU.

Ter verdere illustratie zijn hieronder in tabel 9.2 de relevante jaarscores uit het artikel van Dalton en Duval- die aangeven hoe de balans van positieve en negatieve berichten over de $\mathrm{EU}$ in een bepaald jaar uitviel - afgezet tegen gegevens over de Britse publieke steun voor de EU in diezelfde jaren. In de eerste kolom vindt $u$ het jaartal, daarnaast is aangegeven hoe de balans in de berichtgeving in het betreffende jaar uitpakte. Bij een negatieve (positieve) score overheersen de contra-EU (pro-EU) berichten. In de laatste twee kolommen is aangegeven wat de (gemiddelde) mem- en scrap-scores waren in de verschillende surveys die Dalton en Duval in datzelfde jaar tot hun beschikking hadden. ${ }^{120}$ De jaarscores zijn in de meeste gevallen gemiddelde scores, omdat de resultaten van meerdere opinie-onderzoeken in hetzelfde jaar bij elkaar zijn gevoegd. Tussen haakjes is aangegeven op hoeveel verschillende metingen de gemiddelde memen scrap-scores in een bepaald jaar zijn gebaseerd.

De cijfers in de tabel 9.2 duidelijk zien dat de veranderingen in de stemming in het Britse elite discours over de EU hand in hand gaan met schommelingen in de Britse publieke steun voor de EU in de periode tussen 1972 en 1979 . Beide grootheden zijn, ondanks dat gewerkt wordt met geaggregeerde respectievelijk gemiddelde scores, onderhevig aan aanzienlijke schommelingen. Zowel het elite discours, als de publieke opinie zijn het meest kritisch in 1979, terwijl in 1975 het referendumjaar - steun en stemming hun hoogtepunt bereiken. De samenhang tussen beide

\footnotetext{
${ }^{130}$ Vanwege het feit dat de vraag die ten grondslag ligt aan de UNIF-indicator in 1973 en 1975 anders is gesteld dan in periode $1976-9$ is gekozen voor deze twee verwante indicatoren.
} 
Tabel 9.2 Britse publieke stewn voor de EU en stemming binnen Brits elite discours (The Guardian-Series), 1972-9

\begin{tabular}{|l|c|c|c|}
\hline \multirow{2}{*}{ Jaar: } & stemming elite discours & \multicolumn{2}{|c|}{ publieke steun } \\
\cline { 2 - 4 } & positief - negatief & mem (aantal surveys) & serap (aantal surveys) \\
\hline 1972 & -209 & $+19(1)$ & $-9 \%(1)$ \\
1973 & -948 & $-3 \%(10)$ & $-16 \%(10)$ \\
1974 & -661 & $-3 \%(2)$ & $-17 \%(9)$ \\
1975 & +261 & $+27 \%(2)$ & $+5 \%(3)$ \\
1976 & -1592 & $+10 \%(6)$ & $+1 \%(4)$ \\
1977 & -1090 & $-4 \%(5)$ & $-7 \%(3)$ \\
1978 & -2132 & $-8 \%(3)$ & $-35 \%(2)$ \\
1979 & -2731 & $-12 \%$ & 1 \\
\hline
\end{tabular}

Bron: Dalton en Duval, 1986, 114-5 en 124; \# = geen gegevens.

grootheden is sterk (vgl. Dalton en Duval, 1986: 128-9).

\subsubsection{RAS-model bruikbaar op macro-niveau}

Uit de hierboven gerapporteerde empirische analyses blijken de verschillen in de publieke steun voor de EU tussen en binnen lidstaten (macro-niveau) sterk samen te hangen met de variaties in de stemming in het elite discours over de EU tussen en binnen lidstaten. Dit resultaat is des te opmerkelijk omdat de meetinstrumenten waarmee de stemming binnen het elite discours in de subparagrafen 9.2.1 en 9.2.2 in kaart moest worden allesbehalve optimaal waren. Dit betekent dat waar Ingleharts Silent Revolution-theorie op macro-niveau uiteindelijk volledig faalde, Zallers RAS-model uiteindelijk wel soelaas biedt. Om aanvaardbare resultaten te behalen was het niet eens nodig om veranderingen binnen de lidstaten en verschillen tussen de lidstaten analytisch te onderscheiden. ${ }^{121}$ Om meer zekerheid te krijgen over en inzicht te vergaren in de processen die aan de gevonden samenhang op macro-niveau ten grondslag liggen zal in de volgende paragrafen worden gekeken naar de empirische houdbaarheid van de uit Zallers RAS-model afgeleide hypothesen op meso- en micro-niveau.

\subsection{Partij-aanhang (meso-niveau)}

In deze paragraaf gaan we een stapje verder. Daar waar in de vorige paragraaf de focus primair gericht was op de relatie tussen het nationale elite discours en de publieke opinie op het niveau van de lidstaten (macro-niveau), staan in deze paragraaf de politieke partijen en hun partij-

${ }^{12}$ Hetgeen de nodige problemen zou hebben opgeleverd vanwege het geringe aantal cases. 
aanhang centraal (meso-niveau). De op dit niveau te toetsen hypothese luidt:

Hypothese 2: Partijpoliticke verschillen in de steun voor de EU binnen het elite discours, leiden tot vergelijkbare verschillen in de steun voor de EU tussen de aanhang van politieke partijen binnen de publieke opinie.

In het bijzonder gaat deze paragraaf dus over de lijnen waarlangs partijpolitieke verschillen binnen het elite discours doorwerken in de publieke opinie. Met de toetsing van deze hypothese hopen we iets meer inzicht te krijgen in de achtergrond van de zojuist gevonden samenhang tussen de publieke opinie en het elite discours over de EU op macro-niveau.

In het licht van de resultaten uit de vorige paragraaf luidt de eerste vraag in hoeverre groepen partij-aanhangers zich bij hun opinievorming ten aanzien van abstracte, perifere issues primair laten leiden door de stemming binnen het nationale elite discours als zodanig, dan wel dat ze zich primair laten leiden door de standpunten en argumenten die hun eigen politieke partij (politieke leiders) binnen het elite discours uitdragen? In deze paragraaf zal voor het in kaart brengen van partijstandpunten en het typeren van de bijdrage van verschillende partijen aan het elite discours

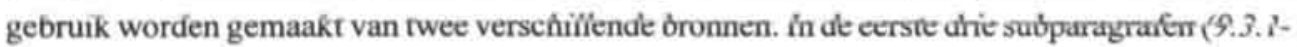
9.3.3) wordt gewerkt met de partijstandpunten zoals die naar voren zijn gekomen tijdens ratificatiedebatten over EU-verdragen (net zoals in subpargraaf 9.2.2). In subparagraaf 9.3.4 zal opnieuw gebruik worden gemaakt van de unieke Britse dataset van Dalton en Duval.

In deze paragraaf zal dus geen gebruik meer worden gemaakt van Party Manifesto-data. De reden daarvoor is gelegen in het feit dat de partij-politieke oppositie tegen de EU relatief vaak afkomstig is van kleine partijen. En juist die partijen ontbreken veelvuldig in dataset van het Party Manifesto-project.

Om te bepalen tot welke partij-aanhang iemand behoort is gebruik gemaakt van de antwoord op de vraag op welke partij iemand zou stemmen als er op het moment van ondervraging nationale verkiezingen zouden zijn. ${ }^{122}$ In de partij-aanhang van iedere politieke partij zitten dus naast fervente partij-aanhangers ook zwevende kiezers.

\subsubsection{Ratificatiedebatten}

Alvorens de resultaten van de empirische analyse naar de relatie tussen de verschillende partijstandpunten over de EU ten tijde van ratificatiedebatten en de steun voor de EU onder de partij-aanhang van de verschillende partijen te bespreken, zal eerst nog enige aandacht worden besteed aan de belangrijkste partij-politieke tegenstellingen over de EU.

${ }^{122}$ De betreffende Eurobarometer-vraag luidt: "If there were [name national election) tomorrow (SAY IF RESPONDENT UNDER 18 YEARS: and you had a vote) which party would you vote for?". In de USIA-surveys is gevraagd tot welke politieke partij de respondent zich het meest aangetrokken voelt. 
De partijpolitieke oppositie tegen de EU vanuit de lidstaten komt nauwelijks van partijen die zich in het midden van het links-rechts spectrum bevinden, maar is nagenoeg exclusief afkomstig van partijen aan de uiteinden van dit spectrum (Hix en Lord, 1997; Nicholson en East, 1987).

In het linkse kamp vormen de nationale communistische partijen de traditionele criticasters van de EU. In de jaren vijftig en zestig waren deze partijen bovenal de spreekbuis van de Russische Communistische Partij die in de EU een verwerpelijk kapitalistisch bolwerk zagen dat primair de belangen van de Amerikanen dient. Hoewel de meeste West-Europese communistische partijen vanaf de jaren zeventig een steeds onafhankelijker ${ }^{123}$ koers van Moskou zijn gaan varen, zijn ze niettemin relatief kritisch gebleven ten opzichte van de EU. Zo stemden in 1992 bijna ${ }^{124}$ alle nog in nationale parlementen vertegenwoordigde communistische partijen (Frankrijk, Luxemburg, Griekenland, Portugal en Spanje) tegen het Verdrag van Maastricht. Tegenwoordig richt de kritiek uit communistische en radicaal linkse hoek zich vooral op het geringe democratische gehalte van de Europese politiek en haar instituties (Hix en Lord, 1997: 40). Een ander veel gehoorde kritiek van linkse zijde is dat de sociale integratie binnen de EU geen gelijke tred houdt met de economische integratic (Hix en Lord, 1997: 39-40). Zo dreigen nationale systemen van sociale zekerheid en strenge of bijzondere nationale productvoorschriften, waar op nationaal niveau vaak jaren voor is gestreden, te worden vermalen in de vrije economische concurrentie tussen lidstaten of worden door Commissie en Hof van Justitie aangemerkt en aangepakt als ongeoorloofde handelsbelemmeringen (Scharpf, 1999: 48 en 50-71). Plannen voor positieve integratie waarbij ook op Europees niveau gestreefd wordt naar een hoog niveau van sociale zekerheid en strenge productvoorschriften behoeven meestal expliciete besluitvorming in de Raad en/of het EP. De consequentie is dat het zetten van positieve stappen veel minder makkelijk en al helemaal niet automatisch gaat (Scharpf, 1999: 45 en 71-83). De onbalans binnen de EU tussen snel voortschrijdende economische eenwording enerzijds en haperende niet-economische (met name sociaal beleid en milieubeleid) eenwording anderzijds is de meeste radicaal linkse partijen in de lidstaten een doorn in het oog.

Kritiek komt er echter ook uit het rechtse kamp. In dat kamp moet nadrukkelijk een onderscheid worden gemaakt tussen nationalistische en conservatieve partijen. Het hoeft weinig verbazing te wekken dat allerlei rechts-extremistische nationalistische partijen weinig voelen voor Europese eenwording (Hix en Lord, 1997: 42-4). In historische zin kan men onder andere denken aan de Franse Poujadisten. De laatste decennia betreft dit vooral het Franse Front National, de Nederlandse Centrum-Democraten, de Deense Fremskridtspartiet, het Belgische

\footnotetext{
${ }^{12}$ De ratificatie van de Europese Akte (1986) wordt op nationaal niveau, onder andere, door de Italiaanse, één van de twee Griekse en de Spaanse communistische partij gesteund.

${ }^{124}$ Alleen de Griekse eurocommunisten van de Griekse KKE-Interior stemden voor het verdrag. In tegenstelling tot de Griekse KKE-Exterior, een van oudsher op Moskou georiēnteerde communistische partij.
} 
Vlaams Blok en het Italiaanse MSI/AN. Daarnaast zijn er ook een aantal rechtse conservatieve partijen die moeite hebben met de EU. De Franse Gaullisten, de Nederlandse protestantschristelijke partijen $S G P, G P V$, en $R P F$ alsmede de Britse Conservatives passen in het rijtje van partijen die sterk hechten aan het behoud van de nationale soevereiniteit (Hix en Lord, 1997: 42).

Zoals gezegd vormen de partijen in het midden van het partij-politieke spectrum de belangrijkste steunpilaren onder het Europese bouwwerk. Daarbij moet vooral gedacht worden aan christen-democratische en liberale partijen in de diverse lidstaten. Zij vormen zonder meer de meest loyale pleitbezorgers voor de EU (Hix en Lord, 1997: 29-35). Dit geldt in iets mindere mate voor de grote sociaal-democratische partijen in de EU-lidstaten. De Griekse (PASOK), Deense (Socialdemokratiet), Franse(PSIO/PS) en Britse(Labour) sociaal-democratische partijen zijn niet altijd onverdeeld positief over de EU. In de meeste lidstaten kan de EU inmiddels echter op loyale steun uit sociaal-democratische hoek rekenen (Hix en Lord, 1997: 36-7). Prominente uitzondering is het Verenigd Koninkrijk, waar binnen Labour voortdurend geruzied wordt over de EU. In nagenoeg alle lidstaten kan de EU dus rekenen op steun van de (veelal grote) christendemocratische, liberale en sociaal-democratische politieke partijen.

Het is derhalve onjuist om te denken dat de EU überhaupt geen onderwerp van partijpolitieke discussie is binnen de lidstaten. De situatie is meestal dat het functioneren, voortbestaan en uitbouw van de EU weliswaar door de belangrijkste politieke partijen binnen de EU-lidstaten wordt onderschreven, maar tegelijkertijd onderwerp blijft van kritiek vanuit de hoek van (veelal) kleine linkse en rechtse partijen. Deze constatering is bepaald belangwekkend. Het betekent namelijk dat de empirische toetsing meer zal behelzen dan het vergelijken van de steun voor de EU onder de aanhang van een klein aantal kritische Deense en Britse politieke partijen versus de steun voor de EU onder de aanhang van alle andere partijen. Onder die omstandigheden zou het namelijk nagenoeg onmogelijk zijn geworden om in de analyse de effecten van partijstandpunten op de steun voor de EU onder de partij-aanhang enerzijds en de invloed van de stemming binnen het (gehele) nationale elite discours op de steun voor de EU onder de partij-aanhang anderzijds van elkaar te kunnen scheiden.

\section{Gegevens}

Voor de oorspronkelijke zes lidstaten was het aanvankelijk de bedoeling om de gegevens over het stemgedrag van de politieke partijen ten tijde van de ratificatie van het EGKS-verdrag (1952), het EEG-verdrag (1957), de Europese Akte (1986) en het Verdrag van Maastricht (1992) te koppelen aan gegevens over de steun voor de EU onder hun aanhang. De ponskaarten van het USIA-onderzoek dat in 1952 in Frankrijk, West-Duitsland, Groot-Brittannië en Italiē is uitgevoerd, zijn helaas verloren gegaan en daardoor is niet meer na te gaan hoe onder de aanhang 
van de verschillende politieke partijen over de EU is geoordeeld. ${ }^{125}$ Daarenboven zijn er uberhaupt geen gegevens over de Luxemburgse publieke opinie in de jaren vijftig voor handen, zodat uiteindelijk alleen de partijstandpunten van Franse, West-Duitse, Italiaanse, Belgische en Nederlandse partijen bij de ratificatie van het EEG-verdrag (1957), de Europese Akte (1986) en het Verdrag van Maastricht (1992) kunnen worden gekoppeld aan gegevens over de steun voor de EU onder de aanhang van deze partijen. De Luxemburgse data hebben slechts betrekking op de ratificatie van de Europese Akte en het Verdrag van Maastricht.

Voor de zes lidstaten in dit onderzoek die niet vanaf het begin lid zijn geweest van de EU zjin de partijstandpunten bij de ratificatie van de Europese Akte (1986), het Verdrag van Maastricht (1992) en de verdragen die de uiteindelijke toetreding van die landen tot de EU regelen (1972, $1980,1985)$ gekoppeld aan opiniegegevens.

In drie gevallen - 1957: de Franse Poujadisten en Gaullisten en de Belgische Volksunie - was de partij-aanhang als zodanig niet te isoleren in de surveygegevens waardoor koppeling aan het partijstandpunt achterwege moest blijven. In een aantal andere gevallen (vaak eensmans-fracties) was het stemgedrag van een partij uiteindelijk niet met zekerheid vast te stellen. Uiteindelijk levert de beschreven exercitie in totaal 202 bruikbare cases op. Een casus betreft een door een zekere partij ingenomen partijstandpunt tijdens een ratificatiedebat gekoppeld aan informatic over de steun voor de EU onder de aanhang van die partij (in hetzelfde of naastliggend jaar). Hoe de cases zijn verdeeld over de landen en jaren enerzijds, en de verdragen anderzijds staat weergegeven in tabel 9.4. Uiteraard zijn de meeste cases afkomstig uit landen met een meerpartijenstelsel.

Bij het classificeren van de partijen aan de hand van het stemgedrag tijdens de ratificatiedebatten in de nationale parlementen is een grove driedeling gehanteerd, te weten: voor, tegen of verdeeld. De verdeelde fracties zijn niet verder onderverdeeld in meer of minder positieve fracties. Het was vaak niet te achterhalen hoe de verhoudingen binnen de fracties precies lagen en wie - partijleider of een backbencher - tot welk kamp behoorde. In de meeste gevallen zijn de fracties unaniem voor (133 keer) of tegen ( $52 \mathrm{keer})$. In slechts 17 gevallen is sprake van een verdeelde fractie.

Om de steun voor West-Europese eenwording onder de aanhangers van de verschillende partijen te bepalen, is het percentage tegenstanders van eenwording (UNIF-indicator) onder de

${ }^{13}$ Bij een bezoek aan het Roper Center in de VS werd mij medegedeeld dat deze data onderdeel uitmaakten van de zogenaamde "flood-data" die door de kelder van dit sociaal-wetenschappelijk data-archief dreven toen die een keer onder water stond. Uit documenten over deze studie en onderzoeken op basis van deze studie (Merritt en Puchala, 1968) zijn wel de macro-gegevens over de publieke steun op het niveau van de lidstaten voor handen. 
Tabel 9.4 Overzicht bruikbare cases naar lidstaat (jaar) en soort verdrag (jaar)

\begin{tabular}{lllll}
\hline Land: & N & Verdrag: & N \\
Frankrijk $(1957,1986,1992)$ & $21 \quad(5,7,9)$ & EEG-verdrag (1957) & 25 \\
Belgie $(1957,1986,1992)$ & $24(4,10,10)$ & Europese Akte (1986) & 86 \\
Nederland $(1957,1986,1992)$ & $25(7,9,9)$ & Verdrag van Maastricht $(1992)$ & 72 \\
W-Duitsland $(1957,1986,1992)$ & II $(3,4,4)$ & Toetreding $(1972,1979,1985)$ & $29(11,7,11)$ \\
Italie $(1957,1986,1992)$ & $23(6,9,8)$ & & \\
Luxemburg $(1986,1992)$ & $9 \quad(5,4)$ & & \\
Denemarken $(1972,1986,1992)$ & $22(5,9,8)$ & & \\
Ierland $(1972,1986,1992)$ & $15(3,5,7)$ & & \\
Gr-Brittannie $((1972,1986,1992)$ & $9 \quad(3,3,3)$ & & \\
Griekenland $(1979,1986,1992)$ & $14(7,4,3)$ & & \\
Spanje $(1985,1986,1992)$ & $16(7,6,3)$ & & \\
Portugal $(1985,1986,1992)$ & $13(4,5,4)$ & & \\
\hline
\end{tabular}

aanhang afgetrokken van het percentage voorstanders. ${ }^{126}$ De steun voor de EU onder de partijaanhang varieert van $-66 \%$ onder de aanhang van de Griekse communisten (KKE-exterior) in 1980, tot $+100 \%$ onder, bijvoorbeeld, de aanhang van de ltaliaanse liberalen in 1992.

\section{Toetsing}

Om een uitspraak te kunnen doen over de houdbaarheid van de hypothese op mesoniveau is nagegaan in hoeverre het partijstandpunt een systematisch positieve samenhang vertoont met de mate van steun voor de EU onder de partij-aanhang. De resultaten van de analyse staan in tabel 9.5 .

In de eerste plaats is gekeken naar de bivariate correlatie tussen partijstandpunt en steun onder de aanhang onder alle beschikbare 202 cases. Er blijkt sprake te zijn van een significant positieve samenhang. Dit duidt erop dat steun voor de EU onder de aanhang van partijen met een pro-EU partijstandpunt in het algemeen hoger is dan onder de aanhang van partijen met een minder positief (verdeeld of anti-EU) partijstandpunt. De bijbehorende correlatiecoëfficiënt is +.62 hetgeen duidt op een relatief sterke samenhang. De correlatie geeft aan dat ongeveer $40 \%$ van de variatie in de steun tussen de aanhang van de politieke partijen in de verschillende lidstaten en op de verschillende tijdstippen terug te voeren is op uiteenlopende partijstandpunten over de EU.

Een uitsplitsing van de analyse naar lidstaten en het soort verdrag levert geen andere inzichten

19\% Als er minder dan 25 aanhangers van een bepaalde partij in de surveydata van een bepaald jaar voorhanden waren, dan is de case van de analyse uitgesloten. Graag had ik deze grens nog hoger gelegd om een meer betrouwbare schatting van de steun binnen de partij-aanhang te krijgen, maar dit zou ertoe geleid hebben dat vooral veel kleine kritische partijen en hun aanhang buiten de analyse zouden moeten blijven. 


\begin{tabular}{|c|c|c|c|c|c|}
\hline \multirow[b]{2}{*}{ EU-totaal (12 lidstaten): } & Correlatie & $\mathbf{N}$ & & & \\
\hline & .62 & 202 & & & \\
\hline Lidstaat: & Correlatie & $\mathbf{N}$ & Lidstaat: & Correlatie & $\mathrm{N}$ \\
\hline Frankrijk & .67 & 21 & Denemarken & .72 & 22 \\
\hline Belgie & .66 & 24 & Ierland & 43 & 15 \\
\hline Nederland & .71 & 25 & Gr-Brittannie & $-34 \cdot$ & 9 \\
\hline West-Duitsland & $-.11 \cdot$ & 11 & Griekenland & .74 & 14 \\
\hline Italie & .72 & 23 & Spanje & .81 & 16 \\
\hline Luxemburg & $.13 \cdot$ & 9 & Portugal & .33 & 13 \\
\hline Verdrag: & Correlatie & $\mathbf{N}$ & Verdrag: & Corretatie & $\mathbf{N}$ \\
\hline 1957: EEG-verdrag & .73 & 25 & 1986: Europese Akte & .59 & 86 \\
\hline Toetreding nieuwe lidstaten & .70 & 29 & 1992: Europese Unie & .60 & 72 \\
\hline
\end{tabular}

Bron: zie tabel $9.4 ; *-$ niet significant, $p<.05$.

op. Behalve een niet-significant negatief verband in West-Duitsland, ${ }^{12}$ leveren al deze partiele analyses significant positieve correlaties op. Dit geeft aan dat ook binnen de twaalf lidstaten verschillen (op een tijdstip) en veranderingen (door de tijd) in partijstandpunten systematisch van invloed zijn op de steun voor de EU onder de aanhang van de nationale partijen. Ook als de situatie ten tijde van achtereenvolgens de ratificatie van het EEG-verdrag (1957), de Akte (1986) en Maastricht (1992) en de toetredingsverdragen apart onder beschouwing wordt genomen, blijft de oorspronkelijke samenhang intact. Dit geeft aan dat ook de verschillen in steun voor de EU tussen de aanhang van politieke partijen uit verschillende landen ten tijde van de ratificatie van de afzonderlijke verdragen voor een belangrijk deel terug te voeren zijn op de verschillen in partijstandpunten ten aanzien van de EU.

De resultaten van deze empirische toetsing geven geen reden om te twijfelen aan de geldigheid van de hypothese. Partijpolitieke tegenstellingen ten aanzien van de EU blijken inderdaad te leiden tot partijpolitieke tegenstellingen tussen de aanhang van die partijen binnen de publieke opinie ten aanzien van de EU.

\subsubsection{Partij-aanhang en de stemming binnen het elite discours}

In Zallers model wordt voorondersteld dat partijvoorkeuren fungeren als negatief selectiecriterium waarmee informatie afkomstig van niet-favoriete partijen wordt geweerd. Dit betekent in Zallers terminologie dat aanhangers cueing messages van hun eigen partij wel

${ }^{12}$ Uit een inspectie van de cases, blijkt de negatieve samenhang vooral het gevolg van de oppositie van de FDP tegen het EEG-verdrag (1957) waarvan weinig tot niets is terug te vinden onder de eigen partij-aanhang. Dit is begrijpelijk omdat de oppositie van de FDP niet zozeer voortkomt uit oppositie tegen de integratie als zodanig, maar uit de angst dat de EEG niet genoeg waarborgen bood voor een vrije Europese markt. De EEG ging in FDP-ogen niet ver genoeg. Zonder deze casus komt er een positief verband uit van $+.21(p=.12 ; \mathrm{N}=10)$. 
oppikken uit de media, en resistance bieden aan informatie met cues naar andere dan hun eigen partij. Het idee is dat op deze manier welhaast uit zichzelf een congruentie ontstaat tussen partijstandpunt en de standpunten van de partij-aanhang. De verwachting is dat de werking van dit mechanisme beter en sterker is, naarmate de mate van partij-identificatie van de aanhang met de partij sterker is. In paragraaf 9.4 zal deze verwachting expliciet op individueel niveau worden getoetst, hier vormt deze verwachting het uitgangspunt voor een nadere analyse van de achtergronden van de steun voor de EU onder de aanhang van politieke partijen.

De kans dat cueing messages worden opgepikt hangt volgens Zallers reception-axiom (zie hoofdstuk 7) samen met de "cognitive engagement" die de ontvanger heeft met de objecten partij én issue (EU) - die in het bericht centraal staan. De betrokkenheid bij de partij zal hier worden aangeduid als de mate van partij-identificatie. De vooronderstelling is dat de betrokkenheid bij het EU-issue onder het grote publiek over het algemeen uiterst gering is, zodat de kans op het oppikken en selecteren van cueing messages in de berichtgeving over de EU primair bepaald wordt de mate van partij-identificatie. In dit onderzoek zijn respondenten ingedeeld bij een bepaalde partij-aanhang op basis van hun antwoord op de vraag op welke partij ze zouden stemmen als er op het moment van ondervraging nationale verkiezingen zouden plaatsvinden. Het is dus welhaast zeker dat zich onder de aanhang van elke partij zowel trouwe partijleden alsook zwevende kiezers bevinden. Aanhangers die minder intens bij een partij betrokken zijn, zijn naar verwachting minder gespitst op het (positief) oppikken ${ }^{128}$ en negatief selecteren op basis van partijpolitieke cues. Het reception-axiom stelt daarenboven dat ook het actieve gebruik van cueing messages, nadat ze zijn opgepikt, als zelfstandig negatief selectiecriterium afhankelijk is van de betrokkenheid van het individu bij de partij (en issue). Minder betrokken aanhangers zullen zich bij hun verdere informatieverzameling minder selectief tonen dan meer fervente partij-aanhangers. De eerste groep staat meer open voor informatie en argumenten van niet-favoriete partijen en andere elites dan de laatste groep. Om die reden valt te verwachten dat verschillen en veranderingen in de steun voor de EU onder de aanhang van politieke partijen in de twaalf lidstaten ook tot op zekere hoogte de verschillen en veranderingen in de stemming binnen het nationale elite discours over de EU weerspiegelen. Dit zou betekenen dat de steun voor de EU onder de aanhang van een kritische partij in een lidstaat waar voor de rest slechts pro-EU partijen actief zijn, naar verwachting, groter is dan de steun onder de aanhang van een kritische partij in een lidstaat met meerdere partijen die de EU met een kritisch attitude volgen.

Als aanvulling op de hypothese dat een partij-standpunt ten aanzien van de EU van invloed

13 Dit is vergelijkbaar met wegdromende studenten die "Sef" heten die tijdens een college wakker kunnen schrikken als het woord "beseffen" - mits goed gearticuleerd - wordt gebruikt. In dat geval kunnen deze studenten als bij toverslag ontwaken uit een soort sluimertoestand. Gevolg is dat de student weer "echt" gaat luisteren en de informatie die wordt gegeven ineens weer actief - aantekeningen maken - oppikt. 
is op de steun voor de EU onder de partij-aanhang zal hieronder worden nagegaan in hoeverre de steun voor de EU onder de aanhang van diverse politieke partijen ook nog afhankelijk is van de stemming binnen het nationale elite discours over de EU. De verwachting is dat zowel het partijstandpunt als ook de stemming binnen het nationale elite discours een onafhankelijke invloed op de steun voor de EU onder de partij-aanhang hebben.

\section{Nadere analyse}

Als eerste stap in de analyse van de beschikbare gegevens is nagegaan in hoeverre de relatie tussen partijstandpunten en de houding ten aanzien van de EU onder de partij-aanhang niet een artefact is van de relatie tussen de stemming binnen het nationale elite discours en de publieke steun voor de EU. Om de stemming binnen het nationale elite discours in de lidstaten te typeren is de stemmingsindex gebruikt die gebaseerd is op de stemverhoudingen bij de ratificatiedebatten (vergelijk subparagraaf 9.2.2).De cijfers in het bovenste gedeelte van tabel 9.6 geven aan dat de invloed van het partijstandpunt op de steun voor de EU onder de partij-aanhang allerminst een artefact van de invloed van de stemming binnen het elite discours is. Onder constanthouding van de stemming binnen het nationale elite discours over de EU blijft sprake van een sterke samenhang tussen partijstandpunt en steun voor de EU onder de partij-aanhang. De partiēle samenhang $(+.60)$ wijkt immers nauwelijks af van de bivariate samenhang $(+.62)$.

De nadere analyse in deze subparagraaf is echter bedoeld om antwoord te krijgen op een andere vraag, namelijk: in hoeverre heeft de stemming binnen het nationale elite discours een van het partijstandpunt onafhankelijke invloed heeft op de steun voor de EU onder partij-aanhangers? Om dit te onderzoeken is de (bivariate en) partiële - onder constanthouding van de invloed van het partijstandpunten op de steun onder de aanhang - correlatie tussen de stemming binnen het nationale elite discours en de steun voor de EU onder de aanhang van politieke partijen berekend. De gevonden partiële correlatie $(+.31)$ duidt erop dat de stemming binnen het nationale elite discours inderdaad een van het partijstandpunt onafhankelijke (positieve) invloed heeft op de steun voor de EU onder de aanhang van partijen in de verschillende lidstaten. Het effect van de stemming in het elite discours op de steun voor de EU onder de partij-aanhang is, zoals verwacht, wel veel minder groot dan de invloed van het partijstandpunt. Dit betekent dat de steun voor de EU onder de aanhang van politieke partijen in een bepaalde lidstaat mede wordt bepaald door stemming binnen het elite discours in dat land.

De uitkomsten van een op de data uitgevoerde regressie-vergelijking (tabel 9.6) bevestigen dit beeld. Beide variabelen leveren een significante en onafhankelijke bijdrage aan de verklaring van de variatie in de steun onder de aanhang van de verschillende partijen. De regressie-coefficiënten geven een schatting van de effecten die partijstandpunt en stemming binnen het nationale elite 
Tabel 9.6 Steun onder partij-aanhang bij partijstandpunt en stemming nationale elite discours

Eerste-orde en partiele correlatie:

correl.

part.corr. $\mathrm{N}$

Steun partij-aanhang $X$ partijstandpunt o.c.v. stemming nation. elite discours

.62

.60202

Steun partij-aanhang $X$ stemming nation. elite discours o.c.v. partijstandpunt

38

$31 \quad 202$

Regressievergelijking

constante + partijstandpunt

constante + partijstandpunt + nat. elite discours

Bron: zie tabel $9.4 ;^{\bullet}=$ niet significant $(p>05)$. constante Partijstandpunt Elite dise.

b (t-value) b (t-value)

$44.8 \quad 24.9(11.2)$

$24.7 \quad 22.7(10.5)$

30

(4.7)
$\mathbf{R}^{2} \quad \mathbf{R}^{2}$

.39

$.45 \quad .06$

discours hebben op de steun voor de EU onder de aanhang van politieke partijen. Het geschatte verschil in netto-steun voor de EU onder de aanhang van pro-EU partij $(+1 * 22.7 \%)$ en een contra-EU partij $(-1 * 22.7 \%)$, bedraagt maar liefst $45.4 \%$. Het geschatte effect van verschillen en veranderingen in de stemming in het nationale elite discours is niettemin ook fors. Als de netto-steun voor een EU-verdrag in het nationale parlement van een lidstaat $33 \%$ hoger is dan in het parlement van een andere lidstaat, dan zal de steun voor de EU onder de aanhang van partijen in het eerste land zo'n 10\% hoger zijn dan onder de aanhang van partijen met een vergelijkbaar EU-standpunt in het laatste land. Tezamen blijken beide variabelen goed voor een verklaarde variantie van $45 \%$. De gegevens over de hoeveelheid verklaarde variantie onderstrepen dat het partijstandpunt meer effect heeft op de steun onder de aanhang dan het elite discours. Het geeft aan dat de houding van partij-aanhangers ten aanzien van de EU zowel door het partijstandpunt van hun favoriete partij, alsook door de stemming binnen het wijdere elite discours beïnvloed wordt.

Toch is dit nog maar een tussenstand. Immers, nagenoeg ongemerkt is een aanzienlijk deel van het publiek ( $\pm 25-30 \%$ ) buiten beschouwing gebleven in bovenstaande analyse. Het gaat om de groep burgers zonder expliciete partijvoorkeur. Aan de bijzondere positie van die groep zal in de volgende subparagraaf expliciet aandacht worden besteed.

\subsubsection{De vergeten groep: partijlozen}

Een groot aantal respondenten in de hier gebruikte surveys geeft aan geen expliciete partijvoorkeur te hebben. In de meeste surveys gaat het om $20 \%$ van de respondenten. In uitzonderlijke gevallen - de Franse data uit 1957, net voor het ineenstorten van de Vierde Republiek- gaat het om bijna $40 \%$ van de respondenten. Deze groepen zonder expliciete partijvoorkeur zullen verder worden aangeduid als partijlozen.

Naar verwachting zullen partijloze burgers zich bij het vergaren van informatie over politieke issues uit de massamedia niet laten leiden door een specifieke politieke partij. Veeleer valt te verwachten dat deze groep in principe open staat voor argumenten van alle kanten die ze direct of indirect via de media oppikken. Dit zou betekenen dat de set van actieve overwegingen die 
deze groep burgers in hun hoofd hebben ten aanzien van een specifiek issue waarschijnlijk een getrouwe afspiegeling vormt van de stemming binnen het nationale elite discours over dat specifieke issues. Dit zou betekenen dat de steun voor de EU binnen deze groep varieert van lidstaat tot lidstaat, en binnen een lidstaat ook door de tijd want de stemming binnen het elite discours varieert immers ook van lidstaat tot lidstaat en van jaar tot jaar.

De steun voor de EU onder partijlozen blijkt inderdaad sterk te variëren. In totaal zijn er 35 verschillende cases beschikbaar voor de analyse. De steun onder partijlozen ten tijde van de ratificatie-debatten varieert van $-9 \%$ (critici overheersen voorstanders) in Groot-Brittannie in 1973 , tot $+77 \%$ in Italiê in 1986 ! Deze variatie is ongeveer even groot als onder de aanhang van de partijen met een positief standpunt - van +8 tot $100 \%$ - en is iets kleiner dan onder partijen met een negatief standpunt - van $-66 \%$ tot $+61 \%$ (FDP in 1957 ).

De volgende vraag luidt: in hoeverre de variatie in de steun voor de EU onder partijlozen te verklaren is uit verschillen en veranderingen in de stemming binnen het nationale elite discours? De gegevens in tabel 9.7 geven het antwoord.

Tabel 9.7 Steun bij stemming nationale elite discours onder partijlozen en partijaanhang (pro, contra, verdeeld)

\begin{tabular}{lccc}
\hline & Correl. & N & sign. \\
Partijlozen & .67 & 35 & .00 \\
Aanhang pro-EU partijen & .39 & 133 & .00 \\
Aanhang contra-EU partijen & $.21 *$ & 52 & .14 \\
Aanhang verdeelde partijen & .49 & 17 & .05 \\
\hline
\end{tabular}

Bron: zie tabel $9.4 ;^{\circ}=$ niet significant, $\mathrm{p}<.05$.

Uit de gegevens blijkt er inderdaad sprake te zijn van een sterk positieve samenhang tussen de steun voor de EU onder partijlozen en de stemming binnen het elite discours over de EU. Er is zonder meer sprake van een sterke correlatie (+.67). De sterkte is vergelijkbaar met de sterkte van het verband zoals dat in subparagraaf 9.3 .1 is gevonden tussen partijstandpunt en steun onder de partij-aanhang. Als men de sterkte van de samenhang tussen nationaal elite discours en steun in het geval van partijlozen enerzijds, en steun onder de aanhang van respectievelijk pro-EU, contraEU en verdeelde partijen anderzijds naast elkaar legt, dan blijkt de samenhang onder partijlozen zoals verwacht - veruit het sterkst te zijn.

Dit alles onderstreept dat Zallers model niet slechts bruikbaar is bij de verklaring van de steun voor de EU onder de aanhang van politieke partijen, maar ook soelaas biedt bij de verklaring van de mening over de EU onder burgers zonder uitgesproken partijvoorkeur. Niet gehinderd door een partijvoorkeur blijken partijlozen zich bij het verwerken van informatie over politieke issues inderdaad minder te laten leiden door de mening van een bepaalde politieke partij dan partijaanhangers doen. De mening van partijlozen weerspiegelt de stemming binnen het elite discours over de EU in een lidstaat op een bepaald moment en varieert (van $-9 \%$ tot $+77 \%$ ) om die reden 
enorm sterk.

\subsubsection{Aanvullende toets: de Britse gegevens van Dalton en Duval}

Zoals reeds in de vorige paragraaf is betoogd, hebben Dalton en Duval op unieke wijze de stemming binnen het Britse elite discours over de EU in de periode 1972-1979 in kaart gebracht. Gelukkigerwijs bevat hun artikel ook de geaggregeerde gegevens over de cues die afkomstig zijn van de twee belangrijkste Britse partijen, te weten: de Labour Party en de Conservative Party. Dit wil zeggen, ze hebben bij het coderen van berichten ook vastgelegd wie de specifieke "elitebron" van een bericht in The Guardian was ("the initiator of an event"). Samen met informatie over de toonzetting van het bericht, het pro- respectievelijk contra-EU karakter, is voor beide partijen afzonderlijk een jaar-index te construeren door het aantal cueing messages van een partij met een contra-EU argument af te trekken van het aantal cueing messages met een pro-EU argument. De uitkomsten hiervan zijn hieronder opgenomen in tabel 9.8 (Dalton en Duval, 1986: 125). Met deze gegevens is het mogelijk om na te gaan in hoeverre de steun voor de EU onder de partij-aanhangers inderdaad fluctueert naar gelang de argumenten die door de partijen worden aangereikt.

Tabel 9.8 Steun onder aanhang Labour en Conservatives bij partijstandpunt (The Guardian), 1973-1979

\begin{tabular}{|l|c|c|c|c|c|}
\hline \multirow{2}{*}{ Jaar: } & $\begin{array}{c}\text { Brits elite } \\
\text { discours }\end{array}$ & \multicolumn{2}{|c|}{ Labour Party } & \multicolumn{2}{c|}{ Conservative Party } \\
\cline { 2 - 6 } & pos-neg & $\begin{array}{c}\text { cueing messages } \\
\text { pos - neg }\end{array}$ & $\begin{array}{c}\text { steun aanhang } \\
\text { (MEM) }\end{array}$ & $\begin{array}{c}\text { cueing messages } \\
\text { pos - neg }\end{array}$ & $\begin{array}{c}\text { steun aanhang } \\
\text { (MEM) }\end{array}$ \\
\hline 1973 & -948 & -75 & -29 & 134 & 29 \\
1975 & +261 & 393 & 4 & 236 & 56 \\
1976 & -1592 & -51 & -18 & 21 & 28 \\
1977 & -1090 & -64 & -16 & 26 & 26 \\
1978 & -2132 & -368 & -11 & -23 & 17 \\
1979 & -2731 & -506 & -26 & -156 & 15 \\
\hline \multicolumn{7}{|c}{ Corr. } \\
steun x partijstandpunt cueing messages 56 & N & 12 & sign \\
\hline
\end{tabular}

Bron: ECS73 en EB3-12 (1975-1979); Dalton en Duval (1986: 125).

Een simpele inspectie van de data maakt duidelijk dat er ook nu weer een verband is te onderkennen tussen (wijzigingen in) partijstandpunten en steun voor de EU onder de aanhang. Als de partij positiever over de EU wordt, dan wordt de aanhang ook positiever. Tegelijkertijd geven de data ook aan dat er meer aan de hand is dan simpelweg aan de knoppen draaien. Zo slaat de balans tussen positieve en negatieve signalen in 1975 bij de Labour Party nog verder in positieve richting door dan bij de Conservative Party. Desalniettemin is de aanhang van Labour 
in 1975 een stuk minder positief over de EU dan de aanhang van de Conservative Party, ${ }^{129} \mathrm{Het}$ verband tussen cueing messages en netto-steun is over beide partijen gerekend +.54 .

\subsubsection{Conclusie}

De resultaten van de uitgevoerde analyses geven geen enkele aanleiding om de hypothese op meso-niveau te verwerpen. De hypothese luidde:

Hypothese 2: Partijpolitieke verschillen in de steun voor de EU binnen het elite discours, leiden tot vergelijkbare verschillen in de steun voor de EU tussen de aanhang van politieke partijen binnen de publieke opinie.

Alle beschikbare data en analyses bevestigen dat partijen inderdaad een cruciale rol vervullen in het proces van publieke-opinievorming ten aanzien van de EU. Veranderingen en verschillen in partijstandpunten over de EU blijken zonder veel moeite terug te vinden in de steun voor de EU onder de partij-aanhang van de verschillende politieke partijen. Naast de empirische steun voor de hypothese, bleek het bij nader inzien ook mogelijk om op basis van de uitgangspunten uit het RAS-model een verklaring te geven voor de variatie in de steun voor de EU onder partijloze burgers in de lidstaten.

\subsection{Partij-identificatie en het elite discours (micro-niveau)}

In deze paragraaf staat de opinievorming op het niveau van individuele burgers (micro-niveau) centraal. Hierboven bij de discussie over de steun voor de EU onder partijlozen is al ingegaan op de verwachting dat de mate van betrokkenheid bij een politieke partij zowel bijdraagt aan het strenger selecteren van informatie afkomstig van niet-favoriete partijen, als ook aan het oppikken

\footnotetext{
${ }^{129}$ De verklaring voor de opmerkelijk verstoring van de "normale" - Conservatives positiever over de EU dan Labour -verhoudingen tussen beide partijen in 1975 behoeft enige toelichting. Het is de conservatieve premier Heath (1970-1974) die zijn land in het begin van de jaren zeventig uiteindelijk de EU inloodst. De voorwaarden voor de toetreding zijn in de ogen van Wilson, de Labour-leider, echter onaanvaardbaar. Tijdens de belangrijkste debatten (1971-1972) in het Britse parlement over de EU-verdragen ontpoppen de socialisten zich dan ook als tegenstanders van de toetreding. Dit alles verandert als de socialisten in 1974 de verkiezingen winnen. De nieuwe premier Wilson gaat met de EU onderhandeien over de voorwaarden waaronder het Verenigd Koninkrijk lid is geworden en legt het door hem bereikte resultaat in 1975 middels een referendum voor aan het Britse volk. Het hoeft dus nauwelijks verbazing te wekken dat de balans in de cueing messages uit Labour-bronnen in 1975 als een blad aan de boom omslaat. De aanhang reageert wel op deze verschuiving, maar niet alle aanhangers lijken de vroegere kritiek te zijn vergeten. Later "normaliseren" de verhoudingen zich weer met de Conservative Party als de relatief meest positieve partij. Wat in de cijfers niet tot uiting komt is dat beide partijen eigenlijk gedurende de hele onderzoeksperiode intern verdeeld zijn over het EU-issue, de aanhangers van beide partijen staan dus voortdurend bloot aan pro- en contra-EU partijsignalen (Nicholson en East, 1987).
} 
van informatie afkomstig van en/of in overeenstemming met het EU-standpunt van de favoriete partij. Dit zou erin moeten resulteren dat de sterkte van de samenhang tussen partijstandpunt en de houding van partij-aanhangers op individueel niveau positief wordt beïnvloed door de mate van partij-identificatie. De te toetsen hypothese luidt:

Hypothese 3: Naarmate iemand zich sterker identificeert met een politieke partij, des te sterker zal de samenhang tussen partijstandpunt en iemands houding ten aanzien van de EU zijn.

\section{Gegevens}

Om dezelfde redenen als in de vorige paragraaf wordt ook in deze paragraaf geen gebruik gemaakt van Party Manifesto-data. De data van Dalton en Duval lenen zich ook niet zo goed voor een analyse op individueel niveau omdat beide Engelse partijen in de onderzoeksperiode ernstig verdeeld waren over de EU. Uit de ons ter beschikking staande gegevens kan de mate van verdeeldheid in een jaar echter niet worden afgeleid. Daarom is voor de analyse in deze paragraaf alleen gewerkt met partijstandpunten uit de ratificatiedebatten.

Helaas bevatten de surveygegevens uit de jaren vijftig en 1973 geen indicator die ons in staat stelt om onderscheid te maken tussen meer en minder betrokken partij-aanhangers. Ook de Griekse dataset uit 1980 bevatten geen gegevens over de partij-identificatie van de respondenten. Dit betekent dat we voor de toetsing primair zijn aangewezen op het ratificatiedebatten over de Europese Akte (1986) en het Verdrag van Maastricht (1992). Voor de toetsing op individueel niveau zal gebruik worden gemaakt van de surveygegevens uit 1986 (EB25/6) en 1992 (EB38/9). In deze Eurobarometers is respondenten de volgende hoofdvraag voorgelegd:

Do you consider yourself to be close to any particular party?; en indien een respondent op deze vraag " ja" antwoordde, dan is doorgevraagd:

Do you feel yourself very close to this party, fairly close or merely a sympathizer?

Aan de hand van deze vragen zijn partij-aanhangers - partijlozen uiteraard niet - in te delen in vier groepen. De eerste groep wordt gevormd door de respondenten die de eerste vraag met "nee" beantwoorden en dus niet aan de tweede vraag toekomen. Dit zijn de respondenten die aangeven wel te willen stemmen op een partij, maar zich verder niet betrokken voelen bij die partij. Ik zal deze groep aanduiden als kiezers. De respondenten in de andere drie groepen beantwoorden de eerste vraag met " ja" ${ }^{130}$ De tweede groep bestaat uit sympathisanten die zich slechts in geringe

\footnotetext{
${ }^{130}$ Het is overigens niet zeker dat de partij waarop een respondent zegt te zullen stemmen als er op het moment van ondervraging verkiezingen zijn, dezelfde is als waarmee hij zich zegt te identificeren. De vraag naar de partijidentificatic is namelijk losgekoppeld van de vraag naar de partijvoorkeur. Het is echter wel aannemelijk dat de voorkeur uitgaat naar dezelfde partij als waarmee men zich identificeert, zeker bij aanhangers die een relatief sterke betrokkenheid bij de partij gevoelen. Aangezien het zonder een dergelijke aanname aberhaupt onmogelijk is om de hypothese te toetsen, is de keus snel gemaakt.
} 
mate identificeren met de partij. De derde groep zijn de betrokkenen die zich relatief sterk tot de partij voelen aangetrokken. Tenslotte zijn er vertrouwelingen die zich sterk betrokken voelen bij de partij. Deze vier groepen zullen hieronder worden onderscheiden om na te kunnen gaan in hoeverre de sterkte van de samenhang tussen de individuele mening van partij-aanhangers over de EU en het partijstandpunt ten aanzien van de EU afhankelijk is van de mate van partijidentificatie.

\section{Resultaten empirische toets}

Alvorens de resultaten van de toets kunnen worden besproken, moet nog een opmerking worden gemaakt over de werkwijze die is gevolgd. In sommige lidstaten is het aantal partijen dat "verdeeld" of "tegen" erg gering. Bovendien gaat het daarbij vaak om kleine partijen. Dientengevolge zijn er in sommige landen, ondanks de combinatie van vier Eurobarometers, niet meer dan 50 aanhangers van verdeelde en/of anti-EU partijen beschikbaar voor de analyse. Dit komt vooral voor in Spanje, Luxemburg, West-Duitsland en Italiě. Dezze groep moet voor onderstaande analyse ook nog verdeeld worden over vier categorieetn partij-aanhangers, zodat er vaak erg weinig partij-aanhangers over blijven binnen een categorie. Het berekenen van een samenhang tussen partijstandpunt en steun voor de EU binnen zo'n categorie wordt hierdoor een hachelijke zaak, die leidt tot onbetrouwbare gamma's. ${ }^{131}$ Daarom is er voor gekozen om slechts in die categorieën een samenhang te berekenen tussen steun en partijstandpunten waar minimaal 25 aanhangers van verdeelde en/of anti-EU partijen beschikbaar zijn. Dit voorkomt bijvoorbeeld dat er niet-significante gamma's van +.22 (mem) respectievelijk -.16 (unif) in de tabel verschijnen voor Spaanse sympathisanten gebaseerd op een vergelijking van de steun onder 5 sympathisanten van een Spaanse anti-EU partij tegenover honderden sympathisanten van diverse andere Spaanse pro-EU partijen.

In tabel 9.9 is te zien dat de sterkte van de samenhang tussen partijstandpunt en de individuele houding ten aanzien van de EU binnen de verschillende categorieěn partij-aanhangers inderdaad systematisch afneemt met de mate van partij-identificatie. In nagenoeg alle lidstaten is een systematische afname van de sterkte van de samenhang te constateren als van "vertrouwelingen" via "betrokkenen" en "sympathisanten" naar "kiezers" wordt gegaan. De verschillen tussen de sterkte van het verband binnen de groep "vertrouwelingen" enerzijds, en de groep "kiezers" anderzijds zijn groot. In de laatste kolom van tabel 9.9 is het verschil in de gamma-waarden tussen de twee uiterste categoriežn partij-aanhangers aangegeven. De verschillen tussen de groepen zijn het grootst in Portugal, Griekenland, Frankrijk en Nederland. In Denemarken, waar

ai Voor de analyse op individueel niveau zal weer gebruik worden gemaakt van gamma's omdat beide variabelen op ordinaal niveau gemeten zijn, te weten: partijstandpunt (voor/verdeeld/tegen) en steun (antwoordcategorieťn unif - en mem-vraag). 
het EU-issue al jaren hoog op de politieke agenda staat en garant staat voor scherpe partijpolitieke tegenstellingen tussen partij-aanhangers, is het verschil tussen de verschillende categorieën relatief beperkt doordat de partij-politieke standpunten in dit land zelfs sterk doorwerken binnen de groep "kiezers", de minst fervente partij-aanhangers.

Het is belangrijk op te merken dat ondanks de verschillen tussen categorieën partijaanhangers, de samenhang in de meeste categorieěn en lidstaten niettemin positief is. In de pooled dataset is onder de "gewone" kiezers nog steeds sprake van een relatief sterke samenhang tussen partijstandpunt en eigen standpunt. Dit onderstreept dat ook gewone "kiezers," die aangeven verder geen bijzondere band met de partij van hun keuze te hebben, zich in hun meningsvorming laten beïnvloeden door partijstandpunten.

De niet-significante coëfficiënten in West-Duitsland en Groot-Brittannië die het patroon enigszins verstoren, zijn verklaarbaar. De geringe samenhang in West-Duitsland heeft vooral te maken met het feit dat in dat land nauwelijks anti-EU partijen zijn die aan de ratificatiedebatten hebben meegedaan. Dit hangt samen met de hoge kiesdrempel die in West-Duitsland wordt gehanteerd waardoor kleine rechtse en linkse partijen nauwelijks kans hebben om in de volksvertegenwoordiging te komen. Het feit dat de coëfficiēnten in Groot-Brittanniē niet altijd significant zijn heeft alles te maken met het feit dat de twee grote partijen op het punt van de EU allebei intern verdeeld zijn. Dit bemoeilijkt het vinden van significante verbanden, doordat partijaanhangers in zo'n geval aan verschillende signalen bloot staan. Het is aardig om te zien dat in dit geval de afname van de sterkte in het verband tussen partijstandpunten en steun voor de EU in de verschillende categorieën partij-aanhangers bij de mem-indicator veel beter uit de verf komt dan bij de unif-indicator. De mem-vraag kent nadrukkelijk een neutrale antwoord-categorie (goed, noch slecht) waarvoor de aanhangers van verdeelde partijen kunnen kiezen. Bij de unifvraag moeten ze kiezen uit voor of tegen. De niet-significante verbanden in tabel 9.9 zijn niet verontrustend, ook al omdat er geen enkel significant negatief verband wordt gevonden.

De analyse geeft geen aanleiding om de in hoofdstuk 7 uit Zallers RAS-model afgeleide hypothese over de vorming van de houding ten aanzien van de EU op individueel niveau te verwerpen. Uit de analyse komt heel duidelijk het beeld naar voren dat de houdingen van meer intense partij-aanhangers inderdaad beter aansluiten bij partijstandpunten dan de houdingen van minder intense partij-aanhangers. De verklaring voor dit fenomeen ligt volgens het RAS-model in het feit dat meer fervente partij-aanhangers beter in staat zijn om standpunten van nietfavoriete partijen uit hun geheugen te weren en standpunten van de eigen (favoriete) partij juist wel op te pikken dan minder intense partij-aanhangers. Het aan Zallers RAS-model ten grondslag liggende idee dat politieke partijen een centrale rol spelen bij de opinievorming van individuele partij-aanhangers blijft ook bij de analyses op individueel niveau recht overeind. Dit onderstreept 


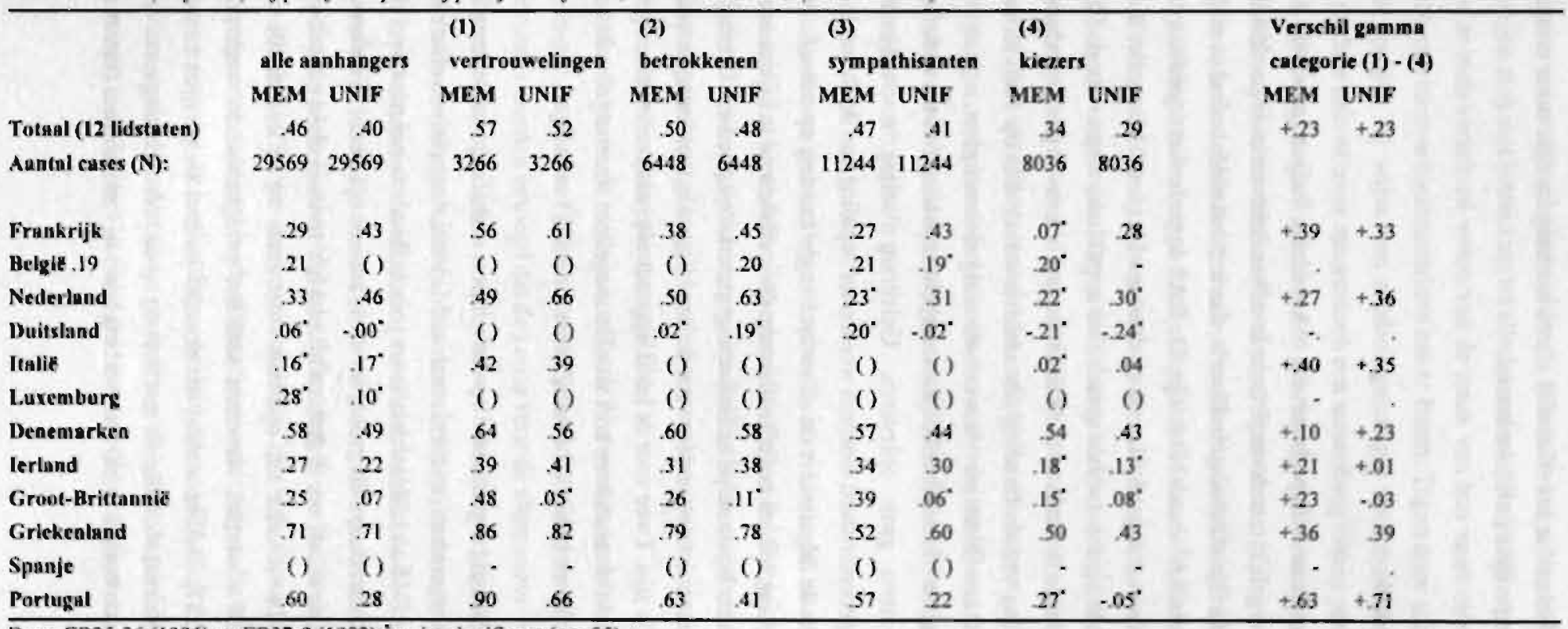

Bron: EB25-26 (1986) en EB37-8 (1992) ${ }^{*}=$ niet significant $(\mathrm{p}>.05)$.

() - er zijn minder dan 25 aanhangers van verdeelde of anti-EU partijen in deze categorie beschikbaar.

- - geen variatie op de onafhankelijke variabele (partijstandpunt) / waarde kan niet worden berekend (lantste kolom). 
dat partij-aanhangers vaak zonder het zelf te beseffen niet alleen aanhangers zijn, maar tevens volgers zijn bij relatief abstracte en perifere politieke issues.

\subsection{Zallers RAS-model: eindoordeel}

Als men de empirische houdbaarheid van de hypothesen die in hoofdstuk 7 zijn afgeleid uit de axioma's van Zallers RAS-model vergelijkt met de empirische houdbaarheid van in de hoofdstuk 6 afgeleide hypothesen uit Ingleharts Silent Revolution-theorie, dan kan het eindoordeel over de empirische houdbaarheid van Zallers RAS-model kort zijn. De RAS-hypothesen doorstaan de empirische toetsing zonder noemenswaardige problemen en daarmee lijkt het RAS-model dus een acceptabele verklaring te kunnen bieden voor de verschillen in publieke steun voor de EU binnen en tussen lidstaten, verschillen in de steun voor de EU tussen en binnen de partij-aanhang van politieke partijen en de vorming van de houding ten aanzien van de EU op individueel niveau. Toch is de conclusie van dit hoofdstuk met deze constatering niet compleet.

Yooraf leek met name de meting van de onafhankelijke yariabele stemming binnen het elite discours nog problemen te kunnen gaan opleveren. Gelet op weinig overtuigende meetinstrumenten die uiteindelijk geconstrueerd moesten worden ter bepaling van de stemming binnen elite discours over de EU in de lidstaten, is de uitkomst van de toetsing opvallend. De keuze voor het meten van de stemming binnen het elite discours door uitsluitend te kijken naar de houding van politieke partijen pakte bij de empirische toetsingopmerkelijk goed uit. Dit roept echter de vraag op of door deze keuzes niet ook andere voor de hand liggende verklaringen voor de gevonden samenhangen mogelijk zijn. Twee voor de hand liggende alternatieve verklaringen zijn denkbaar. Hieronder zullen beide alternatieven kort worden toegelicht waarna getracht zal worden de interpretatie van de resultaten in het licht van Zallers model te verdedigen.

De eerste denkbare alternatieve verklaring is gebaseerd op een simpele omkering van de causale relatic. In die verklaring passen de burgers hun opinie niet aan aan de elite, maar past de elite zijn mening aan aan de publieke opinie. De beschikbare data laten geen keiharde conclusies over de causale volgorde toe. Goede paneldata zouden dit probleem deels kunnen oplossen, maar nooit helemaal. De suggestie om de causale relatie om te draaien lijkt op het eerste gezicht misschien goedkoop, maar is dat zeker niet. In dit kader kan opnieuw - net zoals bij de introductie op Zallers RAS-model in hoofdstuk 7 - worden verwezen naar het gezaghebbende werk van Schumpeter (1957) en Downs (1957). Beiden stellen dat doordat politici en partijen in een democratie primair uit zijn op stemmenmaximalisatie met het oog op de herverkiezing en er om die reden alle belang bij hebben op de hoogte te blijven van hetgeen hun vaste kiezers (klanten) 
wensen en eventueel nieuwe kiezers (klanten) kan aantrekken. In dat kader is het logisch dat partijen zich met betrekking tot allerlei issues op zodanige wijze in de kiezersmarkt positioneren dat ze zich verzekerd weten van de steun van hun vaste clientèle en tegelijkertijd nog zullen proberen nieuwe kiezersmarkten aan te boren. Tegen deze achtergrond is het volstrekt normaal dat partijen bij wijze van marketingstrategie voortdurend hun kiezers proberen te volgen waardoor min of meer automatisch een samenhang tussen partijstandpunten (stemming binnen het elite discours ten aanzien van een issue) en de standpunten van de partij-aanhang ( de publieke opinie ten aanzien van een issue) ontstaat.

De tweede denkbare alternatieve verklaring is dat burgers hun partijvoorkeur baseren op een vergelijking van hun eigen standpunten met die van de beschikbare politieke partijen in hun land en dat langs die weg een automatische match plaats vindt tussen standpunten van partijaanhangers en partijen. Tegen die achtergrond is het logisch dat de verhoudingen tussen vooren tegenstanders over een bepaald issue in het parlement overeenstemmen met de verhoudingen binnen het electoraat; alsmede dat individuen die zeggen op een bepaalde partij te stemmen opvattingen over issues hebben die nauw aansluiten bij de standpunten van diezelfde partij; en dat naarmate iemands opvattingen nauwer aansluiten bij een partij, zo iemand zich ook sterker betrokken voelt bij zo'n partij.

Deze twee voor de hand liggende plausibele verklaringen waarschuwen ons dat we niet al te vlug moeten juichen over de bruikbaarheid van Zallers RAS-model. De beschikbare data bieden geen ruimte voor een kritische toets tussen Zallers RAS-model en deze twee verklaringen. Daarvoor zijn paneldata nodig in combinatie met nauwkeurige en minutieuze gegevens over de inhoud van de massamedia op het punt van de EU.

In het licht van de reeds in hoofdstuk 7 besproken inzichten over de beperkte omvang van het issue-public van het EU-issue en het gebrek aan Europees kiesgedrag bij EP-verkiezingen zal hieronder worden betoogd dat de keuze voor de alternatieve verklaringen niet voor de hand ligt en een keuze voor Zallers model juist wel voor de hand ligt omdat alleen de uitgangspunten van het RAS-model aansluiten bij deze twee belangrijke en empirisch gefundeerde inzichten.

Het eerste inzicht is dat slechts een klein deel van de EU-burgers weldoordachte opvattingen over de EU heeft. Dit inzicht is vooral gebaseerd op de resultaten uit zowel oud als vrij recent panelonderzoek. Daaruit blijkt dat de houdingen van burgers ten aanzien van de EU zeer instabiel zijn (Saris, 1997, Converse en Pierce, 1986: 233-9; Butler en Stokes, 1974: 279). Dit inzicht staat op gespannen voet met beide alternatieve verklaringen die uitgaan van het idee dat individuele burgers uitgesproken opvattingen hebben over de EU. Ook de problemen die we in hoofdstuk 4 hadden om antwoord te geven op de vraag hoe groot de publieke steun voor de EU in de lidstaten is, passen in dit kader. Het beeld dat men van de publieke steun voor de EU krijgt, blijkt namelijk 
extreem gevoelig te zijn voor de vraag die men aan burgers voorlegt (zie hoofdstuk 4 en 5; Janssen, 1991:451-4; Blondel, Sinnott en Svensson, 1998: 56-62).

In relatie tot de tweede alternatieve verklaring moet nog worden gewezen op een inzicht dat afkomstig is uit onderzoek naar kiesgedrag van burgers bij Europese verkiezingen. Juist bij deze verkiezingen zou men mogen verwachten dat de houding ten aanzien van de EU een belangrijke rol speelt bij de partijkeuze van burgers. Uit al het onderzoek op dit terrein komt echter telkens weer naar voren dat de houding ten aanzien van de EU (en EU-zaken) een volstrekt ondergeschikte rol speelt bij de partijkeuze (Reif en Schmitt, 1980; Oppenhuis, 1995: 147 en 163: Van der Eijk, Franklin en Oppenhuis, 1996: 355; Franklin, Van der Eijk en Marsh, 1996: 367-8; Van der Eijk, Franklin en Van der Brug, 1999: 173-81; Thomassen en Schmitt, 1999a: 206). Dit onderstreept dat het ridicuul is te vooronderstellen dat burgers bij het bepalen van hun partijvoorkeur wel acht zouden slaan op partijstandpunten ten aanzien van de EU. Daarmee lijkt dus ook uitgesloten dat de samenhang tussen de stemming binnen het elite discours en partijstandpunten enerzijds en de publieke steun voor de EU respectievelijk de mate van steun onder partij-aanhang anderzijds kan worden verklaard uit de bewuste afwegingen die kiezers zouden maken bij het bepalen van hun partijkeuze.

Zallers model is als enige wel goed verenigbaar met het idee dat burgers geen stabiele en weldoordachte opvattingen over de EU hebben. Het model vooronderstelt geen houdingen bij burgers of kennis van partijstandpunten. Integendeel. Zaller (1992: 28) vooronderstelt slechts enkele politieke predispositions die ervoor zorgen dat burgers bepaalde informatie uit de massamedia negeren en andere juist oppikken. Partijvoorkeur is de meest belangrijke predisposition die burgers gebruiken bij de negatieve selectie van politieke informatie uit de massamedia. Het idee daarbij is dat alle informatie die strijdig is met een predisposition niet geaccepteerd wordt door burgers. In relatie tot de partijvoorkeur betekent dit dat alle informatie van niet-favoriete partijen of hun vertegenwoordigers als ongeldig van de hand wordt gewezen. Partijvoorkeuren zorgen op die manier welhaast vanzelfsprekend en buiten medeweten van de aanhangers zelf dat er een koppeling ontstaat tussen de stemming binnen elite-discours over de EU en partijstandpunten aan de ene kant, en de publieke opinie over de EU en de houdingen van partij-aanhangers aan de andere kant. Die match op macro- en meso-niveau staat in Zallers theorie echter niet in de weg dat er op micro-niveau volop ruimte voor instabiliteit is.

Gelet op de inzichten over de instabiliteit van EU-houdingen en het gebrek aan Europees kiesgedrag bij EP-verkiezingen kan dus moeilijk worden volgehouden dat de beide alternatieve verklaringen net zo goed bij de empirische inzichten uit dit hoofdstuk passen als een interpretatie in termen van Zallers RAS-model. 


\section{Conclusies}

\subsection{Inleiding}

Inmiddels is het bijna een halve eeuw geleden dat zes landen in Parijs het verdrag ter oprichting van de EGKS tekenden. Vrij snel daarna werden de inwoners van een (toentertijd nog) beperkt aantal West-Europese staten voor het eerst geconfronteerd met het fenomeen Europa. Een Europa dat gaandeweg via EEG, Euratom, EG en uiteindelijk EU een economisch-politicke-monetaire grootheid aan het worden is. Bij voortduring kan worden vastgesteld dat besluiten over het nemen van nadere stappen in het integratieproces eigenlijk tijdens de gehele periode van vijftig jaar grotendeels exclusief en op intergouvernementele basis over de hoofden van de bevolking heen genomen worden door de regeringsleiders der lidstaten. Tegelijkertijd echter bestaat bij iedereen de overtuiging dat dit proces en een verdere uitbouw van de EU zich onmogelijk kan voltrekken als er geen sprake is van steun vanuit de bevolking.

Met dit gegeven in het achterhoofd en de constatering dat de steun voor de EU in de verschillende lidstaten nogal uiteenliep, is een aantal jaren geleden het idee voor dit onderzoek ontstaan. Bij het opzetten van het onderzoek is de volgende doelstelling geformuleerd: het vergroten van het inzicht in de oorzaken van veranderingen in de publieke steun voor de $E U$ binnen de lidstaten, en in de oorzaken van de verschillen in de publieke steun voor de EU tussen de lidstaten. Om het doel te bereiken zijn in hoofdstuk 1 , zes onderzoeksvragen opgesteld waar een antwoord op is gezocht in dit onderzoek. In dit hoofdstuk willen we kijken in hoeverre de doelstelling bereikt is. Paragraaf 10.2 bevat de antwoorden op de zes onderzoeksvragen. In paragraaf $10.3 \mathrm{zal}$ worden besproken wat de betekenis van de onderzoeksresultaten is in het licht van de doelstelling en worden suggesties gedaan voor verder onderzoek. Ter afsluiting van deze studie worden de resultaten gerelateerd aan het betoog in hoofdstuk 3 over de relatie tussen publieke steun en het voortbestaan en functioneren van de EU (paragraaf 10.4).

\subsection{Antwoorden op onderzoeksvragen}

In hoofdstuk 1 zijn, gelet op de hierboven aangehaalde doelstelling, zes onderzoeksvragen 
opgesteld waarop in deze studie een antwoord is gezocht. De zes vragen zijn hieronder nog eens op een rijtje gezet:

1. Hoe groot is de publieke steun voor de EU in de lidstaten?

2. Hoe groot zijn de verschillen in de publieke steun voor de EU tussen de lidstaten?

3. Hoe groot zijn de veranderingen in de publieke steun voor de EU binnen de lidstaten?

4. Zijn de verschillen in publieke steun voor de EU tussen de lidstaten stabiel?

5. Welke factoren kunnen de individuele houding van burgers ten aanzien van de EU verklaren?

6. Welke factoren kunnen de mate van publieke steun voor de EU in een land verklaren? Hieronder volgen de antwoorden die we hebben gevonden.

\section{Hoe groot is de publieke steun voor de EU in de lidstaten?}

In hoofdstuk 4 en 5 is gebleken dat het beantwoorden van deze op het eerste gezicht simpele vraag geenszins eenvoudig is. De omvang van de publieke steun voor de EU in een lidstaat blijkt namelijk sterk afhankelijk te zijn van de indicator die men gebruikt. Als men mensen vraagt of ze het EU-lidmaatschap van hun land een goede zaak vinden, dan krijgt men een totaal ander beeld van de steun dan wanneer men burgers vraagt om hun gevoel te beschrijven als de EU morgen zou worden opgeheven. In dit onderzoek zijn drie verschillende indicatoren (unif-, memen scrap-vraag) naast elkaar gebruikt om de steun voor de EU te meten (zie paragraaf 4.2). Elke indicator geeft zijn eigen beeld van de hoogte van de publieke steun in de diverse lidstaten waarbij zo nu en dan forse verschillen optreden tussen de indicatoren.

Een voorbeeld kan verduidelijken hoe sterk de verschilscores op de drie indicatoren verschillen. De Portugese steun voor de EU in het najaar van 1994 komt achtereenvolgens op basis van de unif-, mem- en scrap-vraag uit op: $+63 \%,+45 \%$ en $+22 \%$. Net zoals in dit voorbeeld zijn de unif-scores in de meeste gevallen het hoogst. De unif-scores suggereren bijna in alle gevallen dat de publieke steun in de lidstaten bijzonder hoog is. De antwoorden van dezelfde respondenten op de scrap-vraag doen vaak vermoeden dat de steun veel lager is. De mem-scores liggen bijna standaard tussen de unif-en scrap-scores in.

Wel is het zo dat alledrie de indicatoren een vergelijkbaar beeld schetsen als het gaat om de vraag in welke lidstaten de steun relatief hoog respectievelijk relatief laag is. Zo zou men dus kunnen concluderen dat de unif-scores in zekere zin de bovengrens markeren die aan de publieke steun voor de EU in een land zit, terwijl de koelere reacties die de scrap-vraag oproept in zekere zin de ondergrens aangeven. Met dit als uitgangspunt luidt de conclusie dat de publieke steun voor de EU in alle lidstaten, op nagenoeg alle onderzochte tijdstippen positief is. Dit wil dus zeggen dat het percentage voorstanders van de EU in een lidstaat bijna altijd het percentage tegenstanders overtreft. Alleen in Groot-Brittanniê en Denemarken zijn de scores af en toe 
negatief. In Denemarken komt dit regelmatig voor in de periode tussen 1975 en 1987, in GrootBrittanniē is het een regelmatig (en nog altijd) terugkerend fenomeen sinds de toetreding van het land tot de EU in 1973. In de andere lidstaten is de steun nog nooit onder het nulpunt gedaald.

Behalve in Denemarken en Groot-Brittannič, liggen de unif- én mem-scores (nettoverschilscores) die de publieke steun voor de EU aanduiden over het algemeen op een erg hoog absoluut niveau. De meeste scores op deze twee indicatoren liggen tussen de $45 \%$ en $75 \%$. In heel veel gevallen overtreft het percentage voorstanders in een lidstaat het percentage tegenstanders dus met meer dan $50 \%$, er zijn zelfs uitschieters tot boven de $80 \%$. Dit geeft aan dat de bovengrens aan de steun voor de EU in de lidstaten op een erg hoog absoluut niveau ligt. De ondergrens, afgaande op de scrap-scores, liggen in de meeste gevallen zo'n $20 \%$ tot $35 \%$ lager. Deze scores liggen, behalve in Denemarken en Groot-Brittannię, meestal tussen de $20 \%$ en $50 \%$. Ook de ondergrens ligt dus in de meeste gevallen ruim boven het nulpunt.

Om aan te geven hoe zeer de onder-en bovengrenzen aan de publieke steun voor de EU in de lidstaten kunnen variēren zijn hieronder de maxima en minima binnen de beschikbare nationale tijdreeksen in tabel 10.1 bij elkaar zet. Hierbij dient wel te worden opgemerkt dat met name de onderliggende unif-reeksen in de diverse lidstaten een sterk uiteenlopende tijdsperiode beslaan (zie tabel 5.1), alsmede dat de Griekse, Spaanse en Portugese tijdreeksen korter zijn dan in de andere landen. Het overzicht in de tabel laat duidelijk zien dat de steun voor de EU alleen in Denemarken (drie indicatoren) en Groot-Brittanniě (twee indicatoren) soms negatief is.

\section{Hoe groot zijn de verschillen in de publieke steun voor de EU tussen de lidstaten?}

In hoofdstuk 4 en 5 is aandacht besteed aan de verschillen in de publieke steun voor de lidstaten. Op elk tijdstip gedurende de gehele onderzoeksperiode blijkt er (op zijn minst) sprake te zijn van een significante verschil te zijn in de publieke steun voor de EU tussen de lidstaat met het hoogste niveau van publieke steun en de lidstaat met het laagste niveau van politieke steun.

Door wederom de unif-scores als boven- en de scrap-scores als ondergrens te nemen, kan worden gesteld dat de het publieke opinieklimaat ten aanzien van de EU op heel veel momenten varieert van licht kritisch in Denemarken en/of Groot-Brittanniề tot bijna unaniem positief in één of meerdere andere lidstaten (veelal Nederland, Luxemburg, Italiě of lerland). Met name in de het begin van de jaren tachtig zijn de verschillen tussen de lidstaten erg groot. Het maximale verschil tussen twee lidstaten op enig moment zit in de mem-scores van Luxemburg $(+81 \%)$ en Groot-Brittannië $(-24 \%)$ in het voorjaar van 1980, het verschil bedraagt maar liefst $105 \%$; het geringste verschil in de mem-scores bedraagt $41 \%$ in 1990 tussen Nederland en Groot-Brittanniě. In de unif-reeks zit een maximaal verschil van $90 \%$ in 1985 , en een minimaal verschil van $17 \%$ in 1952 (slechts vier landen); de vergelijkbare gegevens voor de scrap-reeksen bedragen $81 \%$ (voorjaar 1981) en $48 \%$ (voorjaar 1993). De cijfers onderstrepen dat er op elk moment in de 
onderzoeksperiode sprake is van significante verschillen tussen de lidstaten.

Tabel 10.I Extreme scores en veranderingen in tijdreeksen (unif, mem, scrap) per lidstaat (in \%)

\begin{tabular}{|c|c|c|c|c|c|c|c|c|c|c|c|c|c|c|c|}
\hline Lidstaat: & F & B & NL & WD & I & L & DK & EI & GB & GR & E & P \\
UNIF-INDICATOR & \\
maximum & 80 & 79 & 83 & 85 & 87 & $82^{*}$ & 46 & 76 & 74 & 79 & 83 & 80 \\
minimum & 33 & 45 & 52 & 36 & 43 & 46 & -10 & 36 & $21^{*}$ & 29 & 46 & $24 \%^{*}$ \\
verschil & $47^{*}$ & $34^{*}$ & $31^{*}$ & $49^{*}$ & $45^{*}$ & $36^{*}$ & $56^{*}$ & $40^{*}$ & $53^{*}$ & $50^{*}$ & $37^{*}$ & $56^{*}$ \\
\hline
\end{tabular}

Bron: Zie tabel $5.1-5.3 ;{ }^{*}=p<.01$, f-test op verschillen tussen maximum en minimum per lidstaat.

a) De unisscores gebaseera uit Het de sterk atwijkende formulering van de unif-vraag in het begin van de jaren zeventig (1970-5) zijn bij het maken van dit overzicht buiten beschouwing gelaten (zie noot tabel 5.1)

\section{Hoe groot zijn de veranderingen in de publieke steun voor de EU binnen de lidstaten?}

In hoofdstuk 5 zijn de veranderingen in de publieke steun binnen de lidstaten onder de loep genomen. Belangrijkste conclusie was dat er binnen alle lidstaten sprake is van significante veranderingen. De gegevens in tabel 10.1 die al bij de beantwoording van de eerste onderzoeksvraag zijn gebruikt, geven een beeld van de mate waarin de steun varieert binnen de lidstaten.

In Nederland en Luxemburg zijn de veranderingen relatief het kleinst, terwijl in Denemarken, Griekenland en Groot-Brittanniē juist sprake is van relatief grote veranderingen. De gegevens uit tabel 10.1 onderstrepen dat veranderingen van meer dan $40 \%$ binnen de lidstaten geen uitzondering vormen. Zoals reeds gememoreerd leidt dit alleen in Denemarken en GrootBrittannië ertoe dat de steun zo nu en dan overhelt naar de kritische kant. In alle andere lidstaten betreft het "slechts" veranderingen van meer naar minder positief. De meeste veranderingen in de lidstaten zijn in die zin dus wel significant, maar vooralsnog weinig substantieel.

Belangwekkend om te vermelden in dit kader is verder nog dat de veranderingen in de publieke steun voor de EU in de verschillende lidstaten geen gezamenlijke Europese trend volgen, maar bovenal nationale trends lijken te volgen.

\section{Zijn de verschillen in publieke steun voor de EU tussen de lidstaten stabiel?}

Uit de antwoorden op de eerste drie vragen volgt logischerwijs dat het antwoord op deze vraag 
in ieder geval ontkennend moet zijn. Bij de beantwoording van de tweede onderzoeksvraag is al aangegeven dat de verschillen tussen de lidstaten in de steun voor de EU op het ene tijdstip veel groter zijn dan op het andere tijdstip. In de jaren negentig zijn de versehillen tussen de landen relatief het kleinst. Door de veranderingen binnen lidstaten veranderen ook de verschillen tussen de lidstaten. Dit soort veranderingen zijn in hoofdstuk 5 aangeduid als verschuivingen.

Voor een aantal lidstaten gaat de unif-tijdreeksen terug tot in de jaren vijftig. Binnen die lange tijdreeksen zijn relatief grote verschuivingen waarneembaar. De meest opmerkelijke verschuivingen op de lange termijn (sinds de jaren vijftig) hebben te maken met het stijgen van de publieke steun voor de EU in Italiê en, in mindere mate, Frankrijk enerzijds, en de neergang van de steun in Groot-Brittanniē en West-Duitsland anderzijds. In Italiê en Frankrijk loopt het publiek in de jaren vijftig in vergelijking met de andere lidstaten en Groot-Brittanniē (toen nog geen lidstaat) nog niet echt warm voor de West-Europese integratic (unif-vraag), maar in het begin van de jaren negentig behoren deze twee landen echter tot de meest "eurofiele" lidstaten. De publieke steun voor de EU in West-Duitsland daalt heel geleidelijk, terwijl de Britse publieke steun in de jaren voor de toetreding min of meer instort. Deze uiteenlopende nationale trends hebben tot gevolg dat de volgorde van deze vier grote lidstaten in termen van publieke steun voor de EU in minder dan veertig jaar nagenoeg volledig op zijn kop gezet is.

Vanaf 1973 beschikken we over min of meer volledige tijdreeksen voor alle negen toenmalige EU-lidstaten. Ook in deze groep lidstaten heeft sinds 1973 een aantal opmerkelijke verschuivingen plaats gevonden. De toetreding van Denemarken, lerland en het Verenigd Koninkrijk in 1973 leidt aanvankelijk tot een soort tweedeling binnen de groep van negen. Aan de ene kant staan de oorspronkelijke zes lidstaten waar de steun voor de EU op een relatief hoog niveau ligt, en aan de andere kant staan de nieuwkomers waar de publieke steun op een veel lager niveau ligt. Dit wekte de suggestie dat publieke steun iets is dat vanzelf komt naarmate een land langer lid van de EU is. Deze tweedeling tussen oud en nieuw is kenmerkend voor de publieke opinie tot aan het begin van de jaren tachtig.

In het midden van de jaren tachtig komt hier echter verandering in. Ten eerste blijkt de steun voor de EU in lerland ineens vrij snel toe te nemen, en aan de andere kant blijkt de publieke steun voor de EU in Spanje en Portugal (toetreding in 1986) meteen na toetreding reeds op een relatief hoog niveau te liggen. Dit laatste geeft aan dat de oorzaak voor de tweedeling tussen oud en nieuw in de jaren zeventig niet zozeer lijkt te moeten worden gezocht in de lengte van het lidmaatschap, maar in andere zaken. Zo ontstaat in het midden van de jaren tachtig een soort driedeling. Aan kop gaan nog steeds de oorspronkelijke zes lidstaten. $\mathrm{Zij}$ worden op de voet gevolgd door lerland en de drie mediterrane nieuwkomers en aan de staart, op vrij grote afstand van de rest, bungelen Groot-Brittanniē en Denemarken.

In de loop van de jaren negentig vervaagt ook deze driedeling en worden de verschillen tussen 
de lidstaten kleiner. Dit komt vooral doordat de steun in Denemarken en, in minder mate, GrootBrittannie̋ stijgt, terwijl de steun in een aantal oorspronkelijke lidstaten nadrukkelijk daalt. Zo ontstaat in de jaren negentig een soort continuüm dat loopt via lidstaten met een uitgesproken positieve publieke opinie over de EU aan het ene uiteinde (Nederland, Luxemburg, Ierland, Italiē) naar landen met slechts een licht positieve publieke opinie aan de andere kant (Groot-Brittannië, Denemarken, België, West-Duitsland). De aanvankelijk scherpe scheiding tussen oud en nieuw is daarmee volledig vervaagd.

5. Welke factoren kunnen de individuele houding van burgers ten aanzien van de EU verklaren? In hoofdstuk $\mathrm{I}$ is reeds aangegeven dat bij het beantwoorden van deze vraag aan vele verschillende factoren kan worden gedacht, maar dat er in dit onderzoek slechts aan een beperkt aantal factoren aandacht zou worden besteed. Aan de hand van Ingleharts Silent-Revolutiontheorie en Zallers RAS-model is in termen van de in paragraaf 1.4 aangehaalde typologie van Kinder en Sears (1985) vooral aandacht besteed aan de invloed van values, history en leadership. Voor de bespreking van de invloed van andere factoren op de attitudevorming ten aanzien van de EU verwijs ik de lezer gaarne terug naar paragraaf 1.5. De verklaring van Inglehart en Zaller zijn uitgewerkt in hoofdstuk 6 en 7, terwijl de toetsing van de uit beide modellen afgeleide hypothesen in hoofdstuk 8 (Inglehart) en 9 (Zaller) heeft plaats gevonden.

Een belangrijk inzicht is dat de variabele postmaterialisme (values) uit Ingleharts SilentRevolution-theorie geen eenduidig effect blijkt te hebben op de steun voor de EU in de verschillende lidstaten. De postmaterialisme-hypothese wordt hier dan ook verworpen. Het niveau van politieke vaardigheden, de andere centrale variabele uit Ingleharts theorie, heeft wel het verwachte positieve effect op de steun voor de EU in alle lidstaten. Het verband tussen vaardigheden en steun is niet in alle lidstaten even sterk, maar is wel in alle lidstaten terug te vinden (politieke vaardigheden-hypothese). Van de eveneens uit Ingleharts theorie afgeleide hypothese over intergenerationele verschillen in de steun voor de EU tussen jong en oud, blijft bij de empirische toetsing weinig over. Jongeren blijken niet systematisch positiever over de EU te denken dan ouderen. History in de zin van verschillende jeugdervaringen en veranderende maatschappelijke omstandigheden waaronder opeenvolgende generaties politiek gesocialiseerd worden, blijken dus geen eenduidig effect op de steun voor de EU te hebben. Ook het feit dat naoorlogse generaties wel en voor-oorlogse generaties niet onder Europese instituties groot geworden zijn, blijkt er uiteindelijk niet toe te doen. De variabelen uit Ingleharts theorie kunnen ons dus slechts een heel klein stukje - politieke vaardigheden - verder helpen op onze zoektocht naar de achtergronden van de publieke opinievorming ten aanzien van de EU op individueel niveau.

Zallers RAS-model biedt veel meer aanknopingspunten voor een verklaring. De empirische 
toetsing van de uit dit model afgeleide hypothesen onderstrepen dat individuele houdingen van EU-burgers sterk afhankelijk blijken te zijn van de stemming binnen het elite discours over de EU in het eigen land. Partijvoorkeur en partij-identificatie blijken uiteindelijk cen belangrijke rol te spelen in de manier waarop de stemming binnen het elite discours doorwerkt op de individuele attitudevorming van EU-burgers. De empirische toetsing van de hypothesen afgeleid uit Zallers RAS-model geeft aan dat de history in de betekenis van the unfolding of events (inhoud massamedia) en leadership (rol politieke elite en politieke partijen) een hoofdrol spelen bij de verklaring van houdingen ten aanzien van de EU. In de volgende paragraaf wordt dieper ingegaan op de betekenis en implicatie van deze uitkomst in het licht van de doelstelling van dit onderzoek.

\section{Welke factoren kamnen de mate van publieke steun voor de EU in een land verklaren?}

Een van de belangrijkste redenen voor het ontstaan van dit onderzoeksproject was gelegen in de constatering dat er in de jaren zeventig en tachtig tussen de toenmalige lidstaten opmerkelijk grote verschillen in de publieke steun voor de EU bestonden. Deze verschillen behoefden een adequate verklaring.

Ingleharts suggestie dat de verklaring voor verschillen tussen lidstaten en veranderingen binnen lidstaten op het punt van de steun voor de EU verklaard zouden kunnen worden uit verschillen en veranderingen (tussen respectievelijk binnen lidstaten) in het waardenklimaat en het gemiddelde niveau van politieke vaardigheden (cognitive mobilization) blijkt empirisch onhoudbaar (zie hoofdstuk 8). Met deze twee variabelen alleen blijken de belangrijkste veranderingen en verschillen in de publieke steun voor de EU binnen respectievelijk tussen de lidstaten in ieder geval niet te kunnen worden verklaard.

Zaller RAS-model geeft aan dat voor de oplossing van de puzzel van verschillen en veranderingen in een heel andere richting moet worden gekeken. Het feit dat de hypothesen die zijn afgeleid uit Zallers RAS-model zonder noemenswaardige problemen de empirische test doorstaan, geeft aan dat de hoogte van de publieke steun voor de EU in een land primair wordt bepaald door de mate van steun voor de EU onder de politieke elite van een land. Een aanzienlijk deel van de variatie in de publieke steun voor de EU tussen en binnen lidstaten kan immers verklaard worden uit verschillen en veranderingen in het EU-standpunt van de politieke partijen die in de verschillende lidstaten actief zijn. Zoals reeds aangegeven bij de vorige onderzoeksvraag zal in de volgende paragraaf dieper worden ingegaan op de betekenis van Zallers RAS-model in het licht van de doelstelling van dit onderzoek. 


\subsection{Doelstelling}

De doelstelling van dit onderzoek was meer inzicht te krijgen in de oorzaken van veranderingen en verschillen in de publieke steun voor de EU te vergroten. Na de beantwoording van de onderzoeksvragen zou duidelijk moeten zijn of de doelstelling ook bereikt is.

Een belangrijk, hoewel mager, inzicht is dat de hoogte van de publieke steun voor de EU in de lidstaten weinig te maken heeft met een meer of minder postmaterialistisch waardenklimaat of met de mate van cognitive mobilization. Dit inzicht is belangrijk omdat Ingleharts Silent Revolution-theorie lange tijd richtinggevend is geweest voor het onderzoek naar de achtergronden van de publieke steun voor de EU.

Ter verklaring van en ter vergroting van het inzicht in de processen die ten grondslag liggen aan de publieke opinievorming ten aanzien van de EU blijkt Zallers RAS-model uiteindelijk veel waardevoller. Om aan te geven wat het RAS-model nu eigenlijk impliceert zal hieronder nogmaals worden ingegaan op de uitgangspunten van Zallers model.

Uitgangspunt van Zallers model is het idee dat gewone burgers in onze hedendaagse samenleving voor hun politieke informatie nagenoeg volledig zijn aangewezen op de massamedia, immers:

"Citizens in large societies are dependent on unseen and usually unknown others for most of their information about the larger world in which they live. [...] The "others" on whom we depend, directly or indirectly, for information about the world are, for the most part, persons who devote themselves full time to some aspects of political or public affairs - which is to say. political elites. These elites include politicians, higher-level government officials, journalists, some activists, and many kinds of experts and policy specialists. "(Zaller, 1992: 6)

Zeker bij de EU of andere internationale organisaties is het een illusie te denken dat burgers hun houdingen zouden kunnen baseren op eigen ervaringen. ${ }^{132}$ In hoofdstuk 3 en 7 is al uitvoerig betoogd dat er weinig reden is om te verwachten dat burgers de feitelijke invloed van de EU op hun leven als zodanig herkennen. Om zich een mening over de EU te vormen zijn burgers dus primair aangewezen op de informatie uit de massamedia. De "informatie" en "feiten" over de EU die in de massamedia naar voren worden gebracht vormen de interpretaties en selectie van een relatief kleine politieke die zich intensief bezig houdt met het EU-issue. Tot zover is Zallers werk weinig controversieel maar lijkt het eerder een constatering van feiten die slechts weinigen zullen betwisten.

\footnotetext{
${ }^{12}$ Daarmee is nadrukkelijk niet gezegd dat EU-besluiten niet van invloed zijn op het dagelijks leven van EUburgers.
} 
Origineel aan Zallers model is de vooronderstelling dat de meeste burgers ten aanzien van de meeste politieke issues geen houding "hebben". Het idee is dat burgers telkens als ze een houding ten aanzien van een concreet issue nodig hebben, er tijdelijk een construeren op basis van de informatie die ze over dat issue in hun hoofd hebben opgeslagen (waarbij de informatie die ze het meest recent hebben opgeslagen de meeste invloed zal hebben).

Opmerkelijk is verder hoe Zaller denkt dat mensen politieke informatie uit de massamedia verzamelen. Zaller gaat er van uit dat burgers in beginsel ieder bericht uit de massamedia over een politiek issue zonder enige vorm van selectie zullen accepteren als geldig argument en als zodanig in hun geheugen zullen opslaan. Volgens Zaller zijn er slechts twee factoren die burgers kunnen aanzetten tot een meer of minder actieve selectie van politieke informatie; dit wil zeggen, een zelfstandige beoordeling van de (on)geldigheid van bepaalde politieke informatie uit de massamedia. Op deze twee factoren wordt hieronder uitvoerig ingegaan omdat ze het model van Zaller relięf geven waardoor het bruikbaar wordt voor de verklaring van de publiek opinie ten aanzien van de $\mathrm{EU}$ en andere issues.

De verzameling van politieke informatie wordt in de eerste plaats gestuurd door predispositions. Om in de hierboven gebruikte terminologie te blijven: dit zijn politieke objecten of issues ten aanzien waarvan burgers wel een permanente houding "hebben". Burgers gebruiken hun predisposities als negatieve selectiecriteria. In relatie tot het EU-issue leidt dit tot de volgende verbijzondering: burgers zullen in beginsel elke bericht over de EU waar ze in de massamedia tegen aanlopen als geldig argument in hun geheugen opslaan, tenzij de informatie die ze krijgen op gespannen voet staat met hun politieke predisposities. Het aantal predisposities dat "gewone" burgers heeft, is volgens Zaller uiterst beperkt. Zaller meent dat partijvoorkeur zonder meer de meest voorkomende en in veel gevallen ook de veruit belangrijkste politieke predispositie is die burgers gebruiken bij het selecteren van informatie. ${ }^{13}$ Toegepast op het EU. issue betekent dit dat burgers in beginsel elk bericht dat ze via de massamedia (radio, tv, kranten, enzovoort) krijgen over de EU als geldig argument accepteren en opslaan in hun geheugen, behalve als uit het bericht blijkt dat de informatie afkomstig is van een (politicus van een) nietfavoriete partij.

In lidstaten waar het EU-issue geen onderwerp van partij-politieke controverses in de media is, zal toepassing van partijvoorkeur als selectiecriterium verder geen gevolgen hebben voor de houding ten aanzien van de EU. In een situatie waarin het EU-issue wel onderwerp van partijpolitieke discussie in de media is, leidt het er min of meer automatisch toe dat partij-aanhangers slechts informatie in hun hoofd opslaan die consistent is met de opvattingen en standpunten van hun eigen partij. Zo komt bij de vorming van een houding ten aanzien van de EU door een partij-

w Andere politieke predisposities zijn vaak sterk persoonlijk van aard en veel minder geschikt dan partijvoorkeur om te worden aangemerkt als algemeen geldig selectiecriterium in termen van Zallers RAS-model. 
aanhanger min of meer vanzelfsprekend een match tot stand tussen het standpunt van de partij en haar aanhangers. Belangrijk om op te merken is dat het voor de werking van dit mechanisme niet nodig is om te vooronderstellen dat partij-aanhangers ook daadwerkelijk op de hoogte zijn of geraken van het standpunt van hun eigen partij. ${ }^{134}$ Zallers redenering is immers gebaseerd op het idee dat burgers hun partijvoorkeur enkel als negatief selectiecriterium gebruiken. Aanhangers van verschillende politieke partijen maken zodoende uiteenlopende negative selecties uit de informatie die ze via de massamedia binnen krijgen. De uiteenlopende selecties die aanhangers van verschillende partijen op basis van hun partijvoorkeur maken, leiden allen tot verschillen in de houdingen van de partij-aanhang voor zover hun partijen inderdaad van mening verschillen. Voor zover partijen uiteenlopende standpunten ten aanzien van de EU innemen, mag dus worden verwacht dat deze standpunten zich uiteindelijk zullen weerspiegelen in uiteenlopende standpunten van de partij-aanhang ten aanzien van de EU.

De tweede factor die van invloed is op de mate waarin burgers politieke informatie selecteren is de sterkte van de politieke predispositie. Toegepast op de partijvoorkeur betekent dit dat negatieve selectie van informatie strenger is naarmate de partijvoorkeur sterker is. Dit betekent dat de kans dat de houding van een partij-aanhanger ten aanzien van de EU overeenkomt met het partijstandpunt ten aanzien van de EU groter is naarmate de identificatie met de partij groter is. Partijloze burgers (zonder expliciete partijvoorkeur) zijn in dit model het minst selectief bij het selecteren van informatie over de EU uit de massamedia. Zij staan open voor informatie van alle partijen.

Uit de analyses in hoofdstuk 9 blijkt dat Zallers RAS-model op alle punten de toets met de empirie probleemloos weet te doorstaan. De verschillen in de publieke steun voor de EU binnen respectievelijk tussen lidstaten blijken voor een belangrijk te kunnen worden verklaard uit veranderingen en verschillen in de EU-standpunten van de politieke partijen die actief zijn in de verschillende lidstaten. Partij-politieke standpunten ten aanzien van de EU weerspiegelen zich heel nadrukkelijk in de publieke steun voor de EU onder de aanhang van de partijen in de 12 onderzochte lidstaten. Bovendien blijkt de sterkte van het verband tussen partijstandpunt en de houding van individuele partij-aanhangers ten aanzien van de EU inderdaad sterk afhankelijk te zijn van de mate van partij-identificatie.

Is de doelstelling nu bereikt? Afgaande op onderzoeksresultaten blijkt vooral met Zallers RASmodel een wezenlijke bijdrage te kunnen worden geleverd aan de vergroting van ons inzicht in de achtergronden van de publieke-opinievorming ten aanzien van de EU. Zallers Ras-model zou

\footnotetext{
${ }^{19}$ Dat cen partijstandpunt ten aanzien van de EU uiteindelijk uitgroeit tot cen soort predisposition van een partij-aanhanger moet niet te snel worden voorondersteld. Als dit laatste uiteindelijk toch gebeurt, dan stelt dit de aanhangers in staat om informatic die strijdig is met het partijstandpunt nog beter uit hun geheugen te weren.
} 
ons inziens dan ook moeten dienen als belangrijke inspiratiebron voor toekomstig onderzoek naar de publieke opinie over de EU. In dat licht zijn hieronder een viertal concrete suggesties voor verder onderzoek geformuleerd.

\section{Suggesties voor verder onderzoek}

In de eerste plaats zou er meer en vooral systematisch onderzoek moeten worden gedaan naar de inhoud van het elite discours over de EU in de massamedia van de verschillende lidstaten. In dat kader zou ook nadrukkelijk aandacht moeten worden besteed aan de bijdrage van nietpartijpolitieke actoren aan het discours. Een betere meting van het elite discours is een voorwaarde om de effecten van partij-politieke en andere elites op de publicke opinie in kaart te brengen. Het zou voor de hand liggen om een inhoudsanalyse uit te voeren op een of meer kranten rond de ratificatie van een ingrijpende EU-verdragswijziging. Dit zijn immers de periodes waarin het EU-issue vaak uitgebreid voor het voetlicht komen, alsmede de periodes waarin de verschillen in de stemming binnen het elite discours tussen de lidstaten ook het meest scherp zijn.

Idealiter zou een systematische verzameling van gegevens over het elite discours, en dit is de tweede aanbeveling, moeten worden aangevuld met een gelijktijdig en langlopend panelonderzoek onder burgers. In dat geval valt misschien ook empirisch aan te tonen dat de causale relatie loopt van elites naar publieke opinie, en niet omgedraaid. Met paneldata zou bovendien meer inzicht kunnen worden gekregen in de instabiliteit van individuele houdingen ten aanzien van de EU. In zo'n kader zou het vooral interessant zijn om na te gaan in hoeverre de controversen binnen het elite discours de stabiliteit van individuele houdingen beïnvloedt?

Om uiteindelijk de precieze effecten van het elite discours op de publieke opinie te kunnen traceren zou het verder nuttig zijn om de situatie in lidstaten te vergelijken met de situatie in nietlidstaten. Vooral de vergelijking met niet-lidstaten met een sceptisch elite discours (Zwitserland en, in mindere mate, Noorwegen) is in dat kader bijzonder interessant omdat zodoende ook de variatie op de onafhankelijke variabele kan worden vergroot.

Tot slot, zou er meer onderzoek moeten worden gedaan naar de vraag waarom het elite discours van land tot land zo sterk verschilt? Beter inzicht in de drijfveren en beoordelingscriteria van de partijpolitieke elites zou een zinvolle bijdrage kunnen leveren aan het beantwoorden van de vraag wat de publieke opinie uiteindelijk drijft.

\subsection{Publieke opinie en internationale politieke systemen}

Tot slot van dit onderzoek nog een korte beschouwing over de betekenis van de 
onderzoeksresultaten in het licht van de opmerkingen die in hoofdstuk 3 zijn gemaakt over de relatie tussen de publieke opinie en het functioneren en voortbestaan van supranationale politieke organisaties. In hoofdstuk 3 is gesteld dat de EU die met haar besluiten burgers direct kan binden in principe een zekere mate van publieke politieke steun behoeft om te kunnen functioneren en voortbestaan. Doordat intergouvernementele elementen nog steeds een heel belangrijke rol spelen in de EU-besluitvorming en de EU voor de uitvoering (inclusief de financie̋le middelen) en handhaving van zijn beleid min of meer volledig is aangewezen op de lidstaten, is uiteindelijk geconcludeerd dat het voortbestaan en functioneren van de EU in de praktijk vooral afhankelijk is van de politieke steun voor de EU vanuit de nationale politieke elites.

Dit onderzoek onderstreept de noodzaak voor voldoende politieke steun voor de EU vanuit de nationale politieke elites. De houding van de nationale politieke elites blijkt immers in hoge mate bepalend te zijn voor de publieke politieke steun voor de EU. De EU lijkt er vooralsnog nog niet in te slagen om een directe band met haar burgers op te bouwen. Dit komt het pregnant tot uiting in het feit dat bij EP-verkiezingen Europese issues nog altijd nauwelijks een rol van betekenis spelen. Zolang de nationale politieke elites vertrouwen hebben in het functioneren en voortbestaan van de EU is er geen dringende noodzaak om de directe band tussen de EU en de burgers te versterken.

Het is uberhaupt de vraag of een versterking van de directe band tussen EU en burger wel zo wenselijk is in het licht van het feit dat de EU in zijn dagelijks functioneren nog zo nadrukkelijk leunt op de nationale lidstaten. $\mathrm{Bij}$ het versterken van de band gaan de gedachten vaak uit naar de vestiging van een parlementair of presidentieel stelsel binnen de EU. In een parlementair stelsel krijgt het EP vergaande wetgevende bevoegdheden en ontstaat er een vertrouwensrelatie tussen Commissie en EP. Bij de vestiging van een presidentieel stelsel kan gedacht worden aan het direct kiezen van de voorzitter van de Europese Commissie die op deze manier een eigen mandaat krijgt en ook meer bevoegdheden zou moeten krijgen. Het versterken van de band tussen de EU en de burger gaat in beide gevallen ten koste van de relatieve macht van de intergouvernementele Raad en de daarin vertegenwoordigde lidstaten. Het ligt voor de hand dat in zo'n constellatie met een minder machtige Raad makkelijker situaties zullen ontstaan waarbij belangen van lidstaten met voeten worden getreden door een meerderheid in het EP of door het optreden van een democratisch gelegitimeerde Commissievoorzitter. Zolang de EU voor de uitvoering van haar besluiten, de handhaving van en controle op haar regels en haar financiele middelen primair is aangewezen op de welwillende medewerking van diezelfde lidstaten (politici en ambtenaren) draagt deze ontwikkeling een zeker gevaar in zich. De nationale politieke elites kunnen niet alleen de uitvoering en handhaving van EU-beleid frustreren, maar zij vervullen ook een sleutelrol in de publieke-opinievorming ten aanzien van de EU binnen de lidstaten. In dit licht bestaat bij de invoering van een presidentieel of parlementair stelsel binnen de EU een 
gerede kans dat in plaats van een de beoogde versterking van de band tussen burgers en EU uiteindelijk de publieke politieke steun voor de EU binnen de lidstaten in gevaar wordt gebracht (zie ook: Thomassen en Schmitt, 1999b: 264-6; en Gabel, 1998a: 122). Door de invoering van een parlementair of presidentieel stelsel wordt de kans dat nationale politieke elites van de EU vervreemden groter waardoor het gevaar ontstaat dat ook de publieke steun voor de EU in sommige lidstaten onder druk zal komen te staan. Het handhaven van de invloed van lidstaten en nationale politieke elites op de EU-besluitvorming lijkt vooralsnog de beste waarborg tegen het wegvallen van de, voor het goed kunnen functioneren en voortbestaan van een supranationale EU noodzakelijke, publieke politieke steun voor de EU vanuit de betrokken lidstaten. 


\section{Appendix A: Overzicht databestanden met antal cases per land}

Primaire bronnen (tussen haakjes een verwijzing naar een bron met meer informatie over de datasets)

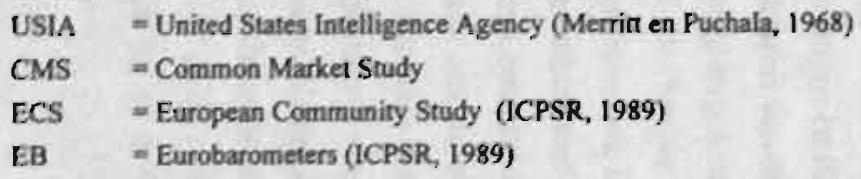

\begin{tabular}{|c|c|c|c|c|c|c|c|c|c|c|c|c|c|}
\hline STUDIE. & JAAR & $\mathbf{F R}$ & BE & NL & WD & IT & $\mathrm{LU}$ & $\begin{array}{l}\text { ND } \\
\text { DK }\end{array}$ & IF & GB & GR & PO & $S P$ \\
\hline USIA XX-1 & 1952 & 1345 & & & 1591 & 1505 & & & & 1503 & & & \\
\hline USIA XX-2 & 1934 & 847 & & & 836 & 808 & & & & 832 & & & \\
\hline USIA $X X-3$ & 1935 & 899 & & & 820 & 814 & & & & 805 & & & \\
\hline USIA XX-6 & 1953 & 803 & & & 813 & 803 & & 867 & & 814 & & & \\
\hline USIA $\times X-7$ & 1956 & 795 & & 826 & 852 & 911 & & & & 799 & & & \\
\hline USIA XX-8 & 1956 & 1206 & 853 & & 1138 & 1188 & & & & 1188 & & & \\
\hline USIA XX-9 & 1957 & 11.44 & & & 1106 & 1266 & & & & 1232 & & & \\
\hline USIA & 1962 & 567 & & & 576 & 665 & & & & & & & \\
\hline$X X-141$ & & & & & & & & & & & & & \\
\hline USIA & 1962 & & & & 551 & 665 & & & & 640 & & & \\
\hline$x x-142$ & & & & & & & & & & & & & \\
\hline CMS'62 & 1962 & 1518 & 772 & 779 & 1523 & & 182 & & & & & & \\
\hline USIA XX-IS & 1963 & 1004 & & & 1195 & & & & & 1176 & & & \\
\hline USIA XX-16 & 1964 & & & & & & & & & & & & \\
\hline USIA XX-17 & 1965 & & & & & & & & & & & & \\
\hline USIA xx-18 & 1967 & 1658 & & & 1703 & 1678 & & & & 1664 & & & \\
\hline ECS70 & 1970 & 2046 & 1296 & 1405 & 2014 & & & & & 1957 & & & \\
\hline ECS73 & 1973 & 2227 & 1266 & 1464 & 1957 & 1199 & 330 & 1199 & 1199 & 1933 & & & \\
\hline EE3 & 1975 & 1156 & 1554 & 1093 & 1039 & 1000 & 324 & 1073 & 1000 & 1028 & & & \\
\hline
\end{tabular}




\begin{tabular}{|c|c|}
\hline$\Rightarrow$ & 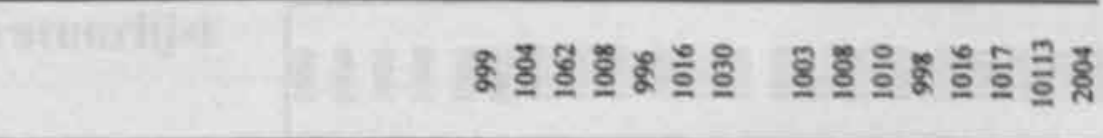 \\
\hline \& & 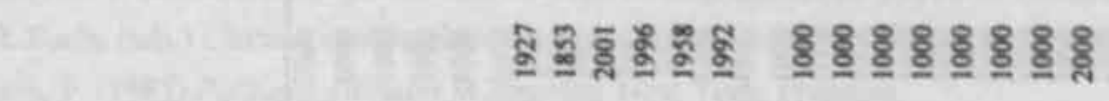 \\
\hline 영 & 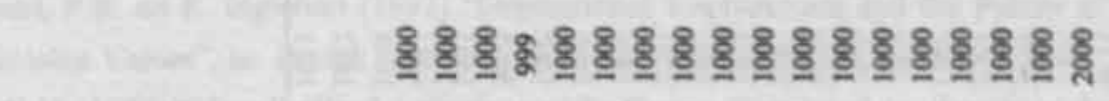 \\
\hline 형 & 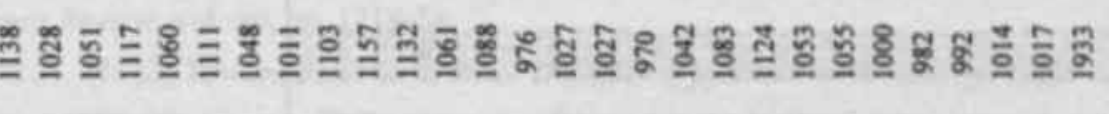 \\
\hline & ริ \\
\hline & 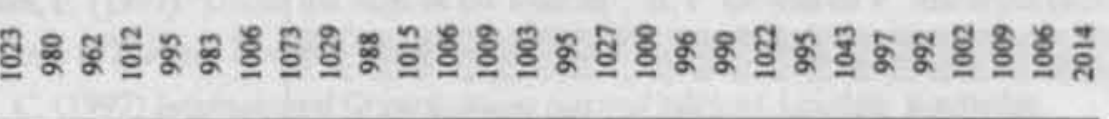 \\
\hline & 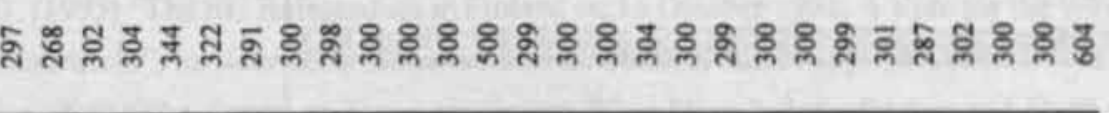 \\
\hline & 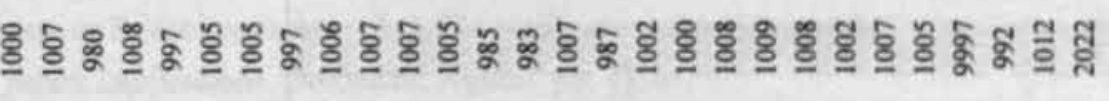 \\
\hline & 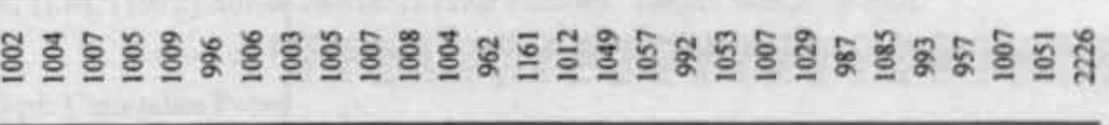 \\
\hline & 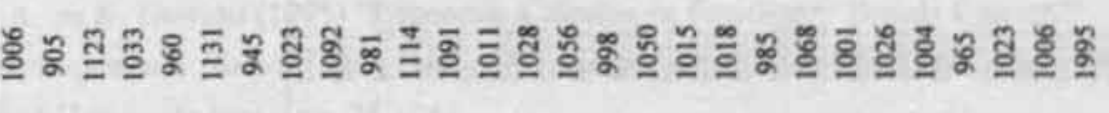 \\
\hline & 흔 \\
\hline & 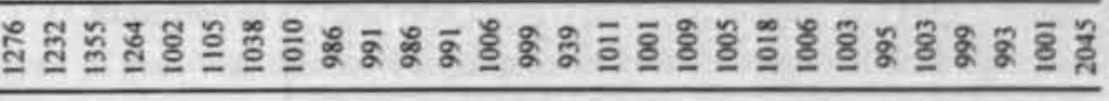 \\
\hline$y$ & 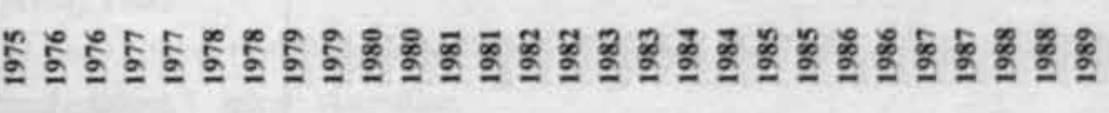 \\
\hline 崖 & 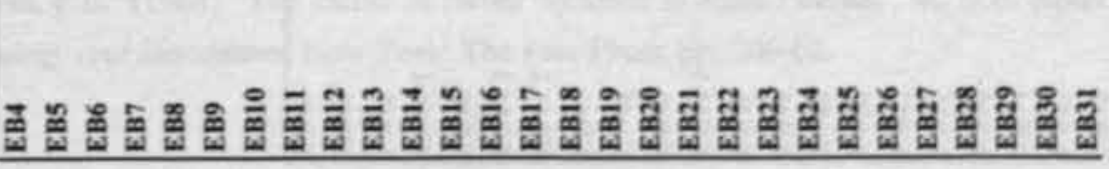 \\
\hline
\end{tabular}




\begin{tabular}{|c|c|}
\hline \multicolumn{2}{|r|}{ 行 } \\
\hline & 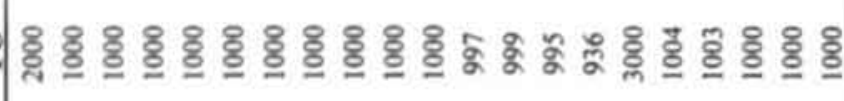 \\
\hline & 家 \\
\hline & 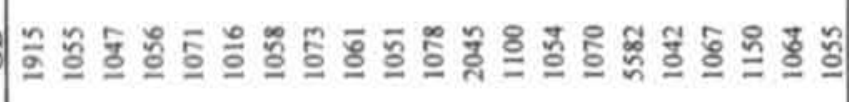 \\
\hline & 主 \\
\hline 首 & 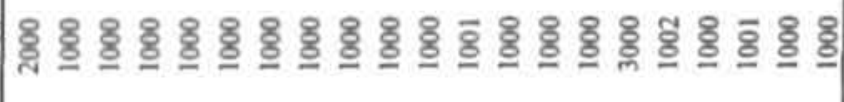 \\
\hline & 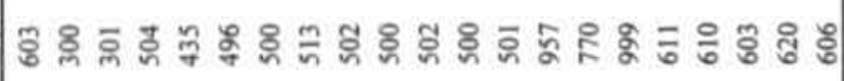 \\
\hline & 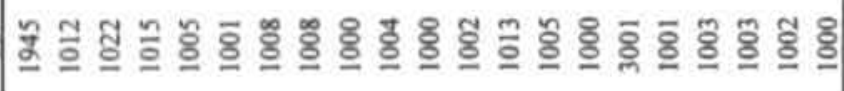 \\
\hline & 긓 \\
\hline & 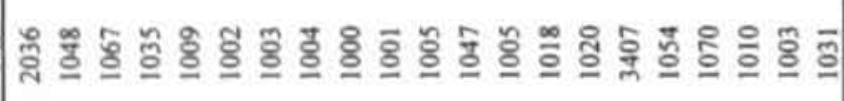 \\
\hline & 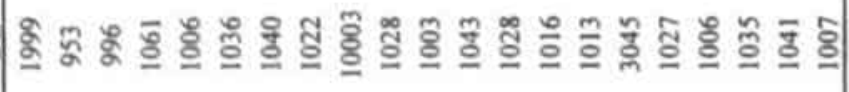 \\
\hline & 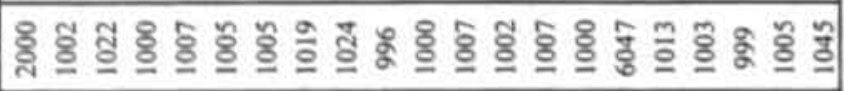 \\
\hline 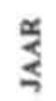 & 玉 \\
\hline 宸 & \\
\hline
\end{tabular}




\section{Literatuurlijst}

Aarts, K. (1995) "Internediate Organizations and Interest Representation", in: H.-D. Klingemann en D. Fuchs (eds.) Citizens and the State.Oxford: Oxford University Press, pp 227-257. Abramson, P. (1983) Political Attitudes in America. New York: Freeman.

Abramson, P.R. en R. Inglehart (1992) "Generational Replacement and the Future of PostMaterialist Values", in: British Journal of Political Science, vol. 22, pp. 183-228.

Achen, C.H. (1975) "Mass Political Attitudes and the Survey Response", in: American Political Science Review, vol. 69, pp. 1218-31.

Achen, C.H. (1983) Toward theories of data: The state of political methodology. Paper APSAcongres 1983, Washington D.C.

Anderson, C. en K. Kaltenthaler (1996) "the Dynamics of Public Opinion toward European Integration, 1973-1993", in: European journal of International Relations, vol. 2, pp. 175-99. Anderson, P. (1997) "Under the Sign of the Interim", in: P. Gowan en P. Anderson (eds.) The Question of Europe. London: Verso, pp. 51-71.

Archer, C. (1992) International Organizations (second edition). London: Routledge.

Arter, D. (1995) "The EU Referendum in Finland on 16 October 1994: A Vote for the West, not for Maastricht", in: Journal of Common Market Studies, vol. 33, pp. 361-88.

Best, E. (1994) "The Treaty on European union: What Does It Actually Say and Do?", in: F. Laursen, en S. Vanhoonacker (eds.), The ratification of the Maastricht Treaty: issues, debates and future implications. Dordrecht: Nijhoff, pp. 17-44.

Blalock, H.M. (1972) Social Statistics (2nd edition). Tokyo: McGraw-Hill.

Blondell, J., R. Sinnott en P. Svensson (1998) People and Parliament in the European Union. Oxford: Clarendon Press.

Bosch, A. en K. Newton (1995) "Economic Calculus or Familiarity Breeds Content?", in: O. Niedermayer en R. Sinnott (eds.), Public Opinion and Internationalized Governance, Oxford: Oxford University Press, pp. 73-104.

Bourdieu, P. (1993) The field of cultural production: essays on art and literature. Cambridge: Polity Press.

Budge, I., D. Robertson en D. Hearl (eds.) (1987) Ideology, Strategy and Party Change: Spatial Analysis of Post-War Election Programmes in 19 Democracies. Cambridge: Cambridge University Press.

Butler, D. en D. Stokes (1974) Political Change in Britain. The Evolution of Electoral Change (second edition). London: Macmillan.

Converse, P.E. (1964) "The nature of Belief Systems in Mass Publics", in: D.E. Apter (ed.), Ideology and Discontent. New York: The Free Press, pp. 206-62. 
Converse, P.E. (1970) "Attitudes and non-attitudes: Continuation of a dialogue", in: E.R. Tufte (ed.), The Quantative Analysis of Social Problems. Reading, Mass.: Addison-Wesley, pp. 16889.

Converse, P.E. (1974) "Comment: The Status of Nonattitudes", in: American Journal of Political Science, vol. 23, pp. 97-100.

Converse, P.E. en G.B. Markus (1979) "Plus ça change ...: The New CPS Election Study Panel", in: American Political Science Review, vol. 73, pp. 32-49.

Converse, P.E. en R. Pierce (1985) Political Representation in France. Cambridge, Mass.: Harvard University Press.

Dalton, R.J. en R. Duval (1986) "The political environment and foreign-policy opinions. British attitudes toward European integration, 1972-1979", in: British Journal of Political Science, vol. 16, pp. 113-34.

Dalton, R.J. en R. Eichenberg (1990) Europeans and the European Community. The Dynamics of Public Support for European Integration. Paper annual APSA-meeting, San Fransisco 1990.

Daiton, R.J. en R. Eichenberg (1993) "Europeans and the European Community: the dynamics of public support for European integration", in: International Organization, vol. 47, pp. 507 34.

Deth, J.W. van (1983) "Ranking the Ratings: The case of Materialist and Postmaterialist Value Orientations", in: Political Methodology, vol. 11, pp. 63-79.

Deth, J.W. van (1984) Politieke waarden: Een onderzoek naar politieke waarde-oriëntaties in Nederland in de periode 1970 tot en met 1982. Amsterdam: CT-Press.

Deth, J.W. van (1989) "Fighting a Trojan Horse: The persistence and Change of Political Orientations", in: H. Ganzeboom en H. Flap (eds.), New Social Movements and Value Change. Amsterdam: SISWO, pp. 89-112.

Deth, J.W. van (1995a) "Comparative politics and the decline of the nation-state in Western Europe", in: European Journal of Political Research, vol.27, pp. 443-62.

Deth, J.W van (1995b) "A macro Setting for Micro politics", in: J.W. van Deth en E. Scarbrough (eds.), The Impact of Values. Oxford: Oxford University Press, pp. 48-75.

Deth, J.W. van en E. Scarbrough (eds.) (1995) The Impact of Values. Oxford: Oxford University Press.

Deutsch, K.W. et al. (1966) "Integration and Arms Control in the European Political Environment: A Summary Report", in: American Political Science Review, vol. 60, pp. 354 65.

Dinan, D. (1994) Ever Closer Union? An Introduction to the European Community. Bastingstoke: Macmillan. 
Dinan, D. (1999) Ever Closer Union? An Introduction to the European Community (second edition). Bastingstoke: Macmillan.

Downs, A. (1957) An Economic Theory of Democracy. New York: Harper \& Row.

Duchesne, S. en A.-P. Frognier (1995) "Is there a European Identity?", in: O. Niedermayer en R. Sinnott (eds.), Public Opinion and Internationalized Governance. Oxford: Oxford University Press, pp. 193-226.

Easton, D.(1973) "System Analysis and its Classical Critics", in: The political science reviewer, vol. 3, pp. 269-301.

Easton, D. (1975) "A Re-Assessment of the Concept of Political Support", in: British Journal of Political Science, vol. 9, pp. 431-48.

Easton, D. (1965, uitgave 1979) A Systems Analysis of Political Life. Chicago: University of Chicago Press.

Eichenberg, R.C. (1989) Public Opinion and National Security in Western Europe. Consensus Lost? Bastingstoke: Macmillan.

Eijk, C. van der, M.N. Franklin et al. (1996) Choosing Europe? The European Electorate and national Politics in the Face of the Union. Ann Arbor: The University of Michigan Press.

Eijk, C. van der, M. Franklin en E. Oppenhuis (1996) "The Strategic Context: Party Choice", in: C. van der Eijk, M.N. Franklin et al., Choosing Europe? The European Electorate and national Politics in the Face of the Union. Ann Arbor: The University of Michigan Press, pp. 332-365.

Eijk, C. van der, M.N. Franklin en W. van der Brug (1999) "Policy Preferences and Party Choice", in: H. Schmitt en J. Thomassen (eds.), Political Representation and Legtimacy in the European Union. Oxford: Oxford University Press, pp. 255-267.

Evans, G. en S. Whitefield (1995) "The Politics and Economics of Democratic Commitment: Support for Democracy in Transition Societies”, in: British Journal of Political Science, vol. 25 , pp. $485-514$.

Festinger, L. (1957) A Theory of Cognitive Dissonance. Stanford: Stanford University Press. Franklin, M., C. van der Eijk en M. Marsh (1996) "Conclusions: The Electoral Connection and the Democratoc Deficit", in: C. van der Eijk, M.N. Franklin et al., Choosing Europe? The European Electorate and national Politics in the Face of the Union. Ann Arbor: The University of Michigan Press, pp. 366-388.

Fuchs, D. (1989) Die Unterstützung des politischen Systems der Bundesrepublik Deutschland. Opladen: Westdeutscher Verlag.

Fuchs D. en H.-D. Klingemann (1991) "The Left-Right Schema", in M. Kent Jennings, J.W. van Deth et al., Continuities in Political Action. A longitudinal Study of Political Orientations in Three Western Democracies. Berlin: De Gruyter, pp. 203-34. 
Gabel, M. en H.D. Palmer (1995) "Understanding variation in public support for European integration", in: European Journal of Political Research, vol 27, pp. 3-20.

Gabel, M.J. (1998) Interests and Integration. Market Liberalization, Public Opinion and European Union. Ann Arbor: The University of Michigan Press.

Gabel, M.(1998a) "Economic Integration and Mass Politics: Market Liberalization and Public Attitudes in the European Union", in: American Journal of Political Science, vol.42, pp. 93653.

Gabriel, O.W. en J.W. van Deth (1995) "Political Interest", in: J.W. van Deth en E. Scarbrough (eds.), The Impact of Values. Oxford: Oxford University Press, pp. 390-411.

Galtung, G. (1969) "Foreign Policy Opinion as a Function of Social Position", in: J.N. Rosenau (ed), International Politics and Foreign Policy: A reader in research and theory. New York: The Free Press.

George, S. (1996) Politics and Policy in the European Union (third edition). Oxford: oxford University Press.

Glenn, N.D. (1977) Cohort Analysis. Beverley Hills, CA: Sage.

Gowan, P. en P. Anderson (eds.) The Question of Europe. London: Verso.

Graaf, N.D. de en P.M. de Graaf (1988) "Family Background, Postmaterialism and Life Style", in: Netherlands' Journal of Sociology, vol. 14, pp. 50-64.

Granberg. D, en S. Holmberg (1996) "Attitude constraint and stability among elite and mass in Sweden”, in: European Journal of Political Research, vol. 29, pp. 59-72.

Gundelach, P. (1995) "Grass-Roots Activity", in: J.W. van Deth en E. Scarbrough (eds.), The Impact of Values. Oxford: Oxford University Press, pp. 412-40.

Handley, D.H. (1981) "Public Opinion and European Integration: The Crisis of the 1970s", in: European Journal of Political Research, vol. 9, pp. 335-64.

Hellevik, O. en N.P. Gledditsch (1973) "The Common Market Decision in Norway: a clash between Direct and Indirect Democracy", in: Scandinavian Political Studies, vol. 3, pp. 22735.

Hellevik, O., N.P Gledditsch en K. Ringdal (1975) "Common-Market issue in Norway: conflict between center and periphery", in: Journal of Peace Research, vol. 12, pp.37-53.

Hix, S. en C. Lord (1997) Political Parties in the European Union. London: Macmillan.

Hyde-Price, A.G.V. (1991) European security beyond the Cold War: four scenarios for the year 2010. London: Sage.

ICPSR (1989) Eurobarometer 28: Relations with Third World Countries and Energy problems, November 1987. Michigan: ICPSR.

Inglehart, R. (1967) "An End to European Integration?", in: American Political Science Review, vol. 61, pp. 91-105. 
Inglehart, R. (1970a) "Cognitive Mobilization and European Identity", in: Comparative Politics, vol. 3, pp. 45-70.

Inglehart, R. (1970b) "Public Opinion and Regional Integration", in: International Organization, vol. 24 , pp. 746-95.

Inglehart, R.(1971) "Changing Value Priorities and European Integration", in: Journal of Common Market Studies, vol. 10, pp. 1-36.

Inglehart, R. (1977a) The Silent revolution: changing Values and Political Styles among Western Publics. Princeton: Princeton University Press.

Inglehart, R. (1977b) "Long Term Trends in Mass Support for European Unification", in: Government and Opposition, vol. 12, pp. 150-77.

Inglehart, R. (1990) Culture Shift in Advanced Industrial Society. Princeton, N.J.: Princeton University Press.

Inglehart R. (1997) Modernization and Postmodernization: Cultural, Economic, and Political Change in 43 Societies. Princeton, N.J.: Princeton University Press.

Inglehart, R. en P.R. Abramson (1999) "Measuring Postmaterialism", in: American Political Science Review, vol. 93, pp. 665-77.

Inglehart R. en J.R. Rabier (1978) "Economic Uncertainty and European Solidarity: Public Opinion Trends", in: The Annals of the American Academy of Political and Social Science, vol. 440, pp. 66-97.

Inglehart, R., J.R. Rabier en K. Reif (1987) "The evolution of public attitudes towards European integration: 1970-1986", in: Journal of European integration, vol. 10, pp.135-55.

Jacobs, F.G. en S. Roberts (eds.) (1987) The Effect of Treaties in Domestic Law. London: Sweet \& Maxwell

Jagodzinski, W. en K. Dobbelaere (1995a) "Religious Cognitions and Beliefs", in: J.W. van Deth en E. Scarbrough (eds.), The Impact of Values. Oxford: Oxford University Press, pp. 197-216. Jagodzinski, W. en K. Dobbelaere (1995b) "Religious and Ethical Pluralism", in: J.W. van Deth en E. Scarbrough (eds.), The Impact of Values. Oxford: Oxford University Press, pp. 218-49. Janssen, J.I.H. (1991) "Postmaterialism, Cognitive Mobilization and Public Support for European Integration", in: British Journal of Political Science, vol. 21, pp. 443-68. Janssen, M. en J.K.de Vree (1985) The Ordeal of Unity. The politics of European integration, 1945-1985. Bilthoven: Prime Press.

Jensen, J.A. (1996) "Prior Parliamentary Consent to Danish EU Policies", in: E. Smith (ed.), National Parliaments as Cornerstones of European Integration. London: Kluwer, pp. 33-53. Kaase, M. en K. Newton(1995) Beliefs in Government. Oxford: Oxford University Press. Kent Jennings, M., J.W. van Deth et al. (1989) Continuities in Political Action. A longitudinal Study of Political Orientations in Three Western Democracies. Berlin: De Gruyter. 
Keraudren, Ph. en S. Dubois (1994) "France and the ratification of the Maastricht Treaty", in: F. Laursen, en S. Vanhoonacker (eds.), The ratification of the Maastricht Treaty: issues, debates and future implications. Dordrecht: Nijhoff, pp. 147-79.

Kinder, D. en D. Sears (1985)"Public Opinion and Political Action", in: G. Lindzey en E. Aronson (eds.), Handbook of Social Psychology (3rd ed.). New York: Random House, pp 659-741.

Kitzinger, U.W. (1973) Diplomacy and persuasion: how Britain joined the Common Market. London: Thames and Hudson.

Klingemann, H.-D. (1995) "Party Positions and Voter Orientations", in: H.-D. Klingemann en D. Fuchs (eds.), Citizens and the State.Oxford: Oxford University Press, pp 183-205.

Klingemann, H.-D. en D. Fuchs (eds.) (1995) Citizens and the State.Oxford: Oxford University Press.

Knutsen, O. (1995) "Left-Right Materialist Value Orientations", in: J.W. van Deth en E. Scarbrough (eds.), The Impact of Values. Oxford: Oxford University Press, pp. 160-96.

Knutsen, O. en E. Scarbrough (1995) "Cleavage Politics", in: J.W. van Deth en E. Scarbrough (eds.), The Impact of Values. Oxford: Oxford University Press, pp. 492-523.

Kooijmans, P.H. (1996) Internationaal publiekrecht in vogelvlucht (zesde druk). Groningen: Wolters-Noordhoff.

Lafferrty, W.M. (1976) "Basic needs and Political values: Some Perspectives from Norway on Europe's 'Silent Revolution'", in: Acta Sociologica, vol. 19, pp. 117-36.

Lane, J.E. en S.O. Ersson (1991) Politics and Society in Western Europe (second edition). London: Sage.

Laursen, F. (1994) "The Not-So Permissive Consensus: Thoughts on the Maastricht Treaty and the Future of European Integration", in: F. Laursen, en S. Vanhoonacker (eds.), The ratification of the Maastricht Treaty: issues, debates and future implications. Dordrecht: Nijhoff, pp. 295-317.

Laursen, F. en S. Vanhoonacker (eds.) (1994) The ratification of the Maastricht Treaty: issues, debates and future implications. Dordrecht: Nijhoff.

Lauwaars, R.H. en C.W.A. Timmermans (1994) Europees gemeenschapsrecht in kort bestek (3de druk). Groningen: Wolters-Noordhoff.

Lewis-Beck, M.S. (1990) Economics and Elections. The Major Western Democracies. Ann Arbor: The University of Michigan Press.

Lieshout, R.H. (1993) "Internationale betrekkingen", in: J.W. van Deth (red.), Handboek Politicologie. Assen: Van Gorcum, pp. 204-28.

Lindberg, L.N. en S.A. Scheingold (1970) Europe's Would-Be Polity. Englewood Cliffs, NJ: Prentice-Hall. 
Lipgens, W. en W. Loth (eds.) (1991) Documents on the history of European Integration. Volume 4: Transnational Organizations of Political Parties and Pressure Groups in the Struggle for European Union, 1945-1950. Berlin: Walter de Gruyter.

Lipset, S.M. en W. Schneider (1987) The confidence gap: business, labor, and government in the public mind. Baltimore: Johns Hopkins University Press.

Lodge, J. (1989) The European Community and the challenge of the future. New York: St. Martin's Press.

Mayhew, D.R. (1980) Europeanism: a study of public opinion and attitudinal integration in the European Community. Ottowa, Ontario: Carleton University (micro-fiche).

Merritt, R.J. (1968) "The USIA-Surveys: Tools for Policy and Analysis", in: R.J. Merritt en D.J.

Puchala (eds.), Western European Perspectives on International Affairs: Public Opinion Studies and Evaluations. New York: Praeger, pp. 3-30.

Merritt, R.J. en D.J. Puchala (eds.) (1968) Western European Perspectives on International Affairs: Public Opinion Studies and Evaluations. New York: Praeger.

Milward, A.S. (1984) The Reconstruction of Western Europe, 1945-1951. Berkeley: University of California Press.

Milward, A.S. (2000) The European Rescue of the Nation-State (second edition). London: Routledge.

Mischler, W. en R. Rose (1994) "Support for Parliaments and Regimes in the Transition Toward Democracy in Eastern Europe, in: Legislative Studies Quarterly, vol. 19, pp. 5-32.

Mischler, W. en Rose, R. (1996) "Trajectories of Fear and Hope: Support for Democracy in Post-Communist Europe", in: Comparative Political Studies, vol. 28, pp. 553-81.

Nas, M. (1995) "Green, Greener, Greenest", in: J.W. van Deth en E. Scarbrough (eds.), The Impact of Values. Oxford: Oxford University Press, pp. 275-300.

Neumann, W.R. (1986) The Paradox of Mass Politics: Knowledge and Opinion in the American Electorate. Cambridge, Mass.: Harvard University Press.

Nicholson, F. en R. East (1987) From the six to the twelve: the enlargement of the European communities. Harlow: Longman.

Niedermayer, O. en R. Sinnott (eds.) (1995) Public Opinion and Internationalized Governance. Oxford: Oxford University Press.

Niedermayer, O. en B. Westle (1995) "A typology of Orientations", in: O. Niedermayer en R. Sinnott (eds.), Public Opinion and Internationalized Governance. Oxford: Oxford University Press, pp. 33-50.

Norton, Ph. (1996) "National Parliaments in Western Europe", in: E. Smith (ed.), National Parliaments as Cornerstones of European Integration. London: Kluwer, pp. 3-15. 
Nugent, N. (1999) The Government and politics of the European Union (Fourth Edition). London: Macmillan.

Oppenhuis, E. V. (1995) Voting Behavior in Europe. A comparative analysis of electoral participation and party choice. Amsterdam: Het Spinhuis.

Petty, R.T. en J.E. Cacioppo (1986) Communication and Persuasion. New York: SpringerVerlag.

Przeworski, A. en H. Teune (1970) The Logic of Comparative Social Inquiry. New York: WileyInterscience.

Puchala, D.J. (1970) "National Distinctiveness and Transnationality in West European Public Opinion, 1954-1962", in: Integration, Vierteljahreshefte zur Europaforschung, pp. 273-8.

Ray, L. (1999) "Measuring party orientations toward European integration: results from an expert survey", in: European Journal of Political Research, vol. 36: pp 283-306.

Reif, K. en H. Schmitt (1980) "Nine Second-order National Elections. A Conceptual Framework for the Analysis of European Election Results", in: European Journal of Political Science, vol. 8, pp. 3-44.

Renckstorf, K. en O. Lange (1990) Niederlaender ueber Deutsche: eine empirische Studie zur Exploration des Bildes der Niederlaender von Deutschen. Nijmegen: Stichting Centrum voor Duitslandstudies.

Riley, M.W. (1963) Sociological Research. Volume I: A Case Approach. New York: Harcourt, Brace en World.

Saris, W.E. (1997) "The Public Opinion About the EU Can Easily Be Swayed in Different Directions", in: Acta politica: International Journal of Political Science, vol. 32, pp. 406-35. Scarbrough, E. (1995) "Materialist-Postmaterialist Value orientations", in: J.W. van Deth en E. Scarbrough (eds.), The Impact of Values. Oxford: Oxford University Press, pp. 48-75.

Scharpf, F. (1999) Governing in Europe: Effective and Democratic? Oxford: Oxford University Press

Schmitt, H. en S. Holmberg (1995) "Political Parties in Decline", in: H.-D. Klingemann en D. Fuchs (eds.) Citizens and the State. Oxford: Oxford University Press, pp 95-133.

Schmitt, H. en J. Thomassen (eds.) (1999) Political representation and Legtimacy in the European Union. Oxford: Oxford University Press.

Schuman, H. en S. Presser (1980) "Pubic opinion and public ignorance. The fine line between attitudes and non-attitudes", in: American Journalof Sociology, vol. 85, pp. 1214-1225.

Schuman, H. en S. Presser (1981) Questions and Answers in Attitude Surveys. Experiments on Question Form, Wording and Context. San Diego: Academic Press.

Schumpeter, J.A.. (1957) Kapitalisme, socialisme en democratie [vertaling: H. Daudt]. Hilversum: De Haan (tweede druk, 1967). 
Shepherd, R.J. (1975) Public Opinion and European Integration. Lexington, Mass.: Saxon House.

Siegel, S. en N.J. Castellan jr. (1988) Nonparametric statistics for the behavioral sciences (2nd ed.). New York: McGraw-Hill.

Sinnott, R. (1995) "Bringing Public Opinion Back In", in: O. Niedermayer en R. Sinnott (eds.), Public Opinion and Internationalized Governance. Oxford: Oxford University Press, pp. 11 32.

Smith, E. (1996) "Introduction: 'Sovereignity' - National and Popular", in: E. Smith (ed.), National Parliaments as Cornerstones of European Integration. London: Kluwer, pp. 3-15. Sogner, I. en C. Archer (1995) "Norway and Europe: 1972 and Now", in: Journal of Common Market Studies, vol.33, pp. 389-410.

Swanborn, P.G. (1984) Methoden van Sociaal-wetenschappelijk onderzoek. Inleiding in ontwerpstrategieèn (derde druk). Boom: Meppel.

J.J.A. Thomassen (red.) (1991) Hedendaagse democratie. Alphen a/d Rijn: Samsom H.D. Tjeenk Willink.

Thomassen, J.J.A (1991) "Kiezers en verkiezingen", in: J.J.A. Thomassen (red.), Hedendaagse democratie. Alphen a/d Rijn: Samsom H.D. Tjeenk Willink, pp. 187-212.

Thomassen, J. en H. Schmitt (1999a) "Issue Congruence", in: H. Schmitt en J. Thomassen (eds.) (1999) Political Rrepresentation and Legtimacy in the European Union. Oxford: Oxford University Press, pp. 188-208.

Thomassen, J. en H. Schmitt (1999b) "In Conclusion: Political Representation and Legitimacy in the European Union", in: H. Schmitt en J. Thomassen (eds.) Political Representation and Legtimacy in the European Union. Oxford: Oxford University Press, pp. 255-267.

Thome, H. (1985) "Wandel zu postmaterialistischer Werten? Theoretische und empirische Einwände gegen Ingleharts Theorie-Versuch", in: Soziale Welt, vol. 36, pp. 27-59.

Tromp, B. (1995) De wetenschap der politiek: verkenningen (2e, herziene druk). Leiden: DSWO Press.

Tutt, N. (1989) Europe on the fiddle: the Common Market scandal. London: Helm.

Vanhoonacker, S. (1994) "From Maastricht to Karlsruhe: The Long Road to Ratification", in: F. Laursen en S. Vanhoonacker (eds.) The ratification of the Maastricht Treaty: issues, debates and future implications. Dordrecht: Nijhoff, pp. 3-15.

Vielemeyer, L. (1991) "Part Three: European Union in Public Opinion Polls, 1945-50", in: W. Lipgens en W. Loth (eds.) Documents on the history of European Integration. Volume 4: Transnational Organizations of Political Parties and Pressure Groups in the Struggle for European Union, 1945-1950. Berlin: Walter de Gruyter, pp. 547-626. 
Volkens, A. en H.-D. Klingemann (1991) Documentation for the Data Sets on Election Programmes in Comtempory Democracies. Berlin: WSB.

Weatherford, M.S. (1992) "Measuring Political legitimacy", in: American Political Science Review, vol.86, pp. 149-66.

Vree, J.K. de, en M. Janssen (1998) The Ordeal of Unity. Integration and Disintegration in Modern Europe. Amsterdam: Instituut voor Internationaal Juridisch Onderzoek (UvA).

Weil, F.D. (1989) "The Sources and Structure of Legitimation in Western Democracies: A Consolidated Model Tested with Time-Series Data in Six Countries since World War II", in: American Sociological Review, vol. 54, pp 682-706.

Wessels, B. (1995a) "Development of Support: Diffusion or Demographic Replacement?", in:

O. Niedermayer en R. Sinnott (eds.), Public Opinion and Internationalized Governance. Oxford: Oxford University Press, pp. 105-36.

Wessels, B. (1995b) "Support for Integration: Elite or Mass-Driven?", in: O. Niedermayer en R. Sinnott (eds.), Public Opinion and Internationalized Governance. Oxford: Oxford University Press, pp. 137-62.

Westerhof, G.J. (1994) Statements and Stories: towards a new methodology of attitude research. Amsterdam: Thesis Publischers.

Westle, B. (1989) Politische Legitimitat: Theorien, Konzepte, empirische Befunde. Baden-Baden: Nomos.

Wildgen, J.K. en W.J. Feld (1976) "Evaluative and Cognitive Factors in the Prediction of European Unification", in: Comparative Political Studies, vol. 9, pp. 309-34.

Wildgen, J.K. en W.J. Feld (1977) "Communist Publics and Activists: Some Implications for European Integration", in: Journal of Common Market Studies, vol. 15, pp. 77-92.

Worre, T. (1995) "First No, Then Yes: The Danish Referendums on the Maastricht Treaty 1992 and 1993", in: Journal of Common Market Studies, vol.33, pp. 235-257.

Zaller, J.R. (1992) The Nature and Origins of Mass Opinion. Cambridge: Cambridge University Press. 


\section{Curriculum Vitae}

Sef Janssen is op 8 september 1965 geboren te Venlo. In 1983 voltooide hij zijn Gymnasium opleiding aan het Sint Thomascollege te Venlo. In datzelfde jaar startte hij met zijn studie Bestuurskunde aan de toenmalige Technische Hogeschool Twente, in 1988 sloot hij zijn studie aldaar af met een onderzoek naar de achtergronden van de Nederlandse publicke opinie ten aanzien van de EU. Vanaf 1988 tot 1992 was hij als OlO werkzaam bij achtereenvolgens de Faculteit Bestuurskunde van de Universiteit Twente en de Faculteit Beleidswetenschappen van de Katholieke Universiteit Nijmegen. In het laatste jaar van zijn OIO-schap was hij tevens werkzaam als projectleider bij het Zentralarchiv van de Universiteit van Keulen in het kader van een internationaal onderzoeksproject. Na de vervulling van zijn diensplicht in 1993 trad Sef Janssen als universitair docent bestuurskunde in dienst bij de vakgroep Metajuridica van de Faculteit der Rechtsgeleerdheid van de Universiteit Maastricht. 



\section{Summary}

\section{Public support for the European Union}

\section{An analysis of public opinion in 12 member states, 1952-1998.}

Following the signing of the Treaty of Maastricht, the European Union (EU) went through a political crisis. The referenda necessary to ratify the Treaty failed to produce the desired clear mandates for further integration. The "nej" in the Danish referendum (1992) on the EU-treaty caused a shock-wave throughout the Union. Although it was not the first occasion on which politicians were confronted with public opposition towards their plans, this time a crisis of political legitimacy lurked. It was not until the second successful Danish referendum (1993) that the crisis passed. This shows that public support for European integration must not be taken for granted or ignored. Against this background, the author studied both changes in public support for the EU within member states (changes) and changes in the differences in support for the EU between member states (shifts) in the period between 1952 and 1998.

Chapter 1 contains the research goal and the research questions. The goal is to gain a better understanding of the causes of changes within, and shifts of public support for the EU at the level of member states. For this pupose, the author choses a longitudinal and cross-national research design. To gain a better understanding, the author also decided not to confine his analyses to the level of member states (macro), but also to pay attention to changes and differences at the individual (micro) and meso-level (groups, cohorts, generations) of aggregation. The six central research questions that guided the research are:

1. What is the level of public support for the EU within the member states?

2. How great are the differences in the level of public support for the EU between the member states?

3. Is the level of public support for the EU within the member states subject to change? (changes)

4. Are the differences in the level of public support for the EU between member states subject to change? (shifts)

5. What factors explain the formation of attitudes (support) towards the EU at the individual level?

6. What factors explain the level of support at the national (member state) level?

In the second chapter a description is given of the post-war (WOII) history of the EU. The 
forming of the EU is part of a much broader process of increasing Western European cooperation after the Second World War. The increasing cooperation was the inevitable outcome of the rising tensions between the two world-superpowers, the United States of America (USA) and the Soviet-Union (SU), still remaining in Europe, which culminated in the Cold War. Within the scope of this war, the Americans demanded closer cooperation of the European states within their hemisphere (Western Europe). Serving their own interests, the various Western European countries comply with the American demand in exchange for economic and military aid and permanent participation of American troops in the defence of Western Europe. The first steps towards Western European cooperation were eventually taken within the framework of the Organisation for European Economic Cooperation (today the OECD), the North Atlantic Treaty Organisation and the Council of Europe in 1948-9. The first shoot on the EU-tree appeared in 1952 when the initial six member states (France, West Germany, Italy and the Benelux countries) joined forces within the European Coal and Steel Community (ECSC). The establishment of the European Economic Community (EEC) and the European Community for Atomic Energy (Euratom) in 1957 are the next two branches. This form of cooperation within the European Community(ies) (EC) is characterised by: a supranational regime, a French-German Axis (excluding the United Kingdom) and acquiescence of the USA. During the recent decades, the scope of the EC has been extended to more policy fields, and the power and influence of its authorities in these fields have increased gradually. In 1993 the EC became part of an even broader framework: the EU. The new member states that acceded were: Denmark, Ireland and the United Kingdom in 1973; Greece in 1986; Portugal and Spain in 1986; and, Austria, Finland and Sweden in 1995. The discussion of EU-history in Chapter 2 ends with the observation that the creation and development of the EC/EU during the first decades have hardly been something on which the mass public had any (direct) influence. Through the introduction of national referenda on EU-matters in the 1970s (and onwards) and direct elections towards the European Parliament since 1979 the situation has improved to some extent, but the actual influence of the public on EU-matters is still very limited.

In Chapter 3, the question is posed as to whether the EU is a proper political system and whether the EU needs public political support to function and be sustained. This question is answered on the basis of Easton's (political) systems-theory. From this theory, it is inferred that proper political systems are authoritative and decisive. Whether international political organisations are political systems is primarily dependent on whether an organisation is supranational and has the power to induce the member states to accept its decisions as binding. On the basis of the supranational regime underlying the EU, it is concluded that the EU is at least to some extent a political system. 
The second part of the question is whether the EU needs public political support to function and be sustained. The answer to this question depends on the answer to the question whether an international organisation can take measures which the citizens of the member states must accept as directly applicable. If that is the case, one can argue on the basis of Easton's theory that some measure of public political support is necessary. The EU can make and take directly applicable decisions and therefore it is concluded that, in principle, the EU needs some form of public political support. The EU relies daily on its member states for the implementation of its policies, the enforcement of its rules, the collection of its financial means and its jurisdiction. This reliance entails that in many instances the EU can rely on the public support for the national political systems and therefore the need for self-sustaining support may be less important.

At the end of the chapter support for the EU is defined as an individual attitude or behaviour by which a person expresses his positive or negative orientation towards the EU or a specific aspect of the EU.

Chapters 4 and 5 offer a first encounter with the data used and the answers to the first four research questions. For the analyses the author has relied on survey data from a-select samples of national populations in twelve member states (excluding Austria, Finland and Sweden). The German data are limited to West Germany and the data from the United Kingdom do not contain the (sometimes) available data from Northern Ireland. The author has used some 50 different surveys from the period between 1952 and 1998. In Chapter 4, the concept of support for the EU (at the individual level) is operationalized in three indicators; and the concept of public support (at the level of nations) is operationalized as the percentage positive support minus the percentage negative support within a country. In Chapter 5 , the available national time series on public support for the EU are discussed. For some countries, these time series go back to the 1950 s, but for the smaller member states that acceded to the EU the series only go back to the year prior to/of their entrance. In total, the available database contains more than 500,000 respondents.

The answers to the first four research questions can be found in the conclusions of Chapters 4 and 5. The first conclusion is that the measurement of the level of public support for the EU within a member state is extremely dependent on the indicator used. It is impossible to say, therefore, what exact the level of public support is in a single country. Nevertheless, there are no signs whatsoever that there is a pervasive majority opposition towards the EU in any of the twelve member states, although at some points in time critics outweigh the supporters in Denmark and Great Britain. Comparing national scores based on the same indicator striking differences are found in support for the EU between member states, as well as major changes within and shifts between member states. 
To explain the changes and shifts at the national level, as well as the formation of individual attitudes towards the EU, two theories are used in this research: Ingleharts Silent Revolutiontheory and Zallers Receive-Accept-and-Sample-model (RAS-model). In Chapters 6 and 7 both theories are discussed and hypotheses are formulated. In Chapters 8 and 9, the hypotheses are tested empirically.

Ingleharts Silent Revolution-theory and its central concepts - postmaterialism and cognitive mobilisation - are put on trial at three levels of aggregation. The idea is that both postmaterialism and cognitive mobilisation (level of political skills) positively contribute to the individual feelings of support for the EU at the individual level, and to the level of public support at the national level. Furthermore it is expected that among the members of each new generation in the member states the percentage of postmaterialists and the level or political skills rises systematically. Therefore, it is also hypothesised that there are systematic inter-generational differences in support for the EU. The results of the empirical tests are poor. Postmaterialism proves to be unrelated to attitudes towards the EU, wheras the concept of cognitive mobilisation makes sense only at the individual level. The idea that there are systematic and pervasive intergenerational differences in all member states is also not borne out by the data. The conclusion reached in Chapter 8 is that Inglehart's theory and concepts are of almost no use in explaining attitudes towards EU, and changes and shifts within and between member states.

Zaller's RAS-model leads to much better results. Based on the idea that people "hold" almost no political attitudes, Zaller argues that people form political attitudes temporarily on the basis of a sample from the information they receive either directly or indirectly from the mass media. In principle, citizens will accept all political information - this is an essential difference with other ficlds of interest - from the media without any filtering, unless the information they receive contains references to one's central political predispositions. It is contended that in virtually no individual case, the attitude towards the EU is a central political predisposition, but rather partypreference. From the assumptions underlying the RAS-model, it is hypothesised that the level of public support for the EC will reflect the balance between arguments in favour and against in the elite discourse on the EU-issue within a member state. The elite discourse is after all the main (only) source of information on an issue for the mass media. The elite consists of persons professionally occupied with the EU-issue, such as politicians, scientists, journalists and lobbyists.

Furthermore, if the EU-issue is subject of a struggle between different political parties, then one would expect public opinion to split along party lines. Supporters of party A will filter the arguments originating from other parties $(B, C, D, \ldots)$ on the basis of their party-preference (negative selection). As a result of this process, the arguments that voters accept as valid - and that will be stored in their heads for the formation of future attitudes - become more or less 
unconsciously and automatically biased towards the point of view of their favourite party. This means that when party-supporters need to form attitudes towards a political issue, it is very likely that their artitude reflects the position of their party on this issue. It is also assumed that the stronger a voter identifies with a certain party, the stronger the functioning of this mechanism will be.

All the hypotheses deduced from Zaller's RAS-model withstand the empirical tests. The empirical results do not rule out two simple and attractive alternative explanations. The first alternative is that voters base their party preferences on the basis of an evaluation of issue positions of different parties; the second is that parties try to reflect the attitudes of their followers in an attempt to hold their share of votes. The alternatives are rejected on the basis of the abundant knowledge available on the national character of European(!) elections and the few, but very strong indications from panel research that EU-citizens have formed stable EU-attitudes to a very limited extent. Zaller's model is the only model that, in the author's view, is compatible with these insights and therefore the author rejects the two alternative explanations. This means that public opinion reflects the balance of arguments pro and con within the mass media and that parties serve (through negative selection) as a kind of prompter for their voters.

In the final chapter, the main conclusions from the different chapters are repeated and an outline for further research is drawn. To gain a further understanding of public opinion formation, attention must be focused on panel research in combination with content analyses of mass media in both member and non-member states. The fact that public opinion is so much dependent on the opinion of the political elites makes it essential that more investigation is conducted into the causes of elite opinion formation. 
